\title{
CAROLINA ANDREA GARISTO GREGÓRIO
}

Método para análise da oportunidade de imobilização em imóveis corporativos 


\section{CAROLINA ANDREA GARISTO GREGÓRIO}

Método para análise da oportunidade de imobilização em imóveis corporativos

Tese apresentada à Escola Politécnica da Universidade de São Paulo para obtenção do título de Doutor em Engenharia

Área de Concentração:

Engenharia de Construção Civil e Urbana

Orientador:

Prof. Dr. João da Rocha Lima Jr. 
Este exemplar foi revisado e alterado em relação à versão original, sob responsabilidade única do autor e com a anuência de seu orientador.

São Paulo, de dezembro de 2010.

Assinatura do autor

Assinatura do orientador

FICHA CATALOGRÁFICA

Gregório, Carolina Andrea Garisto

Método para análise da oportunidade de imobilização em imóveis corporativos / C.A.G. Gregório. -- ed.rev. -- São Paulo, 2010.

$323 \mathrm{p}$.

Tese (Doutorado) - Escola Politécnica da Universidade de São Paulo. Departamento de Engenharia de Construção Civil.

1. Gerenciamento do real estate corporativo 2. Planejamento estratégico 3. Método de análise hierárquica I. Universidade de São Paulo. Escola Politécnica. Departamento de Engenharia de Construção Civil II. t. 


\section{DEDICATÓRIA}

Ao meu marido, Leandro, pela paciência, compreensão e apoio.

Aos meus queridos pais, Iza e Ricardo, pelo exemplo de amor, dedicação e apoio durante toda minha formação acadêmica.

Ao meu irmão, Alexandre, por sempre torcer por mim. 


\section{AGRADECIMENTOS}

Ao meu orientador, Prof. Dr. João da Rocha Lima Jr., pelo aprendizado, pelas críticas oportunas realizadas no desenvolvimento da tese, e por servir de referência e inspiração à minha formação acadêmica e profissional.

Aos professores da Universidade de São Paulo, em especial, do Núcleo de Real Estate da Escola Politécnica, pelos ensinamentos nas demais atividades acadêmicas.

Aos profissionais que gentilmente fizeram parte desta tese.

À Fundação de Amparo à Pesquisa do Estado de São Paulo, pela concessão da bolsa e pelo apoio financeiro para a realização desta pesquisa. 


\section{RESUMO}

$\mathrm{O}$ avanço da economia brasileira e o amadurecimento dos mercados induzem à crescente competitividade nos diferentes setores. Com isso, as corporações buscam por maneiras de investir com maior produtividade de modo a direcionar recursos nas suas atividades fins para desenvolvimento e expansão do negócio principal. Os ativos imobiliários são um dos recursos mais onerosos para muitas empresas, que ainda imobilizam recursos nesses ativos de longo prazo de maturação. É incipiente a percepção das empresas brasileiras em relação às perdas de oportunidade de ganho com os investimentos que são internados nas suas bases instaladas. Nesse contexto, a tese trata da configuração de um método para análise da oportunidade de imobilização e desmobilização em imóveis corporativos sob a ótica das corporações usuárias, por meio da identificação de critérios qualitativos e quantitativos (econômico-financeiros) relevantes à análise, considerando (i) os mecanismos diretos e indiretos atualmente empregados no Brasil, (ii) a sustentação legal, (iii) as práticas tributárias e contábeis, e (iv) as práticas prevalentes de mercado. Os critérios de decisão do método são priorizados pelos administradores das corporações com auxílio de uma ferramenta para análise hierárquica de decisão (Analytic Hierarchy Process - AHP), que indica a alternativa mais adequada entre as opções de imobilização ou não no real estate para cada situação. O método desenvolvido nesta tese pode ser uma importante ferramenta de apoio para as diretrizes de governança corporativa no que tange às decisões em relação ao portfolio de real estate das corporações, podendo ser utilizado por empresas com atuação nos diferentes setores da economia, tais como: manufatura, serviços, varejo, entre outros, inclusive no setor público.

Palavras Chaves: Gerenciamento do real estate corporativo. Planejamento estratégico. Método de análise hierárquica. 


\begin{abstract}
The development of the Brazilian economy and the maturity of the markets have prompted growing competition within different sectors. In this context corporations tend to find ways to invest more productively by focusing on their main activities in an effort to enhance their core business. Real estate assets are generally one of the companies' greatest expenses; even so, companies still invest in these long-term maturity assets. It is still incipient the perception of Brazilian companies as regards the opportunity costs incurred by them as a result of investing in real estate assets. In view of the foregoing, the thesis sets forth an analysis method to guide the decision whether to invest or not in real estate assets from the perspective of corporate users. The analysis is based on qualitative and quantitative attributes by taking in account (i) both direct and indirect procedures currently used in Brazil, (ii) the legal framework, (iii) the tax and accounting practices, and (iv) the prevalent market practices. The method's decision criteria are prioritized by the corporations' officers through the AHP tool (Analytic Hierarchy Process), which indicates the most appropriate decision in each situation. The method herein developed may work as an important corporate governance guideline in the extent real estate portfolio decisions are taken by corporations, and it can be used by companies of different sectors, such as manufacturing, service, retail, among others, including the public sector.
\end{abstract}

Keywords: Corporate real estate management. Strategic planning. AHP (Analytic Hierarchy Process). 


\section{LISTAS DE FIGURAS}

Figura 1 - Níveis táticos a estratégicos para redução de custos nas corporações - adaptado de La Salle, 2003 (CREIS) ................................................................................

Figura 2 - Objetivo da Tese ............................................................................................ 8

Figura 3 - Rotina do Método para Análise da Oportunidade de Imobilização em Imóveis

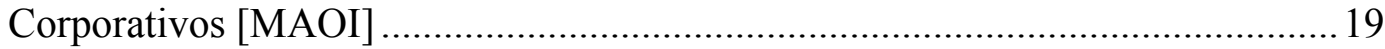

Figura 4 - Mecanismo Genérico de uma Operação de Securitização .........................................33

Figura 5 - Definição dos Critérios de Decisão (rotina do [MAOI]) …………………………....43

Figura 6 - Grau de Importância da Propriedade para a Atividade Operacional - Adaptado de

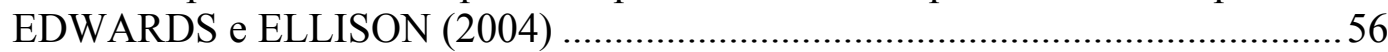

Figura 7 - [alternativas] ' $v$ ' Referências Qualitativas do [MAOI] (rotina do [MAOI])......... 70

Figura 8 - [alternativas] ' $v$ ' ' Referências Quantitativas do [MAOI] (rotina do [MAOI]) .... 110

Figura 9 - Fluxo ilustrativo das entradas e saídas de caixa nas [alternativas] de não imobilização.

Figura 10 - Fluxo ilustrativo das entradas e saídas de caixa na [alternativa] de imobilização a

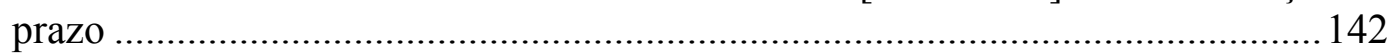

Figura 11 - Estruturação das referências qualitativas e quantitativas na ferramenta de apoio à decisão (AHP - Analytic Hierarchy Process) ...................................................... 174

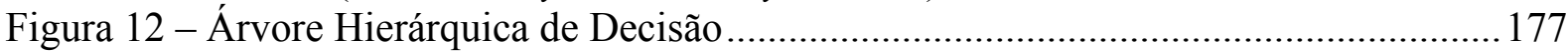

Figura 13 - Matriz das [alternativas] elaborada para cada um dos critérios de decisão ......... 178

Figura 14 - Ponderação das notas das [alternativas] para os critérios de decisão qualitativos, usando como exemplo o [Critério D] - vínculo da operação com o imóvel (Nível 3

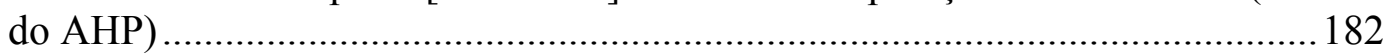

Figura 15 - Ponderação das notas das [alternativas] para os critérios de decisão quantitativos, usando como exemplo o [Critério G] - canalizar recursos em oportunidades do negócio principal (Nível 3 do AHP)

Figura 16 - Priorização dos critérios de decisão do [MAOI] para o Decisor 1 (Nível 2 do

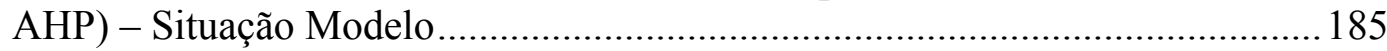

Figura 17 - Hierarquização das [alternativas] para a situação modelo (Resultado do AHP) 186 


\section{LISTAS DE GRÁFICOS}

Gráfico 1 - Porcentagens das Corporações em relação às porcentagens de propriedade dos espaços corporativos - LaSalle, 2005.

Gráfico 2 - Porcentagem de corporações da amostra analisada em relação às estratégias de imobilização e desmobilização dos espaços corporativos- LaSalle , 2005

Gráfico 3 - Taxas de inflação (IGP-DI, FGV) e Taxas de juros básica (SELIC) entre Janeiro

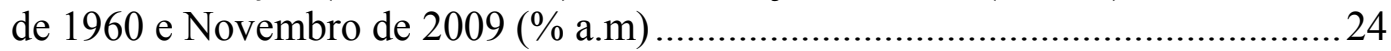

Gráfico 4 - Operações de Crédito Total 'vs’ PIB. (Fonte: IPEA) .............................................28

Gráfico 5 - Intensidade de locação dos espaços por setor de atuação (L = Relação entre espaço locado e total de espaço ocupado pelas corporações) - Adaptado de LASFER (2003).

Gráfico 6 - Alteração na duração dos prazos de locação por setor - Adaptado do IPD Investment Property Databank (Annual Lease Review, 2005) .

Gráfico 7 - Valores de VOI (Valor da Oportunidade do Investimento) para o empreendimento da Situação Modelo (Capítulo 6).

Gráfico 8 - Amostras de laboratório da RRCGA (Renda Relativa do Capital de Giro Ativado) para perturbação sem compensação no ROE (faixa: 0 a -20\%) - Situação Modelo (Capítulo 6).

Gráfico 9 - Pesos Relativos dos critérios para o Decisor 2 - Situação Modelo....................... 187

Gráfico 10 - Hierarquização das [alternativas] para o Decisor 2 - Situação Modelo ............ 188

Gráfico 11 - Participação (pelo valor de transação) de cada imóvel no portfolio de real estate da empresa do caso

Gráfico 12 - Participação (pela área construída) de cada imóvel no portfolio de real estate da empresa do caso.

Gráfico 13 - Intervalo de VOI para o Imóvel 1 da empresa do caso ..................................... 197

Gráfico 14 - Intervalos de valor da RRCGA para o Imóvel 1 ...........................................200

Gráfico 15 - Intervalos de valor da RRIP (Renda Relativa na Imobilização a Prazo) para o

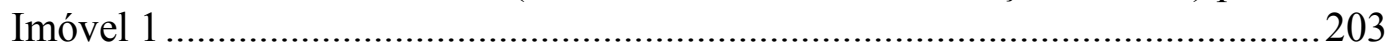

Gráfico 16 - Pesos relativos das [alternativas] para o critério - canalizar recursos em oportunidades do negócio principal [Critério G]: Imóvel 1 ...............................206

Gráfico 17 - Pesos relativos das [alternativas] para o critério - desoneração do balanço [Critério H]:

Gráfico 18 - Pesos relativos das [alternativas] para o critério - redução dos impactos tributários [Critério I]: Imóvel 1

Gráfico 19 - Pesos relativos das [alternativas] para o critério - flexibilidade de mudança [Critério A]: Imóvel 1

Gráfico 20 - Pesos relativos das [alternativas] para o critério - rapidez na mobilização da atividade para o espaço [Critério B]: Imóvel $1 . .$.

Gráfico 21 - Pesos relativos das [alternativas] para o critério - controle operacional no uso do espaço [Critério C]: Imóvel 1

Gráfico 22 - Pesos relativos das [alternativas] para o critério - vínculo da operação com o imóvel

Gráfico 23 - Pesos relativos das [alternativas] para o critério - especificidade do imóvel [Critério E]: Imóvel 1

Gráfico 24 - Pesos relativos das [alternativas] para o critério - oportunidade de tradução da imagem corporativa [Critério F]: Imóvel 1

Gráfico 25 - Pesos relativos dos critérios para o Imóvel 1 conforme priorização do decisor 221 Gráfico 26 - Hierarquia das [alternativas] para o Imóvel 1 
Gráfico 27 - Intervalo de VOI para o Imóvel 3 da empresa do caso ...................................226

Gráfico 28 - Intervalos de Valor da RRCGA para o Imóvel 3 ...........................................228

Gráfico 29 - Intervalos de Valor da RRIP para o Imóvel 3 ................................................230

Gráfico 30 - Pesos relativos das [alternativas] para o [Critério G] - Imóvel 3 ..................... 233

Gráfico 31 - Pesos relativos das [alternativas] para o [Critério H] - Imóvel 3 .....................234

Gráfico 32 - Pesos relativos das [alternativas] para o [Critério I] - Imóvel 3 .......................236

Gráfico 33 - Pesos relativos das [alternativas] para o [Critério A] - Imóvel 3 ......................236

Gráfico 34 - Pesos relativos das [alternativas] para o [Critério B] - Imóvel 3 .......................237

Gráfico 35 - Pesos relativos das [alternativas] para o [Critério C] - Imóvel 3 ......................237

Gráfico 36 - Pesos relativos das [alternativas] para o [Critério D] - Imóvel 3 ......................238

Gráfico 37 - Pesos relativos das [alternativas] para o [Critério E] - Imóvel 3 .......................238

Gráfico 38 - Pesos relativos das [alternativas] para o [Critério F] - Imóvel 3 ......................2239

Gráfico 39 - Pesos relativos dos critérios para o Imóvel 3 conforme priorização do decisor 240

Gráfico 40 - Hierarquia das [alternativas] para o Imóvel 3 .............................................241

Gráfico 41 - Intervalo de VOI para o Imóvel 4 da empresa do caso .....................................245

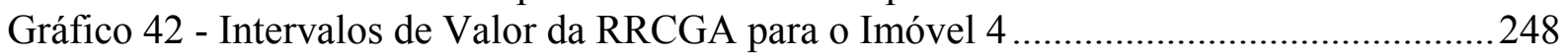

Gráfico 43 - Intervalos de Valor da RRIP para o Imóvel 4 ...............................................250

Gráfico 44 - Pesos relativos das [alternativas] para o [Critério G] - Imóvel 4 ......................252

Gráfico 45 - Pesos relativos das [alternativas] para o [Critério H] - Imóvel 4 .....................256

Gráfico 46 - Pesos relativos das [alternativas] para o [Critério I] - Imóvel 4 .......................257

Gráfico 47 - Pesos relativos das [alternativas] para o [Critério A] - Imóvel 4 .....................258

Gráfico 48 - Pesos relativos das [alternativas] para o [Critério B] - Imóvel 4 ......................258

Gráfico 49 - Pesos relativos das [alternativas] para o [Critério C] - Imóvel 4......................259

Gráfico 50 - Pesos relativos das [alternativas] para o [Critério D] - Imóvel 4 .......................259

Gráfico 51 - Pesos relativos das [alternativas] para o [Critério E] - Imóvel 4 .......................260

Gráfico 52 - Pesos relativos das [alternativas] para o [Critério F] - Imóvel 4 ......................260

Gráfico 53 - Pesos relativos dos critérios para o Imóvel 4 conforme priorização do decisor 261

Gráfico 54 - Hierarquia das [alternativas] para o Imóvel 4 ................................................262 


\section{LISTAS DE QUADROS}

Quadro 1 - Etapas para elaboração do Método para Análise da Oportunidade de Imobilização em Imóveis Corporativos.............................................................................. 15

Quadro 2 - Evolução Histórica - Fatores Influenciadores da Reestruturação do Real Estate Corporativo - Período: 1960 a 1990.

Quadro 3 - Evolução Histórica - Fatores Influenciadores da Reestruturação do Real Estate Corporativo - Período: 1990 a 2010 ................................................................ 42

Quadro 4 - Compilação das informações advindas do levantamento de campo: critérios de decisão ' $v s$ ' tipos de espaços corporativos ' $v s$ ' [alternativas]

Quadro 5 - Critérios de Decisão do [MAOI]

Quadro 6 - Dados do Empreendimento e Cenário Referencial (Situação Modelo - Capítulo 6)

Quadro 7 - Fatores influenciadores do Custo do Capital de Giro Ativado (CCGA) .............. 131

Quadro 8 - Balanço Patrimonial (Grupos de Contas) ........................................................... 152

Quadro 9 - [alternativas] 'vs' Impactos nos Grupos de Contas dos Ativos e Passivos ......... 153

Quadro 10 - Índices Financeiros do [Critério H] (desoneração do balanço) ........................... 160

Quadro 11 - Balanço da Corporação e Índices Financeiros - Situação Modelo (Capítulo 6)161

Quadro 12 - [alternativas] de não imobilização e impactos nos grupos de contas do balanço da corporação - Situação Modelo (Capítulo 6).......................................................... 162

Quadro 13 - [alternativa] - SP e impactos nos grupos de contas do balanço da corporação Situação Modelo (Capítulo 6)

Quadro 14 - [alternativa] - SP a Prazo e impactos nos grupos de contas do balanço da corporação - Situação Modelo (Capítulo 6)...

Quadro 15 - Pertinência das [alternativas] quanto ao atendimento aos critérios - Situação

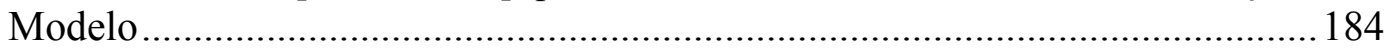

Quadro 16 - Ponderação de notas de atendimento para o [Critério G] - Imóvel 1................205

Quadro 17 - Ponderação de notas de atendimento para o [Critério H] - Imóvel 1 .................209

Quadro 18 - Ponderação de notas de atendimento para o [Critério I] - Imóvel 1 ..................211

Quadro 19 - Ponderação de notas de atendimento para o [Critério A] - Imóvel 1 ................213

Quadro 20 - Ponderação de notas de atendimento para o [Critério B] - Imóvel 1 ................214

Quadro 21 - Ponderação de notas de atendimento para o [Critério C] - Imóvel 1 ................215

Quadro 22 - Ponderação de notas de atendimento para o [Critério D] - Imóvel 1 ................216

Quadro 23 - Ponderação de notas de atendimento para o [Critério E] - Imóvel 1................. 217

Quadro 24 - Ponderação de notas de atendimento para o [Critério F] - Imóvel 1 ................. 218

Quadro 25 - Ponderação de notas de importância entre os critérios de decisão do [MAOI] atribuídas pelo decisor da empresa do caso para o Imóvel1 ...............................220

Quadro 26 - Pesos relativos das [alternativas] por critério de decisão do [MAOI] em cada imóvel da Empresa do Caso (Matrizes do Nível 3 do AHP) .................................2275

Quadro 27 - Pesos relativos dos critérios de decisão para cada imóvel da Empresa do Caso (Matriz do Nível 2 do AHP)

Quadro 28 - Hierarquização das [alternativas] para cada imóvel da Empresa do Caso (Resultado do AHP)

Quadro 29 - [alternativas] - BTS, LLP, LCP e impactos nos grupos de contas do balanço da

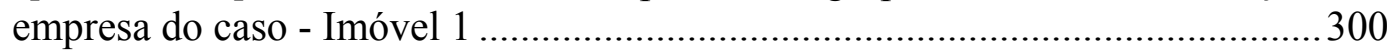

Quadro 30 - [alternativa] - SP e impactos nos grupos de contas do balanço da empresa do caso - Imóvel 1

Quadro 31 - [alternativa] -SP a Prazo e impactos nos grupos de contas do balanço da empresa do caso - Imóvel 1 
Quadro 32 - [alternativa] - SLB e impactos nos grupos de contas do balanço da empresa do caso - Imóvel 1

Quadro 33 - [alternativas] - BTS, LLP, LCP e impactos nos grupos de contas do balanço da empresa do caso - Imóvel 2

Quadro 34 - [alternativa] - SP e impactos nos grupos de contas do balanço da empresa do caso - Imóvel 2 .

Quadro 35 - [alternativa] -SP a Prazo e impactos nos grupos de contas do balanço da empresa do caso - Imóvel 2

Quadro 36 - [alternativa] - SLB e impactos nos grupos de contas do balanço da empresa do caso - Imóvel 2

Quadro 37 - [alternativas] - BTS, LLP, LCP e impactos nos grupos de contas do balanço da empresa do caso - Imóvel 3

Quadro 38 - [alternativa] - SP e impactos nos grupos de contas do balanço da empresa do caso - Imóvel 3

Quadro 39 - [alternativa] -SP a Prazo e impactos nos grupos de contas do balanço da empresa do caso - Imóvel 3.

Quadro 40 - [alternativa] - SLB e impactos nos grupos de contas do balanço da empresa do caso - Imóvel 3

Quadro 41 - [alternativas] - BTS, LLP, LCP e impactos nos grupos de contas do balanço da empresa do caso - Imóvel 4

Quadro 42 - [alternativa] - SP e impactos nos grupos de contas do balanço da empresa do caso - Imóvel 4

Quadro 43 - [alternativa] -SP a Prazo e impactos nos grupos de contas do balanço da empresa do caso - Imóvel 4

Quadro 44 - [alternativa] - SLB e impactos nos grupos de contas do balanço da empresa do caso - Imóvel 4 ......

Quadro 45 - [alternativas] - BTS, LLP, LCP e impactos nos grupos de contas do balanço da empresa do caso - Imóvel 5

Quadro 46 - [alternativa] - SP e impactos nos grupos de contas do balanço da empresa do caso - Imóvel 5

Quadro 47 - [alternativa] -SP a Prazo e impactos nos grupos de contas do balanço da empresa do caso - Imóvel 5.

Quadro 48 - [alternativa] - SLB e impactos nos grupos de contas do balanço da empresa do caso - Imóvel 5

Quadro 49 - [alternativas] - BTS, LLP, LCP e impactos nos grupos de contas do balanço da empresa do caso - Imóvel 6

Quadro 50 - [alternativa] - SP e impactos nos grupos de contas do balanço da empresa do caso - Imóvel 6

Quadro 51 - [alternativa] -SP a Prazo e impactos nos grupos de contas do balanço da empresa do caso - Imóvel 6.

Quadro 52 - [alternativa] - SLB e impactos nos grupos de contas do balanço da empresa do caso - Imóvel 6 


\section{LISTAS DE TABELAS}

Tabela 1 - Critérios de Decisão contemplados nos questionários e fatores influenciadores citados pelas corporações [CR] e empresas de real estate [ERE] ..........................65

Tabela 2 - Vantagens e Desvantagens - Propriedade dos Ativos Imobiliários .......................76

Tabela 3 - Vantagens e Desvantagens - Locação Simples de Curto Prazo (LCP) ................... 86

Tabela 4 - Vantagens e Desvantagens - Locação Simples de Longo Prazo (LLP)................... 86

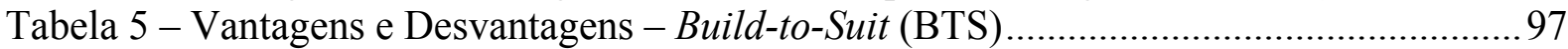

Tabela 6 - Vantagens e Desvantagens - Sale-Leaseback (SLB) ........................................ 104

Tabela 7 - [alternativas] ' $v s$ ' Atendimento aos critérios conforme contexto ......................... 105

Tabela 8 - Intervalos de Valor: VOI, Participação de VOI $_{n}$ e TIR (investidor) para o Cenário

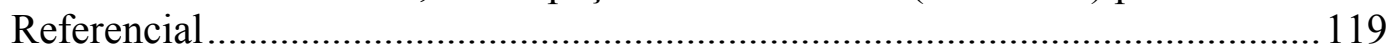

Tabela 9 - Intervalo de Valor para: VOI, Participação de VOI $_{n}$ e TIR (investidor) para Cenários Estressados .................................................................................... 121

Tabela 10 - Modalidade BTS - Intervalos de Valor para VOI, Participação de VOIn e TIR (investidor) - Situação Modelo (Capítulo 6) .......................................................... 133

Tabela 11 - Intervalos de valor dos indicadores: Renda Relativa do Capital de Giro Ativado (RRCGA) e Acréscimo do Resultado Corporativo (ARC), conforme cenário referencial, para as [alternativas] de não imobilização - Situação Modelo (Capítulo 6)

Tabela 12 - Intervalos de valor dos indicadores RRCGA e ARC para as [alternativas] de não imobilização nos cenários estressados com queda de desempenho no ROE da corporação- Situação Modelo (Capítulo 6).

Tabela 13 - Intervalos de valor dos indicadores: Renda Relativa na Imobilização a Prazo (RRIP), Acréscimo do Resultado Corporativo (ARC) e Taxa de Retorno da Imobilização a Prazo (TRIP), conforme cenário referencial, para a [alternativa]: SP a Prazo - Situação Modelo (Capítulo 6)

Tabela 14 - Testes de Cenários para a RRIP em função das condições do financiamento Situação Modelo (Capítulo 6)

Tabela 15 - Intervalos de valor dos indicadores: RRIP, ARC e TRIP, conforme cenários estressados, para a [alternativa]: SP a Prazo - Situação Modelo (Capítulo 6) .... 148

Tabela 16 - Impacto nos Índices Financeiros para as [alternativas] de não imobilização Situação Modelo (Capítulo 6).

Tabela 17 - Impacto nos Índices Financeiros para a [alternativa] - SP - Situação Modelo (Capítulo 6).

Tabela 18 - Impacto nos Índices Financeiros para [alternativa] - SP a Prazo - Situação Modelo (Capítulo 6).

Tabela 19 - Economias tributárias em cada exercício para cada uma das [alternativas] ....... 170

Tabela 20 - Economias tributárias resultantes ' $v s$ ' [alternativas] na análise para novos espaços corporativos

Tabela 21 - Economias tributárias resultantes ' $v s^{\prime}$ ' [alternativas] na análise de desmobilização patrimonial

Tabela 22 - Intervalos de valor dos indicadores: Economia Tributária da Despesa Operacional dedutível (ETDO), Economia Tributária da Depreciação (ETD) e Economia Tributária da Depreciação e Despesa Financeira (ETDDF) - Situação Modelo (Capítulo 6).

Tabela 23 - Decomposição da Decisão - Oportunidade de imobilização em imóveis corporativos

Tabela 24 - Escala de Notas - comparação entre [alternativas]: Nível 3 (adaptado de SAATY, 
1991) 178

Tabela 25 - Valores de Consistência Aleatória do AHP (em função da ordem da Matriz)... 179 Tabela 26 - Escala de Notas - priorização dos atributos: Nível 2 (adaptado de SAATY, 1991)

Tabela 27 - Descrição do contexto - Situação Modelo ......................................................... 181

Tabela 28 - Dados econômico-financeiros da empresa do caso .......................................... 190

Tabela 29 - Imóveis utilizados nas operações da empresa do caso ....................................... 192

Tabela 30 - Intervalos de Valor para VOI, Participação de VOI $_{n}$ e TIR - Imóvel 1 ............. 198

Tabela 31 - Dados do Imóvel 1 para cálculo das referências quantitativas do [MAOI]........ 198

Tabela 32 - Intervalos de Valor dos Indicadores RRCGA e ARC no Cenário Referencial -

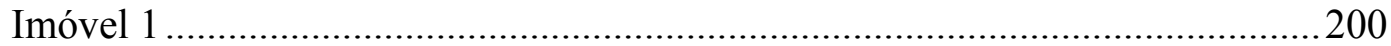

Tabela 33 - Intervalos de Valor dos Indicadores RRCGA e ARC nos Cenários Estressados -

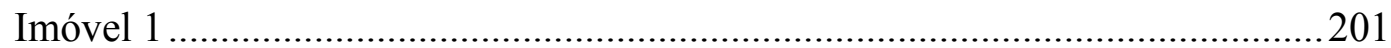

Tabela 34 - Intervalos de valos dos indicadores RRIP, TRIP e ARC no Cenário Referencial -

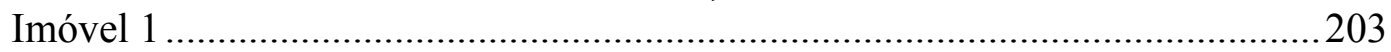

Tabela 35 - Intervalos de valos dos indicadores RRIP, TRIP e ARC nos Cenários Estressados

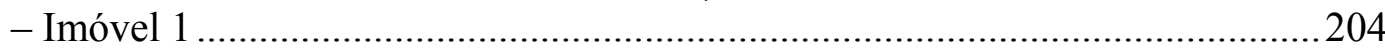

Tabela 36 - Testes de sensibilidade para a RRIP em função de variações nas condições do financiamento para aquisição do Imóvel 1 .......................................................204

Tabela 37 - Matriz de Comparação entre [alternativas] para o [Critério G] - Imóvel 1 .......205

Tabela 38 - Índices financeiros da empresa para análise do impacto das [alternativas] em relação ao Imóvel 1 (Análise a partir das demandas e características do imóvel)

Tabela 39 - Impactos nos índices financeiros do balanço para cada [alternativa] - Imóvel 1

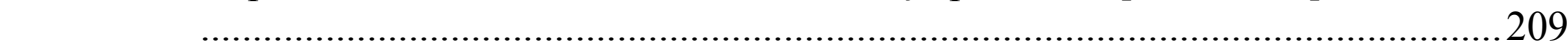

Tabela 40 - Intervalos de Valor dos Indicadores ETDO, ETD e ETDF - Imóvel 1 .............211

Tabela 41 - Pesos Relativos das [alternativas] para todos os critérios de decisão do [MAOI] -

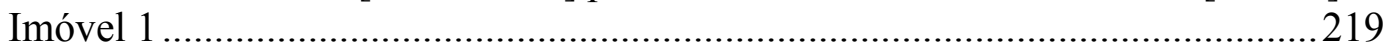

Tabela 42 - Matriz de comparação entre os critérios para o Imóvel 1 ..................................220

Tabela 43 - Quadro com resultado do AHP para o Imóvel 1...............................................221

Tabela 44 - Intervalos de Valor dos Indicadores RRCGA e ARC para a [alternativa] - SLB do

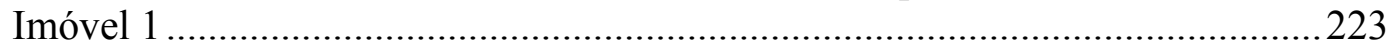

Tabela 45 - Intervalos de Valor dos Indicadores RRCGA e ARC para a [alternativa] - SLB do Imóvel 1 conforme Cenários Estressados........................................................... 223

Tabela 46 - Intervalos de Valor do Indicador Economia Tributária Efetiva da Despesa Operacional dedutível (ETEDO) para a [alternativa] - SLB do Imóvel 1 ...........224

Tabela 47 - Balanço e índices financeiros da empresa do caso, conforme situação atual (com base no balanço de dezembro de 2009) ...............................................................222

Tabela 48 - Índices financeiros para a [alternativa] - SLB do Imóvel 1 ................................225

Tabela 49 - Intervalos de valor para: VOI, Participação de VOI $_{n}$ e TIR - Imóvel 3............ 227

Tabela 50 - Dados do imóvel 3 para cálculo dos referências quantitativas do [MAOI]........227

Tabela 51 - Intervalos de Valor dos Indicadores RRCGA e ARC no Cenário Referencial -

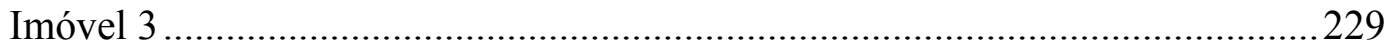

Tabela 52 - Intervalos de Valor dos Indicadores RRCGA e ARC nos Cenários Estressados Imóvel 3

Tabela 53 - Intervalos de Valor dos Indicadores RRIP, TRIP e ARC no Cenário Referencial -

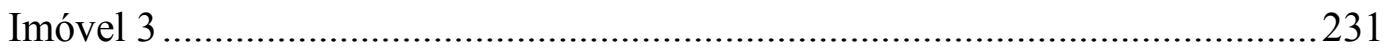

Tabela 54 - Intervalos de Valor dos Indicadores RRIP, TRIP e ARC nos Cenários Estressados - Imóvel 3

Tabela 55 - Testes de sensibilidade para a RRIP em função de variações nas condições do 
financiamento para aquisição do Imóvel 3

Tabela 56 - Índices financeiros da empresa para análise do impacto das [alternativas] em relação ao Imóvel 3 (Análise a partir das demandas e características do imóvel)

Tabela 57 - Impacto nos índices financeiros do balanço para cada [alternativa] - Imóvel 3234 Tabela 58 - Intervalos de Valor dos Indicadores ETDO, ETD e ETDF - Imóvel 3............235

Tabela 59 - Pesos Relativos das [alternativas] para todos os critérios de decisão do [MAOI] Imóvel 3

Tabela 60 - Quadro com resultado do AHP para o Imóvel 3

Tabela 61 - Intervalos de Valor dos Indicadores RRCGA e ARC para a [alternativa] - SLB do Imóvel 3

Tabela 62 - Intervalos de Valor dos Indicadores RRCGA e ARC para a [alternativa] - SLB do Imóvel 3 conforme Cenário Estressado

Tabela 63 - Índices financeiros para a [alternativa] - SLB do Imóvel 3

Tabela 64 - Intervalos de Valor do Indicador ETEDO para a [alternativa] - SLB do Imóvel 3

Tabela 65 - Intervalos de valor para: VOI, Participação de VOI ${ }_{n}$ e TIR - Imóvel 4

Tabela 66 - Dados do imóvel 4 para cálculo dos referências quantitativas do [MAOI]........246

Tabela 67 - Intervalos de Valor dos Indicadores RRCGA e ARC no Cenário Referencial Imóvel 4

Tabela 68 - Intervalos de Valor dos Indicadores RRCGA e ARC nos Cenários Estressados Imóvel 4

Tabela 69 - Intervalos de Valor dos Indicadores RRIP, TRIP e ARC no Cenário Referencial Imóvel 4

Tabela 70 - Intervalos de Valor dos Indicadores RRIP, TRIP e ARC nos Cenários Estressados - Imóvel 4

Tabela 71 - Testes de sensibilidade para a RRIP em função de variações nas condições do financiamento para aquisição do Imóvel 4

Tabela 72 - Índices financeiros da empresa para análise do impacto das [alternativas] em relação ao Imóvel 4 (Análise a partir das demandas e características do imóvel)

Tabela 73 - Impacto nos índices financeiros do balanço para cada [alternativa] - Imóvel 4255

Tabela 74 - Intervalos de Valor dos Indicadores ETDO, ETD e ETDF - Imóvel 4.............257

Tabela 75 - Pesos Relativos das [alternativas] para todos os critérios de decisão do [MAOI] Imóvel 4

Tabela 76 - Quadro com resultado do AHP para o Imóvel 4

Tabela 77 - Indicadores relacionados ao [Critério G] (canalizar recursos em oportunidades do negócio principal) para cada imóvel da Empresa do Caso conforme Cenário Referencial

Tabela 78 - Indicadores relacionados ao [Critério G] (canalizar recursos em oportunidades do negócio principal) para cada imóvel da Empresa do Caso conforme Cenários Estressados.

Tabela 79 - Indicadores relacionados ao [Critério J] (levantar capital de giro para investir em oportunidades do negócio principal) para cada imóvel da Empresa do Caso Análise da Desmobilização (SLB)

Tabela 80 - Indicadores relacionados ao [Critério H] (desoneração do balanço) para cada imóvel da Empresa do Caso .....

Tabela 81 - Indicadores relacionados ao [Critério H] (desoneração do balanço) para cada imóvel da Empresa do Caso - Análise da Desmobilização (SLB)....

Tabela 82 - Indicadores relacionados ao [Critério I] (redução dos impactos tributários) para 
cada imóvel da Empresa do Caso

273

Tabela 83 - Indicadores relacionados ao [Critério I] (redução dos impactos tributários) para

cada imóvel da Empresa do Caso - Análise da Desmobilização (SLB) 


\section{LISTAS DE ABREVIATURAS E SIGLAS}

\begin{tabular}{|c|c|}
\hline AHP & Analytic Hierarchy Process \\
\hline $\mathrm{ARC}$ & Acréscimo no Resultado Corporativo \\
\hline BACEN & Banco Central \\
\hline BNDES & Banco Nacional de Desenvolvimento Social \\
\hline BTS & [Alternativa] - Build-to-Suit \\
\hline CCGA & Custo do Capital de Giro Ativado \\
\hline CDI & Certificados de Depósitos Interbancários \\
\hline CGA & Capital de Giro Ativado \\
\hline CGL & Capital de Giro Líquido \\
\hline $\mathrm{CR}$ & Corporações Respondentes \\
\hline CRI & Certificado de Recebíveis Imobiliários \\
\hline CVM & Comissão de Valores Mobiliários \\
\hline DRS & Direito Real de Superfície \\
\hline ERE & Empresas de Real Estate Respondentes \\
\hline ETA & Economia Tributária da Amortização \\
\hline ETD & Economia Tributária da Depreciação (imobilização à vista) \\
\hline ETDDF & $\begin{array}{l}\text { Economia Tributária da Depreciação e Despesa Financeira } \\
\text { (imobilização a prazo) }\end{array}$ \\
\hline ETDO & Economia Tributária da Despesa Operacional dedutível \\
\hline ETEA & Economia Tributária Efetiva da Amortização (SLB) \\
\hline ETEDO & Economia Tributária Efetiva da Despesa Operacional dedutível (SLB) \\
\hline FII & Fundo de Investimento Imobiliário \\
\hline FRA & Fundo de Reposição de Ativos \\
\hline GIPL & Grau de Imobilização do Patrimônio Líquido \\
\hline IASB & International Accounting Standards Board \\
\hline IBGC & Instituto Brasileiro de Governança Corporativa \\
\hline IC & Índice de Inconsistência \\
\hline IFRS & International Financial Reporting Standards \\
\hline IGP-DI & Índice Geral de Preços - Disponibilidade Interna \\
\hline IGP-M & Índice Geral de Preços do Mercado \\
\hline ILC & Índice de Liquidez Corrente \\
\hline ILI & Índice de Liquidez Imediata \\
\hline IPCA & Índice Nacional de Preços ao Consumidor Amplo \\
\hline IR & Investimento em Reciclagem \\
\hline LCP & [Alternativa] - Locação simples de Curto Prazo \\
\hline LLP & [Alternativa] - Locação simples de Longo Prazo \\
\hline LS & Locação Simples \\
\hline MAOI & $\begin{array}{l}\text { Método para Análise da Oportunidade de Imobilização em Imóveis } \\
\text { Corporativos }\end{array}$ \\
\hline PECP & Índice de Participação do Exigível a Curto Prazo sobre o exigível total \\
\hline PIB & Produto Interno Bruto \\
\hline POGI & Perda da Oportunidade de Ganho na Imobilização \\
\hline PTPL & Índice de Participação de capital de Terceiros sobre o Patrimônio Líquido \\
\hline PTRT & Índice de Participação de capital de Terceiros sobre os Recursos Totais \\
\hline $\mathrm{RC}$ & Razão de Consistência \\
\hline RCGA & Renda do Capital de Giro Ativado \\
\hline RIR & Regulamento do Imposto de Renda \\
\hline
\end{tabular}


ROD Resultado Operacional Disponível

ROE Return On Equity = Resultado sobre Capital Investido

RRCGA Renda Relativa do Capital de Giro Ativado

RRIP Renda Relativa na Imobilização a Prazo

SAC Sistema de Amortização Constante

SELIC Sistema Especial de Liquidação e de Custódia

SLB [Alternativa]-Sale-Leaseback

SP

[Alternativa] - Ser Proprietário (imobilizar no ativo)

SP a Prazo [Alternativa] - Ser Proprietário (imobilizar no ativo por meio de financiamento)

SPE Sociedade de Propósito Específico

TAT Taxa de Atratividade

TATs Taxa de Atratividade Setorial

TIR Taxa Interna de Retorno

TJLP Taxa de Juros de Longo Prazo

TRIP Taxa de Retorno da Imobilização a Prazo

VOI Valor da Oportunidade de Investimento

WACC Custo Médio Ponderado de Capital 


\section{SUMÁRIO}

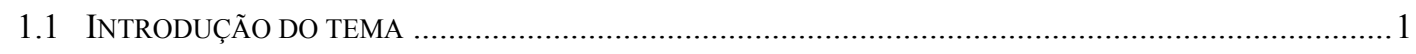

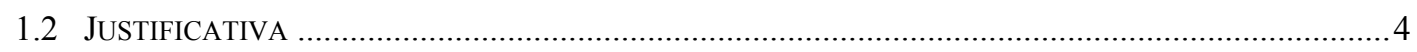

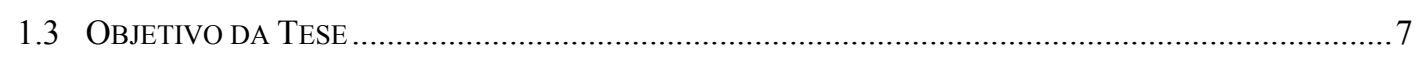

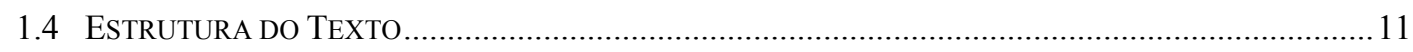

METODOLOGIA PARA CONFIGURAÇÃO DO MÉTODO.........................................................14

3.1 VISÃO GERAL

3.2 FATORES INFLUENCIADORES DA REESTRUTURAÇÃO DO REAL ESTATE CORPORATIVO - REALIDADE BRASILEIRA

3.2.1 Globalização e Novos Modelos de Gestão …………………………………………….....22

3.2.2 Inflação e Taxa de Juros da economia brasileira ................................................................2

3.2.3 Evolução das operações de crédito e a desintermediação financeira por meio da securitização como fator do amadurecimento do mercado imobiliário

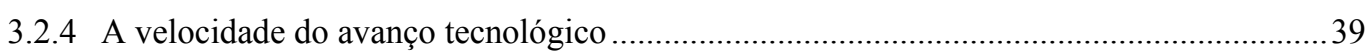

4.1 Fatores Macroeconômicos E dos Mercados de Real Estate na deCisão..........................45

4.1.1 Fatores Macroeconômicos ............................................................................................. 45

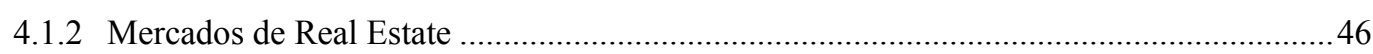

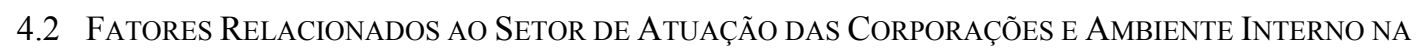

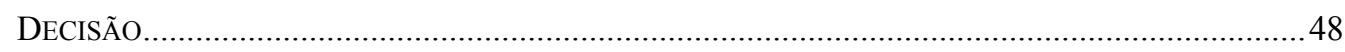

4.2.1 Dinâmica das mudanças no ambiente corporativo ............................................................4 49

4.2.2 Importância do imóvel para a operação da corporação .......................................................55

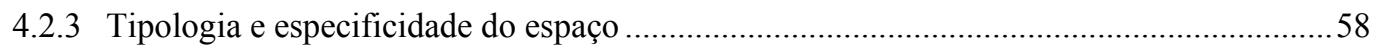

4.2.4 Importância da tradução da imagem corporativa por meio do imóvel ocupado ...................60

4.2.5 Fatores relacionados às estratégias e políticas de cada corporação ......................................62

4.3 COMPILAÇÃO DAS INFORMAÇÕES ADQUIRIDAS NAS ENTREVISTAS - IDENTIFICAÇÃO E VALIDAÇÃO DOS CRITÉRIOS E TIPO DE ESPAÇO CORPORATIVO ‘VS’ [ALTERNATIVAS].. . .64

5 ALTERNATIVAS DO [MAOI] E SUAS RESPECTIVAS PERTINÊNCIAS QUANTO AO ATENDIMENTO AOS CRITÉRIOS DE DECISÃO.............................................................70

5.1 PRopriedade dos Ativos ImobiliáRIOS........................................................................

5.1.1 Motivos da escolha pela propriedade dos ativos imobiliários ............................................ 71 
5.1.2 Impactos contábeis, financeiros e tributários quando proprietária do imóvel

5.1.3 Pertinência da opção pela propriedade do imóvel quanto ao atendimento aos critérios de decisão .74

5.2 LOCAÇÃO SimPleS - CURTO E LONGO PRAZO 76

5.2.1 Pertinências da locação simples - Principais regras jurídicas da lei de locação urbana relevantes à decisão. .77

5.2.2 Impactos contábeis, financeiros e tributários quando locatária do imóvel .......................83

5.2.3 Motivos da escolha pela Locação Simples de Curto e Longo Prazo ...................................84

5.3 OPERAÇÕES ESTRUTURADAS - BUILD-TO-SUIT E SALE-LEASEBACK ......................................... 87

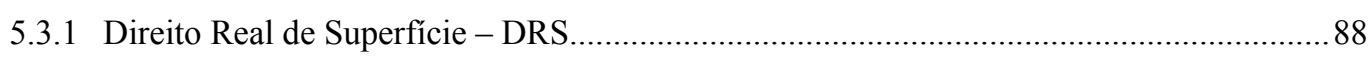

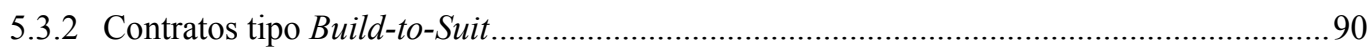

5.3.3 O Sale-Leaseback - SLB como mecanismo para desmobilização patrimonial imobiliária 97

5.4 COMPILAÇÃO DA ANÁLISE DA PERTINÊNCIA DAS [ALTERNATIVAS] QUANTO AO ATENDIMENTO AOS CRITÉRIOS DE DECISÃO DO [MAOI] 104

6.1 VALOR DO IMÓVEL - DOUTRINAS E CONCEITOS 111

6.1.1 Valor do Imóvel no Conceito de Valor da Oportunidade do Investimento (VOI)............ 112

6.1.2 Valor de Transação do imóvel........

6.1.3 Valor Contábil do Ativo Imobiliário 122

6.2 ANÁLISE QUANTITATIVA DOS INDICADORES RELACIONADOS AO CRITÉRIO - CANALIZAÇÃO DE RECURSOS NO NEGÓCIO PRINCIPAL [CRITÉRIO G] E AO CRITÉRIO - LEVANTAR CAPITAL DE GIRO COM A DESMOBILIZAÇÃO PATRIMONIAL IMOBILIÁRIA [CRITÉRIO J] . 128

6.2.1 Custo do Capital de Giro Ativado - CCGA 129

6.2.2 Renda do Capital de Giro Ativado - RCGA 134

6.2.3 Avaliação da RCGA 'vs' CCGA - Indicadores das [alternativas] de não imobilização para o [Critério G] e [Critério J] (RRCGA e ARC) 135

6.2.4 Perda de Oportunidade de Ganho na Imobilização à vista - POGI e Renda Relativa na Imobilização a Prazo - RRIP 140

6.3 ANÁLISE QUANTITATIVA DOS INDICADORES RELACIONADOS AO CRITÉRIO - DESONERAÇÃO DO BALANÇO [CRITÉRIO H] . 148

6.3.1 Ativos e Passivos de uma corporação. 150

6.3.2 Impacto das [alternativas] nos grupos de contas do balanço 152

6.3.3 Índice de Liquidez, Endividamento, Grau de Imobilização e Capital de Giro Líquido (CGL)

6.4 ANÁLISE QUANTITATIVA DOS INDICADORES RELACIONADOS AO CRITÉRIO - REDUÇÃO DOS IMPACTOS TRIBUTÁRIOS [CRITÉRIO I]

7 FERRAMENTA DE APOIO À DECISÃO - PRIORIZAÇÃO DOS CRITÉRIOS POR PARTE DOS DECISORES .174

7.1 FERRAMENTA DE APOIO À DECISÃo - ANALYTIC HIERARCHY PROCESS (AHP) 
7.2 SimUlaÇ̃̃o DA SITUAÇÃO MODELO - FERRAMENTA AHP PARA APOIO À DECISÃO A PARTIR DA PRIORIZAÇÃO DOS CRITÉRIOS PELOS DECISORES................................................................... 180

8.1 SOBRE A EMPRESA DO CASO. 189

8.2 IMÓVEIS UTILIZADOS NAS OPERAÇÕES DA EMPRESA DO CASO... 191

8.3 ROTINA PARA APLICAÇÃO DO [MAOI] NA EMPRESA DO CASO 193

8.4 APLICAÇÃO DO [MAOI] PARA O IMÓVEL 1 (SEDE ADMINISTRATIVA).............................. 196

8.4.1 Referências Quantitativas do [MAOI] para o Imóvel 1. 199

8.4.2 Referências Qualitativas do [MAOI] para o Imóvel 1 212

8.4.3 Pesos relativos das [alternativas] para cada critério - Matrizes Nível 3 do AHP para o Imóvel 1 218

8.4.4 Priorização dos critérios - Matriz Nível 2 do AHP para o Imóvel 1 219

8.4.5 Resultado AHP - [alternativa] Indicada pelo [MAOI] para o Imóvel 1 221

8.4.6 Análise Comparativa da Situação Atual 'vs' [alternativa] Indicada pelo [MAOI]: Imóvel 1222

8.5 APLICAÇÃo DO [MAOI] PARA O IMÓVEL 3 (LABORATÓRIO E ARMAZENAGEM) ............226

8.5.1 Referências Quantitativas do [MAOI] para o Imóvel 3 ...............................................228

8.5.2 Referências Qualitativas do [MAOI] para o Imóvel 3 ................................................2236

8.5.3 Pesos relativos das [alternativas] para cada critério - Matrizes Nível 3 do AHP para o Imóvel 3 239

8.5.4 Priorização dos critérios - Matriz Nível 2 do AHP para o Imóvel 3 239

8.5.5 Resultado AHP - [alternativa] Indicada pelo [MAOI] para Imóvel 3 240

8.5.6 Análise Comparativa da Situação Atual ' $v s$ ' [alternativa] Indicada pelo [MAOI]: Imóvel 3241

8.6 APLICAÇÃO DO [MAOI] PARA O IMÓVEL 4 (COMPLEXO INDUSTRIAL) 244

8.6.1 Referências Quantitativas do [MAOI] para o Imóvel 4..... 247

8.6.2 Referências Qualitativas do [MAOI] para o Imóvel 4. .257

8.6.3 Pesos relativos das [alternativas] para cada critério - Matrizes Nível 3 do AHP para o Imóvel 4 260

8.6.4 Priorização dos critérios - Matriz Nível 2 do AHP para o Imóvel 4 261

8.6.5 Resultado AHP - [alternativa] Indicada pelo [MAOI] para Imóvel 4 262

8.7 RESUltados PARCIAIS E FINAIS DA APLICAÇÃO DO [MAOI] PARA O PORTFOLIO DE REAL EsTATE DA EMPRESA DO CASO.

APÊNDICE A - LEVANTAMENTO DE CAMPO: QUESTIONÁRIOS DAS ENTREVISTAS....291

APÊNDICE B - IMPACTO NOS GRUPOS DE CONTAS DO BALANÇO DA EMPRESA DO CASO ' $V S$ ' [ALTERNATIVAS] PARA CADA IMÓVEL DO PORTFOLIO .300 


\section{INTRODUÇÃO}

\subsection{Introdução do tema}

Com a expansão dos negócios das corporações nas primeiras décadas do século XX (pósRevolução Industrial), surgiam novas necessidades por espaços corporativos. A partir de então, um novo corpo de assessoria nas empresas começou a surgir como agente responsável pelo real estate e gerenciamento de facilidades. Ainda nos anos 60, muitas organizações focavam suas atividades de real estate para construção de novas acomodações. Com o foco das corporações em crescer ainda mais, tornava-se necessária a utilização dos recursos disponíveis nas atividades principais das empresas. Assim, a demanda por espaços alugados aumentou e impulsionou o profissionalismo dos mercados de real estate.

Novas tecnologias empresariais surgiram com o processo de globalização, e os diferentes setores econômicos apresentaram um padrão de competitividade crescente. Isto resultou no aumento dos custos para realização das atividades empresariais, o que obrigou as empresas a se reestruturarem, principalmente a partir da década de 80 , buscando a redução nos seus custos para se manterem competitivas no mercado.

A partir da maturidade dos negócios e o maior profissionalismo nos diversos setores, o uso de capital - em qualquer investimento - tem sido associado a três fatores principais: rentabilidade, período de imobilização e risco do investimento. De modo geral, investidores mais avessos ao risco recebem menor rentabilidade em relação ao investimento e em período maior de imobilização, enquanto investidores mais agressivos esperam obter maior rentabilidade e maior liquidez nos seus investimentos.

Considerando o investimento em real estate e os fundos de pensão como exemplo de um dos grandes investidores desse mercado, percebe-se que esse investimento, por ser de baixo risco, mesmo proporcionando menor rentabilidade e período longo de imobilização, agrega características que se moldam à necessidade desse investidor, em razão do compromisso de longo prazo com os beneficiários. Em contrapartida, o investimento de capital dentro de uma corporação não possui essas características - o capital investido é usado para gerar melhores resultados a partir de investimentos no negócio principal da empresa (que não é real estate).

Levando em conta essa percepção, o que vem ocorrendo de forma mais judiciosa e com mais 
frequência são transações (mesmo que indiretas ${ }^{1}$ ) entre investidores mais agressivos e menos agressivos, cada qual com suas expectativas.

Esse equilíbrio entre o que cada investidor almeja em relação às características de um investimento é o que tem permitido melhores soluções para que empresas não imobilizem seu capital em ativos imobiliários. Evidencia-se também nas empresas brasileiras mudanças nas suas estruturas de capital, envolvendo inclusive o recurso real estate, nas quais as corporações estão saindo da posição de proprietária e passando a pagar pelo uso dos espaços. Isto possibilita direcionar o capital para o negócio principal e, ao mesmo tempo, permite que investidores interessados nas características oferecidas pelo investimento em real estate (caso dos investidores institucionais, por exemplo) passem a investir em ativos imobiliários.

Quando a empresa identifica uma necessidade por mais espaço, o que implica na compra ou locação de novas propriedades, ou uma necessidade por aumento de capital de giro, obtido pela desmobilização patrimonial imobiliária, é necessária uma investigação criteriosa baseada em aspectos qualitativos e quantitativos para a tomada de decisão, visto que o volume de recursos financeiros envolvidos nesse tipo de transação é significativo, além de tratar-se de um ativo que, para a corporação, pode ser um recurso operacional estratégico.

Qualquer que seja a alternativa a ser avaliada (Compra, Locação Simples, Build-to-Suit ${ }^{2}$ e Sale-Leaseback ${ }^{3}$ ) é necessário considerar as estratégias corporativas da organização durante as análises, ou seja, as decisões devem ser alinhadas com os objetivos de curto, médio e longo prazo da corporação (objetivos esses que impactam nas necessidades e características dos

1 Por exemplo, por meio de instrumentos de investimentos como os Certificados de Recebíveis Imobiliários (CRI) e as Quotas dos Fundos de Investimento Imobiliário (FII).

2 A operação de Build-to-Suit (BTS) engloba a construção do imóvel feito sob encomenda para uso específico de certa corporação (futura locatária do imóvel), em conjunto com um contrato de locação de longo prazo. O empreendedor concebe o imóvel com as especificações técnicas e de localização para atender as necessidades da corporação, que fica como locatária, se comprometendo a honrar com os aluguéis firmados no contrato de longo prazo. Também se observa a utilização do termo 'built-to-suit', que significa: imóvel 'construído sob encomenda'. Neste trabalho optou-se por utilizar o termo build-to-suit, que se refere mais especificamente à operação, abreviado no decorrer do texto pela sigla BTS.

3 Sale-Leaseback (SLB) significa a venda de uma propriedade da corporação seguida de um contrato de locação da mesma, em geral de longo prazo. Esse termo é conhecido e já observado em contratos firmados por algumas corporações no Brasil. Porém, é importante ressaltar que o termo SaleLeaseback usado neste texto, assim como, usualmente conhecido no mercado imobiliário brasileiro, refere-se, única e exclusivamente, a desmobilização patrimonial imobiliária, não tendo nenhuma relação com operações de leasing imobiliário, que são pouco usadas no Brasil, tampouco no âmbito internacional. 
espaços a serem usados). Esse alinhamento permite que decisões não sejam tomadas apenas sob a ótica econômico-financeira, mas também sob a ótica da operação, que implica em considerar aspectos qualitativos relacionados ao uso do espaço, também importantes às decisões.

Em muitos casos, é possível desmobilizar o investimento no ativo imobiliário e concentrar o valor do imóvel em investimentos relacionados ao negócio principal. Mecanismos recentes para desmobilização ${ }^{4}$ de propriedades e aumento de capital de giro vêm sendo usados por corporações no Brasil, os quais são principalmente observados a partir da década de $2000^{5}$.

Isso possibilita que as corporações alavanquem o capital, antes imobilizado nas propriedades, nas taxas alcançadas no negócio principal da empresa. O resultado disso é o melhor desempenho global das corporações, que acaba por refletir nas suas margens e preços dos produtos (ou serviços), e por consequência, nos seus padrões de competitividade frente aos mercados alvos.

A Figura 1 ilustra as possíveis ações praticadas no âmbito do gerenciamento do real estate corporativo, comparando os potenciais de ganho em razão de melhorias do nível tático ao estratégico dentro das corporações. A análise da oportunidade de imobilização em imóveis corporativos (conforme Figura 1) configura-se como uma das ações no nível estratégico, sendo uma das tarefas executadas nas - Estratégias no Portfolio -, a qual promove benefícios financeiros mais significativos dentre as outras ações apresentadas, contudo, demanda planejamento de longo prazo.

A identificação dos fatores qualitativos, quantitativos (indicadores econômico-financeiros) e riscos envolvidos pertinentes à escolha pela imobilização ou não nos imóveis utilizados na operação pode ser uma das diretrizes à governança corporativa para decisões em relação ao portfolio de real estate das corporações.

4 Desmobilização de propriedades, no contexto deste trabalho, significa que a corporação sai da posição de proprietária do imóvel que ocupa, porém, continua a ocupá-lo como locatária (não há redução do espaço usado na operação).

5 Contudo, até o momento, raros são os estudos que sustentam tecnicamente essas transações sob a ótica das corporações usuárias dos imóveis. 

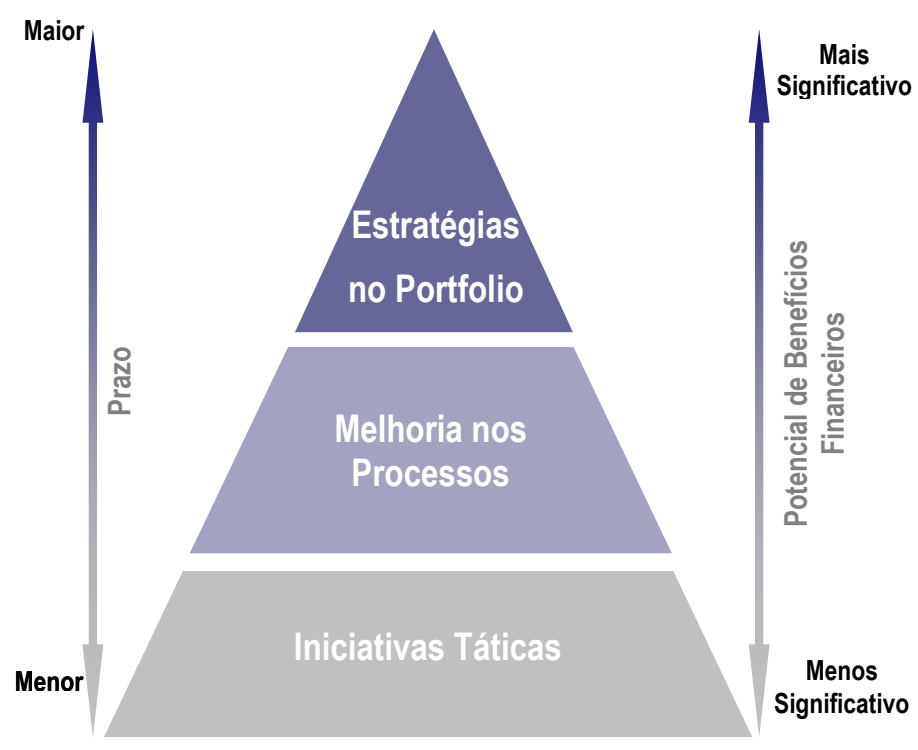

- Estratégias no Portfolio e Desenho Organizacional:

As estratégias em relação ao Portfolio envolvem as análises qualitativa, quantitativa, de localização e estruturação financeira para cada ativo imobiliário do Portfolio das corporações. Desenho Organizacional referese à análise sistêmica para integração das diversas áreas da corporação;

- Melhorias no Processo:

Refere-se às auditorias de custo de construção, terceirização de funções executadas pelo gerenciamento do real estate interno da organização, centralização das informações, entre outras;

- Iniciativas Táticas:

Trata-se das medidas reativas e de curto prazo, como otimização dos espaços, venda de propriedades excedentes, entre outras.

Figura 1 - Níveis táticos a estratégicos para redução de custos nas corporações - adaptado de La Salle, 2003 $\left(\right.$ CREIS $\left.^{6}\right)$

\subsection{Justificativa}

No Brasil nota-se que algumas corporações, embora ainda poucas se comparadas a outros países, estão adotando alternativas para ocupar espaços corporativos sem a necessidade de imobilizar investimento nesse ativo, a exemplo das instituições financeiras que promoveram no início da década de 2000 as transações de SLB (tais como: Banco do Brasil, HSBC, Caixa Econômica, Bradesco). Nessas transações houve a venda direta dos imóveis ao mercado, a securitização $^{7}$ dos CRI ou a venda de quotas dos imóveis transacionados em FII. A partir desses instrumentos, investidores interessados nas características que um investimento em real estate oferece, passam a fazer parte da transação.

Não só as instituições financeiras estão optando por técnicas mais eficientes para acomodação das suas atividades operacionais e aproveitando oportunidades para alavancar seus recursos em operações mais rentáveis relacionadas ao negócio principal. Também no início da década

${ }^{6}$ CREIS - Corporate Real Estate Impact Survey de dezembro de 2003. Trata-se de um levantamento da Jones Lang LaSalle em 96 organizações internacionais, sendo $60 \%$ das respondentes do setor de serviço (predominantemente instituições financeiras) e $40 \%$ do setor produtivo.

7 Securitização significa associar a um ativo um título (security), que circula no mercado, ficando o ativo rigidamente ancorado num ambiente próprio (no Brasil, em uma Sociedade de Propósito Exclusivo (SPE) ou em um FII). 
de 2000, empresas de manufatura, como a Basf (com o SLB, vendeu sua sede administrativa e passou a ser locatária da propriedade) e a Volkswagen (optou pelo BTS de um novo parque industrial, firmando contrato de locação de longo prazo) - de recursos energéticos - como a Petrobrás (optou pelo BTS para ocupar uma nova sede administrativa) - entre outras, adotaram alternativas para acomodar suas atividades sem a necessidade de investir no recurso real estate.

No Brasil, nota-se que essa tendência por desmobilizar ou não imobilizar capital nos novos imóveis demandados, começou a ser verificada, com mais frequência, no final da década de 90. Em contrapartida, em países desenvolvidos, como nos EUA, essa é uma tendência observada desde meados dos anos 80 .

Pesquisa realizada pela Jones Lang LaSalle ${ }^{8}$ constatou, também em países emergentes, informações relevantes sobre as tendências de investimentos em relação aos imóveis corporativos. No Gráfico 1, verificam-se as porcentagens dos espaços corporativos totais que são de propriedade das corporações na amostra analisada para a situação em setembro de 2005 e nos três anos adiante. Na data da pesquisa (2005), apenas 15\% das corporações respondentes eram proprietárias de mais de 50\% dos espaços usados na operação. Não obstante, aproximadamente $43 \%$ das respondentes não eram proprietárias de nenhum dos ativos imobiliários. Pode-se ainda observar que a situação não se alteraria significativamente para os três anos adiante da data da pesquisa. Entretanto, aquelas que possuíam entre $25 \%$ a $50 \%$ e entre $10 \%$ a $25 \%$ dos espaços corporativos apontaram o interesse em reduzir, ainda mais, seus ativos imobiliários.

8 CREIS - Corporate Real Estate Impact Survey de setembro de 2005. Trata-se de um levantamento da Jones Lang LaSalle em 70 organizações de países do Sudeste Asiático, sendo 58\% dos respondentes do setor de serviço, $30 \%$ do setor produtivo e $12 \%$ outros (inclusive do setor público). 


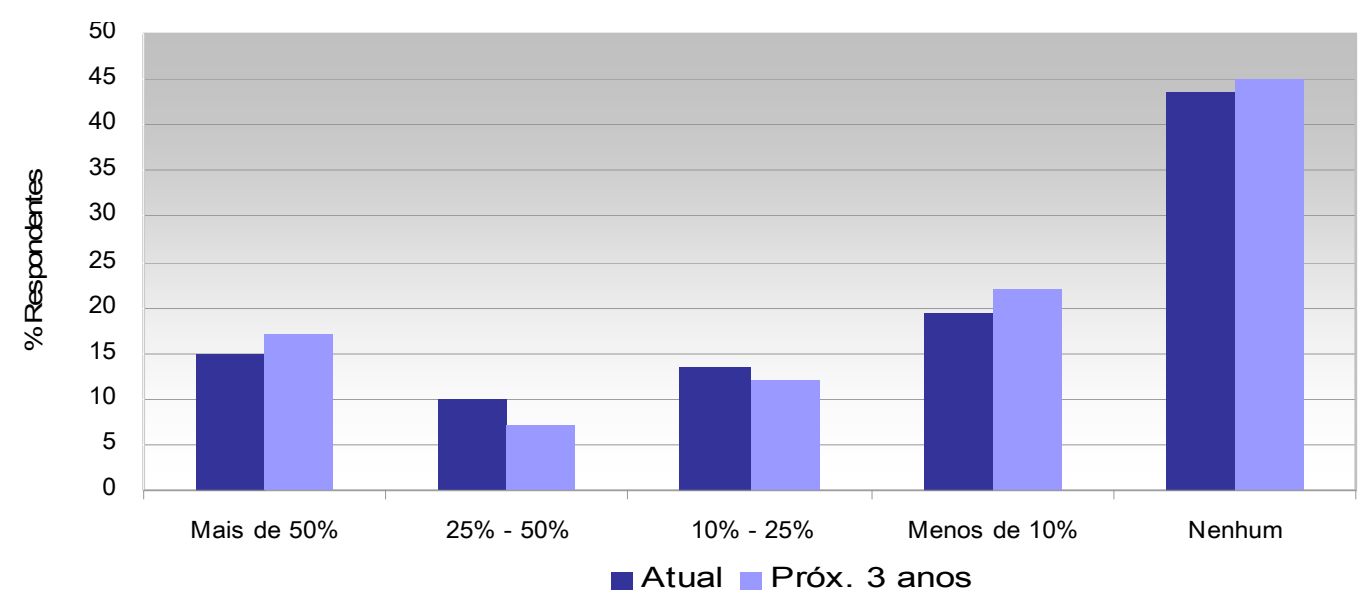

Gráfico 1 - Porcentagens das Corporações em relação às porcentagens de propriedade dos espaços corporativos - LaSalle, 2005

As estratégias em relação à imobilização e desmobilização nos imóveis usadas por essas corporações estão apresentadas no Gráfico 2. Nota-se que 40\% das corporações respondentes utilizaram o mecanismo de SLB nos anos passados (2005, 2004 e 2003) para desmobilização patrimonial imobiliária. As outras estratégias demonstradas são para financiar a compra de novos espaços e para a venda dos espaços excedentes ${ }^{9}$.

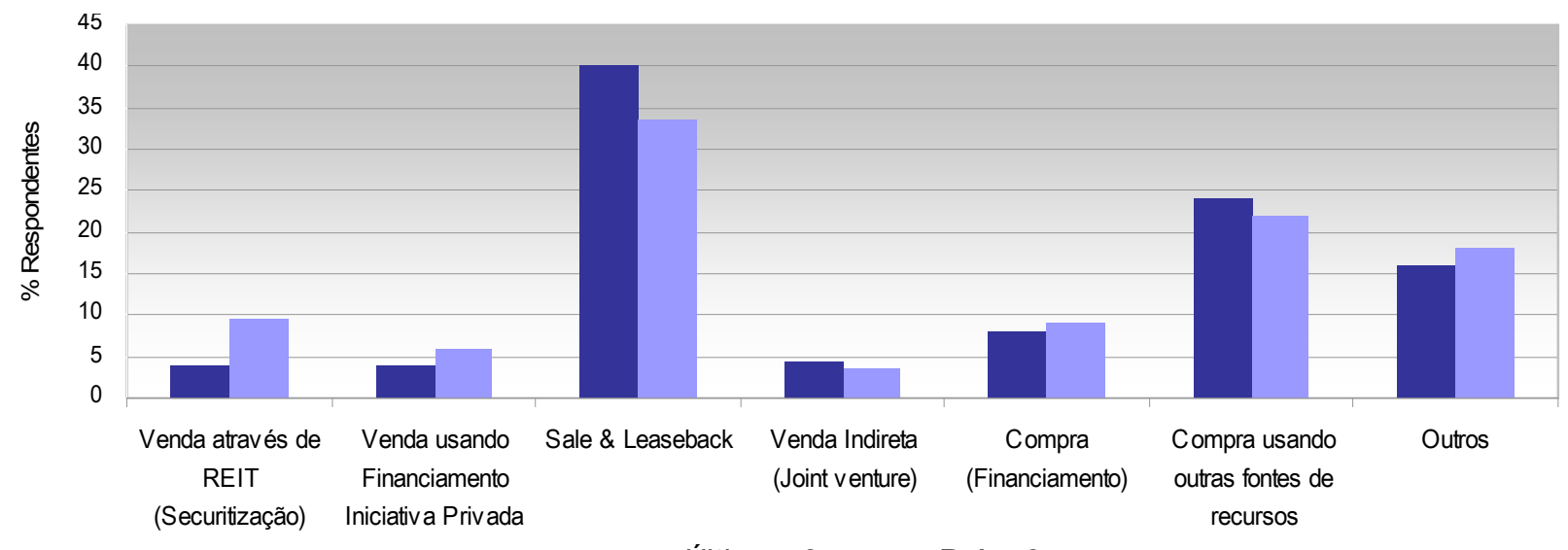

- Últimos 3 anos

Gráfico 2 - Porcentagem de corporações da amostra analisada em relação às estratégias de imobilização e desmobilização dos espaços corporativos- LaSalle , 2005

9 Observa-se no Brasil, principalmente em contratos de locação de longo prazo (SLB ou BTS), a presença da securitização dos recebíveis imobiliários lastreados no imóvel transacionado ou no contrato de locação do mesmo. Essa securitização é fonte relevante ao equacionamento de fundos necessários à implantação ou aquisição dos imóveis corporativos. 
Como ora mencionado, a pesquisa apresentada tem como amostra corporações do sudeste asiático, região com características socioeconômicas bastante distintas da realidade brasileira. No entanto, já é possível observar a quantidade de empresas que adotaram recentemente a estratégia de SLB e que tem optado pela locação dos imóveis. No Brasil, até o momento (2010), não se encontra pesquisa com intuito de identificar as estratégias das corporações brasileiras em relação ao real estate demandado nas operações. No entanto, evidencia-se a partir do início da década de 2000 o aumento de transações de SLB e BTS no Brasil.

Embora estudos sobre imobilizar e desmobilizar investimento em imóveis corporativos tenha sido foco de pesquisas na Europa e nos EUA, poucas produções científicas foram observadas no Brasil. Por outro lado, há uma tendência nas corporações brasileiras, tanto a desmobilização dos ativos imobiliários, como uma maior preocupação nas novas aquisições, que torna relevante a investigação do tema considerando o cenário brasileiro. $\mathrm{O}$ uso direto de metodologias aplicadas em outros países é inviável, visto que o Brasil possui suas peculiaridades em relação às formas de transações dos contratos, garantias necessárias, riscos envolvidos, entre outras. Essas particularidades impactam nos aspectos qualitativos e quantitativos relevantes à escolha das alternativas de imobilização ou não no real estate corporativo.

\subsection{Objetivo da Tese}

Antes de qualquer decisão em relação à compra, locação, venda, ou desmobilização patrimonial dos imóveis de uma corporação é oportuno conhecer a importância relativa do real estate para a operação como ativo que impacta aspectos financeiros, de mercado e organizacionais das corporações (O’MARA, 2000). Conforme POTTINGER et al. (2002), o nível de flexibilidade e os tipos de espaços podem variar para uma mesma corporação. Assim, para cada espaço utilizado na operação as necessidades estratégicas e operacionais são, obrigatoriamente, parte da decisão pela imobilização ou não no real estate corporativo.

Sendo assim, o objetivo geral da tese é configurar um método para análise da oportunidade de imobilização e desmobilização em imóveis corporativos, sob a ótica das corporações usuárias dos imóveis, considerando, portanto, a importância do ativo imobiliário como recurso operacional e o contexto brasileiro no que diz respeito a essa decisão, que inclui tanto aspectos legais, práticas contábeis, tributárias, como também, as práticas prevalentes de mercado (negociações entre investidores e as corporações usuárias dos imóveis). 
Conforme ilustrado na Figura 2 a decisão pela imobilização ou não no real estate corporativo ocorre em duas situações:

[i] na análise quando há necessidade por novos espaços corporativos, na qual se avalia a oportunidade de imobilizar no ativo (SP) ou não, sendo as possíveis [alternativas] de não imobilização: a locação simples de curto prazo - LCP, a locação simples de longo prazo LLP ou o BTS; e,

[ii] na análise de desmobilização patrimonial imobiliária, como mecanismo para levantar capital de giro e reorganizar o perfil de endividamento da corporação, na qual se avalia a oportunidade em optar pelo SLB ou não, ou seja, continuar proprietária - SP do ativo ${ }^{10}$.

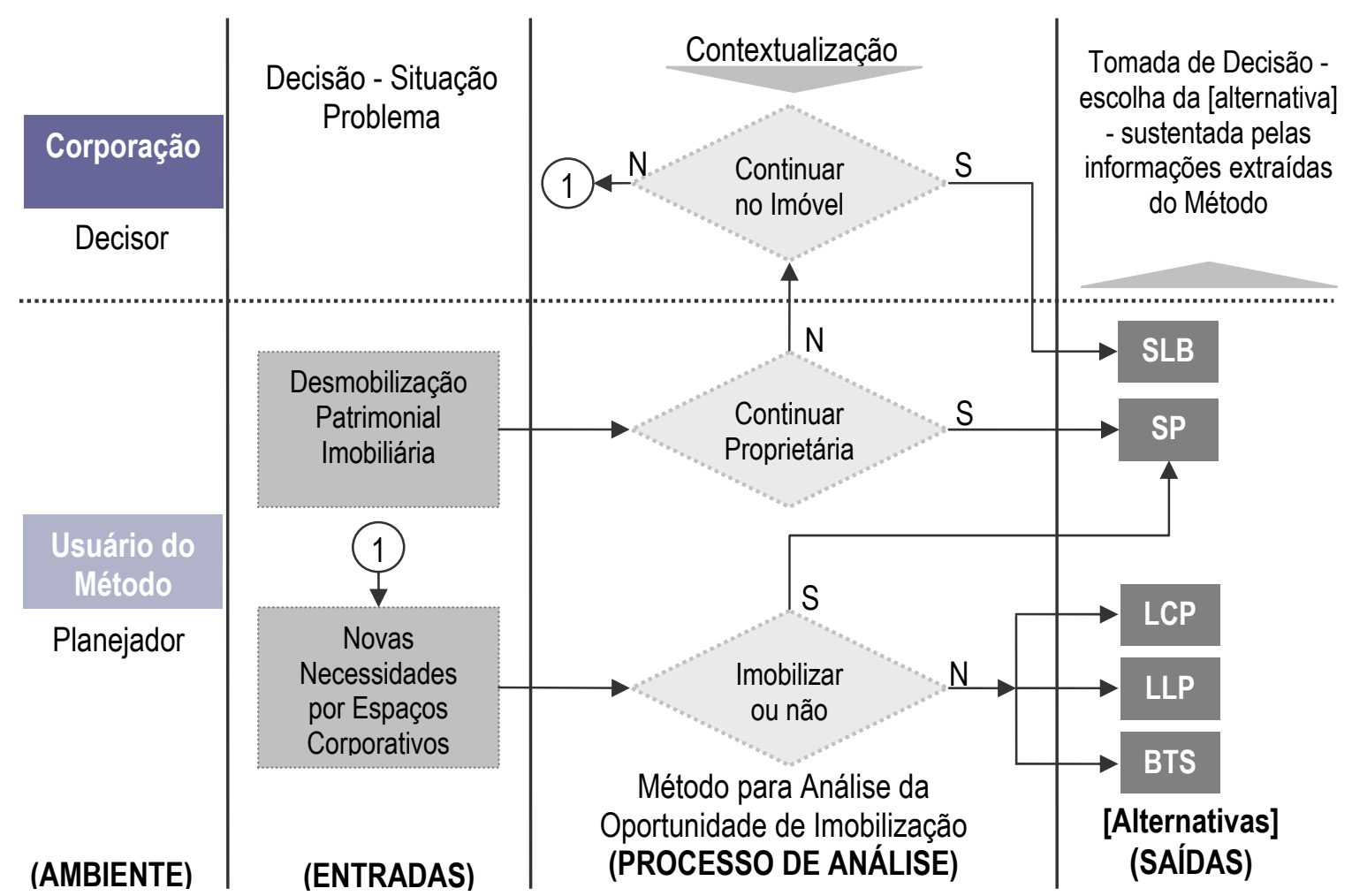

Figura 2 - Objetivo da Tese

Em ambas as situações de análise da oportunidade pela imobilização ou não no real estate

10 Cabe à corporação avaliar se o imóvel atenderá suas necessidades futuras. Caso o imóvel não mais atenda a demanda operacional, recai-se na situação da decisão pela [alternativa] mais apropriada para um novo espaço, na qual se avalia as [alternativas]: SP, BTS, LCP ou LLP. 
corporativo (entradas), o método desenvolvido na tese (processo de análise) tem como finalidade sustentar a decisão pela [alternativa] mais adequada (saídas) para acomodação das atividades da corporação, tendo em vista as necessidades operacionais em relação ao espaço, a importância estratégica do ativo à operação e as estratégias de investimento e políticas da corporação na decisão (contextualização - informações extraídas do ambiente corporativo).

Para tanto, o método contempla critérios (ou atributos) de decisão, qualitativos e quantitativos, relevantes à escolha entre as [alternativas]. Como cada uma das [alternativas] atende diferentemente aos atributos, a consideração destes na análise para a escolha da [alternativa] mais apropriada é que garante o alinhamento do recurso real estate com as necessidades operacionais e os objetivos estratégicos das corporações.

Os critérios qualitativos, não mensuráveis, são relevantes para o atendimento das necessidades operacionais durante o uso do espaço corporativo, tais como; flexibilidade de mudança, tradução da imagem corporativa, entre outros, abordados no decorrer do Capitulo 4. Dos critérios quantitativos, resultam os indicadores que auxiliam a decisão do ponto de vista econômico-financeiro, os quais são relevantes para o atendimento das estratégias de investimento e políticas da corporação, tais como: Renda Relativa do Capital de Giro Ativado [RRCGA], Acréscimo no Resultado Corporativo [ARC], índices de liquidez da corporação, entre outros ${ }^{11}$.

Para a elaboração do método, objetivo geral da tese, um conjunto de objetivos específicos (respostas preliminares) faz-se necessário:

- Identificação das características relacionadas a cada uma das [alternativas] de uso do espaço, considerando a realidade brasileira no mercado de locações comerciais, tais como: garantias necessárias, benefícios e carências em função dos prazos de locação, formas de mitigar riscos e ganhar maior flexibilidade nos contratos, multas rescisórias, direito de sublocação, entre outras ${ }^{12}$;

- Identificar as diferentes necessidades das corporações em relação ao uso do espaço corporativo para alinhamento com os objetivos estratégicos;

- Identificar os possíveis fatores que influenciam os preços de aluguel, como prazos de

11 A definição desses indicadores, assim como dos conceitos e doutrinas proeminentes a esses, é conteúdo abordado no Capítulo 6.

12 Não é foco desta pesquisa estudar formas inovadoras para estruturação de contratos, mas sim identificar as formas mais comuns em cada [alternativa], observadas em transações já feitas no Brasil. 
locação, grau de customização do imóvel, entre outros;

- Identificar a influência dos mercados de real estate: relação de oferta e demanda de espaços corporativos, preços de aluguel praticados no mercado dependendo do tipo, localização e qualidade do imóvel;

- Influência da necessidade de flexibilidade de mudança na decisão;

- Influência da necessidade de controle operacional durante o uso do espaço;

- Influência do grau de customização do espaço corporativo na escolha (que restringe o uso do imóvel para uma particular corporação).

Essas são algumas das respostas preliminares necessárias para configurar o método. Depois de formatado o método - que inclui a identificação dos atributos, a análise da pertinência de cada uma das [alternativas] quanto ao atendimento a esses atributos, e a formatação de um modelo de simulação, de onde são extraídos os indicadores econômico-financeiros - também faz parte do propósito da tese, a aplicação do método em um caso explanatório (neste texto: “o caso") para validar a qualidade das informações geradas pelo uso do método desenvolvido.

Essa aplicação do caso tem como propósito avaliar as [alternativas] mais pertinentes quanto à imobilização ou não do real estate utilizado nas operações da corporação objeto de análise, a depender das características do portfolio de real estate, das suas necessidades operacionais, estratégias de investimento e políticas corporativas. O caso permite avaliar a qualidade do método e discutir com visão crítica, através das respostas extraídas, as decisões tomadas pela corporação.

Não é objetivo do método a definição da melhor [alternativa] para cada tipo de espaço corporativo, uma vez que isso sugere validar uma amostra capaz de representar o comumente observado no âmbito empresarial. Essa amostra dificilmente é validada para todas as situações de análise, pois mesmo para um mesmo tipo de espaço corporativo, as necessidades a serem atendidas são distintas para cada corporação. Assim, o método desenvolvido avalia, para cada caso em particular, qual a [alternativa] mais adequada para acomodação das atividades operacionais da corporação, nos diferentes espaços corporativos utilizados, em função das necessidades operacionais e estratégicas de uma dada corporação.

Além disso, cabe destacar que a aplicabilidade do método não necessariamente é feita a partir de já definido o imóvel que está sendo analisado, mas sim, qual seria a melhor [alternativa] para aquele tipo de espaço corporativo usado na operação a partir da contextualização da situação em análise. 
Vale ressaltar também que o método desenvolvido na tese foi feito sob a ótica de um planejador que atua na área de real estate corporativo. A função do planejador é embasar a decisão dos gestores da corporação. O planejador, para utilizar o método, recebe as informações do ambiente corporativo sobre as necessidades operacionais a serem atendidas durante o uso dos espaços, as estratégias de investimento e políticas corporativas, advindas do planejamento estratégico da corporação, informações sobre o desempenho histórico (econômico-financeiro), entre outras necessárias à decisão em análise.

Essas informações são introduzidas como entradas do método (contextualização) para a identificação da melhor [alternativa]. O resultado final a partir do uso do método para a tomada de decisão é a recomendação de uma hierarquia entre as [alternativas] de escolha, partindo daquela que melhor atende, em conjunto, aos critérios priorizados pelos decisores. Como resultados intermediários extraídos a partir do uso do método, têm-se as referências qualitativas e quantitativas usadas para pontuar os critérios de decisão em cada uma das [alternativas].

\subsection{Estrutura do Texto}

Este texto está estruturado em nove capítulos, os quais contemplam os seguintes conteúdos:

CAPÍTULO 1: trata-se do capítulo introdutório que contextualiza o tema da pesquisa considerando o ambiente produtivo e econômico em que as corporações operam, e a importância de decisões mais judiciosas sobre o recurso real estate. A partir desse contexto, justifica-se na sequência a relevância da proposta do trabalho e o seu objetivo.

CAPÍTULO 2: trata-se da metodologia usada para configurar o - Método para Análise da Oportunidade de Imobilização em Imóveis Corporativos.

CAPÍTULO 3: antes de iniciar a elaboração do método foi feita uma abordagem, sob a ótica macroeconômica, dos possíveis motivos pelos quais as corporações, até meados da década de 90, investiam nos imóveis demandados na operação, e atualmente há uma maior propensão pela não imobilização desse ativo nas corporações brasileiras.

CAPÍTULO 4: neste capítulo são apresentados os fatores influenciadores da decisão em análise e os respectivos atributos, também chamados neste texto de - critérios de decisão - do 
método. A identificação dos atributos baseia-se na revisão bibliográfica e no levantamento de campo. Ao final do capítulo apresenta-se a compilação dos dados a partir das entrevistas, evidenciando os atributos citados pelas respondentes como 'importantes na decisão', agrupados por tipo de espaço corporativo e, também, as [alternativas] prevalentes em cada um desses espaços na amostra analisada. As respostas das corporações respondentes são comparadas com a percepção das empresas que atuam na área de real estate e possuem conhecimento mais amplo das ocorrências predominantes no ambiente empresarial ([alternativas] ' $v s$ ' tipos de espaços corporativos).

CAPÍTULO 5: a análise da pertinência das [alternativas] quanto ao atendimento aos critérios de decisão do método está apresentada no Capítulo 5. Essa análise baseia-se na sustentação legal que rege as locações comerciais, e nas práticas prevalentes de mercado, ou seja, nas negociações entre proprietários e ocupantes (corporações). O conteúdo da revisão bibliográfica e do levantamento de campo estão abordados no decorrer do capítulo, concluindo-se pelos principais motivos que levam as corporações a optarem por cada uma das [alternativas] e as vantagens e desvantagens de cada uma quanto ao atendimento de aspectos operacionais, financeiros e econômicos.

CAPÍTULO 6: os critérios de decisão mensuráveis, os quais resultam nos indicadores econômico-financeiros são avaliados quantitativamente. Este capítulo contempla a revisão bibliográfica para introdução dos conceitos e doutrinas necessários ao cálculo dos indicadores. Para melhor explanar esses conceitos e os cálculos dos indicadores são usados exemplos numéricos no decorrer do capítulo, baseados em uma situação modelo. As referências quantitativas apresentadas neste capítulo somadas às referências qualitativas abordadas no Capítulo 5 são então estruturadas em uma ferramenta de apoio à decisão - AHP (Analytic Hierarchy Process) (Capítulo 7), configurando o Método para Análise da Oportunidade de Imobilização em Imóveis Corporativos.

CAPÍTULO 7: tendo em vista que se trata de uma decisão multicritério e que cada uma das [alternativas] atende diferentemente aos critérios, cabe a cada decisor a priorização dos critérios em função das suas necessidades e estratégias. Para isso, as informações do Capítulo 4, 5 e 6 são estruturadas em uma ferramenta de apoio à decisão (AHP). No final do capítulo a mesma situação modelo usada no decorrer do Capítulo 6 é aplicada para exemplificar o uso dessa ferramenta. 
CAPÍTULO 8: com propósito de avaliar a aplicabilidade e qualidade do método é feito o estudo do caso. Para isso, são identificados os dados relacionados aos espaços utilizados na operação da corporação objeto de análise e, também, informações sobre o contexto da empresa e seu desempenho histórico (tais como: resultado sobre capital investido - ROE, índices financeiros extraídos do balanço, alíquotas de impostos, entre outras). A partir do entendimento do contexto para cada um dos imóveis do portfolio da corporação, dos indicadores econômico-financeiros e das priorizações dos critérios pela corporação, concluise pela [alternativa] mais apropriada para cada um dos imóveis do portfolio.

CAPÍTULO 9: neste capítulo apresentam-se as principais conclusões da tese e aplicação do método. Sugere-se também neste capítulo alguns temas relacionados à tese para pesquisas futuras. 


\section{METODOLOGIA PARA CONFIGURAÇÃO DO MÉTODO}

A metodologia para configuração do método está ilustrada de forma concisa no Quadro 1. A elaboração do método inicia-se pela identificação dos atributos ( $1^{\mathrm{a}}$ Etapa) relevantes à escolha pela imobilização ou não nos imóveis corporativos. Esses atributos garantem o alinhamento entre o recurso real estate usado para acomodações das atividades das corporações e as suas necessidades operacionais e estratégias.

O levantamento dos dados que embasam a proposta dos critérios de decisão do método iniciase pela revisão bibliográfica. Os critérios de decisão propostos são então submetidos à crítica por meio das entrevistas estruturadas nas corporações, tanto no setor de serviços, como de manufatura e varejo. Essas entrevistas são conduzidas com o auxílio de questionários previamente elaborados, com base no conteúdo adquirido a partir das revisões bibliográficas.

A escolha das corporações entrevistadas na pesquisa baseou-se em dois principais desígnios: [i] escolha de corporações que aplicam diferentes estratégias no portfolio de real estate, ou seja, tanto aquelas que ainda mantêm grande parte dos seus imóveis como ativo imobilizado, assim como aquelas que procuram novas alternativas de não investir e desmobilizar, [ii] escolha de corporações que atuam em diferentes setores. Nesse caso, essa abrangência é mais adequada, pois mesmo as estratégias em relação ao real estate corporativo serem similares por setor $^{13}$, até para uma mesma corporação o tipo de ocupação e as necessidades no uso variam ${ }^{14}$. Assim, procurou-se identificar os atributos considerados nas decisões em relação ao real estate corporativo pelas empresas respondentes, visto que segmentar por setor restringiria a coleta dos atributos em função do segmento de análise, e não em função do tipo de espaço corporativo e os respectivos atributos predominantes.

13 Existem setores, como de serviços, que a locação é mais comumente observada comparada ao setor de manufatura, por exemplo.

14 Como sedes administrativas e espaços fabris de uma empresa de manufatura, que apresentam diferentes necessidades durante a operação. 


\begin{tabular}{|c|c|c|c|c|}
\hline \multirow{13}{*}{\multicolumn{2}{|c|}{ 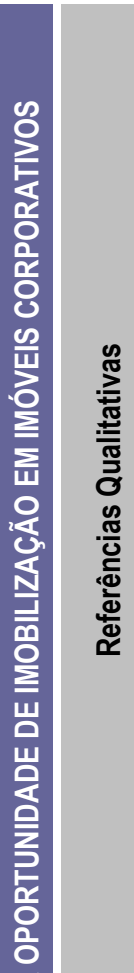 }} & \multirow{6}{*}{$\begin{array}{l}1^{\text {a ETAPA }} \\
\text { Identificação dos } \\
\text { Atributos Relevantes - } \\
\text { Critérios de Decisão } \\
\text { (CAPÍTULO 4) }\end{array}$} & \multicolumn{2}{|l|}{ Processo: } \\
\hline & & & \multicolumn{2}{|c|}{$\begin{array}{l}\text { Revisão Bibliográfica sobre decisões em relação ao real estate corporativo (maioria } \\
\text { publicações internacionais) para embasar a proposta dos possiveis atributos do método }\end{array}$} \\
\hline & & & \multirow{2}{*}{$\begin{array}{l}\text { Levantamento de } \\
\text { Campo: Critérios de } \\
\text { Decisão }\end{array}$} & $\begin{array}{l}\text { Elaboração dos Questionários para as entrevistas nas } \\
\text { corporações (usuárias dos espaços) }\end{array}$ \\
\hline & & & & $\begin{array}{l}\text { Entrevistas nas corporações (de diferentes setores e com } \\
\text { diferentes estratégias em relação ao real estate corporativo) }\end{array}$ \\
\hline & & & \multicolumn{2}{|l|}{ Resultados: } \\
\hline & & & \multicolumn{2}{|c|}{ Atributos relevantes à decisão em análise - Critérios de Decisão do método } \\
\hline & & \multirow{7}{*}{$\begin{array}{c}2^{\mathrm{a}} \text { ETAPA } \\
\text { Análise da Pertinência } \\
\text { das [alternativas] } \\
\text { quanto ao atendimento } \\
\text { aos atributos } \\
\text { (CAPÍTULO 5) }\end{array}$} & \multicolumn{2}{|l|}{ Processo: } \\
\hline & & & \multicolumn{2}{|c|}{$\begin{array}{l}\text { Análise da sustentação legal que rege as locações urbanas no Brasil (Revisão Bibliográfica - } \\
\text { aspectos legais, contábeis e tributários) }\end{array}$} \\
\hline & & & \multirow{3}{*}{$\begin{array}{l}\text { Levantamento de } \\
\text { Campo: } \\
\text { Práticas Prevalentes de } \\
\text { Mercado (negociações: } \\
\text { investidores de real } \\
\text { estate e corporações- } \\
\text { usuárias) }\end{array}$} & $\begin{array}{l}\text { Elaboração dos Questionários para as entrevistas nas empresas } \\
\text { que atuam na área de real estate }\end{array}$ \\
\hline & & & & $\begin{array}{l}\text { Entrevistas nas empresas de real estate (investidores, } \\
\text { consultores, corretores e da área de direito imobiliário) }\end{array}$ \\
\hline & & & & $\begin{array}{l}\text { Análise dos Prospectos de Distribuição Pública (CRI e Quotas) - } \\
\text { informações sobre as negociações (contratos) }\end{array}$ \\
\hline & & & \multicolumn{2}{|l|}{ Resultados: } \\
\hline & & & \multicolumn{2}{|c|}{ Análise de como cada uma das [alternativas] atende a cada um dos atributos } \\
\hline \multirow{7}{*}{ 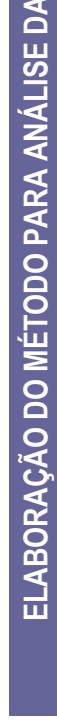 } & \multirow{7}{*}{ 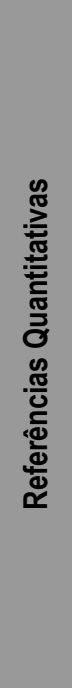 } & \multirow{2}{*}{$\begin{array}{c}3^{\mathrm{a}} \text { ETAPA } \\
\text { Apresentação dos } \\
\text { Indicadores Econômico- } \\
\text { Financeiros para a } \\
\text { decisão } \\
\text { (CAPÍTULO 6) }\end{array}$} & \multicolumn{2}{|c|}{$\begin{array}{l}\text { Processo de Análise: } \\
\text { Revisão Bibliográfica para introdução dos conceitos teóricos necessários aos cálculos dos } \\
\text { indicadores (critérios de decisão mensuráveis) }\end{array}$} \\
\hline & & & \multicolumn{2}{|c|}{$\begin{array}{l}\text { Apresentação das doutrinas e conceitos relacionados aos indicadores econômico-financeiros a } \\
\text { serem extraídos do modelo de simulação }\end{array}$} \\
\hline & & & \multicolumn{2}{|l|}{ Processo: } \\
\hline & & $4^{\mathrm{a}} \mathrm{ET}$ & \multicolumn{2}{|c|}{$\begin{array}{l}\text { Identificação dos elementos dos fluxos de entrada e de saída de recursos referentes às } \\
\text { [alternativas] de imobilização e não imobilização nos imóveis corporativos }\end{array}$} \\
\hline & & $\begin{array}{l}\text { Formatação do Modelo } \\
\text { de Simulação } \\
\text { (CAPÍTULO 6) }\end{array}$ & \multicolumn{2}{|c|}{$\begin{array}{l}\text { Introdução dos conceitos teóricos abordados na } 3^{a} \text { Etapa para formatação do modelo } \\
\text { propriamente dito (inclui as análises dos impactos dos riscos nos indicadores - verificação da } \\
\text { sensibilidade dos indicadores) }\end{array}$} \\
\hline & & & \multicolumn{2}{|l|}{ Resultados: } \\
\hline & & & \multicolumn{2}{|c|}{ Modelo de Simulação para cálculo dos indicadores econômico-financeiros do método } \\
\hline \multirow{4}{*}{\multicolumn{2}{|c|}{ 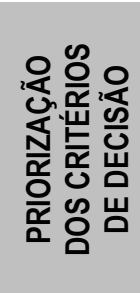 }} & \multirow{4}{*}{$\begin{array}{l}5^{\text {a ETAPA }} \\
\text { Ferramenta de Apoio à } \\
\text { Decisão (AHP) } \\
\text { (CAPÍTULO 7) }\end{array}$} & \multicolumn{2}{|l|}{ Processo: } \\
\hline & & & \multicolumn{2}{|c|}{$\begin{array}{l}\text { Estruturação das Informações do Capítulo 4, } 5 \text { e } 6 \text { valendo-se de um método de análise } \\
\text { hierárquica de decisão (AHP) }\end{array}$} \\
\hline & & & \multicolumn{2}{|l|}{ Resultados: } \\
\hline & & & \multicolumn{2}{|c|}{$\begin{array}{l}\text { Ferramenta para facilitar a decisão em função dos critérios priorizados pela corporação, e das } \\
\text { informações já apresentadas no CAPÍTULO } 5 \text { e } 6-2^{a}, 3^{a} \text { e } 4^{\mathrm{a}} \text { Etapa }\end{array}$} \\
\hline
\end{tabular}

Quadro 1 - Etapas para elaboração do Método para Análise da Oportunidade de Imobilização em Imóveis Corporativos 
Para finalizar a elaboração das referências qualitativas é necessário avaliar a pertinência de cada uma das [alternativas] quanto ao atendimento dos atributos identificados anteriormente ( $2^{\text {a }}$ Etapa). Essa avaliação fundamenta-se nas revisões bibliográficas (sustentação legal que rege as locações urbanas comerciais, práticas contábeis e tributárias), nas informações dos prospectos de distribuição pública dos CRI e das Quotas, e também por meio das entrevistas estruturadas com profissionais da área jurídica, de consultoria imobiliária, corretoras e investidores de real estate, visando à consideração, na análise da pertinência das [alternativas], das práticas prevalentes de mercado no Brasil, observadas nas negociações entre investidores de real estate e as corporações usuárias dos espaços corporativos ${ }^{15}$.

Concluída a análise qualitativa do método inicia-se a elaboração da análise quantitativa. Os critérios de decisão relacionados ao uso do espaço corporativo, os quais são relevantes à análise para garantir alinhamento do recurso real estate com as necessidades operacionais da corporação, não são mensuráveis. Contudo, os critérios de decisão relacionados às estratégias de investimento e políticas das corporações, são mensuráveis. Assim sendo, as referências quantitativas relacionadas aos critérios de decisão mensuráveis, que resultam nos indicadores econômico-financeiros, são calculadas por meio do modelo de análise econômico-financeira.

A análise quantitativa se inicia pela revisão bibliográfica para a introdução dos conceitos teóricos necessários aos cálculos dos indicadores do método ( $3^{\mathrm{a}}$ Etapa). Definidos como esses indicadores são calculados, é feita a identificação dos fluxos de entrada e saída de recursos nas movimentações financeiras para cada uma das [alternativas] em cada um dos indicadores.

O levantamento dos elementos que definem esses fluxos de entrada e saída é feito a partir de revisões bibliográficas, entrevistas nas empresas que atuam na área de real estate e dos prospectos de distribuição pública dos CRI e das Quotas. Nesses prospectos é possível encontrar informações quantitativas sobre as negociações, uma vez que a transparência da operação é obrigatória para avaliação da qualidade do investimento por parte dos investidores desses títulos.

Feita a revisão bibliográfica necessária à introdução dos conceitos teóricos relacionados aos cálculos dos indicadores e identificados os elementos dos fluxos das movimentações

15 Os questionários usados nas entrevistas, tanto para identificação dos atributos, como para avaliação da pertinência das [alternativas] quanto ao atendimento a esses atributos, estão apresentados no Apêndice A deste texto. 
financeiras relevantes à decisão e comparação entre as [alternativas], torna-se possível a formatação do modelo para análise econômico-financeira de onde são extraídos os indicadores ( $4^{\mathrm{a}}$ Etapa). Para avaliação da sensibilidade dos indicadores frente à ocorrência de desvios nas variáveis do cenário tomado como referencial, o modelo formatado permite as análises dos impactos dos riscos a partir de perturbações das variáveis, tais como: preço de aluguel, resultados sobre o capital investido (ROE), entre outras.

As referências qualitativas somadas às referências quantitativas estruturadas em uma ferramenta de apoio à decisão configuram o 'Método para Análise da Oportunidade de Imobilização em Imóveis Corporativos' $-\left[\mathrm{MAOI}{ }^{16}\right.$ desenvolvido na tese.

Tendo em vista que a decisão pela imobilização ou não no real estate corporativo é um problema multicritério e que cada uma das [alternativas] atende diferentemente a cada um dos atributos, para facilitar a tomada de decisão pelos decisores, as informações adquiridas na $1^{\mathrm{a}}$, $2^{\mathrm{a}}, 3^{\mathrm{a}}$ e $4^{\mathrm{a}}$ Etapa são estruturadas valendo-se de uma ferramenta de apoio à decisão para problemas multicritério, conhecida como AHP (Analytic Hierarchy Process) (5 Etapa). Vale ressaltar que essa ferramenta é usada para facilitar ao decisor a escolha entre as [alternativas], em função das suas prioridades - priorização dos critérios de decisão.

Observa-se, portanto, que o [MAOI] permite a ponderação entre critérios qualitativos (relacionados ao uso do espaço) e quantitativos (relacionados às estratégias de investimento e políticas das corporações) na escolha da solução mais adequada, em razão dos objetivos estratégicos e necessidades operacionais de cada corporação, sendo esse o principal propósito do [MAOI].

Para verificar a qualidade do [MAOI] e a sua aplicabilidade por parte das corporações, é feito o estudo do caso. O caso inicia-se pelo entendimento do contexto, onde primeiramente são extraídos junto à corporação escolhida, os dados sobre o portfolio de real estate utilizado nas operações, dados econômico-financeiros da empresa, e estratégias e políticas corporativas no médio e longo prazo. Estas informações do contexto são usadas para avaliar as referências qualitativas e quantitativas da decisão. Para a análise quantitativa é feita a identificação dos elementos de cálculo dos indicadores, tanto para as [alternativas] de não imobilização como de imobilização, atribuídos conforme as características dos espaços em análise - tipo do empreendimento, qualidade do empreendimento, localização, entre outras. Esses elementos de

16 Daqui em diante neste texto, o método, quando se refere ao 'Método para Análise da Oportunidade de Imobilização em Imóveis Corporativos' desenvolvido na tese, será descrito pela sigla: [MAOI]. 
cálculo são aplicados no modelo de simulação, de onde são extraídos os indicadores econômico-financeiros (referências quantitativas da decisão).

Os critérios de decisão são então priorizados pela corporação em relação à importância e relacionados com a pertinência de cada [alternativa] quanto ao atendimento a esses critérios ${ }^{17}$. A ferramenta AHP é utilizada para facilitar ao tomador de decisão a escolha da [alternativa] mais apropriada, em função dos critérios priorizados pela corporação.

Valendo-se das informações advindas do caso, na etapa conclusiva é feita uma comparação entre as respostas extraídas a partir da aplicação do [MAOI] e as decisões tomadas pela corporação objeto de análise para cada imóvel do portfolio. Também nesta etapa é reafirmada a proposta principal do trabalho, pontuando as principais conclusões do trabalho, assim como as considerações relevantes confrontadas no desenvolvimento da pesquisa.

A Figura 3 ilustra a rotina do [MAOI] desenvolvido na tese. A partir do capítulo 4 esta rotina será detalhada para cada uma das etapas envolvida na configuração e aplicação do [MAOI].

A aplicação do [MAOI] pode ser feita individualmente, para cada nova necessidade de espaço corporativo, como também para uma análise do portfolio da corporação, no intuito de direcionar, para cada tipo de espaço corporativo, a [alternativa] mais adequada em função das necessidades operacionais e estratégias corporativas. A partir dos resultados encontrados pela aplicação do [MAOI], recomendam-se as intervenções de imobilização ou desmobilização no portfolio de real estate da corporação.

Mesmo nos casos em que se analisa o portfolio da empresa, segmentando por tipo de espaço corporativo, é necessário calcular as referências quantitativas (indicadores econômicofinanceiros) isoladamente para cada imóvel, para então calcular as referências quantitativas dos grupos segmentados por tipo de espaço corporativo ${ }^{18}$. Para as referências qualitativas, que avaliam os critérios qualitativos relacionados ao uso do espaço, pode ser feito, a juízo da

17 A análise da pertinência das [alternativas] quanto ao atendimento aos critérios de decisão, usada no AHP para atribuição das notas de atendimento das [alternativas] em cada critério, é feita a partir das referências qualitativas (Capítulo 5) para os critérios não mensuráveis, e a partir das referências quantitativas (Capítulo 6) para os critérios mensuráveis.

18 A análise das referências quantitativas feita isoladamente para cada ativo é pelo fato de cada imóvel apresentar parâmetros distintos no cálculo dos indicadores, em função da localização, estado de conservação, horizonte de uso, entre outros elementos de cálculo que diferem de um imóvel para outro (mesmo que iguais em tipologia). 
corporação e usuário do [MAOI], uma mesma ponderação de notas de atendimento das [alternativas] para os critérios qualitativos (atribuída pelo planejador) e uma mesma priorização destes critérios (atribuída pela corporação) por tipo de espaço corporativo, e não necessariamente isoladamente por imóvel, já que tendem a respeitar, para uma mesma empresa, os mesmos julgamentos em relação ao uso do imóvel em função do tipo de espaço.

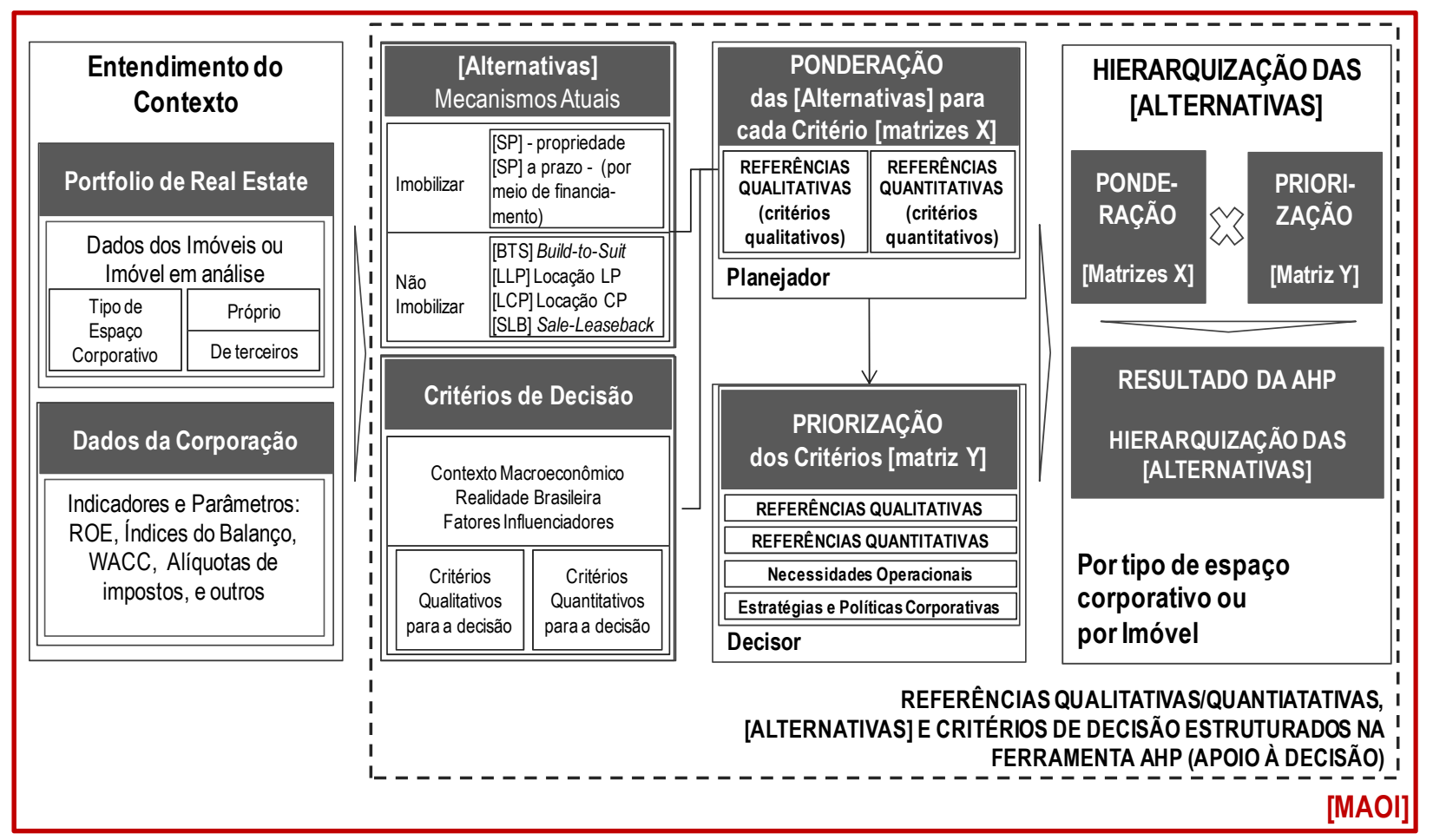

Figura 3 - Rotina do Método para Análise da Oportunidade de Imobilização em Imóveis Corporativos [MAOI]

É importante ressaltar que o [MAOI] apresenta uma rotina de análise original e atemporal, ou seja, o uso do [MAOI] pode ser feito para diferentes situações de análise e em qualquer momento. No entanto, como as [alternativas], os critérios de decisão e os julgamentos com base na realidade brasileira podem se alterar, a mesma rotina feita para configuração do [MAOI] pode ser revista em uma nova amostra de empresas participantes e para uma nova realidade, concluindo-se, assim, pela inclusão de novos critérios, bem como novas [alternativas] de escolha. 


\section{REESTRUTURAÇÃO DO REAL ESTATE NAS CORPORAÇÕES - EVOLUÇÃO HISTÓRICA}

Antes de discutir sobre os principais fatores influenciadores que levam as corporações a utilizarem os mecanismos analisados neste trabalho, assim como os atributos a serem considerados na escolha entre as [alternativas], será descrito brevemente, sob uma visão macroeconômica, a evolução histórica da reestruturação do real estate nas corporações, com propósito de identificar os principais motivos pelos quais as corporações mantinham a posição de proprietárias dos espaços ocupados nas suas operações e atualmente passaram a desmobilizar seus ativos imobiliários, ou ocupar os novos espaços demandados sem imobilizar recursos nas propriedades.

\subsection{Visão geral}

O volume de transações entre investidores de real estate, que disponibilizam os espaços corporativos para locação, e as corporações, que locam esses espaços para desempenhar suas operações, relaciona-se diretamente com o grau de maturidade do sistema financeiro e do mercado imobiliário. No Brasil, em decorrência da abertura econômica no início da década de 90, a economia como um todo, inclusive o mercado imobiliário, mostrou aceleração. $\mathrm{O}$ decréscimo das taxas de juros, a estabilização da moeda e a migração de capital especulativo do mercado financeiro para ativos reais, nos quais se enquadram os imóveis corporativos, configuram um contexto favorável à evolução do mercado imobiliário.

Além disto, o amadurecimento do mercado de capitais e, por consequência, das operações de securitização no Brasil é outro importante aliado dos investidores que se interessam pelo mercado de base imobiliária ${ }^{19}$, por conta [i] da melhor disponibilidade de meios para captação de recursos, que torna a ação empreendedora dos investidores de real estate mais contínua no mercado imobiliário, e [ii] do melhor equilíbrio no que tange aos custos e prazos nas estruturações de funding $^{20}$ para implantação dos empreendimentos corporativos.

19 Empreendimentos de base imobiliária são aqueles implantados para gerar receita a partir da exploração de alguma atividade em sua base física, como os edifícios de escritórios, galpões industriais, centros de distribuição, disponíveis no mercado para locação.

20 Funding significa a estrutura da equação de fundos para implantar certo empreendimento. 
Também para as corporações a evolução do mercado de capitais foi benéfica, uma vez que as novas formas de estruturação das operações para implantação dos empreendimentos permitem melhores resultados aos investidores, que passam a cobrar preços de locação mais acessíveis às corporações locatárias. Soma-se ainda o fato de que com um maior número de investidores dispostos a oferecer espaços para locação, aumenta-se a oferta, impactando também nos preços de locação dos espaços. Essa relação entre oferta e demanda, que configura os ciclos dos mercados de real estate, é fator crucial na atratividade por parte dos investidores de real estate para implantação de novos espaços e, também, para os preços praticados.

No ambiente das corporações, a necessidade de agregar valor aos acionistas e investidores, combinado com a influência da globalização e mudanças nas práticas de conduzir os negócios ${ }^{21}$, têm sido premissas básicas para uma maior preocupação em relação aos ativos imobiliários utilizados na operação das corporações. No contexto atual, os ativos imobiliários precisam ser gerenciados como parte das estratégias corporativas que visam ganhar vantagem competitiva em seus mercados de atuação (MANNING e ROULAC, 1996; MANNING et al. 1997; O’MARA, 1999).

Pelo exposto, o real estate tem sido foco de muitas reestruturações nas corporações desde a década de 70, principalmente nos Estados Unidos. No Brasil a preocupação por parte das corporações em relação a esse ativo começou a se intensificar a partir do final da década de 90 (década em que o mercado imobiliário mostrou aceleração). Foi nesse cenário - estabilidade econômica, redução da taxa de juros, maior desenvolvimento do mercado financeiro e de capitais e maior maturidade do mercado imobiliário - que investidores mais amadurecidos começaram a estruturar operações mais avançadas, como o SLB e o BTS.

A importância destes vetores como possíveis influenciadores da não imobilização ou da desmobilização de imóveis corporativos será tratada nos itens que seguem.

\subsection{Fatores influenciadores da reestruturação do real estate corporativo - realidade brasileira}

Como possíveis fatores influenciadores da reestruturação do real estate corporativo destacamse, [i] a globalização e novos modelos de gestão nas corporações, [ii] a inflação e taxa de

21 Como práticas de terceirização e desmobilização de ativos fixos em corporações que buscam focar em suas atividades fins. 
juros da economia brasileira, [iii] a evolução das operações de crédito e a desintermediação financeira por meio da securitização como fator de amadurecimento do mercado imobiliário, e [iv] a velocidade do avanço tecnológico.

\subsubsection{Globalização e Novos Modelos de Gestão}

Os aspectos referentes à globalização que impactam diretamente a reestruturação do real estate corporativo podem ser observados a partir dos fenômenos decorrentes do processo de abertura de mercado no início dos anos 90. Desde então, uma série de mudanças passou a reestruturar modelos e estabelecer novos parâmetros para os sistemas de produção e relações de trabalho.

Com a primeira abertura de mercado durante a década de 50, quando se estabeleceram as grandes corporações no País, um novo modelo de produção se instituía através de uma estrutura totalmente verticalizada por conta da falta de infraestrutura ou fornecedores compatíveis com a qualidade exigida. Dessa forma, as corporações que aqui se instalaram ocupavam grandes espaços, muitas vezes conquistados com incentivos fiscais, localizados em regiões pouco valorizadas - inclusive com intuito de ser um pólo gerador de desenvolvimento para a região -, onde construíram suas enormes instalações que abrigavam todas as fases do processo produtivo. Aos poucos a indústria de base foi se desenvolvendo e, assim como ela, outras foram se estabelecendo, bem como uma série de organizações passou a enxergar o Brasil como uma oportunidade de investimento, instalando aqui escritórios regionais de suas corporações.

Segundo ROSSI e FERREIRA (1999), este cenário permanece estável até o final da década de 80 por conta de políticas de restrição comercial, como a proteção à indústria nacional, embora este período tenha sido marcado por altas taxas de crescimento a baixos índices de produtividade.

Na década de 90, o processo de abertura comercial, desestatizações, fusões e aquisições de empresas, desregulamentação da economia, adoção de programas de qualidade e novos modelos tecnológicos e de gestão empreenderam profundas alterações nas corporações, criando um "novo paradigma tecnológico-gerencial" (FEIJÓ e CARVALHO 22, 1994 apud

22 FEIJÓ, C., CARVALHO , P. G. M. Sete teses equivocadas sobre o aumento da produtividade industrial nos anos recentes. Boletim de Conjuntura, IEI/UFRJ, jul. 1994. 
ROSSI e FERREIRA, 1999).

As corporações, portanto, tiveram que sair de uma posição de estabilidade para garantir sua competitividade frente a novos concorrentes por meio de reorganizações nas estruturas organizacionais, melhoria da produtividade, maior resiliência e flexibilidade, e redução dos custos de seus processos, os quais passam, ainda hoje, pelo processo de reestruturação do real estate com a desmobilização de ativos, canalizando seus recursos (financeiros e humanos) para as atividades relacionadas ao negócio principal das corporações ${ }^{23}$.

\subsubsection{Inflação e Taxa de Juros da economia brasileira}

Para efeito de análise nesta pesquisa, torna-se válido retratar a dinâmica desses indicadores macroeconômicos desde a década de 60 , já que a partir desse período configura-se o cenário de maior desenvolvimento da economia brasileira, e consequentemente, das corporações que contribuíram para este crescimento, as quais hoje se encontram em meio a reavaliação e reestruturação de seus ativos.

A base de análise está ancorada na divisão de três períodos distintos da inflação brasileira proposta por CERQUEIRA (2006).

O primeiro período compreende os anos de 1960 a 1985, quando a inflação era controlada com políticas de demanda e controles de preços e câmbio, e quando surgiram as primeiras inovações financeiras (fatores de atualização monetária e taxas de juros referenciais, como a $\mathrm{SELIC}^{24}$ ). Até o final deste período, a política de indexação se aprofundou como forma de contenção inflacionária. Em contrapartida, a correção monetária criava dificuldades para o controle inflacionário configurando um círculo vicioso ${ }^{25}$. Como resultado, os prazos de empréstimos bancários foram reduzidos e a cada renovação traziam senão uma taxa de juros

23 Vale aqui citar o peso do ativo imobiliário no custo total da operação das corporações identificados por alguns pesquisadores. Conforme NELSON et al. (1999) o peso apontado foi de 19\% (ativo imobiliário sobre o custo total dos ativos das corporações), já para CURRIE e SCOTT (1991) e AVIS et al. (1989) o ativo imobiliário chegou a 30 a $40 \%$ do custo total dos ativos. Mesmo a variação das porcentagens citadas por esses pesquisadores ser significativa, também possivelmente justificada pelas diferentes datas das análises, denota-se a relevância do custo do ativo imobiliário na operação das corporações.

24 SELIC - É a taxa de juros de referência, praticadas nas transações em títulos públicos, no ambiente do Sistema Especial de Liquidação e de Custódia.

25 O receio do mercado em ver diminuído as suas margens de renda e lucro levava a correção dos preços de seus produtos e serviços sempre acima dos índices de correção nos momentos de flexibilização. 
mais alta, o pagamento de encargos do período, dificultando a disposição de investidores para captação de crédito para investimentos em geral, inclusive no mercado de real estate. As grandes corporações, nesse contexto, utilizavam seus próprios recursos para os investimentos necessários à produção (equipamentos, máquinas, imóveis, entre outros).

O segundo período, entre 1986 e 1994, é marcado pelas tentativas de contenção da inflação, conduzidas por inúmeros planos econômicos, dos quais se destacam como principais características, medidas de austeridade fiscal e monetária, congelamento de preços, salários e câmbio. Embora servindo como mecanismo de controle de inflação, da dolarização da economia e do capital estrangeiro especulativo, a evolução das taxas de juros contribuiu para o baixo crescimento da economia.

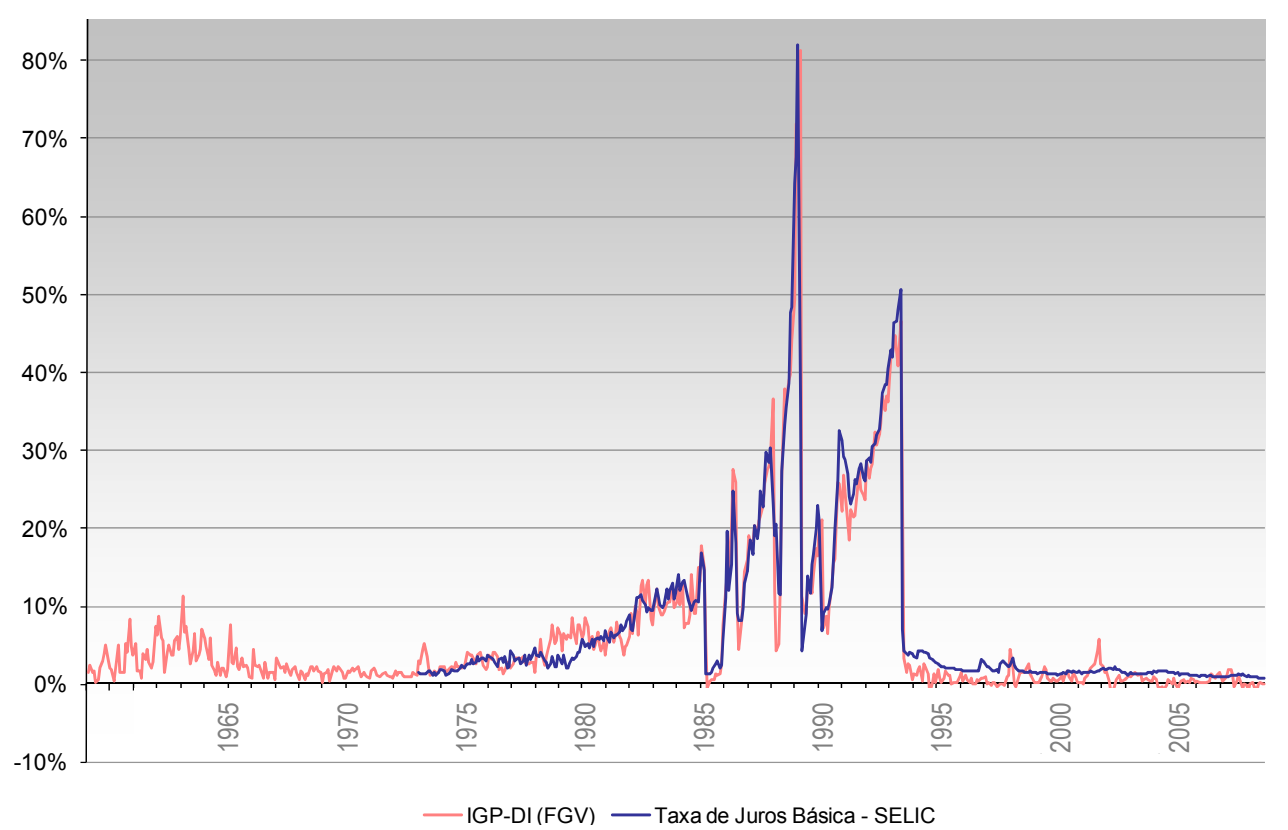

Gráfico 3 - Taxas de inflação (IGP-DI, FGV) e Taxas de juros básica (SELIC ${ }^{26}$ ) entre Janeiro de 1960 e Novembro de 2009 (\% a.m)

Nota-se, portanto, que esses dois primeiros períodos pouco contribuíram para o desenvolvimento do mercado de real estate no tocante à flexibilização de fontes de recursos por conta das altas taxas de juros e inflação (conforme Gráfico 3), uma vez que configuravam um cenário desfavorável para operações de longo prazo que incentivassem investidores a incorporar empreendimentos de base imobiliária para geração de renda. Os ativos imobiliários eram uma forma segura de proteção do patrimônio das corporações, haja vista que o retorno 
desse tipo de aplicação manteve-se acima da perda inflacionária ${ }^{27}$ e imune às oscilações da política econômica.

O terceiro e último período inicia-se em meados de 1994, com a introdução do Plano Real, e segue até o momento presente. Este novo plano econômico representou um marco, por impedir que choques se transformassem em processo inflacionário e, no contexto do mercado imobiliário, por representar o início de um processo de amadurecimento.

Apesar de todo o esforço, as medidas adotadas não colocaram o Brasil numa rota de crescimento sustentável, porém, garantiu uma estabilidade econômica incipiente, invalidando tradicionais paradigmas das corporações que esperam que imóveis funcionem como reserva de capital em períodos de alta inflacionária.

Da mesma forma, a gradual redução da taxa de juros da economia (de 53,08\% em 1995 para 19,04\% em 2005, e agora fechando 2009 com equivalente anual de 9,93\% a.a) propicia um ambiente favorável para investimentos em real estate, em especial para investidores dessa modalidade. Como os investimentos em empreendimentos de base imobiliária, nos quais se enquadram as diversas tipologias de imóveis corporativos expostos no mercado para locação, se assemelham aos investimentos de renda fixa e baixo risco, quando a taxa de juros apresenta-se em queda, o real estate passa a ser uma boa alternativa de investimento.

\subsubsection{Evolução das operações de crédito e a desintermediação financeira por meio da securitização como fator do amadurecimento do mercado imobiliário}

A compreensão do amadurecimento do mercado imobiliário, que tem estrita relação com a reestruturação do real estate nas corporações, não teria sentido se não fossem feitas as análises da evolução do crédito e desintermediação financeira, mesmo porque, é a partir dessa evolução que surgem os novos mecanismos que dão suporte às operações do mercado imobiliário. Para tanto, as análises podem ser estruturadas em dois períodos distintos separados pela conjunção de dois acontecimentos marcantes na década de 90: a abertura de mercado e instituição do Plano Real.

27 No Gráfico 3 é possível observar dois períodos distintos entre a relação da inflação e taxa básica de juros. O primeiro, até 1994, a taxa de juros acompanha reativamente a tendência inflacionária, não estimulando aplicações no mercado financeiro. A partir de 1994 (início do Plano Real), observa-se efetivamente a aplicação da taxa de juros como agente controlador da inflação. Este novo cenário propiciou o crescimento do mercado financeiro e abriu novas perspectivas de reserva de capital e financiamento de recursos. 


\subsubsection{Primeiro período de análise (dos anos 50 ao início da década de 90)}

A década de 80 foi marcada pela queda brusca de quase vinte pontos percentuais na relação com o PIB para os empréstimos concedidos ao setor privado ${ }^{28}$, acentuando o esgotamento de fontes de financiamento, e pela ausência de políticas e mecanismos sustentáveis de fomento ao crédito, haja vista o impacto do passivo nas contas públicas, decorrente do abuso de políticas de subsídio e apoio financeiro às estatais.

A ausência de políticas sérias e igualitárias não promoveu o desenvolvimento do mercado imobiliário enquanto meio de exploração para renda aos investidores durante o ciclo de vida do empreendimento. $\mathrm{O}$ contexto comprometia a viabilidade desse tipo de negócio, que não conferia condições atrativas para ambas as partes. Para o investidor, os recursos imobilizados na implantação de imóveis corporativos se amortizavam em prazos longos (geralmente investimentos constituídos de recursos próprios e alavancagem baixa, visto as condições desfavoráveis dos financiamentos disponíveis - prazos curtos e altas taxas de juros). Dessa forma, a garantia de maior liquidez, e uma possível ação contínua no mercado, seria por meio da cobrança de valores de locação capazes de equacionar a estruturação financeira da operação de forma atrativa para os investidores, comprometendo, assim, a atratividade para as corporações usuárias dos espaços. Por esse motivo e até como forma de reserva de capital, as corporações imobilizam recursos livres em bens imobiliários.

Além disso, um outro aspecto negativo à locação de espaços corporativos, decorrente da incipiência do mercado imobiliário, era a dificuldade de negociação para configuração e ocupação dos espaços corporativos durante o uso, já que esse mercado se constituía de agentes amadores, geralmente proprietários que possuem partes de um mesmo imóvel.

Ao longo dos 40 anos subsequentes ao início do período de industrialização e desenvolvimento econômico do País na década de 50, o processo configurado pelo aumento da necessidade por espaços corporativos deu-se a partir de investimentos em ativos fixos que foram realizados pelas empresas estabelecidas no País. Nas épocas mais favoráveis, em primeira análise, o importante era realizar investimentos e produzir rapidamente, aproveitando as oportunidades de negócio oferecidas. O resultado desse processo foi um elevado número de

28 No período compreendido entre os anos de 1982 e 1988, o volume de crédito concedido ao setor privado caiu de $38,1 \%$ para $18,2 \%$ (fonte: Banco Central, citado em LONGO, 1989). 
corporações excessivamente imobilizadas (FEBRABAN, 1982) ${ }^{29}$.

A consequência imediata da imobilização em excesso foi a necessidade de financiamentos para capital de giro. Contudo, até a década de 90, os bancos comerciais e de investimento não ofereciam atrativas opções de crédito - os instrumentos disponíveis até então constituíam, tradicionalmente, empréstimos de curto prazo que se desdobravam em intermináveis renovações e prorrogações das operações.

Como síntese do primeiro período estruturado neste capítulo, para análise da evolução do crédito e contextualização do amadurecimento do mercado imobiliário, conclui-se por dois principais aspectos: [i] não houve condições, tanto políticas como econômicas, favoráveis para o surgimento de instrumentos financeiros de crédito adequados, já que se observou a estagnação da atuação e desenvolvimento dos agentes do mercado de real estate; e [ii] a grande imobilização das corporações em ativos imobiliários, que ao invés de utilizar os recursos próprios para alavancar o negócio principal, investia no real estate demandado nas operações, contribuindo para falta de liquidez das corporações.

\subsubsection{Segundo período de análise (a partir da década de 90)}

Diferentemente do que se esperava, o cenário de estabilidade econômica, além de não alavancar, deteve o crescimento do crédito observado nos dois anos anteriores à instituição do Plano Real. Até então, as políticas de concessão de crédito não haviam atendido a contento os diversos segmentos da sociedade, seja por conta das altas taxas de juros e inflação - que inviabilizavam outras operações que não as de curtíssimo prazo - seja por não existir mecanismos ou condições sustentáveis para o fomento do crédito.

Referenciado nas experiências de países que passaram por processos de estabilização econômica, e que apresentaram aumento da oferta de crédito, e pelo fato do estoque de crédito bancário brasileiro, antes da estabilização (1993), corresponder a apenas $29 \%$ do $\mathrm{PIB}^{30}$, era esperado um crescimento e não a estabilização das operações de crédito (conforme Gráfico 4).

29 Fonte: Artigo periódico da Febraban - Federação Brasileira de Bancos. A importância do SLB no Brasil.

30 Vale ressaltar que essa relação correspondia, em 2001, a 160\% nos EUA, 143\% no Japão, 130\% nos países membros da União Européia, $73 \%$ nos países asiáticos emergentes, $51 \%$ na Europa emergente e $39 \%$ na América Latina, com destaque para o Chile, com 60\%. (CINTRA apud SOARES, 2001). 
O cenário que se estabelecera (estabilidade econômica incipiente), não foi suficiente para o incremento do crédito e, por consequência, para a viabilização de empreendimentos para efeito de exploração por parte dos agentes do mercado imobiliário. Da mesma forma, as condições de concessão de crédito não configuraram um ambiente favorável para as corporações que vinham buscando ganhar competitividade. Uma alternativa para as corporações seria gerar recursos próprios a partir da desmobilização de seus ativos imobiliários. Todavia, não havia investidores do mercado de real estate para a compra desses ativos, porque não existiam instrumentos mais favoráveis de captação de recursos de terceiros, gerando assim uma situação rígida que comprometia o crescimento de ambas as partes.

A evolução do crédito total em relação ao PIB é demonstrada no Gráfico 4 a seguir.

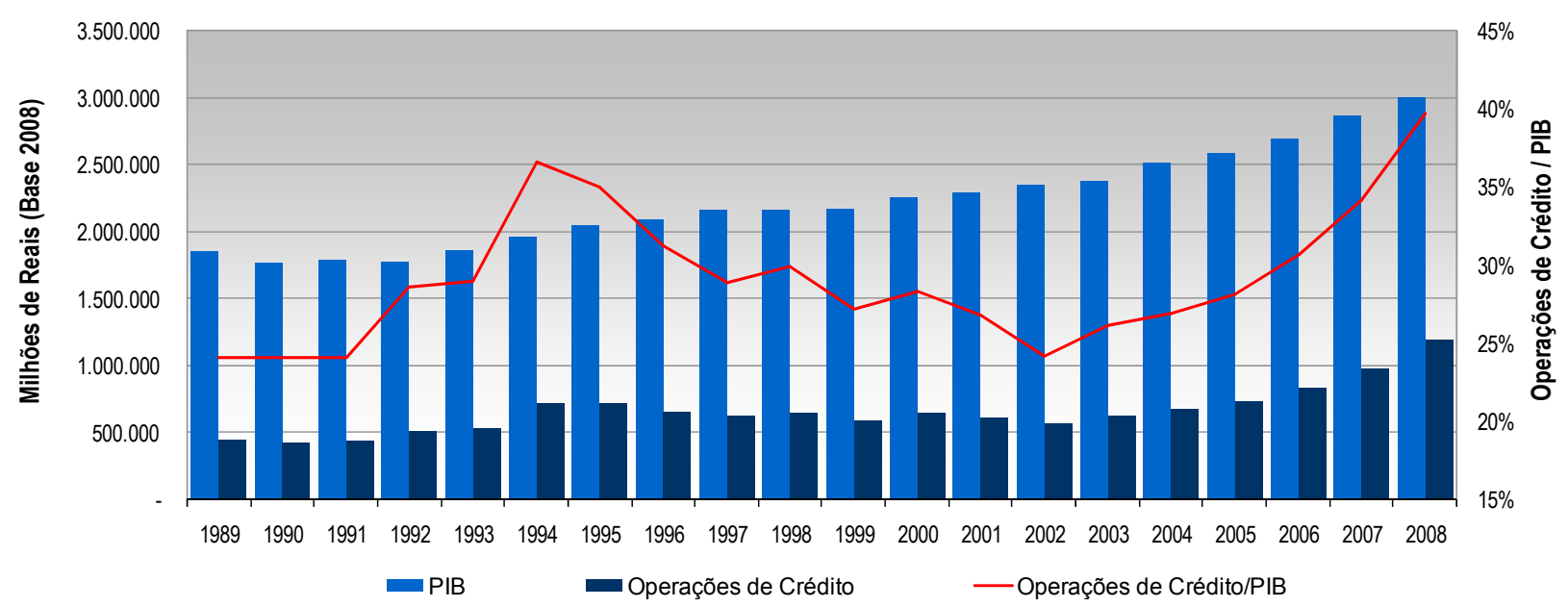

Gráfico 4 - Operações de Crédito Total 'vs' PIB. (Fonte: IPEA)

No período analisado (1989 a 2008), observa-se três fases distintas acerca do comportamento do crédito. O primeiro momento, compreendido entre os anos de 1989 e 1992, apresenta uma estagnação das operações de crédito $\left(24,1 \%\right.$ do PIB) e recessão econômica ${ }^{31}$. O segundo momento, que compreende os dois anos seguintes (1993 e 1994), apresenta uma tendência de crescimento motivada pelo quadro de otimismo estruturado nas bases de um novo plano econômico ainda a se consolidar. Além de perspectivas de ação mais duradoura e

31 Em 1990, 1991 e 1992, sob os impactos da política econômica estabelecida pelo Plano Collor, o PIB brasileiro apresentou a sua pior evolução desde a crise no início da década de $80:-4,3 \%, 1,03 \%$ e $-0,54 \%$, respectivamente (Fonte: IPEA). 
planejamento em longo prazo suportado pelo controle da inflação e das taxas de juros, o Plano Real levaria as instituições bancárias a compensar os ganhos com a perda inflacionária a partir da expansão do crédito. O terceiro e último momento corresponde à vigência do Plano Real propriamente dito. Notadamente, a tendência de crescimento do crédito cedeu lugar à estabilidade.

Uma das justificativas mais plausíveis para a estabilização desse cenário apontada por SOARES (2001), dentre outras levantadas em seu estudo, como as medidas adotadas pelo governo como forma de conter a explosão do crédito e consequente vulnerabilidade dos bancos diante da inadimplência, decorre da adesão do Brasil ao Acordo da Basiléia ${ }^{32}$ em agosto de 1994 com a Resolução 2099 do Banco Central.

A adesão do País a este acordo é um fato relevante porque alterou o padrão de comportamento dos bancos no que diz respeito à realocação dos recursos das aplicações bancárias. A redistribuição desses recursos favorecia a aplicação em ativos de baixa ponderação de risco ${ }^{33}$, dentre eles a carteira de títulos públicos federais (ponderação de risco zero), por não exigirem compensação de aumento do patrimônio líquido exigível dos bancos (como era o caso dos ativos de risco elevado: operações de empréstimo e financiamento rural, agroindustrial, empreendimentos imobiliários, infraestrutura, entre outros; cujo fator de ponderação era de $100 \%)^{34}$. O que se pode observar, portanto, foi a canalização da maior parte das aplicações

32 Corresponde a um acordo estabelecido, em 1988, pelo grupo de países denominado G10 (Bélgica, Canadá, França, Alemanha, Itália, Japão, Holanda, Reino Unido, Estados Unidos e Luxemburgo), com o objetivo de [i] minimizar os riscos das atividades bancárias, visando atingir maiores garantias de solvência e liquidez do sistema bancário internacional; [ii] reduzir a desigual competição entre bancos por conta das disposições estabelecidas em seus países de origem; [iii] estabelecer padrões comuns para capitalização dos bancos, dentre eles o volume de capital em ativos próprios que a instituição deve manter como garantia de suas operações de crédito, conforme a ponderação de risco da operação (SOARES, 2001).

33 A Resolução n. 2099 estabelecia quatro classificações de risco de ativos com suas respectivas ponderações, a saber: [i] risco nulo - fator de ponderação zero; [ii] risco reduzido - fator de ponderação $20 \%$; [iii] risco normal - fator de ponderação $50 \%$; e [iv] risco elevado - fator de ponderação $100 \%$.

34 O patrimônio líquido exigível é o capital que o banco deve possuir em função da sua alavancagem financeira. A alavancagem estabelecida no acordo era uma sistemática para definir o quanto de capital os bancos deviam possuir, que considerava dois fatores: [i] os vários ativos das instituições bancárias - que se referem à razão capital-ativo (o inverso da alavancagem) e define a proporcionalidade de capital que deve ser sustentado pelo banco; e [ii] os seus riscos de perda, que se referem aos riscos diferenciados das operações ativas conforme classificação na nota anterior. A aplicação deste conceito justifica-se na medida em que os bancos assumem mais riscos operacionais em comparação às demais corporações. Por conta disso, é necessário explicitar e ponderar os riscos da sua carteira de empréstimos em relação ao seu patrimônio. 
bancárias para os ativos de baixa ou nenhuma ponderação de risco, já que, com esses ativos, as instituições bancárias conseguiam maiores índices de lucratividade a seus acionistas em razão da maior alavancagem (pela menor necessidade de capital que o banco tinha que possuir).

Bancos Centrais de todo o mundo tendem a tornar mais rígidos os níveis de adequação de capital, de modo a aumentar o nível de capital próprio para garantir o sistema, que por consequência, impacta nos índices de lucratividade das instituições (pela menor alavancagem), assim, para arcar com essa perda de oportunidade, a outorga de empréstimos fica ainda mais custosa.

Soma-se aos índices de lucratividade, uma série de medidas estruturais e ajustes nos modelos operacionais que foram implementados visando a manutenção da competitividade das instituições financeiras nacionais em face da entrada dos bancos estrangeiros após a abertura de mercado no início da década de 90 . A entrada de bancos estrangeiros também ocorreu fruto das associações entre instituições bancárias nacionais com estrangeiras como forma de reestruturar seus ativos, atendendo, assim, as novas resoluções do Banco Central. O spread ${ }^{35}$ bancário e as tarifas sobre serviços cobradas dos correntistas são outros exemplos de formas de compensação dos ganhos da perda inflacionária, e contribuem ainda hoje para o incessante crescimento das instituições bancárias que continuam batendo recordes de lucratividade.

Apesar dos esforços do governo em garantir a estabilidade econômica, eventos externos (como a crise do México em 1995, Asiática em 1997 e da Rússia em 1998) causaram efeitos negativos na economia nacional (como a desvalorização cambial). Por conta disso, o governo adotou medidas mais rígidas de controle inflacionário, como a manutenção das taxas de juros em patamares elevadíssimos, tornando-a uma das mais altas do mundo. Esse contexto promoveu o desenvolvimento do mercado financeiro, que passou a apresentar taxas mais atrativas para os investidores.

Um dos resultados foi a mudança no enfoque das corporações no que diz respeito à propriedade dos imóveis. Como estratégia de combate aos períodos de recessão e como forma de garantir competitividade frente aos novos concorrentes que ingressavam no País, as

35 Spread - é um termo usado para representar a diferença entre a taxa de juros com que a instituição financeira capta seus recursos e aquela paga pelo tomador do crédito. Fatores que contribuem para a composição do spread: inadimplência do tomador do crédito, cenário macroeconômico, despesas administrativas, impostos, entre outros (DEPED - BACEN, 1999). 
corporações começaram a adotar a desmobilização (ou não imobilização) de seus ativos imobiliários, deixando de ser proprietárias para se tornarem locatárias (MAGALHÃES, 1999). Ao invés de manter um grande volume de capital imobilizado em bens imobiliários, as corporações passaram a investir o capital proveniente da venda desses bens em aplicações financeiras e, com os rendimentos obtidos, pagar o aluguel dos novos imóveis ocupados (NOBRE, 2000).

Contudo, visto o ambiente até então explicitado, essa reestruturação no real estate corporativo não ocorreria se não fosse a introdução de novos instrumentos para solucionar o problema da falta de capitais para financiamento de projetos (ou compra dos ativos imobiliários), e opções para reduzir os riscos envolvidos nessas operações.

A securitização foi uma das principais inovações, especialmente no que se refere às operações de crédito e financiamento. Fruto da desintermediação financeira, "a securitização representa o acesso ao mercado de capitais como alternativa de financiamento e investimento, em substituição a outras opções ligadas ao mercado financeiro tradicional" (CAMINHA, 2007, p. 1). Essa desintermediação tem permitido nas últimas duas décadas, aos investidores e as corporações, melhores formas de captação de recursos para financiamentos e investimentos, diluição de riscos e liquidez dos ativos.

A securitização é uma operação por meio da qual se emitem títulos lastreados em ativos ${ }^{36}$, de forma a alargar a base para captação de recursos de terceiros, para financiamentos usados na implantação de ativos (como os imóveis corporativos) e, aos investidores desses títulos, gerar a expectativa de renda em um investimento que circula no mercado de forma mais ágil, podendo também diversificar o risco do portfolio.

Por outro lado, os próprios bancos, que não atenderam a contento a demanda de crédito, mesmo após a estabilidade econômica incipiente introduzida pelo Plano Real, têm se aliado a esse crescimento do mercado de capitais. Os grandes bancos começaram a se desenvolver na negociação de títulos no mercado de capitais, explorando outro tipo de intermediação ${ }^{37}$. Uma vez que, mais ativos podem ser negociados de forma adequada (diluição de risco, maior

36 O ativo pode ser tanto um fluxo de recebimentos como um bem ou um direito de qualquer ordem (desde que possa ser cedido e gerar renda).

37 Enquanto no financiamento tradicional os bancos atuam como intermediário entre o agente deficitário e o superavitário, sendo, nesse caso, o verdadeiro financiador da operação, via mercado de capitais, os bancos exercem diferentes funções: emissor, avaliador, depositário, estruturador, entre outras. 
liquidez dos ativos) o papel dos intermediários mudou. Em linhas gerais, a distinção entre títulos e empréstimos vem se atenuando, já que empréstimos podem ser transformados em títulos. Assim, os bancos têm sido participantes chaves nesse processo em andamento, tanto como fornecedores de ativos a serem securitizados, como investidores em títulos lastreados em ativos imobiliários, ou em geral, e derivativos desses títulos (PHILLIPS, 1996).

Segundo CAMINHA (2005), o próprio mercado imobiliário foi a base do nascimento das operações de securitização no Estados Unidos nos anos 70. Naquela época, a demanda por recursos para financiamento à habitação e a pouca oferta de capitais, fizeram com que o mercado buscasse mecanismos alternativos de financiamento. No Brasil, apesar de estruturar operações de exportação ao final da década de 80, foi somente nos anos 90, com o financiamento de projetos imobiliários, que a securitização iniciou seu desenvolvimento e, em decorrência, o incipiente processo de amadurecimento do mercado de real estate. No Brasil, diferentemente do ocorrido nos Estados Unidos, a securitização, apesar de ter também como alvo o mercado imobiliário, o foco se deu inicialmente em financiamentos de projetos de centros comerciais.

Por meio da securitização, ativos originalmente sem liquidez, caso dos imóveis corporativos, em especial os concebidos nos contratos BTS e os negociados nas transações de SLB, podem ser alocados no mercado de capitais, onde há possibilidade de serem negociados. Isso pelo fato de que, via mercado de capitais essa transação, conforme ROCHA LIMA (1999), produz dois efeitos - [i] a quebra da rigidez do mercado imobiliário e [ii] o alargamento da base para captação de recursos, pela diminuição da unidade de investimento (não mais na unidade do ativo imobiliário, mas no vetor de investimento securitizado associado ao ativo - como as Quotas e os CRI). Isso confere aos agentes do mercado imobiliário, equacionamentos de fundos em condições compatíveis com o vulto e prazo de recuperação dos investimentos para a implantação de imóveis corporativos, garantindo assim uma ação mais contínua no mercado, em razão da antecipação do retorno (fluxo de recebíveis) e, por consequência, aumentando a disponibilidade desses imóveis para locação, para realização das mais diferentes atividades operacionais (logística, produção, administrativa, etc.).

A Figura 4 ilustra, de forma genérica, o mecanismo das operações de securitização. 


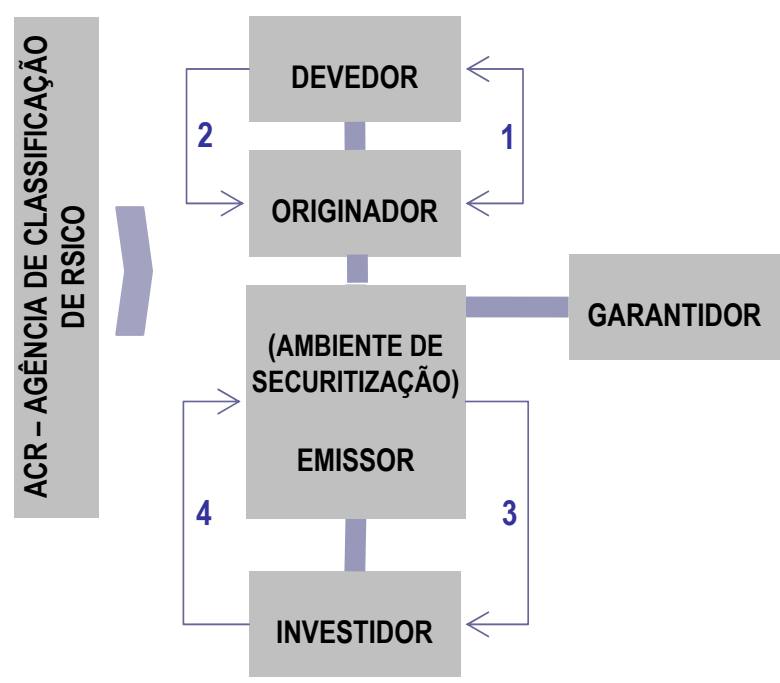

Figura 4 - Mecanismo Genérico de uma Operação de Securitização

\begin{tabular}{|c|c|}
\hline \multicolumn{2}{|r|}{ Definição dos agentes envolvidos nas operações de securitização } \\
\hline Originador & $\begin{array}{l}\text { Empreendedor/Investidor (proprietário do ativo) que negocia com o Devedor a construção (caso } \\
\text { de um BTS ou de novos imóveis corporativos) ou compra (SLB) do empreendimento. }\end{array}$ \\
\hline Devedor & Ocupante do empreendimento (corporações). \\
\hline Garantidor & $\begin{array}{l}\text { Entidade Financeira que oferece garantias colaterais para proteger os direitos dos investidores } \\
\text { dos títulos (como garantia do fluxo de recebíveis no caso de inadimplência do Devedor). }\end{array}$ \\
\hline Ambiente da Securitização & $\begin{array}{l}\text { SPE - empresa formada por sua controladora (Originador) com o objetivo específico de } \\
\text { transformar os recebíveis em títulos securitizados ou Fll. }\end{array}$ \\
\hline Emissor & $\begin{array}{l}\text { Agente financeiro que emite os títulos ou quotas para o mercado (bancos múltiplos ou bancos } \\
\text { de investimento, sociedades corretoras e distribuidoras). }\end{array}$ \\
\hline Investidor & $\begin{array}{l}\text { Indivíduo ou instituição que aplica recursos nos diferentes mercados (financeiro, de capitais) } \\
\text { com a expectativa de ganhos financeiros }\end{array}$ \\
\hline $\begin{array}{l}\text { Agência de Classificação } \\
\text { de Risco }\end{array}$ & $\begin{array}{l}\text { Agente responsável pela análise e classificação do risco da operação (devedor, emissor e } \\
\text { originador), com objetivo de orientar os investidores quanto à qualidade dos títulos emitidos. }\end{array}$ \\
\hline
\end{tabular}

O mecanismo da operação, em linhas gerais, segue a seguinte lógica, utilizando para descrição as transações analisadas neste trabalho (implantação e compra de imóveis corporativos):

[i] o devedor negocia com o originador a implantação do imóvel (ou compra - no caso do SLB) juntamente com o compromisso de locação do imóvel por longo prazo (Contrato de Locação);

[ii] o originador ${ }^{38}$ que possui o ativo a ser securitizado, que pode ser tanto o próprio bem,

38 Caso o originador seja um FII, que já é o ambiente da securitização, o próprio FII faz o papel também do emissor das Quotas. 
como o direito de recebíveis, correspondente ao fluxo de aluguel pago pela corporação durante o ciclo operacional, transfere esse ativo para a SPE ${ }^{39}$. A SPE é uma sociedade, sem atividade operacional, criada exclusivamente para segregar o ativo a ser securitizado, e transformá-lo em títulos. Segundo ROCHA LIMA (2001), no Brasil, os instrumentos para securitização de portfolio de base imobiliária são os títulos emitidos por $\mathrm{SPE}^{40}$, ou as quotas, dos FII, nesse último caso o ambiente que segrega o ativo é o fundo - FII;

[iii] no ambiente da SPE são emitidos os Títulos, ou no caso de um fundo, as Quotas. O vetor de investimento securitizado é exposto ao mercado para aquisição por parte dos investidores interessados (caso dos investidores institucionais, por exemplo). Durante a operação esses investidores receberão a remuneração pelo investimento nos papéis, assim como, nos casos dos CRI, a amortização do investimento, em prazo também acordado nas descrições dos títulos;

[iv] o pagamento pelos Títulos (ou Quotas) que ingressam na SPE servem para quitar o empréstimo ponte feito pelo originador para implantação do imóvel (ou compra), constituindo assim parte importante do equacionamento de fundos, e antecipação dos recebíveis, garantindo assim a alavancagem do investimento e a ação mais contínua desses originadores no mercado de real estate, em especial para empreendimentos de base imobiliária.

Para garantir maior segurança e transparência da operação existem - [i] as Agências de Classificação de Risco, responsáveis pelas análises e classificações de risco das operações (no que diz respeito ao risco de crédito do devedor), com objetivo de orientar os investidores quanto à qualidade dos títulos emitidos, e [ii] o Garantidor, entidade financeira que oferece garantias colaterais para proteger os direitos dos investidores dos títulos, assim, no caso de inadimplemento do Devedor, o fluxo de recebíveis (pagamento dos aluguéis) está garantido.

Diferentemente das operações de financiamento tradicional, as quais as instituições absorviam todo o risco, sustentando o ativo em seu balanço e alocando capital próprio para fazer face a ele, o financiamento via mercado de capitais dispersa os riscos, uma vez que permite a cada investidor decidir o quanto de risco deseja assumir em cada empreendimento, já que a captação de recurso é fracionada por meio de Títulos (CRI) e Quotas. Além disso, os investidores adquirem uma posição de base imobiliária por meio de um instrumento de

39 Nessas operações o originador segrega de seu patrimônio geral (alienação fiduciária) determinado ativo em uma SPE.

40 CRI - Certificado de Recebíveis Imobiliário ou Debêntures. 
investimento com circulação de mercado mais ágil do que se retivesse diretamente a propriedade.

Essas operações de securitização de investimento de base imobiliária tiveram início em 1993, com a criação dos Fundos de Investimento Imobiliário pela Lei 8.668/93 e, posteriormente, em 1997, com a instituição do SFI - Sistema de Financiamento Imobiliário (Lei 9.514/97) que criou o CRI - Certificado de Recebíveis Imobiliários como instrumento de investimento, e regulamentou as Companhias Securitizadora de Créditos Imobiliárias como agente emissor desses títulos. Essa lei disciplina a securitização de ativos imobiliários, inclusive prevê a possibilidade de instituição de regime fiduciário sobre os créditos afetados a uma emissão, de modo a segregá-lo completamente do patrimônio da companhia securitizadora ${ }^{41}$.

As autoridades reguladoras têm se empenhado na formalização e disciplina dessas operações, visando o seu amadurecimento e desenvolvimento. Em 2001 uma nova Medida Provisória (2.221/01), que passou a ser lei em 2004 (Lei 10.931/04), criou o Patrimônio de Afetação, para reduzir o risco de insolvência e do adquirente desses títulos, que obriga a empresa incorporadora a separar o seu patrimônio geral do patrimônio referente a cada empreendimento específico, assim, cada um passa a ser uma sociedade de geração de receitas e despesas que se deve auto-sustentar, protegendo o risco de cada um, dos ricos dos outros empreendimentos, assim como da própria empresa incorporadora.

Para simplificar o processo de securitização, já em 2004 uma nova Lei (10.931/04) determinou que os próprios agentes financeiros pudessem operar a securitização, não havendo a necessidade da companhia securitizadora. Porém, pela emissão de títulos nominativos, chamado de - Letras de Crédito Imobiliário (LCI) - lastreados em créditos imobiliários garantidos por hipoteca ou alienação fiduciária de coisa imóvel.

Até mesmo o Governo Federal tem estimulado o crescimento desse mercado. Em 2004 pela Lei 11.033/04, as letras hipotecárias, as Quotas de FII e os Títulos (CRI) são isentos de imposto de renda para investidores - pessoa física. Em 2008, uma nova instituição criada pela Comissão de Valores Mobiliários - (CVM - 472 de 10 de outubro) permite que os FII invistam, além de imóveis, em ações de empresas de real estate listadas na Bovespa, quotas de

41 O negócio fiduciário também foi exigido pela Lei $8.668 / 93$ que regulamenta os FII. A administradora do fundo age como se fosse proprietário do bem nele segregado, mas sem que esse se misture ao patrimônio da administradora, sendo efetivamente uma modalidade de patrimônio separado. 
outros FII, em CRI, quotas de outras SPE, aguçando o interesse de instituições financeiras, inclusive os bancos de varejo, na composição de FII.

As vantagens mencionadas justificam o motivo do amadurecimento do mercado imobiliário no Brasil a partir de meados da década de 90, e em decorrência, o ambiente favorável à reestruturação do real estate corporativo, permitindo as corporações promoverem a desmobilização dos seus ativos imobiliários e, também, a não imobilização para as novas necessidades de espaço (até mesmo para imóveis específicos e de baixa liquidez).

O ambiente favorável para essa reestruturação se deu visto a - [i] maior disponibilidade, pela melhor viabilidade, do ingresso de poupanças para investir em imóveis corporativos, advinda, agora, daqueles que almejam esse tipo de investimento, como investidores institucionais ${ }^{42}$, e [ii] a maior oferta de espaços corporativos a preços admissíveis aos ocupantes, não só pelo próprio aumento da oferta e dos agentes do mercado imobiliário, interessados em conceber imóveis corporativos (ou comprar imóveis prontos para desmobilização patrimonial das corporações), como também, pela melhor estruturação financeira das operações, que via mercado de capitais, permite a esses agentes equacionamentos de fundos mais adequados, a partir da antecipação dos recebíveis, refletindo por outro lado também em melhores preços de locação e maior profissionalismo às corporações usuárias dos espaços corporativos.

A maturação do mercado financeiro e de capitais, que por um lado favorece a flexibilização de meios para captação de recursos para investimentos, pode também desequilibrar o sistema financeiro se não for bem regulamentada e controlada. Este desequilíbrio no mercado financeiro levou a um dos maiores acontecimentos da história, a Crise Financeira Mundial, que afetou a economia de todos os países, inclusive do Brasil.

A crise financeira mundial, também chamada de crise do subprime, teve sua origem no mercado de crédito norte americano, que em 2007 já não conseguia arcar com o saldo negativo dos investimentos imobiliários, em decorrência da inadimplência e da desvalorização dos imóveis e dos ativos financeiros associados às hipotecas americanas de alto risco, chamadas de subprime.

Entretanto, a crise só foi de fato percebida em setembro de 2008, quando no dia 7 o governo

Os investidores institucionais constituem-se os mais importantes participantes dos mercados financeiros e de capitais, visto que administram a imensa massa de recursos captados junto a seus públicos. São eles: Fundos de Pensão e Entidades de Previdência Privada, Fundações de Seguridade Social, Fundos de Investimento, Companhias de Seguro e Capitalização e Companhias de Investimento. 
norte americano anunciou a estatização do Freddie Mac e da Fannie Mae, duas instituições apoiadas pelo governo, que garantiam cerca de $3 / 4$ das hipotecas nos Estados Unidos, com passivos totais de US\$ 5,4 trilhões. A situação se agravou mais ainda quando no dia $10 \mathrm{o}$ Lehman Brothers anunciou prejuízo recorde de US\$ 3,9 bilhões, desencadeando no pedido de falência. A partir de então a estrutura do sistema financeiro internacional mudou de forma permanente. O principal insumo do sistema financeiro, que é a confianças das instituições, desapareceu do mercado (IPEA - Carta de Conjuntura, dezembro de 2008).

São diversos os fatores que, em conjunto, levaram a crise financeira mundial. Os contratos de financiamento nos Estados Unidos permitem amortização dos empréstimos imobiliários a partir do terceiro ano, sendo até então pago apenas os juros. Ao contrário do Brasil, as taxas de juros são flutuantes e menores nos primeiros anos. Com taxas de juros reais negativas e expectativa de elevação dos preços dos imóveis, os mutuários se estimularam a ingressar em financiamentos acima da sua capacidade de pagamento, já que havia esperança de elevação de preços dos imóveis no mercado, sendo possível refinanciar o imóvel, quitando o antigo financiamento e contratando um novo em valor superior. Isso levou a uma crescente demanda por imóveis, contribuindo para a elevação dos preços. A partir de 2003, iniciam-se as operações de empréstimos imobiliários para o segmento subprime, que são concedidos a mutuários sem comprovação de renda e histórico de crédito duvidoso.

Em 2006, com a elevação da taxa de juros pelo Federal Reserve System (FED), acima da inflação, a inadimplência desses empréstimos cresceu aceleradamente. Como boa parte dos contratos de financiamento imobiliários apresentava como colateral o valor do imóvel, a hipótese de o valor de mercado cair para abaixo do saldo devedor estimulou os mutuários a entregarem os imóveis ao credor (bancos), aumentando a quantidade de imóveis à venda e impulsionando a queda de preços.

Tudo isso, ocorrendo em um ambiente com falta de regulação dos mercados financeiros, provocou o 'efeito dominó' que encadeou na crise. Isso porque, as instituições financeiras concediam empréstimos imobiliários e emitiam títulos lastreados por essas hipotecas, incluindo operações subprime. Esses ativos eram então comprados por investidores privados e negociados no mercado secundário, que já não tinham mais conhecimento da estrutura de risco dos títulos. Os bancos de investimento, por exemplo, não eram obrigados a adotar as práticas recomendadas pelo acordo de Basiléia II, levando aos altos índices de alavancagem nas operações.

Estes fatores favoreceram o surgimento da bolha de preços dos imóveis. Conforme dados da 
carta de conjuntura do IPEA (2008), o valor das novas hipotecas residenciais, que era cerca de US\$ 1 trilhão/ano na média do período de 2004-2006, caiu para US\$ 600 bilhões no segundo semestre de 2007, chegando a virtualmente zero no segundo trimestre de 2008. Em meados de 2007, os prejuízos potenciais com o mercado de subprime passam a ficar evidentes, provocando a queda de preço dos imóveis. Com a queda de preço, os investidores dos títulos lastreados por essas hipotecas tentavam se desfazer deles, levando os preços mais para baixo.

Como efeitos da crise destacam-se a forte retração dos investimentos nos diferentes setores da economia, a redução da oferta de crédito pelas instituições financeiras, e a dificuldade de acesso de capitalização via mercado de capitais, levando a falta de liquidez das empresas de diversos setores, inclusive para as empresas de real estate, em especial as de capital aberto.

Após setembro de 2008, os índices das principais bolsas do mundo sofreram forte queda, que encadeou no abalo das poupanças das empresas e famílias, impactando o consumo e os investimentos. Associado ao maior grau de incerteza em nível global, veio a redução do fluxo de investimentos estrangeiros, que em situações de risco, tendem a migrar seus recursos para ativos mais sólidos, tais como os títulos do tesouro norte americano.

É ainda nesse cenário que houve um crescimento durante o ano de 2008 em concessões de crédito para pessoa jurídica. Os efeitos da crise demoraram a refletir nos mercados brasileiros, principalmente pelas baixas exposições dos fundos de investimento brasileiros em ativos 'podres' internacionais e da boa condição de solvência dos bancos comerciais (IPEA - Carta de Conjuntura, dezembro de 2008). Conforme dados publicados em dezembro de 2008 pela Revista de Conjuntura do Conselho Regional de Economia do Distrito Federal, apesar da crise financeira mundial, verificou-se que em dezembro de 2008 o volume total de oferta de crédito do Sistema Financeiro Nacional (SFN) atingiu cerca de R\$ 1,23 trilhão, volume este equivalente a $41,3 \%$ do PIB, nível recorde, como pode ser observado no Gráfico 4 apresentado (Operações de Crédito Total 'vs' PIB).

Já no final de 2009 e início de 2010 observa-se uma recuperação da economia, com crescente aceleração dos investimentos, que estavam estagnados em 2008 até meados de 2009. O acesso ao mercado de capitais como fonte de captação de recursos volta a crescer, haja vista o volume de operações de FII e CRI que cresceram mais de 190\% no final de 2009, em relação ao fechamento de 2008 , e mais de $116 \%$ em relação ao fechamento das ofertas registradas em 2007 (conforme apresentado a seguir no Quadro 3). 


\subsubsection{A velocidade do avanço tecnológico}

Além dos fatores influenciadores da reestruturação do real estate nas corporações já citados, associa-se também a velocidade do avanço tecnológico.

A velocidade com a qual a tecnologia muda tem reduzido o ciclo de vida de muitos produtos. Não seria diferente com os imóveis corporativos. A década de 70 pode ser considerada um marco importante da evolução tecnológica nos imóveis comerciais - os sistemas HVAC (ventilação e ar-condicionado) deram início ao controle eletrônico dos sistemas prediais. No início dos anos 80, apareceram as tecnologias de automação, de segurança e iluminação. Em 1984, foi construído em Nova York, pela companhia AT\&T, o edifício que incorporava os princípios de flexibilidade e os mais avançados sistemas de automação e telecomunicações existentes da época.

A abertura de mercado, no início da década de 90, promoveu um intenso processo de reestruturação nas organizações por conta das inovações tecnológicas, gestão da qualidade e do conhecimento e, das novas relações de trabalho, em busca de competitividade e resiliência. Esse ambiente de mudança requer flexibilidade em todos os recursos demandados na operação, inclusive no espaço.

Em 1992, com o fim da reserva de mercado de informática no Brasil, a concepção de empreendimentos passou a envolver um crescente número de sistemas de monitoramento predial informatizados, que suportam o conceito hoje conhecido como - edifício inteligente.

Com as novas tecnologias de telecomunicação, sistema wireless, o ambiente de trabalho vai além da fronteira limite do edifício, isso impacta, no layout, na infraestrutura dos espaços, entre outras características do ambiente produtivo.

Segundo EDWARD e ELISSON (2004) os espaços corporativos precisam responder às mudanças, em prazos, não maiores, que cinco a dez anos, sendo a flexibilidade fator determinante na escolha dos empreendimentos. Isso tem influenciado a reestruturação do real estate corporativo ao longo das últimas duas décadas. Por conta dessa acelerada obsolescência tecnológica dos espaços e das novas relações de trabalho, as corporações têm preferido não ser proprietárias de imóveis, principalmente daqueles que se tornam obsoletos mais rapidamente, e que não são considerados estratégicos à operação, caso dos edifícios de escritório, onde se localizam as sedes administrativas de muitas corporações. Sendo locatária, existe a facilidade da corporação, ao final do contrato, procurar no mercado um outro espaço que atenda a sua nova demanda funcional, além de eliminar o risco de desvalorização na 
ocasião da venda, em razão da obsolescência relativamente aos novos espaços corporativos expostos no mercado.

Neste capítulo foram descritos os possíveis fatores que exerceram influência às decisões pela imobilização e desmobilização dos imóveis corporativos ao longo dos anos, partindo-se da década de 60 até os dias atuais (2010). A estruturação dessas informações está apresentada nos quadros demonstrados a seguir. A linha do tempo foi dividida em dois períodos de contextos bastante distintos no que concerne às decisões em relação ao real estate corporativo - da década de 60 até 1990, e dos anos 90 a 2010. 
- Instabilidade econômica (altas taxas de juros e inflação)

- Crescimento econômico (embora as corporações apresentassem baixa eficiência)

- Reserva de mercado (estímulo à produção nacional)

- Ausência de mecanismos de financiamento e crédito sustentáveis (custo do crédito e prazo de amortização)

- As grandes corporações que se instalaram no Brasil nas décadas de 50 e 60 tiveram que desenvolver seus próprios processos internamente por conta da incipiência do mercado interno fornecedor (investimento com instalações e espaços para crescer e atender demanda)

- Proteção de Capital (imóveis - reserva de capital)

- Grande capital imobilizado $\rightarrow$ Baixa liquidez
- Baixa oferta de imóveis

- Imóveis disponíveis dispersos em poder de investidores incipientes do mercado imobiliário (imóveis adquiridos com recursos próprios como reserva de capital)

- Ausência de corporações especializadas em prospecção e administração de imóveis

- Dificuldade de negociação de contratos (diversos proprietários de um único espaço corporativo)

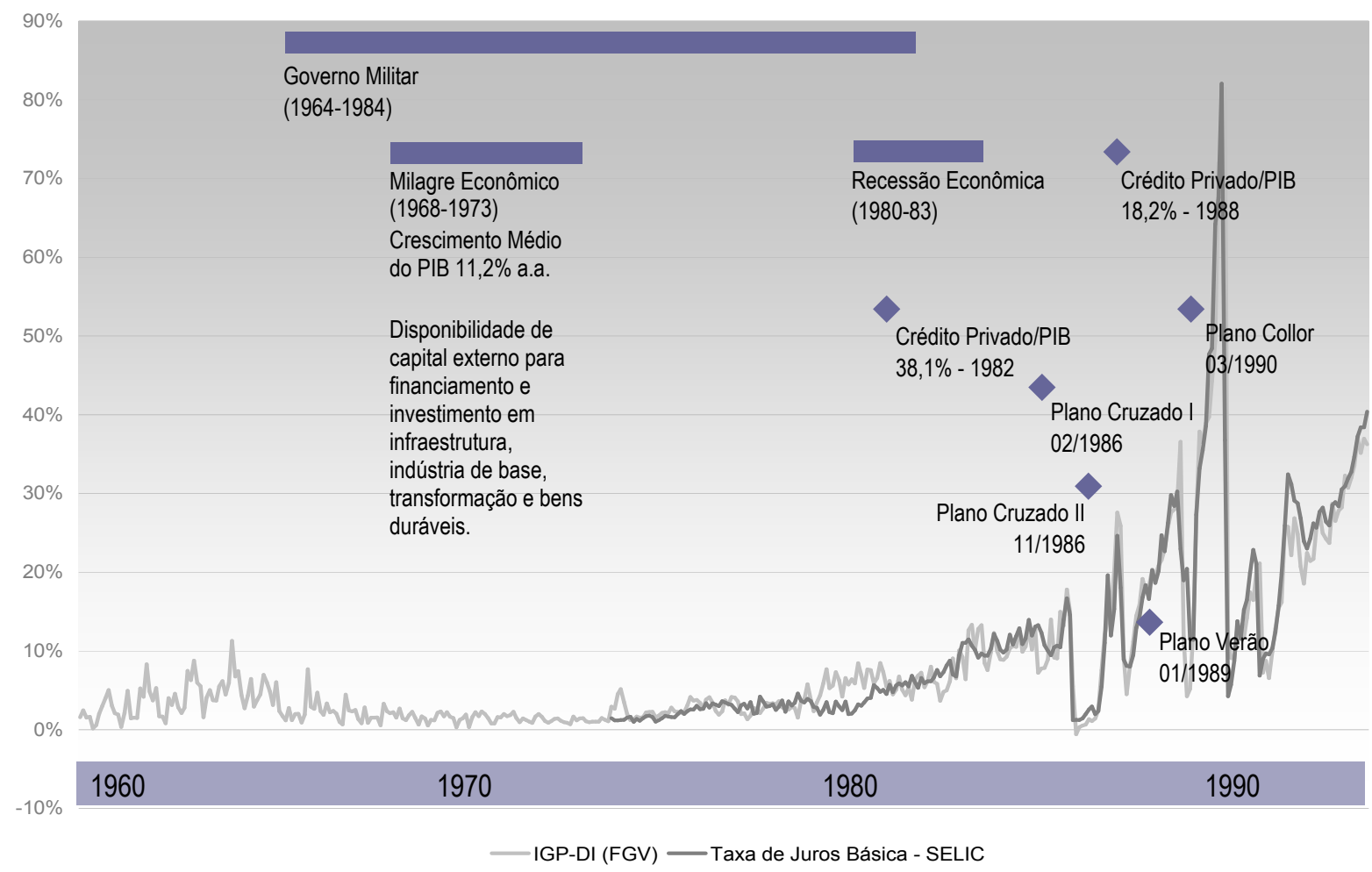

Quadro 2 - Evolução Histórica - Fatores Influenciadores da Reestruturação do Real Estate Corporativo Período: 1960 a 1990 


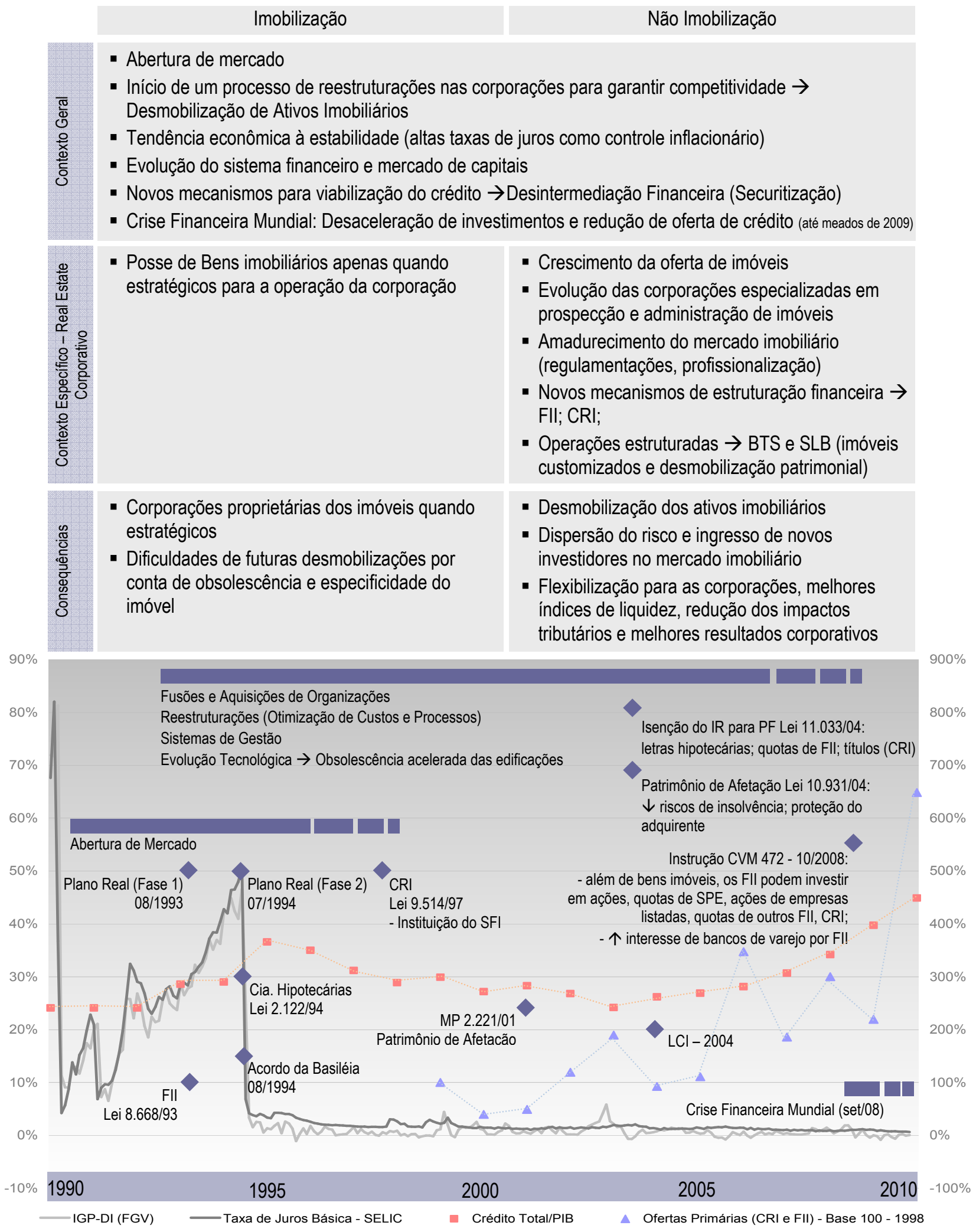

Quadro 3 - Evolução Histórica - Fatores Influenciadores da Reestruturação do Real Estate Corporativo Período: 1990 a 2010 


\section{DECISÃO PELAS OPÇÕES DE LOCAÇÃO OU PROPRIEDADE DO REAL ESTATE CORPORATIVO - FATORES INFLUENCIADORES E CRITÉRIOS DE DECISÃO}

Além de ser um dos recursos demandados na operação de uma corporação, o real estate pode ser um ativo estratégico para o seu desempenho. Decisões em relação ao real estate corporativo não podem ser tomadas apenas sob vistas do planejamento financeiro, mas sim, incluir na análise critérios que considerem aspectos operacionais e estratégicos para cada um dos imóveis utilizados na operação. Esses aspectos operacionais e estratégicos é que garantem o alinhamento das necessidades da corporação com o recurso real estate. É dessa maneira que o real estate irá suportar com eficiência a atividade principal e promover produtividade e vantagem competitiva.

Um dos principais motivos pela opção de não imobilização - ou seja, locação dos espaços - é a canalização dos recursos na atividade principal, que em muitos casos, tem rentabilidade superior ao investimento em real estate. No entanto, cada uma das [alternativas] - tanto as de não imobilização como a de imobilização, atende distintamente as necessidades operacionais e estratégias da corporação. Dessa forma, antes de iniciar a apreciação para decisão do uso de cada uma das [alternativas] do [MAOI], torna-se necessário apresentar as necessidades a serem consideradas na análise e os seus respectivos atributos.

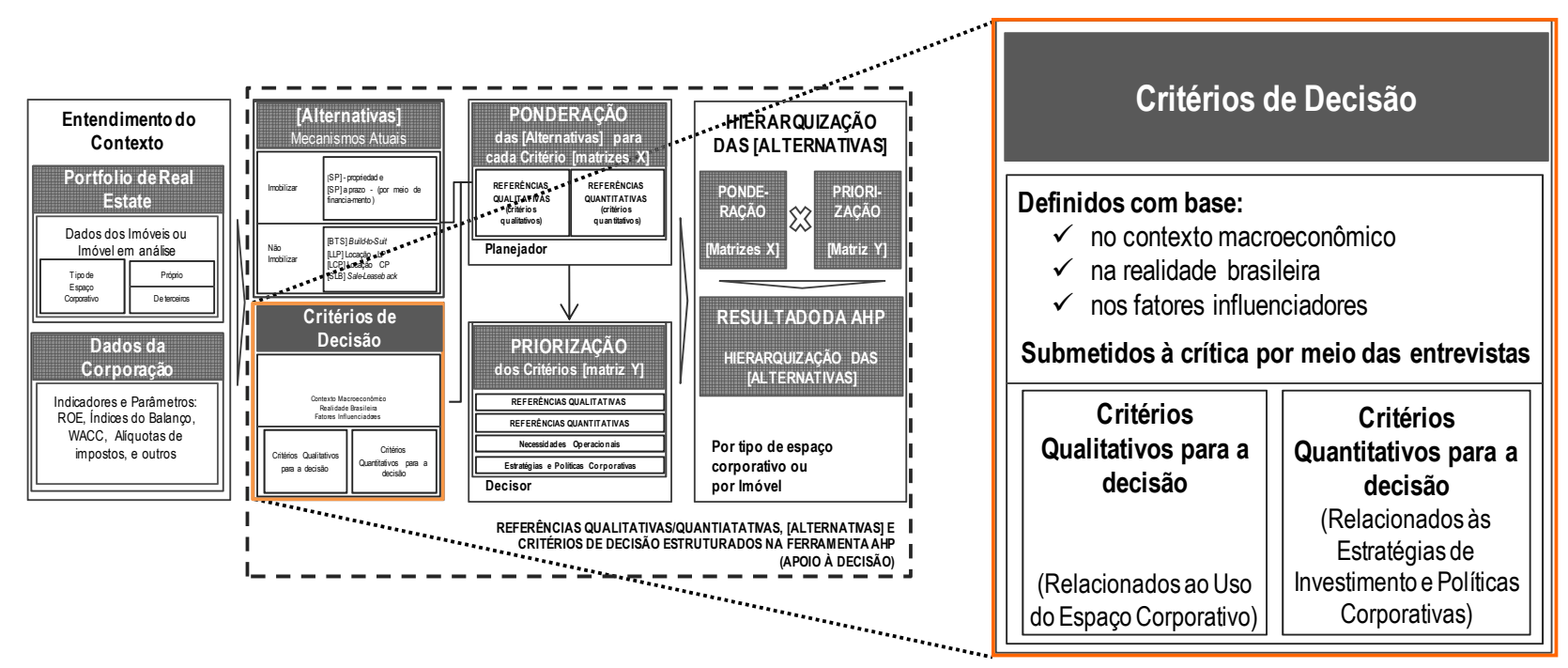

Figura 5 - Definição dos Critérios de Decisão (rotina do [MAOI]) 
O propósito deste capítulo (conforme Figura 5) é discutir sobre os fatores influenciadores da decisão por imobilizar ou não no ativo imobiliário, assim como, apresentar as necessidades operacionais e estratégias consideradas nas decisões em relação ao recurso real estate, as quais direcionam a proposta dos critérios de decisão estipulados para o [MAOI].

Para identificação das necessidades corporativas e dos critérios de decisão, além da revisão bibliográfica foram feitas entrevistas estruturadas em corporações de diferentes setores, com expressivo portfolio de imóveis utilizados na operação, e com distintas estratégias em relação ao recurso real estate. Sendo assim, participaram do levantamento de campo: duas indústrias automobilísticas (uma de fabricação de veículos comerciais e outra de automóveis e veículos comerciais), duas indústrias químicas (uma de fabricação de aromas e outra de tintas, plásticos e outros produtos), uma rede de supermercado, uma empresa seguradora, uma rede de fast-food, uma empresa de automação e tecnologia (produtos e serviços), uma empresa de telecomunicação, e uma instituição financeira privada, totalizando dez corporações ${ }^{43}$. A partir das entrevistas foi possível validar os critérios de decisão propostos inicialmente com base na revisão bibliográfica, assim como, levantar outros critérios e informações importantes à decisão em análise.

Com propósito de identificar as práticas prevalentes de mercado (apresentadas no Capítulo 5), ou seja, as negociações contratuais entre ocupantes (corporações) e proprietários (investidores), e as estratégias usualmente observadas no âmbito corporativo em relação ao real estate a depender do tipo de espaço corporativo, foram feitas entrevistas estruturadas nas empresas que atuam na área de real estate, escolhidas pela significativa presença e atuação no mercado de locações de imóveis corporativos no Brasil, sendo elas: Jones Lang LaSalle, Hines, CB Richard Ellis, Walter Torre, Banco Pátria - Real Estate, e da área de direito imobiliário a Almeida Bugelli e Valença Advogados Associados, totalizando seis empresas [ERE] e sete entrevistas ${ }^{44}$.

Os principais fatores influenciadores das decisões em relação ao real estate corporativo, identificados por meio da revisão bibliográfica, servem de referência para a proposta inicial dos critérios de decisão do [MAOI]. Desta forma, na medida em que são apresentados estes

43 A pedido das corporações respondentes [CR] não foram citados os nomes.

44 A compilação das informações, a partir das entrevistas nas corporações [CR] e nas empresas de real estate [ERE], para identificação e validação dos critérios de decisão, assim como, das [alternativas] predominantes em cada tipo de espaço corporativo, estão apresentadas no Quadro 4 do item 4.3 deste texto. 
fatores influenciadores no decorrer do capítulo, são introduzidos os critérios de decisão propostos inicialmente. Estes critérios são então submetidos à crítica nos questionários das entrevistas estruturadas. Os critérios de decisão definidos para o [MAOI], a partir da proposta inicial e validação por meio do levantamento de campo, estão apresentados no final deste capítulo (Quadro 5 do item 4.3).

\subsection{Fatores Macroeconômicos e dos Mercados de Real Estate na decisão}

Fora do ambiente corporativo e do setor de atuação de cada empresa, a decisão de imobilização ou não no real estate depende também de fatores macroeconômicos do País (inflação e taxa de juros básica da economia brasileira) e de fatores dos mercados de real estate, como os ciclos de oferta e demanda.

\subsubsection{Fatores Macroeconômicos}

A interpretação sobre a evolução histórica dos possíveis fatores influenciadores da reestruturação do real estate corporativo ao longo dos anos nas corporações brasileiras foi apresentada no capítulo anterior. Conhecidos os fatores e a razão de considerá-los na análise sobre - comprar ou alugar um espaço e, continuar proprietária ou desmobilizar seus ativos imobiliários -, no presente, é pertinente considerar na decisão alguns índices econômicos atuais e as suas expectativas adiante.

A depender das expectativas de juros e da inflação, pode-se concluir por cenários mais ou menos favoráveis para escolha pelas opções de locação, ou seja, não imobilização em imóveis, tendo em vista, em função do cenário, a atratividade das oportunidades alternativas de investimento no mercado financeiro (relacionado com os juros) ou na atividade principal das corporações, e a importância de proteção de capital por meio de investimento nos imóveis (relacionado com a inflação - instabilidade econômica).

Atualmente (2010) o cenário mostra-se favorável para a não imobilização ou a desmobilização dos ativos imobiliários das corporações, visto a expectativa de estabilização da taxas de juros básica da economia em patamares abaixo do atual e a estabilidade econômica com baixas expectativas de índices inflacionários. Esse cenário estimula a migração do capital da corporação para o negócio principal, e para os investidores de real estate interessados em investimentos próximos a renda fixa com baixo risco, esse cenário é favorável para investir em imóveis corporativos para renda. A melhora na estabilidade 
econômica, evidenciada no País nos últimos anos e como expectativa adiante, é favorável para o desenvolvimento das corporações e também para a quebra do paradigma da necessidade de reserva de capital por meio de investimentos nos imóveis.

Contudo, a expectativa de queda da taxa de juros pode também estimular as corporações pelo financiamento para construção/aquisição dos novos espaços corporativos demandados na operação (possível tendência já observada pela CB Richard Ellis). Corporações comparam a remuneração a ser paga aos investidores de real estate e as taxas de juros dos financiamentos para construção/aquisição dos imóveis corporativos. Nesse contexto, no entanto, é necessário também avaliar a perda da oportunidade de ganho no negócio principal e os prazos de amortização do financiamento. Quanto menores forem os prazos para amortização do financiamento concedido, mais cedo recursos da empresa são reservados para pagamento da dívida.

Importante ressaltar que esses fatores econômicos, em sua essência, impactam a escolha sob o ponto de vista quantitativo, ou seja, nos indicadores econômico-financeiros que sustentam a decisão e, portanto, serão considerados no modelo de simulação.

\subsubsection{Mercados de Real Estate}

Períodos de expansão, contração, recessão e recuperação podem se suceder, configurando os denominados ciclos dos mercados de real estate, que derivam do equilíbrio dinâmico da oferta e demanda dos espaços corporativos. Esses ciclos são um dos fatores influenciadores na decisão.

De acordo com o período, os valores de mercado dos imóveis apresentam valorização ou desvalorização. Na expansão, os preços de mercado dos imóveis tendem a valorizar, assim como os preços dos aluguéis dos espaços corporativos. Por outro lado, na contração, os preços dos imóveis e dos aluguéis tendem a apresentar queda.

Assim, tratando-se de períodos de recessão do mercado, caracterizado pela oferta maior do que a demanda por espaços ${ }^{45}$, pode-se indagar três possíveis estratégias no real estate das corporações - [i] os preços dos aluguéis desses espaços em queda podem estimular as

45 Os ciclos dos mercados de real estate variam de acordo com a tipologia do empreendimento e com a localização. Em um mesmo momento, para uma certa tipologia, por exemplo, edifícios de escritório na cidade de São Paulo, o mercado pode apresentar-se saturado, enquanto que para outra, como galpões logísticos, em aquecimento. 
corporações pela locação dos novos espaços demandados; [ii] as corporações, em contrapartida, podem aguardar a venda dos seus ativos imobiliários no momento de uma valorização do imóvel; e [iii] a depender das perspectivas de longo prazo nas necessidades da corporação em relação ao uso dos espaços demandados no momento da desvalorização, a corporação pode optar pela compra do ativo, levando em consideração a oportunidade de ganho na compra e o alinhamento das necessidades operacionais com a opção de ser proprietária, como expectativa de uso do imóvel no longo prazo, controle sobre o uso do espaço durante a operação, entre outras.

Em relação aos riscos, derivados dos mercados de real estate, quando proprietária dos imóveis, a corporação está exposta ao risco de desvalorização do ativo. Em contrapartida, quando locatária, há o risco de oscilação no valor cobrado pelo aluguel. Conforme Lei do Inquilinato, Art. 18, é lícito às partes (locador e locatário) fixar, de comum acordo, novo valor para o aluguel, bem como inserir ou modificar cláusula de reajuste. No entanto, conforme Art. 19, não havendo acordo, o locador ou locatário, após três anos de vigência do contrato ou do acordo anteriormente realizado, podem pedir revisão judicial do aluguel, a fim de ajustá-lo ao preço de mercado ${ }^{46}$. Sendo assim, em primeira análise, quando a corporação é locatária ainda há uma maior proteção a variações derivadas da situação dos mercados de real estate, evidenciada pelos ciclos de oferta e demanda de cada tipologia.

A partir das entrevistas nas corporações [CR] verificou-se que embora o risco de desvalorização do valor de mercado do imóvel exista, isso não é um fator decisor nas situações em que a corporação opta por ser proprietária do imóvel. Isso ocorre em razão da expectativa de uso do imóvel ser no longo prazo, pela importância do imóvel e do investimento imobilizado no espaço (caso das unidades produtivas, por exemplo).

Outro fator de variações nos valores de mercado é o avanço da tecnologia e da automação que tem aumentado, notadamente, o risco de obsolescência das edificações. A obsolescência implica na desvalorização do valor de mercado do imóvel caso não sejam feitos os investimentos para repor a qualidade da edificação no novo patamar de demanda funcional imposto pelo mercado. Quando locatária a corporação transfere esse risco ao proprietário do

46 Nos contratos das operações estruturadas, como no BTS, o que se observa como prática de mercado é um acordo entre as partes para renunciar o Art. 19 da Lei do Inquilinato referente à revisional do valor do aluguel. Apenas há o reajuste anual do valor do aluguel pelos índices de variação de preço (como: IGP-M, IPCA) durante toda vigência do prazo contratual. Os motivos dessa ocorrência serão discutidos no item 5.3.2 (Capítulo 5). 
imóvel. Na ocasião da expiração do prazo contratual, a corporação pode procurar no mercado por um novo espaço que atenda sua nova demanda funcional. Essa ocorrência foi observada principalmente nos casos das sedes administrativas e dos escritórios em geral utilizados pelas corporações. Os edifícios de escritório expostos no mercado para locação estão mais sujeitos a obsolescência funcional, quando comparados aos espaços fabris, por exemplo. Sendo assim, ao optar pela locação da sede a corporação tem maior flexibilidade de mudar e ocupar os espaços mais modernos do mercado, se essa for a intenção (importância da imagem corporativa traduzida pelo edifício ocupado).

É, contudo, escolha de cada corporação, optar entre o risco de desvalorização do imóvel quando esse não for mais demandado na operação, ou pelo risco de negociar novos preços de aluguel em um futuro mercado de locação desconhecido. Essa escolha está diretamente relacionada com o horizonte esperado para uso do espaço em análise e com a importância desse ativo para o desempenho da operação.

\subsection{Fatores Relacionados ao Setor de Atuação das Corporações e Ambiente Interno na Decisão}

A decisão por investir nos imóveis relaciona-se também aos aspectos vinculados com o ambiente de cada empresa, como - a dinâmica do seu setor de atuação e o seu grau de maturidade, que conferem maior ou menor dinamismo às mudanças. Para os fatores relacionados diretamente com cada imóvel em análise, considera-se: [i] a importância do imóvel na operação da corporação, [ii] a tipologia e especificidade do imóvel, e [iii] a importância da tradução da imagem corporativa por meio do espaço ocupado. Para os fatores relacionados às estratégias e políticas de cada corporação, considera-se: [i] proteção do capital, [ii] diversificação de investimentos, [iii] canalização dos recursos em oportunidades do negócio principal, [iv] desoneração do balanço, [v] redução dos impactos tributários, e [vi] montante de capital de giro levantado com a desmobilização de ativos imobiliários.

Compreendida a importância desses fatores na decisão, que se relacionam às necessidades operacionais a serem atendidas durante o uso dos espaços e as estratégias e políticas de cada corporação, estipula-se os atributos relevantes para a escolha entre as [alternativas] contemplados no [MAOI]. 


\subsubsection{Dinâmica das mudanças no ambiente corporativo}

A dinâmica das mudanças nas necessidades dos espaços corporativos é um dos aspectos mais importantes na decisão por comprar ou locar os espaços. Esse dinamismo é reflexo de dois principais fatores - primeiro, o grau de maturidade da corporação e, segundo, o setor de atuação. Corporações mais recentes estão mais vulneráveis as incertezas quanto à aceitação pelo público alvo dos seus produtos ou serviços quando expostos no mercado e, portanto, mais facilmente vulneráveis a alterações na necessidade de espaços corporativos. A própria dinâmica do setor de atuação faz também com que as corporações se adaptem com uma periodicidade diferenciada para manterem-se competitivas no mercado. Essa periodicidade está diretamente relacionada com as forças externas da corporação, que são mais ou menos intensas de acordo com o setor.

O conceito de PORTER (1998) sobre as forças externas de uma corporação é conhecido nas diferentes áreas de planejamento. PORTER (1998) define cinco forças, sendo elas: ameaça de novos concorrentes potenciais, ameaça de produtos ou serviços substitutos, poder de negociação com fornecedores, poder de negociação com clientes e a rivalidade entre as corporações existentes.

Dependendo do setor a ameaça de produtos substitutos, por exemplo, é maior, como no caso das empresas da área de tecnologia, que se adaptam com mais frequência para atender às novas tendências, isso implica, em muitos casos, em alterações nos espaços corporativos, tanto em quantidade, como adaptabilidade dos espaços e localização. Em relação ao poder de negociação com fornecedores, pode-se citar o caso dos condomínios industriais que são construídos para agregar os fornecedores de uma corporação em um mesmo local, perto da área de produção. Nesse modelo, fornecedores podem praticar preços diferenciados para a corporação em relação ao praticado no mercado, pela redução dos custos com logística e transporte.

Essas forças aumentam, em intensidades e frequência distintas por setor, o dinamismo no ambiente corporativo.

Pesquisa realizada por LASFER $(2003)^{47}$ comprova a influência dos dois fatores ora citados

47 LASFER, Meziane (2003). Driving Shareholder Value - Corporate Real Estate Freehold ' $v$ s' Leasehold, London. Patrocinado por Donaldsons Research. A pesquisa de LASFER teve como amostra 1.500 corporações de UK em média por ano, desenvolvida entre 1989 a 2002, tais como: 
(maturidade da corporação e setor de atuação) para a dinâmica de mudanças nas necessidades dos espaços e, por consequência, na propensão pela opção de locação ${ }^{48}$. Nessa pesquisa o autor constatou que corporações em elevado estágio de crescimento apresentam uma maior propensão para alugar os espaços em comparação às corporações já amadurecidas. Pelos dados encontrados, as corporações com 100\% dos espaços alugados apresentam um crescimento médio no movimento de vendas de $31 \%$ para o período analisado, enquanto a média de crescimento das corporações com nenhum dos espaços sendo alugado foi de $15 \%$. Sobre o investimento em pesquisa e desenvolvimento [P\&D] foi verificado que as corporações com menores porcentagens de espaços alugados investem significativamente menos em [P\&D].

Como possíveis motivos pelo quais corporações em estágio inicial de crescimento preferem locar os espaços utilizados na operação, pode-se citar: [i] a maior imprevisibilidade do fluxo de caixa das corporações, que acabam por inibir o compromisso de pagamento das parcelas de compra do imóvel; [ii] a necessidade intensiva de canalização de recursos (financeiros e humanos) no negócio principal, como investimento em [P\&D] de produtos ou serviços; [iii] na locação há uma menor importância do rating ${ }^{49}$ de crédito da corporação em comparação com a situação de compra do imóvel e, em estágio inicial, a corporação pode apresentar um rating menos favorável para captação de financiamentos, pela própria carência de dados históricos; e [iv] a maior vulnerabilidade por alterações nas necessidades de espaços, em razão da maior incerteza sobre a aceitação do produto ou serviço exposto ao mercado.

Em relação ao setor de atuação, LASFER (2003) constatou a variação na intensidade de locação dos espaços corporativos dependendo do setor, conforme Gráfico 5. Verifica-se que as corporações que atuam em setores mais dinâmicos, como de Tecnologia da Informação (TI), apresentam uma maior propensão pela locação. Na amostra analisada, o autor constatou

corporações de tecnologia da informação, financeiras, serviços, indústrias automobilísticas, de mineração, gás e óleo, varejo, hotel e lazer, entre outras.

EDWARDS e ELLISON (2004) também relacionam a influência do estágio inicial de desenvolvimento da corporação na decisão. Segundo os autores as corporações em estágio inicial optam por locação de curto prazo para ganhar flexibilidade, em razão da falta de conhecimento do mercado e informações para prognosticar as necessidades futuras.

O Rating de uma corporação é a classificação de risco de ocorrer default de suas obrigações financeiras, usada tanto para captação de novos financiamentos no mercado financeiro e de capitais, como para avaliação do risco de investimentos na corporação. Essa classificação, traduzida em uma nota, é feita por agências especializadas, baseando-se na saúde financeira, inclusive no histórico de balanços de exercícios passados da corporação. 
que mais de $50 \%$ das corporações da área de TI locam 100\% dos espaços utilizados na operação. Essa porcentagem cai para pouco mais de 20\% tratando-se das indústrias de base.

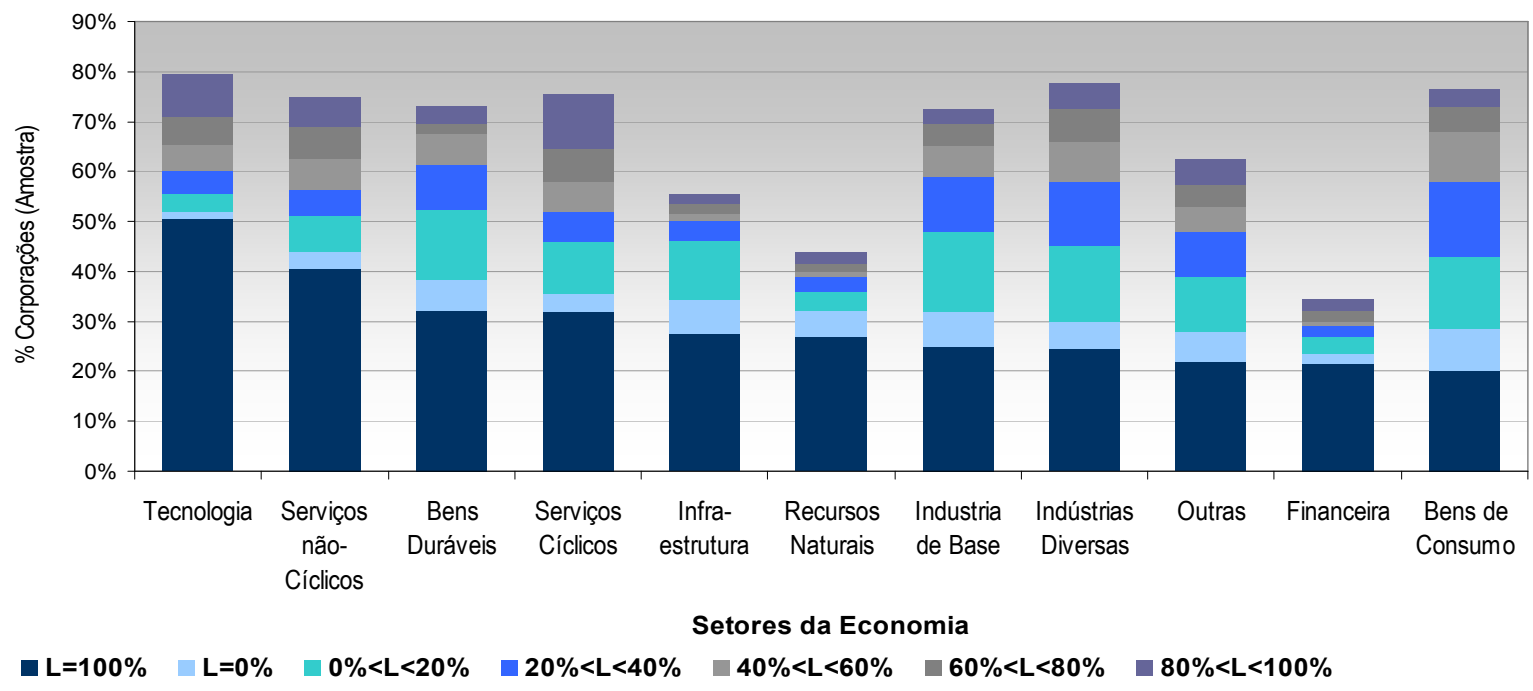

Gráfico 5 - Intensidade de locação dos espaços por setor de atuação ( $\mathrm{L}=$ Relação entre espaço locado e total de espaço ocupado pelas corporações) - Adaptado de LASFER (2003)

\begin{tabular}{l:l}
\hline \multicolumn{2}{c}{ Classificação dos setores da economia da pesquisa de LASFER (2003) } \\
\hline Recursos Naturais & Mineração, Petróleo e Gás \\
\hline Indústria de Base & Química, Construção/Materiais, Papel/Celulose, Siderúrgicas e Metalúrgicas \\
\hline Indústrias Diversas & Aeroespacial e Bélica, Eletro-eletrônico, Máquinas e Equipamentos \\
\hline Bens Duráveis & Automobilística, Eletrodomésticos e Têxtil \\
\hline Bens de Consumo & Bebidas, Alimentos, Higiene Pessoal e Limpeza, Cosméticos, Farmacêutica \\
\hline Serviços Cíclicos & Varejo, Hotelaria, Lazer e Entretenimento, Transporte \\
\hline Serviços Não-Cíclicos & Telecomunicações \\
\hline Infraestrutura & Fornecimento de Água e Energia Elétrica \\
\hline Tecnologia & Hardware, Software e Serviços de Informática \\
\hline Financeira &
\end{tabular}

Quanto maior for esse dinamismo no ambiente corporativo, mais flexibilidade as corporações precisam nos seus recursos de real estate para que esses suportem eficientemente as variações nas necessidades operacionais e, assim, o negócio principal da corporação. Para atender esse dinamismo de forma resiliente, a flexibilidade de mudança ${ }^{50}$ é o atributo determinante na decisão entre ser proprietário dos espaços corporativos ou locatário de contratos de curto e longo prazo.

50 Desta forma, estipula-se a - flexibilidade de mudança - como um dos critérios do [MAOI]. 
Neste trabalho a flexibilidade de mudança está relacionada com a facilidade da corporação em atender às variações nas necessidades de espaço. A definição de variações nas necessidades do espaço, a esse atributo relacionado, refere-se aquelas em que o espaço ocupado não mais atende em função de: [i] alterações na quantidade de área, [ii] alterações na demanda funcional, considerando espaços limitados tecnicamente para as adequações necessárias, ou [iii] necessidade de alterações na localização. Ou seja, são variações em que a corporação necessita desocupar o espaço, e ocupar outro que atende sua nova demanda (por necessidade de logística, crescimento da produção, entre outras) ${ }^{51}$.

A necessidade de flexibilidade de mudança pode ser avaliada pelo horizonte de uso do espaço, advindo do planejamento estratégico da corporação. O ideal é a máxima equalização entre os prazos firmados nos contratos de locação e os horizontes de usos planejados para os espaços corporativos. Existem espaços que o prazo máximo presumível no planejamento é de cinco anos de uso, visto as incertezas em planejar para horizontes mais longos. Nesses casos a flexibilidade de mudança para escolher entre as [alternativas] tem um peso mais significativo na decisão. Em contrapartida, pode-se citar o caso das unidades produtivas das corporações que em geral são espaços planejadas para usos em períodos mais longos.

Pelo Gráfico 6 nota-se que, tanto na área de varejo, como de escritórios e indústrias, a duração dos contratos de locação tem apresentado queda. Para uma maior flexibilidade, as corporações têm optado por prazos menores de locação. A velocidade com a qual a tecnologia tem mudado e, em decorrência, estimulado a dinâmica de mudanças nos processos de produção dos diferentes setores e a redução dos ciclos de vida dos negócios, tem sido um dos principais fatores influenciadores à necessidade de flexibilidade dos recursos demandados na operação das empresas, inclusive o real estate.

51 A flexibilidade de mudança não está associada, nesse caso, a adequações nos espaços internos de um imóvel. Essa consideração faz parte de outro atributo qualitativo citado a seguir. 


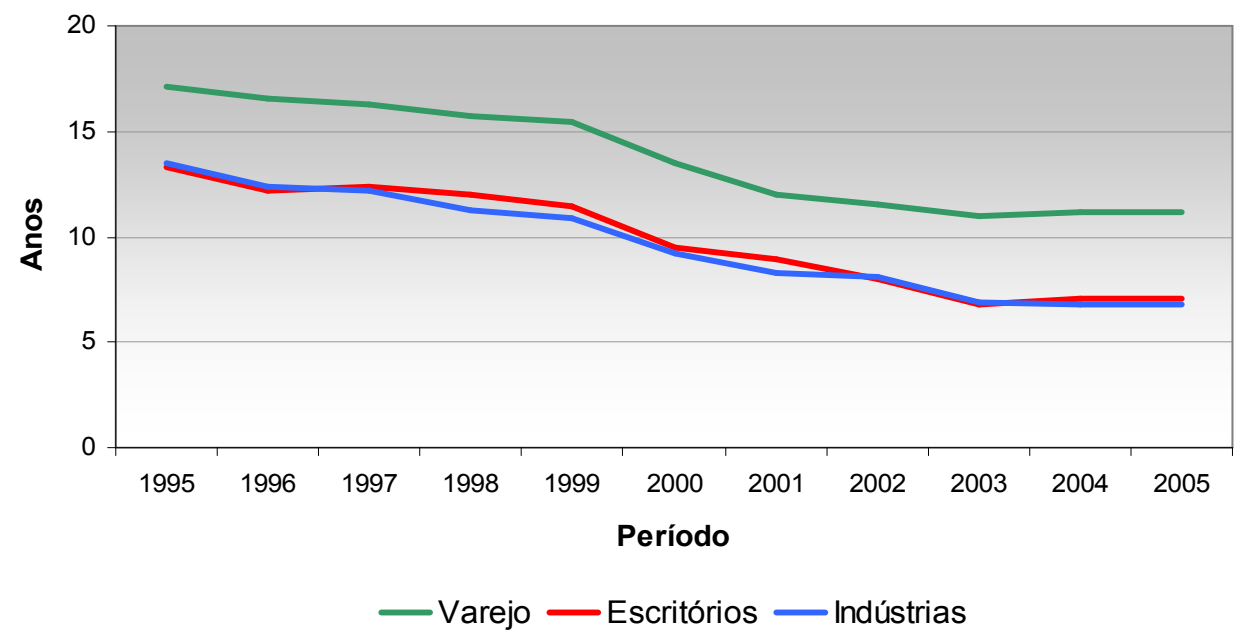

Gráfico 6 - Alteração na duração dos prazos de locação por setor - Adaptado do IPD - Investment Property Databank (Annual Lease Review, 2005) ${ }^{52}$

$\mathrm{Na}$ falta de alinhamento entre a flexibilidade de mudança necessária e as estratégias corporativas, o real estate se torna uma barreira para o desempenho da corporação, e não um recurso facilitador de vantagem competitiva.

Foi observado nas corporações [CR] e nas empresas [ERE] que, na maioria dos casos, são negociados contratos com prazos de cinco anos ou mais. Na maioria das situações de locação dos espaços (exceto os espaços fabris), a flexibilidade de mudança foi citada como parte da decisão pelas respondentes. Essa flexibilidade não é necessariamente traduzida pela curta periodicidade entre as necessidades de mudança, mas sim, a facilidade da corporação sair do espaço atual, no momento desejado, e ocupar outro que atenda sua nova demanda operaciona $^{53}$. Essa ocorrência foi observada, conforme demonstrado no Quadro 4, para edifícios de escritórios e galpões para operações logísticas. Tanto pelo curto ou médio horizonte de uso (caso dos escritórios e galpões locados para atividades de prestação de serviço no mesmo prazo do contrato com a contratante), como nos casos dos edifícios de

52 Esse levantamento, realizado pelo IPD - Investment Property Databank, baseou-se em 91.000 contratos de locação de diferentes setores em UK. Disponível em: www.ipdindex.co.uk. Acesso em 15 de outubro de 2006.

53 Foram citados dois casos atípicos em que flexibilidade de mudança foi parte da decisão. Um contrato de BTS no qual a corporação tinha como horizonte de uso do imóvel exatos dez anos (prazo do contrato), e de um SLB de uma Sede Administrativa, que a corporação além de desejar reorganizar seu perfil de endividamento com a desmobilização, pretendia ao final do contrato desocupar a sede e mudar para um espaço menor (otimização de espaços ociosos) e melhor localizado (tradução da imagem corporativa). Com a estratégia adotada pelas duas corporações, a dificuldade de venda do imóvel ao final do contrato, em razão da especificidade desses imóveis, foi transferida aos proprietários. 
escritórios em geral, em razão da imprevisibilidade das necessidades de espaço para períodos longos e da possibilidade de escolha de edifícios mais modernos e melhor localizados quando findo o contrato.

A dinâmica no ambiente corporativo pode também resultar na necessidade frequente de intervenções no espaço já ocupado pela corporação para atender as novas necessidades demandadas na operação. Contudo, o espaço deve permitir tecnicamente essas intervenções, caso contrário, recai-se no critério qualitativo mencionado acima (flexibilidade de mudança), tendo a corporação que desocupar o espaço, por esse não mais atender suas novas necessidades. Assim, na escolha do espaço corporativo a ser ocupado é importante analisar o grau de flexibilidade do ambiente para atender as mudanças na demanda funcional: como superdimensionamento de shafts (quantidade e/ou tamanho), construção de salas para equipamentos de telecomunicações, dimensionamento do pé-direito dos andares visando conforto atual e suporte de eventual embarque de novas tecnologias na edificação, entre outras.

Dessa forma, além do espaço ter que permitir tecnicamente as futuras intervenções, consideração importante no momento da escolha do imóvel (ou concepção / formatação do produto), a corporação deve relevar na escolha entre as [alternativas] o grau de liberdade de intervenções no espaço durante o uso. Essa necessidade requer, portanto, a consideração de outro critério a ser contemplado no [MAOI], denominado daqui por diante como - controle operacional no uso do espaço corporativo. As intervenções relacionadas a esse critério são as adequações funcionais nas instalações do espaço para atender as mudanças na demanda operacional. Essas intervenções são aquelas além da recuperação das instalações devido ao desgaste decorrente do uso ou referente à manutenção ordinária, trata-se de intervenções que alteram a condição original das instalações, como intervenções na infraestrutura (automação, sistemas de proteção e alarme, telecomunicações, sistemas prediais e utilidades), no layout (configuração interna dos espaços e acabamentos) e na envoltória do edifício (fachadas e cobertura).

Esse critério foi citado pelas corporações [CR] como importante na decisão principalmente nos casos das unidades produtivas, dos pontos de venda e serviço e das centrais operacionais (como centros de processamento de dados - CPD, prédios de centrais telefônicas, entre outras), todos imóveis considerados estratégicos para a operação das corporações. Para atender as variações na demanda operacional são feitas as intervenções durante o uso dos espaços corporativos, muitas vezes intervenções úteis apenas para a operação realizada no 
espaço. Observou-se tanto nas corporações [CR], como nas empresas [ERE], que a prática comum de mercado é negociar previamente essa liberdade nos contratos de locação, com devolução do imóvel nas condições originais. A devolução no estado original pode não ser necessária, caso as intervenções tenham agregado valor ao imóvel na percepção do proprietário. Por esse motivo, a depender da necessidade e tipo de intervenções durante a operação (volume de investimento envolvido e utilidade muito particular à corporação) a propensão pela propriedade do imóvel é maior na decisão.

A separação em dois critérios - flexibilidade de mudança e controle no uso do espaço corporativo - para responder ao dinamismo no ambiente corporativo é pertinente, visto que cada uma das [alternativas] atende diferentemente aos respectivos critérios.

Para responder a dinâmica do setor de atuação, foi constatado por meio do levantamento de campo a consideração de outro critério relevante à decisão, que também será contemplado no [MAOI] - rapidez na mobilização da atividade operacional para o espaço. A depender da atividade a ser realizada no espaço, o início mais breve possível é fator essencial na escolha, mesmo que para isso seja necessário comprometer outros atributos. Essa ocorrência foi citada por algumas das corporações [CR] para os casos das atividades de prestação de serviço (escritórios) e, também, por algumas das empresas [ERE] para os casos dos pontos de venda e serviço, sedes e galpões, os quais verifica-se a preferência por imóveis já prontos disponíveis para locação, ou em certas situações, até mesmo para compra.

\subsubsection{Importância do imóvel para a operação da corporação}

O real estate corporativo pode também ser um ativo estratégico para a operação. Na decisão por ser proprietário ou locatário do imóvel torna-se necessário identificar a importância da propriedade para o desempenho da corporação. GIBSON e LAUARGAND (2002) recomendam a avaliação do impacto do real estate para o negócio principal, propondo a classificação entre propriedades que podem ser críticas para a atividade fim e aquelas que são apenas necessárias para dar suporte às atividades operacionais, porém não são críticas.

Muitas razões podem fazer de um imóvel um recurso estratégico. Alguns pesquisadores da área de real estate corporativo relacionam a importância da propriedade em função da dependência das atividades operacionais com o espaço nele executadas (EDWARDS e ELLISON, 2004), outros relacionam essa importância com questões de localização (GIBSON e LOUARGAND, 2002), devido a aspectos geográficos, logísticos ou mercadológicos da 
operação $^{54}$.

Para EDWARDS e ELLISON (2004) quanto mais as atividades principais dependem da propriedade nela executadas, maior é a importância desse ativo para a corporação. A Figura 6 ilustra a linha de grau de importância da propriedade segundo classificação proposta pelos autores. As atividades executadas nas propriedades rurais, por exemplo, possuem dependência direta com o espaço, os quais são essenciais para a operação. No varejo e lazer a dependência com o espaço também é direta, já que os consumidores e clientes passam toda a experiência de compra ou de lazer no espaço, localizados em pontos atrativos para os consumidores alvos. Nesses casos, a propriedade traduz a marca e imagem da empresa e tem importante papel na geração de receita. Os escritórios, por exemplo, interferem na produtividade dos funcionários, mas a relação da atividade é indireta com o espaço. Já nos casos de centros de distribuição, a propriedade em si é uma estrutura de proteção para os recursos utilizados na operação, por isso são periféricas e com pouca relação com as atividades operacionais nela executadas.

\begin{tabular}{c|c|c|c}
\hline $\begin{array}{c}\text { Propriedades Rurais } \\
\text { Mineração }\end{array}$ & $\begin{array}{c}\text { Varejo } \\
\text { Lazer }\end{array}$ & $\begin{array}{c}\text { Escritórios } \\
\text { Educação }\end{array}$ & $\begin{array}{c}\text { Centros de Distribuição } \\
\text { Armazéns }\end{array}$ \\
\hline $\begin{array}{c}\text { Essencial pela } \\
\text { dependência direta }\end{array}$ & $\begin{array}{c}\text { Importantes pela } \\
\text { dependência direta }\end{array}$ & $\begin{array}{c}\text { Significativo, mas } \\
\text { dependência indireta }\end{array}$ & $\begin{array}{c}\text { Periférico e com pouca } \\
\text { relação }\end{array}$ \\
\hline \multicolumn{4}{|l}{} \\
\hline
\end{tabular}

Figura 6 - Grau de Importância da Propriedade para a Atividade Operacional - Adaptado de EDWARDS e ELLISON (2004)

Um imóvel pode também ser estratégico pela importância de sua localização na operação. A localização é considerada estratégica em razão de três principais aspectos - [i] logístico, como o caso de centros de distribuição em locais com fácil acesso às vias principais de escoamento dos produtos, armazéns próximos de portos, plantas industriais próximas dos fornecedores, entre outras localidades que facilitam a logística da operação; [ii] geográfico, nesse caso a localização apresenta aspectos geográficos essenciais à atividade principal, como o caso de indústrias que precisam localizar-se próximas aos recursos naturais utilizados na produção; e [iii] mercadológico, trata-se da localização que causa impactos relacionados à atuação de mercado da corporação, ou pela proximidade e atratividade da localização aos consumidores alvos, como no caso dos pontos de venda de uma empresa de varejo, ou pela localização 
atribuir notoriedade à corporação e ser um ponto comercialmente consolidado, como instituições financeiras em pólos de concentração de edifícios de alto padrão.

Pode-se, portanto, concluir por uma localização estratégica quando esta impacta na produtividade ou na vantagem competitiva da corporação.

Pelo exposto, estipula-se outro critério do [MAOI] relevante à escolha entre as [alternativas], denominado adiante como - vínculo da operação com o imóvel.

Quanto maior a importância da localização do imóvel como fator provedor de vantagem competitiva, maior é o vínculo com a operação. Essa importância deve ser relevada na decisão da corporação pelas opções de locação ou propriedade do imóvel, visto que se a localização for de fato estratégica para o desempenho da operação, dificilmente, mesmo considerando imóveis idênticos, esses operariam e gerariam resultados ou facilidades nas mesmas condições em localidades distintas. Assim, conhecida a importância do imóvel, a escolha pelas [alternativas] que possibilitem maior segurança para a corporação em relação a sua permanência no imóvel são as mais pertinentes ${ }^{55}$.

Contudo, é no ambiente corporativo que se define a localização para todos os ativos imobiliários em função das atividades nele executadas, que ora são atividades diretamente relacionadas ao negócio principal, ora são apenas atividades de suporte. Como o [MAOI] é usado a partir de já definido, no ambiente corporativo, a localização (pelo menos a região ${ }^{56}$ ) e as atividades a serem executadas no espaço em análise, para o planejador, usuário do [MAOI], cabe saber a importância do imóvel em razão da importância da localização escolhida.

Durante as entrevistas nas corporações [CR] foi constatado um outro fator que caracteriza o imóvel como estratégico. A depender da operação realizada no imóvel, o investimento imobilizado com instalações, máquinas e equipamentos no espaço, o torna estratégico. Nessas situações, uma possível transferência da operação para outro local seria significativamente onerosa, além de provocar a descontinuidade da operação ${ }^{57}$.

55 Como o caso de contratos de locação com renovatória compulsória, ou a opção pela propriedade do imóvel caso a corporação opte pela eliminação do risco de depender de negociações com os locadores em um mercado de locação futuro desconhecido.

56 A partir da definição da região é que são identificados alguns dos parâmetros usados no cálculo dos indicadores (como os preços de locação).

57 São os casos, como exemplo, das unidades produtivas, as quais há também a necessidade de escolher por [alternativas] que possibilitem o compromisso de longo prazo entre locador e locatário, 
Conforme apresentado no Quadro 4 (item 4.3) o critério - vínculo da operação com o imóvel foi citado como parte importante da decisão nos casos das unidades produtivas (estratégico pelo investimento imobilizado com as instalações), pontos de venda e serviço (estratégico pela localização e atividade realizada), centrais operacionais (estratégico pelo investimento imobilizado com as instalações) e galpões (estratégico pela localização).

\subsubsection{Tipologia e especificidade do espaço}

A tipologia e especificidade do imóvel são também relevantes na decisão entre a imobilização ou não em imóveis corporativos. Dependendo da tipologia, o imóvel tende a ser específico e, portanto, dificilmente se encontra um espaço disponível no mercado para locação que atenda a demanda operacional.

Pode-se citar como exemplo comparativo as seguintes tipologias - edifícios de escritório e centros de distribuição de uma empresa de varejo - a primeira facilmente é encontrada no mercado para locação, principalmente nas grandes metrópoles, variando a escolha em função da apreciação entre a qualidade dos empreendimentos e a demanda funcional requerida; a segunda já tende a apresentar particularidades nos empreendimentos, assim como na localização, para atender a demanda funcional específica e aspectos logísticos ou geográficos de cada empresa e, em consequência, dificilmente se encontra disponível no mercado para locação.

Essas especificidades implicam em uma maior dificuldade por parte das corporações em angariar investidores interessados em empreender imóveis de uso muito restrito. Nessa situação a nota de rating de crédito da corporação tem um peso maior na atratividade de investidores interessados em construir o imóvel, visto a dificuldade de locação por outro usuário, caso a corporação não cumpra com seus compromissos. Sendo assim, em certos casos a única opção para a corporação é a imobilização ${ }^{58}$.

ou a propriedade do imóvel, para assegurar uma duração possível para recuperação dos investimentos feitos nos espaços corporativos e a não descontinuidade da operação.

58 Nota-se um acréscimo de investidores interessados em empreender imóveis na modalidade BTS para garantia de renda homogênea em longo prazo. Em geral essas transações são negociadas com corporações caracterizadas como de baixo risco, como multinacionais, instituições financeiras, grandes redes de supermercado, entre outras. Durante as entrevistas nas empresas [ERE] foi observado que a depender do grau de especificidade do imóvel, até mesmo para essas corporações, dificilmente há interesse de investidores da modalidade BTS em empreender imóveis muito customizados. Quanto maior é a customização, maior é o risco para o investidor e maiores são os 
Segundo categorização proposta por CILLI (2004), os imóveis se dividem em: [i] imóveis de padronização comum, [ii] imóveis específicos e [iii] imóveis customizados. Os imóveis de padronização comum são formatados para atender a um público alvo, de demanda avistada e não atendida, e não para atender a um único usuário, sendo assim, o propósito é atender a uma demanda generalizada com projeto e especificações que atenda a uma faixa de possíveis locatários, caso dos edifícios de escritório multiusuários, tendo o usuário final que se adaptar ao produto imobiliário. Os imóveis específicos são aqueles formatados seguindo especificações técnicas que fogem do convencional do mercado, sendo desenvolvidos para um tipo de atividade específica (como exemplo, galpões industriais para armazenagem em proximidade com vias de acesso). Os imóveis customizados são feitos para atender um único usuário já definido, que determina as diretrizes das características de localização, arquitetônicas e técnicas que atendam as suas necessidades. Nas duas últimas categorias a especificidade do imóvel é um fator influenciador na decisão entre as [alternativas]. Estipulase, portanto, outro critério do [MAOI], denominado: especificidade do imóvel.

Conforme ROCHA LIMA (1998b), o valor de saída de empreendimentos de base imobiliária não depende do investidor, mas deste encontrar outro investidor que tome a posição, ocorrendo então uma transação em que dois juízos de valor estarão em confronto, de um lado o investidor que sai do investimento e de outro aquele que toma a posição, até que se atinja um equilíbrio que permita a conclusão da transação ${ }^{59}$. Partindo-se dessa premissa, os imóveis específicos e, principalmente, os customizados, apresentam maior dificuldade de atingir um valor de saída satisfatório para o proprietário que quer vendê-lo, visto a dificuldade de encontrar investidores que aceitam tomar a posição de investir em um imóvel de uso muito restrito para certa corporação.

Quando essa especificidade é caracterizada no imóvel as corporações podem preferir locar o imóvel por longo período, e na não necessidade do espaço no final do ciclo operacional fica o investidor com a dificuldade de inserção do imóvel no mercado. Contudo, nessa situação há uma maior preocupação com a garantia de permanência da corporação no imóvel na escolha entre as [alternativas], visto que assim como para o critério: vínculo da operação com o

valores e prazos de locação dos contratos. Por essa razão, na maioria dos casos as corporações são proprietárias dos imóveis quando muito customizados, como os casos dos: laboratórios, torres para teste de elevadores, unidades produtivas, entre outros.

59 O valor a ser transacionado um bem de base imobiliária não depende do seu investimento, mas sim da percepção de valor do mercado, que está relacionada com a capacidade de geração de renda na exploração do imóvel durante a operação. 
imóvel, na maioria dos casos esses imóveis específicos/customizados são estratégicos para o desempenho da corporação. Não considerar na decisão as garantias de permanência, em condições previamente acordadas entre as partes (proprietário e usuários), pode interferir na continuidade da operação ou acarretar em penosas negociações com o proprietário, que tem conhecimento da especificidade e da dependência da operação da corporação com o imóvel.

Essa propensão pela locação em decorrência do baixo valor residual do imóvel foi apontada por BRYAN (2003). O autor sugere que para os imóveis com baixas expectativas no valor residual, a opção mais adequada para a corporação é a locação, se houver no mercado locações com preços aceitáveis. No entanto, se o imóvel tem expectativa de preservar valor e é estratégico para a corporação, inclusive pela importância da localização, o autor sugere a propriedade do imóvel.

A especificidade do imóvel foi considerada como fator importante na decisão entre as [alternativas] pelas corporações [CR] principalmente nos casos das unidades produtivas, centrais operacionais, pontos de venda ou serviços e galpões para armazenagem. Nesses tipos de espaço foram observadas três ocorrências predominantes - [i] a opção pela propriedade do imóvel, pela sua importância estratégica e alta especificidade (caso das unidades produtivas e centrais operacionais); [ii] a opção pela locação de longo prazo, quando se encontra disponível no mercado, na localização requerida, um imóvel que possa ser adaptado pela corporação (caso dos pontos de venda ou serviços e galpões para armazenagem); e [iii] a opção pelo BTS, para galpões e pontos de venda ou serviços, quando não estão disponíveis no mercado imóveis para locação nas especificidades e localização requerida.

\subsubsection{Importância da tradução da imagem corporativa por meio do imóvel ocupado}

Um imóvel, em certos casos, exerce importante papel no valor intangível agregado para a corporação. Os espaços ocupados pelas corporações muitas vezes traduzem a sua identidade (marca). Não se preocupar com a tradução da imagem da corporação por meio dos imóveis ocupados pode minar gradativamente a marca e reduzir o valor da corporação (GIBSON e LOUARGAND, 2002).

Conforme EDWARDS e ELLISON (2004) os imóveis da corporação apresentam próxima interface com seus clientes e consumidores. Isto não se limita ao setor de varejo e lazer. Nos escritórios de uma empresa, independente do seu setor de atuação, ocorrem os principais encontros com clientes e prestadores de serviço. O espaço que reflete a identidade da 
corporação transmite uma mensagem positiva para os visitantes e clientes, resultando em geração de valor agregado para a corporação.

A importância da imagem corporativa como apelo mercadológico é também um dos fatores a ser relevado inclusive na escolha do imóvel a ser locado, levando em consideração o contexto urbano e a notoriedade que se pretende traduzir por meio do empreendimento escolhido. São os casos de escritórios de bancos de investimentos que locam espaços em edifícios de alto padrão, ocupado por grandes instituições financeiras.

Para O'MARA (1999) a função do real estate corporativo se reduz em duas: prover espaço para suportar as atividades e apresentar a imagem da corporação para o ambiente externo. Sendo assim, para a escolha entre as [alternativas] torna-se necessário relevar a importância da tradução da imagem corporativa para agregar valor à corporação pelo maior apelo mercadológico, que em muitas situações é essencial para a geração de receita da corporação. Assim, estipula-se para o [MAOI] o critério: oportunidade de tradução da imagem corporativa.

A oportunidade de tradução da imagem corporativa a esse atributo relacionada pode ser tanto para os casos de tradução da imagem apenas em ambientes internos ${ }^{60}$, como também por meio do ambiente externo, ou seja, das fachadas, como o caso dos edifícios monousuário ${ }^{61}$. $\mathrm{O}$ atendimento das [alternativas] em relação a este critério vai depender da oportunidade de tradução almejada.

A oportunidade de traduzir a imagem corporativa foi citada como parte importante da decisão pelas corporações [CR], principalmente nos casos dos edifícios de escritórios, tanto para as sedes administrativas (tradução da imagem interna e externa), como para os escritórios regionais (tradução da imagem interna), e também nos pontos de venda e serviços (tradução da imagem interna e externa).

Como o caso das corporações com escritórios regionais ou sedes administrativas em edifícios multiusuários. Nessa situação há investimentos iniciais para adaptar o espaço (em geral de padronização comum) para incorporar a imagem da corporação. Por conta disso, a garantia da corporação no imóvel deve ser considerada na escolha, para que a duração de ocupação do espaço seja compatível à recuperação do investimento. Por esse motivo, foi observada nas corporações [CR] e nas empresas [ERE] a negociação de contratos de cinco anos ou mais de duração, para os casos em que são feitos investimentos significativos pela corporação usuária no espaço locado.

${ }^{61}$ Como o caso das sedes de instituições financeiras que pretendem transmitir notoriedade nas fachadas dos edifícios e consolidar ponto comercial em regiões de concentração de edifícios de alto padrão. O mesmo ocorre para os pontos de venda ou serviços, onde a tradução da imagem ao ambiente externo também é importante. 
Foi mencionado durante as entrevistas com as corporações [CR] que a oportunidade de tradução da imagem, em especial para os escritórios e sedes administrativas, já é atendida na escolha da localização e do empreendimento no contexto urbano. Para estes casos não há a necessidade de atribuir a imagem por meio de elementos (logomarca, acabamentos externos, entre outros) que vinculem o edifício única e exclusivamente à corporação. Quando a oportunidade de traduzir a imagem corporativa restringe-se apenas na escolha da localização e do empreendimento, todas as [alternativas] atendem igualmente a esse critério.

\subsubsection{Fatores relacionados às estratégias e políticas de cada corporação}

A decisão pela imobilização ou não no real estate corporativo pode também ser influenciada pelas estratégias e políticas de cada corporação, e não apenas por aspectos relacionados ao uso do imóvel durante a operação (conforme os critérios mencionados anteriormente). Essas políticas e estratégias podem receber a influência dos seguintes fatores: cenário macroeconômico, saúde financeira da empresa, cultura, estratégias da organização como um todo (diretrizes da matriz), órgãos reguladores do segmento que a empresa atua, entre outros.

Foram citados no capítulo 3 os motivos que levavam as corporações a serem proprietárias de seus ativos imobiliários até meados da década de 90 . Fatores macroeconômicos, como as altas inflacionárias, faziam com que as corporações que aqui se instalavam, comprassem seus imóveis, tanto pela falta de maturidade do mercado imobiliário como para proteção de capital. As empresas capitalizadas diversificavam seus investimentos em imóveis. Por essa razão ainda há empresas com quantidades significativas de ativos imobiliários imobilizados nos balanços. Contudo, essas duas estratégias (proteção de capital e diversificar investimento em imóveis) não são mais práticas comuns nas corporações, até mesmo em empresas capitalizadas com independência financeira ${ }^{62}$.

Há também casos em que as decisões em relação ao real estate não são uma opção, mas sim diretrizes a serem seguidas, ou por compreender estratégias da organização, ou por imposições de órgãos ou instituições reguladoras do segmento em que a empresa atua.

Durante as entrevistas nas corporações [CR] constatou-se que o investimento em imóveis, tanto para proteção de capital, como para diversificar investimento, são uma das razões de algumas delas serem atualmente imobilizadas, mas essa cultura não é mais comum. Os novos imóveis demandados são de propriedade da corporação quando estratégicos para a operação, ou quando não há investidores na modalidade BTS para empreender o imóvel customizado à taxas atrativas para a corporação. 
Em certas multinacionais, como as européias, que são capitalizadas com independência financeira, a diretriz da matriz é não recorrer de recursos de terceiros para implantação de seus ativos imobiliários, sendo nessas corporações a predominância pela propriedade dos imóveis (em sua maioria, unidades produtivas com sedes administrativas incorporadas).

Há também os casos dos órgãos e instituições reguladoras que interferem na decisão em relação ao real estate, a exemplo da desmobilização patrimonial dos bancos no início da década anterior. Para atender a uma regra imposta pelo Banco Central, as instituições financeiras foram obrigadas a desonerarem seus balanços, reduzindo a relação entre patrimônio líquido e ativos imobiliários imobilizados, motivo que deu início a venda e posterior locação dos imóveis (agências bancárias). Ainda há os órgãos reguladores que podem exigir reserva de capital em imóveis (como o caso da Superintendência de Seguros Privados - SUSEP - órgão regulador das empresas seguradoras, que exige uma reserva técnica em imóveis para maior segurança de garantia de pagamento das obrigações aos segurados).

A depender também da estratégia de atuação da empresa no mercado a decisão pela compra do real estate pode não ser uma opção, mas sim uma questão de oportunidade na ocasião da necessidade do espaço, como ocorre nos pontos de venda e serviços. Quando a empresa avista um ponto potencial (demanda avistada e não atendida), o principal é a garantia do ponto, visto a ameaça de se instalar concorrentes para atender a demanda local. Dessa forma, se o imóvel no ponto desejado está apenas à venda a empresa pode comprá-lo mesmo que a propensão em relação ao recurso real estate seja pela locação. Essa ocorrência foi apontada durante as entrevistas nas corporações [CR], tanto pelas empresas respondentes de varejo, como de serviços.

As estratégias e políticas acima mencionadas são determinantes à decisão e, por isso, não cabe sua consideração no [MAOI] para escolha entre as [alternativas].

Contudo, quando a corporação decide em relação aos seus recursos de real estate existem estratégias que devem ser levadas em consideração para a escolha entre as [alternativas], cabendo a cada corporação a ponderação dos critérios de decisão.

Os critérios relacionados às estratégias de investimento e políticas da corporação contemplados no [MAOI] são: [i] canalização dos recursos em oportunidades do negócio principal, ou seja, a não imobilização em imóveis para investimento na atividade fim; [ii] não oneração ou desoneração do balanço, ou seja, a locação dos novos espaços ou a 
desmobilização dos ativos imobiliários imobilizados no balanço, para melhora dos índices de liquidez e endividamento da empresa (entre outras medidas financeiras); [iii] levantar capital de giro com a desmobilização dos ativos imobiliários, para alavancar o negócio principal e/ou reorganizar o perfil de endividamento da empresa; e [iv] redução dos impactos tributários, como nos casos das [alternativas] de não imobilização, em que o aluguel é uma despesa operacional dedutível gerando economia tributária pela redução do lucro tributável ${ }^{63}$.

Essas estratégias devem ser ponderadas comparativamente com os critérios relacionados ao uso de cada imóvel necessário à operação. Assim, é no ambiente corporativo que se decide quais são os atributos com maior importância. Há casos em que a corporação prefere canalizar recursos no negócio principal, mesmo para imóveis estratégicos ao desempenho da operação, ou prefere levantar capital de giro, a partir da desmobilização de um imóvel, para aproveitar oportunidades no negócio principal. Por outro lado, existem casos em que a corporação não prioriza a canalização de recursos no negócio principal quando o imóvel é estratégico e há dependência entre o mesmo e a atividade operacional nele executada.

\subsection{Compilação das informações adquiridas nas entrevistas - identificação e validação dos critérios e tipo de espaço corporativo ' $v$ s' [alternativas]}

As entrevistas nas corporações [CR] foram utilizadas para validar os critérios de decisão do [MAOI]. Os critérios introduzidos no questionário foram submetidos à validação da seguinte maneira - para cada tipo de espaço corporativo utilizado nas operações das [CR] identificouse a [alternativa] adotada e quais critérios foram: [i] importante na decisão, [ii] fez parte da decisão, ou [iii] não fez parte da decisão.

Além dos critérios já estruturados no questionário (conforme Tabela 1), foram citados outros fatores influenciadores pelas respondentes durante as entrevistas (agrupados e denominados de $\mathrm{x}_{1}, \mathrm{x}_{2}, \mathrm{x}_{3}$ e $\mathrm{x}_{4}$, com definições apresentadas na Tabela 1). Nas empresas [ERE] foram analisados, pela abrangência de atuação das [ERE] em diferentes tipos de corporações brasileiras, quais são os critérios entendidos como relevantes à decisão em relação ao real estate corporativo e as [alternativas] prevalentes para cada tipo de espaço.

As informações foram estruturadas e compiladas para identificação dos critérios mais

63 A consideração desse critério (redução dos impactos tributários) na decisão foi identificada no levantamento de campo. A vantagem tributária foi citada como fator influenciador das decisões em relação ao real estate tanto pelas corporações [CR], como pelas empresas [ERE]. 
relevantes, ou seja, aqueles que foram citados como 'importante na decisão' ou que 'fizeram parte da decisão', para cada tipo de espaço corporativo, assim como as [alternativas] usadas pelas corporações [CR] em cada um dos tipos de espaço utilizados nas operações.

Os tipos de espaços corporativos agrupados são: [i] pontos de venda e serviços (lojas de empresas de varejo e serviços: como supermercados, agências bancárias, pontos de prestação de serviços, entre outros); [ii] centrais operacionais (como centrais de processamento de dados - CPD's, prédios de centrais telefônicas, entre outros); [iii] unidades produtivas (onde são fabricados os produtos); [iv] sedes administrativas (escritórios onde são agrupadas as funções administrativas da corporação); [v] escritórios regionais (escritórios distribuídos geograficamente para atividades administrativas regionais e/ou prestações de serviços); e [vi] galpões (são os centros de distribuição, armazenagem em geral, centros de operações logísticas, entre outros).

\begin{tabular}{|c|c|c|c|c|}
\hline \multicolumn{5}{|c|}{ TABELA AUXILIAR - NOMENCLATURAS } \\
\hline \multicolumn{5}{|c|}{ CRITÉRIOS DE DECISÃO (propostos nos questionários para validação) } \\
\hline \multirow{5}{*}{$\begin{array}{l}\text { Relação com o } \\
\text { Espaço } \\
\text { Corporativo }\end{array}$} & \multicolumn{4}{|c|}{ Flexibilidade de Mudança } \\
\hline & \multicolumn{4}{|c|}{ Controle no Uso do Espaço } \\
\hline & \multicolumn{4}{|c|}{ Vínculo da Operação com o Imóvel } \\
\hline & \multicolumn{4}{|c|}{ Especificidade do Imóvel } \\
\hline & \multicolumn{4}{|c|}{ Oportunidade de Tradução da Imagem Corporativa } \\
\hline \multirow{3}{*}{$\begin{array}{l}\text { Relação com } \\
\text { Política/Estratégia } \\
\text { da Corporação }\end{array}$} & \multicolumn{4}{|c|}{ Canalizar Recursos em Oportunidades do Negócio Principal } \\
\hline & \multicolumn{4}{|c|}{ Não Oneração (ou Desoneração) do Balanço da Empresa } \\
\hline & \multicolumn{4}{|c|}{ Levantar Capital de Giro com a Desmobilização Patrimonial Imobiliária (SLB) } \\
\hline \multicolumn{5}{|c|}{ [alternativas] UTILIZADAS PELAS CORPORAÇÕES EM RELAÇÃO AOS ATIVOS IMOBILIÁRIOS } \\
\hline SP: Ser Proprietário & BTS: Build-to-Suit & LCP: Loc. Curto Prazo & LLP: Loc. Longo Prazo & SLB: Sale Leaseback \\
\hline \multicolumn{5}{|c|}{ FATORES INFLUENCIADORES NA DECISÃO CITADOS PELAS RESPONDENTES - [CR] E [ERE] } \\
\hline \multicolumn{5}{|c|}{$\begin{array}{l}\text { Política da empresa ser proprietária de imóveis estratégicos e/ou trata-se de imóveis adquiridos antes da década de } 90 \\
\text { (período que os imóveis funcionavam como proteção de capital em razão da instabilidade econômica do País e do } \\
\text { mercado imobiliário ainda incipiente, não havendo ofertas no volume e preços de locação acessíveis, além da falta de } \\
\text { profissionalização dos agentes desse mercado) }\end{array}$} \\
\hline \multicolumn{5}{|c|}{$\begin{array}{l}\text { A escolha pela imobilização não é uma opção na ocasião da decisão: trata-se de imóveis que estão somente à venda no } \\
\text { mercado, ou quando não há imóvel disponível que atenda a demanda operacional (investidores da modalidade BTS, na } \\
\text { ocasião da decisão, apresentam altas taxas de remuneração, não atrativas para a corporação usuária) }\end{array}$} \\
\hline \multicolumn{5}{|c|}{$\begin{array}{l}\text { Importância da rapidez no início das atividades no espaço corporativo, sendo nesses casos, a propensão pela escolha } \\
\text { de imóveis prontos já disponíveis no mercado (tanto os expostos para a locação, como para a venda) }\end{array}$} \\
\hline \multicolumn{5}{|c|}{ Importância da vantagem tributária na decisão (redução dos impactos tributários) } \\
\hline
\end{tabular}

O Quadro 4 a seguir refere-se aos resultados adquiridos com o levantamento de campo. A nomenclatura apresentada no Quadro 4 respeita a apresentada na Tabela 1 para cada critério. 
As respostas apresentadas no Quadro 4 já estão compiladas, representando a soma dos critérios, fatores influenciadores da decisão e as [alternativas] citadas pelas respondentes, para cada tipo de espaço corporativo. Com isso foi possível identificar quais são os critérios e fatores influenciadores prevalentes nas decisões a depender do tipo de espaço e, também, as [alternativas] prevalentes na amostra analisada ${ }^{64}$.

Verifica-se que os critérios relevantes à decisão nas corporações [CR] para cada um dos tipos de espaços corporativos, são, em geral, semelhantes à percepção das empresas [ERE], o mesmo ocorre na escolha das [alternativas] em função do tipo de espaço corporativo. Vale citar algumas exceções, como nos casos das sedes administrativas e das unidades produtivas. Verifica-se que as sedes administrativas, na amostra analisada, tiveram o - $\mathrm{x}_{1}$ - como fator influenciador da decisão pela propriedade do ativo (sedes implantadas antes da década de 90). Com isso houve maior predominância da [alternativa] SP em detrimento da LLP. Nas unidades produtivas, verifica-se uma maior importância dada pelas [CR] ao critério oportunidade da tradução da imagem corporativa - em comparação à percepção das empresas [ERE]. Isso ocorreu pelo fato dessas unidades produtivas, em sua maioria, terem as suas sedes administrativas incorporadas. Para os fatores influenciadores citados pelas respondentes durante as entrevistas $\left(\mathrm{x}_{1}\right.$ e $\left.\mathrm{x}_{2}\right)$ houve maior variação nas respostas, visto que se referem a fatores particulares de algumas respondentes, não sendo práticas comuns na amostra analisada. Porém, pela amostra, já se evidencia a predominância de cada uma das [alternativas] em função do tipo de espaço corporativo. Vale ainda ressaltar que o atributo levantar capital de giro - foi apresentado com menor peso (mesmo quando considerado importante na decisão), em razão da [alternativa] SLB ter menor ocorrência na amostra analisada, assim como no âmbito das empresas brasileiras em geral.

64 Foram somados para cada tipo de espaço corporativo os critérios considerados: 'importantes na decisão' e 'fez parte da decisão'. Aqueles que apresentaram soma resultante maior na coluna importante na decisão - foram considerados nessa classificação, e aqueles que apresentaram soma maior na coluna - fez parte da decisão - foram considerados nessa segunda classificação. Essa soma foi apresentada em porcentagem, calculada a partir do peso relativo, ou seja, relativamente ao total de vezes que os critérios poderiam ser citados (sendo 100\% o total de cada tipo de espaço corporativo citado pelas respondentes na amostra analisada). O mesmo foi feito para as [alternativas] apontadas pelas respondentes, em cada tipo de espaço corporativo. 


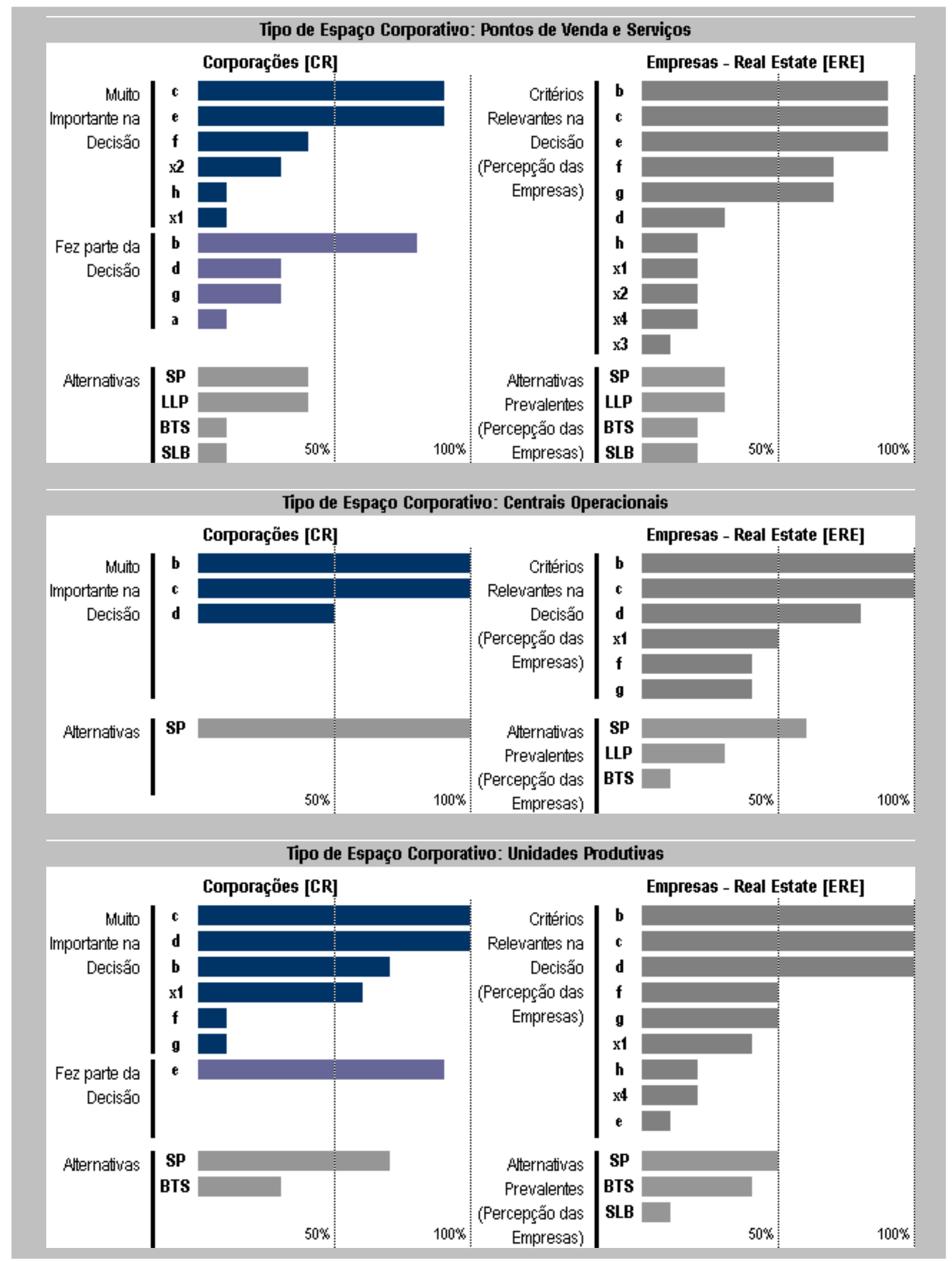

Quadro 4 - Compilação das informações advindas do levantamento de campo: critérios de decisão ' $v s$ ' tipos de espaços corporativos ' $v s$ ' [alternativas] 


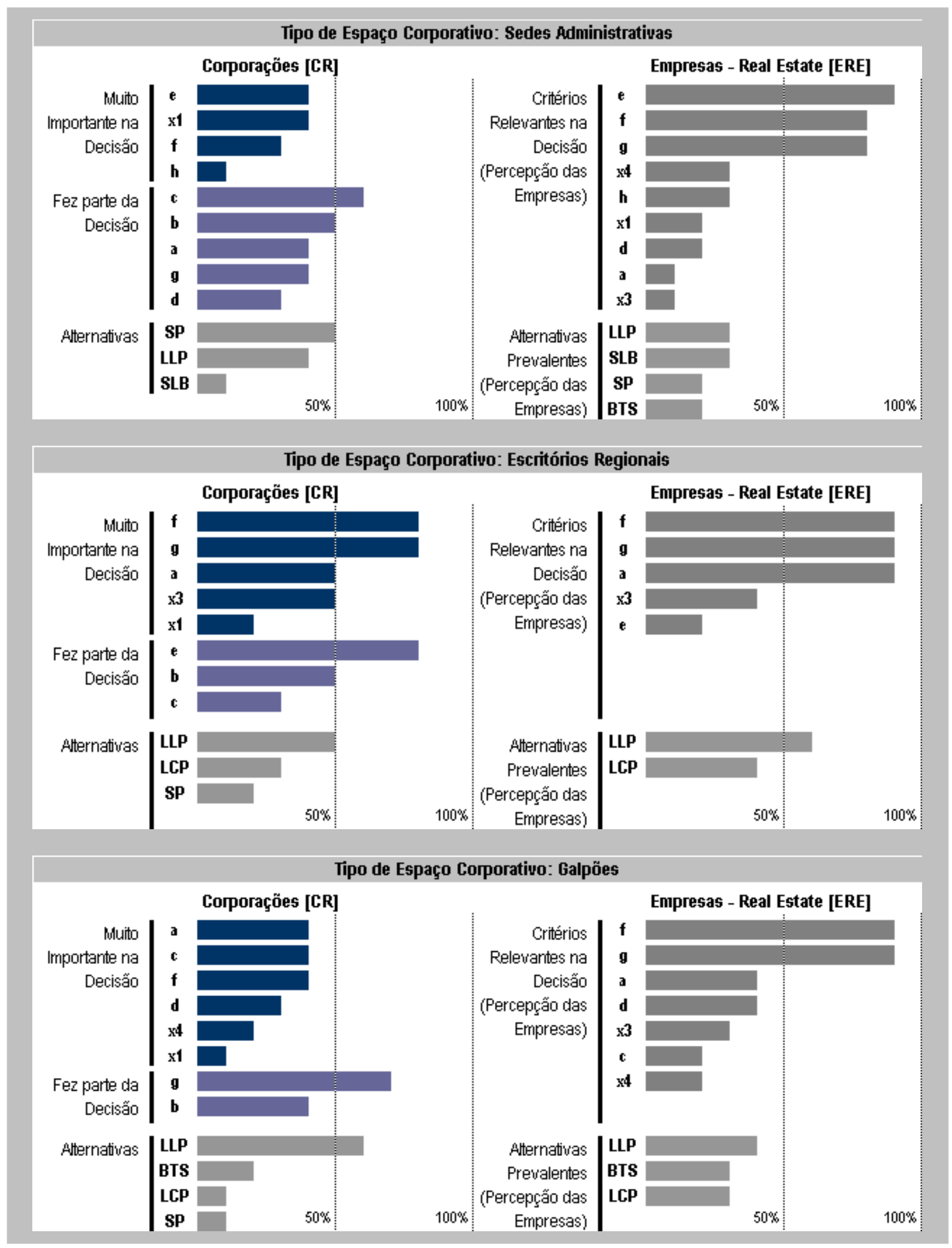

Quadro 4 - Compilação das informações advindas do levantamento de campo: critérios de decisão ' $v$ ' tipos de espaços corporativos ' $v s$ ' [alternativas]

(conclusão) 
Por meio do levantamento de campo, conforme resultados apresentados, são definidos os critérios de decisão do [MAOI] (apresentados no Quadro 5).

Os critérios estão divididos em dois grupos:

[i] critérios relacionados ao uso do espaço corporativo. Esses critérios impactam aspectos operacionais, mercadológicos e estratégicos para a operação realizada no espaço e não são objetivamente mensuráveis, os quais serão tratados qualitativamente no [MAOI];

[ii] critérios relacionados às estratégias de investimento e políticas da corporação. Esses critérios impactam aspectos econômicos e financeiros para a corporação e são mensuráveis, os quais serão avaliados quantitativamente no [MAOI].

\begin{tabular}{|c|c|c|}
\hline \multicolumn{3}{|c|}{ CRITÉRIOS DE DECISÃO DO [MAOI] } \\
\hline \multirow{6}{*}{ 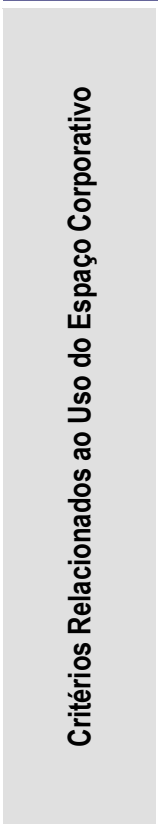 } & A - Flexibilidade de Mudança & $\begin{array}{l}\text { Importância da facilidade (prazo e custo) da corporação mudar de espaços } \\
\text { corporativos para atender as variações nas necessidades operacionais, como } \\
\text { alterações na quantidade de área, de localização elou na demanda operacional } \\
\text { do espaço. }\end{array}$ \\
\hline & $\begin{array}{l}\text { B - Rapidez na mobilização da atividade para } \\
\text { o espaço }\end{array}$ & $\begin{array}{l}\text { Importância do breve início da atividade operacional no espaço (para atender } \\
\text { aumento de demanda, crescimento da produção, etc.). }\end{array}$ \\
\hline & $\begin{array}{l}\text { C - Controle Operacional no Uso do Espaço } \\
\text { Corporativo }\end{array}$ & $\begin{array}{l}\text { Importância da liberdade de intervenções durante o uso (infraestrutura, layout, } \\
\text { envoltória externa) para atender as alterações na demanda operacional } \\
\text { (considerando espaços que permitam tecnicamente essas intervenções). }\end{array}$ \\
\hline & D - Vínculo da Operação com o Imóvel & $\begin{array}{l}\text { Importância estratégica do imóvel pelos seguintes aspectos: a atividade nele } \\
\text { executada tem dependência direta; a localização é estratégica (aspectos: } \\
\text { logísticos, geográficos e mercadológicos) e/ou o investimento imobilizado nas } \\
\text { instalações do local é expressivo. }\end{array}$ \\
\hline & E - Especificidade do Imóvel & $\begin{array}{l}\text { Importância do atendimento a todas as especificidades demandadas à } \\
\text { operação realizada no imóvel, como: particularidades na localização, } \\
\text { funcionalidade e/ou arquitetura do espaço (que dificultam a sua disponibilidade } \\
\text { no mercado já pronto para locação). }\end{array}$ \\
\hline & $\begin{array}{l}\text { F - Oportunidade de Tradução da Imagem } \\
\text { Corporativa }\end{array}$ & $\begin{array}{l}\text { Importância da tradução da imagem corporativa para a operação realizada no } \\
\text { espaço. Essa tradução pode ser na escolha da localização, do } \\
\text { empreendimento, no ambiente interno (quando pronto e disponível para } \\
\text { locação), e no ambiente externo, por meio de elementos que vinculem o imóvel } \\
\text { à corporação (arquitetura da fachada, acabamentos externos e logomarca). }\end{array}$ \\
\hline \multirow{4}{*}{ 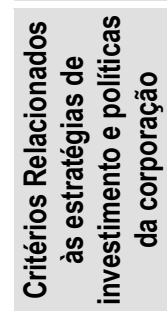 } & $\begin{array}{l}\text { G - Canalização de recursos em } \\
\text { oportunidades do negócio principal }\end{array}$ & $\begin{array}{l}\text { A canalização de recursos pode ser um atributo priorizado quando se vislumbra } \\
\text { oportunidades estratégicas no negócio principal. }\end{array}$ \\
\hline & $\begin{array}{l}\mathrm{H} \text { - Desoneração (ou não oneração) do } \\
\text { balanço65 }\end{array}$ & $\begin{array}{l}\text { Importância da melhora nos índices do balanço da corporação, como: índices } \\
\text { de liquidez, índices de endividamento, entre outros. }\end{array}$ \\
\hline & I - Redução dos Impactos Tributários & Importância da redução dos encargos tributários pagos pela corporação. \\
\hline & $\begin{array}{l}\text { J - Levantar capital de giro com a } \\
\text { desmobilização do ativo imobiliário }\end{array}$ & $\begin{array}{l}\text { Importância do capital de giro incorporado com a venda do imóvel para } \\
\text { reorganização do perfil de endividamento e / ou alavancagem do negócio } \\
\text { principal. }\end{array}$ \\
\hline
\end{tabular}

65 Este atributo denominado adiante apenas por - desoneração do balanço - refere-se tanto à oportunidade de 'não oneração' do balanço na decisão pela imobilização ou não dos novos espaços demandados como à 'desoneração do balanço' para o caso da desmobilização patrimonial imobiliária. 


\section{ALTERNATIVAS DO [MAOI] E SUAS RESPECTIVAS PERTINENCIAS QUANTO AO ATENDIMENTO AOS CRITÉRIOS DE DECISÃO}

No capítulo anterior foram apresentados os critérios de decisão do [MAOI], tanto para atendimento das necessidades operacionais durante o uso dos espaços, como para atendimento das estratégias de investimento e políticas da corporação.

Neste capítulo serão apresentadas as [alternativas] do [MAOI], apontando os principais motivos da escolha por cada uma delas pelas corporações, e suas respectivas vantagens e desvantagens operacionais e financeiras, assim como, quando necessário, as particularidades das transações - caso das operações estruturadas de BTS e SLB.

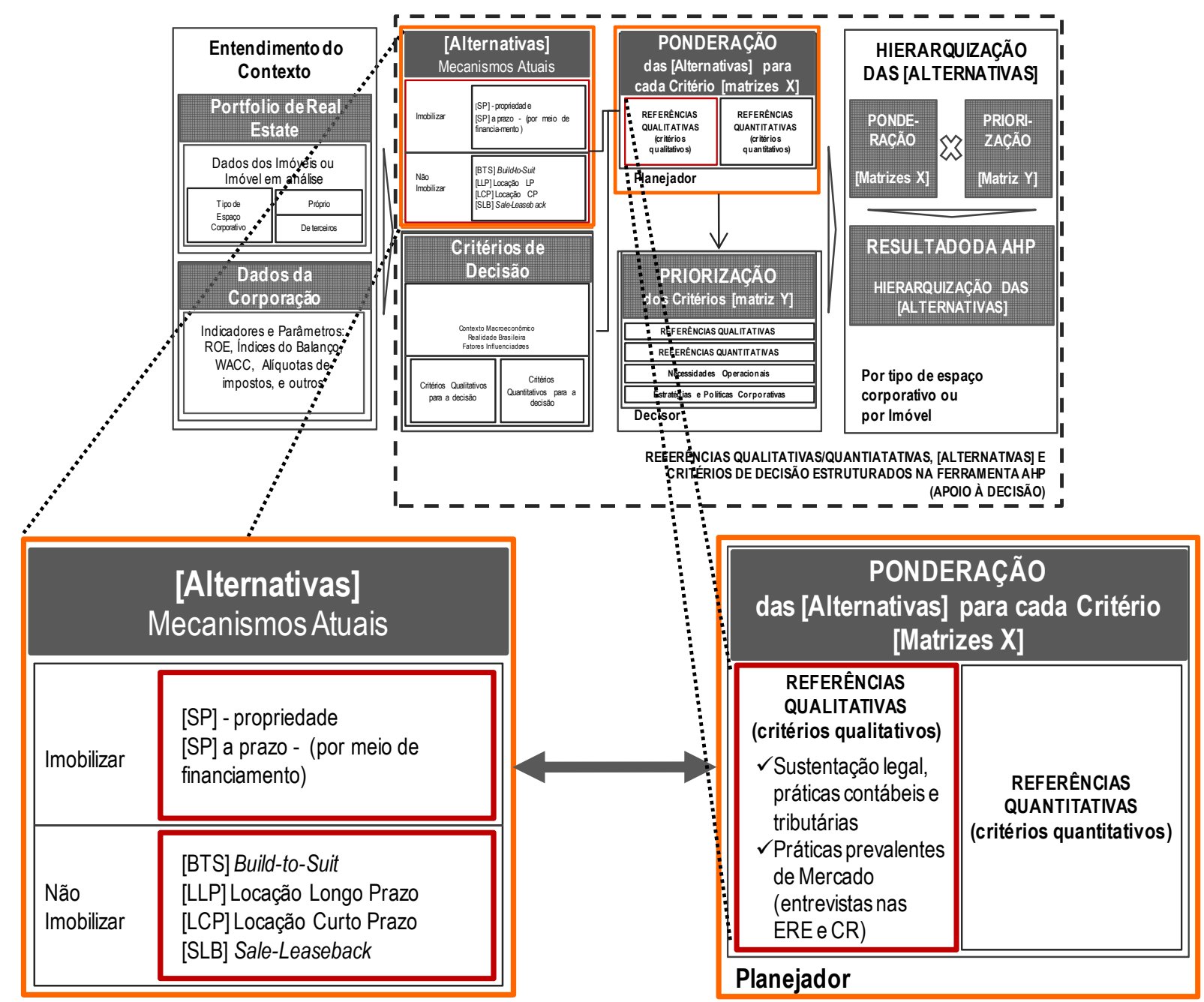

Figura 7 - [alternativas] ' $v s$ ' Referências Qualitativas do [MAOI] (rotina do [MAOI]) 
A proposta principal deste capítulo é o esclarecimento de como cada uma das [alternativas] atende aos critérios de decisão do [MAOI] (análise da pertinência das [alternativas] quanto ao atendimento aos atributos, ainda de maneira qualitativa). Essa análise de pertinência baseia-se na sustentação legal que rege as locações urbanas comerciais, nas práticas contábeis e tributárias e nas práticas prevalente de mercado, ou seja, nas negociações entre proprietários dos imóveis e corporações usuárias.

Para isso, além da revisão bibliográfica, foi necessário também um levantamento de campo na finalidade de identificar essas práticas prevalentes de mercado. Esse levantamento foi feito por meio de entrevistas estruturadas nas empresas [ERE], escolhidas pela significativa atuação no mercado brasileiro de real estate corporativo.

\subsection{Propriedade dos Ativos Imobiliários}

Ainda é comum nas corporações brasileiras a opção pela propriedade dos imóveis demandados na operação. Em muitos casos, as corporações são proprietárias em razão da herança dos períodos de instabilidade econômica e falta de maturidade dos mercados de real estate, período que persistiu até meados dos anos 90. Foi neste contexto que muitas corporações se instalaram no Brasil, comprando seus espaços para acomodação das atividades operacionais e crescimento da produção. No entanto, há uma recente tendência, observada durante o levantamento de campo, pela desmobilização dos ativos imobiliários, e concentração dos investimentos no negócio principal, movimento pressionado pelo mercado cada vez mais competitivo.

$\mathrm{Na}$ situação em que são necessários novos espaços a decisão depende principalmente: do horizonte de uso do imóvel; da sua tipologia e especificidade, que podem dificultar a disponibilidade de espaços no mercado de locação adequados para atender a demanda operacional; e da importância estratégica do imóvel.

No entanto, independente do motivo que leva a corporação a ser proprietária, essa decisão pode levar à perda de oportunidades no negócio principal e, em consequência, à perda de competitividade no seu setor de atuação.

\subsubsection{Motivos da escolha pela propriedade dos ativos imobiliários}

Pelo exposto no capítulo 4 e pelo identificado nas corporações [CR] e nas empresas [ERE], pode-se concluir que a escolha por essa opção é apropriada quando: 
[i] é pertinente investir em imóveis para proteção de capital, em função do cenário macroeconômico - como ocorrido na década de 80 para muitas corporações brasileiras. Porém, considerando o cenário atual e a expectativa adiante (estabilidade dos índices inflacionários), essa proteção, em primeira análise, perde o sentido;

[ii] o horizonte de uso do imóvel advindo do planejamento estratégico da corporação é para longo prazo, não exigindo flexibilidade de mudança a curto e médio prazo;

[iii] há expectativa do imóvel em preservar valor e apresentar liquidez no mercado, que é mais provável para os imóveis de padronização comum, e mais difícil para imóveis customizados ${ }^{66}$;

[iv] - há dinâmica nas instalações do espaço para atender as variações nas tecnologias de produção/operação. Nesses casos o controle no uso do espaço durante o ciclo operacional é importante $^{67}$. Nas locações urbanas comerciais é comum nos contratos a devolução do imóvel no estado original e o aceite do proprietário para as intervenções que alteram os sistemas originais. Dessa forma, a depender do tipo e da periodicidade das intervenções no espaço, essa liberdade é relevante à escolha pela propriedade do imóvel;

[v] há o vínculo da operação com o imóvel, ou seja, o ativo é estratégico à operação. A depender da cultura da corporação, pode-se optar pela eliminação do risco de depender de negociações com proprietários no futuro;

[vi] o imóvel é específico ou customizado para operação da corporação ou deseja-se traduzir a imagem corporativa ao ambiente externo, pela arquitetura específica da fachada e acabamentos externos. Essa especificidade restringe as [alternativas], pois mais difícil será a disponibilidade no mercado de imóveis para locação que atendam as necessidades da corporação. Nessa situação, resta à corporação optar pela imobilização, ou mostrar-se atrativa aos investidores das modalidades BTS e SLB, que estruturam o funding da implantação (ou

${ }^{66}$ Porém, preservar valor não está apenas relacionado com a especificidade. Essa característica limita a capacidade de geração de renda, visto a baixa liquidez do imóvel no mercado. Porém, conforme ROCHA LIMA (1997), o valor do ativo que está associado à sua capacidade de geração de renda, só preserva valor (capacidade de geração de renda homogênea), se for possível manter a qualidade do empreendimento homogênea, por meio da conservação, manutenção continuada, adequação e atualização funcional, até um momento que é necessário reciclá-lo por desgaste dos seus atributos, relativamente às inovações que vão ocorrendo no meio.

67 Observou-se durante as entrevistas que o controle durante o uso do espaço é um atributo importante nos casos de operações que utilizam instalações mais complexas, como as unidades produtivas, mas não é um atributo relevante tratando-se dos escritórios. Nesses espaços, pela própria atividade realizada, as intervenções durante o uso são mais simples, como mudanças de layout (intervenções facilmente aprovadas pelos proprietários dos imóveis, quando a corporação é locatária). 
compra) desses imóveis com recursos do sistema financeiro por meio de empréstimos pontes, pagos, posteriormente, com o recebimento do aluguel (recebíveis). Por essa razão, a nota de rating de crédito da corporação não só é avaliada pelos investidores/empreendedores dessas modalidades, como também pelas instituições financeiras que concedem o empréstimo. Soma-se o fato desses imóveis serem estratégicos para o desempenho da corporação, favorecendo em certos casos a escolha pela propriedade.

A escolha também sofre influência dos ciclos dos mercados de real estate para a tipologia de cada imóvel em análise, sendo favorável comprar ou a não desmobilizar quando os preços de mercado estão em queda, caso dos períodos de contenção ou recessão dos ciclos, visto a oportunidade de ganho na compra de novos imóveis ou a perda na venda dos ativos imobiliários da corporação. Porém, levando sempre em consideração o alinhamento das necessidades de uso do espaço com a opção de ser proprietário, principalmente no que tange o horizonte de uso e as oportunidades alternativas de investimento, como oportunidades estratégicas e urgentes no negócio principal.

Quanto mais cumulativos forem os aspectos mencionados acima, maior será a propensão pela propriedade do imóvel.

\subsubsection{Impactos contábeis, financeiros e tributários quando proprietária do imóvel}

Uma das desvantagens para as corporações que predominam como proprietárias dos imóveis no portfolio, além da perda de oportunidade de investimento no negócio principal, é o impacto nos índices do balanço. Como os imóveis da corporação são considerados no balanço como ativo permanente e é um dos ativos mais onerosos à operação, isso pode afetar a estrutura da corporação e suas medidas financeiras, avaliada pelo seu índice de liquidez, grau de imobilização, endividamento, entre outras ${ }^{68}$. Dessa forma, as corporações mais imobilizadas tendem a apresentar piores índices financeiros, medidos a partir dos balanços patrimoniais e demonstrativos de resultados.

Os indicadores de estrutura da corporação impactam na sua atratividade pelo mercado, já que traduzem o grau de risco da corporação (liquidez e endividamento). Essa atratividade é mais importante para empresas de capital aberto. BROUNEN e EICHHOLTZ (2005) analisaram as

68 Esses indicadores são contemplados na análise quantitativa do [MAOI], conteúdo apresentado no Capítulo 6. 
implicações do grau de imobilização em real estate no desempenho da corporação - avaliado a partir do valor da ação das corporações no mercado de capitais, dividendos distribuídos e informações do balanço patrimonial ${ }^{69}$. A pesquisa do autor baseou-se em uma amostra de 4.636 corporações de nove países. Nessa pesquisa o autor constatou que as corporações com maior grau de imobilização em real estate apresentaram pior desempenho, medido pela variação da atratividade da corporação no mercado, avaliada a partir do valor $\operatorname{Beta}^{70}$ nos anos analisados e do retorno anual (dividendos aos investidores) ${ }^{71}$.

Quanto aos impactos tributários, quando proprietária do imóvel considera-se para efeito tributário a dedução da depreciação dos imóveis no cálculo do lucro real, para empresas tributadas nesse regime. Essa depreciação é distribuída pelo ciclo de vida do ativo, calculado sobre o valor da construção, ou seja, desconta-se o valor do terreno para cálculo da depreciação ${ }^{72}$.

\subsubsection{Pertinência da opção pela propriedade do imóvel quanto ao atendimento aos critérios de decisão}

Tratando-se do [Critério A] - flexibilidade de mudança - quando proprietária essa facilidade é comprometida. Parte-se da premissa que o uso dessa [alternativa] é apenas apropriado para os imóveis com longo horizonte de uso. Isso pelo fato do negócio principal da corporação não ser investimento em real estate para se especular oportunidades de ganho com a compra e venda de imóveis no curto prazo. Na necessidade de mudança do espaço ocupado, antes do horizonte planejado, a corporação terá que se desfazer do ativo imobiliário, com todos os investimentos feitos no local, se expondo aos riscos de mercado na ocasião da necessidade da

69 Essas informações foram levantadas em um software chamado Compustat, desenvolvido pela Standard \& Poor's, utilizando valores de 1992, 1995, 1998 e 2000.

70 O valor beta de uma corporação é uma das variáveis para calcular o valor da sua ação no mercado e espelha a atratividade da corporação em relação a outras oportunidades de investimento, tanto no mesmo setor (comparando com o Beta setorial) como em outros setores.

71 No entanto, esse impacto negativo não ocorreu em todos os setores. No setor de empresas de transporte o impacto da imobilização foi positivo. Em razão disso, o autor concluiu que este impacto depende do setor de atuação, que apresenta diferentes estratégias em relação ao real estate. Isso justifica a importância de analisar, em conjunto, todos os critérios do [MAOI], pois nem sempre a desmobilização, ou a não imobilização, são as [alternativas] mais apropriadas.

72 Os impactos tributários são avaliados quantitativamente no modelo de simulação, tanto para o caso da imobilização (depreciação do ativo), como para os casos de não imobilização (aluguel - despesa operacional dedutível). 
venda. A depender do volume de investimento e do prazo decorrido até a necessidade de desocupação do imóvel, pode ocorrer da corporação não ter uma duração capaz de diluir do balanço o passivo referente ao volume dos investimentos feitos nas instalações do espaço.

Além disso, os fatores relacionados aos mercados de real estate e especificidade do imóvel (que restringe o uso para terceiros) podem fazer com que essa desmobilização seja não atrativa ou demorada, podendo assim comprometer tanto do ponto de vista econômicofinanceiro como operacional.

Quanto ao [Critério C] - controle no uso do espaço corporativo, [Critério D] - vínculo da operação com o imóvel, [Critério E] - especificidade do imóvel e [Critério F] - oportunidade de tradução da imagem corporativa - essa opção é a que melhor atende a todos esses atributos dentre as outras [alternativas] do [MAOI]. Sendo proprietária a corporação tem total liberdade de intervenção no imóvel durante a operação; total garantia de permanência, desfazendo do imóvel apenas quando o espaço não mais atender as suas necessidades; conceber o imóvel com todas as especificações técnicas, arquitetônicas e de localização, por mais específicas e customizadas que sejam.

Contudo, caso a opção pela propriedade seja de imóveis prontos já disponíveis no mercado, pela priorização do início breve das atividades operacionais, mesmo com as devidas intervenções no espaço para atender a demanda operacional requerida, pode ocorrer da corporação ter que abdicar algumas especificidades para aproveitar o imóvel disponível na localização requerida. Nessas situações, priorizando o [Critério B] - rapidez na mobilização da atividade operacional ao espaço - podem ser comprometidos alguns dos critérios acima mencionados (como a especificidade do imóvel e a oportunidade de tradução da imagem corporativa).

Quando a corporação opta pela propriedade do imóvel, os critérios relacionados às estratégias de investimento não são prioridades na escolha. Pelo observado, tanto nas corporações [CR] como nas empresas [ERE], na maioria dos casos a opção pela propriedade prioriza: o [Critério D] - vínculo da operação com o imóvel; o [Critério C] - controle no uso do espaço durante a operação; e o [Critério E] - especificidade do imóvel. Por essa razão, os tipos de espaço predominantemente imobilizados pelas corporações são as unidades produtivas e as centrais operacionais, imóveis estratégicos, específicos e com alto investimento em instalações e equipamentos.

A Tabela 2 aponta as principais vantagens e desvantagens para a corporação, tanto 
operacionais como financeiras, quando proprietária do imóvel.

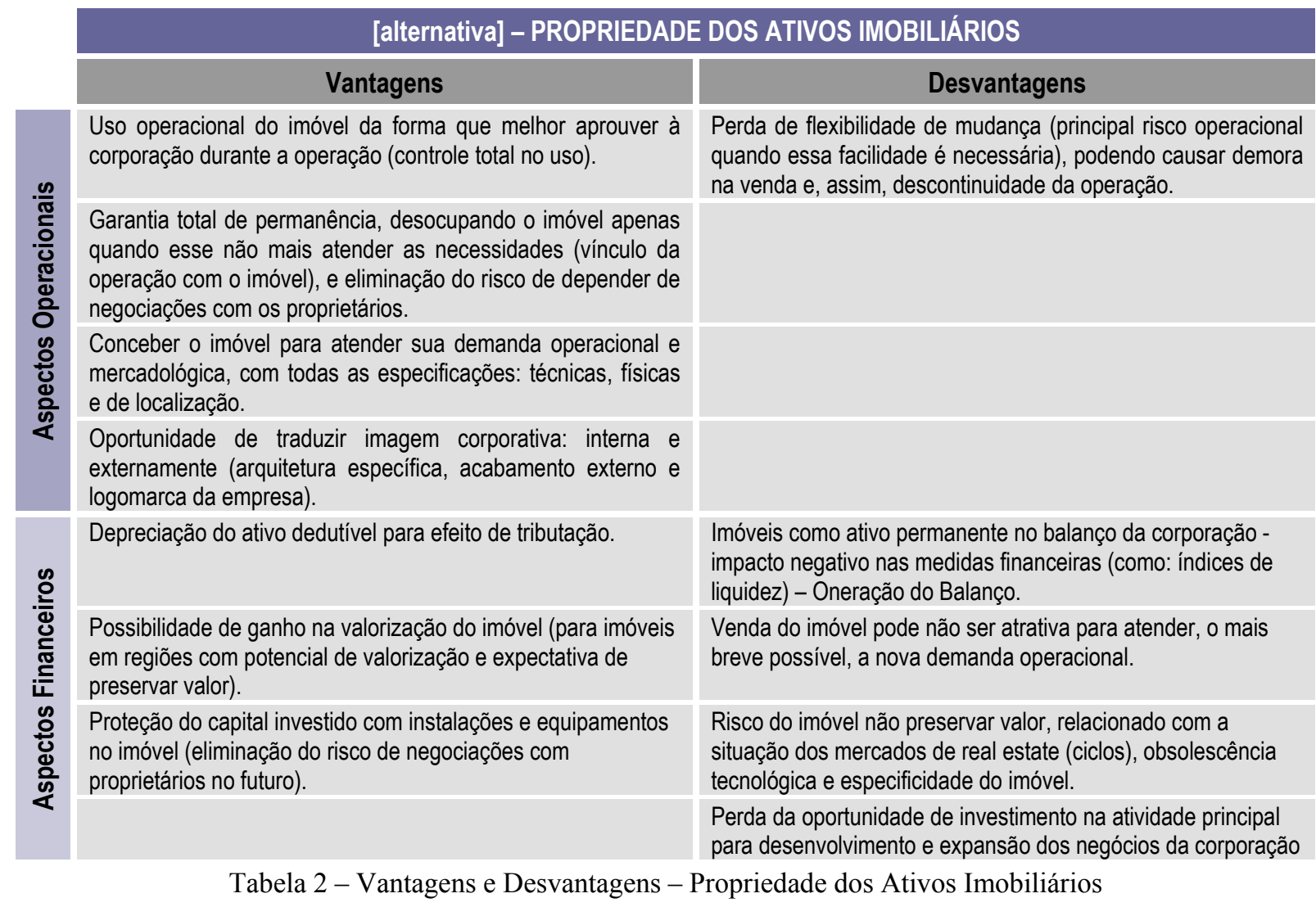

\subsection{Locação Simples - Curto e Longo Prazo}

Ao optar por uma locação, a corporação estará vinculada legalmente ao proprietário do imóvel através de um instrumento jurídico, o - contrato de locação - regido por legislação específica à locação dos imóveis urbanos: Lei 8.245 de 18 de outubro de $1991^{73}$. A locação não residencial simples é aquela destinada aos fins de instalação de comércio, indústria, escritórios, depósitos, ou qualquer outra atividade que não seja residencial, caso dos imóveis corporativos tratados nesta tese.

Os contratos de locação denominados como 'simples' refere-se àquelas locações de curto e longo prazo negociadas para imóveis comerciais já prontos e disponíveis no mercado para locação (imóveis em que a oferta, ou seja, a exposição ao mercado, antecede a procura).

As [alternativas] de locação permitem a corporação canalizar seus recursos na sua atividade

73 Lei $\mathrm{n}^{\circ}$ 8.245, de 18 de outubro de 1991, com última revisão em 2009 (alterações conforme Lei 12.112 de 2009). Dispõe sobre as locações dos imóveis urbanos. Disponível em: www.planalto.gov.br/ccivil_03/Leis/L8245.htm. Acesso em Julho de 2010. 
principal para desenvolvimento e expansão do seu negócio, e também conferem maior flexibilidade de mudança. Esses são os principais motivos pela escolha em locar os espaços demandados na operação.

A escolha de prazos de locação adequados para cada situação é feita pela equalização com o horizonte de uso do espaço planejado em função das estratégias corporativas.

Antes de tratar sobre os motivos da escolha pela locação de curto e longo prazo, assim como as principais vantagens e desvantagens destas [alternativas], vale citar as principais regras jurídicas presentes na Lei de Locação Urbana que impactam no atendimento aos critérios, tais como: direito de renovatória, permissão de sublocação, multas rescisórias, entre outras.

\subsubsection{Pertinências da locação simples - Principais regras jurídicas da lei de locação urbana relevantes à decisão}

Neste item serão descritas as regras que interferem positiva ou negativamente no atendimento aos critérios de decisão durante o uso do espaço, relacionando cada um dos critérios descrito no Capítulo 4 com as regras pertinentes da Lei de Locação.

$\mathrm{O}$ [Critério A] - flexibilidade de mudança, que confere à corporação facilidade de mudança para espaços que atendam as variações na sua demanda, relaciona-se com o custo e prazo para essa mudança. Portanto, para análise dessa flexibilidade na sustentação legal das locações urbanas comerciais é importante avaliar: a liberdade de desocupação do imóvel na ocasião desejada, as multas rescisórias e o direito de sublocação do espaço.

Antes da Lei 12.112/09, que alterou algumas regras da Lei 8.245, a corporação locatária tinha o direito de devolver o imóvel, quando assim desejar, pagando multa pactuada segundo a proporção prevista no Art. 924 do Código Civil. Essa multa era equivalente a três meses de aluguel proporcionais. Proporcional, nesse caso, era o pagamento da multa em valor proporcional ao período que faltaria para término do prazo contratual estipulado. No entanto, a Lei 12.112/09 alterou este Art. 4, passando a vigorar da seguinte forma: "durante o prazo estipulado para a duração do contrato, não poderá o locador reaver o imóvel alugado. $\mathrm{O}$ locatário, todavia, poderá devolvê-lo, pagando a multa pactuada, proporcionalmente ao período de cumprimento do contrato, ou, na sua falta, a que for judicialmente estipulada”. Esta alteração permite ao locador e locatário pactuarem uma multa proporcional ao período de contrato, ou seja, a corporação precisa adequar o horizonte de uso do imóvel com o prazo de contrato para evitar problemas judiciais e multas. Essa equalização de prazos permite a 
corporação ter flexibilidade de mudança quando desejado. Porém, caso a flexibilidade desejada seja no curto prazo, a melhor opção é firmar um contrato de curta duração, que em contrapartida compromete o [Critério D] - vínculo da operação com o imóvel.

Em relação ao direito de sublocação, pelo Art. 13 da lei, a corporação tem o direito de cessão de locação, de sublocação e empréstimo do imóvel, total ou parcialmente, porém com consentimento prévio e escrito do locador. Vale ressaltar que nessa situação a responsabilidade por todas as obrigações contratuais é da corporação locatária e é proibido sublocar por um valor de aluguel acima do negociado no contrato original.

Pelo exposto, pode-se concluir que no Brasil ao se optar pela locação simples baseando-se nas regras jurídicas regidas pela Lei, a corporação tem certa flexibilidade de mudança quando se firma contrato de menor duração, e para contrato de longa duração, quando se acorda previamente com o locador multa admissível para o caso da corporação rescindir o contrato antes do prazo estipulado. Além disso, se ganha flexibilidade em contratos que contemplam o direito de sublocação do imóvel.

Nos contratos de prazo indeterminado essa flexibilidade é ainda maior, a corporação não paga multa rescisória caso avise ao proprietário, com trinta dias de antecedência, o interesse pela desocupação.

Pelo levantamento de campo constatou-se como prática prevalente de mercado a permissão de sublocação apenas para empresas do mesmo grupo da corporação locatária. Tratando-se de locação de longo prazo, as quais em geral são oferecidas melhores condições à locatária, como desconto do valor de locação e carências ${ }^{74}$, a corporação além do aviso prévio sobre o interesse de desocupação do imóvel, paga uma multa diferenciada, acordada previamente no contrato (essa multa varia de três a seis meses de locação e não são proporcionais ao tempo restante para término do prazo contratual). Mesmo nessas condições praticadas pelo mercado de locação brasileiro, pode-se concluir que na locação simples a flexibilidade de mudança é um atributo atendido quando necessário à corporação.

No entanto, a escolha pela locação de curto prazo é pertinente apenas quando necessário. Além da perda dos benefícios (desconto nos preços de locação ou carências), os imóveis

74 O locador ao garantir um fluxo de renda mais homogêneo pode praticar melhores preços de locação ou melhores carências para a corporação locatária. Esses benefícios variam em função dos ciclos de mercado para a tipologia e localização de cada imóvel. No caso dos edifícios de escritórios na cidade de São Paulo, é comum carência de dois meses e desconto de 5\% a $10 \%$ do valor de locação para contratos com prazos maiores (com no mínimo cinco anos de duração). 
disponíveis para locação são, na maioria das situações, entregues com padronização comum, tendo a corporação que adequar o produto imobiliário a sua atividade. Assim, os investimentos para adequação do ambiente interno, como: cabeamento, divisórias, forros, pisos, são feitos pela locatária. Dessa forma, o ideal é uma permanência que permita a recuperação do investimento feito no espaço.

A permanência da locatária no imóvel relaciona-se com o [Critério D] - vínculo da operação com o imóvel. Para análise dessa permanência na sustentação legal das locações urbanas comerciais é importante avaliar: o direito de permanência da corporação locatária no imóvel durante o contrato, direito de renovatória e direito preferencial de compra.

Conforme Art. 4 da Lei, durante o prazo contratual o locador não poderá reaver o imóvel alugado. No caso de venda, promessa de venda, cessão ou promessa de cessão de direitos ou dação de pagamentos, pelo Art. 27 o locatário tem preferência de adquirir o imóvel locado, em igualdade de condições com terceiros. Em relação ao direito de renovatória, conforme Art. 51 , o locatário tem o direito de renovatória, caso o prazo do contrato seja de no mínimo cinco anos (ou a soma dos prazos ininterruptos dos contratos escritos seja de cinco anos). Assim, pode-se concluir que para melhor garantia de permanência no imóvel, quando for esse o interesse da corporação, como nos casos que se pretende consolidar ponto comercial, ou pela importância do imóvel à operação, há essa vantagem legal (direito de renovatória) para locação com prazo igual ou superior a cinco anos ${ }^{75}$.

Entretanto, conforme descrito no Art. 52, o proprietário pode recusar a ação renovatória para uso próprio ou reforma do imóvel, tendo a corporação que desocupá-lo, definitivamente, ou até término da reforma. Além disso, é também direito do proprietário a não renovação se no imóvel for ocorrer modificações de tal natureza que aumente o valor do negócio ou da propriedade, como no caso das incorporações imobiliárias (permutas). A ocorrência desse risco é mais provável para os casos de imóveis localizados em regiões com potencial de incorporações residenciais ou comerciais, com zoneamento que permita a sua verticalização.

75 Em razão disso, no [MAOI] define-se como locação de curto prazo [LCP] aquelas com prazo inferior a cinco anos ou de prazo indeterminado, e como locação de longo prazo [LLP] aquelas com duração igual ou superior a cinco anos. A corporação com intenção de renovação negocia contratos de pelo menos cinco anos para ganhar a vantagem legal do direito de renovatória compulsória. Durante as entrevistas, tanto nas corporações [CR] como nas empresas [ERE], foi possível verificar essa ocorrência. Os contratos de locação são predominantemente de cinco anos (ou mais), e em alguns casos de um a dois anos (quando se requer maior flexibilidade e/ou o locador não pretende ter a obrigação da renovatória). 
Esse risco é minimizado quando, [i] o imóvel já for uma incorporação de vulto expressivo (como edifícios de escritório), [ii] quando a localização não for potencial para incorporações de outra natureza (caso dos galpões localizados nas proximidades das vias de acesso), e [iii] os proprietários do imóvel sejam agentes especializados no mercado de real estate para renda, pela maior certeza do que desejam com o imóvel, que nesses casos é a renda gerada com a locação.

Esse risco de desocupação foi citado por uma das corporações [CR], conforme situação ocorrida em um dos seus pontos de venda com localização estratégica. Como esses pontos são bem localizados e em muitas situações são imóveis monousuários com baixo aproveitamento do terreno (ainda não verticalizados), a possibilidade de uma incorporação no local é um risco para a corporação quando locatária desses pontos.

Sendo assim, a depender da situação e, em decorrência, do risco, compromete-se o [Critério D] - vínculo da operação com o imóvel. Nas situações em que o imóvel é de fato estratégico, pelos motivos ora mencionados, mesmo para contratos com prazos iguais ou superiores a cinco anos, a desocupação do imóvel pode ser legalmente aprovada caso se enquadre nas situações citadas acima. Por conta disso, quando não se pretende desocupar o espaço pela sua importância estratégica à corporação, o ideal é firmar contratos com prazos de dez anos ou mais, visto que durante o prazo contratual o locador não poderá reaver o imóvel.

O [Critério C] - controle no uso do espaço - relaciona-se com a liberdade da corporação em realizar benfeitorias no imóvel durante a operação. Pelo observado na Lei Art. 23 (item VI), o locatário é obrigado a não modificar a forma interna ou externa do imóvel sem consentimento prévio do locador. Dessa forma, na opção peça locação há uma redução no controle operacional do espaço. É decisão de cada corporação, a depender do tipo e da frequência das intervenções durante o uso, aceitar a condição de negociação com o locador para as benfeitorias necessárias ao atendimento das necessidades operacionais.

A depender da classificação da benfeitoria como - necessária, útil ou voluptuária - a locatária tem direito de ser indenizada pela benfeitoria realizada no imóvel. A classificação que respeita as regras da Lei de Locação é:

[i] necessárias - quando se destinam à conservação do imóvel ou evitam que ele se deteriore, como por exemplo, reparos de telhado, substituição dos sistemas prediais danificados, entre outras. Essas benfeitorias quando introduzidas pelo locatário, são indenizáveis e dão direito de 
reter o imóvel até o recebimento dos gastos comprovados ${ }^{76}$;

[ii] úteis - são as intervenções que tornam o imóvel mais confortável, seguro ou ampliam sua utilidade, como por exemplo, a construção de garagens, rampas, introdução de outra utilidade, entre outras. Essas benfeitorias somente serão indenizáveis se previamente acordado com o locador. Pelo que se observou no levantamento de campo, na maioria dos casos as benfeitorias úteis não são indenizáveis, pois o que é útil para a operação da corporação dificilmente é considerado útil pelo proprietário. Portanto, a maioria das benfeitorias realizadas nos espaços corporativos não é indenizável, e ou se incorporam no imóvel ou são retiradas pelo locatário (devolução do imóvel como estado original ${ }^{77}$;

[iii] voluptuárias - são as intervenções que não aumentam ou facilitam o uso do imóvel, apenas podem torná-lo mais agradável, como por exemplo, obras de decoração. Essas benfeitorias não geram direito de retenção do imóvel, nem indenização.

Verificou-se no levantamento de campo que a importância, assim como o atendimento do [Critério C] - controle no uso do espaço nas locações simples, depende de três principais fatores - [i] se o edifício é monousuário ou multiusuário; [ii] se o contrato é de curto ou longo prazo; e [iii] da atividade realizada no espaço.

No caso dos edifícios monousuários, como sedes administrativas e pontos de venda e serviços, a corporação locatária tem maior liberdade de intervenções. Nesses casos a predominância é pelos contratos de longo prazo. Pelo fato do imóvel atender as necessidades operacionais de um único locatário, quanto maior for a liberdade durante o uso, maior será a probabilidade da corporação permanecer no espaço, que é uma vantagem para ambas as partes envolvidas. Quando o imóvel é multiusuário, como o caso dos edifícios de escritórios e galpões para armazenagem, as intervenções são mais controladas pelos proprietários, pois o espaço corporativo atende diferentes usuários, principalmente tratando-se de contratos de

76 Conforme observado no levantamento de campo, na prática, para espaços corporativos, isso dificilmente ocorre. $\mathrm{Na}$ maioria das situações são os próprios usuários que promovem as intervenções no espaço para sua melhor utilização, sem, contudo, ser totalmente indenizados por isso. Podem ocorrer negociações entre proprietários e locatários para descontos na locação, alguma carência, ou divisão das despesas, mas em geral, a intervenção é feita pelo ocupante do espaço corporativo.

77 Verificou-se pelo levantamento de campo que na maioria das situações o proprietário permite essa liberdade de intervenções, já que contratualmente o imóvel deve ser devolvido no estado original. Contudo, quando na percepção do proprietário a benfeitoria agrega valor ao imóvel não há a exigência de devolução no estado original, mas dificilmente a benfeitoria é enquadrada como útil (para não ocorrer a indenização). 
curto prazo, já que o espaço deve manter a padronização comum do imóvel para atender rapidamente a um próximo locatário.

A depender da atividade realizada no imóvel, a necessidade e a complexidade das intervenções variam. Atividades realizadas nos escritórios demandam na maioria dos casos apenas mudanças de layout, que são liberadas pelos proprietários, até mesmo sem consentimento prévio. Já se tratando de pontos de venda e serviço, as intervenções são maiores, como mudanças nas utilidades e melhorias constantes nas fachadas, sendo nessas situações maior a importância desse atributo e há necessidade de aceite do proprietário para as intervenções mais representativas (como: sistemas de abastecimento, utilidades, fachadas). Nas unidades produtivas as instalações são mais complexas e as intervenções exigem obras maiores, sendo uma das razões pela predominância da propriedade observada para esse tipo de espaço corporativo (conforme Quadro 4 do item 4.3).

Nas locações simples, pelo identificado nas entrevistas, o [Critério F] - oportunidade de tradução da imagem corporativa - também varia, tanto em importância à corporação, como quanto ao seu atendimento, pelos seguintes fatores: [i] se o edifício é monousuário ou multiusuário; [ii] prazos de locação; e [iii] tipo de espaço corporativo.

Nos edifícios monousuários, independente do tipo de espaço (sedes, pontos de venda) há a oportunidade de tradução da imagem corporativa, tanto interna como externamente, já nos edifícios multiusuários a tradução se restringe à escolha da localização, do empreendimento e no ambiente interno, que é para muitas situações a oportunidade de tradução desejada. Contudo, nas duas situações a corporação deve encontrar no mercado um empreendimento que atende a arquitetura e localização desejadas, assim como todas as especificações técnicas demandadas na operação, se adequando ao produto imobiliário disponível para locação. Embora exista essa necessidade de adaptação ao produto imobiliário pronto, verificou-se que essa é uma preferência pelas corporações, ao invés de recorrer pela modalidade BTS, que é uma [alternativa] mais demorada e envolve na maior parte dos casos contratos mais amarrados e complexos ${ }^{78}$.

A importância da tradução da imagem também varia com o tipo do espaço corporativo. Nos espaços onde há relação direta com consumidores ou clientes, a importância dada a esse atributo é maior, como os casos das sedes administrativas e dos pontos de venda e serviços.

78 Nessas situações o [Critério B] - rapidez na mobilização da atividade operacional para o espaço - é mais importante que o atendimento de todas as especificidades desejadas pela corporação. 
Nas unidades produtivas, galpões e centrais operacionais, essa tradução não é usualmente importante.

Como exposto anteriormente, nas locações simples a corporação que se adapta ao produto imobiliário exposto no mercado para locação. Dessa forma, o [Critério E] - especificidade do imóvel - é comprometido nas locações simples a depender do nível de especificidade requerida.

Algumas outras regras jurídicas da Lei de Locação Urbana (como a ação revisional), também relevantes à análise, impactam do ponto de vista quantitativo da decisão e, portanto, são tratadas na análise quantitativa e no modelo de simulação.

\subsubsection{Impactos contábeis, financeiros e tributários quando locatária do imóvel}

As vantagens tributárias e contábeis são um dos fatores da escolha pela locação dos espaços corporativos. O pagamento do aluguel pode ser deduzido do lucro real, o que reduz, portanto, o valor pago pelos impostos para as corporações que sejam tributadas neste regime (lucro real).

Quando proprietária a corporação pode deduzir do lucro para cálculo dos impostos a depreciação do imóvel. Contudo, as corporações com maiores porcentagens de espaços alugados pelo total de espaço usado na operação tendem a apresentar menores obrigações com tributos, já que a dedução, referente à depreciação do ativo, é mais diluída em razão da sua distribuição ser em todo o ciclo de vida do ativo, que para imóveis é de 25 anos, além de ser descontado o valor do terreno do valor a ser depreciado.

A vantagem contábil ocorre em razão do pagamento do aluguel não transparecer nos índices financeiros apurados em uma análise de demonstrações financeiras do locatário. A obrigação referente ao fluxo de pagamento do aluguel pode ser lançada nas notas explicativas das demonstrações financeiras contábeis, e não no balanço patrimonial como passível exigível ou como ativo imobilizado. Isso traz melhores índices de estrutura à corporação, evidenciados pelo grau de imobilização, endividamento e liquidez. Além disso, medidas financeiras mais atrativas podem auxiliar na busca de crédito comercial ${ }^{79}$ para investimentos na atividade produtiva (BLATT, 1998).

79 Para crédito bancário isto em geral não ocorre. O analista de crédito das instituições financeiras tem mais acesso às informações dessa 'obrigação oculta' do que o analista de crédito comercial. 
As corporações com menor grau de imobilização em ativos imobiliários podem, portanto, apresentar melhores índices financeiros, em razão do menor impacto do recurso real estate no balanço.

Os impactos contábeis, que interferem nos índices financeiros das corporações, e tributários, relacionados aos critérios de decisão mensuráveis (desoneração do balanço e redução dos impactos tributários), são avaliados quantitativamente no [MAOI].

\subsubsection{Motivos da escolha pela Locação Simples de Curto e Longo Prazo}

Pelo exposto no item anterior, é possível identificar os principais motivos da escolha pela locação simples como alternativa para acomodação das atividades das corporações.

Ao optar pela locação dos espaços corporativos a priorização é dada para a canalização de recursos em oportunidades estratégicas do negócio principal, a desoneração do balanço, redução dos impactos tributários e a flexibilidade de mudança.

Os contratos de curto prazo são preferências pelas corporações quando:

[i] há incertezas quanto às necessidades futuras de espaço, caso das corporações em estágio inicial de crescimento, ou para atender a dinâmica do setor de atuação, ou ainda em razão do curto horizonte de uso para a atividade realizada no espaço, motivos esses que requerem flexibilidade de mudança no curto prazo;

[ii] há necessidade de rapidez na mobilização da atividade operacional para o espaço locado, por esse já estar pronto para operar;

[iii] o imóvel não é estratégico para a corporação e existem disponíveis no mercado outros imóveis que igualmente atendem à operação. Ou seja, o vínculo da operação com o imóvel não é fator relevante na escolha;

[iv] a oportunidade de traduzir a imagem corporativa refere-se apenas à escolha da localização, do empreendimento, e no máximo no ambiente interno. Para locação de curto prazo é vantagem locar espaços que exijam o mínimo possível de investimento para sua adequação ao uso, visto a curta duração para recuperação dos investimentos feitos e a não garantia de renovação do contrato.

Pelo identificado a partir das entrevistas, os espaços que comumente são alugados pelo curto prazo são escritórios para atividades de prestação de serviço das corporações. Nesses casos as 
durações dos contratos de locação seguem a mesma duração dos contratos com a contratante do serviço. O mesmo ocorre no caso de galpões para operações logísticas, os quais se firmam contratos de locação em conformidade com a duração do contrato de prestação dos serviços de logística.

Os contratos de longo prazo são preferências pelas corporações quando:

[i] a corporação tem conhecimento das necessidades futuras de espaço (localização, área e demanda operacional), sendo menor a necessidade de flexibilidade de mudança, assim é possível negociar valores de locação mais atrativos e carências;

[ii] não há especificidades que dificultam a disponibilidade de imóveis no mercado apropriados para atender a demanda operacional e mercadológica da operação. Esses imóveis podem já atender a demanda no modo como expostos no mercado, ou com as adequações promovidas pela própria corporação;

[iii] é conhecida a importância estratégica do imóvel para a operação nele realizada. Nesses contratos há melhor garantia de permanência da corporação no imóvel, quando comparado à locação de curto prazo, em razão do direito de renovatória. Contudo, conforme exposto no item 5.2.1, essa garantia de permanência tem seus riscos. Cabe ao decisor (corporação) sua aceitação, visto a importância estratégica do imóvel e a situação de risco (como o potencial do local para incorporações futuras);

[iv] a oportunidade de traduzir a imagem corporativa refere-se apenas à escolha da localização, do empreendimento e no ambiente interno. Para os edifícios monousuários, ou pontos de venda e serviços, a tradução da imagem corporativa, interna e externamente, é permitida pelo proprietário, tendo a corporação que encontrar um imóvel com características arquitetônicas compatíveis à imagem desejada.

Quando locatária a corporação elimina o risco de desvalorização do imóvel. Entretanto, a depender da situação do mercado para a tipologia e localização do imóvel, o preço de locação do espaço pode aumentar na ocasião da ação revisional (se houver a revisional, já que conforme Art. 18 da Lei de Locação é lícito às partes fixar, de comum acordo, novo valor para o aluguel, bem como inserir ou modificar cláusula de reajuste, que pode se limitar a algum índice de preços e não ao preço de mercado).

A escolha pela locação de longo prazo é comum, conforme levantamento de campo, para os seguintes espaços corporativos: sedes administrativas, escritórios regionais, pontos de venda e serviços e galpões para armazenagem. 
As Tabela 3 e 4 resumem as vantagens e desvantagens da locação simples de curto e longo

prazo, respectivamente, tanto relacionadas aos aspectos operacionais como financeiros.

\begin{tabular}{|c|c|c|}
\hline & [alternativa] - LOCAÇ & O DE CURTO PRAZO \\
\hline & Vantagens & Desvantagens \\
\hline & $\begin{array}{l}\text { Alta flexibilidade de mudança para atender a dinâmica das } \\
\text { alterações nas quantidades de área, localização e demanda } \\
\text { operacional dos espaços. }\end{array}$ & $\begin{array}{l}\text { Perda de controle operacional do espaço - a corporação deve } \\
\text { se adaptar a configuração do espaço pronto para operar e tem } \\
\text { pouca liberdade de intervenções durante o uso do espaço. }\end{array}$ \\
\hline 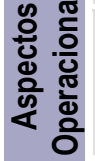 & $\begin{array}{l}\text { Rapidez na mobilização da atividade operacional para o espaço } \\
\text { locado por este já estar pronto para operar. }\end{array}$ & $\begin{array}{l}\text { Perda da oportunidade de traduzir imagem corporativa ao } \\
\text { ambiente externo - tradução da imagem se restringe a: } \\
\text { escolha da localização, do empreendimento, e a depender do } \\
\text { caso no ambiente interno. }\end{array}$ \\
\hline & & $\begin{array}{l}\text { Caso a corporação pretenda estender sua ocupação no } \\
\text { espaço, não há garantia de permanência. }\end{array}$ \\
\hline ๓ : & $\begin{array}{l}\text { As despesas com a locação são dedutíveis para efeito de } \\
\text { tributação. }\end{array}$ & $\begin{array}{l}\text { Preços de locação maiores em comparação aos contratos de } \\
\text { maior duração, além da perda de carências. }\end{array}$ \\
\hline 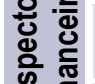 & $\begin{array}{l}\text { Não causa impacto negativo no balanço (melhores medidas } \\
\text { financeiras à corporação: como os índices de liquidez). }\end{array}$ & $\begin{array}{l}\text { Duração de ocupação do espaço pode não ser suficiente para } \\
\text { recuperar o investimento feito no local. }\end{array}$ \\
\hline 是 & $\begin{array}{l}\text { Canalização de recursos em oportunidades estratégicas do } \\
\text { negócio principal, gerando melhores resultados corporativos. }\end{array}$ & \\
\hline
\end{tabular}

Tabela 3 - Vantagens e Desvantagens - Locação Simples de Curto Prazo (LCP)

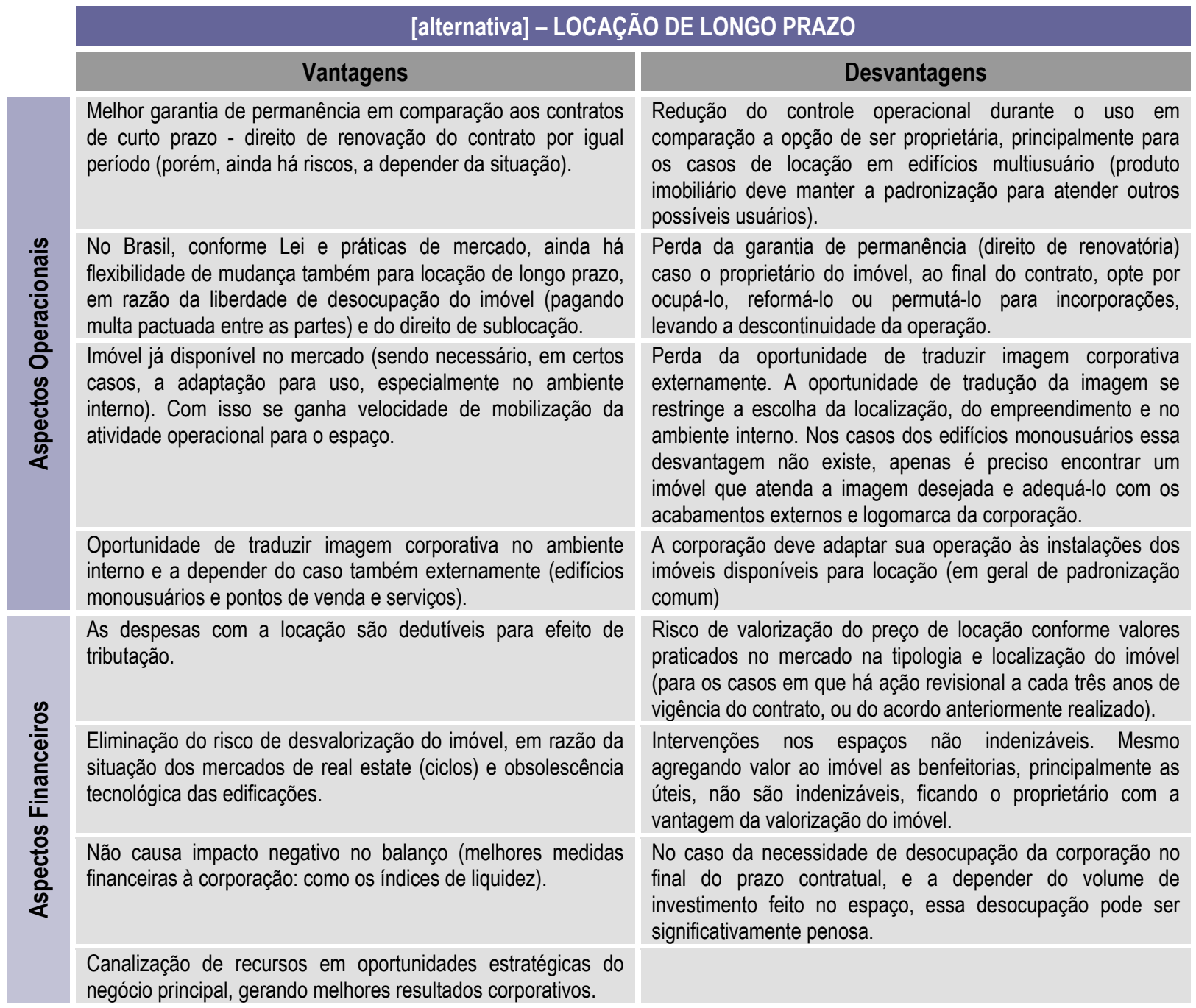

Tabela 4 - Vantagens e Desvantagens - Locação Simples de Longo Prazo (LLP) 


\subsection{Operações Estruturadas - Build-to-Suit e Sale-Leaseback}

As transações de BTS e SLB são denominadas como operações estruturadas pela relação entre corporação usuária e proprietário do imóvel ir além de uma simples relação locador e locatário. Antecedente a locação do imóvel, no caso do BTS, há a sua construção e entrega com características específicas de uso para a corporação, futura usuária. No caso do SLB, antecedente à locação há a compra do imóvel já ocupado pela corporação. Nessas transações a procura antecede a oferta. O imóvel não é um produto imobiliário exposto no mercado para locação. Essas especialidades incubem a essas transações características que vão além da operação imobiliária: trata-se também de uma operação financeira que envolve, em conjunto, todas as demais relações além da locação propriamente dita.

Soma-se outro aspecto que as tornam estruturadas: a captação de recursos no sistema financeiro por meio dos veículos de securitização lastreados nos recebíveis (fluxo dos aluguéis pago pela corporação usuária durante o prazo do contrato de locação). O pagamento dos aluguéis é usado para a liquidação dos recursos captados nesse mercado, chamado de empréstimo ponte. Essa captação antecipada dos recebíveis é parte importante no funding para implantação (ou compra) de empreendimentos nessas duas modalidades, motivo que impulsionou o crescimento dessas transações no Brasil desde o início da década de 2000.

Isso induz a existência de algumas particularidades nas negociações contratuais entre proprietários e corporações usuárias, quando comparadas a uma locação simples regida pela Lei de Locação Urbana. Vale ressaltar, que as particularidades aqui apresentadas são práticas prevalentes de mercado, porém não se configuram, categoricamente, como jurisprudência.

Antes de aventar sobre os motivos que levam as corporações a adotarem esses mecanismos para reestruturação do real estate, bem como as particularidades dessas transações conferidas à realidade brasileira, vale citar as principais características de outro instrumento jurídico que tem sido utilizado nas transações de SLB e BTS no Brasil, denominado como Direito Real de Superfície (DRS). 


\subsubsection{Direito Real de Superfície - DRS}

Embora investidores/empreendedores ${ }^{80}$ tenham conseguido equacionamentos de fundos apropriados para implantação (ou compra) dos empreendimentos concebidos nessas modalidades - BTS e SLB - por conta do avanço do sistema financeiro impulsionado pela securitização, ainda há um ponto nevrálgico dessas transações no Brasil, - a falta de amadurecimento nas negociações, principalmente no que tange aos aspectos jurídicos que vinculam legalmente as partes envolvidas. A partir do levantamento de campo nas empresas [ERE] constatou-se que um dos obstáculos para o maior volume de operações de BTS no Brasil é a insegurança jurídica, visto que ainda há casos em que essas operações são comparadas com uma isolada transação de locação simples aplicada aos imóveis já disponíveis no mercado ${ }^{81}$.

Essa insegurança tem feito com que os investidores se empenhem para a escolha de mecanismos que confiram maior proteção na operação. Um desses mecanismos é a escolha da - Cessão de Direito Real de Superfície - em substituição aos contratos de locação (mesmo que com todas as avenças neles descritas). Esse instrumento jurídico que vincula legalmente o proprietário do imóvel da corporação usuária é regido por legislação específica - Lei Federal 10.257/01 ${ }^{82}$, instituído pelo Estatuto da Cidade em 2001 e introduzido no Código Civil Brasileiro em 2002.

De acordo com o disposto na legislação, a superfície pode ser definida como a faculdade do proprietário de romper, pelo prazo de vigência da superfície, com o princípio da acessão, segundo o qual tudo que existe sobre o solo a ele se incorpora e pertence ao proprietário do solo, permitindo a co-existência, durante a vigência da superfície, de um titular do domínio sobre o solo e de um titular com domínio sobre a construção existente no imóvel. Dessa

80 Há casos em que a figura do empreendedor e do investidor se confunde. Isso ocorre quando o próprio empreendedor do imóvel é o investidor, sendo responsável por toda a estruturação financeira da transação. Neste texto, a figura desse agente será denominada - investidor.

81 Esse assunto é polêmico e ainda não totalmente esclarecido no âmbito jurídico. Essa obliquidade impede que imóveis, quando extremamente customizados, sejam concebidos por investidores de BTS. Essa ocorrência foi constatada nas empresas [ERE], que analisam a possibilidade de relocação do imóvel no mercado, ou seja, sua liquidez, antes da aceitação pelo investimento no imóvel. No entanto, isso vai depender da percepção de risco dos investidores em cada situação.

82 Lei $^{\circ}$ 10.257/01 de 10 de Julho de 2001. Estabelece normas de ordem pública e interesse social que regulam o uso da propriedade urbana em prol do bem coletivo, da segurança e do bem estar dos cidadãos, bem como do equilíbrio ambiental. Disponível em: www.planalto.gov.br. Acesso em Dezembro de 2006. 
forma, o direito real de superfície é um direito real autônomo, conferindo ao seu titular, nesse caso chamado de superficiário, o direito amplo e pleno de uso, gozo e fruição da superfície, incluindo a possibilidade de transferir o direito de superfície para um terceiro. Caso a superfície seja outorgada por prazo determinado, quando findo esse prazo, o proprietário readquirirá a propriedade plena sobre o terreno, construção (benfeitoria) ou plantação, independentemente de indenização, salvo se as partes não tiverem estipulado o contrário (Art. 1.375 do Código Civil; Art. 24 do Estatuto da Cidade).

Em linhas gerais, o DRS limita a propriedade do ativo no tempo. A corporação é como proprietária do imóvel ocupado enquanto o prazo do DRS estiver vigente, podendo assim utilizar o espaço da forma que melhor lhe aprouver (exceto em caráter desapropriatório ${ }^{83}$ ). Nesse tipo de contrato a corporação paga um preço pelo direito de uso da superfície. Isso inibe a rescisão da corporação usuária, antes do término do contrato, visto a necessidade de pagamento integral do preço negociado entre as partes. Assim, para o investidor, isso garante maior proteção quanto ao cumprimento das obrigações contratuais por parte das corporações, que deve cumprir com o pagamento do preço da outorga de uso.

No entanto, existem pontos positivos e negativos para a corporação quando se utiliza esse instrumento, razão pela qual ainda há corporações que não aceitam o uso do DRS nessas transações. Na prática, o tratamento contábil e fiscal se difere. O preço da outorga no DRS passa a ser para a corporação um ativo permanente, sendo contabilizado na conta do imobilizado (ativo não circulante), e um dos objetivos da escolha pelo BTS e SLB é a desoneração do balanço. Sendo assim, o uso desse instrumento impacta nos seus índices financeiros. Por outro lado, gera para a corporação uma 'amortização acelerada', reduzindo significativamente os impactos tributários.

Conforme Regulamento do Imposto de Renda (RIR) ${ }^{84}$, pode ser amortizado o capital aplicado na aquisição de direitos cuja existência ou exercício tenha duração limitada. O DRS assim se enquadra. A corporação paga um preço pelo direito de superfície com duração limitada (prazo da outorga). Dessa forma, a amortização de todo o preço deve se encaixar no prazo contratual

83 Pelo Art. 24 da Lei Estatuto da Cidade, antes do término do contrato, extinguir-se-á o direito de superfície, caso o superficiário der ao terreno destinação diversa daquela para a qual for concedida ou pelo descumprimento das obrigações contratuais.

84 RIR/1999, Art. 325, inciso I. Dispõe sobre tributação e imobilização de direitos, para pessoas jurídicas - concessão de direito real de uso. Disponível em: www.receita.fazenda.gov.br. Acesso em Dezembro de 2006. 
do direito de superfície, isso gera um efeito fiscal como uma 'depreciação acelerada', reduzindo o imposto de renda e contribuição social pagos pela corporação.

Outra vantagem do DRS é a menor importância na avaliação da nota de classificação de rating de crédito da corporação, visto a obrigatoriedade do ocupante honrar com todas as obrigações contratuais. Como em geral essas transações só são feitas com corporações de elevada credibilidade, isso pode aumentar a gama de corporações capazes de desmobilizar seus ativos imobiliários ou não imobilizar nas novas necessidades de imóveis customizados. Por outro lado, a atratividade dos veículos securitizados, a depender da corporação, pode ser comprometida, impactando no equacionamento de fundos por parte dos investidores.

Além disso, com esse tipo de instrumento a corporação tem total liberdade de intervenções durante o uso do imóvel. Enquanto superficiária, o imóvel é como sua propriedade, podendo a corporação usar o espaço da forma que melhor lhe aprouver, salvo intervenções que alterem o uso original do imóvel (ou em caráter desapropriatório).

Outros dois contrapontos para a corporação superficiária, além do impacto no balanço, são:

[i] não existência da renovatória compulsória no final do prazo da outorga. No entanto, como nesses casos a negociação é uma relação entre dois agentes profissionais, que sabem o que pretendem com o imóvel (um, a acomodação de sua atividade operacional e, outro, a renda gerada pelo pagamento das contraprestações do DRS), o risco de não ser feito outro contrato de DRS é baixo. Soma-se ainda a questão da infungibilidade do imóvel nessas transações, tanto da operação, como muitas vezes funcional (especificidades técnicas e de localização);

[ii] quando superficiária a corporação é responsável por quaisquer danos na superfície, assim como, pelas benfeitorias necessárias (reposição do ativo), que no caso da locação são responsabilidades do proprietário.

\subsubsection{Contratos tipo Build-to-Suit}

Uma operação é caracterizada como BTS quando a corporação negocia com um investidor a construção de um imóvel feito 'sob encomenda'. Assim, no BTS a parte interessada em ocupar o imóvel (usuário), contrata com um investidor imobiliário - [i] a aquisição do terreno, em localização estratégica para o ocupante; [ii] a construção do imóvel com todas as especificações técnicas e arquitetônicas requeridas pelo usuário, e [iii] a locação de longo prazo do imóvel com o investidor. 
Esse modelo de negócio imobiliário é voltado à maximização do aproveitamento econômico, financeiro e fiscal da utilização do espaço corporativo destinado ao desenvolvimento das atividades das corporações. Conforme VALENÇA (2005), o uso desse modelo de negócio traz vantagens para todas as partes nele envolvidas - [i] na corporação modernizam-se as instalações, na medida em que se empreendem imóveis customizados que podem contemplar as mais modernas tecnologias, melhora os índices de liquidez e outras medidas financeiras (exceto no uso do DRS), e gera despesa operacional dedutível; [ii] o investidor imobiliário comercializa os projetos antes deles serem desenvolvidos, e [iii] o agente financeiro concede crédito garantido com recursos próprios ou de terceiros, com diferentes possibilidades de amortização, e não necessariamente vinculados a qualquer sistema de financiamento imobiliário disponível (que para financiamento imobiliário são o SFI - Sistema Financeiro Imobiliário e o SFH - Sistema Financeiro da Habitação).

Quando a corporação não encontra no mercado um imóvel que atenda suas especificações, o modelo BTS é uma [alternativa] atrativa para a não imobilização ou para o leasing imobiliário. Nesta última opção, há três aspectos negativos e, por isso, não são mais praticados no Brasil, tampouco no âmbito internacional - [i] aspectos regulatórios: o arrendador mercantil deve ser obrigatoriamente uma instituição financeira e, portanto, está sujeito às regras aplicáveis às instituições financeiras, já o investidor não está sujeito a nenhuma regulamentação específica; [ii] funding: na qualidade de instituição financeira, o arrendador mercantil está sujeito às taxas daquele mercado para captação de funding, em contrapartida, o investidor pode utilizar recursos próprios, captar privada ou publicamente os recursos (por meio dos CRI, por exemplo), seja de partes financeiras ou não financeiras; [iii] custo da operação: as instituições financeiras incorporam na remuneração das contraprestações pagas pelo usuário, entre outras variantes, o risco de ficar com o imóvel no final (de uso específico para um particular usuário), já no BTS é da essência do negócio para os investidores dessa modalidade ficar com o imóvel no final do contrato (VALENÇA, 2005).

O BTS pode também ser um mecanismo para a desmobilização imobiliária com possibilidade de modernização dos espaços. Muitas corporações são proprietários dos seus espaços corporativos pelos motivos ora mencionados. A depender da credibilidade da corporação e do nível de especificidade do espaço demandado na operação, a corporação poderá optar pelo BTS, vendendo seu atual imóvel e ocupando uma nova acomodação, com as mais modernas instalações, concebido no BTS, porém como locatária.

As primeiras transações de BTS no Brasil foram observadas, em sua maioria, no setor 
industrial em razão dos espaços ocupados por essas corporações serem customizados, não estando disponível no mercado para locação, e por serem corporações de grande porte, que traduz certo grau de confiabilidade no que diz respeito à capacidade de crédito. Contudo, atualmente já se observa o uso desse mecanismo no setor de serviços, inclusive o setor de educação, como o caso recente da Ibmec, que optou pelo BTS para construção do novo campus em São Paulo. No setor de varejo a opção pelo BTS também tem se intensificado, como as redes de supermercado (caso do Carrefour). No setor de logística essa modalidade mostra forte tendência, as grandes corporações que precisam de galpões de estocagem e centros de distribuição optam pelo BTS para não imobilizar em ativos fixos, e ao mesmo tempo para ocupar seus espaços na localidade escolhida de modo a atender seus interesses logísticos.

\subsubsection{Particularidades dos contratos Build-to-Suit no Brasil - análise de pertinência quanto ao atendimento aos critérios de decisão}

Neste item serão apresentadas as principais particularidades dos BTS no Brasil, a sustentação legal dos contratos e as práticas prevalentes de mercado nas negociações ${ }^{85}$. As características dessas operações de BTS foram confrontadas com os critérios de decisão para análise da pertinência desta [alternativa] em relação ao atendimento aos critérios.

As duas grandes diferenciações desses contratos comparadas a uma locação simples, portanto própria da Lei de Locação Urbana, e prática usualmente verificada nas negociações, são: [i] a garantia de permanência do usuário até fim do prazo contratual, ou seja, na ocasião de uma rescisão a corporação está sujeita a aplicação de uma multa com caráter indenizatório, e [ii] a renúncia bilateral da ação revisional durante toda vigência do contrato. Não cabe a este trabalho avaliar a jurisprudência dessas práticas no âmbito jurídico, mas sim discutir os motivos pelos quais essas particularidades são comuns nas negociações e, em decorrência, a

Como essas transações envolvem em geral a securitização dos recebíveis, é de domínio público a divulgação das informações referente às negociações. Dessa forma, é possível encontrar nos prospectos de distribuição pública dos títulos lastreados nos contratos, em especial nos anexos, os contratos que vinculam as partes legalmente. Portanto, além das entrevistas nas empresas [ERE], fazem parte da identificação das práticas de mercado os seguintes prospectos: as operações de BTS realizadas pela Petrobras em 2005 (sede administrativa), Tok Stok em 2006 (ponto de venda), Carrefour em 2006 (centro de distribuição) e Atento em 2006 (edifício para instalação de central de atendimento). Os prospectos analisados encontram-se disponíveis no site da CVM - Comissão de Valores Mobiliários. Disponível em < www.cvm.org.br. Acesso em outubro de 2006. 
importância disso na escolha pelo BTS no ambiente corporativo.

A alegação pela existência dessas particularidades por parte dos investidores é pelo fato da Lei de Locação Urbana não ser capaz de regulamentar por si só todas as relações econômicas relacionadas à operação de BTS. Por isso são feitas as devidas avenças nos contratos. Tal orientação jurisprudencial leva em conta fatores que não estão presentes no BTS, tais como [i] que o proprietário já dispunha do bem quando ajustou a locação com o locatário; [ii] que o proprietário pode facilmente locar novamente seu imóvel a terceiros, e [iii] que o locatário está em condição jurídica e econômica inferior ao proprietário. Na relação BTS - [i] o proprietário não dispunha do imóvel; [ii] o imóvel foi concebido para atender as necessidades da locatária e, portanto, apresenta dificuldades para relocação por terceiros, e [iii] a condição jurídica e econômica do proprietário e da locatária são similares, razão pelo qual não existe nessa relação a hipossuficiência ou necessidade de especial proteção ${ }^{86}$.

Nesse sentido, na prática prevalece nesses contratos:

[i] multa em caráter indenizatório, previamente pactuada entre as partes, para o caso de devolução do imóvel pela corporação locatária antes do prazo estipulado no contrato, de modo a proteger o investimento feito pelo investidor em um imóvel específico para o uso da corporação;

[ii] a outra particularidade está relacionada com o Art. 19 da Lei do Inquilinato, sobre a ação revisional do aluguel. As partes também renunciam a revisão do aluguel a cada três anos ao preço de mercado, ficando o reajuste apenas pela variação do índice de preço acordado no contrato (o Art.18 torna lícito às partes modificarem cláusulas de reajuste do preço de locação).

Essas particularidades são condições necessárias ao equilíbrio econômico-financeiro de toda a operação envolvida na modalidade de BTS.

Conforme OLIVEIRA (2002), a legislação locatícia brasileira tem esse caráter cogente, ou seja, que o legislador proíbe negociações livres entre as partes envolvidas nos contratos, fundamentada no desequilíbrio econômico bastante comum na relação entre locadores e locatários (caso das locações residenciais). Contudo, no BTS essa natureza cogente é questionável, uma vez que se trata de uma modalidade de locação distinta, inclusive no tocante ao perfil das partes envolvidas (similar condição econômica). No âmbito jurídico essa questão é ainda não totalmente esclarecida, no entanto, o exposto acima mostra que a renúncia de algumas regras da Lei do Inquilinato tem sua lógica de existir e, por isso, tem sido praticada no mercado. A nova Lei 12.112 de 2009 alterou algumas regras da Lei 8.245 com intuito de tornar mais flexíveis algumas negociações pactuadas de comum acordo entre as partes, tais como: multas rescisórias e ação revisional (cláusula de reajuste). 
Contudo, também não é função do locatário proteger o locador dos riscos de mercado, visto que a escolha pelo investimento no imóvel, mesmo conhecida sua falta de liquidez no mercado, foi do investidor. Assim, trata-se de um investimento que, de um lado há a vantagem da procura anteceder a oferta e da credibilidade da operação (tanto pela credibilidade da locatária, como pela infungibilidade do imóvel) e, do outro, o risco pela falta de liquidez do imóvel.

Conforme VALENÇA ${ }^{87}$, a remuneração de todas as obrigações contratuais para definir a multa rescisória é questionável. Por esse motivo, possíveis mecanismos mitigadores para a aceitação da multa judicialmente, se for necessário, são tendências para as práticas indenizatórias nesse modelo de negócio, tais como:

[i] separar o período de amortização do investimento do período de remuneração pelo uso do imóvel;

[ii] a multa confere apenas ao primeiro período referente à amortização do investimento, assim, o locatário deve garantir contratualmente as obrigações até o final desse período e não até final do prazo contratual ${ }^{88}$;

[iii] a cobrança ocorre no fluxo original do contrato (anual ou mensalmente);

[iv] é cessada a cobrança da multa no ato da nova locação do imóvel. Dessa forma, no final do período de permanência garantida, referente ao período de remuneração pelo investimento no imóvel, o proprietário estará sujeito ao risco relacionado à vacância do imóvel até uma nova locação ${ }^{89}$.

Pelo exposto, verifica-se a partir das práticas prevalentes de mercado que a multa rescisória nas transações de BTS é significativa e, portanto, o [Critério A] - flexibilidade de mudança

87 Entrevista realizada em 12 de Dezembro de 2006 com Marcelo Valença, da Almeida Bugelli e Valença Advogados Associados, que atua em transações de BTS no Brasil.

88 De acordo com VALENÇA (2005) essa multa é conhecida como Remuneração Global Extraordinária, que é a amortização do investimento feito pelo empreendedor, tendo respaldo no Art. 473 do novo código civil de 2004. Conforme esse artigo, dado a natureza do contrato, em que uma das partes tenha feito investimentos consideráveis para a sua execução (caso do BTS), a denúncia unilateral de resilição só produzirá efeito depois de transcorrido prazo compatível com a natureza e vulto dos investimentos.

89 Como os pagamentos dos aluguéis são voltados à liquidação dos recursos captados no mercado, os quais compõem parte relevante do funding para compra do terreno e construção do imóvel, é importante para garantir melhor segurança da operação que o prazo para amortização dos títulos lastreados nos contratos de BTS seja menor que o prazo contratual (como exemplo, até o período referente à recuperação do investimento). 
fica comprometido (no curto e médio prazo).

Também é prática comum nos contratos de BTS o direito de sublocação do imóvel, ficando a corporação com a responsabilidade de todas as obrigações contratuais e autorizações legais exigidas para regularizar a nova ocupação do imóvel.

Quanto ao [Critério C] - controle operacional no uso do espaço, na modalidade de BTS a liberdade de intervenção durante o uso do imóvel é maior, em comparação à locação simples de longo prazo. Como o imóvel já foi concebido na formatação específica para uso do locatário, pragmaticamente, a existência dessa liberdade segue a lógica das operações de BTS. A corporação tem liberdade durante o uso de realizar a conservação, ampliação e benfeitorias no imóvel, com prévia anuência do locador, para as intervenções que interferem nos sistemas e estruturas do imóvel. Porém, respeitando todas as exigências legais (posturas municipais) e aprovação das autoridades competentes. No entanto, o ideal é que haja previsão contratual que permita tal liberdade.

Como o imóvel concebido na modalidade de BTS é customizado, seguindo as diretrizes de formatação específicas para operação de uma certa corporação, nessa [alternativa] o [Critério F] - oportunidade de traduzir a imagem corporativa é plenamente atendido por meio de uma propriedade com identidade própria.

É importante ressaltar que, tanto a oportunidade de traduzir a imagem corporativa, como atender todas as especificações técnicas e de localização do imóvel, ou seja, atender ao [Critério E] - especificidade do espaço, depende não somente do rating de crédito da corporação como do grau de especificidade do imóvel, que impacta na sua liquidez no mercado. Esse dois fatores podem interferir na atratividade dos investidores, tendo a corporação que optar pela imobilização, ou pelo uso do DRS como instrumento jurídico, pela maior segurança aos investidores quanto ao cumprimento das obrigações contratuais pela corporação.

O [Critério D] - vínculo da operação com o imóvel é um importante atributo para imóveis concebidos no BTS, pois são estratégicos pela sua customização, por aspectos operacionais, logísticos, e em geral também pelo alto investimento com as instalações e equipamentos no espaço. O direito de renovatória compulsória e preferencial de compra também são comuns nos contratos BTS. Nesses casos, o risco de não ocorrer a renovatória é desprezível, pelo fato do imóvel já ser uma incorporação de vulto expressivo e por tratar-se de uma negociação com investidores especializados do mercado de real estate, que esperam do imóvel apenas a renda 
homogênea gerada pela locação.

\subsubsection{Motivos da escolha pelo Build-to-Suit}

Apresentadas as particularidades dos contratos BTS e a pertinência desta [alternativa] quanto ao atendimento aos critérios relevantes à decisão, é possível identificar os principais motivos pela escolha dessa opção.

Como a [alternativa] - BTS envolve contratos mais complexos e o imóvel ainda deve ser concebido, observou-se no levantamento de campo a preferência pela [alternativa] - LLP de imóveis já disponíveis no mercado, com as devidas adequações no espaço feitas pela futura corporação usuária. Dessa forma, quando a corporação opta pela [alternativa] - BTS a priorização da corporação é dada para os seguintes critérios:

[i] atendimento de todas as especificidades do espaço, de modo que imóveis já prontos, nem mesmo adaptados, atendam a demanda operacional, logística ou mercadológica da corporação. Nesse caso, a operação da corporação não precisa se adequar ao produto imobiliário disponível no mercado. Soma-se ainda o fato do imóvel, quando não há expectativa de preservar valor, ser um problema do proprietário quando findo o prazo contratual;

[ii] oportunidade de tradução da imagem corporativa, por meio de um imóvel com identidade própria;

[iii] canalização dos recursos em oportunidades estratégicas do negócio principal, e a desoneração do balanço (exceto no caso do DRS), que resulta em melhores indicadores financeiros e econômicos da corporação, principalmente pelo fato desses imóveis customizados, concebidos nessa modalidade, envolverem expressivo montante de recursos para implantação. Há também a consideração da redução dos impactos fiscais (despesas operacionais dedutíveis ou, no caso do DRS, amortização do preço da outorga).

Além disso, no BTS a corporação tem maior liberdade de intervenções no espaço quando comparada a uma locação simples de longo prazo, pelo fato do imóvel já ser customizado para seu uso. Nesses contratos, assim como na locação de longo prazo, há o direito de renovatória compulsória, importante pelo vínculo da operação com o imóvel. O risco do investidor reaver o imóvel no final prazo contratual é desprezível, apenas há necessidade de negociações no futuro para definição dos novos preços de locação. 
A partir das entrevistas verificou-se que os espaços predominantemente concebidos na modalidade BTS são: galpões (centros de distribuição, por exemplo); pontos de venda e serviço (a depender do volume de investimento envolvido); sedes administrativas (quando não há disponíveis no mercado imóveis que atendam a localização, aspectos arquitetônicos e funcionais); unidades de produção (a depender da especificidade do espaço); e as centrais operacionais (como CPD - que também dependem do grau de especificidade do imóvel).

A Tabela 5 apresenta as principais vantagens e desvantagens quando se opta pelo BTS, tanto em relação aos aspectos operacionais como financeiros.

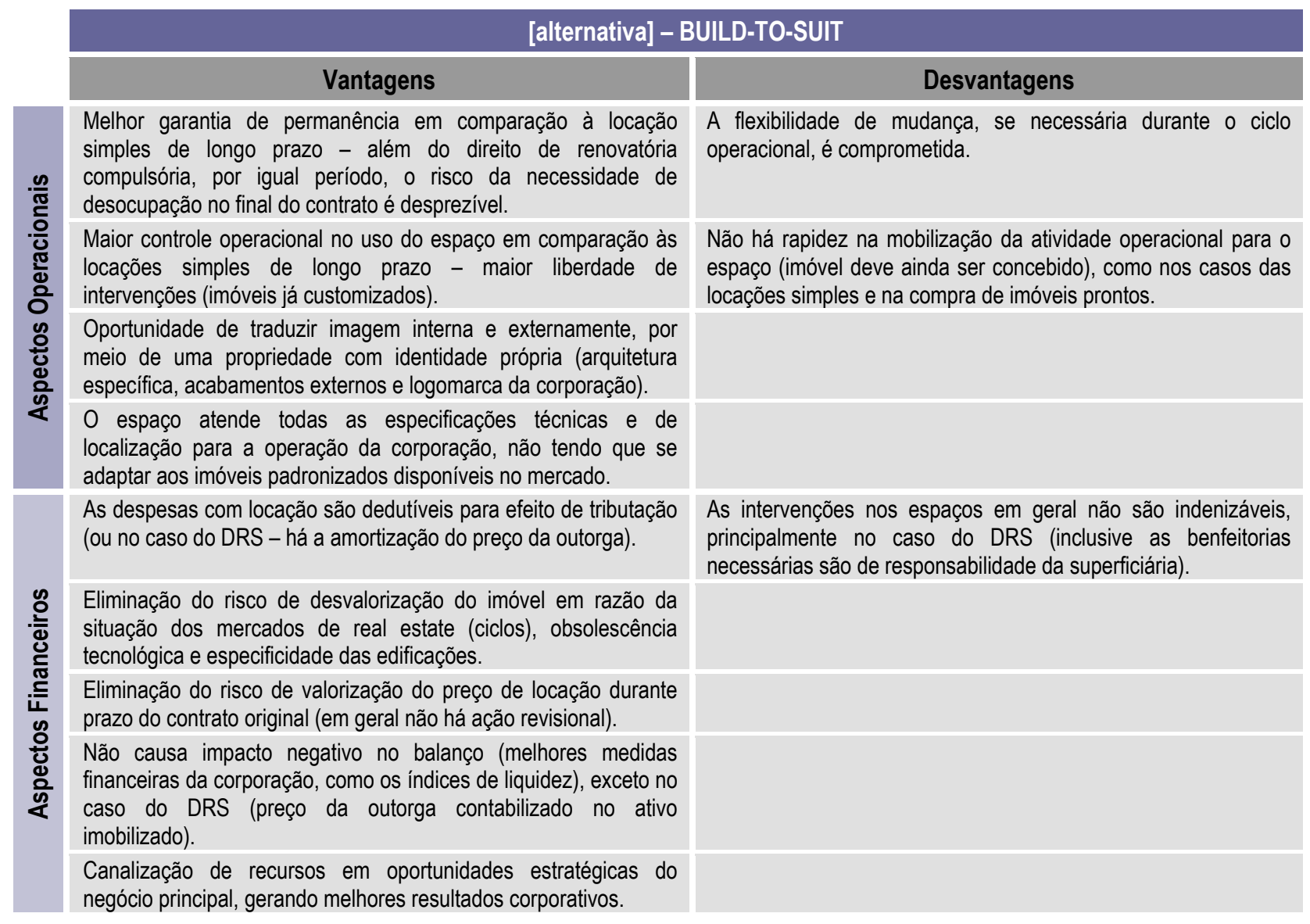

Tabela 5 - Vantagens e Desvantagens - Build-to-Suit (BTS)

\subsubsection{O Sale-Leaseback - SLB como mecanismo para desmobilização patrimonial imobiliária}

Pelos princípios de uma apropriada prática financeira, ativos de longo prazo de maturação devem ser financiados com recursos de longo prazo, proporcionando estabilidade e, quando bem administrados, também lucratividade às corporações. Dessa forma, as necessidades de curto prazo, como investimentos na produção, inovações nos processos operacionais, entre 
outras, podem ser atendidas com o capital de giro incorporado com a venda do imóvel, isso permite corrigir e alongar o perfil de endividamento de curto para longo prazo. O mecanismo de SLB está em conformidade com esse princípio. Com a venda do imóvel da corporação, seguida de um contrato de locação de longo prazo com o investidor, a corporação utiliza o recurso disponível, que corresponde ao valor de transação do imóvel, para investimento de curto prazo na atividade principal, deixando o endividamento de longo prazo para o que realmente compete ao longo prazo, que nesse caso é o compromisso de pagamento do aluguel pelo uso do espaço durante o ciclo operacional.

Quando o mercado de dívida e equity ${ }^{90}$ estão em baixa, as possibilidades de captação de recursos e injeção de capital para investimentos no negócio principal da corporação são reduzidas. Nessa situação, o SLB é uma [alternativa] para prover capital de giro (PEDERSON e WOOTEN, 2003).

Com a utilização desse mecanismo há possibilidade de investimentos do capital de giro ativado com a venda do imóvel no negócio principal da corporação, que em geral geram melhores resultados em relação aos investimentos nos mercados de real estate para renda.

Um setor que tem usado o SLB nos últimos anos foi o bancário. A venda das agências com posterior locação por longo prazo foi iniciada pelo Bradesco e Unibanco em julho de 2002. Isso ocorreu pelo fato do Banco Central, em cumprimento ao acordo da Basiléia, exigir que as instituições financeiras reduzissem, até dezembro de 2002, para no máximo $50 \%$ a participação do ativo imobilizado em relação ao patrimônio líquido. No entanto, essa exigência tornou-se uma oportunidade para os bancos, que aproveitaram a turbulência nos mercados, a saída de investidores dos fundos de investimento e a atração por ativos reais, para vender seus próprios imóveis, locando-os em seguida. Em razão desse cenário e da credibilidade das instituições bancárias, as transações de SLB foram negociadas com os investidores a taxas mais baixas relativamente às praticadas no mercado ${ }^{91}$.

Por esta razão, muitas instituições financeiras durante o ano de 2002 promoveram por meio de leilões a venda dos imóveis das agências. Nos contratos de compra e venda desses imóveis já

90 Equity refere-se à compra de participação acionária em uma empresa por investidores, para alavancar o negócio com ingresso de capital no caixa da empresa. Nos casos de empresas em estágio ainda pré-operacional (start-up), a participação dos investidores no negócio é conhecida como: venture-capital (capital especulativo), e envolve maior risco do capital investido.

91 Fonte: Jornal Valor Econômico. Aluguel Garantido por um lance, publicado em 10 de setembro de 2002. 
fazia parte das cláusulas contratuais o compromisso de locação por longo prazo predeterminado $^{92}$.

O varejo também tem utilizado desse mecanismo para desmobilização dos ativos. Um dos primeiros projetos de desmobilização dos ativos imobiliários em larga escala no Brasil foi o das Lojas Americanas e, posteriormente, da Redevco, braço imobiliário da C\&A, que também adotou a mesma estratégia em 2004.

Empresas de manufatura que em geral são as que apresentam maior grau de imobilização, também começam a mostrar interesse por esse mecanismo, porém ainda pontualmente. Podese citar como exemplo a Basf. Em 2003 vendeu sua sede administrativa com posterior locação do imóvel por dez anos.

Como esse mecanismo pode ser apropriado para corporações que desejam reorganizar o seu perfil de endividamento, pode ser uma possível ferramenta financeira para a reorganização do perfil de endividamento do setor público. No Brasil não se encontrou, durante as pesquisas, nenhum caso dessa transação para o setor público. Porém, verificou-se esta ocorrência em alguns países - como o caso da BBC em UK, que desmobilizou $700.000 \mathrm{~m}^{2}$ de suas propriedades (POTTINGER et al., 2001).

\subsubsection{Particularidades das transações de SLB no Brasil - análise da pertinência quanto ao atendimento aos critérios de decisão}

Neste item serão apresentadas as principais particularidades das transações de SLB no Brasil, a sustentação legal dos contratos e as práticas prevalentes de mercado nas negociações, relacionando as particularidades desse mecanismo de desmobilização aos critérios de decisão ${ }^{93}$.

92 De meados de 2002 até janeiro de 2004 foram 1.671 unidades vendidas, que arrecadaram aos bancos aproximadamente R \$ 1,8 bilhões. Fonte: Jornal Valor Econômico. Redevco coloca a venda 19 lojas da C\&A, publicado em 25 de abril de 2004.

93 Nesses casos também é comum a distribuição dos veículos securitizados lastreados nos imóveis (casos dos FII) ou nos contratos de Locação (caso da emissão dos CRI). Por isso, além das entrevistas nas [ERE], fazem parte da identificação das práticas prevalentes de mercado as seguintes desmobilizações patrimoniais: Contrato de Locação do Bradesco - Agências (2002), Contrato de Locação da Caixa Econômica Federal - Sede Administrativa (2002), Contrato de Locação do Banco do Brasil - Sedes Administrativas (2004) e Contrato de Direito Real de Superfície Basf Sede Administrativa (2004). 
No caso do SLB, diferentemente das outras [alternativas] analisadas, as práticas de mercado variam e não há uma prevalência evidente das suas particularidades. Existem situações em que as transações são tratadas como no BTS (multa rescisória em caráter indenizatório e renúncia pelas partes da ação revisional), e outras em que as multas são aplicadas segundo um prazo mínimo de permanência previamente acordado no contrato ${ }^{94}$, e há ação revisional durante o prazo contratual.

Nota-se que no Brasil esta multa diferenciada é um acordo entre as partes, e que a sua definição nas cláusulas contratuais depende do perfil de aceitação de risco dos envolvidos. Porém, diferentemente dos contratos de locação simples, a existência de alguma proteção é prática de mercado, variando a forma e grandeza a depender do imóvel, riscos envolvidos e perfil de cada investidor.

Quando há securitização dos recebíveis nota-se uma maior preocupação dos investidores quanto ao cumprimento da corporação com suas obrigações contratuais. Porém, no que tange à sustentação legal dessas transações, verifica-se que não há o mesmo tratamento jurídico dado aos contratos de BTS (Art. 473 do código civil). No caso do SLB, o imóvel já está pronto e, em tese, o investidor tem mais conhecimento, tanto da credibilidade da operação nele realizada, como da liquidez do ativo no mercado.

Essa insegurança jurídica, ainda mais presente nas transações de SLB, faz com que os investidores utilizem mecanismos mitigadores de risco. Um deles foi citado anteriormente, trata-se do uso do DRS como instrumento jurídico para vincular legalmente as partes, em substituição ao contrato de locação. O outro envolve três etapas: [i] formação de uma SPE, subsidiária da corporação, que passa a ser proprietária do imóvel a ser desmobilizado; [ii] locação simples de longo prazo do imóvel, firmado com a SPE, que tem como resultado operacional, o fluxo dos aluguéis; [iii] venda da SPE ao comprador (investidor), por meio de um contrato de compra e venda de empresa, sendo já descrito nesse contrato uma declaração da vendedora (corporação) garantindo que todos os contratos da SPE vendida são válidos e eficazes, e no caso de inadimplemento desses contratos a vendedora se compromete a pagar pelos prejuízos causados.

Esse último mecanismo traz benefícios para ambas as partes. A corporação não onera seu

94 Como exemplo, prazo contratual de dez anos e tempo de permanência mínimo garantido de cinco anos, ou seja, caso a corporação desocupe o imóvel antes de completar cinco anos, a multa refere-se aos aluguéis restantes até esse prazo. 
balanço e melhora seus índices de liquidez, já que na locação simples o aluguel é despesa operacional e não é contabilizado no balanço. O investidor compra uma empresa com fluxo de caixa garantido, e não um fluxo de aluguéis, mitigando os riscos no caso do inadimplemento causado por uma futura desocupação da locatária.

Isso evidencia que se tratando de operações estruturadas, e principalmente aquelas em que a emissão dos veículos securitizados tem como devedor uma única corporação (caso dos BTS e SLB) os investidores estão, pela própria maturidade e profissionalização dos mercados de real estate, procurando por mecanismos que garantam relações bilaterais, de modo a trazer benefícios e proteções para ambas as partes: devedores (ocupantes dos espaços) e investidores (proprietários).

Por essa razão, pode-se concluir que também para o SLB o [Critério A] - flexibilidade de mudança - a curto e médio prazo, é comprometido. É prática comum nos contratos de SLB o direito de sublocação para empresas do mesmo grupo, com a co-responsabilidade da corporação por todas as obrigações contratuais.

No SLB a corporação tem maior controle operacional no uso do espaço - [Critério C] quando comparada a uma locação simples, pelo fato do proprietário ter o interesse em manter a corporação no imóvel, e por ser monousuária o espaço atende as necessidades operacionais e mercadológicas de um único ocupante. $\mathrm{O}$ aceite do proprietário é necessário apenas para as maiores intervenções que interferem na estrutura e sistemas de abastecimento (infraestrutura) do imóvel. No levantamento de campo, verificou-se que a liberdade é ainda maior quando se utiliza o DRS como instrumento jurídico. Contudo, não se pode assegurar que a liberdade de adequações durante o uso, na opção pelo SLB, seja a mesma da condição de ser proprietária, em especial para imóveis menos específicos, como o caso das sedes administrativas, que poderão ser ocupadas por outros usuários, caso não seja interesse da corporação permanecer no imóvel.

Todas as especificidades técnicas, de localização, e arquitetônicas, continuam a atender igualmente as necessidades da corporação como quando proprietária do imóvel. Porém, vale ressaltar que, assim como no BTS, o rating de crédito da corporação é parte relevante na atratividade dos investidores. Somam-se ainda dois aspectos que interferem nessa atratividade: o quão específico é o imóvel e a sua obsolescência tecnológica.

Como mencionado, muitas corporações brasileiras são proprietárias dos imóveis concebidos nas décadas de 70 e 80 , que já se encontram obsoletos quando comparados aos novos 
empreendimentos disponíveis no mercado. Essa obsolescência impacta não só no valor do imóvel, como também na atratividade de investidores, em razão da falta de liquidez do ativo. Nessas situações a infungibilidade do imóvel para operação da corporação é essencial à decisão por parte dos investidores, ou seja, é necessário reconhecer a importância estratégica do imóvel para a corporação, pois os investidores dessa modalidade estão interessados na renda gerada pelo uso e não pela venda do ativo.

No que diz respeito ao [Critério D] - vínculo da operação com o imóvel - nos contratos de SLB, que são contratos de longo prazo, há tanto o direito de renovatória compulsória como o direito preferencial de compra, exceto no uso do DRS. No entanto, os riscos quanto à necessidade de desocupação da corporação do imóvel no final do prazo contratual, como no BTS, são desprezíveis, pelos mesmos motivos - o empreendimento já é uma incorporação de vulto expressivo para ter atraído investidores dessa modalidade, que em geral são investidores do mercado de real estate interessados na geração de renda com a locação. Porém, é imperativa para a corporação a necessidade de negociações com o proprietário. Em certos casos, a depender da cultura da corporação e da importância estratégica do imóvel, prefere-se a eliminação desse risco, continuando proprietária dos imóveis estratégicos ao seu desempenho e desmobilizando aqueles menos críticos ao negócio principal.

\subsubsection{Motivos da escolha pelo Sale-Leaseback}

Pelo exposto nos itens anteriores, torna-se possível apontar os principais motivos da escolha pelo SLB como mecanismo para desmobilização patrimonial.

Quando a corporação consegue atrair investidores para compra do imóvel e quando a matriz ou os investidores private equity, ou ainda os acionistas da corporação, concordam com a desmobilização do ativo, o SLB em primeira análise traz mais vantagens do que desvantagens.

As principais vantagens e, portanto, os motivos mais relevantes pela escolha do SLB são:

[i] prover capital de giro para alavancar o negócio principal, que gera melhores resultados corporativos;

[ii] desonerar o balanço da corporação, a partir da redução do ativo imobilizado e aumento do capital de giro, que impacta positivamente nos índices financeiros da corporação, como os índices de liquidez e grau de imobilização. No caso do uso do DRS, essa vantagem não 
ocorre. Em economias onde o mercado de capitais é mais avançado e a prática de SLB é mais antiga, foi constatado que essa melhora no balanço pode refletir na classificação da corporação (rating) e, por consequência, para empresas de capital aberto, melhorar a atratividade das suas ações no mercado (LASALLE, 2002) ${ }^{95}$;

[iii] redução do impacto tributário, independente do instrumento jurídico utilizado ${ }^{96}$. Quando se utiliza contrato de locação simples os aluguéis (conforme já exposto no item 5.2.3) são considerados como despesa operacional dedutível. No caso do DRS, as contraprestações pagas pelo preço da outorga são amortizadas no prazo do DRS;

[iv] a corporação quando opta pelo SLB continua a traduzir sua imagem corporativa (interna e externamente) e atendendo todas suas especificidades técnicas e de localização características essas que impactam somente na atratividade para aceitação da compra ou não do imóvel por parte dos investidores.

Os ciclos dos mercados de real estate referente à tipologia e localização do imóvel a ser vendido são aspectos importantes na decisão pela desmobilização. Mercados aquecidos são favoráveis para uma melhor venda, e mercados em recessão, tendem a inibir a demanda, portanto, são desfavoráveis à venda. Porém, há necessidade da analisar, mesmo para mercados em recessão, as oportunidades alternativas de investimento, principalmente aquelas urgentes e estratégicas para o negócio principal da corporação.

Os espaços corporativos que comumente tem sido desmobilizado pelas corporações, conforme levantamento de campo, são: sedes administrativas, pontos de venda e serviços e, em alguns casos, também foram citadas as unidades produtivas. Nota-se que também nas transações de SLB é predominante a desmobilização de ativos não muito específicos e que apresentam certa

Outros autores têm feito pesquisas para analisar o impacto do valor das ações no mercado de capitais em razão do SLB. DEVANEY e LIZIERI (2004) fizeram essa análise utilizando cinco corporações que optaram pelo SLB: Abbey National (Instituição Financeira), British Telecom (Empresa de Telecomunicação), Marks \& Spencer (Varejo - Geral), J Sainsbury's (Varejo Alimentação) e Shell Trading (Empresa de Gás e Óleo). Para algumas, o impacto nas ações foi positivo, para outras, não houve relação clara dessa prática com o valor das ações. Contudo, segundo os autores da pesquisa, o resultado está relacionado à destinação dos recursos com a venda dos imóveis (como investimentos para expansão da presença de mercado, pagamento de dívida, entre outros), bem como, com acontecimentos do mercado do setor de atuação e de outros setores que influenciam na oscilação do valor das ações (como empresas dot.com).

Importante ressaltar que o prejuízo apurado na venda do imóvel, que ocorre quando o valor de transação é menor que o valor contábil do imóvel, não é dedutível para efeito de tributação. No entanto, se houver lucro na venda, este será considerado no cálculo do lucro real no exercício do ano em que ocorrer a venda. 
liquidez. Porém, isso vai depender da credibilidade da operação, avaliada pelo rating de crédito da corporação, infungibilidade do imóvel e mecanismos mitigadores de risco, assim como do perfil de risco de cada investidor.

A Tabela 6 apresenta de modo resumido as principais vantagens e desvantagens, financeiras e operacionais, quando a corporação opta por essa [alternativa] de desmobilização patrimonial.

[alternativa] PARA DESMOBILIZAÇÃO PATRIMONIAL - SALE-LEASEBACK

\begin{tabular}{|c|c|c|}
\hline & Vantagens & Desvantagens \\
\hline \multirow{4}{*}{ 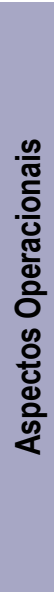 } & $\begin{array}{l}\text { Garantia de permanência pelo direito de renovatória compulsória e } \\
\text { pelo risco de desocupação no final do contrato ser desprezível. }\end{array}$ & $\begin{array}{l}\text { A flexibilidade de mudança durante o ciclo operacional (curto e } \\
\text { médio prazo) é comprometida. }\end{array}$ \\
\hline & $\begin{array}{l}\text { O espaço continua a atender as especificações técnicas para a } \\
\text { operação da corporação. Contudo, durante o uso, pode haver } \\
\text { restrições quanto às intervenções permitidas para as novas } \\
\text { especificações necessárias (a depender da liquidez do imóvel as } \\
\text { intervenções permitidas pelo proprietário serão aquelas que } \\
\text { agregam valor, caso contrário, será necessária a devolução no } \\
\text { estado original). }\end{array}$ & $\begin{array}{l}\text { Redução do controle operacional do espaço durante o uso, } \\
\text { quando comparada à situação de continuar proprietária, em } \\
\text { especial para os casos de imóveis com liquidez no mercado } \\
\text { (como o caso de sedes administrativas ou galpões bem } \\
\text { localizados), em razão da possibilidade de relocação do imóvel. }\end{array}$ \\
\hline & $\begin{array}{l}\text { Oportunidade de continuar a traduzir imagem corporativa - interna } \\
\text { e externamente (arquitetura específica, acabamentos externos e } \\
\text { logomarca da corporação). }\end{array}$ & \\
\hline & $\begin{array}{l}\text { Por meio do SLB, a empresa pode melhorar seus processos } \\
\text { operacionais, quando o capital incorporado com a venda do imóvel } \\
\text { é utilizado na atividade principal e, ao mesmo tempo, não há em } \\
\text { nenhum momento a descontinuidade da operação. }\end{array}$ & \\
\hline \multirow{4}{*}{ 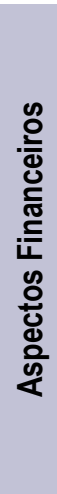 } & $\begin{array}{l}\text { As despesas com locação são dedutíveis para efeito de tributação } \\
\text { (ou no caso do DRS - há a amortização do preço da outorga). }\end{array}$ & $\begin{array}{l}\text { As intervenções nos espaços em geral não são indenizáveis, } \\
\text { principalmente no caso do DRS (inclusive as benfeitorias } \\
\text { necessárias são responsabilidades da superficiária). }\end{array}$ \\
\hline & $\begin{array}{l}\text { Em alguns casos, a depender da negociação, há a eliminação do } \\
\text { risco de valorização do preço de locação durante prazo do contrato } \\
\text { original (quando as partes envolvidas renunciam contratualmente a } \\
\text { ação revisional). }\end{array}$ & $\begin{array}{l}\text { Risco de valorizações dos preços de locação no caso da } \\
\text { existência da ação revisional. }\end{array}$ \\
\hline & $\begin{array}{l}\text { Aumento do capital de giro para alavancar o negócio principal, } \\
\text { gerando melhores resultados corporativos. }\end{array}$ & \\
\hline & $\begin{array}{l}\text { Desoneração do balanço e melhora dos índices financeiros da } \\
\text { corporação (como os indices de liquidez e índices de } \\
\text { endividamento), exceto no caso do DRS (preço da outorga } \\
\text { contabilizado no ativo imobilizado) }\end{array}$ & \\
\hline
\end{tabular}

Tabela 6 - Vantagens e Desvantagens - Sale-Leaseback (SLB)

\subsection{Compilação da Análise da Pertinência das [alternativas] quanto ao atendimento aos Critérios de Decisão do [MAOI]}

A análise da Pertinência das [alternativas] abordada no decorrer deste capítulo evidenciou os pontos fortes e fracos de cada uma quanto ao atendimento aos critérios. Umas comprometem certos critérios, em contrapartida, melhor atendem outros. Contudo, essa análise depende também de variáveis do contexto de cada situação, que ora melhoram o atendimento ao critério, ora mais comprometem. A Tabela 7 apresenta, baseando-se no conteúdo abordado neste capítulo, os critérios melhor atendidos por cada uma das [alternativas], bem como os 
que são mais comprometidos, considerando, para tanto, as informações do contexto necessárias ao planejador (usuário do [MAOI]), e uma escala de atendimento, que traduz como a [alternativa]: 'compromete' (-) ou 'atende' $(+)$ cada um dos critérios do [MAOI], feita de modo comparativo entre elas.

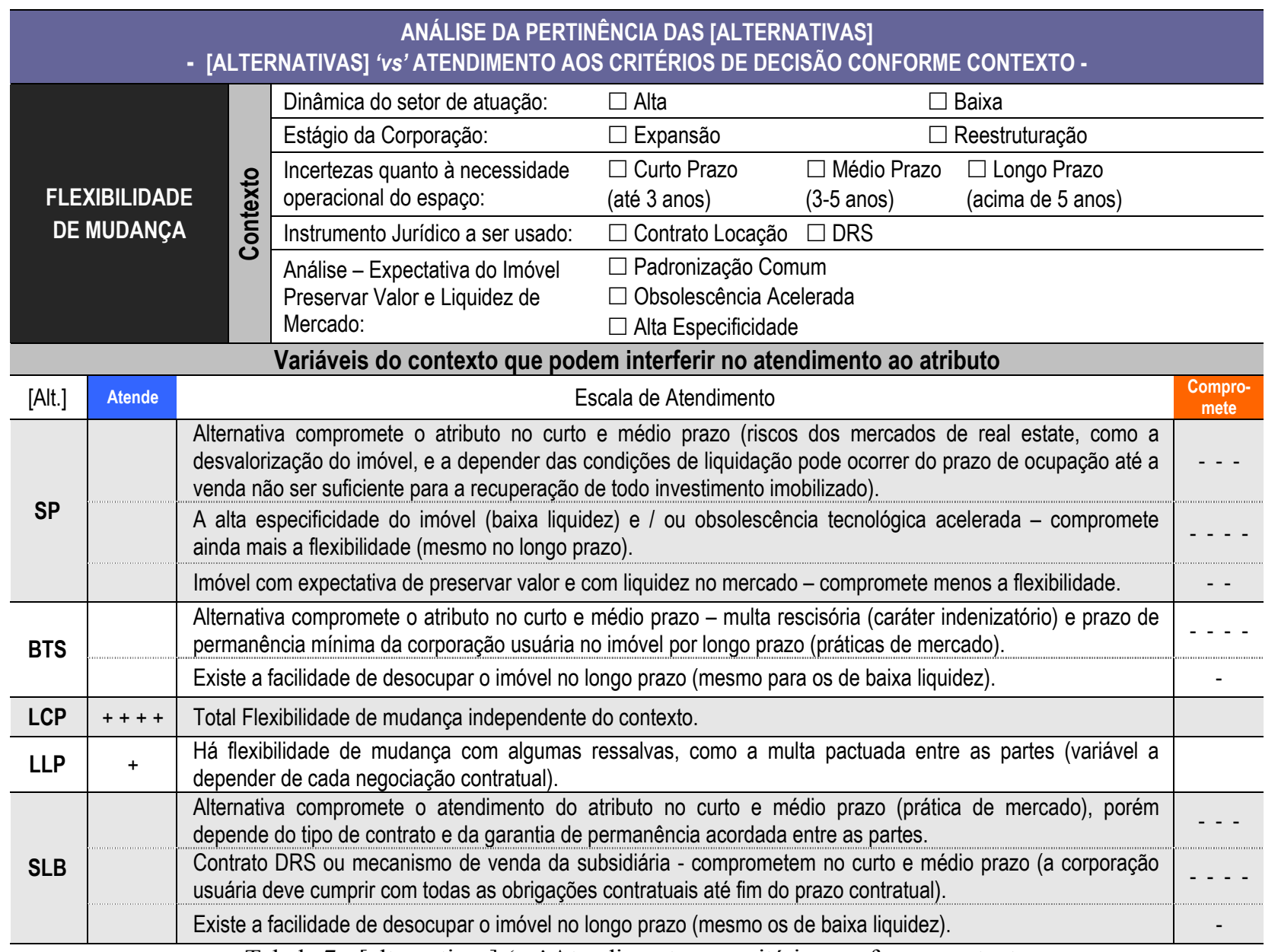

Tabela 7 - [alternativas] ' $v s$ ' Atendimento aos critérios conforme contexto 


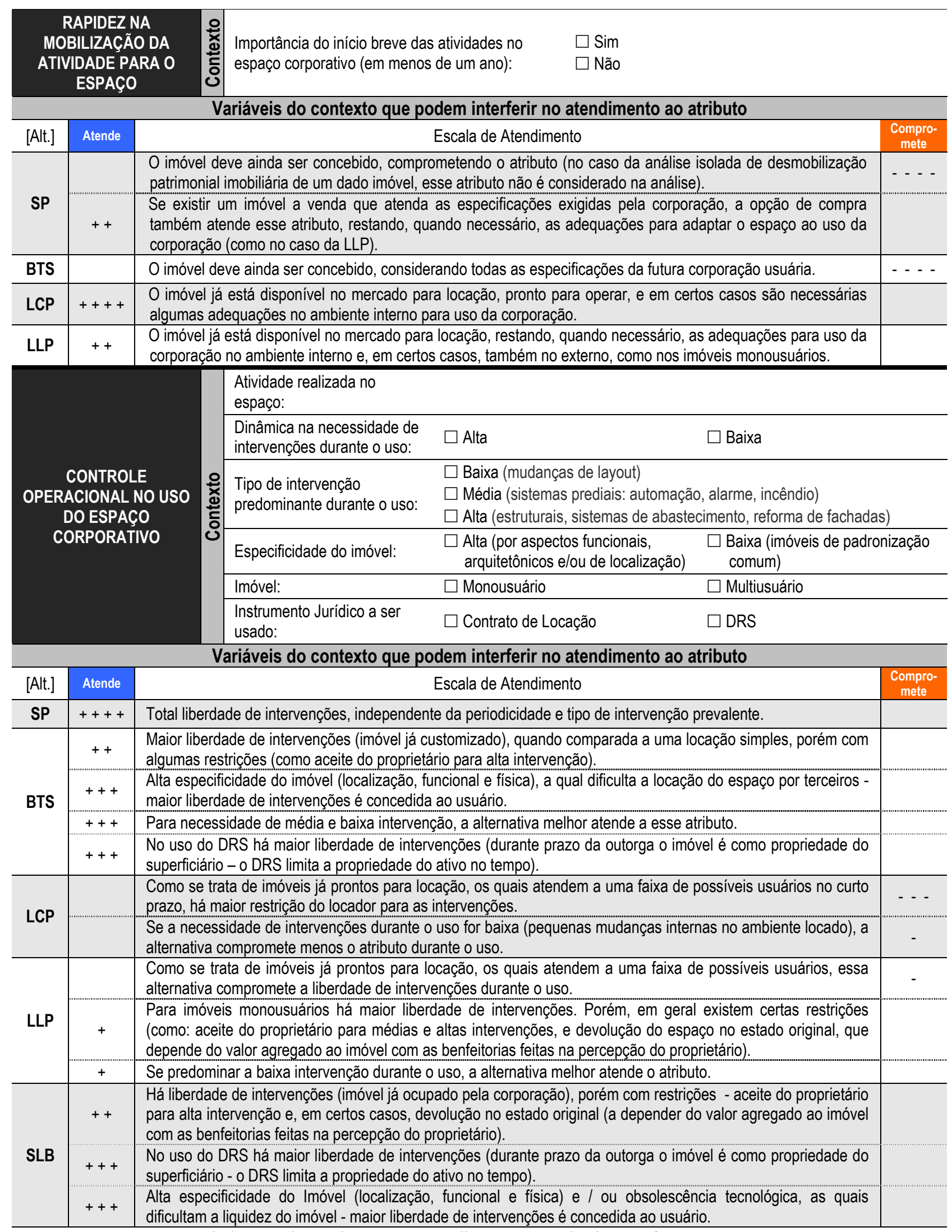

Tabela 7 - [alternativas] ' $v s$ ' Atendimento aos critérios conforme contexto

(continuação) 


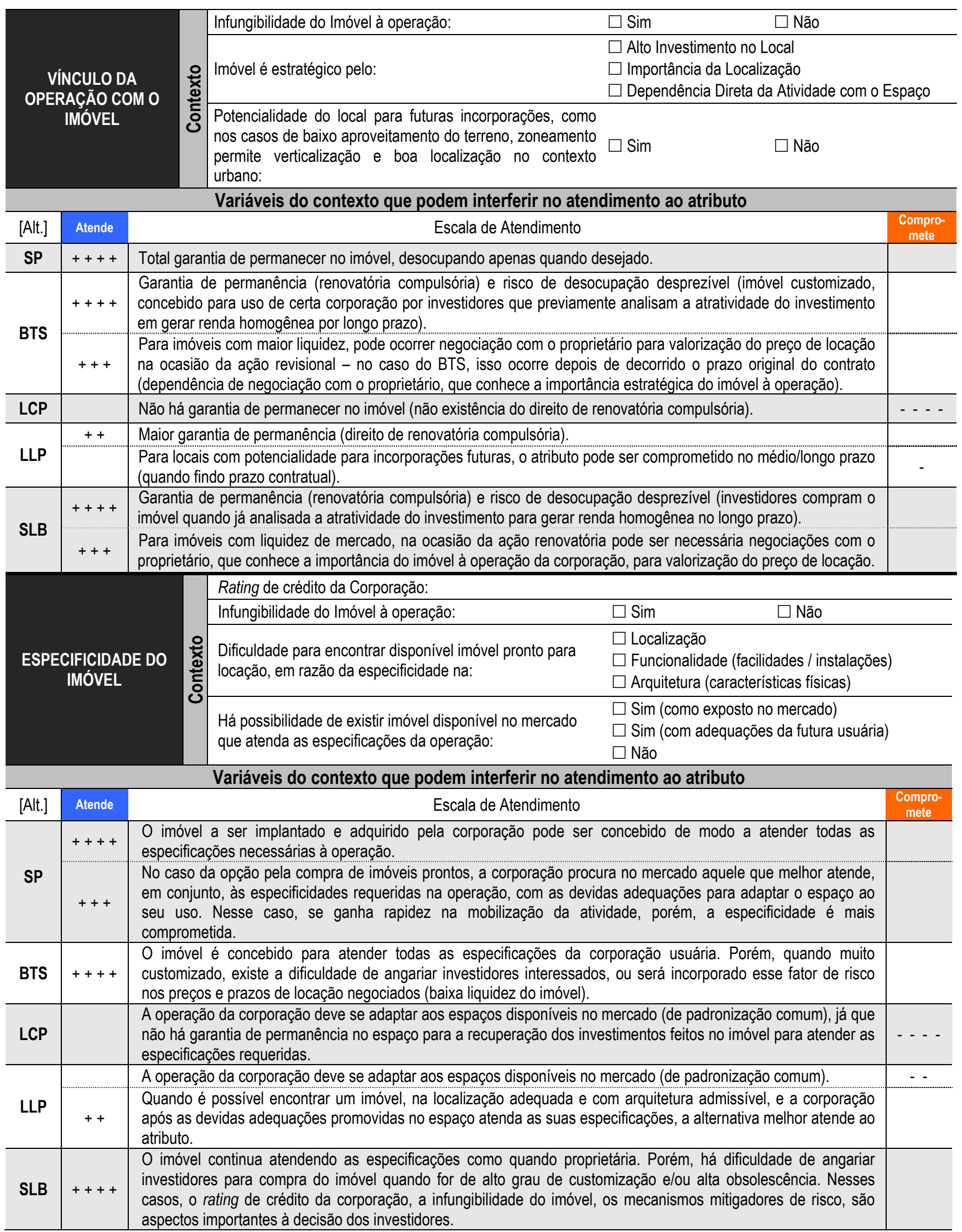

Tabela 7 - [alternativas] ' $v s$ ' Atendimento aos critérios conforme contexto 


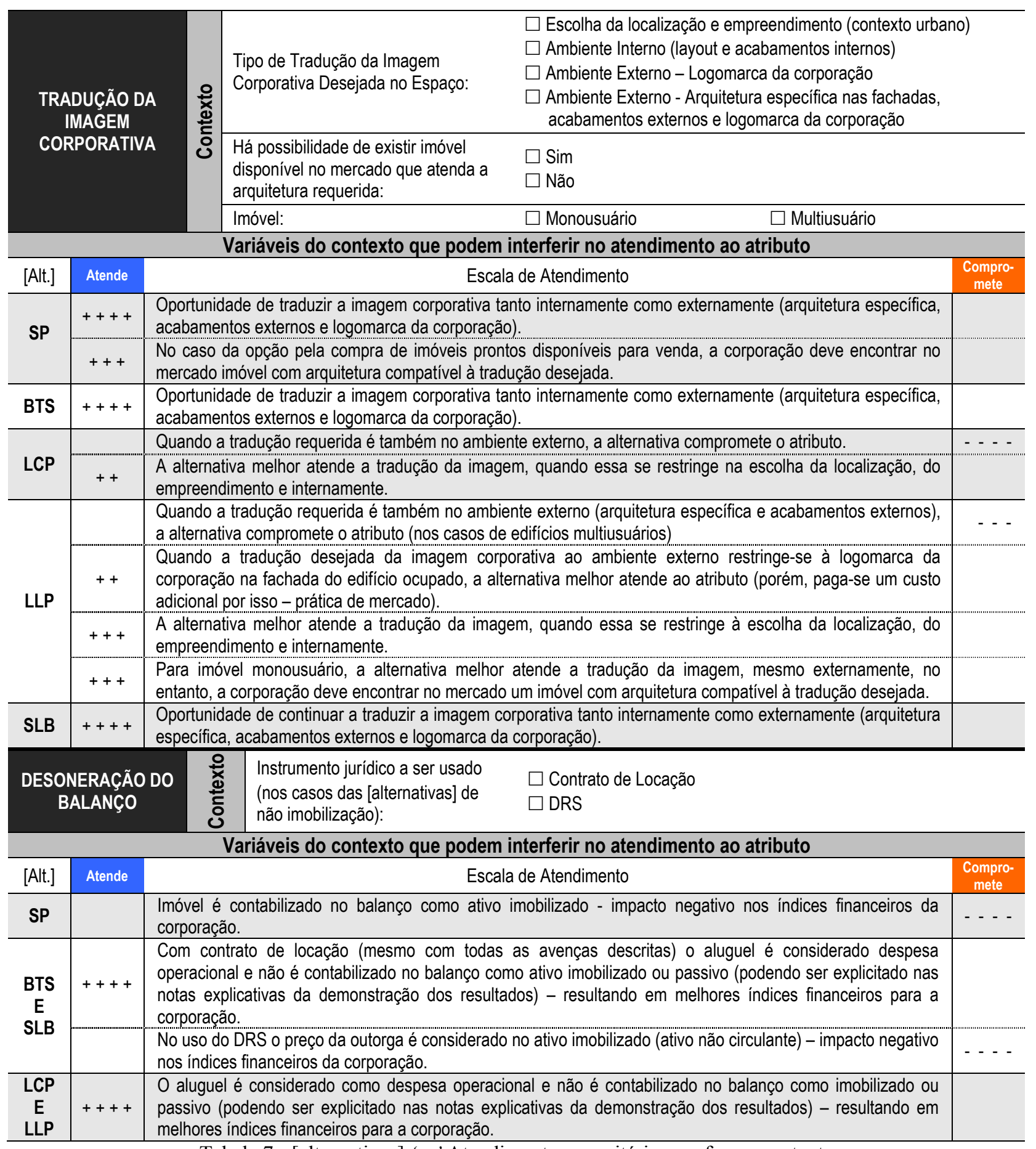

Tabela 7 - [alternativas] ' $v s$ ' Atendimento aos critérios conforme contexto 


\begin{tabular}{|c|c|c|c|c|c|}
\hline \multicolumn{2}{|c|}{$\begin{array}{l}\text { REDUÇÃO DOS } \\
\text { IMPACTOS } \\
\text { TRIBUTÁRIOS }\end{array}$} & 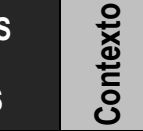 & $\begin{array}{l}\text { Instrumento jurídico a ser usado } \\
\text { (nos casos das [alternativas] de } \\
\text { não imobilização): }\end{array}$ & $\begin{array}{l}\square \text { Contrato de Locação } \\
\square \text { DRS }\end{array}$ & \\
\hline \multicolumn{6}{|c|}{ Variáveis do contexto que podem interferir no atendimento ao atributo } \\
\hline [Alt.] & Atende & \multicolumn{3}{|c|}{ Escala de Atendimento } & $\begin{array}{l}\text { Compro- } \\
\text { mete }\end{array}$ \\
\hline SP & & \multicolumn{3}{|c|}{$\begin{array}{l}\text { Para efeito tributário, na imobilização tem-se a depreciação do ativo. Essa depreciação é calculada sobre o } \\
\text { valor do imóvel, subtraído do valor do terreno, e é distribuída em todo o ciclo de vida do ativo - isso gera, em } \\
\text { primeira análise, uma menor redução dos encargos tributários quando comparada à redução gerada nas } \\
\text { [alternativas] de não imobilização com a despesa operacional dedutível da locação. }\end{array}$} & $\cdots$ \\
\hline \multirow{2}{*}{$\begin{array}{l}\text { BTS } \\
\text { e } \\
\text { SLB }\end{array}$} & +++ & \multicolumn{3}{|c|}{$\begin{array}{l}\text { Com contrato de locação, o aluguel pago pela corporação usuária é despesa operacional dedutível, a qual é } \\
\text { descontada do resultado corporativo no cálculo do lucro real durante a vigência do prazo contratual. }\end{array}$} & \\
\hline & +++ & \multicolumn{3}{|c|}{$\begin{array}{l}\text { No uso do DRS o preço pago pela outorga, para efeito tributário, é amortizado. Esse preço, assim como na } \\
\text { locação, é amortizado no prazo do contrato de DRS. }\end{array}$} & \\
\hline $\begin{array}{l}\text { LCP } \\
\text { LLP }\end{array}$ & +++ & \multicolumn{3}{|c|}{$\begin{array}{l}\text { O aluguel pago pela corporação usuária é despesa operacional dedutível, a qual é descontada do resultado } \\
\text { corporativo no cálculo do lucro real durante a vigência do prazo contratual. }\end{array}$} & \\
\hline
\end{tabular}

Tabela 7 - [alternativas] ' $v s$ ’ Atendimento aos critérios conforme contexto

(conclusão)

Sob a ótica qualitativa, as [alternativas] de não imobilização atendem $[++++]$ ao [Critério G] - canalizar recursos em oportunidades do negócio principal e ao [Critério J] - levantar capital de giro com a desmobilização, enquanto que a imobilização compromete [- - - - ] ambos. Portanto, o contexto não influencia na definição das escalas de atendimento apresentadas na Tabela 7.

Para esses dois critérios, assim como para os outros dois critérios mensuráveis: [Critério H] desoneração do balanço e o [Critério I] - redução dos impactos tributários, essa escala de atendimento, baseada nas referências qualitativas, não é suficiente para avaliar cada uma das [alternativas]. Sendo assim, para os critérios mensuráveis são avaliadas também as referências quantitativas do [MAOI], ou seja, os indicadores econômico-financeiros relacionados a cada um desses critérios. 


\section{ANÁLISE QUANTITATIVA - CRITÉRIOS DE DECISÃO MENSURÁVEIS}

Neste capítulo os critérios de decisão mensuráveis, relacionados às estratégias de investimento e políticas das corporações, os quais resultam nos indicadores econômicofinanceiros relevantes à decisão pela imobilização ou não no real estate corporativo, são analisados e explorados no modelo de simulação formatado para este propósito. Essa análise permite aos decisores ter conhecimento: [i] das perdas e ganhos de oportunidade no negócio principal, [ii] dos impactos nos índices financeiros da corporação, como índices de liquidez e endividamento, e [iii] da redução dos impactos tributários, na escolha por cada uma das [alternativas].

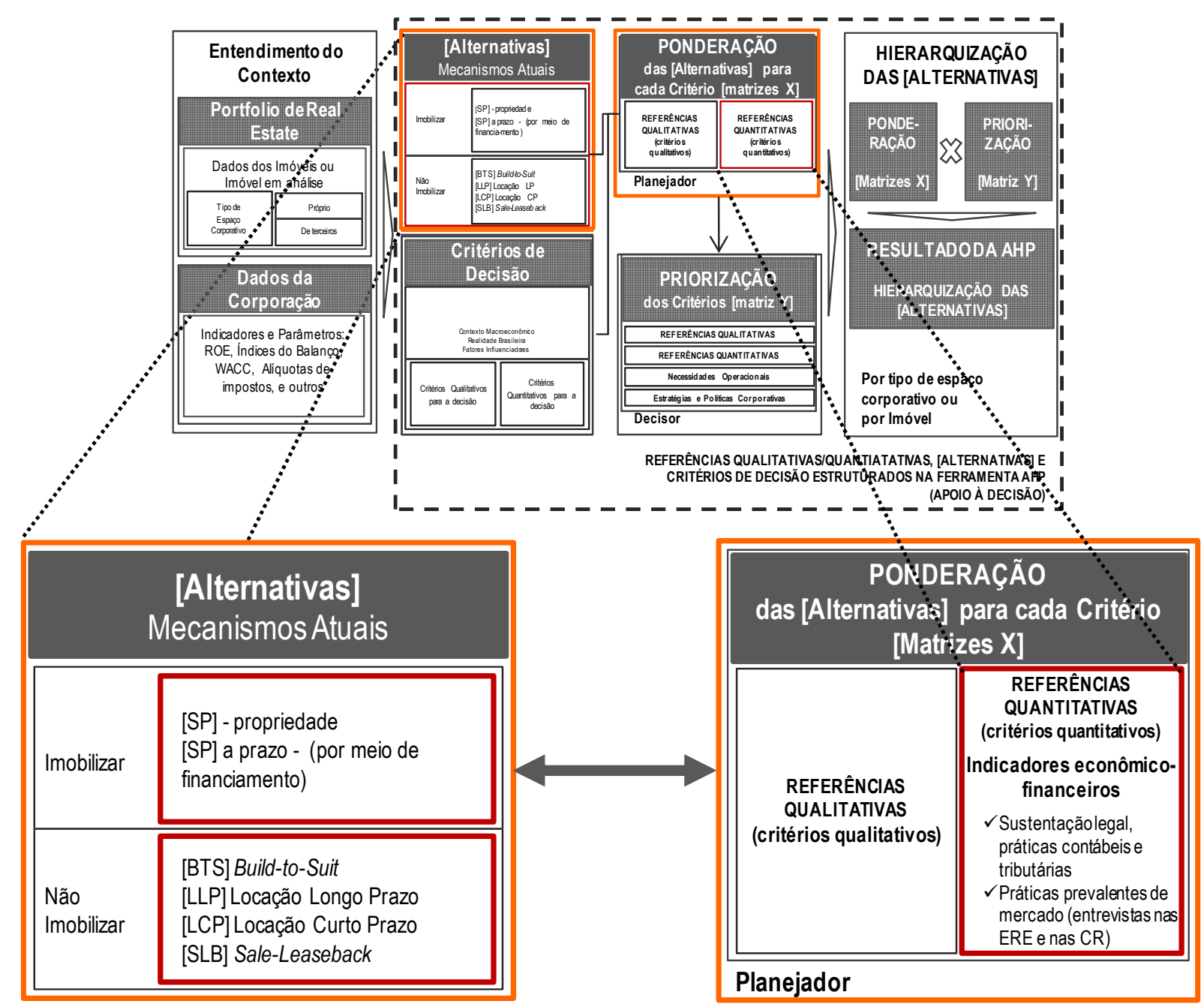

Figura 8 - [alternativas] ' $v s$ ' Referências Quantitativas do [MAOI] (rotina do [MAOI]) 
As doutrinas e conceitos proeminentes ao cálculo dos indicadores são apresentados no decorrer deste capítulo. Na finalidade de melhor elucidar esses conceitos e doutrinas, bem como os cálculos dos indicadores, são usados exemplos numéricos, inclusive contemplando as devidas variações entre as [alternativas], e a exploração do modelo, a partir de perturbações nas variáveis de entrada que configuram o comportamento do cenário tomado como referencial, com propósito de analisar a sensibilidade desses indicadores ${ }^{97}$.

\subsection{Valor do Imóvel - Doutrinas e Conceitos}

Para cálculo dos indicadores referentes aos critérios relacionados às estratégias de investimento e políticas da corporação é necessário conhecer o valor do ativo imobiliário em análise.

Existem três referências para arbitragem de valor de um imóvel, que são relevantes para o [MAOI]:

[i] o fair value ${ }^{98}$ de um ativo, segundo ROCHA LIMA (2009) e o International Valuation Standards - IVS (Oitava Edição), é entendido como o valor pelo qual ele pode ser transacionado no mercado, sem que comprador ou vendedor estejam submetidos a pressões na decisão de investir ou de liquidar o investimento. O fair value pode ser inclusive medido no conceito de value at risk ${ }^{99}$, no qual a melhor recomendação técnica é que seja definido em intervalo, conforme a transação se situe em uma zona mais ou menos protegida aos riscos de comportamento do empreendimento, quando inserido no mercado, para produzir o fluxo de renda que fundamenta a arbitragem de valor ${ }^{100}$;

[ii] o 'valor' de transação é o preço efetivamente contemplado entre o vendedor e comprador do ativo (informação de entrada no modelo), que pode, ou não, estar no intervalo de valor no

97 Entre a realidade e o cenário tomado como referencial (expectativa do planejador, considerando o ambiente macroeconômico, dos mercados de real estate, e da corporação em análise), podem ocorrer distúrbios de comportamento. Assim, a análise de risco oferece ao decisor informações que indicam o efeito desses distúrbios nos indicadores econômico-financeiros relevantes à decisão.

98 Segue-se a recomendação do Núcleo de Real Estate da Poli-USP em usar fair value do inglês, por não se reconhecer um termo na língua portuguesa mais enfático e preciso.

99 Value at risk é o procedimento de arbitragem de valor de transação de um ativo que protege o investidor do efeito de riscos de comportamento, mantendo a sua renda no patamar de atratividade arbitrado na precificação.

100 Neste texto o valor, no conceito de fair value, será também denominado como Valor da Oportunidade de Investimento - VOI. 
conceito de fair value, uma vez que preço não significa valor, pois preço se refere a uma transação efetuada. Conforme o Appraisal Institute ${ }^{101}$ (1996, apud GAIARSA, 2010, p. 35), "o preço representa o montante em que um comprador aceita pagar e um particular vendedor concorda em receber em determinadas condições que definem a transação”, e

[iii] o valor de registro, considerado para efeito de tributação e para lançamento do ativo nos demonstrativos financeiros da corporação.

\subsubsection{Valor do Imóvel no Conceito de Valor da Oportunidade do Investimento (VOI)}

Os ativos imobiliários são ativos individuais $\mathrm{e}$, portanto, há dificuldade sobre a comparabilidade de preços e parâmetros de risco de uma mesma classe para análise de valor (DAMODARAN, 2002). Conforme ROCHA LIMA (1998b) usa-se a avaliação por comparações para aqueles bens que tenham trânsito regular no mercado, ou aqueles para os quais se pode construir uma amostra representativa, a partir de ajuste de uma matriz de seus principais atributos. No contexto dos imóveis corporativos não é válida a análise de valor por método de comparação, visto que empreendimentos de base imobiliária são únicos e objeto de transações discretas, ou seja, não há como encontrar amostra representativa, pela dificuldade de caracterizar a semelhança e, também, de encontrar um universo de transações para se construir uma amostra validada.

O método de reprodução também não é satisfatório para análise de valor de imóveis corporativos, pois esse conceito sugere validar custo e não valor. $\mathrm{O}$ valor não é atributo do empreendimento, mas sim de sua capacidade de gerar renda ${ }^{102}$. Não necessariamente a reprodução dos custos para implantação de um empreendimento aproxima-se do valor de transação junto ao mercado. O processo de estimar custo de reprodução, além de complexo, dificilmente envolve variantes necessárias à análise de valor do empreendimento, como: localização, ciclos de oferta e demanda, cenário macroeconômico, entre outras variantes, que impactam na geração da renda.

Segundo DAMODARAN (1997), o valor de um ativo é determinado pelos fluxos de caixa que geram, pela incerteza associada a esses fluxos e pelo seu crescimento esperado. Quanto

101 APPRAISAL INSTITUTE. The appraisal of real estate. 11. ed. Chicago: 1996. 820 p.

102 Segundo AMATO (2001), a própria obsolescência tecnológica do empreendimento dificulta a aplicabilidade desse método, em razão de dificultar a arbitragem do valor face à situação física e funcional no momento da análise. 
maior o nível e o crescimento dos fluxos de caixa, e quanto menor o risco associado a esses fluxos, maior será o valor do ativo. O procedimento de análise de valor no conceito de VOI fundamenta-se nessa abordagem, baseada na capacidade de gerar fluxo de caixa e, nos riscos associados ao fluxo esperado. Para utilizar a metodologia do fluxo de caixa descontado para avaliar ativos imobiliários é preciso: [i] avaliar o grau de risco do investimento imobiliário, [ii] estimar uma taxa de desconto baseada no grau de risco, e [iii] estimar os fluxos de caixa esperados do investimento imobiliário durante a vida do ativo (DAMODARAN, 2002).

Conforme ROCHA LIMA (2006), os parâmetros usados para o cálculo de VOI, segundo o procedimento mais difundido e adequado para análise de valor de ativos que geram renda, são: [i] o horizonte de análise no qual se fundamentará o cálculo; [ii] a taxa de retorno (tat) capaz de atrair um investidor a pagar VOI, considerando que essa taxa é a remuneração do investimento no horizonte n; [iii] o fluxo de renda esperado (Resultado Operacional Disponível - ROD), advindo dos aluguéis pagos pelos usuários do imóvel, descontados todas as despesas e reservas (como o Fundo de Reposição de Ativos - FRA ${ }^{103}$ ); e, [iv] o valor do ativo ao final do horizonte $\mathrm{n}\left(\mathrm{VOI}_{\mathrm{n}}\right)$, calculado com base no cenário de comportamento esperado para a operação do ativo em um novo ciclo e em critérios subjetivos de exaustão. A partir desses parâmetros calcula-se o VOI para empreendimentos de base imobiliária segundo a expressão:

$$
\text { VOI }=\frac{\text { VOI }_{n}}{(1+\text { tat })^{n}}+\sum_{k=1}^{n} \frac{\text { ROD }_{k}}{(1+\text { tat })^{k}}
$$

Esse procedimento de análise de valor é simples, porém pode provocar distorções significativas no VOI em função dos parâmetros de partida. Em ROCHA LIMA (2006) foram analisadas as distorções provocadas no VOI a partir de variações nos parâmetros arbitrados (h, tat, e $\mathrm{VOI}_{\mathrm{n}}$ ), concluindo-se que pode se chegar a valores bastantes divergentes para VOI

${ }^{103}$ Cabe destacar que a ocorrência do FRA na operação é usada para suportar o desgaste no conceito de atualização e adequação funcional, não para manutenção e conservação decorrente do desgaste ao uso (considerado como despesa operacional). Assim sendo, quando a corporação é proprietária do imóvel, a reserva de recurso referente ao FRA, quando essa for praticada, é de sua responsabilidade, já a despesa de manutenção decorrente do uso é em geral do usuário do imóvel e, portanto, comum entre as [alternativas]. Porém, o que ocorre na prática é que essas benfeitorias são, na maioria dos casos, feitas pelos usuários dos espaços corporativos, independente se a intervenção é pelo desgaste ao uso ou para atualização e adequação funcional. 
em função dessas arbitragens ${ }^{104}$. Assim, quando um consultor independente impõe esses parâmetros, deve-se valer de elementos que traduzem uma visão prevalente do mercado e, ainda, apresentar o VOI em faixa de valor, cujas referências de fronteira se sustentam em parâmetros de mercado, principalmente no que tange à arbitragem da tat.

Quanto à arbitragem de n, segundo ROCHA LIMA (2006), recomenda-se considerar horizontes de comportamento baseados na evolução do mercado do negócio submetido à valuation, sua história de transformações tecnológicas (que impactam na obsolescência do ativo), e o grau de competitividade do ativo frente a novos concorrentes. No contexto de imóveis, o que se observa comumente é o uso de horizonte de análise próximo de 20 anos (usado para negócios cuja pesquisa envolve muito investimento, ou operações que demandam investimentos pesados, com longos prazos de recuperação - payback, como é o caso de investimentos em real estate).

Conforme DAMODARAN (2002), a taxa de atratividade é obtida pesquisando-se no mercado, junto aos potenciais investidores em imóveis para renda, qual taxa de retorno exigiriam para investir em diferentes tipos de imóveis corporativos. Isso porque, a depender da tipologia do imóvel, assim como, dependendo da situação, também dos devedores ${ }^{105}$, configuram-se diferentes características ao investimento, tanto do ponto de vista do payback, como dos riscos de variações no fluxo de caixa, que por consequência impactam no prêmio de risco dos investidores.

Antes de elucidar sobre a arbitragem de $\mathrm{VOI}_{\mathrm{n}}$ cabe discutir sobre a influência do fluxo do ROD na análise de valor de ativos imobiliários. O cenário de comportamento esperado em relação ao fluxo dos ROD no ciclo operacional é outro aspecto a ser tratado com sustentação na análise de valor. Considerando um horizonte de análise longo (20 anos, por exemplo), caso dos investimentos em imóveis corporativos, o fluxo dos ROD corresponde à maior parcela

104 Quanto maior n, maior é o VOI calculado, e maior é o risco, já que para validar o valor investido o empreendimento deve gerar renda, mantendo-se competitivo no seu segmento de mercado durante o horizonte $\mathrm{n}$. A tat é parametrizada em função das taxas de retorno praticadas no mercado e exerce significativas distorções no VOI. Quanto maior for a tat almejada pelo investidor, menor será o valor a ser pago pelo ativo para um mesmo fluxo de caixa esperado (ROD). O VOI também interfere no VOI, sendo menor sua influência quanto maior for o prazo de retenção do investimento na propriedade. Para horizontes longos, como no caso de investimentos em imóveis para renda, esse valor exerce pouca influência no VOI, relativamente à influência do fluxo de caixa (ROD) no horizonte $\mathrm{n}$.

105 Como no caso do BTS e SLB, em que o rating de crédito da corporação que paga pelo uso do imóvel faz parte da análise de risco da operação. 
para a composição da taxa de retorno ${ }^{106}$. Dessa forma, o impacto desse fluxo, em especial os valores dos ROD no curto prazo, exerce importante influência no $\mathrm{VOI}^{107}$.

A natureza do negócio relativamente à sua capacidade de gerar fluxos de caixa mais homogêneos reflete no preço de venda do ativo. Quanto maior for a variância do fluxo no negócio submetido à valuation, maior é o risco e maior será o prêmio do risco desejado pelo investidor, o que resulta em um menor VOI.

ROCHA LIMA (2006) sugere que para desenho do fluxo do ROD no horizonte n é preciso considerar o cenário de comportamento (tais como: os preços, custos, margens, inserção de mercado) como uma expectativa para o futuro. Sendo assim, o uso de informações históricas de comportamento, ou do momento da valuation, pode ser usado como referência, depois de submetido à crítica ${ }^{108}$, para servir de imagem para o futuro. Cenários mais favoráveis, resultam em maior VOI, ao inverso, ou seja, para cenários menos favoráveis, menor será o VOI. Assim, o desenho do cenário dos fluxos de caixa em fronteiras (agressiva e conservadora), conduz o cálculo de VOI a uma faixa, tornando a negociação do empreendimento mais confortável para os investidores.

$\mathrm{O} \mathrm{VOI}_{\mathrm{n}}$ é um parâmetro arbitrado considerando a posição de um investidor que compra o ativo para gerar um fluxo de renda durante um período de análise (denominado de ciclo de exaustão, com início após o ciclo operacional e com igual extensão). Além do $\mathrm{VOI}_{\mathrm{n}}$ é também feito no início do ciclo de exaustão o investimento em reciclagem [IR], necessário para que o imóvel seja capaz de gerar a renda nos padrões esperados em um novo ciclo. Quanto maior for o IR necessário para gerar ROD, menor será o VOI $_{n}$. A depender do uso do FRA para adequações funcionais e modernizações nas instalações do empreendimento durante a operação, que é observado em maior ou menor intensidade dependendo do tipo de negócio, menor será a necessidade de IR, e maior será o $\mathrm{VOI}_{\mathrm{n}}$. O VOI $\mathrm{V}_{\mathrm{n}}$ pode ser arbitrado pela expressão:

106 O fluxo dos ROD durante todo o ciclo operacional é em geral responsável por mais de $85 \%$ da taxa de retorno do investimento.

107 É comum no procedimento de valuation de imóveis corporativos expostos no mercado para locação, considerar um período de estabilização referente à inserção do imóvel no mercado no início da operação, até que se atinja a capacidade de ocupação esperada.

108 A partir de análise comparativa do ambiente macroeconômico, político e social, dos mercados de real estate (como os ciclos de oferta e demanda), e outros fatores que podem advertir o uso indiscriminado de informações históricas. 


$$
\mathrm{IR}+\mathrm{VOI}_{\mathrm{n}}=\frac{\mathrm{VOI}_{2 \mathrm{n}}}{\left(1+\operatorname{tat}_{\mathrm{s}}\right)^{n}}+\sum_{\mathrm{k}=\mathrm{n}+1}^{2 \mathrm{n}} \frac{\mathrm{ROD}_{\mathrm{k}}}{\left(1+\operatorname{tat}_{\mathrm{s}}\right)^{\mathrm{k}-\mathrm{n}}}
$$

A Taxa de Retorno Setorial ( tat $_{\mathrm{s}}$ ) é a taxa de retorno observada para investimentos em empreendimentos de mesmo segmento de mercado, classificados como isentos de risco na geração de renda. $\mathrm{O} \mathrm{VOI}_{2 \mathrm{n}}$ é o valor do empreendimento no final do ciclo de exaustão. Para efeito de análise, admite-se que a taxa de agregação de mais valia ao negócio dentro desse ciclo é proporcionalmente idêntica à verificada no ciclo operacional, conforme a expressão:

$$
\mathrm{VOI}_{2 \mathrm{n}}=\frac{\mathrm{VOI}_{\mathrm{n}}^{2}}{\mathrm{VOI}}[3]
$$

Segundo ROCHA LIMA (2000), quando não se tem os custos de implantação do empreendimento $^{109}$, a arbitragem de IR, para ser mais segura, deve seguir a seguinte rotina:

[i] calcular um $\mathrm{VOI}_{\mathrm{n}}$, arbitrando na expressão [4] um valor $\alpha$ de partida equivalente a 75\% (sendo $\alpha$ um fator de ajuste usado para promover um teste de consistência para a arbitragem do valor a ser aportado na reciclagem do empreendimento no final do ciclo operacional):

$$
\mathrm{VOI}_{n}=\alpha \times \sum_{k=n+1}^{2 n} \frac{\operatorname{ROD}_{k}}{\left(1+\operatorname{tat}_{s}\right)^{k-n}}[4]
$$

[ii] a partir do valor encontrado para $\mathrm{VOI}_{\mathrm{n}}$ calcula-se VOI valendo-se da expressão [1],

[iii] com VOI e $\mathrm{VOI}_{n}$ calcula-se $\mathrm{VOI}_{2 \mathrm{n}}$ na expressão [3] e IR na expressão [2],

[iv] verifica-se então, se o valor de IR encontrado é satisfatório, comparando a relação entre $\mathrm{VOI}_{\mathrm{n}}$ somado ao IR e VOI,

[v] caso o IR não seja consistente, altera-se IR, retornado-se à expressão [4] para calcular um novo $\mathrm{VOI}_{\mathrm{n}}$ e retornar ao passo [i].

Assim, definido $\mathrm{VOI}_{\mathrm{n}}$, calcula-se VOI a partir da expressão [1]. O VOI encontrado é um valor técnico para o ativo e, portanto, considera que as partes envolvidas (vendedor e comprador) não estão submetidas a qualquer tipo de pressão no momento da negociação.

109 Para o objetivo de análise de valor no contexto da decisão de imobilização ou não nos imóveis corporativos, tanto no caso da desmobilização patrimonial imobiliária como para a decisão de novos espaços, essa análise de valor é conduzida sem o conhecimento dos custos de implantação, já que dificilmente a corporação terá sido a empreendedora do imóvel, ou a implantação foi há muito tempo, o que dificulta o acesso às informações sobre custos de implantação. 
O Quadro 6 apresenta as principais características do empreendimento em análise, bem como as variáveis do cenário referencial usadas para cálculo do VOI.

Os edifícios de escritório considerados como triple A na região em análise apresentam preço de locação na faixa de $\mathrm{R} \$ 75-\mathrm{R} \$ 90$ por $\mathrm{m}^{2}$ de área privativa. No modelo de simulação considera-se para efeito de cálculo do VOI esta faixa de preço de locação, que multiplicada pela área privativa equivalente a $20.000 \mathrm{~m}^{2}$ do empreendimento, resulta em uma receita mensal de locação no intervalo de [1.500 - 1.800] R $\$$ mil, sem ajuste no ciclo de 1 ano.

A taxa de atratividade do investidor (TAT) também foi considerada em faixa de valores, situada entre $11 \%$ e $13 \%$ ao ano efetiva acima do IGP. Para o período de exaustão, considerase uma taxa inferior a taxa de atratividade do empreendimento, pois indica a atratividade de empreendimentos do mesmo segmento, classificados como isentos de risco na geração de renda. Além disso, ao longo do ciclo operacional a taxa básica de juros da economia brasileira tende a se estabilizar em patamares inferiores aos atuais, o que leva todas as decisões de investimento para menores taxas de atratividade.

Como rotina de cálculo apresentada, adota-se um fator de reciclagem $(\alpha)$ de partida equivalente a $75 \%$ de VOI para cálculo do $\mathrm{VOI}_{\mathrm{n}}$. A depender do ano de saída um diferente $(\alpha)$ é calculado, a partir de uma expressão exponencial, ou seja, para saídas mais cedo o ( $\alpha$ ) é maior que $75 \%$, sendo este considerado para a venda no ano 20 .

As contas para cálculo do ROD estão apresentadas também no Quadro 6, as quais são: impostos (14,53\% sobre a receita bruta), FRA (3\% sobre a Receita Bruta) e outras despesas operacionais (2\% sobre a receita bruta). Além destas despesas, considera-se as despesas com IPTU e Condomínio no valor de $\mathrm{R} \$ 10,00$ por $\mathrm{m}^{2}$ durante o período de estabilização, já que as áreas ainda não ocupadas do empreendimento geram esta despesa mensal ao investidor.

Os índices inflacionários, também considerados em intervalo [3,5\% a 5,0\%] ao ano, estão estimados com base nos índices de inflação observados nos últimos três anos e como expectativa adiante. Como premissa de valuation, considera-se a prática de mercado para os reajustes dos preços de locação ao índice geral de preço (IGP-M) a cada 12 meses. Sendo assim, considera-se uma perda inflacionária durante todo o horizonte de análise, já que o recebimento dos alugueis é mensal e o reajuste de preço é anual.

a situação atual com a [alternativa] indicada pelo [MAOI]. Porém, para os imóveis de propriedade da corporação é necessário considerar algumas ressalvas tratadas no decorrer deste capítulo no que tange aos cálculos dos indicadores para a desmobilização patrimonial imobiliária (SLB). 
O modelo de simulação para cálculo do VOI, segundo a rotina apresentada, indica uma faixa de valores no qual este empreendimento se situaria no conceito de fair value. Os fatores de comportamento apresentados no cenário referencial, definidos em faixas de valores (tais como: preço de locação, TAT, TATs, índices inflacionários), são aplicados no modelo entre fronteiras, encontrados de forma randômica durante todo o horizonte de análise. Sendo assim, a partir de amostras de laboratório se conclui, com alto grau de confiabilidade (90\%), pela faixa de valores de VOI para o empreendimento em análise.

O Gráfico 7 apresenta os valores de VOI na amostra de laboratório. O valor médio de VOI na amostra é $120.460 \mathrm{R} \$$ mil da base da análise (julho de 2010) ${ }^{111}$, e com 90\% de confiabilidade o VOI do empreendimento se situa no intervalo [118.499 - 122.421] R \$ mil da base. O valor de saída $\left(\mathrm{VOI}_{\mathrm{n}}\right)$ é responsável por produzir a taxa interna de retorno (TIR) sobre $8,9 \%$ do ativo na média da amostra. Como o horizonte de análise é de 20 anos, há pouca dependência do $\mathrm{VOI}_{\mathrm{n}}$ na composição do VOI.

\begin{tabular}{|c|c|c|c|c|}
\hline \multicolumn{5}{|c|}{$\begin{array}{l}\text { Intervalos de Valor para: VOI, Participação de VOIn e TIR (investidor) } \\
\text { (Cenário Referencial) }\end{array}$} \\
\hline \multirow{2}{*}{ Indicadores } & \multirow{2}{*}{ Média } & \multirow{2}{*}{ Desvio } & \multicolumn{2}{|c|}{ Fronteiras da Amostra* } \\
\hline & & & Inferior & Superior \\
\hline VOI (em R\$ mil da base) & 120.460 & 1.192 & 118.499 & 122.421 \\
\hline Participação de VOln & $8,9 \%$ & $0,1 \%$ & $8,7 \%$ & $9,1 \%$ \\
\hline TIR (\% ao ano efetiva acima do IGP) & $12,0 \%$ & $0,1 \%$ & $11,8 \%$ & $12,2 \%$ \\
\hline
\end{tabular}

Tabela 8 - Intervalos de Valor: VOI, Participação de VOI e TIR (investidor) para o Cenário Referencial

111 Daqui por diante neste texto esta unidade será tratada somente como R\$ mil da base. 


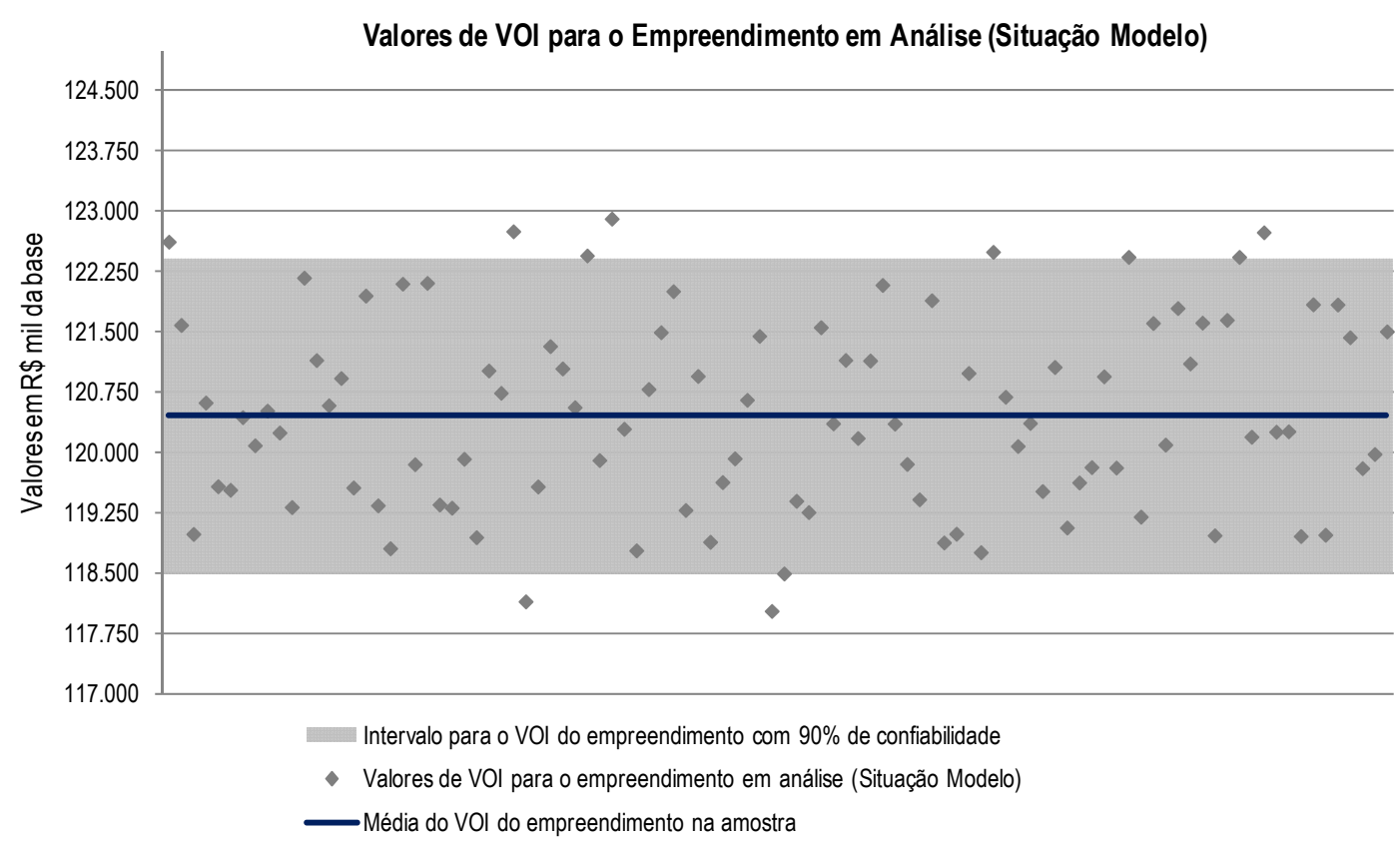

Gráfico 7 - Valores de VOI (Valor da Oportunidade do Investimento) para o empreendimento da Situação Modelo (Capítulo 6)

Conforme rotina de cálculo apresentada, o $\alpha$ de partida adotado em $75 \%$, é então avaliado a partir do cálculo do IR correspondente. O valor encontrado para IR pode ou não ser satisfatório, comparando a relação entre $\mathrm{VOI}_{\mathrm{n}}$ somado ao IR e VOI. Neste caso em análise o IR equivale a $47.393 \mathrm{R} \$$ mil da base. Ou seja, ao final do ciclo operacional um investimento na ordem de 38,9\% em relação ao inicial precisa ser feito para garantir o fluxo de ROD homogêneo durante o próximo ciclo (exaustão). Como este investimento é feito no ano 20, é possível considerar como satisfatório o IR encontrado, já que provavelmente o imóvel se apresentará obsoleto relativamente aos demais disponíveis no mercado.

Conforme demonstrado, o intervalo de valor do imóvel é calculado a partir de fatores de comportamento arbitrados em faixa de valores. Esta análise de valor, no conceito de value-atrisk, indica ao investidor um intervalo no qual o ativo pode ser transacionado. O valor a ser escolhido pelo investidor, dentro deste intervalo, depende da transação se situar em uma zona mais ou menos protegida aos riscos de comportamento do empreendimento.

A Tabela 9 apresenta a análise de risco de comportamento do empreendimento para uma queda de receita na faixa de 0 a $-10 \%$, aplicada de forma randômica durante o horizonte de análise. Para se manter a mesma taxa de atratividade arbitrada no cenário referencial o VOI para este empreendimento, protegido desta queda, se situaria no intervalo [112.451 - 116.388] R\$ mil da base, com $90 \%$ de confiabilidade. 


\begin{tabular}{c|c|c|c|c}
\hline \multicolumn{4}{c}{ Intervalos de Valor para: VOI, Participação de VOIn e TIR (investidor) } \\
(Desvio na Receita Bruta - faixa: + +0\% a - 10\%) \\
\cline { 4 - 5 } Indicadores & \multirow{2}{*}{ Média } & \multirow{2}{*}{ Desvio } & \multicolumn{2}{|c}{ Fronteiras da Amostra* } \\
\cline { 4 - 5 } & & 1.197 & Inferior & Superior \\
\hline VOI (em R\$ mil da base) & 114.420 & $0,1 \%$ & $8,8 \%$ & 116.388 \\
\hline Participação de VOIn & $9,0 \%$ & $0,1 \%$ & $11,7 \%$ & $12,2 \%$ \\
\hline TIR (\% ao ano efetiva acima do IGP) & $11,9 \%$ & &
\end{tabular}

${ }^{*} 90 \%$ de confiabilidade do indicador se situar entre estas fronteiras

NOTA: estes indicadores são medidos em amostras de laboratório diferentes.

Nesse sentido, as fronteiras dos intervalos não representam pares de valores.

Tabela 9 - Intervalo de Valor para: VOI, Participação de VOI $_{n}$ e TIR (investidor) para Cenários Estressados

\subsubsection{Valor de Transação do imóvel}

O procedimento de valuation resulta em um valor técnico para um ativo, com base na renda capaz de ser gerada, e nos riscos envolvidos para a geração da renda conforme as expectativas dos investidores. Contudo, não necessariamente a efetivação da transação será feita dentro da faixa de valor encontrada na valuation. O preço que será definido como satisfatório para ambas as partes, nesse caso corporação e investidor, pode estar em um patamar distinto dessa faixa.

Isso porque, na prática, pode ocorrer de ambas as partes incorporarem ao valor técnico parcelas especulativas que podem levar esse valor para mais ou para menos.

Essas parcelas especulativas podem advir de oportunidades alternativas de investimento no negócio principal vislumbrada pela corporação, que acabam por estimular a venda de seus ativos imobiliários (SLB), podendo, a depender da situação, assumir uma postura mais agressiva, vendendo o imóvel a um valor mais baixo para investir em suas oportunidades estratégicas.

O próprio ambiente macroeconômico e dos mercados de real estate da tipologia do imóvel em análise podem pressionar a compra ou a venda. Como exemplo, uma expectativa de elevação na taxa de juros pode estimular a venda de ativos reais para compra de ativos financeiros, por outro lado, uma expectativa de instabilidade econômica, e altas inflacionárias, podem aguçar o interesse por ativos reais. Os ciclos de oferta e demanda do mercado de real estate também podem incorporar parcelas especulativas nas transações de ativos imobiliários. É o caso, por exemplo, dos momentos de desvalorização dos imóveis, os quais acabam pressionando a venda de imóveis por investidores que antecedem o comportamento do mercado, e acabam 
assumindo uma postura mais agressiva vendendo os imóveis a preços mais baixos ${ }^{112}$.

Dessa forma, o valor de transação estará em um patamar de preço resultante de uma negociação no mercado, a qual será um valor entendido, por ambas as partes, como aceito, em razão das oportunidades e expectativas de cada uma, sendo, portanto, próprio de cada transação.

\subsubsection{Valor Contábil do Ativo Imobiliário}

Um ativo também tem seu valor contábil. O conceito desse valor faz parte da análise quantitativa do [Critério H] (desoneração do balanço) e do [Critério I] (redução dos impactos tributários).

O valor contábil de um ativo durante o ciclo operacional é a diferença entre o preço de aquisição desse ativo e o valor total acumulado da depreciação até o momento da avaliação do valor. Consequentemente, o valor contábil do ativo diminui à medida que esse envelhece.

Em economias inflacionárias o uso do custo histórico como base de valor para os registros contábeis é inconsistente, com evidentes prejuízos à determinação dos produtos, serviços e do lucro contábil. Por esse motivo a legislação brasileira permitiu no passado o uso do custo histórico ajustado pela variação do nível geral de preços, que mede a variação do poder aquisitivo da moeda no período transcorrido. Com a redução dos índices inflacionários da economia brasileira essa correção passou a ser vedada no Brasil (IUDÍCIBUS et. al, 1998).

Segundo DAMODARAN (2002), o valor de mercado de um ativo é medido pelo conceito de valor econômico, e não de custo de aquisição, portanto, reflete seu poder de lucro e os fluxos de caixa esperados. Como o valor contábil reflete seu custo original, esse pode se desviar significativamente do valor de mercado caso o poder de realização de lucros do ativo tiver aumentado ou declinado desde sua aquisição (DAMODARAN, 2002).

Quando um bem de propriedade da corporação estava registrado por um valor abaixo do valor de mercado, as empresas podiam adotar a prática de reavaliação do ativo, revisando seu valor

112 Como as 'bolhas' ocorridas no mercado imobiliário americano no ano de 2005 e 2006 e, depois, a queda acelerada dos preços dos imóveis em 2007, que levou a crise financeira mundial, conhecida em meados de 2008. 
contábil com base em laudos de avaliação. A nova Lei 11.941 de 2009 alterou a Lei $6.404^{113}$, modificando a forma de ajustar os valores dos ativos a partir de critérios utilizados para determinar a vida útil econômica do bem. Atualmente (2010) não é mais permitido reavaliar ativos do imobilizado.

Esta alteração da Lei obriga as corporações efetuarem periodicamente análises sobre a recuperação dos valores registrados no imobilizado e intangível, a fim de que sejam revisados e ajustados conforme a vida útil econômica de cada ativo, ou seja, ajustado a valor justo do bem (nomenclatura atualmente utilizada nas bibliografias sobre práticas contábeis e na Lei revisada em 2007 e 2009). O valor do ativo não pode ser contabilizado nas demonstrações financeiras por um valor acima do seu valor justo.

O valor econômico do ativo, conforme (IUDÍCIBUS, MARTINS e GELBCKE, 2007), é o valor presente dos benefícios líquidos futuros decorrentes de seu uso. O Art. 82 da Lei 6.404, alterado pela Lei 11.941 de 2009, determina que estes ajustes de aumento ou diminuição de valor atribuídos a elementos do ativo (e do passivo), em decorrência da sua avaliação a valor justo, devem ser contabilizados como ajustes de avaliação patrimonial, enquanto não computadas no resultado do exercício em obediência ao regime de competência. Esta nova regra pode trazer os valores dos ativos hiper avaliados, a partir da adoção da antiga prática de reavaliação de ativos, para valores mais próximos da realidade da empresa, uma vez que se devem ajustar os valores periodicamente, inclusive as perdas de valor (quando o valor de registro for maior que o valor justo) ${ }^{114}$.

Assim, no Brasil, o valor de registro de um ativo imobilizado nas demonstrações financeiras da corporação ao longo da sua utilização é: [i] depreciado ou amortizado, e [ii] ajustado, periodicamente.

Nos itens a seguir são abordadas as doutrinas relacionadas às práticas de depreciação e ajustes de avaliação de bens do ativo imobilizado, proeminentes ao conceito de valor contábil e, por

113 A Lei 6.404/76 dispõe sobre as regras de demonstrações contábeis e de demonstrações de resultados das Sociedades por Ações. Disponível em: www.planalto.gov.br/ccivil 03/LEIS/L6404. Acesso em Julho de 2010.

114 Esse procedimento é internacionalmente conhecido como Impairment Test (Teste de Recuperabilidade do Custo). O impairment of assets, instituído em 1999 pelo IASB (International Accounting Standards Board), insere os procedimentos adotados para o ativo que apresentar redução de seu valor recuperável. Sendo assim, um ativo não pode ser contabilizado nas demonstrações contábeis por um valor maior do que o seu valor recuperável, seja pelo seu uso, como pela venda ou baixa (CARVALHO, LEMES E COSTA, 2006). 
consequência, ao cálculo dos indicadores relacionados ao [Critério H] e ao [Critério I].

\subsubsection{Conceitos de depreciação de um ativo imobiliário}

Conforme IUDÍCIBUS et. al (1998) a depreciação vincula-se a três distintas acepções: tecnológica, econômica e contábil. Na acepção tecnológica a depreciação aplica-se no sentido de perda de eficiência funcional do ativo. Na econômica, está intimamente relacionada com a idéia de diferença entre valores (valor de mercado e valor do ativo para o proprietário). $\mathrm{Na}$ contabilidade, a depreciação é um custo a ser amortizado, no montante do custo não recuperável (custo de aquisição menos valor residual de venda).

O conceito econômico da depreciação, conforme CATELLI, PARISI e SANTOS (2003), considera que o ativo representa um estoque de serviços que são liberados durante a sua vida útil, sendo o declínio desse potencial de serviço, a depreciação, a qual pode incorrer por deterioração física, consumo pelo uso, ou perda de valor econômico por obsolescência ou por mudanças na demanda. Em razão dessa perda de benefício o Fisco permite deduzir do lucro tributável a despesa referente à depreciação do ativo.

A depreciação do ativo adquire uma nomenclatura específica de acordo com o tipo do bem. Para bens tangíveis (tais como: imóveis, máquinas), denomina-se como: depreciação. Para bens intangíveis (tais como: patentes, direitos autorais), denomina-se como: amortização. Para bens naturais (tais como: minas, reservas petrolíferas), denomina-se como: exaustão ${ }^{115}$.

Duas importantes definições são necessárias ao cálculo da depreciação: [i] a vida útil do ativo, e [ii] a escolha do método. As taxas de depreciação são calculadas a partir dessas duas definições. Normalmente, as taxas admitidas pelo Fisco, para imóveis, são calculadas para uma vida útil de 25 anos. Sendo assim, para o método de depreciação das quotas constantes ${ }^{116}$ conclui-se por uma taxa de $4 \%$ ao ano (considerando nulo o valor residual do imóvel).

O método das quotas constantes é o mais praticado no Brasil para depreciação dos ativos. Por

115 A depreciação e amortização são as nomenclaturas pertinentes à análise tratada no [MAOI]. A primeira para os ativos imobiliários da corporação, e a segunda, quando a corporação tem como instrumento jurídico para uso do imóvel o DRS, nesse caso o preço pago por esse direito é submetido à amortização durante o prazo do contrato.

116 Como não é objetivo do trabalho uma análise aprofundada sobre depreciação, utiliza-se para cálculo dos indicadores relacionados a esse conceito (indicadores do Critério $\mathrm{H}$ e do Critério I) o método mais usado e permitido pelo Fisco no Brasil: Método das Quotas Constantes. 
esse método, o valor a ser depreciado periodicamente equivale à fração entre o custo do ativo (incluindo eventuais reavaliações contabilizadas) subtraído do valor residual estimado (numerador) e o período de sua vida útil (denominador).

A depreciação pode também ser alterada em razão de intervenções significativas no ativo durante a sua utilização como recurso operacional. Uma avaliação do ativo, a partir dos serviços que geram para contribuição do resultado da corporação, permite identificar a conveniência de se reinvestir no mesmo, prolongando a sua vida útil, ou incrementando seu potencial de benefícios futuros. Assim, quando a corporação faz uma intervenção, não só referente a reparos e manutenção (contabilizada, nesse caso, apenas como despesa operacional), mas que seja capaz de melhorar a potencialidade do ativo quanto aos benefícios que geram e aumentar a sua vida útil, torna-se necessário calcular a nova taxa de depreciação a partir desses novos parâmetros (valor do ativo revisado e nova vida útil remanescente).

\subsubsection{Reavaliação dos Ativos Imobiliários, Recuperação dos Valores Registrados no Imobilizado e Ajustes de Avaliação Patrimonial}

A lei $\mathrm{n}^{0}$ 6.404/76 introduziu a possibilidade da corporação avaliar seus ativos pelo valor de mercado, chamando isso de reavaliação. Esse processo de reavaliação difere, em sua essência, da correção do valor do ativo pela variação do poder aquisitivo da moeda, que é tão somente a atualização monetária do custo de aquisição, continuando o vínculo com o preço pago pelo ativo.

Na reavaliação abandona-se o custo, ou o custo corrigido, e utiliza-se o valor econômico do ativo em análise. A legislação fiscal (Art. 434 do RIR/99) por sua vez, só admitia reajustes de valor para ativos permanentes, como é o caso dos ativos imobiliários contabilizados no ativo imobilizado. Quando aplicada a elementos integrantes dos ativos circulantes e realizável a longo prazo, considerava-se como receita tributável (IUDÍCIBUS, MARTINS e GELBCKE, 2007).

Conforme comentado, a reavaliação de ativos foi revogada. A partir da revisão da Lei 6.404 em 2009 (pela Lei 11.941), passa a ser obrigado às empresas efetuarem periodicamente análises sobre a recuperação dos valores registrados no imobilizado e no intangível.

Quando a depreciação é aplicada a ativos avaliados pelo custo, pressupõe-se o sentido de retenção de parte dos lucros como recuperação do capital investido no imobilizado que não 
será recuperável na ocasião de venda do bem. Quando o valor é revisado, depreciar o ativo reajustado faz com que o resultado fique próximo do sentido de contraposição entre a receita e o investimento a ser feito para repor o ativo consumido. Esse conceito, com vistas à manutenção da capacidade física da empresa, foge do conceito de lucro dos princípios fundamentais da contabilidade. Assim, os ajustes de aumento ou diminuição do valor do ativo, em decorrência da sua avaliação a valor justo, procuram apresentar a real capacidade instalada da corporação a partir da reposição e manutenção da capacidade do ativo ao longo de sua utilização.

Segundo (IUDÍCIBUS, MARTINS e GELBCKE, 2007), muitas empresas usaram a reavaliação de ativos para propósitos distintos dos quais a mesma foi criada, que nada mais é que ter os ativos e resultados futuros mais próximos da realidade a preços de reposição. Utilizaram, de forma deliberada, para reduzir a distribuição de dividendos, mesmo para ativos que não seriam repostos, ou também, por aquelas que se valiam da reavaliação quando os índices de exigibilidade frente ao patrimônio líquido estavam baixos ${ }^{117}$, que acabavam comprometendo as exigências de algumas instituições nas concessões de empréstimos e financiamentos.

A lei revisada em 2009 exige a contabilização tanto de aumentos como reduções de valor dos ativos e passivos da seguinte forma ${ }^{118}$ : [i] o ativo passa a ter novo valor, sendo esse o valor justo do ativo, [ii] pelos princípios contábeis o aumento do valor não deve ser considerado lucro, pois ainda não foi realizado, [iii] considera-se esse aumento de valor no Patrimônio Líquido na conta de Ajustes de Avaliação Patrimonial, enquanto não computado no resultado do exercício em obediência ao regime de competência, [iv] à medida que o ativo é realizado transfere-se a parcela consumida do ativo da conta de Ajustes de Avaliação Patrimonial para a conta de Lucros ou Prejuízos Acumulados.

117 Em inglês utiliza-se para esse índice o termo debt/equity. A redução desse índice quando da reavaliação é dada pelo fato de ser contabilizado no patrimônio líquido a diferença entre o custo (ou custo corrigido) e o valor reavaliado a preço de mercado, aumentando assim o valor total do patrimônio líquido e melhorando, portanto, a relação entre a exigibilidade e os recursos próprios da corporação.

118 A reavaliação para cima do valor de registro para valor de mercado do bem não é mais permitida para os ativos do imobilizado, como é o caso dos imóveis. Só é permitido aos ativos do imobilizado o registro das perdas de valor do capital aplicado quando houver decisão de interromper os empreendimentos/atividades a que se destinavam, ou quando comprovado que não poderão produzir resultados suficientes para recuperação desse valor (Art. 183 da Lei 6.404/74 alterada pela Lei 11.838 de 2007 e pela Lei 11.941 de 2009). 
No que diz respeito à depreciação dos ativos imobiliários reavaliados a cima do valor de registro (quando era permitido, até 2007), como se trata de uma nova avaliação é como se o ativo fosse adquirido naquele momento, passando a ser depreciado com base na sua vida útil remanescente e no novo valor, ambos avaliados por empresas especializadas em laudos de avaliação. Contudo, do ponto de vista fiscal, esse acréscimo da depreciação e, portanto, de redução do lucro tributável, não traz vantagem físcal, visto que essa redução do lucro é compensada pela transferência da conta Ajustes de Avaliação Patrimonial (anteriormente conhecida como Reservas de Reavaliação), no montante equivalente a parte depreciada relativa à parcela revisada do ativo, para a conta de Lucros/Prejuízos Acumulados, já líquido de tributação. Ou seja, o que se reduz do lucro tributável pelo aumento da depreciação, se paga, para o mesmo montante, a tributação da transferência da conta ajuste de avaliação para lucro/prejuízo acumulado.

A perda de valor dos ativos, contabilizada da mesma forma a partir da revisão da Lei em 2009, dificilmente ocorrerá para os imóveis do ativo imobilizado de uma empresa, já que em geral os imóveis tendem a preservar valor, e muitas vezes o valor justo está acima do valor de registro.

Na venda do ativo, caso da desmobilização patrimonial imobiliária, é dada a baixa do ativo no valor revisado e o montante da conta de Ajustes de Avaliação Patrimonial é transferido para conta de Lucros/Prejuízos Acumulados, líquido de tributação, incluindo nesse valor a ser transferido o lucro ou prejuízo da venda do ativo ${ }^{119}$. Nesse sentido, o reajuste do valor contábil dos ativos não traz vantagem fiscal, tanto durante o uso do ativo como na ocasião da venda $^{120}$.

Abordadas as três distintas referências de valor de um ativo imobiliário (VOI, Valor de Transição e Valor Contábil), necessárias aos cálculos dos indicadores relacionados aos critérios de decisão mensuráveis, apresenta-se nos itens a seguir a análise quantitativa de tais indicadores.

Na situação modelo usada para transcorrer este capítulo, adota-se um valor de transação para o imóvel em análise situado no intervalo de valor encontrado no conceito de VOI (que se situa entre: 118.499 - 122.421 R\$ mil da base), ou seja, entende-se que comprador e vendedor não

119 O lucro será a diferença a maior entre o valor de venda e o valor de registro (revisado), e o prejuízo a diferença a menor entre esses valores.

120 A baixa por perda de valor do ativo não é dedutível fiscalmente. 
estejam submetidos a pressões na ocasião da transação. Dessa forma, para cálculo dos indicadores apresentados a seguir, relacionados aos critérios mensuráveis do [MAOI], considera-se o valor de transação de $120.000 \mathrm{R}$ \$ mil da base para o imóvel em análise (valor médio do intervalo de valor no conceito de VOI).

\subsection{Análise Quantitativa dos indicadores relacionados ao critério - canalização de recursos no negócio principal [Critério G] e ao critério - levantar capital de giro com a desmobilização patrimonial imobiliária [Critério J]}

Ao optar pelo [Critério G] (canalização de recursos no negócio principal) e pelo [Critério J] (levantar capital de giro com a desmobilização patrimonial imobiliária), a corporação contrai a obrigação referente ao pagamento dos aluguéis na locação, ou das contraprestações da outorga de uso no DRS. Desta forma, a escolha das [alternativas] de não imobilização precisam ser validadas comparando o custo pago pelo capital de giro ativado e a renda gerada pelos investimentos, no montante equivalente ao valor de transação do imóvel, no negócio principal da corporação. A validação pelas [alternativas] de não imobilizar se dará quando a renda do capital de giro ativado for maior que o custo pago pela oportunidade desse capital ativado, em faixa de parâmetros para esta - renda relativa - determinada por cada decisor ${ }^{121}$.

Mesmo a renda sendo maior, ainda não é o suficiente para a validação da escolha pelas [alternativas] de não imobilização. Nessa avaliação também é pertinente incluir as incertezas quanto ao fluxo de caixa gerado pelo investimento na atividade fim da corporação, ou seja, o risco associado a essa renda.

Em linhas gerais, o custo está associado ao prêmio de risco do investidor no imóvel corporativo e a renda está associada ao prêmio de risco de investimentos no negócio da corporação. Para tanto, a renda gerada é comparada com o custo, não somente em valores, mas também em termos de risco. Assim, quanto maior for o risco do negócio principal relativamente ao risco do investimento no imóvel (considerando o segmento de mercado e as características do imóvel em análise), maior será a relação da renda com o custo para que a

121 Tratando-se da análise na decisão por novos espaços corporativos o capital de giro ativado [CGA] é um capital 'virtual', equivalente ao valor de transação do imóvel, que a corporação deixa de imobilizar no ativo. Na desmobilização patrimonial imobiliária (SLB) é o capital já incorporado no caixa da corporação para investimentos na atividade fim ou para reorganização do seu perfil de endividamento com a venda do ativo imobiliário. Esse capital, no SLB, refere-se ao valor de transação do ativo líquido de tributação. 
validação da escolha pela não imobilização seja confortável à corporação. A partir dessa análise é possível avaliar, do ponto de vista da corporação, se o preço de locação é satisfatório. Vale ressaltar que o planejador, usuário do [MAOI], não decide qual renda e custo do CGA configuram uma condição confortável para a tomada de decisão, cabendo a cada decisor a definição da condição aceita a partir do seu perfil de risco e das suas expectativas e oportunidades no momento da decisão.

Para avaliação das [alternativas] de não imobilização quanto ao [Critério G] e ao [Critério J] têm-se os seguintes parâmetros de cálculo: [i] o CCGA - Custo do CAPITAL De Giro Ativado, e a [ii] RCGA - Renda do Capital de Giro Ativado, concluindo-se pelos indicadores [i] RRCGA - Renda Relativa do Capital de Giro Ativado, e [ii] ARC ACréscimo no Resultado Corporativo. Para avaliar quantitativamente as [alternativas] de imobilização, têm-se como indicadores: [i] POGI - PERdA da OPORTUnidade De Ganho nA ImobilizaÇão, [ii] RRIP - Renda Relativa na ImobilizaÇão a Prazo (por meio de financiamento), e [iii] ARC - ACRÉSCIMO NO RESUlTAdo CORPORATIVO na imobilização por meio de financiamento.

\subsubsection{Custo do Capital de Giro Ativado - CCGA}

O CCGA para a corporação depende da classificação do investimento no imóvel corporativo, em termos de rentabilidade e risco, por parte dos investidores em real estate. Assim, quanto maior o risco associado ao fluxo de caixa, do ponto de vista de quem investe no imóvel, maior é o prêmio de risco almejado e maior será o CCGA para a corporação usuária do espaço.

Esse custo, portanto, varia de acordo com as [alternativas] de não imobilização, já que as características dos fluxos de caixa e os riscos associados a esse fluxo se diferem entre as [alternativas]: BTS, SLB e a Locação Simples (LS) ${ }^{122}$. De modo geral, a LS tem um fluxo de

\footnotetext{
$\mathrm{Na}$ análise quantitativa não se distingue a locação de curto e longo prazo. As duas são consideradas como locação simples (LS) referente à locação de imóveis já expostos no mercado. Isso porque, para a avaliação das [alternativas] em relação aos critérios mensuráveis, considera-se no cálculo dos indicadores sempre um mesmo horizonte de análise. Assim, se o horizonte for maior que o contrato de locação de curto prazo, seria como se o contrato fosse renovado até se igualar o prazo de locação com o horizonte de análise. Além disso, as características de locação (tais como: preços, garantias) não se alteram significativamente entre a locação simples de curto e longo prazo. Portanto, para efeito de cálculo dos indicadores e análise das [alternativas] - LCP e LLP quanto ao atendimento aos critérios mensuráveis, serão considerados os mesmos indicadores econômico-financeiros, contábeis e tributários. Isto também se justifica pelo fato do modelo de simulação considerar os
} 
caixa menos homogêneo que no BTS e SLB, assim como, diferentes riscos, resultando em valores distintos para o ativo e para os preços de locação praticados.

Imóveis são concebidos na modalidade de BTS quando a corporação não encontra no mercado um espaço corporativo que atenda a sua demanda operacional. Assim, parte-se da premissa que o uso do BTS se aplica quando um imóvel apresenta certas particularidades que dificultam sua disponibilidade no mercado. Diferentemente da LS, que o imóvel apresenta uma padronização comum para atender a uma faixa de público alvo.

Essas particularidades do ativo impactam na sua liquidez no mercado e no risco associado ao fluxo de caixa, visto que maior é o tempo de vacância até a ocupação do imóvel por outro usuário no caso da desocupação pela corporação. Por outro lado, há uma melhor expectativa de um fluxo mais homogêneo, inclusive sem período de estabilização, que é positiva ao fluxo de caixa na opção do BTS e SLB. Nota-se, portanto, que existem, concomitantemente, duas vertentes que influenciam o CCGA, uma que leva o custo para mais, relativamente à LS, e outra que leva o custo para menos.

Usando a abordagem genérica de DAMODARAN (2002) para qualquer tipo de avaliação de investimento, a composição do CCGA é uma função da renda capaz de ser gerada pelo investimento no ativo e dos riscos associados a essa renda, assim o investidor avalia as vertentes que podem influenciar no fluxo de caixa esperado, as quais podem levar esse para mais ou para menos. Dessa avaliação resulta o prêmio de risco almejado que, por consequência, implica no maior ou menor valor para o CCGA. O Quadro 7 apresenta as vertentes que podem levar o CCGA para mais ou para menos.

Os fatores externos (macroeconomia e mercados de real estate) também exercem importante influência no CCGA. Nos cenários de estabilidade econômica e queda da taxa de juros há um maior interesse por investimento em ativos imobiliários para renda, isso pode levar a uma maior oferta, inclusive de operações de BTS e SLB, que por consequência facilitam a negociação por preços de locação mais acessíveis às corporações. Os mercados de real estate podem também influenciar no preço. Mercados aquecidos tendem a apresentar valorização dos preços de locação e mercados em recessão tendem a levar os preços para baixo. Isso 
impacta no CCGA na ocasião da ação revisional, se houver ${ }^{123}$.

Fazem parte do cálculo do CCGA, além do pagamento dos aluguéis, as garantias contratuais pagas pela corporação, que também se diferem entre as [alternativas] ${ }^{124}$. Essas garantias são introduzidas no fluxo pago pela corporação para avaliação do CCGA resultante.

\begin{tabular}{|c|c|c|c|c|c|}
\hline \multicolumn{2}{|c|}{ Fatores influenciadores (vertentes) } & $\begin{array}{l}\text { Classificação } \\
\text { dos Fatores }\end{array}$ & $\begin{array}{l}\text { Influência } \\
\text { no CCGA }\end{array}$ & $\begin{array}{l}\text { Comparação entre } \\
\text { as [alternativas] de } \\
\text { não imobilização }\end{array}$ & Observações \\
\hline \multirow{4}{*}{ 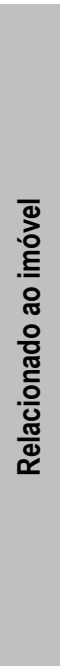 } & \multirow{2}{*}{$\begin{array}{l}\text { - Liquidez do Ativo no Mercado } \\
\text { (facilidade de comercialização: } \\
\text { avaliada pelo grau de } \\
\text { padronização, grau de } \\
\text { customização e obsolescência } \\
\text { do imóvel) }\end{array}$} & Maior Liquidez & & 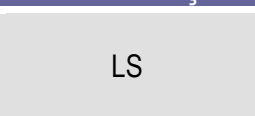 & \multirow{2}{*}{$\begin{array}{l}\text { Os imóveis de maior liquidez, em geral, } \\
\text { são os disponíveis no mercado para } \\
\text { locação (LS). No BTS e SLB a liquidez é } \\
\text { avaliada a partir da especificidade e da } \\
\text { obsolescência do imóvel }\end{array}$} \\
\hline & & Menor Liquidez & $\uparrow$ & BTS e SLB & \\
\hline & \multirow[t]{2}{*}{ - Período de Estabilização } & $\begin{array}{l}\text { Em geral três anos } \\
\text { para estabilização }\end{array}$ & $\uparrow$ & LS & $\begin{array}{l}\text { O período de estabilização impacta } \\
\text { significativamente no fluxo de caixa do } \\
\text { empreendimento. Para empreendimentos } \\
\text { expostos no mercado para locação, } \\
\text { considera-se em geral três anos para } \\
\text { ocupação plena do imóvel. Isto causa um } \\
\text { impacto negativo no fluxo e aumento do } \\
\text { CCGA, ou redução do VOI, para manter a } \\
\text { mesma taxa de atratividade }\end{array}$ \\
\hline & & $\begin{array}{l}100 \% \text { ocupado no } \\
\text { início do ciclo } \\
\text { operacional }\end{array}$ & & BTS e SLB & $\begin{array}{l}\text { Não há período de estabilização, a } \\
\text { empresa já ocupa o imóvel quando pronto } \\
\text { para operação }\end{array}$ \\
\hline \multirow{7}{*}{ 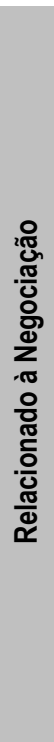 } & \multirow{2}{*}{$\begin{array}{l}\text { - Rating de Crédito da } \\
\text { Corporação (usuária) }\end{array}$} & Alta Credibilidade & & \multirow{2}{*}{ LS, BTS e SLB } & \multirow{2}{*}{$\begin{array}{l}\text { Este fator é mais relevante no BTS e SLB } \\
\text { em razão de envolver, em geral, a } \\
\text { securitização dos recebíveis, e pelo fato da } \\
\text { corporação usuária ser a única devedora }\end{array}$} \\
\hline & & Baixa Credibilidade & $\uparrow$ & & \\
\hline & \multirow{2}{*}{$\begin{array}{l}\text { - Prazos de Locação ou da } \\
\text { Cessão do DRS }\end{array}$} & Maiores Prazos & $\downarrow$ & \multirow{2}{*}{ LS, BTS e SLB } & \multirow{2}{*}{$\begin{array}{l}\text { Para todas as [alternativas] quanto maiores } \\
\text { os prazos de locação (ou do DRS) melhor } \\
\text { é a expectativa de fluxos de caixa mais } \\
\text { homogêneos }\end{array}$} \\
\hline & & Menores Prazos & $\uparrow$ & & \\
\hline & \multirow{3}{*}{$\begin{array}{l}\text { - Instrumento Jurídico usado } \\
\text { para vincular legalmente as } \\
\text { partes envolvidas }\end{array}$} & $\begin{array}{l}\text { Contrato de } \\
\text { Locação }\end{array}$ & $\uparrow$ & BTS e SLB & $\begin{array}{l}\text { Menor garantia de fluxo de caixa } \\
\text { homogêneo. Na LS, utiliza-se contrato de } \\
\text { locação, e não o DRS, não sendo um fator } \\
\text { influenciador no CCGA }\end{array}$ \\
\hline & & DRS & $\downarrow$ & BTS e SLB & $\begin{array}{l}\text { Maior garantia de fluxo de caixa } \\
\text { homogêneo (a corporação tem obrigação } \\
\text { de pagar o preço da outorga até findo o } \\
\text { prazo contratual) }\end{array}$ \\
\hline & & $\begin{array}{l}\text { Mecanismo de } \\
\text { venda da } \\
\text { subsidiária }\end{array}$ & $\downarrow$ & SLB & $\begin{array}{l}\text { Usado na desmobilização patrimonial que, } \\
\text { assim como no DRS, oferece maior } \\
\text { garantia de fluxo homogêneo }\end{array}$ \\
\hline
\end{tabular}

Quadro 7 - Fatores influenciadores do Custo do Capital de Giro Ativado (CCGA)

${ }^{123}$ Como visto no capítulo 5, em geral nos contratos de BTS e SLB há a renúncia da revisional pelas partes envolvidas, com ajustado anual do aluguel pelo índice de variação de preço escolhido contratualmente.

124 Quanto maior o risco do investimento, maior é a garantia contratual dada pela corporação. Nos casos das operações de BTS e SLB, as quais têm uma corporação como única devedora, somada a falta de liquidez do ativo e a forma de estruturação de funding (securitização dos recebíveis), o risco é maior e as garantias contratuais também. 
Como são muitos os fatores que podem levar o CCGA para cima ou para baixo, no cálculo dos indicadores do [MAOI] considera-se esta variável (CCGA) em faixa de valores, com fronteiras definidas a partir de um comportamento esperado para os preços de locação, tendo em vista as características do imóvel, o comportamento esperado do mercado de real estate, e os riscos da operação. Como esta variável, assim como outras necessárias aos cálculos dos indicadores, é aplicada no modelo em faixa de valores, os resultados para os indicadores do [MAOI] não são respostas determinísticas, mas sim intervalos no qual estes indicadores podem se situar com alto grau de confiabilidade.

Os fatores citados no Quadro 7 podem impactar no fair value, indicadores e, por consequência, no CCGA. A partir do empreendimento modelo deste capítulo, é feita uma comparação entre uma locação simples de longo prazo e um contrato de BTS para explanação do impacto no CCGA em função dos fatores do Quadro 7.

Supondo que o empreendimento em análise, nos moldes de um BTS, deva ser formatado para atender todas as especificidades da corporação locatária (empresa de serviços), tornando-se um empreendimento com menor liquidez no mercado. Isso impacta, a depender da credibilidade da corporação, da infungibilidade do imóvel à operação e das negociações contratuais, em maior ou menor risco ao investidor, futuro locador. Se a percepção de risco for maior para um empreendimento mais específico, o cálculo do valor no conceito de valueat-risk é feito para diferentes fronteiras de comportamento das variáveis do cenário, possíveis de ocorrer na realidade, na percepção do investidor.

Para um imóvel BTS, não há período de estabilização, uma vez que a corporação passa a ocupar o imóvel assim que pronto para operação. Isto é favorável ao fluxo de caixa e, portanto, reduz o CCGA para uma mesma taxa de atratividade do investimento no empreendimento. No entanto, para uma percepção de maior risco por parte do investidor, pela menor liquidez do ativo e, ainda, considerando ao final do ciclo operacional um fator de partida para o investimento em reciclagem $(\alpha)$ menor (de 50\%), na hipótese do investimento ter que ser maior para adequar o produto para uma padronização comum, estes dois últimos fatores desfavorece o fluxo de caixa esperado e, assim, impactam negativamente no CCGA.

O exemplo numérico exemplifica esta situação. Considerando na análise do valor do imóvel BTS uma fronteira de perturbação sem compensação de $0 \%$ a $-20 \%$ randomicamente no fluxo de receita pela hipótese de riscos de vacância e dificuldade de recolocação por novos locatários durante o ciclo operacional, calcula-se um novo intervalo de valor para manter a mesma atratividade do investidor, protegido do risco de desempenho do empreendimento 
nesta faixa de perturbação sem compensação (de $0 \%$ a $-20 \%$ ), conforme apresentado na Tabela 10. Mesmo considerando $100 \%$ de ocupação já no primeiro ano do ciclo, os valores indicam intervalos bem próximos entre os dois empreendimentos:

[i] na faixa de [112.451 - 116.388] $\mathrm{R} \$$ mil da base para o empreendimento exposto no mercado para locação, no qual a oferta antecede a demanda e o empreendimento apresenta uma padronização mais comum, com fronteiras de risco entre 0 a $-10 \%$ para a análise do valor no conceito de value-at-risk, e

[ii] na faixa de [114.630- 117.739] $\mathrm{R} \$$ mil da base para o empreendimento mais específico para atender as necessidades da corporação locatária (BTS), onde a demanda antecede a oferta, com fronteira de risco de desempenho entre 0 a - 20\% pelo maior risco na relocação do imóvel.

\begin{tabular}{c|c|c|c|c}
\hline \multicolumn{4}{c}{ Intervalos de Valor para: VOI, Participação de VOIn e TRR (investidor) } \\
(Desvio na Receita Bruta - faixa: +0\% a -20\%) - Imóvel BTS \\
\cline { 4 - 5 } & \multirow{2}{*}{ Média } & \multirow{2}{*}{ Desvio } & \multicolumn{2}{|c}{ Fronteiras da Amostra* } \\
\cline { 4 - 5 } & & & Inferior & Superior \\
\hline Indicadores & 116.185 & 945 & 114.630 & 117.739 \\
\hline VOI (em R\$ mil da base) & $5,6 \%$ & $0,1 \%$ & $5,4 \%$ & $5,7 \%$ \\
\hline Participação de VOIn & $12,0 \%$ & $0,1 \%$ & $11,8 \%$ & $12,1 \%$ \\
\hline TIR (\% ao ano efetiva acima do IGP) & $12, \%$ &
\end{tabular}

${ }^{*} 90 \%$ de confiabilidade do indicador se situar entre estas fronteiras NOTA: estes indicadores são medidos emamostras de laboratório diferentes.

Nesse sentido, as fronteiras dos intervalos não representam pares de valores.

Tabela 10 - Modalidade BTS - Intervalos de Valor para VOI, Participação de VOIn e TIR (investidor) Situação Modelo (Capítulo 6)

Pelo exemplo é possível verificar que as vertentes apresentadas no Quadro 7 impactam no VOI e, consequentemente, no CCGA, para se manter a mesma taxa de atratividade do investimento no empreendimento. A depender da percepção de risco de cada investidor e da zona de proteção desejada para se decidir por investir no empreendimento, pode-se concluir por valores bem distintos para o ativo.

No exemplo é possível notar a importância do período de estabilização do empreendimento. Para um mesmo valor de locação e mesma taxa de atratividade do investidor, resulta-se em intervalos próximos de valor, no entanto, no primeiro (LS) o investidor está protegido para uma queda de até $10 \%$ no fluxo de receita, enquanto no outro (BTS) está protegido para uma queda de $20 \%$.

Pelo exposto, no modelo de simulação considera-se o mesmo valor de transação para o 
imóvel, independente da [alternativa], e a mesma faixa de valor para o CCGA, com intervalo definido a partir das características do imóvel em análise, comportamento esperado do mercado de real estate para a mesma tipologia e localização.

\subsubsection{Renda do Capital de Giro Ativado - RCGA}

O investimento no montante equivalente ao valor de transação do imóvel no negócio principal da corporação gera uma renda denominada no [MAOI] por - RENDA DO CAPITAL DE GIRO ATIVADO - RCGA.

Os mesmos conceitos e doutrinas abordados anteriormente sobre análise de valor de investimentos em imóveis aplicam-se à análise do investimento do capital de giro ativado na atividade fim da corporação, que apresenta as particularidades do negócio quanto à capacidade de gerar renda e incertezas em relação a essa capacidade durante o ciclo de análise.

Essa capacidade e incerteza são informações advindas do ambiente corporativo. Conhecido o ROE $^{125}$ - RESULTADO SOBRE CAPITAL INVESTIDO da corporação e o CGA (valor de transação do imóvel), calcula-se a RCGA. Para cálculo da RCGA considera-se o CGA sendo remunerado ao ROE da corporação durante o horizonte de análise. O ROE é calculado a partir dos demonstrativos de resultados e balanços da corporação registrados em um dado período (últimos três anos, por exemplo). Para cálculo da RCGA considera-se o ROE em faixa de valor, com fronteiras definidas a partir do desempenho observado nos períodos anteriores e expectativas adiante, com base nas estratégias de atuação da corporação, quando conhecidas. Utilizar o ROE como parâmetro de desempenho generaliza o comportamento da corporação a partir do conjunto de seus investimentos e retornos, bem como da suas estratégias de distribuição de dividendos e aumento do patrimônio líquido (capital social). Como o ROE pode variar bastante de um ano para outro, o ideal é considerar um histórico do resultado líquido ao longo de um período de tempo e comparar ao valor do patrimônio líquido.

Conhecida as incertezas em relação a esse resultado, julga-se o investimento (binômio: risco ' $v s$ ' rentabilidade). $\mathrm{Na}$ maioria das situações, a rentabilidade alcançada a partir de investimentos no negócio da corporação é maior que a rentabilidade de investimentos em imóveis corporativos para renda, sendo o risco em cada situação também distinto. $\mathrm{O}$

125 Sigla em inglês - ROE: Return on Equity. 
investimento em real estate é caracterizado como de baixo risco e de longos prazos de maturação, diferente de muitos negócios das corporações, que apresentam menores prazos de payback, maiores rentabilidades e, por outro lado, maiores riscos.

Dessa forma, para avaliação das [alternativas] o decisor precisa ter o conhecimento não só da RCGA, como também, dos impactos nessa renda frente a desvios no comportamento do cenário esperado (riscos do investimento). Nesse sentido, o ROE da corporação também sofre perturbações na análise, dentro de fronteiras limites que consideram o risco do investimento na atividade fim da corporação, para a avaliação do impacto nos indicadores.

Esse parâmetro de cálculo - RCGA - é equivalente para todas as [alternativas], já que está associado à capacidade da corporação gerar resultados, e não às características do imóvel e das negociações entre usuários e investidores.

\subsubsection{Avaliação da RCGA ' $v$ ' CCGA - Indicadores das [alternativas] de não imobilização para o [Critério G] e [Critério J] (RRCGA e ARC)}

Como a RCGA só é possível ser gerada ocorrendo, concomitantemente, o CCGA pago por essa oportunidade, a avaliação das [alternativas] de não imobilização é feita a partir do saldo disponível, que é a RCGA subtraída do CCGA em cada período do horizonte de análise. A relação entre esse saldo disponível e o investimento (CGA) no início do horizonte de análise, resulta na RENDA RELATIVA DO CAPITAL DE GIRO ATIVADO - RRCGA.

$$
\mathrm{RRCGA}=\frac{(\mathrm{RCGA}-\mathrm{CCGA})}{\mathrm{CGA}}[1]
$$

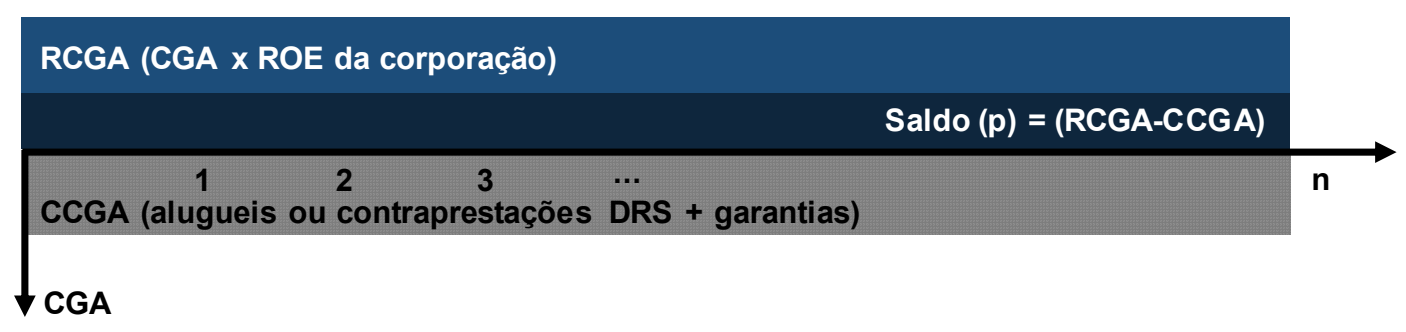

Figura 9 - Fluxo ilustrativo das entradas e saídas de caixa nas [alternativas] de não imobilização

O CCGA é influenciado pelas vertentes apresentadas no Quadro 7, pelo mercado de real estate da tipologia em análise, e pelo cenário macroeconômico, que impactam no prêmio de risco dos investidores em imóveis para renda, e assim, nos preços de locação praticados. A RCCA é influenciada pela atuação da corporação no mercado e suas estratégias de 
investimento, que impactam no prêmio de risco da corporação, em função do resultado esperado e das incertezas quanto a esse resultado.

O cálculo da RRCGA é conduzido em faixa de valor, uma vez que o CCGA e a RCGA também são calculados em intervalos em função das faixas de valores arbitradas para os parâmetros de ROE da corporação (desempenho) e CCGA (aluguéis/contraprestações). Conduzir a análise da RRCGA desta maneira é mais adequado, já que não tem o propósito de indicar um resultado determinístico, e sim uma faixa de valores em que a RRCGA poderia se situar com alto grau de confiabilidade.

Outro indicador para avaliação das [alternativas] quanto ao [Critério G] e ao [Critério J] é o ACréscimo no Resultado Corporativo - ARC. O ARC retrata a variação do resultado corporativo a partir das oportunidades de ganho na escolha por cada uma das [alternativas] de não imobilização. Encontrado o valor do saldo em função da diferença entre RCGA e o CCGA, calcula-se o ARC pela relação entre o resultado atual e o futuro, que considera o acréscimo equivalente ao saldo de cada período (saldo $(\mathrm{p})=$ RCGA-CCGA). Este indicador revela o acréscimo do resultado corporativo em função da oportunidade de ganho (RCGA) e do custo pago por essa oportunidade (CCGA) em cada uma das [alternativas].

$$
\mathrm{ARC}=\frac{\text { Re sultadoAtual }+(\mathrm{RCGA}-\mathrm{CCGA})}{\text { Re sultadoAtual }}-1
$$

Pelos motivos ora mencionados, esses dois parâmetros de cálculo (RCGA e CCGA) relacionados ao indicador RRCGA apresentam diferentes características em relação a sua composição e riscos envolvidos. Para tanto, a avaliação dos indicadores (RRCGA e ARC) é feita adotando-se um cenário referencial (determinado em faixa de valores) para compor a RCGA e o CCGA, e conhecido o contexto em análise, definem-se as fronteiras de perturbações possíveis de ocorrer na realidade para o desempenho da corporação (o ROE é submetido à perturbação sem compensação para análise dos impactos nos indicadores).

O desvio do CCGA depende de cada situação. Existem situações em que as partes, por exemplo, renunciam a ação revisional e ajustam o preço de locação apenas pelo índice geral de preço negociado em contrato. Sendo assim, no [MAOI] o CCGA é tratado em faixa de valores possíveis para o imóvel em análise, e as perturbações de cenário, para análise do impacto nos indicadores, são feitas para o parâmetro de desempenho da corporação (ROE). 


\subsubsection{Situação Modelo - Cálculo da RRCGA e ARC para as [alternativas] de não imobilização}

A partir do empreendimento modelo e dos demonstrativos financeiros da corporação objeto de análise, ilustra-se o cálculo dos indicadores: RRCGA e ARC. O decisor estipula como parâmetro entendido como satisfatório para estes indicadores $6 \%$ ao ano efetiva acima do IGP para a RRCGA e um ARC de no mínimo 2\% ao ano para compensar a escolha pelas [alternativas] de não imobilização.

Com base no desempenho histórico da corporação calcula-se o ROE a partir dos demonstrativos de resultados e balanços dos últimos três anos (2007, 2008 e 2009). Os demonstrativos da corporação em análise indicam uma faixa de valor para este parâmetro entre $25 \%$ e $30 \%$ ao ano (com base no lucro líquido, após tributação, dos exercícios analisados). O resultado líquido atual é de $40.487 \mathrm{R} \$$ mil da base (média mensal dos últimos três anos).

Para um valor de transação do imóvel de 120.000 R\$ mil da base, equivalente ao CGA para esta situação modelo, a RCGA mensal se situa no intervalo [2.253 - 2.653] R\$ mil para as [alternativas] de não imobilização. Esta variável é encontrada de forma randômica no fluxo.

As informações relacionadas ao imóvel já foram apresentadas no Quadro 6. A faixa de valor para o parâmetro do CCGA, baseada nas características do imóvel e localização, gera um custo mensal com despesas de locação no intervalo [1.500 - 1.800] R\$ mil.

Um fluxo de caixa anual é composto a partir das faixas de valor para o CCGA e para a RCGA, conforme os parâmetros indicados. A RRCGA, com $90 \%$ de confiabilidade, se situa entre $[7,46 \%-8,85 \%]$ ao ano efetiva acima do IGP, e o ARC se situa entre $[1,78 \%-2,10 \%]$ ao ano. Ambos os indicadores atendem aos parâmetros de referência estipulados pelo decisor para esta situação modelo. 


\begin{tabular}{|c|c|c|c|c|}
\hline \multicolumn{5}{|c|}{$\begin{array}{c}\text { Intervalos de Valor dos Indicadores: RRCGA e ARC } \\
\text { para as [Alternativas] de não imobilização }\end{array}$} \\
\hline \multicolumn{5}{|c|}{ (Cenário Referencial) } \\
\hline \multirow{2}{*}{ Indicadores } & \multirow{2}{*}{ Média } & \multirow{2}{*}{ Desvio } & \multicolumn{2}{|c|}{ Fronteiras da Amostra* } \\
\hline & & & Inferior & Superior \\
\hline RRCGA (\% ao ano efetiva acima do IGP) & $8,16 \%$ & $0,42 \%$ & $7,46 \%$ & $8,85 \%$ \\
\hline RCGA (R\$ mil da base/ano) & 28.820 & 401 & 28.161 & 29.479 \\
\hline Saldo(p): RCGA - CCGA (em R\$ mil da base/ano) & 9.441 & 472 & 8.664 & 10.218 \\
\hline ARC (\% ao ano) & $1,94 \%$ & $0,10 \%$ & $1,78 \%$ & $2,10 \%$ \\
\hline
\end{tabular}

${ }^{*} 90 \%$ de confiabilidade do indicador se situar entre estas fronteiras NOTA: estes indicadores são medidos em amostras de laboratório diferentes.

Nesse sentido, as fronteiras dos intervalos não representam pares de valores.

Tabela 11 - Intervalos de valor dos indicadores: Renda Relativa do Capital de Giro Ativado (RRCGA) e Acréscimo do Resultado Corporativo (ARC), conforme cenário referencial, para as [alternativas] de não imobilização - Situação Modelo (Capítulo 6)

Para as [alternativas] de não imobilização a corporação tem a oportunidade de gerar um saldo anual no intervalo [8.664 - 10.218] R \$ mil da base com 90\% de confiabilidade, considerando apenas um dos imóveis do seu portfolio de real estate (a sede administrativa). Tratando-se da análise do portfolio de real estate utilizado nas demais atividades operacionais e administrativas da corporação, pode-se concluir por um ganho representativo a partir deste saldo gerado entre RCGA e CCGA.

Para a análise do impacto nos indicadores (RRCGA e ARC) frente a desvios no desempenho da corporação gerar a RCGA é feita uma perturbação sem compensação de ROE no fluxo, entre a fronteira de $0 \%$ a $-20 \%$ de desempenho em relação ao cenário referencial. Esta faixa de perturbação é definida com base nas variações registradas para o ROE no ciclo histórico analisado e reflete o risco de desempenho do investimento na atividade fim da corporação. Pela Tabela 12 é possível observar a queda expressiva dos indicadores RRCGA e ARC para os cenários estressados. Para esta perturbação de cenário, a RRCGA se situaria no intervalo $[4,53 \%-6,52 \%]$ ao ano e o ARC entre $1,10 \%$ e $1,57 \%$ ao ano. A queda na RRCGA é de aproximadamente $32 \%$ em relação ao cenário referencial, para um desvio de até $20 \%$ no ROE, o que indica alta sensibilidade do indicador para esta variável. 


\begin{tabular}{|c|c|c|c|c|}
\hline \multicolumn{5}{|c|}{$\begin{array}{c}\text { Intervalos de Valor dos Indicadores: RRCGA e ARC } \\
\text { para as [Alternativas] de não imobilização }\end{array}$} \\
\hline \multicolumn{5}{|c|}{ (Desvio de ROE - faixa: +0\% a -20\%) } \\
\hline \multirow{2}{*}{ Indicadores } & \multirow{2}{*}{ Média } & \multirow{2}{*}{ Desvio } & \multicolumn{2}{|c|}{ Fronteiras da Amostra* } \\
\hline & & & Inferior & Superior \\
\hline RRCGA (\% ao ano efetiva acima do IGP) & $5,53 \%$ & $0,60 \%$ & $4,53 \%$ & $6,52 \%$ \\
\hline RCGA (R\$ mil da base/ano) & 25.826 & 655 & 24.747 & 26.904 \\
\hline Saldo(p): RCGA - CCGA (em R\$ mil da base/ano) & 6.472 & 690 & 5.338 & 7.606 \\
\hline ARC (\% ao ano) & $1,33 \%$ & $0,14 \%$ & $1,10 \%$ & $1,57 \%$ \\
\hline
\end{tabular}

${ }^{*} 90 \%$ de confiabilidade do indicador se situar entre estas fronteiras

NOTA: estes indicadores são medidos em amostras de laboratório diferentes.

Nesse sentido, as fronteiras dos intervalos não representam pares de valores.

Tabela 12 - Intervalos de valor dos indicadores RRCGA e ARC para as [alternativas] de não imobilização nos cenários estressados com queda de desempenho no ROE da corporação- Situação Modelo (Capítulo 6)

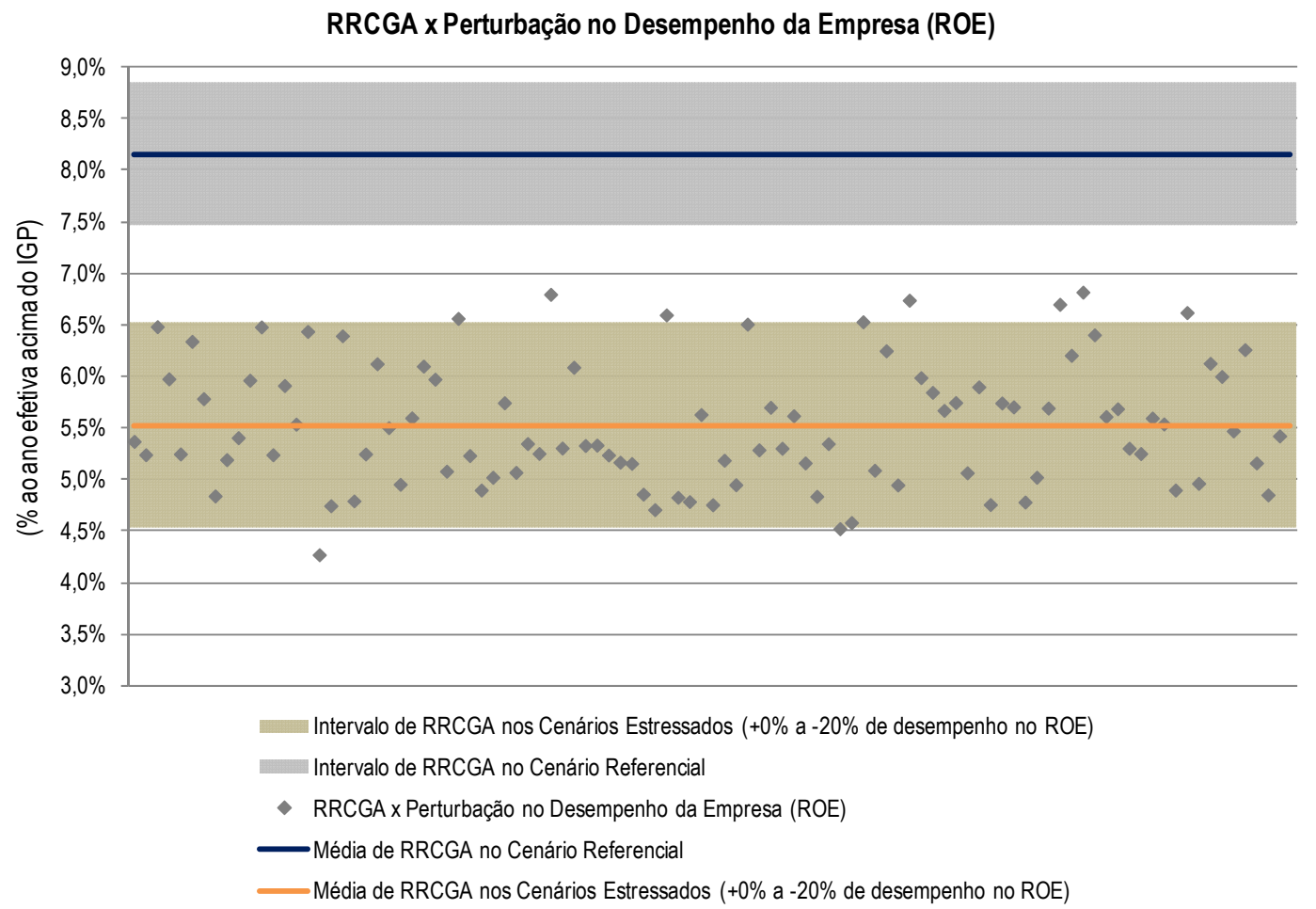

Gráfico 8 - Amostras de laboratório da RRCGA (Renda Relativa do Capital de Giro Ativado) para perturbação sem compensação no ROE (faixa: 0 a -20\%) - Situação Modelo (Capítulo 6)

O Gráfico 8 apresenta as amostras de laboratório para o indicador RRCGA calculadas a partir de diferentes cenários compostos pela perturbação sem compensação de ROE na faixa de 0 a $20 \%$ de desempenho. A média da amostra e intervalos de valor para a RRCGA nos cenários estressados podem ser comparados no gráfico com a média e intervalos da amostra calculados a partir do cenário referencial. 


\subsubsection{Perda de Oportunidade de Ganho na Imobilização à vista - POGI e Renda Relativa na Imobilização a Prazo - RRIP}

Ao optar pela imobilização a corporação precisa ter o conhecimento das perdas de oportunidade de ganho no negócio principal. A opção pela propriedade do ativo pode ocorrer tanto imobilizando recursos à vista ou a prazo por meio de financiamento ${ }^{126}$. Nessas duas situações as perdas e oportunidades de ganho são distintas. Uma, por imobilizar recursos, no montante total do valor de transação do imóvel, mais cedo; e outra, por incorporar na análise: os juros do financiamento, parcelas do valor financiado e prazos de amortização. Nessa segunda opção, a corporação deixa de imobilizar todo o montante no início, podendo aplicar a parcela financiada do imóvel, no negócio principal da corporação, porém passa a pagar o custo por essa oportunidade, relacionado às condições do financiamento.

Os fluxos de caixa, e a identificação dos custos e oportunidades de ganho, relacionados a esses fluxos, nas duas situações de imobilização, são partes relevantes da escolha pela imobilização ou não no ativo imobiliário. A identificação dos custos e oportunidades de ganho na análise pela imobilização ou não no ativo imobiliário inclui os elementos de fluxo de caixa que diferem uma situação da outra. Assim, os custos que ocorrem em comum nas [alternativas] não são considerados no cálculo dos indicadores. Como custos comuns têm-se: despesa operacional, manutenção decorrente do desgaste ao uso, seguros da propriedade (como contra incêndio), impostos ${ }^{127}$, que em geral são equivalentes tanto quando a corporação é locatária como proprietária.

Tratando-se do FRA para reposição e adequação funcional do ativo durante sua utilização,

${ }^{126}$ Neste texto a imobilização por meio de financiamento, que permite uma imobilização dos recursos no imóvel no longo prazo por meio do pagamento das parcelas referentes à amortização do principal e juros, será denominada como: imobilização a prazo (SP a Prazo).

A imobilização denominada neste texto como à vista (SP), trata-se das situações em que a corporação investe $100 \%$ no ativo sem recorrer a financiamento, mesmo que o pagamento do imóvel ocorra em algumas parcelas, como pode ocorrer em certas ocasiões. Porém, para efeito de análise dos indicadores considera-se para a imobilização à vista sempre a perda de oportunidade de ganho com o investimento no imóvel ocorrendo no início do fluxo do horizonte de análise, uma vez que relativamente às outras [alternativas] esta simplificação não vai alterar representativamente o cálculo dos indicadores e a comparação entre elas.

127 Os impostos relacionados ao imóvel são: o IPTU - Imposto Predial e Territorial Urbano (com alíquota variando em cada município sobre o valor venal do imóvel) e o ITBI - Imposto sobre Transmissão de Bens Imóveis por Ato Oneroso "inter vivos". O IPTU é igual para as [alternativas], já que no Brasil é prática comum o locatário pagar esse imposto durante sua ocupação no imóvel. Já o ITBI só ocorre no momento da compra/venda do imóvel. 
que embora seja uma despesa de responsabilidade do proprietário do imóvel, muitas vezes o próprio ocupante promove as adequações no espaço para melhor atender suas necessidades operacionais e mercadológicas. Sendo assim, como para a análise da decisão pela imobilização ou não no imóvel são considerados no cálculo dos indicadores os elementos do fluxo de entradas e saídas de recursos que se diferem entre as [alternativas], não será considerada na análise a parcela de despesa referente ao $\mathrm{FRA}^{128}$.

Desse modo, para a imobilização à vista pode-se concluir que a PERDA DE OPORTUNIDADE DE GANHO - POGI é equivalente à RRCGA. Isso porque, imobilizando à vista os recursos no imóvel, que é um recurso operacional (não de investimento), a corporação deixa de gerar RCGA e pagar o CCGA pelo uso do espaço, resultando em uma perda de oportunidade de ganho igual a RRCGA.

$\mathrm{Na}$ imobilização por meio de financiamento, outro fluxo de caixa é composto. O recurso é imobilizado no imóvel em parcelas, as quais incorporam, não só a remuneração de quem vendeu ou concebeu o ativo, mas também os juros cobrados pelo financiamento. Há, contudo, a oportunidade de ganho no negócio principal, em razão dos recursos não serem imobilizados na totalidade do valor do imóvel no início da análise. Nessa opção, considera-se para avaliação da oportunidade de ganho: [i] os juros do financiamento, [ii] o prazo de amortização, [iii] a parcela financiada, e [iv] a parcela não financiada, que será imobilizada à vista. De acordo com a credibilidade da corporação é possível angariar taxas de juros menores, maiores prazos de amortização e maior parcela do valor do imóvel financiada junto às instituições financeiras e aos bancos de desenvolvimento, como o BNDES (Banco Nacional de Desenvolvimento Social). Assim, é pertinente avaliar as condições do financiamento em conjunto com a possibilidade de investir os recursos disponíveis, ainda não imobilizados no imóvel, no negócio principal.

O fluxo de caixa para análise da opção pela imobilização por meio de financiamento tem

${ }^{128}$ Um elemento que se difere no fluxo de entrada e saída de recursos das [alternativas] é a redução dos impactos tributários em função das despesas de depreciação no caso da imobilização, ou das despesas operacionais dedutíveis de locação no caso da não imobilização. Contudo, para uma melhor avaliação das economias tributárias em cada uma das [alternativas], o impacto tributário na decisão será analisado isoladamente no [MAOI], nos indicadores relacionados ao Critério I (Redução dos Impactos Tributários). Isso porque, as vantagens tributárias dependem de variáveis do contexto de cada situação, que dificultariam a sua avaliação quando considerado junto a outros elementos. Além disso, nenhum dos indicadores é considerado de modo absoluto no [MAOI], uma vez que os critérios são tratados em conjunto na análise quando ponderados pelo decisor e, portanto, seus respectivos indicadores são considerados de modo relativo na escolha entre as [alternativas]. 
como elementos de saída: [i] a parcela do imóvel não financiada no início do ciclo de análise, [ii] as parcelas do financiamento durante o prazo de amortização (pagamento dos juros e principal), e [iii] a perda de oportunidade de ganho, equivalente a parcela não financiada que deixa de gerar a renda a partir do investimento no negócio principal da corporação. Como elementos de entrada do fluxo têm-se: [i] o fluxo de caixa gerado a partir do investimento no negócio principal no montante equivalente aos recursos mantidos em caixa (parcela financiada do imóvel) alavancados ao ROE da corporação durante todo o horizonte de análise, [ii] o valor do imóvel ao final do ciclo de análise, e [iii] o não custo do pagamento pelo uso do imóvel durante o ciclo de análise, que equivale ao fluxo 'virtual' do CCGA que a corporação deixa de pagar por ser proprietária do imóvel.

O fluxo composto por essas entradas e saídas resulta em um saldo em cada período do horizonte de análise. A relação entre esse saldo e o investimento, equivalente ao valor de transação do imóvel, indica a RENDA RELATIVA DA IMOBILIZAÇÃO A PRAZO - RRIP, a ser comparada com a oportunidade de ganho nas [alternativas] de não imobilização. Calcula-se também o indicador ARC a partir da relação entre o resultado atual e o futuro, que equivale ao resultado atual acrescido do saldo (p').

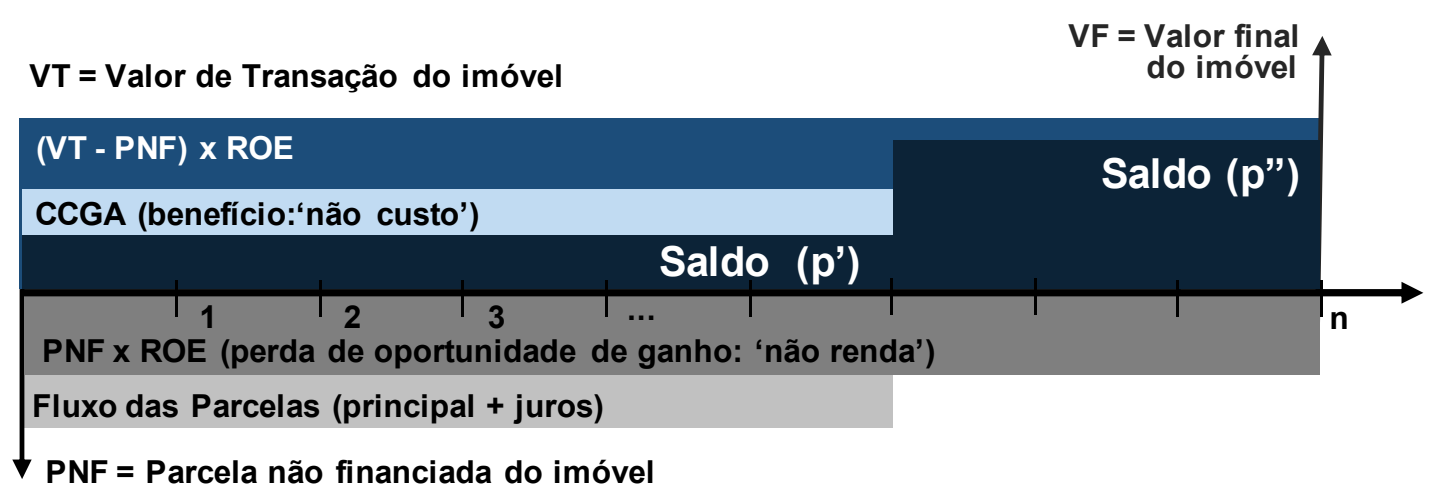

Figura 10 - Fluxo ilustrativo das entradas e saídas de caixa na [alternativa] de imobilização a prazo

Contudo, conduzir a análise apenas em termos de renda, não é suficiente para a [alternativa] de imobilização a prazo, uma vez que o fluxo não é homogêneo em todo horizonte de análise (conforme Figura 10). Na imobilização por meio de financiamento o fluxo formado pelo saldo disponível após as entradas e saídas de recursos, pode não ser homogêneo quando o prazo de financiamento for menor que o horizonte de análise e as parcelas não forem constantes. Nessa situação, após término do pagamento das parcelas do financiamento, o fluxo é composto 
apenas pelos rendimentos gerados pelo investimento no negócio principal e pelos fluxos virtuais compostos: [i] pelo benefício do 'não custo' durante o uso do imóvel, e [ii] pela perda de oportunidade em gerar a renda no montante equivalente a parcela não financiada do imóvel, que deixa de gerar o fluxo de rendimento no negócio principal.

Pelo exposto, considera-se para análise da imobilização a prazo também o conceito de taxa de retorno do fluxo de investimento ' $v s$ ' retorno composto pelas entradas e saídas de recursos nessa opção, sendo o investimento equivalente ao valor de transação do imóvel no início do ciclo de análise e o fluxo de retorno composto, em um primeiro momento, pelo saldo disponível (p'), e em um segundo momento, após a liquidação do financiamento até o final do horizonte de análise, pelo saldo (p"), somado, ainda, ao valor do imóvel no último período do ciclo. Esse fluxo de investimento e retorno resulta na TAXA DE RETORNO DA IMOBILIZAÇÃo A PRAZO - TRIP. A TRIP é um indicador auxiliar a RRIP.

A TRIP será tratada como indicador auxiliar, pois indica a qualidade da RRIP como indicador para a comparação das [alternativas] em relação ao [Critério G], e também é usado como um balizador da qualidade do ganho na opção pela imobilização a prazo, em função do peso do valor de saída do imóvel e das condições do financiamento na composição da TRIP e, assim, na variação entre a RRIP e a TRIP. Para um fluxo de retorno homogêneo e um valor de saída do capital investido igual ao valor de entrada, a taxa de retorno equivalente é igual a renda do investimento $^{129}$.

Assim, a diferença entre a TRIP e a RRIP é dada pelo peso do valor do imóvel ao final do ciclo de análise e pelas condições do financiamento (prazos de amortização e juros). Quanto maior for a TRIP em relação a RRIP maior é o peso do valor do imóvel na composição da TRIP, e/ou, também, mais desfavoráveis são as condições do financiamento. Para horizontes de análise longos, menor é o peso do valor do imóvel na composição da TRIP, assim como,

129 A taxa de retorno, no conceito de média anual equivalente, mede o ganho de riqueza, ou seja, o crescimento relativo do poder de compra numa certa unidade de tempo pré-definida, que o investidor espera quando investe no negócio (empreendimento) para obter retorno por meio do fluxo de resultados disponíveis, agregado ainda ao valor do empreendimento no final do ciclo de análise. Na ocasião da venda do ativo, para um valor de saída igual ao valor de entrada do investimento, e para um fluxo de retorno homogêneo (saldo), a taxa de retorno será igual a renda do investimento. Dessa forma, a taxa de retorno pode se diferenciar significativamente da renda do investimento, pois considera o ganho de poder de compra em um determinado ciclo de análise, considerando todas as entradas e saídas de recurso nesse horizonte (inclusive o valor de saída do investimento), e é medida do ponto de vista do final do ciclo de análise, olhando para trás, já a renda é tão somente a rentabilidade do investimento em um dado período (como os juros de uma aplicação financeira). 
com menores taxas de juros e maiores prazos de amortização, maior será o saldo disponível para compor o retorno e menor será a dependência do valor do imóvel na composição da TRIP.

Como o negócio da corporação não é obter ganho com a venda do ativo, quanto mais próximo for a RRIP da TRIP mais confortável será a decisão. Dessa forma, o papel do planejador é encontrar uma faixa para as condições do financiamento (prazo de amortização, juros e parcela financiada), possíveis de ocorrer na realidade, que remetem a uma RRIP próxima a TRIP para a tomada de decisão e comparação das oportunidades de ganho entre as [alternativas]. Por essa razão, a TRIP é considerada como um balizador da qualidade do ganho na opção pela imobilização a prazo, e da qualidade da RRIP como indicador para comparação das [alternativas] quanto às oportunidades de ganho que geram ${ }^{130}$.

Além da comparação entre RRIP e RRCGA (para as [alternativas] de não imobilização), é importante para a corporação também considerar na decisão o fato do ativo ser um recurso operacional, que pode ser estratégico ao seu desempenho. $\mathrm{O}$ ambiente macroeconômico e dos mercados de real estate podem também configurar cenários mais ou menos favoráveis à contração de financiamento ou à locação de imóveis com investidores em real estate.

Também para o cálculo dos indicadores na opção pela imobilização a prazo (RRIP, da TRIP e $\mathrm{ARC}$ ), considera-se os parâmetros de cálculo - CCGA e ROE da corporação - em faixas de valores, encontrados no fluxo de forma randômica durante todo o horizonte de análise, conduzindo o resultado destes indicadores em intervalos de valores com alto grau de confiabilidade.

\subsubsection{Situação Modelo - Cálculo da RRIP e ARC para a [alternativa]: SP a Prazo}

Com base nas condições de financiamento definidas para a situação modelo, as quais são: [i] parcela financiada do imóvel (55\%), prazo de amortização (6 anos), sistema de amortização

${ }^{130} \mathrm{Na}$ imobilização à vista calcula-se somente a POGI (que equivale a RRCGA). Como na imobilização à vista não há oportunidade de ganho no negócio principal, visto a imobilização de todo recurso no imóvel, e a economia do não custo (CCGA) é menor do que a perda da oportunidade de ganho (RCGA), nessa opção se aplica apenas o cálculo da perda da oportunidade de ganho, pois nesse caso um possível ganho só se confirmaria com a venda do imóvel em condições capazes de superar o fluxo de caixa negativo durante o horizonte de análise. Além do valor de saída ter que superar essa perda de ganho durante o ciclo (situação improvável de ocorrer), o ganho a partir da venda do imóvel é irrelevante para a corporação, que não tem como negócio principal a venda de imóveis. 
(Price) e taxa de juros do financiamento (fixada em 16\% ao ano nominal), calcula-se os indicadores relacionados ao [Critério G] para a [alternativa] - SP a prazo. O horizonte de uso do imóvel, conforme apresentado no Quadro 6, é de 15 anos e o valor de transação é de $120.000 \mathrm{R} \$$ mil da base, que resulta em uma parcela financiada de $66.000 \mathrm{R} \$$ mil da base, equivalente ao CGA desta [alternativa].

O saldo p', conforme fluxo ilustrativo apresentado na Figura 10, é composto por:

[i] Renda mensal situada no intervalo [1.239 - 1.459 ] $\mathrm{R} \$$ mil, calculada a partir da faixa de valores de $\operatorname{ROE}(25 \%$ a $30 \%$ ao ano) e da parcela financiada do imóvel no valor de 66.000 $\mathrm{R} \$$ mil da base;

[ii] Parcela mensal do financiamento durante o prazo de 6 anos no valor de $1.393 \mathrm{R} \$$ mil $^{131}$;

[iii] Benefício virtual do 'não custo' no valor equivalente ao CCGA para o imóvel em análise no intervalo [1.500 - 1.800] R\$ mil por mês (este intervalo é corrigido anualmente ao IGP-M);

[iv] Perda de oportunidade na geração de renda, no montante da parcela não financiada do imóvel, que deixa de gerar o ROE, no intervalo [1.014 - 1.194 ] R \$ mil por mês (este intervalo também é corrigido anualmente ao IGP-M);

As variáveis apresentadas no item [i], [iii] e [iv] são aplicadas de forma randômica no fluxo, resultando nos intervalos de valor para a RRIP e ARC, conforme indicado na Tabela 13. Com $90 \%$ de confiabilidade a RRIP se situa no intervalo [4,37\% - 5,68\%] ao ano e o ARC no intervalo $[1,06 \%-1,37 \%]$ ao ano. A TRIP indica a taxa de retorno do fluxo composto pelo saldo p', saldo p" (após prazo de amortização) e do $\mathrm{VOI}_{\mathrm{n}}$ ao final do horizonte de análise (15 anos). Embora a amostra indique uma TRIP situada entre [11,34\% - 11,62\%] equivalente ano efetiva acima do IGP, o valor de saída $\left(\mathrm{VOI}_{\mathrm{n}}\right)$ ao final do ciclo é responsável por produzir TRIP sobre $18,12 \%$ do investimento (valor de transação) na média da amostra.

${ }^{131}$ No ambiente do financiamento calcula-se os valores em R\$ nominais, para depois descontar na movimentação financeira do financiamento a inflação acumulada em cada período até final do prazo de amortização. 


\begin{tabular}{c|r|r|r|r}
\hline \multicolumn{3}{|c}{ Intervalos de Valor dos Indicadores: RRIP, ARC e TRIP } \\
(Cenário Referencial) \\
\hline \multirow{2}{*}{ Indicadores } & \multicolumn{1}{|c|}{ Média } & \multicolumn{1}{c}{ Desvio } & \multicolumn{2}{|c}{ Fronteiras da Amostra* } \\
\cline { 4 - 5 } & & & \multicolumn{1}{c}{ Inferior } & \multicolumn{1}{c}{ Superior } \\
\hline RRIP (\% ao ano efetiva acima do IGP) & $5,02 \%$ & $0,40 \%$ & $4,37 \%$ & $5,68 \%$ \\
\hline RCGA (R\$ mil da base/ano) & 15.838 & 236 & 15.451 & 16.226 \\
\hline Saldo P' (R\$ mil da base/ano) & 5.893 & 458 & 5.139 & 6.647 \\
\hline ARC (\% ao ano) & $1,21 \%$ & $0,09 \%$ & $1,06 \%$ & $1,37 \%$ \\
\hline TRIP (\% ao ano efetiva acima do IGP) & $11,48 \%$ & $0,09 \%$ & $11,34 \%$ & $11,62 \%$ \\
\hline Participação VOln & $18,12 \%$ & $0,22 \%$ & $17,77 \%$ & $18,47 \%$ \\
\hline
\end{tabular}

${ }^{*} 90 \%$ de confiabilidade do indicador se situar entre estas fronteiras

NOTA: estes indicadores são medidos em amostras de laboratório diferentes.

Nesse sentido, as fronteiras dos intervalos não representam pares de valores.

Tabela 13 - Intervalos de valor dos indicadores: Renda Relativa na Imobilização a Prazo (RRIP), Acréscimo do Resultado Corporativo (ARC) e Taxa de Retorno da Imobilização a Prazo (TRIP), conforme cenário referencial, para a [alternativa]: SP a Prazo - Situação Modelo (Capítulo 6)

A Tabela 14 apresenta os testes de sensibilidade para a RRIP considerando diferentes condições do financiamento do imóvel. É possível verificar que para uma parcela financiada do imóvel acima de $65 \%$ e para uma taxa de juros entre $13 \%$ e $18 \%$ ao ano, a RRIP se situaria acima da RRCGA para as [alternativas] de não imobilização.

A renda relativa se situaria acima do parâmetro entendido como satisfatório para o decisor para justificar o endividamento no imóvel ( $6 \%$ ao ano efetiva acima do IGP), para parcelas financiadas de pelo menos $60 \%$ e juros de até $15 \%$ ao ano, como indica a mesma tabela ${ }^{132}$.

Quanto menor o prazo do financiamento, menor será a RRIP. Para um prazo inferior a 7 anos a RRIP reduz significativamente, sendo maior que a RRCGA apenas para parcela financiada superior a $70 \%$ do valor de transação do imóvel.

A depender das condições de financiamento que a corporação obtém junto às instituições financeiras, como o BNDES, a opção pela imobilização a prazo pode trazer melhores resultados relativamente às [alternativas] de não imobilização, conforme demonstrado para esta situação modelo a partir dos testes de sensibilidade.

132 Como o modelo aplica os parâmetros de custo e renda de forma randômica a partir dos intervalos definidos para estas variáveis, pode ocorrer da RRIP ser ligeiramente maior para uma taxa de juros um pouco superior a outra adjacente da tabela. 
Testes de Sensibilidade para RRIP em função de variações na parcela financiada e taxa de juros do financiamento

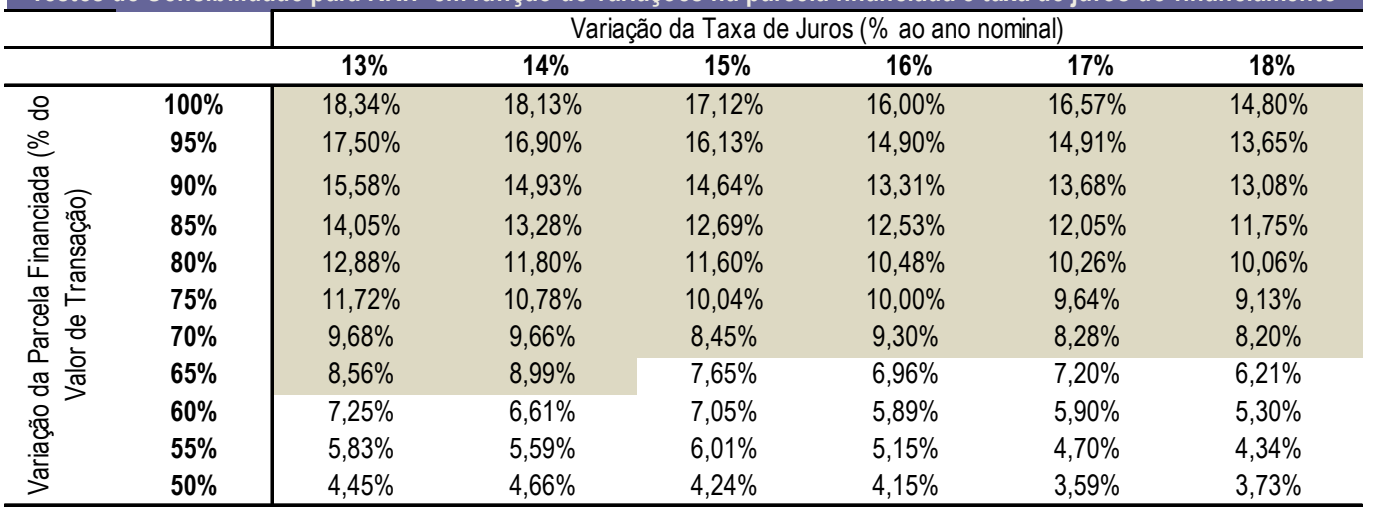

Testes de Sensibilidade para RRIP em função de variações na parcela financiada e no prazo do financiamento

\begin{tabular}{|c|c|c|c|c|c|c|c|}
\hline & & \multicolumn{6}{|c|}{ Variação do Prazo do Financiamento (em anos) } \\
\hline & & 15 & 12 & 10 & 8 & 7 & 5 \\
\hline \multirow{7}{*}{ 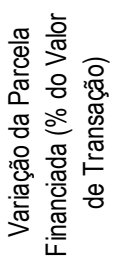 } & $100 \%$ & $26,62 \%$ & $24,61 \%$ & $22,94 \%$ & $21,45 \%$ & $19,61 \%$ & $13,33 \%$ \\
\hline & $90 \%$ & $22,34 \%$ & $21,33 \%$ & $19,92 \%$ & $17,35 \%$ & $16,20 \%$ & $9,84 \%$ \\
\hline & $80 \%$ & $19,00 \%$ & $17,64 \%$ & $16,58 \%$ & $14,44 \%$ & $13,60 \%$ & $8,83 \%$ \\
\hline & $70 \%$ & $14,77 \%$ & $13,83 \%$ & $12,83 \%$ & $12,40 \%$ & $9,59 \%$ & $6,51 \%$ \\
\hline & $60 \%$ & $11,18 \%$ & $10,87 \%$ & $9,60 \%$ & $8,59 \%$ & $7,51 \%$ & $4,25 \%$ \\
\hline & $55 \%$ & $10,22 \%$ & $9,72 \%$ & $8,54 \%$ & $6,73 \%$ & $6,82 \%$ & $3,58 \%$ \\
\hline & $50 \%$ & $9,04 \%$ & $7,15 \%$ & $6,71 \%$ & $5,59 \%$ & $5,28 \%$ & $2,18 \%$ \\
\hline
\end{tabular}

Tabela 14 - Testes de Cenários para a RRIP em função das condições do financiamento - Situação Modelo (Capítulo 6)

Assim como para as [alternativas] de não imobilização, faz parte da avaliação dos indicadores a análise de risco, a partir de perturbações em variáveis importantes do cenário referencial. Valendo-se da mesma perturbação usada para a análise dos impactos dos indicadores nas [alternativas] de não imobilização é feita para análise dos impactos na RRIP, ARC e TRIP. O ROE da corporação é então submetido à perturbação sem compensação na faixa de 0 a $-20 \%$ de desempenho.

A Tabela 15 apresenta os intervalos de valor para RRIP, ARC e TRIP identificados a partir de amostras de laboratório, para o cenário com perturbação em relação ao desempenho da corporação em gerar ROE. Nesta amostra, com 90\% de confiabilidade, a RRIP se situaria no intervalo [2,88\% - 4,31\%] ao ano efetiva acima do IGP. Nota-se que esta [alternativa] para a situação modelo é um pouco menos sensível à queda de desempenho da corporação em relação às [alternativas] de não imobilização, registrando uma queda de aproximadamente $28 \%$ em relação à RRIP identificada para o cenário referencial. Isto pelo fato do fluxo composto pela RCGA nesta [alternativa] ser gerado por uma parcela do valor do imóvel, e não pelo valor integral, e o juros do financiamento ser fixo, além da economia do 'não custo' (CCGA), que passa a ser mais representativa no caso de queda de desempenho do ROE da corporação durante o horizonte de análise. 


\begin{tabular}{c|r|r|r|r}
\hline \multicolumn{5}{|c}{ Intervalos de Valor dos Indicadores: RRIP, ARC e TRIP } \\
(Desvio de ROE - faixa: +0\% a -20\%) \\
\hline \multirow{2}{*}{ Indicadores } & \multicolumn{1}{c|}{ Média } & \multicolumn{1}{c}{ Desvio } & \multicolumn{2}{|c}{ Fronteiras da Amostra* } \\
\cline { 4 - 5 } & & & \multicolumn{1}{c}{ Inferior } & \multicolumn{1}{c}{ Superior } \\
\hline RRIP (\% ao ano efetiva acima do IGP) & $3,60 \%$ & $0,44 \%$ & $2,88 \%$ & $4,31 \%$ \\
\hline RCGA (R\$ mil da base/ano) & 14.163 & 348 & 13.591 & 14.735 \\
\hline Saldo P' (R\$ mil da base/ano) & 4.246 & 505 & 3.415 & 5.077 \\
\hline ARC (\% ao ano) & $0,87 \%$ & $0,10 \%$ & $0,70 \%$ & $1,05 \%$ \\
\hline TRIP (\% ao ano efetiva acima do IGP) & $10,26 \%$ & $0,11 \%$ & $10,08 \%$ & $10,45 \%$ \\
\hline Participação VOIn & $21,37 \%$ & $0,33 \%$ & $20,82 \%$ & $21,91 \%$ \\
\hline
\end{tabular}

${ }^{*} 90 \%$ de confiabilidade do indicador se situar entre estas fronteiras

NOTA: estes indicadores são medidos em amostras de laboratório diferentes.

Nesse sentido, as fronteiras dos intervalos não representam pares de valores.

Tabela 15 - Intervalos de valor dos indicadores: RRIP, ARC e TRIP, conforme cenários estressados, para a [alternativa]: SP a Prazo - Situação Modelo (Capítulo 6)

Os indicadores abordados nos itens 6.2.1, 6.2.2, 6.2.3 e 6.2.4 finalizam a avaliação comparativa das [alternativas] quanto ao [Critério G] e ao [Critério J] sob a ótica quantitativa.

Os itens a seguir apresentam os indicadores relacionados ao [Critério H] (desoneração do balanço) e ao [Critério I] (redução dos impactos tributários).

\subsection{Análise Quantitativa dos Indicadores relacionados ao critério - desoneração do balanço [Critério $\mathbf{H}$ ]}

Quando a corporação considera a desoneração do balanço na decisão, importância é dada aos seus índices financeiros. Os índices financeiros são subprodutos calculados a partir dos demonstrativos financeiros (demonstrativo de resultados e balanço patrimonial), os quais oferecem medidas padronizadas de lucratividade e grau de risco de uma empresa ${ }^{133}$. Conforme DAMODARAN (2002), os demonstrativos financeiros continuam sendo a fonte primária de informações para a maioria de investidores e analistas.

Tendo em vista que o recurso real estate é um dos mais onerosos para a base instalada das corporações, a imobilização dos ativos imobiliários utilizados na operação pode impactar nos seus índices financeiros. Esses índices influenciam, na atratividade de investidores no mercado de capitais, na atratividade para negociar parcerias, no acesso aos empréstimos e financiamentos pelas instituições financeiras, e para atrair recursos de terceiros para

133 Os demonstrativos de resultados medem fluxos ao longo de um período de tempo, o balanço fornece um resumo daquilo que a empresa possui em termos de ativos e daquilo que deve (para credores, bancos, acionistas, investidores). 
investimento e desenvolvimento do negócio, como os fundos de investimento, investidores em equity, investidores estrangeiros, entre outros.

Os investidores e analistas avaliam o balanço em termos de: [i] liquidez, relacionada à capacidade de transformar os bens e direitos em recursos disponíveis e [ii] exigibilidade, que corresponde ao total dos valores que serão exigidos por terceiros. Nesse sentido, desonerar o balanço implica na melhora dos índices de liquidez e na melhora dos índices de endividamento, avaliados não somente pelo montante da exigibilidade, como também pela qualidade desse exigível (curto e longo prazo).

A partir do balanço extraem-se também os índices de rentabilidade. Porém, a desoneração do balanço relaciona-se com o grau de liquidez e endividamento da corporação para realização das suas atividades e geração de seus resultados. Os índices financeiros são avaliados em conjunto pelos analistas e investidores para uma melhor interpretação sobre a real saúde financeira da corporação e, também, para uma comparação entre índices de rentabilidade e risco de outras empresas do mesmo segmento. Uma empresa pode apresentar maior alavancagem e, por consequência, maior grau de exigibilidade, no entanto, ter melhores índices de rentabilidade. Porém, não cabe analisar para o [Critério H] os índices de rentabilidade, sendo o efeito isolado da decisão pelas [alternativas] no que tange às oportunidades e perdas de ganho já avaliadas nos indicadores relacionados ao [Critério G] e ao [Critério J].

Esta forma de segmentação para análise do [Critério H], permite uma leitura primária de como o imóvel por si só impacta nos grupos de contas do balanço, sendo este o principal motivo deste atributo. Além disso, cada critério é considerado de modo relativo junto aos demais critérios do [MAOI] para as decisões em relação às estratégias do portfolio de real estate da corporação (principal objetivo do uso do [MAOI]).

A partir do entendimento de como cada uma das [alternativas] impacta nos grupos de contas da corporação (ativo, passivo e patrimônio líquido) é possível calcular diferentes índices financeiros e econômicos. Cabe ao planejador identificar quais são os índices analisados com mais frequência pela corporação e analistas (internos e externos) e, assim, calcular os indicadores pertinentes ao [Critério H], comparando-os com os parâmetros desejados pelos decisores para cada um destes indicadores. A [alternativa] que apresentar indicadores mais próximos aos parâmetros desejados pelos decisores, será aquela com maior pontuação no [Critério $\mathrm{H}]$ na matriz do AHP. 
Antes de abordar os possíveis indicadores relacionados ao [Critério H], cabe apresentar os principais conceitos inerentes a esses indicadores.

\subsubsection{Ativos e Passivos de uma corporação}

Pelo Balanço Patrimonial identificam-se as aplicações e origens de recursos utilizados pelas corporações. Os ativos apontam os investimentos (aplicações), os passivos e patrimônio líquido apontam os financiamentos (origens). As corporações se diferenciam de acordo com suas decisões e estratégias de investimento e financiamento e, por consequência, se diferenciam em termos de qualidade à atratividade em relação ao risco e lucratividade.

Em breve descrição apresenta-se os grupos de contas do balanço de onde são extraídos os principais índices financeiros das corporações já em conformidade com as alterações das Leis 11.638 de 2007 e 11.941 de 2009:

[i] os ativos são ordenados no balanço de acordo com o grau de liquidez, ou seja, pela capacidade dos bens e direitos serem transformados em recursos disponíveis (ativo circulante e ativo não circulante, este último composto por ativo realizável a longo prazo, investimentos, imobilizado e intangível).

[ii] os passivos são ordenados pelo grau de exigibilidade, ou seja, pela rapidez com que serão pagos (passivo circulante, passivo não circulante e patrimônio líquido, este último composto por capital social, reservas de capital, ajustes de avaliação patrimonial, reservas de lucro, ações em tesouraria, e lucros/prejuízos acumulados).

[iii] o Quadro 8 demonstra sucintamente os grupos de contas e como os ativos e passivos são ordenados no balanço.

[iv] como os ativos retratam a composição dos investimentos, que dependem não só das decisões da corporação, mas também da natureza do próprio negócio, existem diferenças no grupo dos ativos de empresas de manufatura, serviços e comerciais. Empresas de manufatura em geral apresentam ativo imobilizado mais alto em razão dos altos investimentos em plantas industriais, equipamentos e máquinas. As empresas comerciais apresentam menor ativo imobilizado e maior ativo em estoques e nas contas a receber. Já as empresas de serviços apresentam baixos investimentos em ativos, tanto imobilizados, como em estoques, sendo o ativo composto, basicamente, por investimento em instalações e, principalmente, por contas a receber. Nesse sentido, os índices tendem a ser mais similar entre corporações do mesmo segmento, e dificilmente a comparação entre índices de corporações de diferentes setores é 
oportuna.

[v] no que diz respeito ao passivo, que retrata a estrutura de capital da corporação, identificase as fontes de recursos, tanto de terceiros (instituições financeiras, fornecedores, entre outros), como de capital próprio (patrimônio líquido). Dessa forma, quanto maior for o capital de terceiros maior é o endividamento da corporação, sendo maior o risco em contrair novas dívidas. Em contrapartida, empresas capitalizadas apresentam maior proporção de capital próprio (recurso de sócios acionistas) e, portanto, se caracterizam como menos arriscadas ${ }^{134}$. Não somente o volume de recursos advindos de capital próprio e de terceiros são avaliados por investidores e analistas do mercado, a qualidade da dívida também faz parte da análise. Essa qualidade relaciona-se com o perfil da dívida em relação aos prazos de liquidação. Empresas com maiores dívidas de curto prazo apresentam uma estrutura de capital mais arriscada em comparação às empresas que concentram suas dívidas no exigível a longo prazo. As [alternativas] de não imobilização, como a opção pelo SLB, são meios de melhorar o perfil de endividamento da corporação no que tange à qualidade da dívida (reduzir dívidas de curto prazo e transferir para dívidas de longo prazo).

${ }^{134}$ Os recursos advindos do capital de sócios acionistas não são exigíveis (são devolvidos na ocasião do encerramento da corporação). 


\section{BALANÇO PATRIMONIAL}

\section{ATIVOS}

Ativo Circulante: recursos disponíveis em caixa, banco, aplicações financeiras, contas a receber pela prestação de serviços ou venda de produtos dentro de um período de um ano.

Realizável a Longo Prazo: contas a receber pela prestação de serviços ou venda de produtos em período superior a um ano.

Imobilizado: direitos por bens corpóreos destinados à manutenção das atividades da empresa. São os imóveis, máquinas, equipamentos, entre outros ativos utilizados nas atividades operacionais, inclusive os decorrentes de operações que transfiram à empresa os benefícios, riscos e controle desses bens (como o DRS - Direito Real de Superfície).

Depreciação Acumulada: conta redutora do ativo imobilizado (advinda da depreciação periódica pelo desgaste do uso em cada período de utilização dos bens do ativo imobilizado).

Amortização Acumulada: conta redutora do capital aplicado em direitos da propriedade industrial ou comercial e quaisquer outros com existência ou duração limitada, amortizados em cada período, como o caso das contraprestações do DRS.

Investimento: inversões financeiras de caráter permanente que geram rendimentos e não são necessários para a manutenção da atividade principal.

Intangível: direitos por bens incorpóreos destinados à manutenção da empresa (algumas empresas contabilizam concessões, como o DRS, no ativo intangível. Porém, ambas as contas pertencem ao ativo não-circulante, não alterando, portanto, a análise pertinente ao [MAOI]).

\section{PASSIVOS}

Passivo Circulante: dívidas que serão liquidadas em curto prazo, ou seja, dentro de um ano (dívida com fornecedores, despesas com funcionários e impostos, parcelas de financiamentos, despesas com locação, entre outras despesas e dívidas).

\section{Passivo Não Circulante:}

Passivo Exigível a Longo Prazo: dívidas que serão liquidadas em prazo superior a um ano (financiamentos: principal e juros, empréstimos bancários, preço da outorga do DRS entre outras despesas e dividas).

Capital Social: capital investido pelos sócios acionistas da corporação.

Lucros ou Prejuízos Acumulados: lucros ou prejuizos obtidos e ainda não destinados, os quais podem ser distribuídos (dividendos), transferidos para alguma conta reserva ou incorporados ao capital. Essa conta representa a integralização entre o balanço e a demonstração do resultado do exercício.

Ajustes de Avaliação Patrimonial: contrapartidas de aumentos ou diminuições de valores atribuídos a elementos do ativo e passivo, em decorrência de avaliações a valor justo.

Reservas: recursos gerados ainda não distribuídos aos acionistas.

\section{Quadro 8 - Balanço Patrimonial (Grupos de Contas)}

\subsubsection{Impacto das [alternativas] nos grupos de contas do balanço}

Para melhor elucidação dos impactos nos índices financeiros relacionados ao [Critério $\mathrm{H}$ ] (desoneração do balanço), no Quadro 9 apresenta-se as relações de cada uma das [alternativas] nos grupos de contas do ativo e passivo do balanço e, por consequência, nos índices de liquidez e endividamento das corporações.

O entendimento destes impactos para cada [alternativa] será compreendido com mais clareza a partir da situação modelo usada para transcorrer este capítulo, a ser apresentada para o [Critério $\mathrm{H}]$ no item 6.3.3.5 a seguir. 
[alternativas] e Impactos nos Grupos de Contas dos Ativos e Passivos

\section{ATIVOS}

\section{Ativo Circulante}

\section{Escolha das [alternativas] - Novos Espaços Corporativos:}

- Redução do circulante, no montante equivalente ao valor de transação do imóvel, na escolha pela Imobilização à Vista.

- Redução do circulante referente à parcela não financiada do valor do imóvel, na escolha pela Imobilização a Prazo.

\section{Análise da Desmobilização Patrimonial Imobiliária (SLB):}

- Acréscimo do circulante, no montante equivalente ao valor de transação do imóvel, na escolha pelo SLB (e perda da oportunidade de acréscimo no circulante, no mesmo montante, na escolha por continuar proprietária).

\section{Ativo Realizável a Longo Prazo}

Quadro 9 - [alternativas] 'vs' Impactos nos Grupos de Contas dos Ativos e Passivos

\section{Passivo Circulante}

Escolha das [alternativas] - Novos Espaços Corporativos:

- Acréscimo do circulante, no valor da parcela do financiamento do período (principal mais juros), na escolha pela Imobilização a Prazo.

- Acréscimo do circulante, referente à despesa no valor do aluguel do período, na escolha pela LS e BTS.

- Acréscimo do circulante, referente à contraprestação (DRS) do período, na escolha pelo BTS com DRS.

\section{Análise da Desmobilização Patrimonial Imobiliária (SLB):}

- Acréscimo do circulante, referente à provisão dos impostos no caso da existência de lucro na venda do ativo, na escolha pelo SLB.

- Acréscimo do circulante, referente à despesa no valor do aluguel do período, na escolha pelo SLB

- Acréscimo do circulante, referente à contraprestação (DRS) do período, na escolha pelo SLB com DRS

\section{Passivo Não Circulante Passivo Exigível a Longo Prazo}

Escolha das [alternativas] - Novos Espaços Corporativos:

- Acréscimo do exigível a longo prazo, no montante equivalente ao valor financiado do imóvel acrescido dos encargos financeiros, na escolha pela Imobilização a Prazo. Os encargos financeiros a apropriar são incluídos na conta de encargos futuros e são reduzidos na medida em que os juros são pagos (ou seja, encargos do período que são transferidos para resultados).

- Redução do exigível a longo prazo, no valor acumulado das parcelas já amortizadas do financiamento, na escolha pela Imobilização a Prazo.

- Acréscimo do exigível a longo prazo, no montante equivalente ao preço da outorga, na escolha pelo BTS com DRS.

- Redução do exigível a longo prazo, no valor acumulado da amortização referente às contraprestações de cada período na escolha pelo BTS com DRS.

\section{Análise da Desmobilização Patrimonial Imobiliária (SLB):}

- Acréscimo do exigível a longo prazo, no montante equivalente ao preço da outorga, na escolha pelo SLB com DRS.

- Redução do exigível a longo prazo, no valor acumulado da amortização referente às contraprestações de cada período na escolha pelo SLB com DRS.

(continua) 
[alternativas] e Impactos nos Grupos de Contas dos Ativos e Passivos

\section{ATIVOS}

Imobilizado

\section{Escolha das [alternativas] - Novos Espaços Corporativos:}

- Acréscimo do imobilizado, no montante equivalente ao valor de transação do imóvel, na escolha pela Imobilização à Vista e a Prazo.

- Acréscimo do imobilizado, no montante dos encargos financeiros do financiamento para produção, na escolha pela Imobilização a Prazo para imóveis em construção (somente durante o período de construção), ou seja, estes juros podem ser ativados no imobilizado até o momento em que 0 ativo em construção estiver em condições de uso.

- Acréscimo do imobilizado, no montante equivalente ao preço da outorga do DRS, na escolha pelo BTS com DRS.

- Redução do imobilizado, referente à depreciação do ativo no período (somada à acumulada), na escolha pela Imobilização à Vista e a Prazo.

- Redução do imobilizado, referente à amortização da contraprestação (DRS) do período (somada à acumulada), na escolha pelo BTS com DRS.

\section{Análise da Desmobilização Patrimonial Imobiliária (SLB):}

- Redução do imobilizado, no montante equivalente ao valor contábil do imóvel (que pode ter sido corrigido ou reavaliado), na escolha pelo SLB (e perda da oportunidade de redução no imobilizado na escolha por continuar proprietária).

- Acréscimo do imobilizado, no montante equivalente ao preço da outorga do DRS, na escolha pelo SLB com DRS.

- Redução do imobilizado, referente à amortização da contraprestação (DRS) do período (somada à acumulada), na escolha pelo SLB com DRS.

\section{Investimento}

Intangível

\section{PASSIVOS}

Capital Social

\section{Lucros ou Prejuízos Acumulados}

Escolha das [alternativas] - Novos Espaços Corporativos:

- Redução na conta de lucros/prejuízos acumulados (lucro líquido do exercício), no montante equivalente ao valor do aluguel do período, na escolha pela LS e BTS.

- Redução na conta de lucros/prejuízos acumulados (lucro líquido do exercício), no montante equivalente ao valor da contraprestação do período, na escolha pelo BTS com DRS.

- Redução na conta de lucros/prejuízos acumulados (lucro líquido do exercício), no montante equivalente à depreciação do ativo no período, na escolha pela Imobilização à Vista e a Prazo.

- Redução na conta de lucros/prejuízos acumulados (lucro líquido do exercício), no valor do pagamento do juros do financiamento no período, na escolha pela Imobilização a Prazo. Para imóveis em construção, os encargos financeiros do financiamento para produção podem ser acrescidos do imobilizado até que o mesmo esteja em condições de uso (ou seja, nestas situações estes encargos podem não ser contabilizados nesta conta, mas sim na conta do ativo imobilizado).

Análise da Desmobilização Patrimonial Imobiliária (SLB):

- Acréscimo na conta de lucros/prejuízos acumulados (lucro líquido do exercício) no montante equivalente à diferença entre o valor contábil do ativo e o valor de venda (já deduzido os impostos pagos com o lucro da venda) na escolha pelo SLB.

- Redução na conta de lucros/prejuízos acumulados (lucro líquido do exercício), no montante equivalente ao valor do aluguel do período, na escolha pelo SLB.

- Redução na conta de lucros/prejuízos acumulados (lucro líquido do exercício), no montante equivalente ao valor do contraprestação do período, na escolha pelo SLB com DRS.

\section{Ajustes de Avaliação Patrimonial}

\section{Reservas}

Quadro 9 - [alternativas] 'vs' Impactos nos Grupos de Contas dos Ativos e Passivos

(conclusão)

A imobilização à vista impacta no imobilizado e no ativo circulante, resultando em piores índices de liquidez, pela redução do circulante e aumento do ativo imobilizado. O passivo não é impactado, creditando apenas as despesas com a depreciação periódica do ativo no 
patrimônio líquido (na conta lucros/prejuízos acumulados). $\mathrm{Na}$ imobilização a prazo, o ativo circulante é menos afetado, no entanto, aumenta-se o passivo exigível a longo prazo.

A LS, BTS e SLB são as [alternativas] que causam menor impacto no balanço, visto que o circulante não é reduzido no valor do imóvel, ou ainda é incorporado nesse valor na escolha pelo SLB, e no passivo, apenas a parcela referente ao pagamento do aluguel do período é contabilizada no circulante como despesa operacional. A obrigação das parcelas do contrato de locação deve ser explicitada nas notas explicativas, e não no balanço. Essa prática contábil, a qual permite o uso de obrigações ocultas fora do balanço (como aluguéis), em que o passivo é criado, mas não reconhecido, é uma atitude em reavaliação em alguns países, inclusive no Brasil, que está em um processo de convergência das normas atuais adotadas com aquelas constantes nas normas internacionais de contabilidade (IFRS - International Financial Reporting Standards). No entanto, no Brasil está obrigação oculta com a locação ainda é uma vantagem para a escolha pelas [alternativas] de locação.

No BTS e SLB valendo-se do DRS como instrumento jurídico o preço da outorga é contabilizado no ativo imobilizado, que é amortizado à medida que as contraprestações são pagas durante todo o prazo da outorga de uso do imóvel. Porém, como não há redução dos recursos do ativo circulante para imobilização no ativo, ou ainda, há acréscimo na escolha pelo SLB, os índices de liquidez de curto prazo são também melhores quando comparados aos índices na escolha pela imobilização. Contudo, o DRS causa impacto negativo no grau de imobilização da corporação e no passivo exigível a longo prazo.

Explicitado como cada elemento é contabilizado nos grupos de contas do balanço na escolha por cada uma das [alternativas], tanto para a decisão de novos espaços corporativos, como para a decisão pela desmobilização patrimonial imobiliária, apresenta-se na sequência os principais índices relacionados à desoneração do balanço.

Conforme tratado em DAMODARAN (2002), vale ressaltar que os índices financeiros são fáceis de calcular e úteis na avaliação da saúde e lucratividade de uma empresa, bem como para a comparação de empresas do mesmo segmento. Porém, estes índices têm que ser utilizados com cautela, já que as empresas podem manipulá-los de acordo com suas necessidades. Além disso, muitas vezes são baseados em demonstrativos financeiros de um período, que podem não refletir significativas variabilidades dos números subjacentes. 


\subsection{3 Índice de Liquidez, Endividamento, Grau de Imobilização e Capital de Giro Líquido (CGL)}

A desoneração do balanço relaciona-se com a maneira da corporação investir (ativos) e financiar seus investimentos (passivos), refletindo na sua situação de liquidez e endividamento, e consequentemente no grau de risco. Nesse sentido, desonerar o balanço implica em melhorar o grau de risco de uma corporação, oriundas tanto de pressões de liquidez quanto de pressões em atender seus compromissos (endividamento).

\subsubsection{1 Índices de Liquidez ' $v$ s' [alternativas]}

Os índices de liquidez comumente avaliados por investidores e analistas, citados por DAMODARAN (2002), IUDÍCIBUS et. al (1998), e IUDÍCIBUS e MARION (2000) são: [i] ÍNDICE DE LIQUideZ CORRENTE - ILC e, [ii] ÍNDICE DE LIQUIDEZ IMEDIATA - ILI.

O ILC é a relação entre o ativo circulante e o passivo circulante. Uma liquidez corrente próxima de um (1), indica que a corporação tem obrigações vencendo no montante similar à quantidade de ativos que possam ser transformados em dinheiro, sendo, portanto, uma indicação de risco de liquidez. Por outro lado, uma liquidez corrente extremamente alta indica uma empresa pouco saudável, que pode estar enfrentando problemas em reduzir seus estoques. Na avaliação do ILI diferenciam-se os ativos circulantes que podem ser rapidamente convertidos em dinheiro (caixa disponível, títulos mobiliários negociáveis), dos que não são passíveis de conversões imediatas, como os estoques e contas a receber. Sendo assim, o ILI é a relação entre as disponibilidades (caixa e títulos negociáveis) e o passivo circulante, que representa a razão de quanto a corporação dispõe imediatamente para saldar as dívidas de curto prazo.

Pelo exposto, nota-se que a melhora de ambos os índices de liquidez é dada pelo aumento (ou oportunidade de não redução) do ativo circulante (disponibilidades), ou pela redução do passivo circulante. Assim, na necessidade de novos espaços corporativos as [alternativas] de não imobilização proporcionam a oportunidade de manter o circulante, sem aumentar significativamente o passivo circulante (é contabilizado apenas o exigível do período, referente ao valor do aluguel ou contraprestação do DRS).

Já no caso da escolha pela imobilização à vista a redução do circulante, no valor de transação do imóvel, implica em piores índices de liquidez. Na imobilização a prazo, menor impacto ocorre no ativo circulante, resultando em melhores índices relativamente à imobilização à vista, porém, na maioria dos casos, ainda piores que os índices de liquidez referente às 
[alternativas] de não imobilização.

Na decisão pela desmobilização patrimonial imobiliária a escolha pelo SLB aumentaria o circulante, no valor de transação do imóvel. A corporação pode também reorganizar seu perfil de endividamento reduzindo, com o capital disponível com a venda do ativo, o passivo circulante, ou seja, as dívidas de curto prazo, passando a contrair dívidas de longo prazo com os contratos de locação ou de DRS. Como há imóveis que são ocupados por longos períodos, esse mecanismo permite uma reorganização das contas que deveriam ser pagas no curto prazo e contas que podem ser pagas no longo prazo. Por essa razão a escolha pelo SLB pode melhorar a qualidade da dívida ${ }^{135}$ da corporação.

\subsubsection{2 Índices de Endividamento vs [alternativas]}

Os índices de endividamento também são influenciados pela decisão de imobilização ou não no real estate corporativo. Esses índices retratam a estrutura de capital da corporação, ou seja, a posição do capital próprio com relação ao capital de terceiros. São também importantes na análise de risco de uma corporação por indicarem a relação de dependência da empresa com relação à capital de terceiros e à qualidade da dívida.

Conforme DAMODARAN (2002) e IUDÍCIBUS e MARION (2000), os índices de endividamento comumente avaliados são: [i] ÍNDICE DE PARTICIPAÇão DE CAPITAis DE Terceiros sobre os Recursos Totais - PTRT, que é o quociente entre o passivo total (circulante e não circulante) sobre o total do passivo somado ao patrimônio líquido; [ii] Índice de ParticipaÇÃo de Capital de Terceiros sobre o CaPital PróPrio, ou seja, sobre o PATrimônio LíQuido - PTPL, que é o quociente entre o passivo total sobre o patrimônio líquido; e o índice de endividamento que retrata a qualidade da dívida, citado em IUDÍCIBUS e MARion (2000) - [iii] Índice de ParticipaÇão do Exigível a Curto Prazo sobre o Exigível TOTAL - PECP, sendo esse índice a relação entre o passivo circulante sobre o passivo total (passivo circulante e não circulante).

Conforme demonstrado no Quadro 9 o passivo circulante e não circulante são impactados distintamente em cada uma das [alternativas]. Como visto na necessidade por novos espaços

135 O mesmo ocorre na escolha pela não imobilização dos novos espaços corporativos. A oportunidade de manter em caixa o recurso disponível e não investir no imóvel permite à corporação saldar dívidas de curto prazo, passando a locar os novos espaços demandados por longo prazo. 
corporativos, a escolha pela imobilização à vista leva a perda da oportunidade de redução do passivo circulante, visto a redução do caixa disponível a ser imobilizado no ativo. A imobilização a prazo permite uma reorganização do perfil de endividamento a partir da realocação da parcela disponível em caixa, que não foi imobilizada no imóvel, para saldar dívidas de curto prazo. Desse modo, melhora-se o PECP, ou seja, a qualidade da dívida, porém os índices PTRT e PTPL são negativamente impactados, visto que o principal mais juros do financiamento é contabilizado no passivo não circulante.

Já nas [alternativas] de não imobilização, com contrato de locação, o caixa disponível pode ser usado para reduzir o passivo circulante, sem, contudo, transparecer no balanço o acréscimo do passivo não circulante, resultando em melhores índices de endividamento, tanto para o PTRT e PTPL, como para o PECP. Considerando o uso do DRS existe a possibilidade de melhorar a qualidade da dívida, ou seja, o índice PECP da corporação, no entanto, como o preço da outorga é contabilizado no passível não circulante, os índices PTRT e PTPL são negativamente impactados.

O mesmo ocorre na análise pela desmobilização patrimonial imobiliária. A escolha pelo SLB pode ser um mecanismo para melhorar a qualidade da dívida da corporação. O valor de transação do ativo, livre de tributação, é utilizado para saldar dívidas de curto prazo, reduzindo o passivo circulante, sem causar acréscimo do passivo não circulante, gerando também melhores índices de endividamento.

\subsubsection{Grau de Imobilização 'vs' [alternativas]}

O volume de aplicações no ativo permanente depende do ramo de atividade de cada corporação. No entanto, a meta de investimento no imobilizado almejada nas corporações é conseguir o máximo de rendimento do imobilizado, investindo o mínimo possível. Por conta disso, investir em imóveis implica na perda da oportunidade de ganho em investimentos de melhor rentabilidade relacionados à atividade fim. É essa capacidade de melhor gerir as aplicações e fontes de recurso que diferenciam uma corporação da outra. Dessa forma, importância é dada também para o grau de imobilização da corporação, que indica a proporção do capital próprio que está imobilizada em plantas e instalações, entre outros imobilizados que não estão em giro.

Vale ressaltar que a análise desse índice deve considerar o tipo da corporação em questão, 
pela maior disparidade encontrada entre o grau de imobilização de corporações de diferentes setores. Assim, outro índice relacionado à desoneração do balanço, citado em IUDÍCIBUS et. al (1998) e IUDÍCIBUS e MARION (2000), é o - GRAU DE IMOBILIZAÇÃo DO PATRIMÔNIO LíQUIDO - GIPL, medido pelo quociente entre o total do ativo imobilizado,investimentos e intangível sobre o patrimônio líquido.

As [alternativas] de imobilização tanto à vista como a prazo, impactam negativamente nesse índice, pois o valor de transação do imóvel é contabilizado no imobilizado. As [alternativas] de não imobilização não geram ativo imobilizado, somente despesa operacional no passivo circulante referente ao pagamento do aluguel do período, o que resulta em melhores índices de GIPL. Já nos casos da escolha pelo BTS ou SLB valendo-se do DRS como instrumento jurídico, o preço da outorga é contabilizado no ativo imobilizado (ou intangível), resultando em piores índices de GIPL, mesmo optando pela não imobilização.

\subsubsection{Capital de Giro Líquido 'vs’ [alternativas]}

Outro possível indicador para avaliar a desoneração do balanço em cada um das [alternativas] é a análise do CAPITAL DE GIRO LíQUIDO - CGL, que retrata a saúde financeira da corporação (ou folga financeira) e é rotineiramente calculado por investidores e analistas internos e externos, citado em IUDÍCIBUS et. al (1998), IUDÍCIBUS e MARION (2000) e DAMODARAN (2002). O CGL é a subtração do ativo circulante pelo passivo circulante. O aumento do ativo circulante ou redução do passivo circulante causa aumento do CGL, no inverso, ou seja, a redução do ativo circulante ou aumento do passivo circulante reduz o CGL. Assim, a imobilização à vista reduz o ativo circulante, reduzindo também o CGL. Na imobilização a prazo, o valor correspondente à parcela financiada do valor de transação do imóvel, permanece no ativo circulante ou é usado para redução do passivo circulante, gerando melhores índices de CGL relativamente à imobilização à vista.

Nas [alternativas] de não imobilização, independente do tipo de instrumento jurídico utilizado, tem-se a oportunidade de manter o ativo circulante, ou incorporar no mesmo o valor de venda do imóvel no caso do SLB, resultando em melhores índices de CGL que as [alternativas] de imobilização.

O Quadro 10 demonstra os possíveis indicadores relacionados ao [Critério $\mathrm{H}$ ], os quais avaliam esse critério do ponto de vista quantitativo para cada uma das [alternativas] 
analisadas no [MAOI]. Importante ressaltar que existem outros índices que podem retratar o grau de risco de uma corporação quanto à sua liquidez e endividamento. Porém, foram apresentados aqueles que já são capazes de retratar como cada uma das [alternativas] impacta no balanço e, assim, nos seus índices financeiros.

A partir da identificação dos impactos nos grupos de contas do balanço outros indicadores podem ser derivados e avaliados. No entanto, não é o foco deste trabalho a análise detalhada dos índices do balanço, mas sim uma leitura primária de como esses índices se alteram na escolha por cada uma das [alternativas]. Nada impede da corporação, objeto de análise do [MAOI], indicar ao planejador usuário do [MAOI], aqueles indicadores mais rotineiramente analisados por analistas internos e externos à corporação.

\section{ÍNDICES FINANCEIROS PARA ANÁLISE QUANTITATIVA DA DESONERAÇÃO DO BALANÇO - CRITÉRIO H}

\begin{tabular}{|c|c|c|c|}
\hline \multicolumn{3}{|r|}{ Índices } & Equação \\
\hline \multirow{2}{*}{$\begin{array}{l}\text { Índices de } \\
\text { Liquidez }\end{array}$} & ILC & Índice de Liquidez Corrente & ILC = Ativo Circulante $/$ Passivo Circulante \\
\hline & ILI & Índice de Liquidez Imediata & $\begin{aligned} \text { ILI }= & \text { Disponibilidades } / \text { Passivo Circulante } \\
& { }^{*} \text { Caixas e Títulos Negociáveis }\end{aligned}$ \\
\hline \multirow{3}{*}{$\begin{array}{c}\text { Índices de } \\
\text { Endividamento }\end{array}$} & PTRT & $\begin{array}{l}\text { Índice de Participação de Capitais de } \\
\text { Terceiros sobre os Recursos Totais }\end{array}$ & $\begin{array}{l}\text { PTRT = Passivo Total** / (Passivo Total + Patrimônio Líquido) } \\
{ }^{* *} \text { Circulante + Não Circulante (Exigível a Longo Prazo) }\end{array}$ \\
\hline & PTPL & $\begin{array}{l}\text { Índice de Participação de Capital de } \\
\text { Terceiros sobre o Capital Próprio }\end{array}$ & PTPL = Passivo Total / Patrimônio Líquido \\
\hline & PECP & $\begin{array}{l}\text { Índice de Participação do Exigível a } \\
\text { Curto Prazo sobre o Exigível Total }\end{array}$ & PECP = Passivo Circulante / Passivo Total \\
\hline $\begin{array}{c}\text { Grau de } \\
\text { Imobilização }\end{array}$ & GIPL & $\begin{array}{l}\text { Grau de Imobilização do Patrimônio } \\
\text { Líquido }\end{array}$ & $\begin{array}{c}\text { GIPL = (Ativo Imobilizado, Investimentos e Intangível) / Patrimônio } \\
\text { Líquido }\end{array}$ \\
\hline $\begin{array}{l}\text { Saúde } \\
\text { financeira }\end{array}$ & CGL & Capital de Giro Líquido & CGL = Ativo Circulante - Passivo Circulante \\
\hline
\end{tabular}

Importante ressaltar que a análise desses índices é feita mediante parâmetros que o decisor (corporação) define para os mesmos. Assim, as [alternativas] que resultam na melhora dos índices em parâmetros mais próximos do desejado são as que melhor atendem ao [Critério H]. Ou seja, os resultados calculados para os índices por si só não são referências para a decisão por parte da corporação, a análise será feita relativamente aos parâmetros desejados pelos decisores. Além disso, o Quadro 10 apresenta os índices do balanço que podem ser alterados em função da decisão por uma [alternativa] ou outra. Porém, não significa dizer que todos os índices serão concomitantemente alterados, uma vez que dependerá da destinação dos recursos disponíveis dada por cada empresa em função das suas estratégias e políticas. 


\subsubsection{Situação Modelo - Impacto nos índices financeiros extraídos do balanço ‘vs' [alternativas]}

No Quadro 11 estão demonstradas as contas do ativo e passivo da corporação para esta situação modelo, conforme demonstrativos de Julho de 2010. Os índices financeiros atuais da corporação estão apresentados no mesmo quadro.

\begin{tabular}{|c|c|c|c|}
\hline \multicolumn{4}{|c|}{$\begin{array}{l}\text { Balanço e Índices Financeiros - Situação Modelo } \\
\text { (Balanço de Julho/2010 - Valores em R\$ mil da base) }\end{array}$} \\
\hline Ativo Total & 4.320 .000 & \multirow{3}{*}{\multicolumn{2}{|c|}{$\begin{array}{c}\text { Índices de Liquidez, } \\
\text { Endividamento e Grau de } \\
\text { Imobilização }\end{array}$}} \\
\hline Ativo Circulante & 1.270 .000 & & \\
\hline Disponibilidades & 205.000 & & \\
\hline Ativo não Circulante & 3.050 .000 & ILC & 0,94 \\
\hline Ativo Realizável a Longo Prazo & 650.000 & $\mathrm{ILI}$ & 0,15 \\
\hline Ativo Permanente & 2.400 .000 & PTRT & 0,51 \\
\hline Passivo Total & 4.320 .000 & PTPL & 1,06 \\
\hline Passivo Circulante & 1.350 .000 & PECP & 0,61 \\
\hline Passivo Não Circulante (Exigível a Longo Prazo) & 870.000 & GIPL & 1,14 \\
\hline Patrimônio Líquido & 2.100 .000 & CGL & $(80.000)$ \\
\hline
\end{tabular}

Quadro 11 - Balanço da Corporação e Índices Financeiros - Situação Modelo (Capítulo 6)

É possível verificar por meio do ILC da corporação que as exigências de curto prazo são próximas aos recebimentos de curto prazo, já que a relação entre ativo circulante e passivo circulante está próxima de (1) um. No entanto, tratando-se do ILI, calculada a partir das disponibilidades imediatas da corporação para pagamento das obrigações de curto prazo, já verifica-se uma relação mais desequilibrada com ILI de 0,15 , ou seja, as disponibilidades (caixa e títulos negociáveis) são capazes de pagar 15\% do total das dívidas de curto prazo.

Em relação aos índices de endividamento destaca-se uma participação de aproximadamente $50 \%$ entre passivo e patrimônio líquido. Os recursos oriundos de terceiros para financiar as atividades da corporação são equivalentes aos recursos dos sócios (patrimônio líquido). Uma observação importante pode ser dada à participação do exigível de curto prazo em relação às exigências totais da corporação, que representa $61 \%$ do total a ser pago a terceiros (bancos, fornecedores, etc.).

O grau de imobilização indica que os ativos imobilizados, investimentos e intangíveis, ou seja, ativos que não estão em giro, são 14\% superiores ao patrimônio líquido.

A folga financeira da corporação avaliada pelo capital de giro líquido indica que as obrigações de curto prazo (passivo circulante) são maiores que as contas a receber e 
disponibilidades (ativo circulante). Como este déficit representa apenas duas vezes o resultado líquido mensal da corporação, não há um comprometimento significativo na avaliação da empresa em relação a seu grau de risco. No entanto, a empresa escolhe como parâmetros de decisão para os indicadores relacionados ao [Critério $\mathrm{H}$ ]: [i] não comprometer sua participação de dívida de terceiros em relação ao patrimônio líquido em mais de $10 \%$ e, [ii] não comprometer em mais de $60 \%$ a sua folga financeira.

Nesta situação modelo a corporação optará por contrato de locação como instrumento jurídico a ser utilizado nas [alternativas] de não imobilização. Para os indicadores relacionados ao [Critério H] utiliza-se no [MAOI] um CCGA fixo (para esta situação modelo equivalente a 19.800 R\$ mil por ano), calculado a partir da média do intervalo de valores usado nos demais indicadores. Esta simplificação é pelo fato do balanço representar uma imagem instantânea da corporação. Assim, em um momento da imagem o CCGA pode se situar na fronteira superior e no momento adjacente na fronteira inferior, ou seja, não se ganha qualidade de informação no cálculo dos índices financeiros introduzindo esta sofisticação no modelo.

A partir destas premissas, apresenta-se no Quadro 12 os impactos nos grupos de contas do balanço da corporação e, assim, nos seus índices financeiros, para as [alternativas] de não imobilização (LCP, LLP e BTS).

\begin{tabular}{|c|c|c|c|c|c|}
\hline \multicolumn{3}{|c|}{ IMPACTO NO ATIVO: [ALTERNATIVAS] DE NÄO IMOBILIZAÇÄO } & \multicolumn{3}{|c|}{ IMPACTO NO PASSIVO: [ALTERNATIVAS] DE NÄO IMOBILIZAÇÃO } \\
\hline & Atual & $\begin{array}{c}\text { Impactos } \\
\text { [alternativas]: } \\
\text { BTS, LLP, LCP }\end{array}$ & & Atual & $\begin{array}{l}\text { Impactos } \\
\text { [alternativas]: } \\
\text { BTS, LLP, LCP }\end{array}$ \\
\hline ATIVO & 4.320 .000 & 4.320 .000 & PASSIVO & 4.320 .000 & 4.320 .000 \\
\hline 1) Circulante & 1.270 .000 & 1.270 .000 & 1) Circulante & 1.350 .000 & 1.369 .800 \\
\hline 1.1) Disponibilidades & 205.000 & - & $\begin{array}{l}\text { Acréscimo do circulante no valor da despesa } \\
\text { com alugueis e/ou contraprestações do período }\end{array}$ & & 19.800 \\
\hline 2) Não Circulante & 3.050 .000 & 3.050 .000 & 2) Não Circulante & 870.000 & 870.000 \\
\hline 2.1) Ativo realizável a longo prazo & 650.000 & - & 2.1) Passivo Exigível a Longo Prazo & 870.000 & - \\
\hline 2.2) Ativo Imobilizado & 2.400 .000 & - & $\begin{array}{l}\text { Acréscimo do exigível a longo prazo no } \\
\text { montante equivalente ao preço da outorga } \\
\text { (para DRS) }\end{array}$ & & - \\
\hline $\begin{array}{l}\text { Acréscimo do imobilizado no montante } \\
\text { equivalente ao preço da outorga, no caso do } \\
\text { DRS como instrumento jurídico }\end{array}$ & & - & $\begin{array}{l}\text { Redução do exigível a longo prazo no valor } \\
\text { acumulado da amortização referente às } \\
\text { contraprestações de cada período (para DRS) }\end{array}$ & & - \\
\hline $\begin{array}{l}\text { Redução do imobilizado referente à } \\
\text { amortização da contraprestação do DRS do } \\
\text { período (somada à acumulada) }\end{array}$ & & - & 3) Patrimônio Líquido & 2.100 .000 & 2.080 .200 \\
\hline & & & $\begin{array}{l}\text { Redução na conta de lucros/prejuízos } \\
\text { acumulados (lucro líquido) no montante } \\
\text { equivalente ao valor do aluguel do período (ou } \\
\text { contraprestação para DRS) }\end{array}$ & & $(19.800)$ \\
\hline
\end{tabular}

Quadro 12 - [alternativas] de não imobilização e impactos nos grupos de contas do balanço da corporação Situação Modelo (Capítulo 6) 
Conforme apresentado no Quadro 9, que identifica como as [alternativas] impactam no balanço, calcula-se para esta situação modelo as alterações nas contas do ativo e passivo da corporação para as opções de: LLP, BTS e LCP utilizando o contrato de locação como instrumento jurídico.

Como é possível observar no Quadro 12 as [alternativas] de não imobilização são as que menos impactam no balanço, alternando somente o passivo circulante com a despesa de locação e o patrimônio líquido no mesmo valor na conta de lucros/prejuízos acumulados. Sendo assim, os índices financeiros para as [alternativas] de não imobilização, apresentados na Tabela 16, atendem aos parâmetros desejados pela corporação nesta situação modelo, já que a participação de capital de terceiros em relação ao patrimônio líquido aumenta em apenas $1,85 \%$ em relação ao atual, em função do acréscimo do circulante no valor do aluguel do exercício, e o CGL só aumenta em 24,75\%.

\begin{tabular}{|l|r|r|}
\hline \multicolumn{3}{|c|}{ Impacto nos Índices - [Alternativas]: LCP, LLP, BTS } \\
\hline [LC] - Índice de Liquidez Corrente & 0,93 & $-1,45 \%$ \\
\hline [LL] - Índice de Liquidez Imediata & 0,15 & $-1,45 \%$ \\
\hline $\begin{array}{l}\text { [PTRT] - Participação de recursos de } \\
\text { terceiros sobre recursos totais (passivo+PL) }\end{array}$ & 0,52 & $0,89 \%$ \\
\hline $\begin{array}{l}\text { [PTPL] - Patricipação de recursos de } \\
\text { terceiros sobre patrimônio líquido }\end{array}$ & 1,08 & $1,85 \%$ \\
\hline $\begin{array}{l}\text { [PECP] - Parbicipação do exigivel de curto } \\
\text { prazo }\end{array}$ & 0,61 & $0,57 \%$ \\
\hline $\begin{array}{l}\text { [GIPL] - Grau de imobilização do patimônio } \\
\text { liquiido }\end{array}$ & 1,15 & $0,95 \%$ \\
\hline [CGL] - Capital de giro líquido & $\mathbf{( 9 9 . 8 0 0 )}$ & $\mathbf{2 4 , 7 5 \%}$ \\
\hline
\end{tabular}

Tabela 16 - Impacto nos Índices Financeiros para as [alternativas] de não imobilização - Situação Modelo (Capítulo 6)

Para a [alternativa] de imobilização à vista, conforme observado no Quadro 13, há um maior impacto no grau de imobilização da corporação, bem como no CGL, em função da redução do circulante para pagamento do imóvel no valor de $120.000 \mathrm{R} \$$ mil da base ${ }^{136}$.

136 Em função do tamanho do imóvel e do volume de investimento envolvido nesta situação modelo, para efeito de análise do impacto no ativo circulante para as [alternativas] de imobilização (SP e SP a Prazo) considera-se o pagamento do valor de transação do imóvel em 24 meses. Ou seja, parte do valor é pago com as disponibilidades do exercício e o restante a partir de 12 meses. Por isso, parte do pagamento será deduzida apenas do ativo circulante do próximo exercício, conforme demonstrado no Quadro 13 e no Quadro 14. 


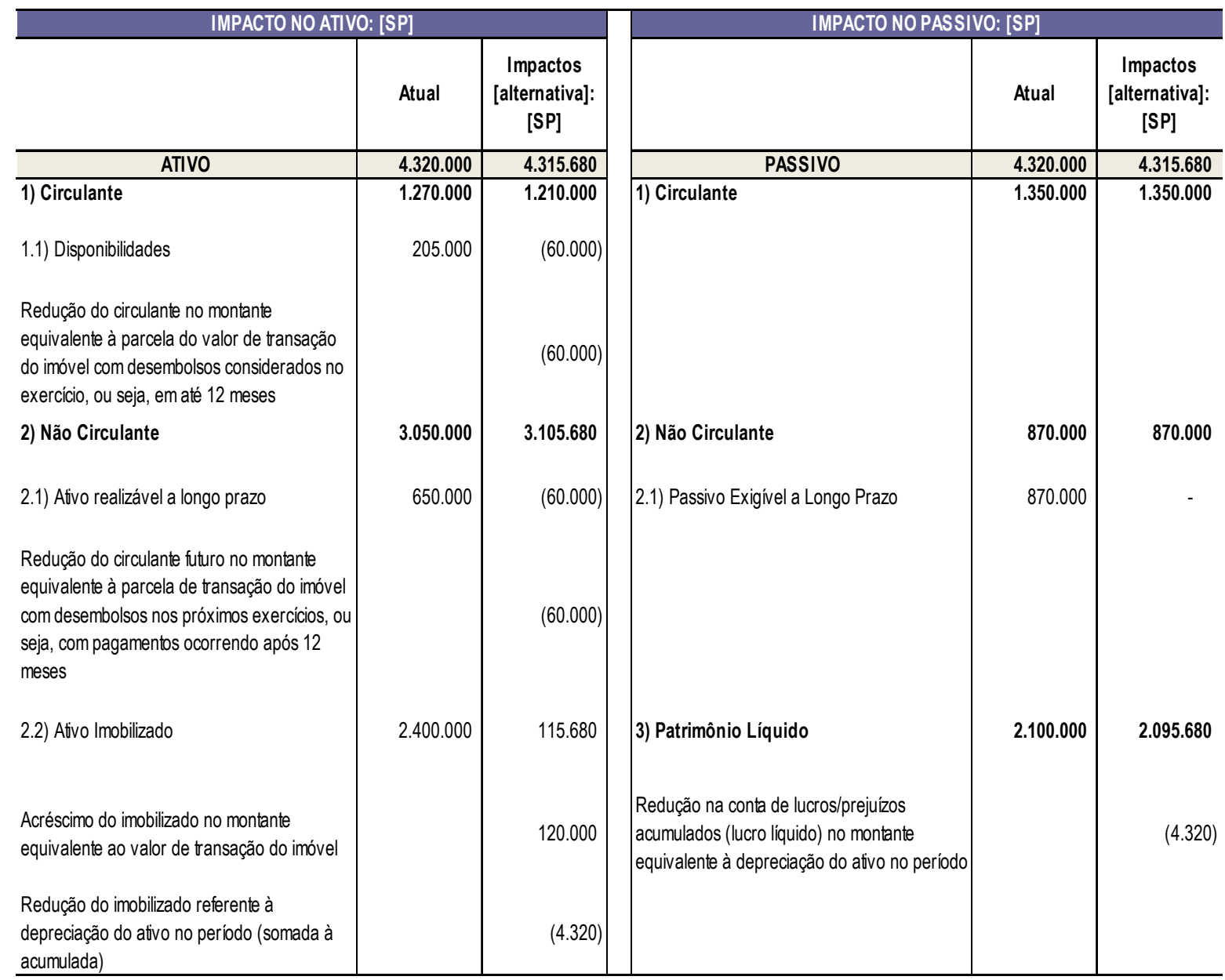

Quadro 13 - [alternativa] - SP e impactos nos grupos de contas do balanço da corporação - Situação Modelo (Capítulo 6)

Os índices financeiros para esta [alternativa] estão na Tabela 17. O comprometimento na folga financeira da corporação, com acréscimo equivalente a $75,00 \%$ em relação ao atual déficit, está significativamente acima do parâmetro estipulado pelos decisores, que determinaram um comprometimento em até $60 \%$ no CGL para a avaliação das [alternativas] no que tange ao [Critério $\mathrm{H}]$.

Além disso, considera-se para análise do impacto das [alternativas] de imobilização a situação do ativo em regime operacional, ou seja, quando em uso, mesmo que existam parcelas do imóvel a serem pagas nos próximos exercícios. Portanto, os encargos financeiros do financiamento do imóvel estão contabilizados como despesa operacional, e a depreciação já começa a ser contabilizada como conta redutora do ativo imobilizado.

Estas premissas adotadas para efeito de cálculo dos indicadores do Critério $\mathrm{H}$ do [MAOI] (Desoneração do Balanço) não alteram significativamente a análise, já que os impactos mais representativos são contabilizados sempre da mesma forma: [i] no ativo circulante (redução do caixa com as parcelas não financiadas do imóvel), [ii] no ativo imobilizado (valor de transação) e, [iii] no passivo exigível a longo prazo (valor do financiamento, incluindo os encargos financeiros). 


\begin{tabular}{|l|r|r|}
\hline \multicolumn{3}{|c|}{ Impacto nos Índices [Alternativa]: SP } \\
\hline [LCC] - Índice de Líquidez Corrente & 0,90 & $-4,72 \%$ \\
\hline [LL] - Índice de Liquidez Imediata & 0,11 & $-29,27 \%$ \\
\hline $\begin{array}{l}\text { [PTRT] - Participação de recursos de } \\
\text { terceiros sobre recursos totais (passivo+PL) }\end{array}$ & 0,51 & $0,10 \%$ \\
\hline $\begin{array}{l}\text { [PTPL] - Patricipação de recursos de } \\
\text { terceiros sobre patrimônio líquido }\end{array}$ & 1,06 & $\mathbf{0 , 2 1 \%}$ \\
\hline $\begin{array}{l}\text { [PECP] - Participação do exigível de curto } \\
\text { prazo }\end{array}$ & 0,61 & $0,00 \%$ \\
\hline $\begin{array}{l}\text { [GIPL] - Grau de imobilização do patrimônio } \\
\text { líquido }\end{array}$ & 1,20 & $5,04 \%$ \\
\hline [CGL] - Capital de giro líquido & $(140.000)$ & $\mathbf{7 5 , 0 0 \%}$ \\
\hline
\end{tabular}

Tabela 17 - Impacto nos Índices Financeiros para a [alternativa] - SP - Situação Modelo (Capítulo 6)

No caso da imobilização a prazo (aquisição por meio de financiamento), o comprometimento no imobilizado é equivalente, conforme apresentado no Quadro 14. No entanto, há também o impacto no passivo não circulante (exigível a longo prazo), acrescido no montante equivalente ao valor da dívida do financiamento do imóvel (principal mais juros). Para efeito de análise do impacto no balanço para esta [alternativa], considera-se o valor médio dos juros da parcela Price do financiamento, os quais são decrescentes durante o prazo de amortização.

Os índices financeiros para a [alternativa] - SP a Prazo estão apresentados na Tabela 18, e indicam um comprometimento tanto na participação do capital de terceiros em relação ao patrimônio líquido, como também no CGL da corporação. O impacto no índice de endividamento (PTPL) nesta [alternativa] está dentro do aceitável, conforme os parâmetros estipulados pelos decisores (comprometimento em até 10\%). No entanto, a saúde financeira da corporação piora em 54,65\%, próximo ao limite estipulado pelos decisores (comprometimento em até $60 \%$ ).

\begin{tabular}{|l|r|r|}
\hline \multicolumn{3}{|c|}{ Impacto nos Índices - [Alternativa]: SP A PRAZO } \\
\hline [ILC] - Índice de Líquidez Corrente & 0,91 & $-3,32 \%$ \\
\hline [ILI] - Índice de Liquidez Imediata & 0,13 & $-14,23 \%$ \\
\hline $\begin{array}{l}\text { [PTRT] - Participação de recursos de } \\
\text { terceiros sobre recursos totais (passivo+PL) }\end{array}$ & 0,52 & $1,78 \%$ \\
\hline $\begin{array}{l}\text { [PTPL] - Patricipação de recursos de } \\
\text { terceiros sobre patrimônio líquido }\end{array}$ & 1,10 & $\mathbf{3 , 7 3 \%}$ \\
\hline $\begin{array}{l}\text { [PECP] - Participação do exiǵvel de curto } \\
\text { prazo }\end{array}$ & 0,60 & $-1,93 \%$ \\
\hline $\begin{array}{l}\text { [GIPL] - Grau de imobilização do patimônio } \\
\text { líquido }\end{array}$ & 1,20 & $5,32 \%$ \\
\hline [CGL] - Capital de giro líquido & $\mathbf{( 1 2 3 . 7 1 9 )}$ & $\mathbf{5 4 , 6 5 \%}$ \\
\hline
\end{tabular}

Tabela 18 - Impacto nos Índices Financeiros para [alternativa] - SP a Prazo - Situação Modelo (Capítulo 6) 
IMPACTO NO ATIVO: [SP] a prazo (por meio de financiamento)

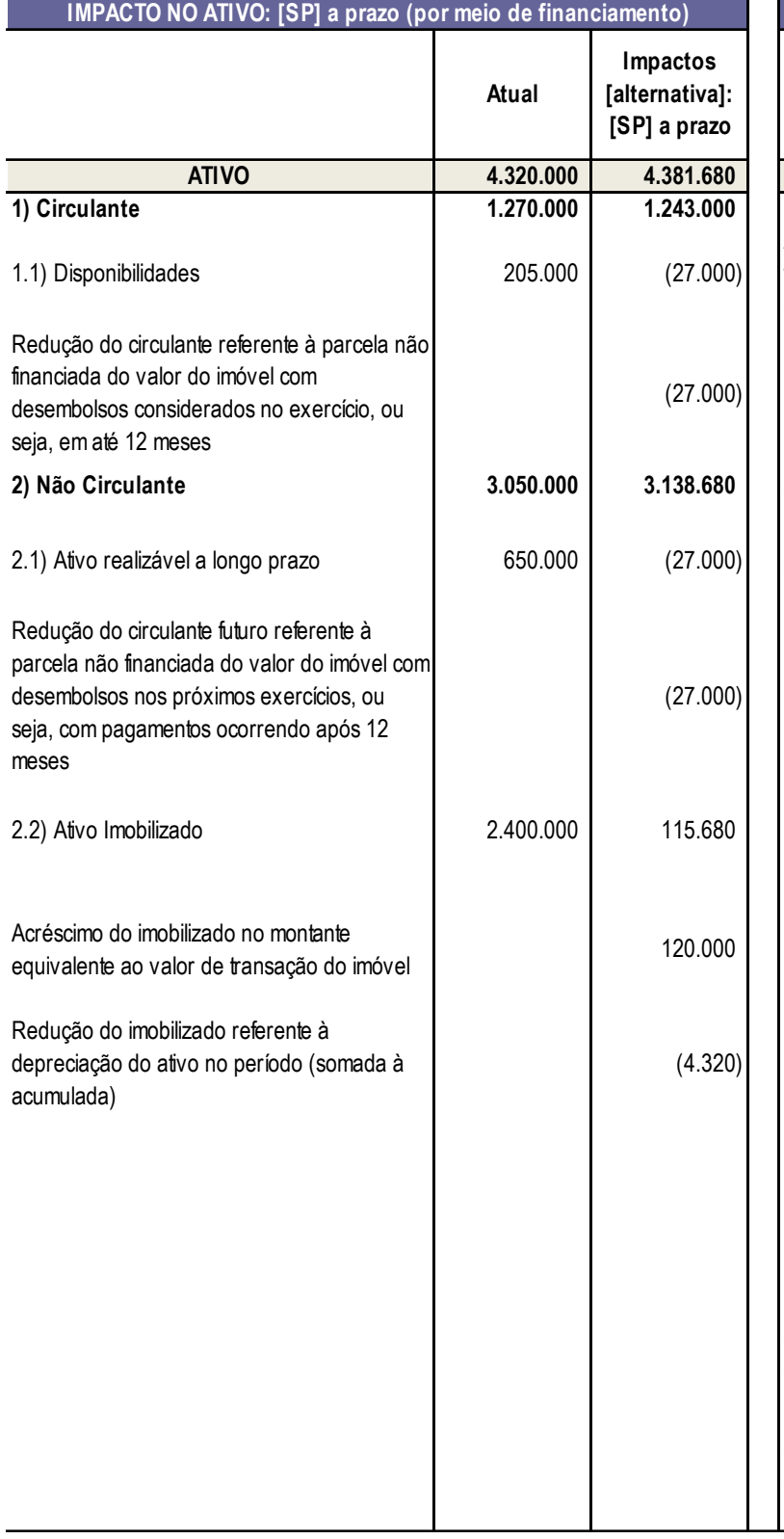

IMPACTO NO PASSIVO: [SP] a prazo (por meio de financiamento)

\begin{tabular}{|c|r|r|}
\hline & Atual & $\begin{array}{c}\text { Impactos } \\
\text { [alternativa]: } \\
\text { [SP] a prazo }\end{array}$ \\
\hline PASSIVO & 4.320 .000 & 4.381 .680 \\
\hline 1) Circulante & 1.350 .000 & 1.366 .719
\end{tabular}

Acréscimo do circulante referente à parcela do

financiamento do imóvel (principal e juros) em

cada exercício

16.719

870.000

925.000

2.1) Passivo Exigivel a Longo Prazo

870.000

55.000

83.593

Acréscimo do exigivel a longo prazo no montante equivalente ao valor financiado do imóvel acrescido dos encargos

Redução do exigível a longo prazo no valor acumulado das parcelas já

amorizadas do financiamento

Encargos dos exercícios futuros

Encargos financeiros a apropriar

Encargos do ano transferidos

para resultado

3) Patrimônio Líquido

Redução na conta de lucros/prejuízos acumulados (lucro líquido) no montante equivalente à depreciação do ativo no período

Redução na conta de lucros/prejuizos acumulados (lucro líquido) no montante equivalente aos encargos financeiros do período

Quadro 14 - [alternativa] - SP a Prazo e impactos nos grupos de contas do balanço da corporação - Situação Modelo (Capítulo 6)

Pelo exposto a partir da situação modelo, evidencia-se que as [alternativas] de não imobilização comprometem menos os índices financeiros relacionados a endividamento, liquidez e grau de imobilização. A ponderação das notas das [alternativas] em relação ao [Critério $\mathrm{H}$ ] no método AHP é feita a partir dos indicadores e parâmetros desejados pela corporação objeto de análise, conforme ilustrado nesta situação modelo. 


\subsection{Análise Quantitativa dos indicadores relacionados ao critério - redução dos impactos tributários [Critério I]}

O impacto tributário é outro fator que apresenta variações entre as [alternativas]. No que diz respeito à decisão pela imobilização ou não no real estate corporativo, três distintos redutores do lucro são usados no cálculo dos impactos tributários: [i] a depreciação do imóvel, quando a corporação é proprietária do ativo imobiliário; [ii] a amortização no caso da escolha pela não imobilização (BTS e SLB) valendo-se do DRS como instrumento jurídico; e [iii] a despesa operacional periódica referente ao aluguel, no caso da escolha pela não imobilização com contrato de locação (LS, BTS e SLB).

Embora a depreciação seja tratada como despesa dedutível de impostos no demonstrativo de resultados, essa despesa se diferencia das demais por ser encargos não caixa; isto é, não há saídas de caixa associadas a essa. Assim, a depreciação oferece uma economia tributária por reduzir o resultado tributável da corporação, e assim os impostos pagos, que é função da alíquota de impostos da corporação e do seu regime tributário.

No caso da amortização relacionada à decisão em análise, o preço da outorga de uso no DRS, que como ora mencionado é contabilizado como ativo imobilizado, sofre amortização dentro do prazo do contrato de DRS, gerando também uma economia tributária variável em função da alíquota de impostos paga pela corporação.

Nas [alternativas] de não imobilização com contrato de locação, o aluguel é considerado despesa operacional dedutível, assim durante todo o prazo do contrato essa despesa referente ao pagamento do aluguel é deduzida do resultado tributável do exercício.

Dessa forma, para análise quantitativa do [Critério I] calcula-se as economias tributárias em cada uma das [alternativas], sendo: [i] na LS, BTS e SLB com contrato de locação a Economia Tributária da Despesa Operacional Dedutível - Etdo; [ii] no BTS e SLB com DRS, a ECONOMIA Tributária da AMORTIZAÇÃo do preço da outorga - ETA; e [iii] na imobilização, a ECONOMIA TributÁRIA DA DEPRECIAÇÃo do ativo imobiliário - ETD $^{137}$.

$\mathrm{Na}$ análise pela desmobilização patrimonial imobiliária o ativo apresenta seu valor contábil

137 No caso da imobilização a prazo, o cálculo da economia tributária resultante inclui também a despesa com encargos financeiros a ser paga em cada exercício referente aos juros do financiamento. Essa despesa financeira reduz o resultado tributável gerando também uma economia tributária até liquidação do financiamento, que é somada à economia tributária gerada pela depreciação periódica. 
líquido de depreciação acumulada, conforme já discutido no item 6.1.3. Nesse sentido, a depender da vida útil remanescente do ativo e, por consequência, da depreciação restante, as economias tributárias com a depreciação - ETD são significativamente inferiores quando comparada à economia que será gerada na escolha pelo SLB, tanto com contrato de locação (ETDO), como com DRS (ETA). Por outro lado, torna-se necessário também incluir o lucro com a venda do ativo no exercício da ocasião da venda, que também gera uma receita não operacional tributável a ser considerada na análise. Assim, quanto maior for o valor de venda relativamente ao valor contábil do ativo, maior será esse lucro, e maiores serão os impostos devidos.

Pelo exposto, tratando-se da análise pela desmobilização patrimonial imobiliária, calcula-se o ETEDO e ETEA, na opção pelo SLB com contrato de locação e DRS, respectivamente. Estas economias tributárias são comparadas com a economia tributária da depreciação do ativo considerando, nesse caso, a vida útil remanescente do imóvel. Além disso, inclui-se também no cálculo dos indicadores da opção pelo SLB a tributação gerada com o lucro da venda do ativo. Portanto, para a análise da desmobilização patrimonial calcula-se a ECONOMIA Tributária Efetiva da Despesa Operacional Dedutível - ETEDO e, para contratos de DRS, a ECONOMia Tributária EFEtiva da AMORTIZAÇão do preço da outorga - ETEA, as quais consideram no início do período de análise o pagamento dos impostos referente ao lucro da venda do imóvel, caso esse venha a existir.

A depreciação é distribuída em quotas constantes durante toda a vida útil do ativo, que para imóveis é de $25 \operatorname{anos}^{138}$. Já a despesa operacional (aluguel) e a amortização dependem dos prazos dos contratos de locação e do DRS.

Para uma melhor análise das economias tributárias em cada uma das [alternativas], os quais representam os indicadores relacionados ao [Critério I] do ponto de vista quantitativo, calculase o valor dos fluxos de caixa formados pelas economias tributárias em cada exercício para

138 Vale ressaltar que para as novas edificações a duração de vida útil permitida pelo fisco é de 25 anos. No entanto, tratando-se da compra de imóveis já utilizados por um período é permitido ao comprador (corporação usuária) depreciar o valor pago pelo ativo (descontado o valor do terreno) dentro do prazo da vida útil remanescente, apenas para os casos em que é possível a comprovação ao Fisco da ocorrência da depreciação nos períodos em que o ativo foi utilizado. Caso contrário, o valor pago pelo imóvel (descontado o valor do terreno) deve ser depreciado em 25 anos. Pode também ser feita a depreciação pelo valor do imóvel e prazo definidos em laudos de avaliação feitos por empresas especializadas. 
cada uma das [alternativas] descontados ao wacc $^{139}$ da corporação, considerando para esse cálculo um mesmo período de análise e uma mesma taxa de desconto, que nesse caso será o custo médio ponderado do capital da corporação. O uso do wacc é apropriado, uma vez que o cálculo da economia tributária indica quanto de recursos financeiros a empresa economiza para investir nas atividades da empresa, ou seja, investir em negócios com riscos semelhantes.

Para escolha do período de análise, considera-se a ocasião da última movimentação que compõe o fluxo de caixa das economias tributárias das [alternativas] a serem comparadas. Sendo assim, na análise de novos espaços corporativos, a qual se compara as [alternativas]: LS, BTS e SP, tem-se como duração para as movimentações dos fluxos compostos pelas economias tributárias: [i] a duração do contrato de locação (ou DRS) na escolha pela não imobilização e [ii] a vida útil do ativo que será distribuída a depreciação na escolha pela imobilização. O período de análise deve ser escolhido de modo a contemplar todas as movimentações referentes às economias tributárias relacionadas ao espaço corporativo. Dessa forma, se a vida útil é maior que a duração dos contratos de locação, considera-se, para efeito de cálculo, o período de análise igual a vida útil do ativo. Como o ativo é um recurso operacional, para qualquer [alternativa] o imóvel estará em uso. Portanto, deve-se considerar a despesa com o aluguel paga pelo uso do imóvel durante esse mesmo período de utilização do ativo (como se os contratos fossem renovados até a duração do período de análise estipulada).

Na análise pela desmobilização patrimonial imobiliária comparam-se as economias tributárias na opção da corporação continuar proprietária do ativo imobiliário, com as economias tributárias da opção pelo SLB. Assim, as durações das [alternativas] nesse caso são: [i] a vida útil remanescente do ativo e [ii] a duração do contrato de locação (ou DRS). Escolhe-se como período de análise a maior duração dentre as duas. Nessa situação, caso a vida útil do ativo seja menor que a duração do contrato de locação (ou DRS), o período de análise será igual a duração do contrato. Nesse caso, compara-se o valor do fluxo de caixa composto pela economia tributária da despesa operacional do aluguel até findo prazo contratual descontado ao wacc, com o valor do fluxo de caixa da economia tributária da depreciação periódica descontado ao wacc até fim da vida útil remanescente, que pode se encerrar antes do término do período de análise.

139 Conforme DAMODARAN (1997, p. 77), o Custo Médio Ponderado de Capital [wacc] - pode ser definido como "a média ponderada dos custos dos diversos componentes de financiamento, incluindo dívida, patrimônio líquido e títulos híbridos, utilizados por uma empresa para financiar suas necessidades financeiras". 
A Tabela 19 demonstra as economias tributárias em cada exercício para cada uma das [alternativas], as quais compõem os fluxos de caixa para cálculo dos indicadores relacionados ao [Critério I].

\begin{tabular}{|c|c|c|}
\hline \multicolumn{3}{|c|}{ ECONOMIAS TRIBUTÁRIAS EM CADA EXERCICIO 'vs' [alternativas] } \\
\hline \multicolumn{2}{|c|}{ Economias Tributárias em cada exercício } & Equação \\
\hline $\begin{array}{l}\text { Imobilização à } \\
\text { vista }\end{array}$ & $\begin{array}{l}\text { Economia Tributária da Depreciação do Ativo } \\
\text { Imobiliário em cada exercício }\end{array}$ & $\begin{array}{l}\text { ETD do exercício = Depreciação periódica 'vs' alíquota de } \\
\text { impostos da corporaçãoo }(\mathrm{IR}+\mathrm{CS})^{*} \\
{ }^{*} \mathrm{IR}=\text { Imposto de Renda e CS = Contribuição Social }\end{array}$ \\
\hline $\begin{array}{l}\text { Imobilização a } \\
\text { Prazo }\end{array}$ & $\begin{array}{l}\text { Economia Tributária da Depreciação do Ativo } \\
\text { Imobiliário em cada exercício somada a } \\
\text { Economia Tributária das Despesas Financeiras }\end{array}$ & $\begin{array}{c}\text { ETDDF do exercício = Depreciação periódica ' } v s \text { ' alíquota de } \\
\text { impostos da corporação }(I R+C S)+\text { Despesa Financeira ' } v \text { ' } \\
\text { alíquota de impostos da corporação (IR + CS) }\end{array}$ \\
\hline $\begin{array}{l}\text { LS, BTS e SLB } \\
\text { (contrato de } \\
\text { locação) }\end{array}$ & $\begin{array}{l}\text { Economia Tributária com a despesa operacional } \\
\text { dedutível referente ao pagamento do aluguel } \\
\text { em cada exercício }\end{array}$ & $\begin{array}{c}\text { ETDO do exercício }=\text { Despesa com aluguel no exercício 'vs' } \\
\text { alíquota de impostos da corporação (IR + CS) }\end{array}$ \\
\hline $\begin{array}{l}\text { BTS e SLB com } \\
\text { DRS }\end{array}$ & $\begin{array}{l}\text { Economia Tributária da Amortização do preço } \\
\text { da outorga em cada exercício }\end{array}$ & $\begin{array}{l}\text { ETA do exercício = Amortização periódica 'vs' alíquota de } \\
\text { impostos da corporação (IR + CS) }\end{array}$ \\
\hline
\end{tabular}

$\mathrm{Na}$ análise entre as [alternativas] no que tange ao [Critério I], tratando-se de novos espaços corporativos, compara-se os indicadores: ETD (para imobilização à vista), ETDDF (para imobilização a prazo), ETDO (para as [alternativas] de não imobilização com contrato de locação) e ETA (para as [alternativas] de não imobilização com contrato de DRS), calculados pelas expressões apresentadas na Tabela 20.

$\mathrm{Na}$ análise pela desmobilização patrimonial imobiliária compara-se a os indicadores da escolha pelo SLB com contrato de locação ou DRS, denominados por ETEDO e ETEA, respectivamente, com o ETD referente à economia tributária da depreciação na opção da corporação continuar proprietária do imóvel, considerando a vida útil remanescente do ativo e, portanto, a depreciação restante. Esses indicadores são calculados pelas expressões apresentadas na Tabela 21. 


\section{ECONOMIAS TRIBUTÁRIAS 'vs' [alternativas] - Na Análise por Novos Espaços Corporativos}

\begin{tabular}{|c|c|}
\hline Economias Tributárias & Equação \\
\hline Imobilização à vista & $\mathrm{ETD}=\sum_{\mathrm{k}=0}^{\mathrm{n}} \frac{\text { ETDexercício }}{(1+\text { wacc })^{\mathrm{k}}}$ \\
\hline Imobilização a prazo & ETDDF $=\sum_{\mathrm{k}=0}^{\mathrm{n}} \frac{\text { ETDexercício }}{(1+\mathrm{wacc})^{\mathrm{k}}}+\sum_{\mathrm{j}=\mathrm{if}}^{\mathrm{pf}} \frac{\text { DFexercício } \times \text { alíquota(IR,CS })}{(1+\mathrm{wacc})^{\mathrm{j}}}$ \\
\hline $\begin{array}{l}\text { LS e BTS } \\
\text { (contrato de locação) }\end{array}$ & $\mathrm{ETDO}=\sum_{\mathrm{k}=0}^{\mathrm{n}} \frac{\text { ETDOexercício }}{(1+\mathrm{wacc})^{\mathrm{k}}}$ \\
\hline BTS com DRS & ETA $=\sum_{\mathrm{k}=0}^{\mathrm{n}} \frac{\text { ETAexercício }}{(1+\text { wacc })^{\mathrm{k}}}$ \\
\hline \multicolumn{2}{|c|}{$\begin{array}{l}\text { Sendo: } \\
\text { n = horizonte de análise. } \\
\text { wacc = custo médio ponderado do capital da corporação. } \\
\text { DF do exercício = despesa financeira de cada exercício na opção pela imobilização a prazo. } \\
\text { if = data de início para pagamento das despesas financeiras do financiamento } \\
\text { pf = prazo do financiamento - não, necessariamente, igual a n. O financiamento pode ter prazo menor que n. } \\
\mathrm{k} \text { e j = contador de tempo. }\end{array}$} \\
\hline
\end{tabular}

Tabela 20 - Economias tributárias resultantes ' $v s$ ' [alternativas] na análise para novos espaços corporativos

\section{ECONOMIAS TRIBUTÁRIAS 'vs' [alternativas] - Na Análise de Desmobilização Patrimonial Imobiliária}

\begin{tabular}{|c|c|}
\hline Economias Tributárias & Equação \\
\hline $\begin{array}{l}\text { Imobilização } \\
\text { (continuar proprietária) }\end{array}$ & ETD $=\sum_{\mathrm{j}=0}^{\text {vur }} \frac{\text { ETDexercício }}{(1+\text { wacc })^{\mathrm{j}}}$ \\
\hline $\begin{array}{c}\text { SLB } \\
\text { (contrato de locação) }\end{array}$ & ETEDO $=\sum_{\mathrm{k}=0}^{\mathrm{n}} \frac{\text { ETDOexercício }}{(1+\text { wacc })^{\mathrm{k}}}-\mathrm{LV} \times$ alíquota $(\mathrm{IR}, \mathrm{CS})$ \\
\hline $\begin{array}{l}\text { SLB } \\
\text { (DRS) }\end{array}$ & ETEA $=\sum_{\mathrm{k}=0}^{\mathrm{n}} \frac{\text { ETAexercício }}{(1+\text { wacc })^{\mathrm{k}}}-\mathrm{LV} \times$ alíquota $(\mathrm{IR}, \mathrm{CS})$ \\
\hline \multicolumn{2}{|c|}{$\begin{array}{l}\text { Sendo: } \\
\mathbf{n}=\text { período de análise. } \\
\text { wacc = custo médio ponderado do capital da corporação. } \\
\mathbf{L V}=\text { lucro na venda do ativo, que ocorre no início do ciclo de análise (valor contábil menor que o valor de venda). } \\
\text { vur = prazo da vida útil remanescente do ativo em análise - não necessariamente igual a n. Pode ocorrer do ativo já } \\
\text { ter sofrido a depreciação total, sendo ETD nesses casos igual a zero. } \\
\text { k e j = contador de tempo. }\end{array}$} \\
\hline
\end{tabular}

Tabela 21 - Economias tributárias resultantes 'vs' [alternativas] na análise de desmobilização patrimonial

\subsubsection{Situação Modelo - Economias tributárias ‘vs’ [alternativas]}

A partir da situação modelo são apresentados os cálculos das economias tributárias geradas em cada uma das [alternativas]. O parâmetro de referência que indica uma economia tributária satisfatória para o decisor é definido pela diferença mínima de 20.000 R \$ mil da base entre a economia tributária das [alternativas] de não imobilização contra as [alternativas] de imobilização (SP e SP a Prazo). 
Conforme demonstrado na Tabela 20 os fluxos para cálculo das economias tributárias em cada um das [alternativas] são compostos pelos seguintes parâmetros:

[i] horizonte de análise de 25 anos, que é o maior prazo entre a duração do contrato de locação (15 anos, conforme horizonte de uso do imóvel) e a duração da vida útil do imóvel (25 anos);

[ii] wacc no intervalo [14\% - 17\%] ao ano nominal, aplicado também em faixa no modelo;

[iii] Alíquota para o imposto de renda e contribuição social de 34\%;

[iv] ETD de cada exercício - Economia tributária da depreciação do imóvel em cada exercício no valor de $122 \mathrm{R} \$$ mil por mês, referente à depreciação mensal de $360 \mathrm{R} \$$ mil (4\% ao ano Método Linear) multiplicada pela alíquota de 34\%. Para cálculo da depreciação do imóvel é necessário subtrair o valor do terreno, que não é depreciável. Neste caso o valor do terreno é 12.000 R \$ mil da base, sendo, portanto, a parcela depreciável de 108.000 R \$ mil da base. Esta depreciação é considerada nos 25 anos do horizonte de análise. Para calcular a economia tributária da depreciação em valores da base, como os demais indicadores do [MAOI], é necessário descontar a inflação acumulada em todo o fluxo de ETD no horizonte de análise (a inflação considerada nesta situação modelo está no intervalo [3,5\%-5,0\%] ao ano);

[v] ETDO de cada exercício - Economia tributária da despesa operacional com a locação do imóvel em cada exercício no intervalo [510 - 612] R\$ mil, visto que o CCGA é tratado no intervalo [1.500 - 1.800] R\$ mil por mês, que multiplicado pela alíquota de $34 \%$ gera o intervalo de ETDO do exercício. Esta despesa operacional é considerada nos 25 anos do horizonte de análise. Para cálculo de ETDO em valores da base, como os demais indicadores do [MAOI], é necessário descontar a inflação acumulada em todo o fluxo de ETDO no horizonte de análise, porém nesse caso há também os ajustes dos preços de locação a cada 12 meses pelo IGP-M (no intervalo [3,5\%-5,0\%] ao ano);

[vi] para a imobilização a prazo, considera-se a economia tributária da despesa financeira, durante o prazo de financiamento, que nesta situação modelo é de 6 anos (72 meses). O fluxo da despesa financeira mensal no sistema Price de amortização é decrescente, ou seja, tem maior participação na composição da parcela do financiamento no início do prazo de amortização. Este fluxo decrescente da despesa financeira multiplicado pela alíquota de $34 \%$ no prazo de 72 meses gera o fluxo da economia tributária advinda dos juros do financiamento. Assim como na depreciação, o encargo financeiro mensal é nominal e, portanto, para cálculo da economia tributária gerada pela despesa financeira em valores da base é necessário descontar a inflação acumulada em cada exercício até findo prazo do financiamento. 
A partir destes variáveis calcula-se os intervalos dos indicadores relacionados ao [Critério I] para cada uma das [alternativas]. Como as variáveis de cálculo são aplicadas em faixa de valores nos fluxos apresentados nas expressões da Tabela 20, os indicadores para o [Critério I] também são calculados em intervalos de valor.

A Tabela 22 apresenta os intervalos de valor para os indicadores: ETDO para as [alternativas] de não imobilização, ETD para a imobilização à vista e ETDDF para a imobilização a prazo. Verifica-se que a economia tributária gerada pelas [alternativas] de não imobilização é aproximadamente seis vezes superior a economia tributária gerada na imobilização à vista para esta situação modelo, que equivale a uma diferença de $36.494 \mathrm{R} \$$ mil da base entre as economias tributárias (diferença significativamente superior ao parâmetro de referência estipulado pelo decisor).

A economia tributária da imobilização a prazo é de $15.822 \mathrm{R} \$$ mil da base, superior a imobilização à vista, já que além da depreciação é considerada a economia tributária gerada pela despesa dedutível com os encargos financeiros referentes ao financiamento do imóvel. Também para a imobilização a prazo a diferença entre a economia tributária gerada por esta [alternativa] contra as [alternativas] de não imobilização (28.441 R \$ mil da base) é superior ao parâmetro entendido como satisfatório para o decisor.

\begin{tabular}{|c|c|c|c|c|}
\hline \multicolumn{5}{|c|}{ (Cenário Referencial) } \\
\hline \multirow{2}{*}{ Indicadores (em $\mathrm{R} \$$ mil da base) } & \multirow{2}{*}{ Média } & \multirow{2}{*}{ Desvio } & \multicolumn{2}{|c|}{ Fronteiras da Amostra* } \\
\hline & & & Inferior & Superior \\
\hline ETDO para: LLP, BTS e LCP & 44.264 & 229 & 43.888 & 44.640 \\
\hline ETD: SP & 7.785 & 26 & 7.742 & 7.828 \\
\hline ETDDF: SP a Prazo & 15.822 & 39 & 15.759 & 15.886 \\
\hline
\end{tabular}

Tabela 22 - Intervalos de valor dos indicadores: Economia Tributária da Despesa Operacional dedutível (ETDO), Economia Tributária da Depreciação (ETD) e Economia Tributária da Depreciação e Despesa Financeira (ETDDF) - Situação Modelo (Capítulo 6) 


\section{FERRAMENTA DE APOIO À DECISÃO - PRIORIZAÇÃO DOS CRITÉRIOS POR PARTE DOS DECISORES}

A partir das informações apresentadas no Capítulo 5, que aborda as referências qualitativas para análise das [alternativas] quanto ao atendimento aos critérios, e no Capítulo 6, que aborda as referências quantitativas para avaliação dos indicadores econômico-financeiros relacionados aos critérios de decisão mensuráveis, torna-se possível estruturar essas referências qualitativas e quantitativas com auxílio de uma ferramenta de apoio à decisão. $\mathrm{O}$ propósito deste capítulo é apresentar a ferramenta AHP (Analytic Hierarchy Process) usada para estruturar as referências qualitativas e quantitativas do [MAOI], com intuito de facilitar o processo decisório.

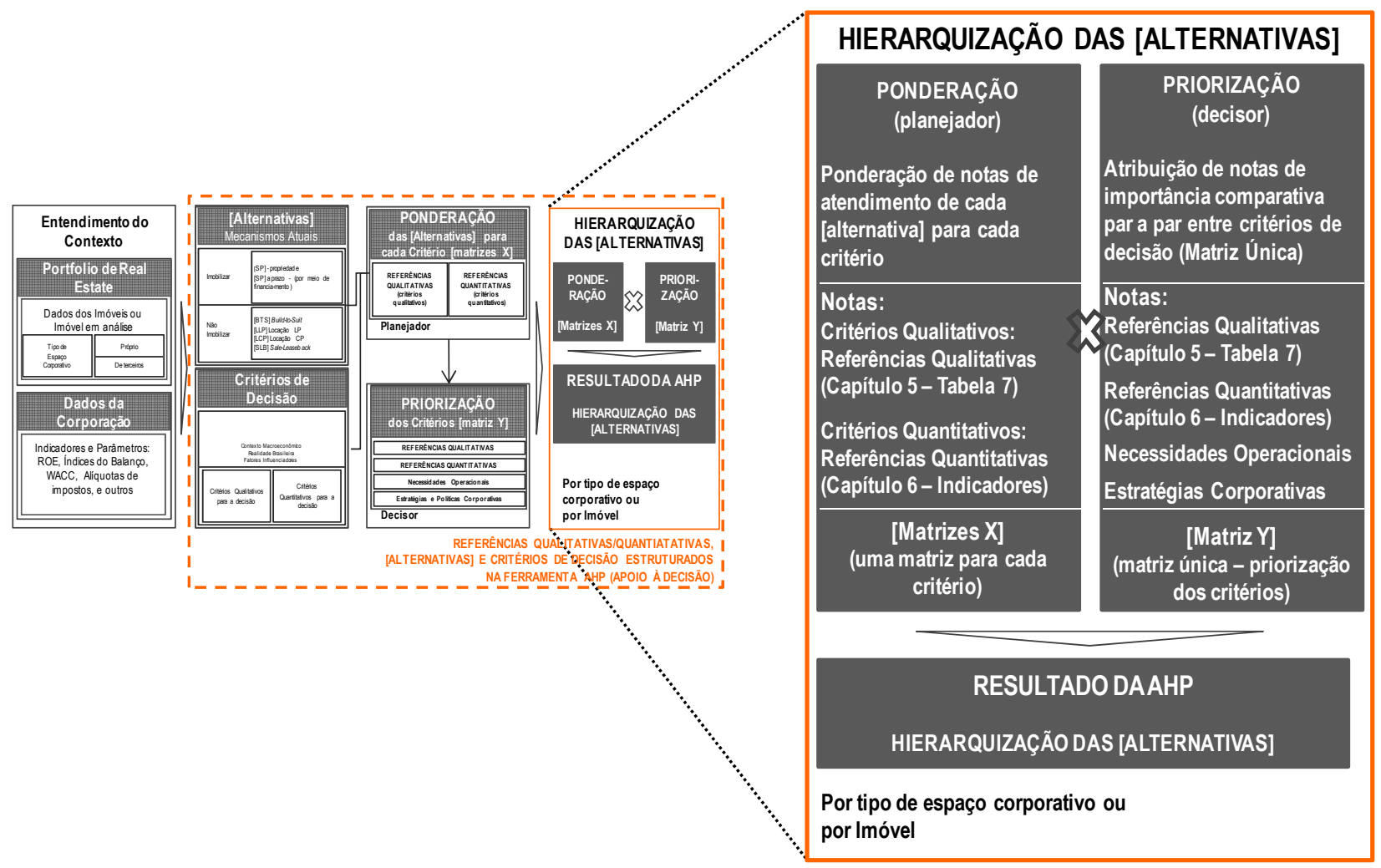

Figura 11 - Estruturação das referências qualitativas e quantitativas na ferramenta de apoio à decisão (AHP Analytic Hierarchy Process)

Pelo exposto no capítulo 5 e 6 verifica-se que cada uma das [alternativas] apresenta - Pontos Fortes e Fracos - tanto no que tange aos aspectos operacionais, relacionados ao uso dos espaços corporativos durante a operação, como aos aspectos econômico-financeiros, 
relacionados às oportunidades de melhores resultados corporativos, melhora dos índices de liquidez da corporação, redução dos impactos tributários, entre outros.

O papel do planejador nas decisões frente às estratégias e investimentos da corporação se restringe à estruturação das informações relevantes, que sustentam tecnicamente a decisão, para assim facilitar ao tomador de decisão (acionistas e administradores da corporação) qual é a [alternativa] mais adequada tendo em vista as suas necessidades operacionais e estratégias. Nesse sentido, cabe a cada corporação a priorização dos critérios, e ao planejador, encontrar a hierarquização das [alternativas], indicando aquela que melhor atenderá aos critérios priorizados pelo decisor.

\subsection{Ferramenta de apoio à decisão - Analytic Hierarchy Process (AHP)}

O método de análise hierárquica AHP, desenvolvido por Saaty em 1971, consiste em uma ferramenta de apoio à decisão para problemas multicritério. Esse método tem como propósito estruturar a decisão de maneira hierárquica. Segundo SAATY (1991), os modelos precisam incluir e medir todos os fatores importantes, qualitativa e quantitativamente mensuráveis, sejam eles tangíveis ou intangíveis. Sendo assim, um dos objetivos do AHP é aumentar a objetividade e diminuir, ao máximo, a subjetividade da decisão. Por essa razão, o uso desse método é pertinente para estruturação das informações apresentadas nos capítulos 5 e 6 , e como ferramenta de apoio, que permite a divisão da decisão em partes menores para, então, por meio de uma série de comparações e ponderações de importância entre os critérios, escolhidos pelo tomador de decisão, expressar a hierarquia da escolha em função dos critérios priorizados.

Os critérios de decisão mensuráveis são submetidos à avaliação do ponto de visto quantitativo por meio do cálculo dos indicadores econômico-financeiros apresentados no decorrer do capítulo 6. Contudo, é preciso que no AHP o tomador de decisão priorize todos os critérios, mensuráveis ou não, para decidir pelas [alternativas].

A vantagem dessa ferramenta é permitir ao decisor atribuir pesos relativos para os critérios de maneira intuitiva, ao mesmo tempo em que realiza comparações par a par entre os mesmos. Dessa forma, para cada decisor, em função das suas necessidades e prioridades (operacionais e financeiras), uma hierarquização distinta será gerada para a escolha entre as [alternativas].

A primeira etapa do AHP consiste na decomposição da decisão em uma hierarquia composta de, no mínimo, um objetivo, critérios para a decisão em análise e alternativas a serem 
hierarquizadas. A Tabela 23 demonstra a decomposição da decisão de imobilização ou não em imóveis corporativos (Nível 1), os critérios de decisão (Nível 2) e as [alternativas] do [MAOI] (Nível 3).

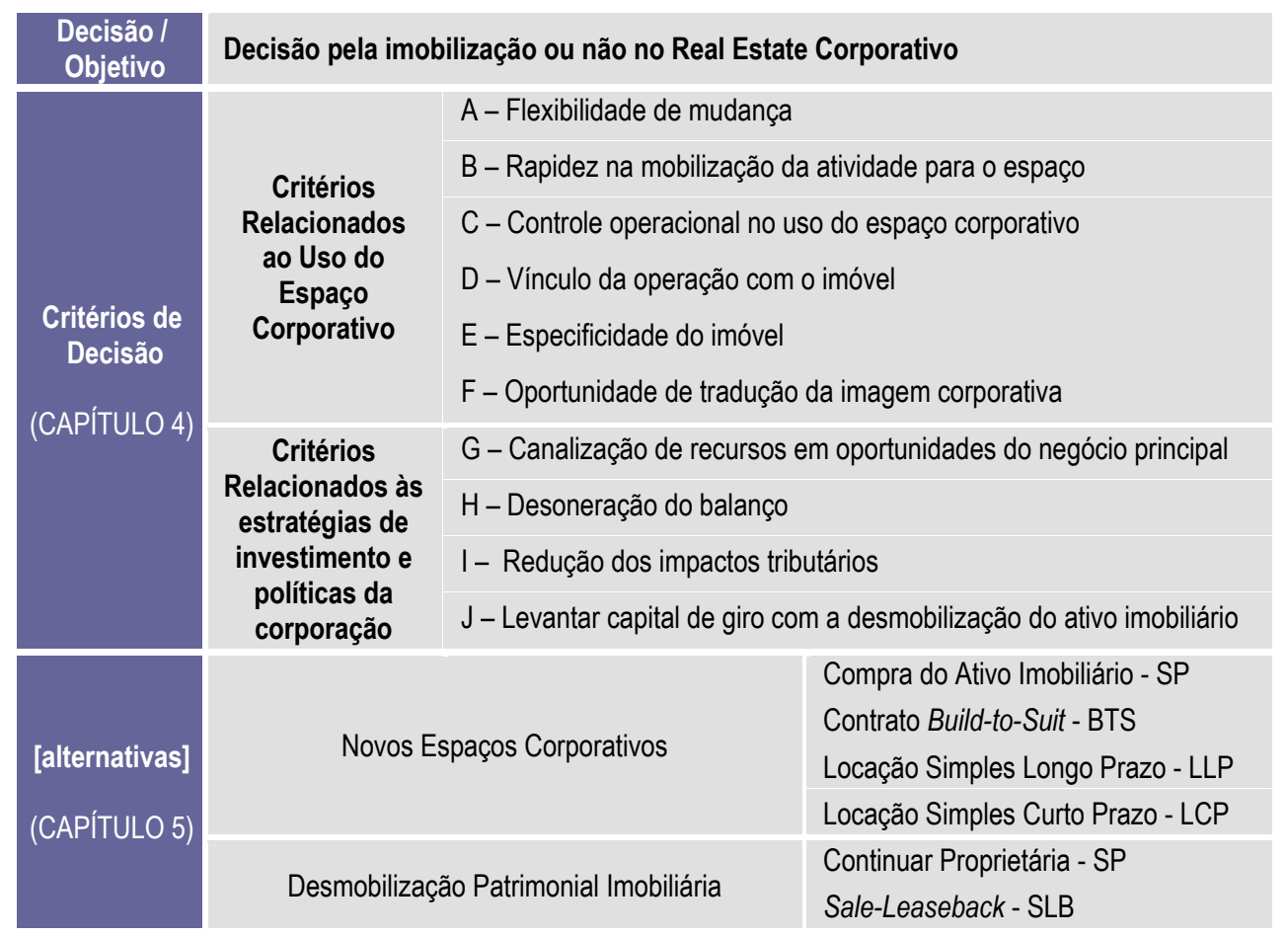

Tabela 23 - Decomposição da Decisão - Oportunidade de imobilização em imóveis corporativos

A árvore hierárquica de decisão está apresentada na Figura 12. Definidos os critérios e as [alternativas], a próxima etapa refere-se à elaboração da matriz no Nível 3 da análise.

A matriz das [alternativas] - Nível 3 retrata como cada uma atende a cada um dos critérios de decisão, tanto os qualitativos como os quantitativos. Como visto nos Capítulo 5 e 6, existem vantagens e desvantagens, operacionais e financeiras, distintas entre elas. Enquanto uma, por exemplo, apresenta maior flexibilidade, compromete-se o vínculo da operação com imóvel, pelo maior risco de depender de negociações com o proprietário no futuro, em contrapartida, outra favorece o vínculo e compromete a flexibilidade.

Diferentemente de outras aplicabilidades dessa ferramenta, observadas nas publicações sobre AHP, a matriz das [alternativas] nesse caso não será uma matriz fixa (constante). Isso se deve ao fato das [alternativas] atenderem de forma distinta, cada um dos atributos, a depender do contexto de cada caso em particular. Dessa forma, antecedente a elaboração da matriz das 
[alternativas] é necessário o planejador conhecer informações do contexto da situação em análise $^{140}$.

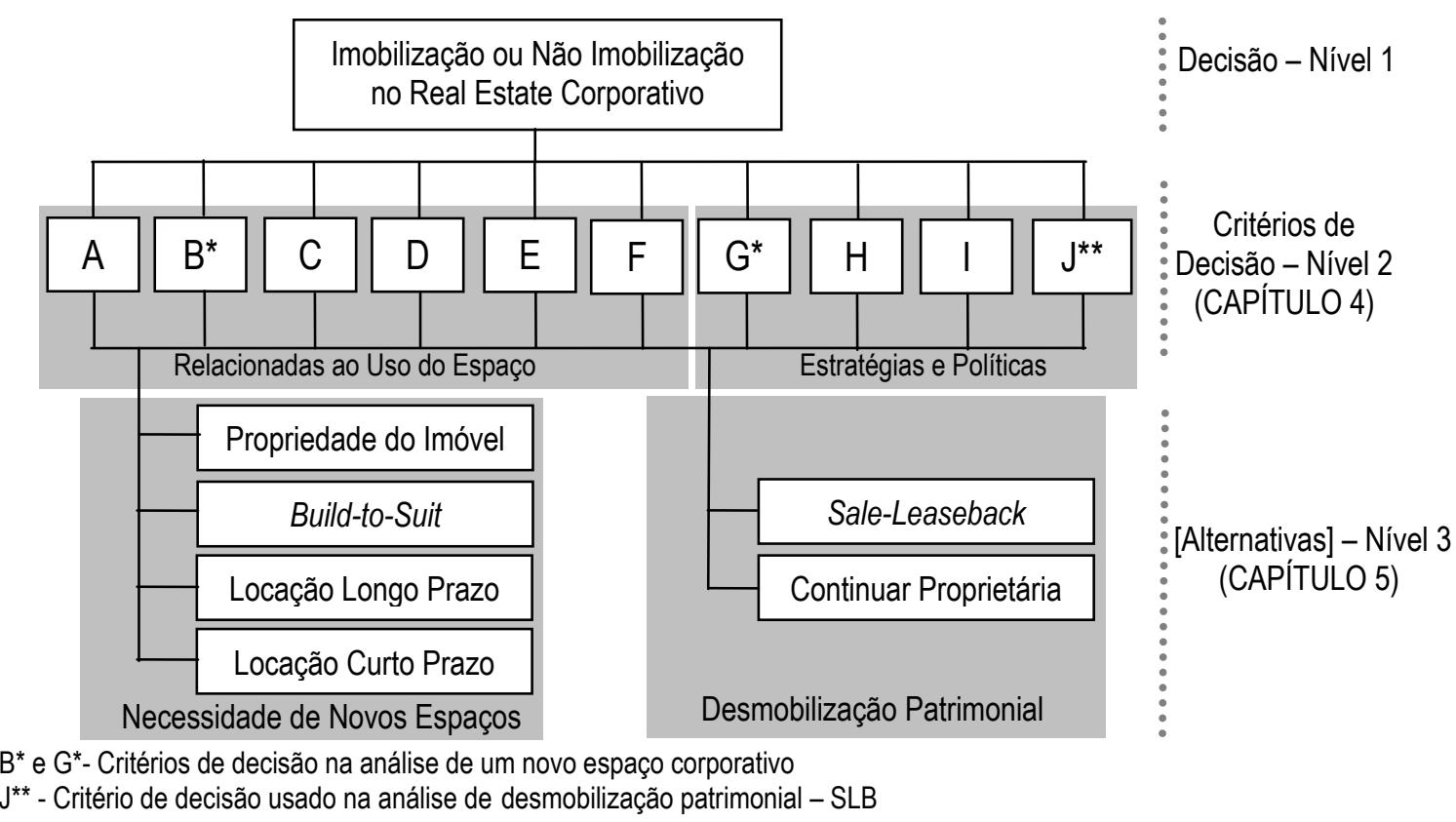

Figura 12 - Árvore Hierárquica de Decisão

A Tabela 7 apresentada no final do Capítulo 5 (item 5.4) contempla as informações do contexto, necessárias ao planejador (usuário do [MAOI]), para cada um dos critérios de decisão. A elaboração da matriz das [alternativas] - Nível 3 baseia-se, portanto, no contexto em análise, na escala de atendimento apresentada na Tabela 7, e nos indicadores econômicofinanceiros apresentados no Capítulo 6, que avaliam quantitativamente cada uma das [alternativas]. Essas referências qualitativas e quantitativas são usadas para orientar a atribuição das notas nas matrizes no Nível 3.

Para cada um dos critérios de decisão é feito comparação par a par entre as [alternativas], utilizando para isso a escala de notas demonstrada na Tabela 24, resultando na matriz ilustrada de forma genérica na Figura 13, a ser elaborada para cada um dos critérios de decisão do [MAOI]. A ponderação das notas das [alternativas] para cada um dos critérios, que geram as matrizes no Nível 3, é feita pelo planejador, enquanto que a priorização dos

${ }^{140}$ No decorrer do Capítulo 5 foram descritos os critérios que recebem influências do contexto do espaço corporativo em análise, do instrumento jurídico usado, entre outras, evidenciando as variações na importância e no atendimento aos critérios conforme descrições do contexto. 
critérios, que gera a matriz no Nível 2, é feita pelo decisor.

\begin{tabular}{c|l}
\hline \multicolumn{2}{|c}{ ESCALA DE VALORES PARA COMPARAÇÃO } \\
\hline Nota a ser atribuída & \multicolumn{1}{c}{ Importância Atribuída } \\
\hline 1 & As duas alternativas comparadas atendem igualmente ao atributo \\
\hline 3 & Alternativa $X$ aparenta atender melhor ao atributo que a $Y$ \\
\hline 5 & Alternativa $X$ atende melhor ao atributo que a $Y$ \\
\hline 7 & Alternativa $X$ atende bem melhor ao atributo que a $Y$ \\
\hline 9 & Alternativa $X$ atende excepcionalmente melhor ao atributo que a $Y$ \\
\hline $2,4,6,8$ & Escalas intermediárias para atribuição da nota \\
\hline
\end{tabular}

Tabela 24 - Escala de Notas - comparação entre [alternativas]: Nível 3 (adaptado de SAATY, 1991)

\begin{tabular}{c|c|c|c|c}
\hline \multicolumn{5}{c}{ MATRIZ DE COMPARAÇÃO DAS [alternativas] } \\
\hline Alternativas & $\mathbf{A}_{1}$ & $\mathbf{A}_{2}$ & $\ldots$ & $\mathbf{A}_{\mathbf{n}}$ \\
\hline $\mathbf{A}_{1}$ & 1 & $\mathrm{a} 12$ & & $\mathrm{a}_{1 \mathrm{n}}$ \\
\hline $\mathbf{A}_{2}$ & $\mathrm{a}_{21}=1 / \mathrm{a}_{12}$ & 1 & & $\mathrm{a}_{2 \mathrm{n}}$ \\
\hline$\ldots$ & & & 1 & \\
\hline $\mathbf{A}_{\mathrm{n}}$ & $\mathrm{a}_{\mathrm{n} 1}=1 / \mathrm{a}_{1 \mathrm{n}}$ & $\mathrm{a}_{\mathrm{n} 2}=1 / \mathrm{a}_{2 \mathrm{n}}$ & & 1 \\
\hline$\sum$ Pesos $[\mathrm{T}]$ & $\mathbf{1 + \mathrm { a } _ { 2 1 } + \ldots + \mathrm { a } _ { \mathrm { n } 1 }}$ & & & $\mathrm{a}_{\mathrm{n} 1}+\mathrm{a}_{2 \mathrm{n}}+\ldots+1$ \\
\hline
\end{tabular}

Figura 13 - Matriz das [alternativas] elaborada para cada um dos critérios de decisão

Para efeito de notação, a matriz de comparação para $n$ elementos é demonstrada da seguinte

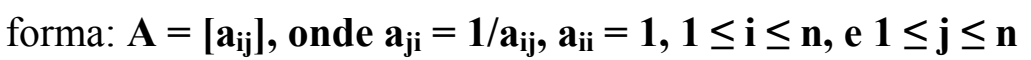

Ou seja, se a alternativa $\mathrm{X}$ atende melhor ao atributo (escala de nota $=5$ ) que a alternativa $\mathrm{Y}$, a $\mathrm{Y}$ atende 1/5 em comparação a X. Essa ponderação é feita para todos os critérios. A partir da avaliação se calcula a ponderação relativa das alternativas niveladas a uma mesma unidade, a qual é obtida através da normalização da matriz de comparação. A matriz normalizada é uma matriz de mesma ordem na qual o respectivo valor normalizado (ou seja, cada nota atribuída segundo a escala de valores) é obtido através do quociente entre a nota atribuída na comparação e a somatória dos valores da respectiva coluna [T]. Desta matriz, obtém-se o peso relativo, ou autovetor.

A obtenção do peso relativo é encontrada, segundo a teoria de SAATY, de diversas formas. No modelo adotado, o peso relativo é obtido através de uma sequência de passos com o objetivo de estabilizar a importância relativa entre os elementos comparados. Esta estabilização é realizada através da multiplicação da matriz inicial por ela mesma. Os valores de cada linha são somados, de forma a obter um único vetor, o autovetor (coluna absoluta), os 
quais devem ser normalizados. A partir da segunda interação, calcula-se a diferença dos valores obtidos para o autovetor normalizado com os da primeira interação. Essas interações devem se repetir até que a diferença entre os autovetores não seja maior que 0,00099, indicando que a matriz esteja estabilizada. Neste momento, determinam-se os valores definitivos dos pesos dos elementos. Essas interações são usadas para conferir mais precisão aos pesos.

Segundo a teoria de SAATY, se todos os julgamentos forem perfeitos em todas as comparações, então a seguinte condição faz-se verdadeira: $\mathbf{A}_{\mathbf{i k}}=\mathbf{a}_{\mathbf{i j}} \cdot \mathbf{a}_{\mathbf{j k}}$, para todo $\mathbf{i}, \mathbf{j}, \mathbf{k}$.

De acordo com SOARES (2002), as comparações realizadas requerem a atribuição subjetiva de valores através da escala apresentada na Tabela 24. O elevado número de comparações pode levar o avaliador a conferir gradientes de importância de maneira diferente para uma alternativa em comparação a várias outras, o que denota, nessa ocasião, inconsistência na comparação. SAATY (apud SOARES, 2002) apresenta um procedimento para medição da inconsistência do teste, baseado no índice de inconsistência [IC], o qual incide na fórmula:

$$
\mathrm{IC}=\left(\lambda_{\text {máx }}-1\right) /(\mathbf{n}-1), \text { para } n=\text { dimensão da matriz quadrada }
$$

O $\lambda$ máx corresponde ao autovetor, obtido a partir da multiplicação de duas matrizes - a primeira formada a partir do autovetor (peso relativo) e a segunda pela soma dos valores atribuídos na matriz de comparação [T]. Além disso, SAATY apresenta o índice de aleatoriedade que consiste em um IC gerado para matrizes aleatórias de diferentes dimensões, descritos na Tabela 25 .

VALORES DE CONSISTÊNCIA ALEATÓRIA (em função da ordem da Matriz)

\begin{tabular}{|c|c|c|c|c|c|c|c|c|c|c|c|}
\hline $\mathrm{n}$ & 1 & 2 & 3 & 4 & 5 & 6 & 7 & 8 & 9 & 10 & 11 \\
\hline CA & 0,00 & 0,00 & 0,58 & 0,90 & 1,12 & 1,24 & 1,32 & 1,41 & 1,45 & 1,49 & 1,51 \\
\hline
\end{tabular}

Finalmente é possível obter a razão de consistência [RC] através da seguinte expressão:

$$
\mathbf{R C}=\mathbf{I C} / \mathbf{C A}
$$

Uma razão de consistência menor ou igual a 0,1 é considerada aceitável para efeito de análise. Assim, avaliada a consistência das ponderações e concluída a matriz das [alternativas], resta 
agora, para hierarquizar as [alternativas], a priorização dos critérios de decisão pelo decisor (corporação usuária do espaço corporativo). Para isso, é feito o mesmo procedimento (para que a matriz tenha consistência) gerando, assim, a matriz de priorização - Nível 2.

A escala usada para priorização dos critérios pelo decisor está apresentada na Tabela 26. A partir de comparações par a par de importância entre os critérios de decisão, se conclui pela matriz de priorização. Essa matriz multiplicada pela matriz das [alternativas] conferirá o resultado da AHP - hierarquização das [alternativas] para decisão pela imobilização ou não no real estate corporativo.

\begin{tabular}{c|l}
\hline \multicolumn{2}{c}{ ESCALA DE VALORES PARA PRIORIZAÇÃO DOS ATRIBUTOS (CRITÉRIOS DE DECISÃO) } \\
\hline Nota a ser atribuída & \multicolumn{1}{c}{ Importância Atribuída } \\
\hline $\mathbf{1}$ & Os dois atributos têm igual importância \\
\hline 3 & O atributo A aparenta ter maior importância que B \\
\hline $\mathbf{5}$ & O atributo A tem maior importância que B \\
\hline $\mathbf{7}$ & O atributo A tem bem maior importância que B \\
\hline $\mathbf{9}$ & O atributo A tem excepcionalmente maior importância que B \\
\hline $2,4,6,8$ & Escalas intermediárias para atribuição da nota \\
\hline
\end{tabular}

Tabela 26 - Escala de Notas - priorização dos atributos: Nível 2 (adaptado de SAATY, 1991)

\subsection{Simulação da situação modelo - Ferramenta AHP para apoio à decisão a partir da priorização dos critérios pelos decisores}

Para melhor entendimento do AHP como ferramenta de apoio à decisão pela imobilização ou não no real estate corporativo um exemplo prático é simulado. Trata-se da mesma situação modelo usada para transcorrer o Capítulo 6. O contexto da situação, contemplando as informações necessárias ao planejador para a atribuição das notas na matriz das [alternativas] está descrito na Tabela 27. Para esse mesmo contexto são simuladas duas priorizações distintas para os nove critérios de decisão do [MAOI], que resultam em diferentes hierarquizações das [alternativas] em função dessas duas priorizações. 
DESCRIÇÃO DO CONTEXTO: SITUAÇÃO MODELO - DECISÃO DE IMOBILIZAÇÃO OU NÃO NO REAL ESTATE

PARA UM NOVO ESPAÇO CORPORATIVO A SER UTILIZADO NA OPERAÇÃO

\begin{tabular}{|c|c|}
\hline Setor de Atuação & Serviços de telefonia. \\
\hline Estágio da Empresa & $\begin{array}{l}\text { Expansão da presença de mercado. Por isso, a empresa atualmente prioriza destinar os } \\
\text { recursos disponíveis em P\&D e tecnologias inovadoras. }\end{array}$ \\
\hline Tipo de Espaço Corporativo & Sede Administrativa da empresa em SP. \\
\hline Incertezas quanto ao uso do espaço & Somente no longo prazo (horizonte de uso do imóvel é de 15 anos). \\
\hline Especificidade requerida no espaço & $\begin{array}{l}\text { Embora seja uma sede administrativa, há especificidade na arquitetura, fachada e nas } \\
\text { utilidades do espaço, que deve contemplar algumas instalações cruciais ao atendimento } \\
\text { dos clientes (instalações em geral, sistemas operacionais, entre outras especificidades). }\end{array}$ \\
\hline Disponibilidade do imóvel no mercado & $\begin{array}{l}\text { Existe a possibilidade de encontrar imóvel no mercado, e atender as especificações } \\
\text { necessárias, desde que seja possível promover intervenções para adequar o espaço ao } \\
\text { uso da corporação. Também é desejado traduzir a imagem ao ambiente externo por meio } \\
\text { de arquitetura específica. }\end{array}$ \\
\hline Imóvel & Monousuário. \\
\hline Atividade Realizada & $\begin{array}{l}\text { O espaço suportará principalmente as atividades administrativas. No entanto, contempla } \\
\text { parte de sistemas operacionais vinculados à prestação dos serviços aos clientes. }\end{array}$ \\
\hline $\begin{array}{l}\text { Intervenções predominantes durante } 0 \\
\text { uso }\end{array}$ & $\begin{array}{l}\text { Média Intervenção (sistemas de automação, layout) e média periodicidade entre } \\
\text { intervenções. }\end{array}$ \\
\hline Importância do Imóvel & Pela tradução da imagem corporativa e investimento em instalações no espaço. \\
\hline Rating da Corporação & Uma das empresas líder no setor que atua - alta credibilidade (rating de crédito elevado). \\
\hline Tradução da imagem desejada & Externamente (logomarca e acabamentos externos) e internamente. \\
\hline Início das atividades no espaço & Deve ocorrer no prazo máximo de três anos. \\
\hline Condição na opção pela imobilização & $\begin{array}{l}\text { SP a prazo. A corporação não pretende dispor de suas disponibilidades de recursos para } \\
\text { investir na compra de ativos imobiliários. }\end{array}$ \\
\hline Situação do Balanço & $\begin{array}{l}\text { Equilibrada. No entanto, não pretende comprometer em mais de } 60 \% \text { seu CGL e em mais } \\
\text { de } 10 \% \text { a participação de capital de terceiros em relação ao patrimônio líquido. }\end{array}$ \\
\hline Renda Relativa do Capital de Giro Ativado & $\begin{array}{l}\text { Para a tomada de decisão em relação às [alternativas] a corporação determina como } \\
\text { parâmetro mínimo } 6 \% \text { ao ano (efetiva acima do IGP) para a renda relativa gerada pelas } \\
\text { [alternativas] de não imobilização e imobilização a prazo. }\end{array}$ \\
\hline Acréscimo do Resultado Corporativo & $\begin{array}{l}\text { A corporação entende como satisfatório o acréscimo de pelo menos } 2 \% \text { ao ano no } \\
\text { resultado corporativo a partir das oportunidades de ganho geradas pelas [alternativas] de } \\
\text { não imobilização e imobilização a prazo. }\end{array}$ \\
\hline Economia Tributária & $\begin{array}{l}\text { A diferença entendida como satisfatória para a corporação entre as economias tributárias } \\
\text { geradas pelas [alternativas] de não imobilização e as [alternativas] de imobilização é de } \\
20.000 \text { R\$ mil da base. }\end{array}$ \\
\hline $\begin{array}{l}\text { Instrumento jurídico preferido para as } \\
\text { [alternativas] de não imobilização }\end{array}$ & ação. \\
\hline
\end{tabular}

Tabela 27 - Descrição do contexto - Situação Modelo

A partir do contexto descrito é possível ponderar as notas nas matrizes das [alternativas], feita uma para cada critério de decisão (Nível 3) ${ }^{141}$. Esta ponderação de notas é feita pelo planejador de acordo com as referências qualitativas e quantitativas do [MAOI], conforme demonstrado na Figura 14 (para um dos critérios qualitativos) e na Figura 15 (para um dos critérios quantitativos).

141 As atribuições das notas das [alternativas] para cada critério se baseiam nas informações apresentadas no Capítulo 5, compiladas na Tabela 7 (item 5.4), e nos indicadores econômicofinanceiros, apresentados no decorrer do Capítulo 6. 


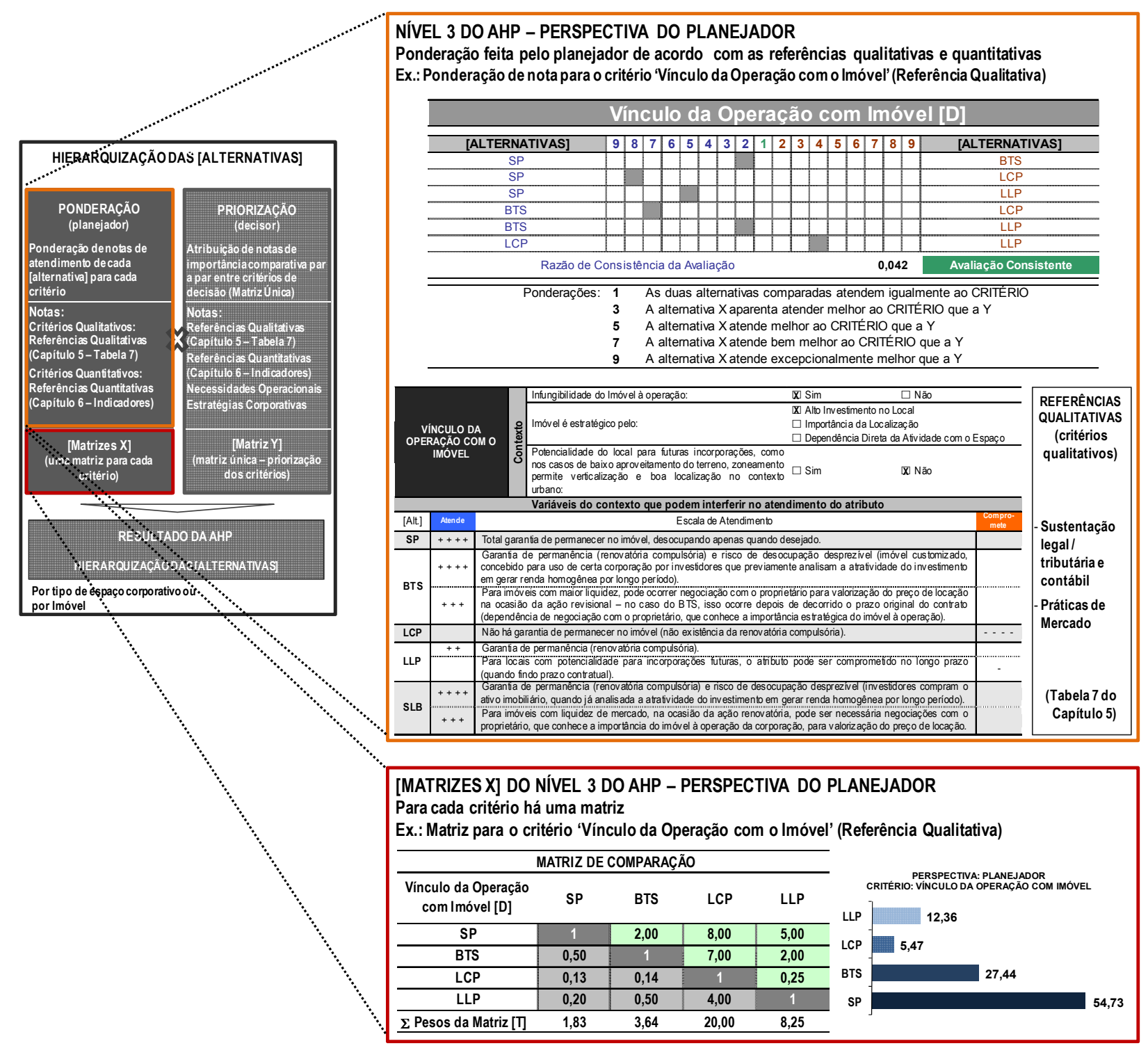

Figura 14 - Ponderação das notas das [alternativas] para os critérios de decisão qualitativos, usando como exemplo o [Critério D] - vínculo da operação com o imóvel (Nível 3 do AHP) 


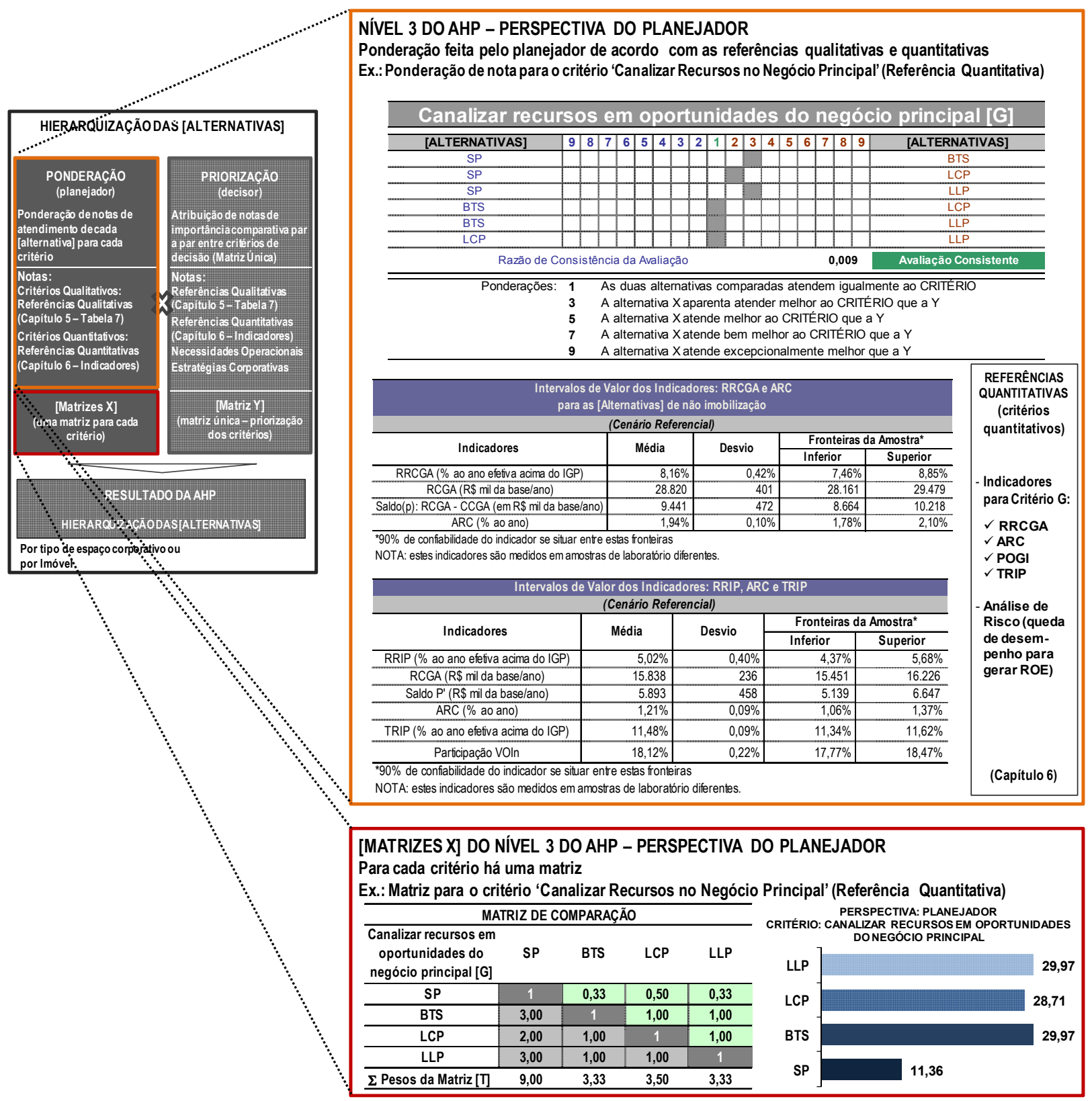

Figura 15 - Ponderação das notas das [alternativas] para os critérios de decisão quantitativos, usando como exemplo o [Critério G] - canalizar recursos em oportunidades do negócio principal (Nível 3 do AHP)

Feita essa ponderação para os nove critérios de decisão, calcula-se os pesos relativos das [alternativas], conforme procedimento apresentado no item 7.1. Estes pesos relativos indicam a pertinência das [alternativas] quanto ao atendimento a cada um dos critérios, que para esse contexto são os apresentados no Quadro 15. 


\begin{tabular}{|c|c|c|c|c|c|c|c|c|c|}
\hline \multicolumn{10}{|c|}{ PESOS RELATIVOS DAS [ALTERNATIVAS] X CRITÉRIOS - SITUAÇÃO MODELO } \\
\hline \multirow[t]{2}{*}{$\begin{array}{c}\text { [ALTERNA- } \\
\text { TIVAS] }\end{array}$} & $\begin{array}{l}\text { Flexibili- } \\
\text { dade de } \\
\text { Mudança }\end{array}$ & $\begin{array}{c}\text { Rapidezna } \\
\text { Mobilização } \\
\text { da Atividade } \\
\text { para o Espaço }\end{array}$ & $\begin{array}{l}\text { Controle } \\
\text { Operacional } \\
\text { no Uso do } \\
\text { Espaço }\end{array}$ & $\begin{array}{l}\text { Vínculo da } \\
\text { Operação } \\
\text { com Imóvel }\end{array}$ & $\begin{array}{l}\text { Especifi- } \\
\text { dade do } \\
\text { Imóvel }\end{array}$ & $\begin{array}{l}\text { Oportunidade } \\
\text { de Tradução } \\
\text { da Imagem } \\
\text { Corporativa }\end{array}$ & $\begin{array}{c}\text { Canalizar } \\
\text { recursos em } \\
\text { oportunidades } \\
\text { do Negócio } \\
\text { Principal }\end{array}$ & $\begin{array}{c}\text { Desone- } \\
\text { ração } \\
\text { do Balanço }\end{array}$ & $\begin{array}{c}\text { Redução dos } \\
\text { Impactos } \\
\text { Tributários }\end{array}$ \\
\hline & {$[\mathrm{A}]$} & [B] & [C] & [D] & [E] & [F] & [G] & {$[\mathrm{H}]$} & [l] \\
\hline SP & 8,88 & 30,77 & 52,61 & 54,73 & 40,61 & 36,24 & 11,36 & 6,25 & 4,00 \\
\hline BTS & 6,15 & 7,69 & 28,40 & 27,44 & 40,61 & 36,24 & 29,97 & 31,25 & 32,00 \\
\hline LCP & 65,93 & 30,77 & 6,33 & 5,47 & 4,74 & 8,14 & 28,71 & 31,25 & 32,00 \\
\hline LLP & 19,04 & 30,77 & 12,65 & 12,36 & 14,04 & 19,37 & 29,97 & 31,25 & 32,00 \\
\hline \multirow[t]{2}{*}{ Soma } & 100,00 & 100,00 & 100,00 & 100,00 & 100,00 & 100,00 & 100,00 & 100,00 & 100,00 \\
\hline & \multicolumn{9}{|c|}{ Pesos Relativos das Matrizes X - Nível 3 do AHP (Ponderação feita pelo Planejador) } \\
\hline $\begin{array}{c}\text { CRITÉRIOS } x \\
\text { [ALTERNATIVAS] }\end{array}$ & {$[\mathrm{A}]$} & [B] & {$[\mathrm{C}]$} & [D] & [E] & [F] & [G] & {$[\mathrm{H}]$} & [l] \\
\hline melhor atende & LCP & SP;LCP;LLP & SP & SP & SP;BTS & SP;BTS & BTS;LLP & BTS;LLP;LCP & BTS;LLP;LCP \\
\hline mais compromete & BTS & BTS & LCP & LCP & LCP & LCP & SP & SP & SP \\
\hline
\end{tabular}

Quadro 15 - Pertinência das [alternativas] quanto ao atendimento aos critérios - Situação Modelo

No Nível 2 do AHP, ambiente do decisor, são priorizados os critérios de decisão de acordo com as referências qualitativas, referências quantitativas, necessidades operacionais em relação ao espaço em análise e estratégias corporativas. Esta priorização é feita atribuindo notas de importância comparativa par a par entre os critérios de decisão do [MAOI], conforme demonstrado na Figura 16.

Nesta situação modelo um dos decisores da corporação prioriza os critérios conforme apresentado na matriz da Figura 16. A partir dessa ponderação de importância são calculados os pesos relativos dos critérios (pelo mesmo procedimento descrito no item 7.1 - estabilização da matriz por meio das interações e teste de consistência com [RC] inferior a 0,1). Estes pesos relativos estão apresentados no gráfico da Figura 16.

Nesta situação modelo o empreendimento em análise é a sede administrativa da companhia. Por isso, foi priorizada a tradução da imagem corporativa. Pelo mercado competitivo que a empresa atua é necessário canalizar recursos no negócio principal, assim como, para a matriz financiar outros projetos, a filial deve desonerar seu balanço.

O controle operacional durante o uso é menos relevante à decisão, já que as intervenções necessárias durante uso seriam facilmente aceitas pelos locadores. No entanto, existem contínuas e médias intervenções nos sistemas operacionais instalados no imóvel. Por esta razão o [Critério C] - controle operacional no uso do espaço - foi o segundo critério relacionado ao uso priorizado pelo decisor.

O critério priorizado na sequência, seguido do [Critério C], foi [Critério E] - especificidade do imóvel. O espaço deve atender algumas particularidades, em especial nos sistemas operacionais e arquitetura. No entanto, existe a possibilidade de adequar um empreendimento 
pronto disponível no mercado, ainda que comprometa algumas especificidades desejadas. Os critérios menos relevantes foram: [Critério A] - flexibilidade de mudança, e a [Critério B] rapidez na mobilização da atividade ao espaço.

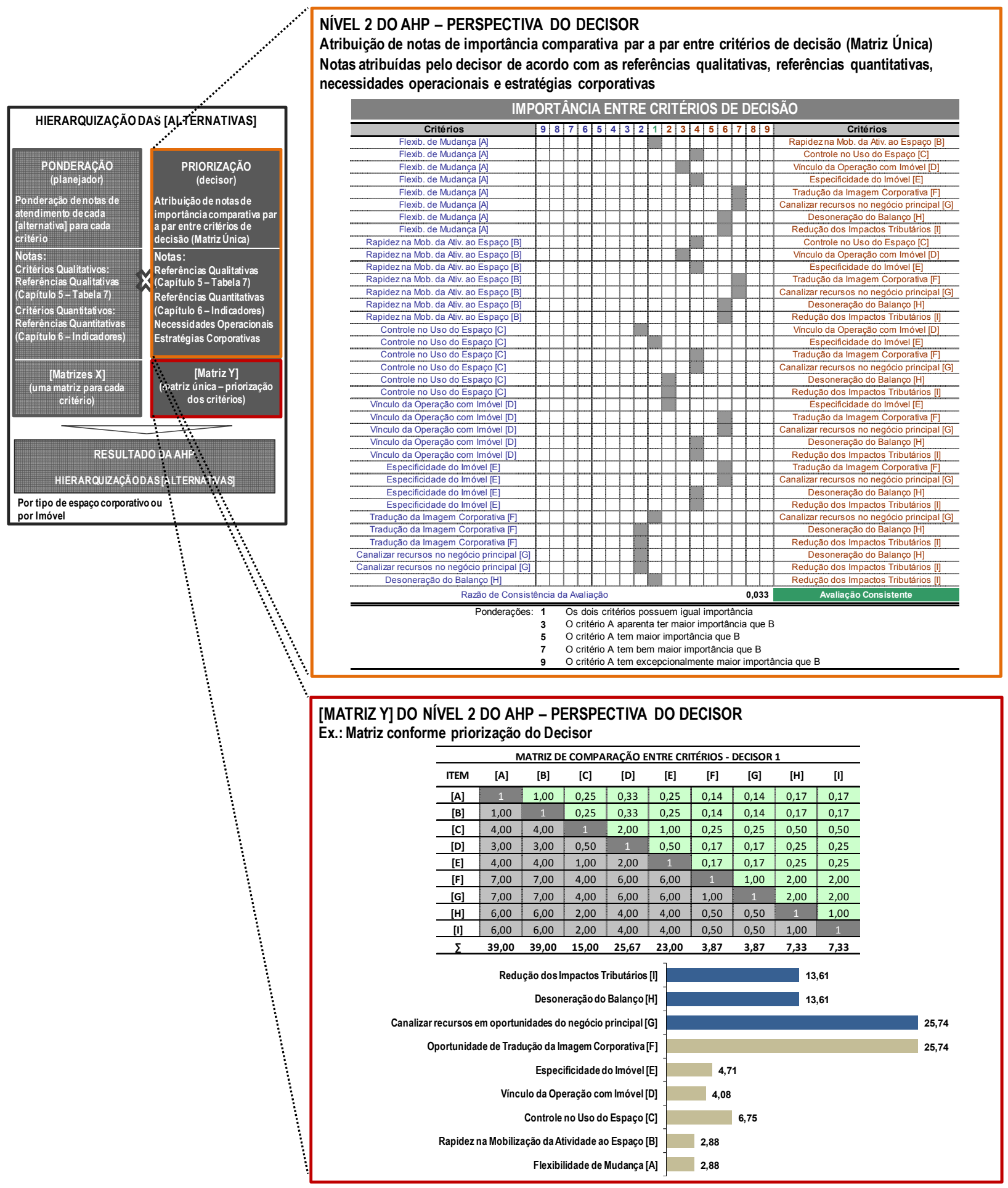

Figura 16 - Priorização dos critérios de decisão do [MAOI] para o Decisor 1 (Nível 2 do AHP) - Situação Modelo

O [Critério D] - vínculo da operação com o imóvel - se dá pelo fato do alto investimento feito 
no local com os sistemas operacionais instalados, além da importância do imóvel como marco de notoriedade para a corporação.

Os pesos relativos das matrizes das [alternativas] - Nível 3 multiplicados pelos pesos relativos dos critérios (Nível 2) - conferem o resultado da hierarquização das [alternativas] para a situação modelo, conforme priorização do decisor 1 (Figura 17).

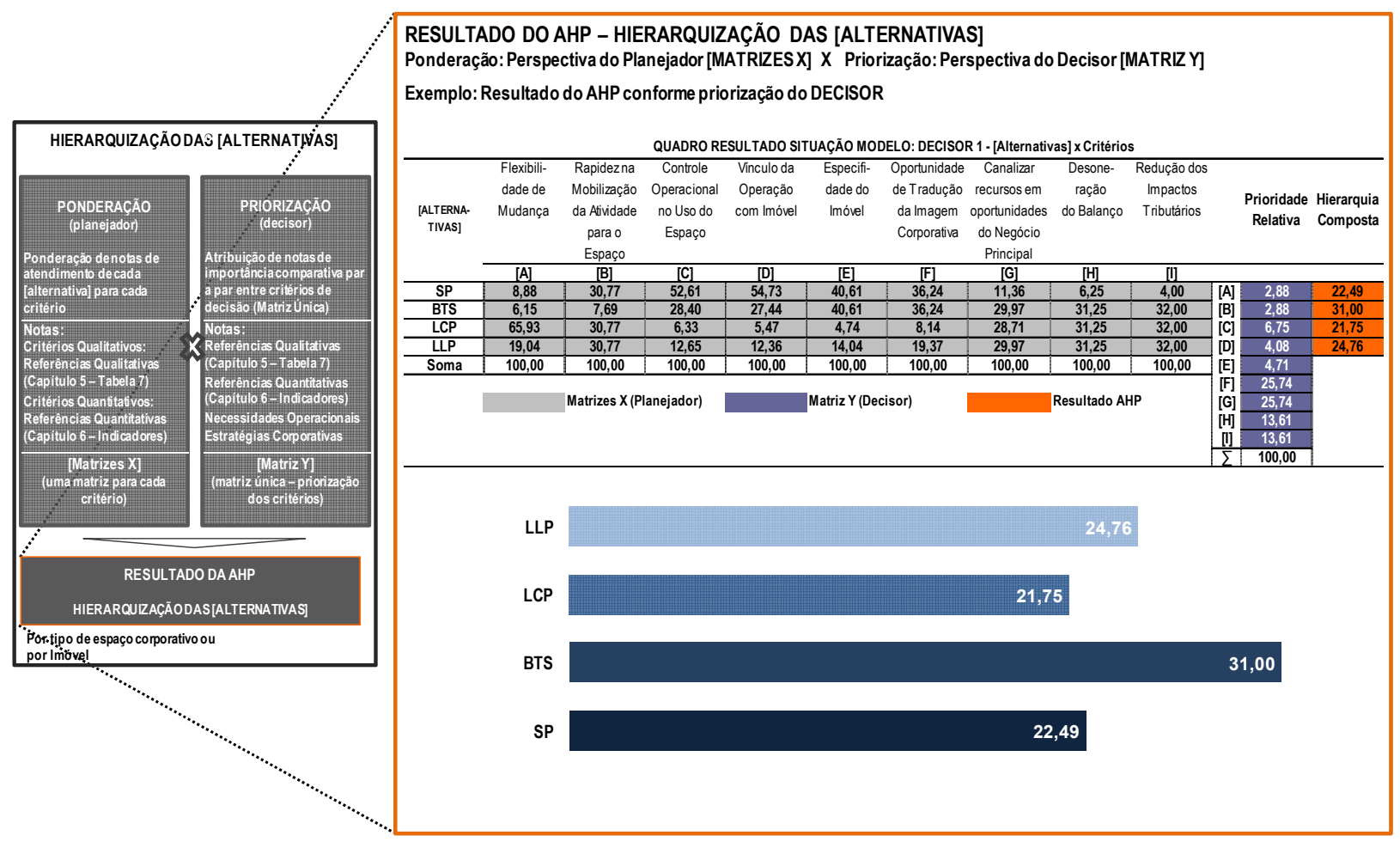

Figura 17 - Hierarquização das [alternativas] para a situação modelo (Resultado do AHP)

Pelo observado na Figura 17 a melhor [alternativa] para atender a priorização dos critérios, segundo a ponderação do decisor 1, é o BTS. Analisando os pesos relativos dos critérios de decisão concomitantemente aos pesos das [alternativas], verifica-se que essa [alternativa] é a que melhor atende, em conjunto, aos critérios priorizados pelo decisor 1 - tradução da imagem corporativa (no BTS se concebe o imóvel na arquitetura e fachada desejadas pela corporação), canalização de recursos no negócio principal, redução dos impactos tributários e desoneração do balanço. Em seguida, a [alternativa] que melhor atenderia, seria a LLP.

A escolha pela propriedade do imóvel, que nesse caso refere-se à compra do imóvel por meio de financiamento, ficaria como terceira opção, já que nessa [alternativa] os critérios relacionados às estratégias de investimento e políticas corporativas priorizados pelo decisor seriam comprometidos (principalmente a desoneração do balanço e redução dos impactos 
tributários).

Por último seria a locação de curto prazo (LCP), já que as vantagens que essa [alternativa] oferece (como flexibilidade de mudança e rapidez na mobilização da atividade ao espaço) não tiveram importância para esta situação modelo, além de comprometer o vínculo da operação com o imóvel pela não garantida de permanência (não há direito de renovatória).

Para esse mesmo contexto outro decisor da corporação (decisor 2) faz uma priorização distinta para os critérios de decisão do [MAOI]. Em função do alto investimento com sistemas operacionais instalados no imóvel durante o uso, o decisor 2 prioriza o [Critério D] - vínculo da operação com o imóvel. Em seguida, o decisor prioriza o [Critério F] - tradução da imagem corporativa e o [Critério G] - canalizar recursos no negócio principal, critérios priorizados também pelo decisor 1. Com essa ponderação os pesos relativos dos critérios calculados a partir da matriz de comparação para o decisor 2 são os apresentados no Gráfico 9.

\begin{tabular}{|c|c|c|c|c|c|c|c|c|c|}
\hline \multicolumn{10}{|c|}{ MATRIZ DE COMPARAÇÃO ENTRE CRITÉRIOS } \\
\hline ITEM & [A] & [B] & [C] & [D] & [E] & [F] & [G] & {$[\mathrm{H}]$} & [l] \\
\hline [A] & 1 & 1,00 & 0,33 & 0,17 & 0,33 & 0,14 & 0,14 & 0,33 & 0,25 \\
\hline [B] & 1,00 & 1 & 0,33 & 0,11 & 0,33 & 0,14 & 0,14 & 0,33 & 0,17 \\
\hline [C] & 3,00 & 3,00 & $\overline{1}$ & 0,14 & 1,00 & 0,20 & 0,20 & 1,00 & 0,33 \\
\hline [D] & 6,00 & 9,00 & 7,00 & 1 & 5,00 & 1,00 & 1,00 & 5,00 & 4,00 \\
\hline [E] & 3,00 & 3,00 & 1,00 & 0,20 & 1 & 0,25 & 0,25 & 0,50 & 0,50 \\
\hline [F] & 7,00 & 7,00 & 5,00 & 1,00 & 4,00 & 1 & 1,00 & 4,00 & 3,00 \\
\hline [G] & 7,00 & 7,00 & 5,00 & 1,00 & 4,00 & 1,00 & $\overline{1}$ & 4,00 & 3,00 \\
\hline$[\mathrm{H}]$ & 3,00 & 3,00 & 1,00 & 0,20 & 2,00 & 0,25 & 0,25 & 1 & 1,00 \\
\hline [I] & 4,00 & 6,00 & 3,00 & 0,25 & 2,00 & 0,33 & 0,33 & 1,00 & 1 \\
\hline$\Sigma$ & 35,00 & 40,00 & 23,67 & 4,07 & 19,67 & 4,32 & 4,32 & 17,17 & 13,25 \\
\hline
\end{tabular}

Matriz 1 - Matriz de Priorização dos critérios para o Decisor 2 (com RC = 0,028) - Situação Modelo

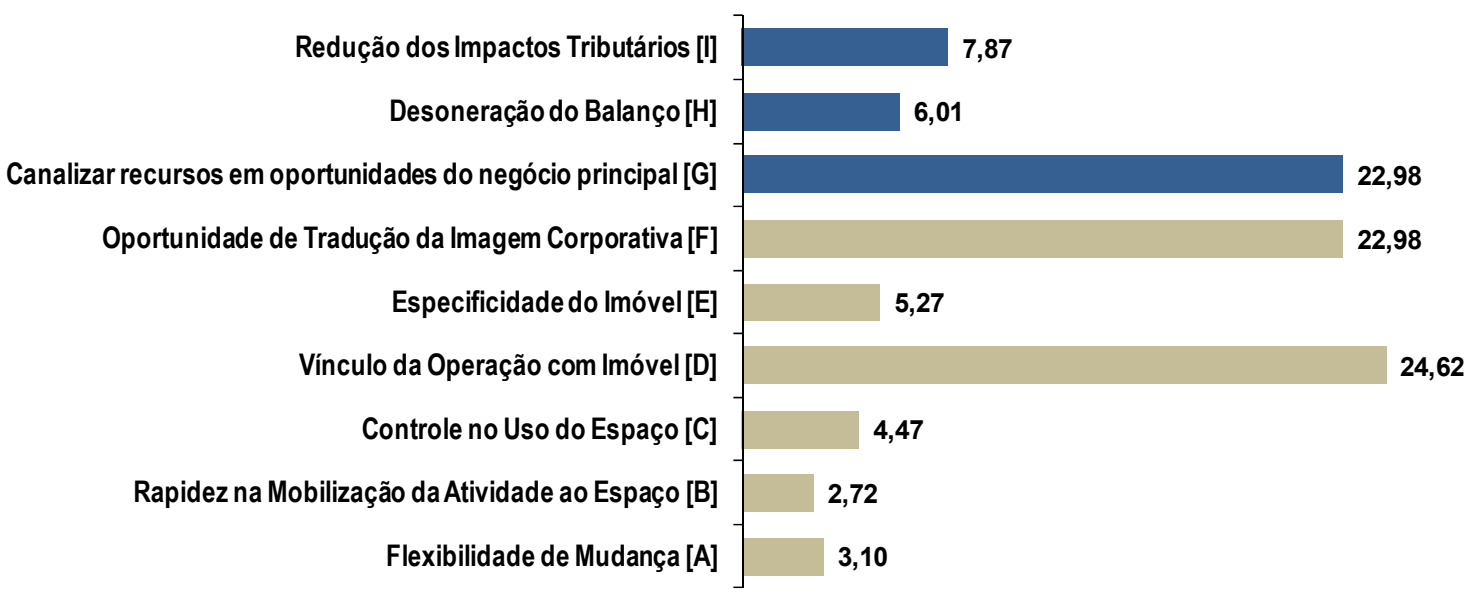

Gráfico 9 - Pesos Relativos dos critérios para o Decisor 2 - Situação Modelo 
Essa segunda priorização gera uma nova hierarquia entre as [alternativas], conforme demonstrado no Gráfico 10. Nessa situação a opção pela imobilização a prazo é a que melhor atende, em conjunto, aos dois critérios priorizados pelo decisor 2, que nesse caso foram o [Critério D] - vínculo da operação com o imóvel, e o [Critério F] - tradução da imagem corporativa. O [Critério G] - canalizar recursos no negócio principal foi igualmente pontuado em relação ao [Critério F], no entanto, a [alternativa] - BTS melhor atende ao [Critério G] em relação à opção pela imobilização a prazo, conforme indicadores demonstrados.

Além de comprometer o [Critério G], a opção pela imobilização a prazo compromete também os outros critérios relacionados às estratégias de investimento e políticas da corporação, priorizados na sequência pelo decisor 2: [Critério I] - redução dos impactos tributários e [Critério H] - desoneração do balanço. Por isso, a segunda [alternativa] é o BTS, com pontuação ainda bem semelhante à imobilização a prazo na hierarquização resultante.

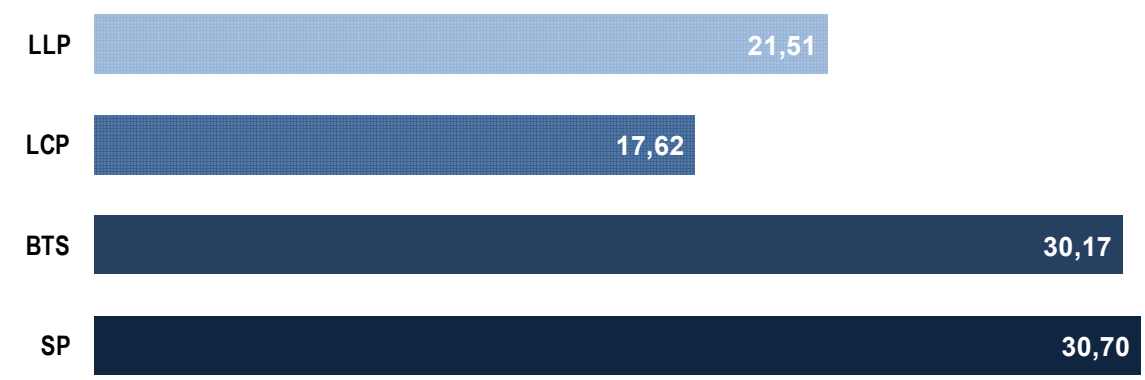

Gráfico 10 - Hierarquização das [alternativas] para o Decisor 2 - Situação Modelo

Valendo-se da situação modelo, simulada para duas priorizações distintas, verifica-se a importância em considerar na análise as necessidades operacionais em relação ao uso do espaço, estratégias de investimento e políticas corporativas para a escolha pelas opções de imobilização ou não no real estate corporativo, encontrada a partir da priorização dos critérios de decisão do [MAOI]. Isso justifica a aplicabilidade do [MAOI] - como ferramenta para ponderação de aspectos operacionais, estratégias corporativas e indicadores financeiros e econômicos na escolha pela [alternativa] mais adequada em relação ao real estate corporativo a depender de cada situação. 


\section{ESTUDO DO CASO}

Neste capítulo será explorado o estudo do caso explanatório com o intuito de avaliar a qualidade da informação gerada pelo [MAOI] em uma empresa objeto de análise, a sua aplicabilidade, além de reforçar a rotina para aplicação do [MAOI].

A escolha da empresa para estudo do caso baseou-se em dois principais objetivos: [i] empresa brasileira de médio a grande porte, preferencialmente de manufatura e [ii] com expressivo portfolio de real estate utilizado nas operações. Sendo assim, o caso explanatório foi feito com uma das empresas líderes no ramo da indústria farmacêutica brasileira, que atualmente está em fase de expansão, inclusive em nível internacional. Como se trata de uma empresa de capital fechado e por questões de confidencialidade, não será indicado o nome da empresa, tampouco os endereços dos imóveis foco de análise do [MAOI].

\subsection{Sobre a Empresa do Caso}

A empresa do caso tem mais de 30 anos de operação. No início a empresa fabricava medicamentos para terceiros e já possuía laboratórios de pesquisas nacionais e internacionais. A empresa antecipou um processo comum na indústria farmacêutica mundial, que é a terceirização para fabricação de produtos de outras marcas. Com o passar dos anos a empresa cresceu, investiu em sua capacidade instalada, em tecnologia, adquiriu outras companhias e passou a fabricar e comercializar marcas próprias.

Até 2011 um complexo industrial da empresa será totalmente ocupado, concentrando as principais atividades produtivas em um único espaço, com infraestrutura e tecnologia adequada para suportar as demandas do mercado interno e atender ao projeto de internacionalização.

Os dados relacionados ao desempenho econômico-financeiro da empresa, entre outros dados necessários ao cálculo das referências quantitativas do [MAOI] estão apresentados na Tabela 28. Neste caso, são utilizados os dados de 2008 e 2009, pois os dados de 2007 foram muito abaixo do desempenho histórico da empresa, em função de uma ocorrência que impactou na produção e comercialização dos produtos. 


\begin{tabular}{l|r|c}
\hline \multicolumn{3}{c}{$\begin{array}{c}\text { Dados da Empresa do Caso } \\
\text { (Valores em R\$ mil da base) }\end{array}$} \\
\hline \multicolumn{1}{c|}{ Dois últimos exercícios (2008 e 2009) } & \multicolumn{1}{c|}{2008} & \multicolumn{1}{c}{2009} \\
\hline Patrimônio Líquido (30/12/08 e 30/12/09) & 301.869 & 454.705 \\
\hline Resultado Operacional Líquido de IR e CS (anual) & 92.655 & 127.903 \\
\hline Resultado Operacional Líquido de IR e CS (eq. mês) & 7.721 & 10.659 \\
\hline ROE (\% equivalente ao mês) & $2,26 \%$ & $2,09 \%$ \\
\hline ROE (\% ao ano) & $30,69 \%$ & $28,13 \%$ \\
\hline WACC (\% ano ano) & $11,80 \%$ & $23,22 \%$ \\
\hline Alíquota de IR + CS & \multicolumn{2}{|c|}{$34,00 \%$} \\
\hline
\end{tabular}

Tabela 28 - Dados econômico-financeiros da empresa do caso

O resultado operacional é calculado a partir da receita bruta deduzida dos impostos sobre a receita e dos custos operacionais e administrativos. A partir do resultado operacional reduz-se o imposto de renda e contribuição social para cálculo do resultado operacional líquido. $\mathrm{Ou}$ seja, para cálculo do $\mathrm{ROE}$ da empresa não se considera as despesas e receitas não operacionais. Os valores de ROE calculados para 2008 e 2009 são próximos, 30,69\% e $28,13 \%$ ao ano, respectivamente, o que resulta em um intervalo fechado de valor para este indicador, que será aplicado no modelo de simulação de forma randômica, conforme apresentado no Capítulo 6 para a situação modelo.

Para cálculo do wacc foram coletados: [i] os dados dos financiamentos e arrendamentos (leasing) que a empresa adquiriu, incluindo os juros e demais encargos pagos a terceiros referentes a estas obrigações, [ii] a remuneração dos sócios e [iii] a participação dos sócios e do capital de terceiros (bancos e sociedades mercantis).

Embora o wacc de 2009 tenha registrado um aumento em relação a 2008, a qualidade deste custo do capital para a empresa melhorou, uma vez que a remuneração dos sócios é que apresentou aumento. A remuneração de terceiros em 2009 caiu em relação a 2008, em função da maior participação de financiamentos adquiridos junto ao BNDES com menores taxas de juros e prazos longos de amortização. O wacc apresentado na Tabela 28 foi calculado em múltiplo da taxa CDI (certificados de depósitos interbancários) registrados nos anos de 2008 e 2009, e transportados para um múltiplo do CDI projetado para 2010 e como expectativa adiante, adotado em $10 \%$ ao ano (que corresponde ao CDI Líquido de 7,9\% ao ano). Embora este indicador (wacc) esteja com fronteiras de valor muito abertas, também será considerado no modelo em intervalo, aplicado de forma randômica durante todo o horizonte de análise nos 
fluxos que utilizam esta variável.

\subsection{Imóveis Utilizados nas Operações da Empresa do Caso}

A Tabela 29 apresenta os dados dos imóveis utilizados nas operações da empresa, com a descrição das atividades realizadas em cada um, áreas construídas, horizontes de uso dos imóveis, valores de transação (conforme laudos de avaliação fornecidos pela empresa), e a situação atual dos imóveis em relação aos seus respectivos valores de registro e vidas úteis remanescentes. Como é possível observar, todos os imóveis são de propriedade da empresa e foram adquiridos há muito tempo. Por isso, dos seis imóveis quatro deles estão totalmente depreciados.

No total a empresa utiliza $116.981 \mathrm{~m}^{2}$ de área construída para realização das suas atividades, sendo deste total 78,02\% em unidades fabris, o restante na sede administrativa, com 11.139 $\mathrm{m}^{2}$ de área construída, laboratório e armazenagem $\left(12.954 \mathrm{~m}^{2}\right)$ e centro de pesquisa (1.617 $\mathrm{m}^{2}$ ). A partir dos valores dos laudos de avaliação fornecidos pela empresa calcula-se um total de $435.500 \mathrm{R} \$$ mil da base como valor de mercado de todo seu portfolio de real estate.

O imóvel 4 é o de maior participação no portfolio, representando $64,3 \%$ e $68,4 \%$ de participação com base no seu valor avaliado e na sua área construída, respectivamente, conforme apresentado nos Gráfico 11 e Gráfico 12 . Este imóvel é o novo complexo industrial da empresa que estará completamente ocupado em 2011. Neste imóvel concentra-se $70 \%$ de toda a produção. 


\begin{tabular}{|c|c|c|c|c|c|c|}
\hline IMÓVEIS & IMÓVEL 1 & IMÓVEL 2 & IMÓVEL 3 & IMÓVEL 4 & IMÓVEL 5 & IMÓVEL 6 \\
\hline $\begin{array}{c}\text { Principal } \\
\text { Atividade } \\
\text { Desenvolvida }\end{array}$ & $\begin{array}{l}\text { Edifício de Escritórios, } \\
\text { com maior parte do } \\
\text { imóvel ocupada pela } \\
\text { administração e área } \\
\text { comercial da Empresa }\end{array}$ & $\begin{array}{l}\text { Unidade fabril onde se } \\
\text { produz toda a linha de } \\
\text { antibióticos da } \\
\text { empresa. }\end{array}$ & \begin{tabular}{|c|} 
Laboratório de \\
biotecnologia, produção \\
de ampolas e frascos de \\
vidros, com operações \\
de armazenagem e \\
expedição de amostras \\
grátis e materiais \\
promocionais
\end{tabular} & $\begin{array}{l}\text { Complexo industrial } \\
\text { que concentra } 70 \% \text { de } \\
\text { toda a produção da } \\
\text { empresa }\end{array}$ & \begin{tabular}{|c|} 
Centro de Pesquisas \\
Clínicas e \\
Bioequivalência \\
Além das pesquisas o \\
imóvel abriga dois \\
projetos sociais: \\
enfermagem e inclusão \\
digital
\end{tabular} & $\begin{array}{l}\text { Unidade fabril onde é } \\
\text { feita a produção de } \\
\text { produtos veterinários }\end{array}$ \\
\hline $\begin{array}{c}\text { Área } \\
\text { Construída }\left(\mathrm{m}^{2}\right)\end{array}$ & 11.139 & 7.883 & 12.954 & 80.000 & 1.617 & 3.388 \\
\hline $\begin{array}{l}\text { Horizonte de } \\
\text { Uso - n (anos) }\end{array}$ & 20 & 20 & 20 & 25 & 10 & 20 \\
\hline $\begin{array}{c}\text { Valor de } \\
\text { Transação* (em } \\
\text { R\$ mil da base) }\end{array}$ & 41.500 & 44.000 & 51.000 & 280.000 & 12.000 & 7.000 \\
\hline $\begin{array}{c}\text { Valor do } \\
\text { Terreno* (em R\$ } \\
\text { mil da base) }\end{array}$ & 12.224 & 4.727 & 14.021 & 12.500 & 1.568 & 1.355 \\
\hline \multicolumn{7}{|c|}{ DADOS DE REGISTRO DOS IMÓVEIS - SITUAÇÃO ATUAL } \\
\hline $\begin{array}{c}\text { Vida Útil } \\
\text { Remanescente } \\
\text { (anos) }\end{array}$ & $\begin{array}{c}\text { - } \\
\text { (imóvel totalmente } \\
\text { depreciado) }\end{array}$ & $\begin{array}{c}\text { - } \\
\text { (imóvel totalmente } \\
\text { depreciado) }\end{array}$ & 7 & 25 & $\begin{array}{c}- \\
\text { (imóvel totalmente } \\
\text { depreciado) }\end{array}$ & $\begin{array}{c}- \\
\text { (imóvel totalmente } \\
\text { depreciado) }\end{array}$ \\
\hline $\begin{array}{c}\text { Valor de } \\
\text { Registro (em R\$ } \\
\text { mil da base) }\end{array}$ & 247 & 62 & 2.566 & 280.000 & 152 & 0 \\
\hline
\end{tabular}

Tabela 29 - Imóveis utilizados nas operações da empresa do caso

O Gráfico 11 e Gráfico 12 apresenta a participação de cada imóvel no portfolio de real estate da empresa, tanto em função dos valores de transação, como também em relação às suas áreas construídas.

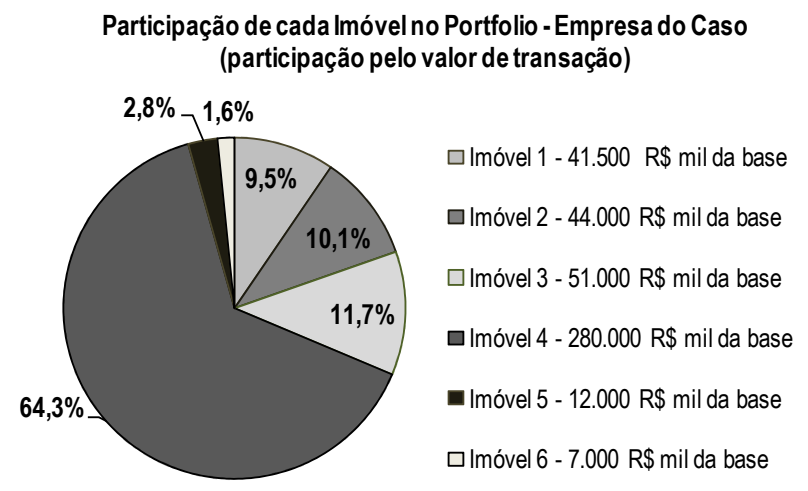

Gráfico 11 - Participação (pelo valor de transação) de cada imóvel no portfolio de real estate da empresa do caso 


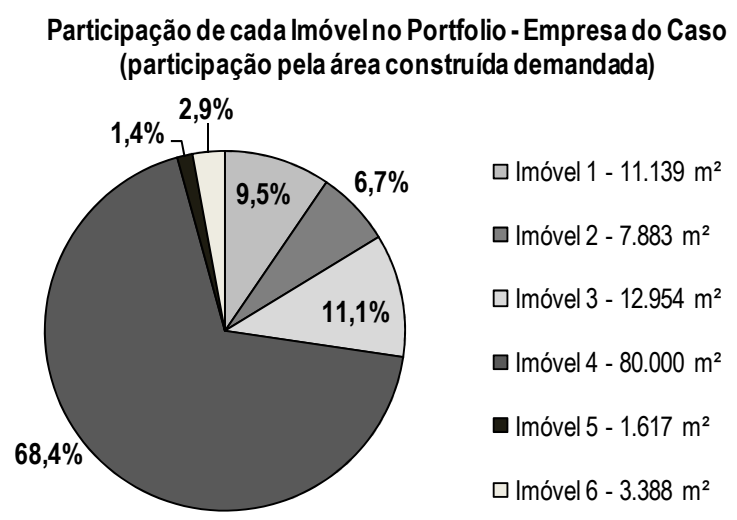

Gráfico 12 - Participação (pela área construída) de cada imóvel no portfolio de real estate da empresa do caso

Como os imóveis 5 e 6 (centro de pesquisas clínicas e fábrica de produtos veterinários) representam pequena participação em relação aos demais, tanto em relação à área construída, como valor de transação, será apresentado nos próximos itens a rotina de aplicação do [MAOI] para três imóveis da empresa do caso: Imóvel 1 (Sede Administrativa), Imóvel 3 (Laboratório de Biotecnologia e Armazenagem) e Imóvel 4 (Complexo Industrial). O imóvel 2 (Fábrica de Antibióticos) também é outra unidade fabril, no entanto, o detalhamento da aplicação do [MAOI] para este tipo de espaço corporativo já será feito para o Complexo Industrial (Imóvel 4). Para os imóveis 2, 5 e 6, a mesma rotina apresentada nos itens a seguir é aplicada. Ao final deste capítulo demonstra-se os resultados finais para os seis imóveis do portfolio da empresa.

\subsection{Rotina para aplicação do [MAOI] na Empresa do Caso}

$\mathrm{O}$ [MAOI] pode ser usado tanto para análise de novos espaços corporativos demandados pelas empresas, que estão em processo de expansão/reestruturação ou início de operação, como também para análise da desmobilização patrimonial imobiliária (SLB).

Na situação modelo usada para transcorrer o Capítulo 6, a análise baseia-se em avaliar a melhor [alternativa] para um novo espaço corporativo de uma empresa de serviços que está em processo de expansão. A aplicação do [MAOI] na empresa do caso tem o mesmo propósito, ou seja, indicar a [alternativa] mais adequada para cada imóvel utilizado nas operações, em função das referências qualitativas e quantitativas do [MAOI], necessidades operacionais e estratégias da empresa.

Nesse sentido, com o intuito de que o método desenvolvido na tese seja utilizado para uma 
gama de empresas já instaladas, que em geral apresentam boa parte dos imóveis demandados como ativos imobilizados nos balanços (como a empresa do caso), propõe-se uma análise sem vieses de decisões pretéritas da empresa. Entende-se que na ocasião da tomada da decisão em relação à escolha das [alternativas] para cada imóvel, a situação da empresa objeto de análise, do contexto macroeconômico e dos mercados de real estate, configuravam um cenário distinto ao atual, que pode ter influenciado na decisão da empresa.

Para tanto, a análise se inicia pelas demandas operacionais em relação aos espaços corporativos necessários para suportar as atividades da empresa, sem considerar, em um primeiro momento da análise, a situação atual do imóvel no portfolio da empresa e a [alternativa] adotada. Ou seja, a análise é desenvolvida como se cada imóvel fosse um novo espaço corporativo com as mesmas demandas e características para identificar a [alternativa] mais adequada, em função dos critérios de decisão do [MAOI] priorizados pelos decisores. Para cada um dos imóveis, a [alternativa] indicada pelo [MAOI] é então comparada à [alternativa] adotada pela empresa objeto de análise, para então serem propostas intervenções no portfolio. No entanto, esta comparação requer uma análise crítica complementar entre quais seriam os resultados (referências quantitativas do [MAOI]) se considerada a situação atual do ativo no balanço da empresa.

Com o objetivo de sustentar esta proposta de análise, vale citar as referências quantitativas do imóvel 1 da empresa do caso (Sede Administrativa). O cálculo dos indicadores do [MAOI] para o imóvel 1 considerando somente a situação atual, indicaria RRCGA de apenas 3,91\% ao ano na média da amostra para a [alternativa] de não imobilização, e o indicador que mede a 'economia tributária' seria negativo em (1.761) R \$ mil da base na média da amostra, uma vez que o lucro da venda do ativo geraria um imposto de $14.026 \mathrm{R} \$$ mil da base no início do horizonte de análise. Com base apenas nessas referências o decisor da empresa priorizaria os critérios sem saber as reais vantagens de não imobilizar no ativo, o que acaba por conduzir a análise com vieses no momento da priorização dos critérios de decisão do [MAOI]. Neste caso, a análise com base nas demandas e características do espaço, como se a empresa estivesse decidindo hoje qual seria a melhor [alternativa] para este imóvel, resultaria na RRCGA de $11,76 \%$ ao ano na média da amostra, e no indicador 'economia tributária' de $12.603 \mathrm{R} \$$ mil da base para as [alternativas] de não imobilização.

Portanto, a análise com base nas demandas, para em seguida comparar com a situação atual e, assim, propor as intervenções mais adequadas no portfolio, é a rotina mais indicada para o planejador usuário do [MAOI] em empresas já instaladas que desejam avaliar a qualidade das 
decisões em relação a seu portfolio de real estate e as intervenções mais adequadas no portfolio, considerando a situação atual dos ativos no balanço ${ }^{142}$.

Com base nessa proposta de análise, a rotina para aplicação do [MAOI] na empresa é feita da seguinte forma:

[i] identificam-se as demandas por espaços corporativos e as características dos imóveis necessários para suportar as atividades da empresa em relação a: localização, áreas, especificidades, horizonte de uso, preços de locação e valores de transação;

[ii] identificam-se as [alternativas] atuais de cada imóvel, ou seja, se é próprio ou alugado, prazos de locação, modelos de contrato (locação ou DRS), valor contábil, vida útil remanescente e como o imóvel está contabilizado no balanço (se for o caso);

[iii] aplica-se o [MAOI] a partir das demandas e características dos espaços, como se análise fosse feita para um novo espaço corporativo com as mesmas demandas e características, considerando a realidade atual, tanto da empresa como dos mercados de real estate. Ou seja, a partir das referências qualitativas e quantitativas, necessidades operacionais e estratégias da empresa adiante os decisores priorizam os critérios do [MAOI] para cada imóvel;

[iv] compara-se a [alternativa] indicada pelo [MAOI] com a situação atual de cada imóvel. Nesta comparação serão avaliadas as intervenções no portfolio para os imóveis em que a [alternativa] indicada pelo [MAOI] for diferente da adotada pela empresa;

[v] para os imóveis em que a empresa é proprietária e o [MAOI] indicar uma das [alternativas] de não imobilização, é necessário repetir o cálculo de todos os indicadores do [MAOI], agora considerando a situação atual do ativo no balanço (ou seja, o lucro contabilizado na venda e os dados de registro do ativo) para análise da desmobilização patrimonial do ativo. Esta análise pode indicar que, mesmo o decisor optando pela não imobilização, promover o SLB pode não ser muito vantajoso, em função dos impostos pagos no início do fluxo e do pouco impacto que o ativo já causa no balanço a depender de quanto tempo o imóvel foi adquirido e do seu estado de obsolescência ${ }^{143}$.

${ }^{142}$ Nada impede do planejador usuário do [MAOI] analisar diretamente a [alternativa]-SLB para os imóveis de propriedade da empresa. Entretanto, será uma análise mais simplista e com vieses que podem interferir na priorização dos critérios, principalmente tratando-se dos critérios quantitativos.

${ }^{143} \mathrm{Na}$ análise do SLB é o decisor da empresa que avalia se o imóvel continuará atendendo suas demandas operacionais durante o horizonte de uso planejado do imóvel. Cabe ao planejador apenas 


\subsection{Aplicação do [MAOI] para o Imóvel 1 (SEDE ADMINISTRATIVA)}

O imóvel 1 é a sede da empresa, onde estão concentradas as áreas administrativas e a área comercial. Para realizar esta atividade a empresa utiliza $11.139 \mathrm{~m}^{2}$ de área construída ${ }^{144}$. Para este imóvel o horizonte de uso é de 20 anos a partir da data da entrevista (julho de 2010). O laudo de avaliação feito recentemente pela empresa indicou um valor de mercado de 41.500 R\$ mil da base para o imóvel 1. Para efeito de análise, considera-se que este valor é fair e, portanto, corresponde ao CGA para este imóvel.

Para identificar qual seria o intervalo de valor de locação para o imóvel 1, que corresponde ao seu CCGA, aplica-se a rotina de cálculo do VOI deste empreendimento, conforme detalhado no item 6.1.1, porém de forma inversa, ou seja, a partir de conhecido o VOI arbitra-se as faixas de valores para as variáveis de entrada do modelo de modo a resultar em um intervalo de VOI que contenha o valor de transação de $41.500 \mathrm{R} \$$ mil da base.

São variáveis de entrada no modelo para cálculo de VOI e consequentemente do CCGA:

[i] TAT - arbitrada no intervalo [10\% - 11\%] equivalente ano efetiva acima do IGP. A arbitragem deste intervalo baseia-se na rentabilidade de fundos de investimento imobiliário contendo apenas um imóvel na carteira, e um único locatário.

[ii] TATs - arbitrada no intervalo [7,5\% - 8,0\%] equivalente ano efetiva acima do IGP. A arbitragem deste intervalo baseia-se na rentabilidade do fundo de investimento imobiliário Almirante Barroso, que tem um único imóvel em carteira ocupado pela Caixa Econômica Federal, por ser considerado como empreendimento do segmento classificado como isento de risco na geração de renda.

[iii] Horizonte de análise para cálculo de VOI: 20 anos.

[iv] Fator de reciclagem $(\alpha)$ equivalente a 75\% (fator considerado para investimento em reciclagem do empreendimento no final do ciclo operacional).

[v] Correção dos preços de locação a cada 12 meses ao índice IGP-M. A inflação considerada está no intervalo $[3,5 \%-5,0 \%]$ ao ano.

identificar as referências qualitativas e quantitativas do [MAOI] para o imóvel, as quais são priorizadas pelo decisor em função das suas demandas e estratégias.

${ }^{144}$ A empresa apresentou apenas as áreas construídas dos imóveis. No entanto, isto não altera os cálculos dos indicadores, apenas torna-se mais difícil comparar os preços de locação dos imóveis com preços de mercado, que em geral são expressos em $\mathrm{R} \$$ por $\mathrm{m}^{2}$ de área privativa. 
[vi] Os impostos sobre a receita são de $14,53 \%$.

[vii] Os custos operacionais e FRA somam 5\% sobre a receita bruta.

[viii] Como se trata de um edifício administrativo de padronização comum, para efeito de análise de VOI considera-se um período de estabilização do empreendimento de dois anos, sendo $50 \%$ de ocupação no primeiro ano de operação, $75 \%$ no segundo ano e $100 \%$ de ocupação a partir do terceiro ano de operação ${ }^{145}$.

A partir destas variáveis: [i], [ii], [iii], [iv], [v], [vi], [vii] e [viii], as quais são iguais para os demais imóveis da empresa do caso, arbitra-se o intervalo para os preços de locação até que o intervalo de VOI contenha o valor de transação deste imóvel. Neste caso, o preço de locação no intervalo [485 - 529] R $\$$ mil por mês resulta no intervalo [41.427 - 42.323] R \$ mil da base para VOI, conforme indicam o Gráfico 13 e a Tabela 30. Este intervalo contempla o valor de transação equivalente a $41.500 \mathrm{R} \$$ mil da base apresentado no laudo de avaliação fornecido pela empresa.

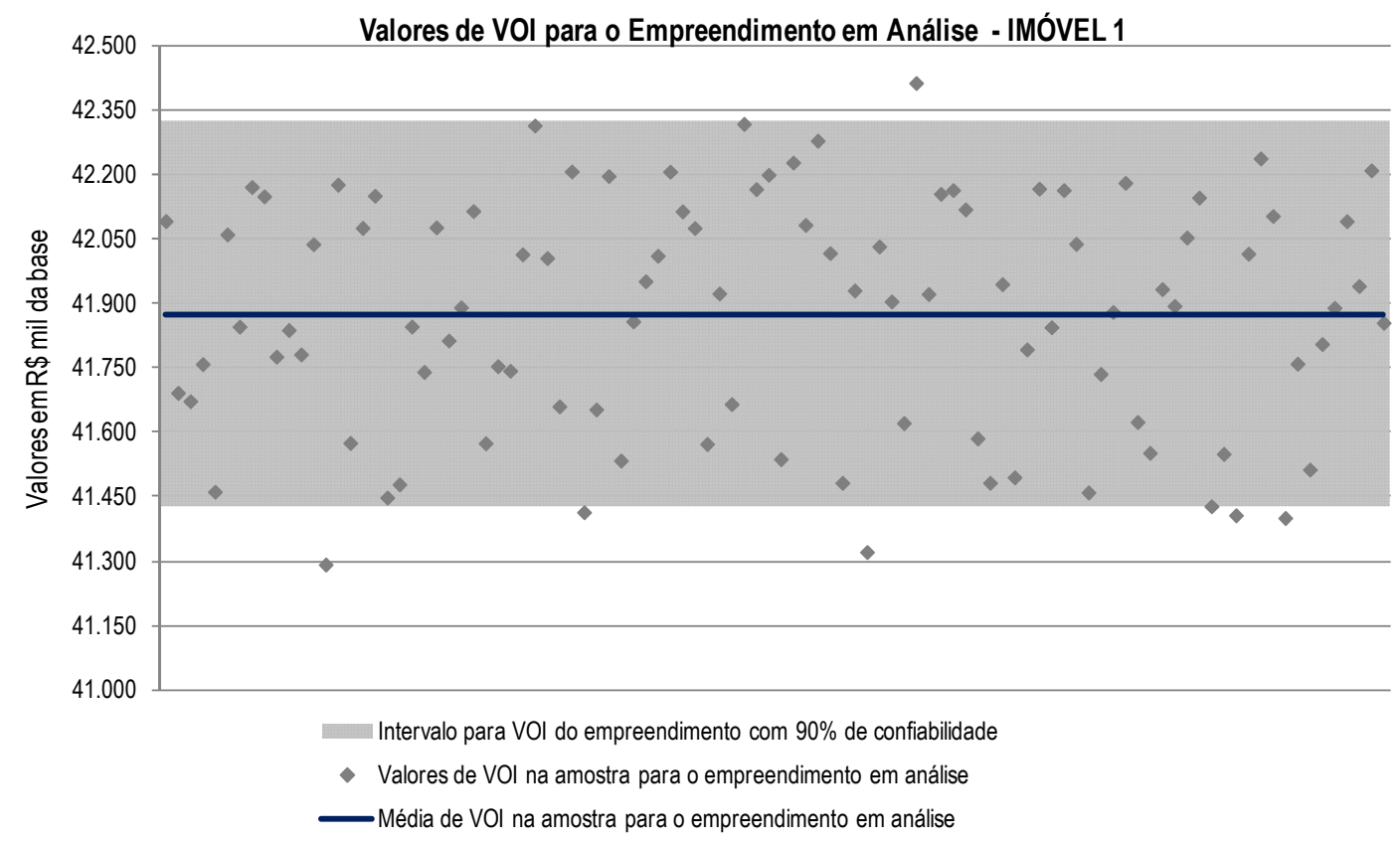

Gráfico 13 - Intervalo de VOI para o Imóvel 1 da empresa do caso

145 Para os demais imóveis, que necessariamente são monousuários, considera-se para efeito de análise do VOI do empreendimento $100 \%$ de ocupação já no primeiro ano de operação. Ou seja, a empresa ocuparia todo o imóvel quando pronto para operação. 
Intervalos de Valor para: VOI, Participação de VOIn e TIR (investidor) - IMÓVEL 1

\begin{tabular}{c|c|c|c|c}
\multicolumn{5}{c}{ (Cenário Referencial) } \\
\hline \multirow{2}{*}{ Indicadores } & \multirow{2}{*}{ Média } & \multirow{2}{*}{ Desvio } & \multicolumn{2}{|c}{ Fronteiras da Amostra* } \\
\cline { 4 - 5 } & & & Inferior & Superior \\
\hline VOI (em R\$ mil da base) & 41.875 & 272 & 41.427 & 42.323 \\
\hline Participação de VOIn & $12,0 \%$ & $0,1 \%$ & $11,9 \%$ & $12,2 \%$ \\
\hline TIR (\% ao ano efetiva acima do IGP) & $10,5 \%$ & $0,1 \%$ & $10,3 \%$ & $10,6 \%$ \\
\hline
\end{tabular}

${ }^{*} 90 \%$ de confiabilidade do indicador se situar entre estas fronteiras

NOTA: estes indicadores são medidos em amostras de laboratório diferentes.

Nesse sentido, as fronteiras dos intervalos não representam pares de valores.

Tabela 30 - Intervalos de Valor para VOI, Participação de VOI $_{n}$ e TIR - Imóvel 1

A Tabela 31 apresenta os dados do imóvel 1 considerados para cálculo das referências quantitativas do [MAOI], bem como os parâmetros do decisor da empresa do caso para qualificar os indicadores dos critérios quantitativos.

\begin{tabular}{|c|c|c|c|}
\hline \multicolumn{4}{|c|}{$\begin{array}{c}\text { DADOS DO IMÓVEL } 1 \text { (SEDE ADMINISTRATIVA) - ESTUDO DO CASO } \\
\text { Valores em R\$ mil da base }\end{array}$} \\
\hline Tipologia e Atividades: & \multicolumn{3}{|c|}{$\begin{array}{l}\text { Edifício de Escritórios, com maior parte do imóvel ocupada pela administração e área } \\
\text { comercial da Empresa. }\end{array}$} \\
\hline Área Construída & 11.139 & $m^{2}$ & \\
\hline Horizonte de uso (n) & 20 & anos & \\
\hline $\begin{array}{l}\text { Valor de Transação (CGA) } \\
\text { Valor do Terreno }\end{array}$ & $\begin{array}{l}41.500 \\
12.224\end{array}$ & Valores infor & los pela empresa a partir de laudo de avaliação \\
\hline Preço de Locação (CCGA) & $\begin{array}{l}\text { Superior } \\
485\end{array}$ & $\begin{array}{c}\text { Inferior } \\
529\end{array}$ & $\begin{array}{l}\text { (faixas encontradas pela rotina de cálculo do VOI) } \\
\mathrm{R} \$ \text { mil por mês sem ajuste no ciclo de } 1 \text { ano }\end{array}$ \\
\hline $\begin{array}{r}\text { Instrumento Jurídico Preferido } \\
\text { PARÂMETROS }\end{array}$ & \multicolumn{3}{|c|}{ Contrato de Locação } \\
\hline $\begin{array}{l}\text { Renda Relativa do Capital de } \\
\text { Giro Ativado }\end{array}$ & $\begin{array}{l}\text { Mínimo de } \\
8 \% \text { ao ano }\end{array}$ & $\begin{array}{l}\text { parâmetro d } \\
\text { não imobilizo }\end{array}$ & $\begin{array}{l}\text { erência para a renda relativa gerada pelas [alternativas] de } \\
\text { ou imobilzação a prazo }\end{array}$ \\
\hline $\begin{array}{l}\text { Acréscimo no resultado } \\
\text { corporativo }\end{array}$ & $\begin{array}{l}\text { Mínimo de } \\
4 \% \text { ao ano }\end{array}$ & $\begin{array}{l}\text { parâmetro d } \\
\text { pelas [alterna }\end{array}$ & $\begin{array}{l}\text { erência para o acréscimo do resultado corporativo gerado } \\
\text { s] de não imobilização ou imobilzação a prazo }\end{array}$ \\
\hline Impacto no Balanço & $\begin{array}{c}\text { Até } 80 \% \\
>1,0 \\
>10.000 \mathrm{R} \$ \text { mil }\end{array}$ & $\begin{array}{l}\text { PTRT } \\
\text { ILC } \\
\text { CGL }\end{array}$ & $\begin{array}{l}\text { manter o PTRT inferior a } 80 \% \\
\text { manter o ILC superior a } 1,0 \\
\text { manter o CGL superior a } 10.000 \mathrm{R} \$ \text { mil }\end{array}$ \\
\hline Economia Tributária & $\begin{array}{c}7.000 \\
\mathrm{R} \$ \text { mil da base }\end{array}$ & $\begin{array}{l}\text { parâmetro d } \\
\text { [alternativas] }\end{array}$ & $\begin{array}{l}\text { erência para a diferença entre a economia tributária das } \\
\text { ão imobilização e a economia tributária da imobilização }\end{array}$ \\
\hline \multicolumn{4}{|c|}{ SITUAÇĀO ATUAL DO IMÓVEL 1 (SEDE ADMINISTRATIVA) } \\
\hline Vida Útil Remanescente & 0 & imóvel totaln & e depreciado \\
\hline Valor de Registro & 247 & & \\
\hline
\end{tabular}

Tabela 31 - Dados do Imóvel 1 para cálculo das referências quantitativas do [MAOI] 


\subsubsection{Referências Quantitativas do [MAOI] para o Imóvel 1}

Com base nos dados do imóvel 1 e nas demandas da empresa do caso em relação a este imóvel, identifica-se os indicadores do [MAOI] para cada uma das [alternativas].

\subsubsection{Canalização de recursos em oportunidades do negócio principal - [Critério G]}

A renda gerada a partir do investimento no montante equivalente ao CGA de $41.500 \mathrm{R} \$$ mil da base no negócio principal da empresa está no intervalo [866 - 936] R\$ mil por mês, considerando o ROE no intervalo [2,09\% - 2,26\%] equivalente ao mês, de acordo com o desempenho histórico da empresa. Para gerar esta renda, a empresa tem o CCGA referente ao pagamento dos aluguéis no intervalo [485 - 529] R\$ mil por mês.

Estas variáveis aplicadas de forma randômica no modelo, resultam no saldo (p), encontrado pela diferença entre RCGA e CCGA. Este saldo (p) gerado pelo investimento equivalente ao CGA do imóvel 1 (41.500 R\$ mil da base), gera a RRCGA referente a este imóvel para as [alternativas] de não imobilização ${ }^{146}$. O Gráfico 14 apresenta o intervalo de valor da RRCGA para este imóvel, assim como a amostra de laboratório calculada para este indicador em cenários estressados (com perturbação sem compensação no ROE da empresa na faixa [0\% a 20\%] de desempenho).

146 Tanto a RCGA como o CCGA são reajustados anualmente pelo IGP-M. No estudo do caso a inflação também é aplicada em intervalo $[3,5 \%$ - 5,0\%] ao ano, encontrada de forma randômica no modelo para cada período do horizonte de análise. 


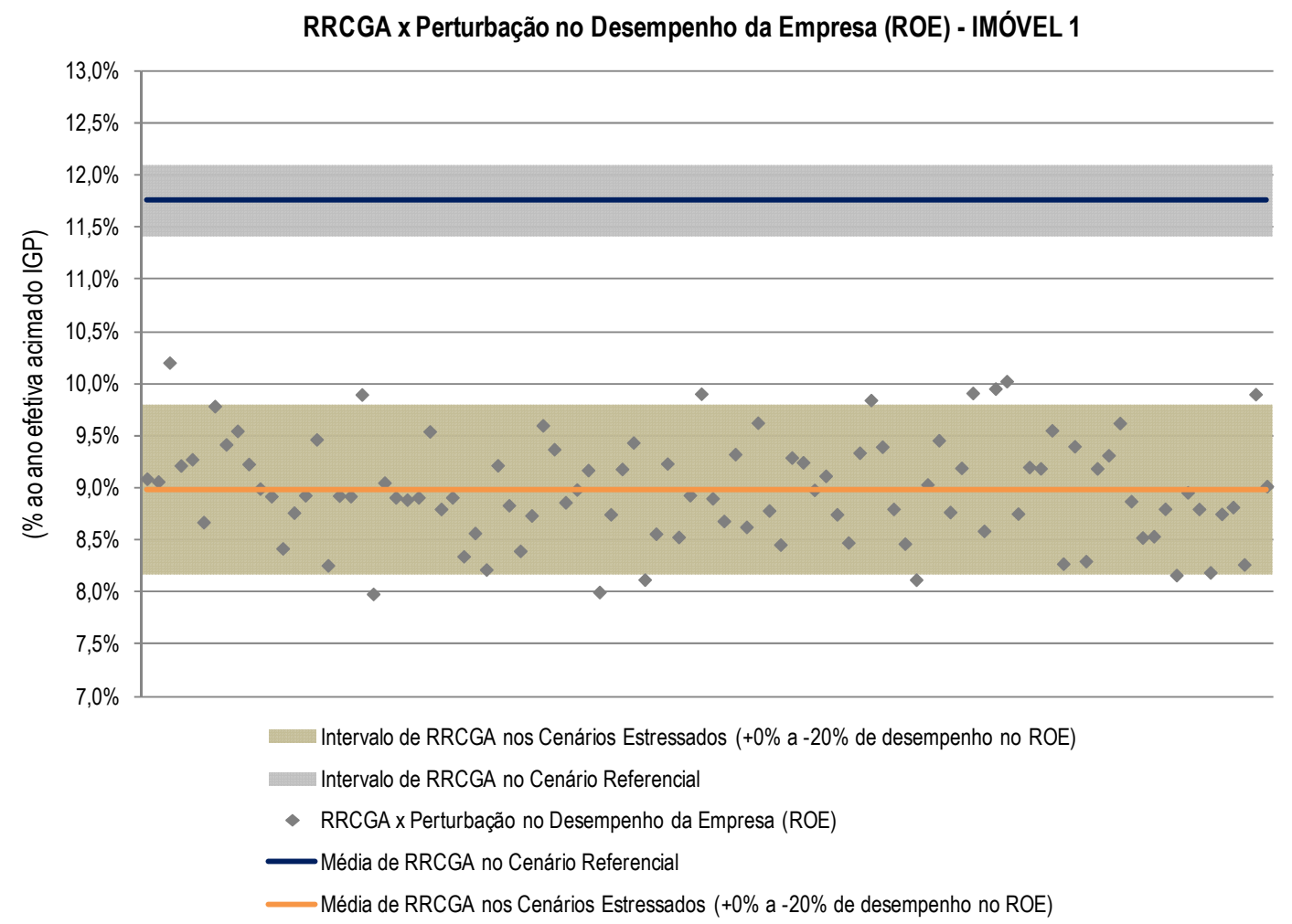

Gráfico 14 - Intervalos de valor da RRCGA para o Imóvel 1

Na Tabela 32 estão demonstrados os intervalos de valor dos indicadores RRCGA e ARC para as [alternativas] de não imobilização, conforme cenário referencial. É possível verificar que a RRCGA está acima do parâmetro desejado pelo decisor (com mínimo estipulado em $8 \%$ ao ano efetiva acima do IGP para compensar a escolha pela não imobilização ou o endividamento na imobilização a prazo). O acréscimo no resultado corporativo é de $4,20 \%$ ao ano na média da amostra, também acima do parâmetro de referência entendido como satisfatório para o decisor.

CRITÉRIO G - IMÓVEL 1 (SEDE ADMINISTRATIVA)
\begin{tabular}{c|r|r|r|r}
\hline Intervalos de Valor dos Indicadores: RRCGA e ARC \\
(Cenário Referencial) \\
\hline $\begin{array}{c}\text { Indicadores } \\
\text { [Alternativas]: BTS, LLP e LCP }\end{array}$ & \multicolumn{1}{c}{ Média } & Desvio & \multicolumn{1}{c}{ Fronteiras da Amostra* } \\
\cline { 4 - 6 } & & & Inferior & \multicolumn{1}{c}{ Superior } \\
\hline RRCGA(\% ao ano efetiva acima do IGP) & $11,76 \%$ & $0,21 \%$ & $11,41 \%$ & $12,10 \%$ \\
\hline RCGA (R\$ mil da base/ano) & 10.581 & 70 & 10.466 & 10.695 \\
\hline Saldo(p): RCGA- CCGA (em R \$ mil da base/ano) & 4.635 & 79 & 4.505 & 4.765 \\
\hline ARC (\% ao ano) & $4,20 \%$ & $0,07 \%$ & $4,08 \%$ & $4,32 \%$ \\
\hline
\end{tabular}

\footnotetext{
${ }^{*} 90 \%$ de confiabilidade do indicador se situar entre estas fronteiras

NOTA: estes indicadores são medidos em amostras de laboratório diferentes.
}

Nesse sentido, as fronteiras dos intervalos não representam pares de valores.

Tabela 32 - Intervalos de Valor dos Indicadores RRCGA e ARC no Cenário Referencial - Imóvel 1 
$\mathrm{Na}$ Tabela 33 demonstra-se os intervalos de valor para os indicadores RRCGA e ARC conforme cenários estressados (perturbação sem compensação no ROE). Pela análise de risco é possível verificar que mesmo o ROE sofrendo perturbação de forma randômica até $-20 \%$ de desempenho, ainda os indicadores mostram-se atrativos, conforme parâmetro determinado pelo decisor (o ARC está um pouco abaixo do parâmetro de referência mais ainda muito próximo, mesmo em cenários estressados).

\begin{tabular}{|c|c|c|c|c|}
\hline \multicolumn{5}{|c|}{ CRITÉRIO G - IMÓVEL 1 (SEDE ADMINISTRATIVA) } \\
\hline \multicolumn{5}{|c|}{ Intervalos de Valor dos Indicadores: RRCGA e ARC } \\
\hline \multicolumn{5}{|c|}{ (Desvio de ROE - faixa: + 0\% a -20\%) } \\
\hline \multirow{2}{*}{$\begin{array}{c}\text { Indicadores } \\
\text { [Alternativas]: BTS, LLP e LCP }\end{array}$} & \multirow{2}{*}{ Média } & \multirow{2}{*}{ Desvio } & \multicolumn{2}{|c|}{ Fronteiras da Amostra* } \\
\hline & & & Inferior & Superior \\
\hline RRCGA (\% ao ano efetiva acima do IGP) & $8,98 \%$ & $0,50 \%$ & $8,16 \%$ & $9,80 \%$ \\
\hline RCGA(R\$ mil da base/ano) & 9.528 & 189 & 9.217 & 9.838 \\
\hline Saldo(p): RCGA - CCGA (em R $\$$ mil da base/ano) & 3.581 & 191 & 3.267 & 3.895 \\
\hline ARC (\% ao ano) & $3,25 \%$ & $0,17 \%$ & $2,96 \%$ & $3,53 \%$ \\
\hline
\end{tabular}

${ }^{*} 90 \%$ de confiabilidade do indicador se situar entre estas fronteiras

NOTA: estes indicadores são medidos em amostras de laboratório diferentes.

Nesse sentido, as fronteiras dos intervalos não representam pares de valores.

Tabela 33 - Intervalos de Valor dos Indicadores RRCGA e ARC nos Cenários Estressados - Imóvel 1

Para analisar os indicadores referentes ao [Critério G] na opção pela imobilização a prazo é preciso conhecer as condições de financiamento do imóvel, conforme linhas de crédito obtidas pela empresa do caso.

Para este imóvel e os imóveis 2, 3, 5 e 6, considera-se a seguinte linha de crédito para análise dos indicadores da [alternativa] - SP a Prazo ${ }^{147}$ :

[i] parcela financiada do imóvel: $50 \%$ do valor de transação;

[ii] juros de $13 \%$ ao ano;

[iii] prazo de amortização: 7 anos.

Como existem diferentes formas de pagamento do principal e juros, para efeito de análise

147 Estas condições foram definidas pela empresa do caso. Também são realizados testes de sensibilidade nestas condições de financiamento para avaliar o impacto no indicador: RRIP. Quanto ao imóvel 4, por ser um complexo industrial de grande porte, que gerará empregos no município onde se instala, entre outros benefícios à sociedade, a empresa consegue uma linha especial no BNDES com juros de TJLP (Taxa de Juros de Longo Prazo) $+3 \%$ ao ano, 8 anos de prazo de amortização e até $40 \%$ de financiamento em relação ao investimento total no imóvel. 
considera-se para todos os imóveis o sistema Price de amortização.

A partir destas condições de financiamento o CGA na opção pela imobilização a prazo para investimento no negócio principal da empresa é de $20.750 \mathrm{R} \$$ mil da base, que aplicado ao ROE no intervalo $[2,09 \%-2,26 \%$ ] equivalente ao mês, gera uma renda mensal no intervalo [433 - 468] R\$ mil, aplicada de forma randômica no fluxo composto por esta [alternativa]. Para gerar esta renda a empresa tem como custo as parcelas do financiamento durante 84 meses no valor de $369 \mathrm{R} \$$ mil, e a perda de oportunidade de ganho referente à parcela não financiada do imóvel (20.750 R\$ mil da base) que deixa de gerar ROE, resultando em uma perda de oportunidade de ganho no intervalo [433 - 468] R\$ mil por mês durante todo o fluxo do horizonte de análise.

Além da renda mensal gerada no intervalo [433 - 468] R \$ mil, tem-se como elementos de entrada no fluxo da [alternativa] - SP a Prazo: [i] o custo virtual que a empresa deixa de pagar com os aluguéis no intervalo [485 - 529] $\mathrm{R} \$$ mil por mês durante o horizonte de uso do imóvel, e [ii] o $\mathrm{VOI}_{\mathrm{n}}$ no valor de $36.872 \mathrm{R} \$$ mil da base no final do ciclo de análise.

A partir do fluxo gerado pelas entradas e saídas de recursos desta [alternativa], conforme valores apresentados, encontra-se a RRIP para o imóvel 1. Pelo Gráfico 15 é possível verificar o intervalo de valor para a RRIP conforme cenário referencial e a RRIP na amostra de laboratório para os cenários estressados.

Verifica-se que esta [alternativa] - SP a Prazo não atende aos parâmetros mínimos desejados pelo decisor mesmo para o cenário referencial adotado, que resulta em uma RRIP no intervalo $[3,70 \%-4,27 \%]$ ao ano efetiva acima do IGP e um ARC no intervalo [1,37\% - 1,58\%] ao ano, conforme Tabela 34. Os indicadores para os cenários estressados, apresentados na Tabela 35, estão bem inferiores aos parâmetros desejados pelo decisor, com RRIP no intervalo $[2,19 \%-3,07 \%]$ ao ano efetiva acima do IGP e ARC no intervalo $[0,82 \%-1,14 \%]$ ao ano. 


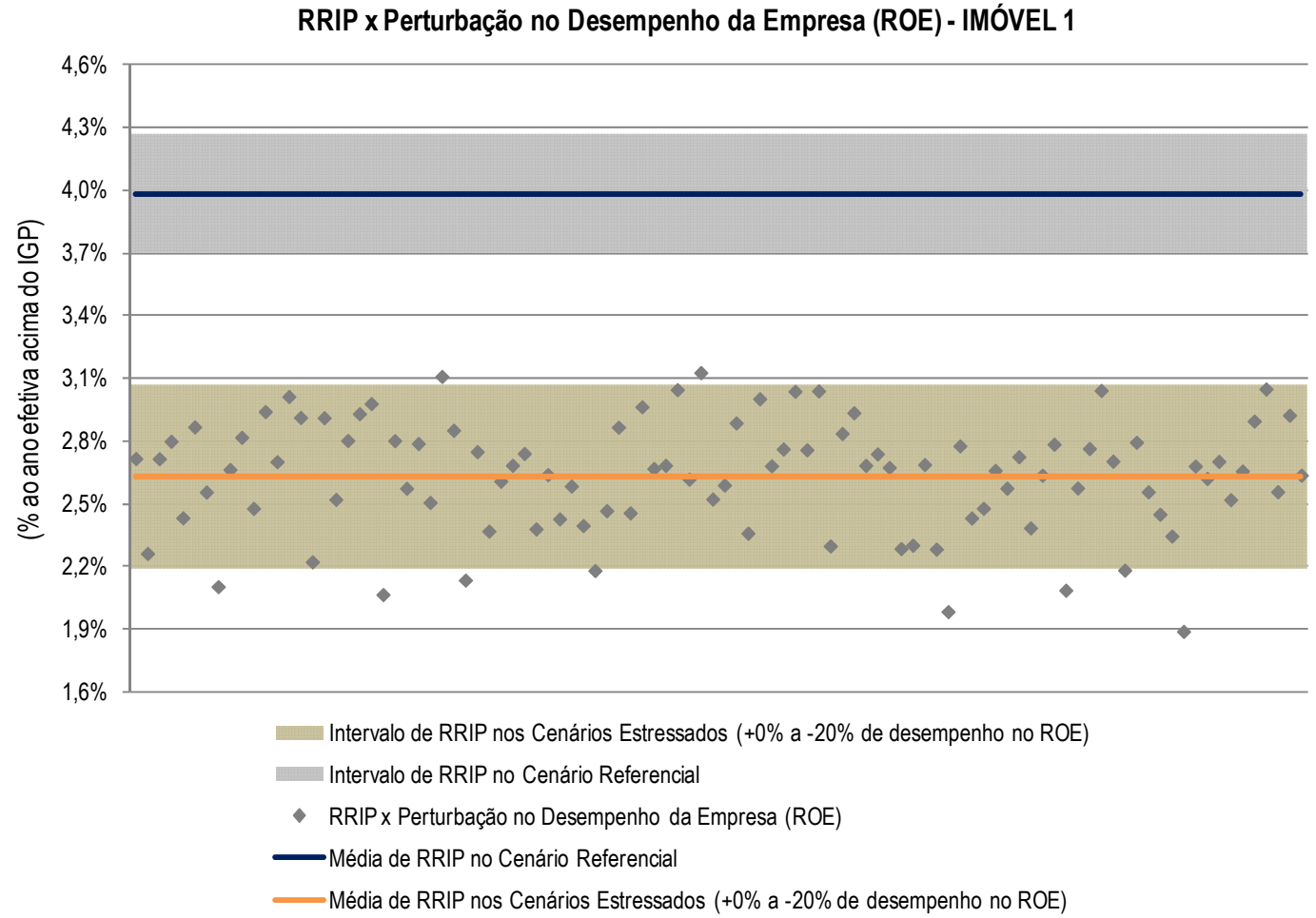

Gráfico 15 - Intervalos de valor da RRIP (Renda Relativa na Imobilização a Prazo) para o Imóvel 1

\begin{tabular}{|c|c|c|c|c|}
\hline \multicolumn{5}{|c|}{ CRITÉRIO G - IMÓVEL 1 (SEDE ADMINISTRATIVA) } \\
\hline \multicolumn{5}{|c|}{ Intervalos de Valor dos Indicadores: RRIP, TRIP e ARC } \\
\hline \multicolumn{5}{|c|}{ (Cenário Referencial) } \\
\hline \multirow{2}{*}{$\begin{array}{c}\text { Indicadores } \\
\text { [Alternativa]: SP a prazo }\end{array}$} & \multirow{2}{*}{ Média } & \multirow{2}{*}{ Desvio } & \multicolumn{2}{|c|}{ Fronteiras da Amostra* } \\
\hline & & & Inferior & Superior \\
\hline RRIP (\% ao ano efetiva acima do IGP) & $3,98 \%$ & $0,17 \%$ & $3,70 \%$ & $4,27 \%$ \\
\hline RCGA (R\$ mil da base/ano) & 5.292 & 37 & 5.230 & 5.353 \\
\hline Saldo P' (R\$ mil da base/ano) & 1.624 & 70 & 1.509 & 1.738 \\
\hline ARC (\% ao ano) & $1,47 \%$ & $0,06 \%$ & $1,37 \%$ & $1,58 \%$ \\
\hline TRIP (\% ao ano efetiva acima do IGP) & $9,28 \%$ & $0,04 \%$ & $9,22 \%$ & $9,34 \%$ \\
\hline Participação VOIn & $15,10 \%$ & $0,11 \%$ & $14,93 \%$ & $15,27 \%$ \\
\hline
\end{tabular}

${ }^{*} 90 \%$ de confiabilidade do indicador se situar entre estas fronteiras

NOTA: estes indicadores são medidos em amostras de laboratório diferentes.

Nesse sentido, as fronteiras dos intervalos não representam pares de valores.

Tabela 34 - Intervalos de valos dos indicadores RRIP, TRIP e ARC no Cenário Referencial - Imóvel 1 


\begin{tabular}{|c|c|c|c|c|}
\hline \multicolumn{5}{|c|}{ CRITÉRIO G - IMÓVEL 1 (SEDE ADMINISTRATIVA) } \\
\hline \multicolumn{5}{|c|}{ Intervalos de Valor dos Indicadores: RRIP, TRIP e ARC } \\
\hline \multicolumn{5}{|c|}{ (Desvio de ROE - faixa: + 0\% a -20\%) } \\
\hline \multirow{2}{*}{$\begin{array}{c}\text { Indicadores } \\
\text { [Alternativa]: SP a prazo }\end{array}$} & \multirow{2}{*}{ Média } & \multirow{2}{*}{ Desvio } & \multicolumn{2}{|c|}{ Fronteiras da Amostra* } \\
\hline & & & Inferior & Superior \\
\hline RRIP (\% ao ano efetiva acima do IGP) & $2,63 \%$ & $0,27 \%$ & $2,19 \%$ & $3,07 \%$ \\
\hline RCGA(R\$ mil da base/ano) & 4.752 & 90 & 4.605 & 4.900 \\
\hline Saldo $\mathrm{P}^{\prime}(\mathrm{R} \$$ mil da base/ano) & 1.079 & 108 & 901 & 1.257 \\
\hline ARC (\% ao ano) & $0,98 \%$ & $0,10 \%$ & $0,82 \%$ & $1,14 \%$ \\
\hline TRIP (\% ao ano efetiva acima do IGP) & $8,13 \%$ & $0,06 \%$ & $8,03 \%$ & $8,23 \%$ \\
\hline Participação VOIn & $18,66 \%$ & $0,20 \%$ & $18,33 \%$ & $19,00 \%$ \\
\hline
\end{tabular}

${ }^{*} 90 \%$ de confiabilidade do indicador se situar entre estas fronteiras

NOTA: estes indicadores são medidos em amostras de laboratório diferentes.

Nesse sentido, as fronteiras dos intervalos não representam pares de valores.

Tabela 35 - Intervalos de valos dos indicadores RRIP, TRIP e ARC nos Cenários Estressados - Imóvel 1

A Tabela 36 demonstra os testes de sensibilidade da RRIP para diferentes condições de financiamento do imóvel 1. A RRIP somente se situaria acima do parâmetro desejado pelo decisor ( $8 \%$ ao ano efetiva acima do IGP) caso a parcela financiada do imóvel 1 correspondesse a mais de $65 \%$ para um juros de até $14 \%$ ao ano. Em relação aos prazos de amortização, para prazos superiores a 10 anos e parcela financiada superior a 60\%, a RRIP já se situaria acima do parâmetro desejado pelo decisor. Porém, caso a empresa apenas consiga financiar por um prazo de 5 anos, a parcela financiada do imóvel 1 deveria ser superior a 80\% para resultar em uma RRIP acima de $8 \%$ ao ano.

\begin{tabular}{|c|c|c|c|c|c|c|c|}
\hline & & \multicolumn{6}{|c|}{ Variação da Taxa de Juros (\% ao ano nominal) } \\
\hline & & $11 \%$ & $12 \%$ & $13 \%$ & $14 \%$ & $15 \%$ & $16 \%$ \\
\hline \multirow{11}{*}{ 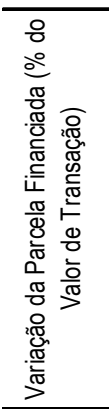 } & $100 \%$ & $21,77 \%$ & $21,30 \%$ & $20,78 \%$ & $20,28 \%$ & $19,14 \%$ & $18,75 \%$ \\
\hline & $95 \%$ & $19,92 \%$ & $19,15 \%$ & $18,90 \%$ & $18,15 \%$ & $17,84 \%$ & $17,31 \%$ \\
\hline & $90 \%$ & $18,20 \%$ & $17,52 \%$ & $17,10 \%$ & $16,71 \%$ & $16,23 \%$ & $15,17 \%$ \\
\hline & $85 \%$ & $16,27 \%$ & $15,67 \%$ & $15,38 \%$ & $14,75 \%$ & $14,24 \%$ & $13,98 \%$ \\
\hline & $80 \%$ & $14,55 \%$ & $14,46 \%$ & $13,59 \%$ & $13,23 \%$ & $12,73 \%$ & $12,15 \%$ \\
\hline & $75 \%$ & $13,25 \%$ & $12,71 \%$ & $11,99 \%$ & $11,17 \%$ & $10,99 \%$ & $10,61 \%$ \\
\hline & $70 \%$ & $11,39 \%$ & $10,69 \%$ & $10,40 \%$ & $9,75 \%$ & $9,24 \%$ & $8,91 \%$ \\
\hline & $65 \%$ & $9,18 \%$ & $9,31 \%$ & $8,67 \%$ & $8,47 \%$ & $7,71 \%$ & $7,40 \%$ \\
\hline & $60 \%$ & $7,81 \%$ & $7,37 \%$ & $7,27 \%$ & $6,73 \%$ & $6,32 \%$ & $6,03 \%$ \\
\hline & $55 \%$ & $6,18 \%$ & $5,96 \%$ & $5,40 \%$ & $5,10 \%$ & $4,76 \%$ & $4,35 \%$ \\
\hline & $50 \%$ & $4,53 \%$ & $4,15 \%$ & $3,81 \%$ & $3,87 \%$ & $3,36 \%$ & $3,09 \%$ \\
\hline \multicolumn{8}{|c|}{\begin{tabular}{l|} 
Testes de Sensibilid \\
\end{tabular}} \\
\hline & & 15 & 12 & 10 & 8 & 7 & 5 \\
\hline \multirow{7}{*}{ 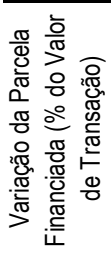 } & $100 \%$ & $28,63 \%$ & $26,86 \%$ & $25,47 \%$ & $22,33 \%$ & $20,83 \%$ & $14,21 \%$ \\
\hline & $90 \%$ & $24,13 \%$ & $22,43 \%$ & $20,95 \%$ & $18,70 \%$ & $17,27 \%$ & $11,72 \%$ \\
\hline & $80 \%$ & $19,77 \%$ & $18,56 \%$ & $17,16 \%$ & $15,40 \%$ & $14,00 \%$ & $9,00 \%$ \\
\hline & $70 \%$ & $15,67 \%$ & $14,55 \%$ & $13,35 \%$ & $11,91 \%$ & $10,69 \%$ & $6,64 \%$ \\
\hline & $60 \%$ & $11,65 \%$ & $10,48 \%$ & $9,64 \%$ & $8,19 \%$ & $6,95 \%$ & $3,77 \%$ \\
\hline & $55 \%$ & $9,36 \%$ & $8,92 \%$ & $7,99 \%$ & $6,76 \%$ & $5,25 \%$ & $2,46 \%$ \\
\hline & $50 \%$ & $7,30 \%$ & $6,94 \%$ & $6,08 \%$ & $5,10 \%$ & $4,18 \%$ & $1,37 \%$ \\
\hline
\end{tabular}

Tabela 36 - Testes de sensibilidade para a RRIP em função de variações nas condições do financiamento para aquisição do Imóvel 1 
A partir dos indicadores apresentados para o [Critério G] pontua-se as notas no Nível 3 do AHP para este critério (Matriz das [alternativas] - [Critério G]).

Como se verifica pelos indicadores apresentados, as [alternativas] de não imobilização geram indicadores mais atrativos e acima do estipulado como parâmetro mínimo desejado pelo decisor, conferindo, portanto, nas ponderações de notas de atendimento das [alternativas] feita comparativamente par a par entre elas como demonstrado no Quadro 16. A matriz de comparação gerada a partir das ponderações do Quadro 16 está ilustrada na Tabela 37, que resulta nos pesos relativos das [alternativas] para o [Critério G] apresentados no Gráfico $16^{148}$.

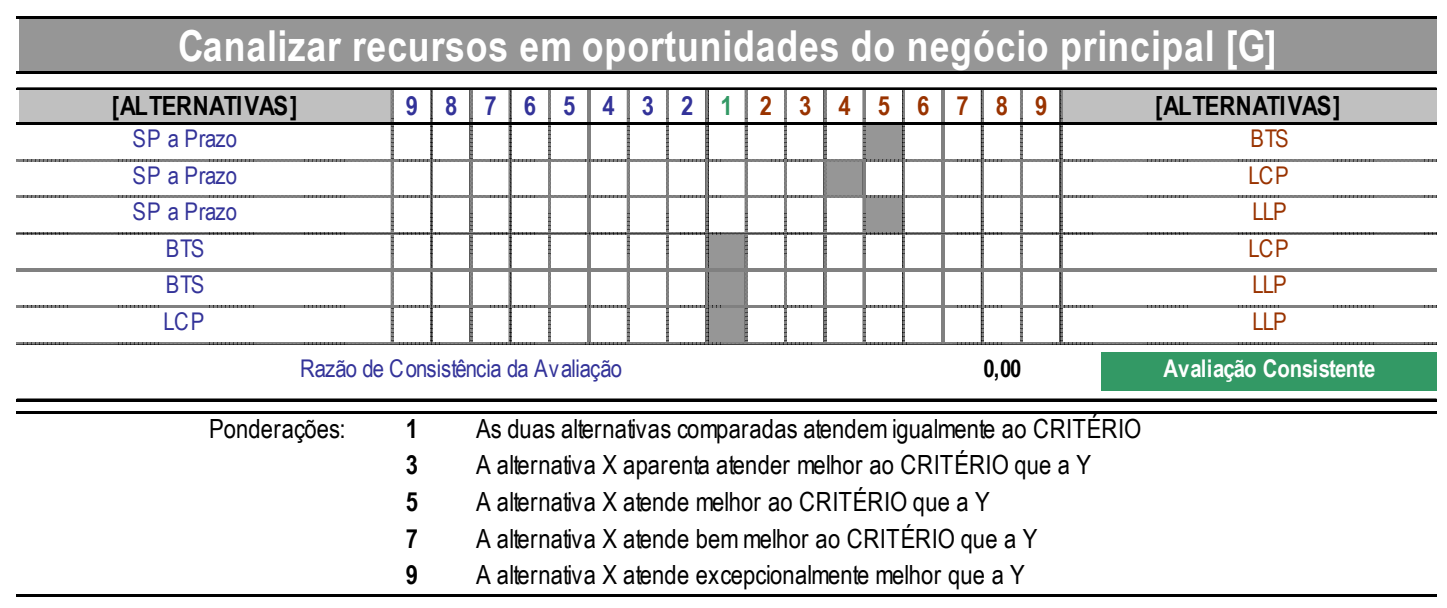

Quadro 16 - Ponderação de notas de atendimento para o [Critério G] - Imóvel 1

\begin{tabular}{ccccc}
\hline \multicolumn{5}{c}{ MATRIZ DE COMPARAÇÃO - IMÓVEL 1 } \\
\hline $\begin{array}{c}\text { Canalizar recursos em } \\
\text { oportunidades do } \\
\text { negócio principal [G] }\end{array}$ & SP a Prazo & BTS & LCP & LLP \\
\hline SP a Prazo & 1 & 0,20 & 0,25 & 0,20 \\
\hline BTS & 5,00 & 1 & 1,00 & 1,00 \\
\hline LCP & 4,00 & 1,00 & 1 & 1,00 \\
\hline LLP & 5,00 & 1,00 & 1,00 & 1 \\
\hline$\Sigma$ Pesos da Matriz [T] & 15,00 & 3,20 & 3,25 & 3,20 \\
\hline
\end{tabular}

Tabela 37 - Matriz de Comparação entre [alternativas] para o [Critério G] - Imóvel 1

148 A matriz de comparação para os demais critérios é feita da mesma forma, conforme rotina para aplicação do AHP apresentada no Capítulo 7. Portanto, não há necessidade de demonstrar a matriz de comparação para todos os critérios do [MAOI]. 
Perspectiva: Planejador (IMÓVEL 1) - CRITÉRIO G

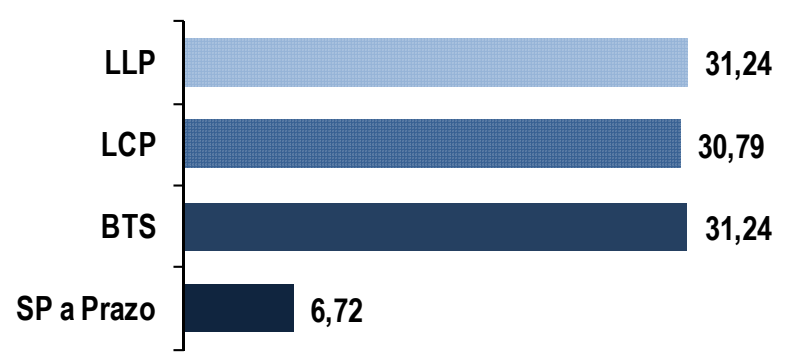

Gráfico 16 - Pesos relativos das [alternativas] para o critério - canalizar recursos em oportunidades do negócio principal [Critério G]: Imóvel 1

Como a [alternativa] - SP gera priores indicadores para os critérios quantitativos em relação à opção pela imobilização por meio de financiamento (SP a Prazo), e os critérios qualitativos são igualmente pontuados, considera-se no AHP a [alternativa] - SP a Prazo para representar a opção pela imobilização no imóvel ${ }^{149}$.

Para atribuição das notas das [alternativas] no [Critério G], considera-se que a [alternativa] - LCP geraria uma RRCGA mais próxima da fronteira inferior da amostra de laboratório, pois para contratos de menor prazo os preços de locação praticados tendem a ser ligeiramente superiores relativamente aos contratos de longo prazo (BTS e LLP). Por isso, a pontuação da [alternativa] - LCP em relação à [alternativa] - SP a Prazo está com nota 4, enquanto que para as [alternativas] - BTS e LLP está com nota 5 em relação à imobilização (SP a Prazo).

\subsubsection{Desoneração do Balanço - [Critério H]}

Para avaliar os impactos das [alternativas] no balanço da empresa a partir das demandas e características do imóvel, como se a análise fosse feita para um novo espaço corporativo com as mesmas demandas e características, é preciso entender como este imóvel está contabilizado no balanço. Antes de incluir as alterações no balanço para cada um das [alternativas],

149 Para a análise de novos espaços corporativos pode ocorrer do [MAOI] indicar a [alternativa] - SP a Prazo e a empresa não conseguir linhas de financiamento atrativas. Neste caso, a aplicação do [MAOI] pode ser refeita considerando os indicadores da opção pela imobilização à vista para ponderar a [alternativa] de imobilização no AHP. Como mencionado no capítulo 6, para o [Critério G] os indicadores da imobilização à vista são os mesmos das [alternativas] de não imobilização em valores absolutos, no entanto, como perda de oportunidade de ganho (POGI). Esta nova aplicação do [MAOI], considerando os indicadores da imobilização à vista, pode indicar novos pesos para as [alternativas] e talvez uma nova hierarquia entre elas. 
conforme demonstrado no item 6.3.3.5 para a situação modelo, encontra-se os índices financeiros do balanço de modo a não contemplar o imóvel 1.

Nesse sentido, como o imóvel 1 tem um valor de registro baixo (247 R \$ mil da base) e foi adquirido há muito tempo, o balanço quase não se altera quando é feita a baixo do ativo no imobilizado e patrimônio líquido. Esta premissa usada para efeito de análise pode ser considerada como uma postura conservadora, pois os resultados da empresa provavelmente seriam ainda melhores, refletindo também em melhores índices financeiros, se a empresa não imobilizasse no imóvel no passado e focasse os investimentos no seu negócio principal, conforme indicadores apresentados para o [Critério G] $]^{150}$.

A Tabela 38 apresenta os índices financeiros da empresa antes dos impactos nos grupos de contas do balanço para as [alternativas] referentes ao imóvel 1.

\begin{tabular}{|c|c|c|c|}
\hline \multicolumn{4}{|c|}{$\begin{array}{l}\text { Balanço - EMPRESA DO CASO - IMÓVEL } 1 \text { (SEDE ADMINISTRATIVA) } \\
\text { Análise das [Alternativas] a partir das demandas e características do imóvel } \\
\text { (com base no Balanço de Dezembro/2009 - Valores em R\$ mil) }\end{array}$} \\
\hline Ativo Total & 926.542 & \multirow{3}{*}{\multicolumn{2}{|c|}{$\begin{array}{l}\text { Índices de Liquidez, } \\
\text { Endividamento e Grau } \\
\text { de Imobilização }\end{array}$}} \\
\hline Ativo Circulante & 286.853 & & \\
\hline Disponibilidades & 41.285 & & \\
\hline Ativo não Circulante & 639.689 & ILC & 1,10 \\
\hline Ativo Realizável a Longo Prazo & 32.414 & ILI & 0,16 \\
\hline Ativo Imobilizado+Investimentos+Intangível & 607.275 & PTRT & 0,51 \\
\hline Passivo Total & 926.542 & PTPL & 1,04 \\
\hline Passivo Circulante & 261.618 & PECP & 0,55 \\
\hline Passivo Não Circulante (exigível a longo prazo) & 210.466 & GIPL & 1,34 \\
\hline Patrimônio Líquido & 454.458 & CGL & 25.235 \\
\hline
\end{tabular}

Tabela 38 - Índices financeiros da empresa para análise do impacto das [alternativas] em relação ao Imóvel 1 (Análise a partir das demandas e características do imóvel)

Para análise do impacto de cada [alternativa] no balanço e assim nos seus índices financeiros, introduz-se nas contas do ativo, passivo e patrimônio líquido, as alterações que o imóvel 1 causam para cada uma das [alternativas], considerando: [i] o valor de transação de 41.500 R \$

${ }^{150}$ Para os demais imóveis (2, 3, 5 e 6), exceto para o imóvel 4, que é o novo complexo industrial e ainda não está sendo depreciado, ocorrerá o mesmo, ou seja, como os valores de registro são baixos, quando é feita a baixa do ativo no imobilizado e patrimônio líquido o balanço permanece quase equivalente à situação atual. No entanto, para o imóvel 4, que apresenta alto volume de investimento e está em fase de implantação é preciso identificar junto à empresa do caso como este imóvel está sendo contabilizado no balanço, inclusive em relação aos desembolsos feitos recentemente, aumento da dívida, pagamentos do principal e juros já ocorridos, no intuito de encontrar um balanço mais próximo possível ao antes da entrada deste ativo. 
mil da base, [ii] a depreciação conforme método linear (4\% ao ano), [iii] a despesa com aluguéis no valor de $507 \mathrm{R} \$$ mil por mês e $6.082 \mathrm{R} \$$ mil por ano (média do intervalo [485 529] R\$ mil do CCGA), [iii] o pagamento das parcelas do financiamento no valor de 4.433 R \$ mil em cada exercício conforme condições já apresentadas, e [iv] a dívida com a parcela financiada do imóvel (20.750 R \$ mil). Estes elementos de cálculo são introduzidos no balanço de forma distinta para cada [alternativa], conforme apresentado para a situação modelo (item 6.3.3.5), o que gera diferentes impactos nos índices financeiros da empresa ${ }^{151}$.

Como é possível observar na Tabela 38 a empresa possui $10 \%$ a mais de ativos circulantes em relação às obrigações de curto prazo (passivo circulante). Em relação às disponibilidades, a empresa consegue cumprir com $16 \%$ das obrigações de curto prazo com seus ativos de alta liquidez (caixas e títulos negociáveis). A folga financeira da empresa avaliada pelo CGL aponta uma sobra de $25.235 \mathrm{R} \$$ mil, que equivale ao resultado líquido operacional acumulado de quase três meses. Os índices de endividamento (PTRT e PTPL) mostram uma participação similar entre recursos de terceiros e patrimônio líquido, ou seja, metade dos recursos para suportar a empresa é advinda dos sócios e outra metade de terceiros (bancos, fornecedores, sociedades de arrendamento mercantil, entre outros).

Como indicado na Tabela 31, os parâmetros de decisão pelas [alternativas] em relação aos impactos no balanço estipulados pelo decisor da empresa são: [i] manter em no máximo $80 \%$ a participação de terceiros sobre os recursos totais (ou seja, manter o índice PTRT abaixo de 0,8), [ii] manter o índice de liquidez circulante - ILC sempre acima de 1,0, ou seja, as obrigações de curto prazo são no máximo equivalentes aos ativos circulantes de curto prazo (com recebimento previsto para acontecer em até um ano), e [iii] manter a folga financeira maior que $10.000 \mathrm{R} \$$ mil, que equivale aproximadamente a um (1) resultado líquido mensal. Conforme mencionado, estes parâmetros servem como referência para ponderar as notas das [alternativas] em relação ao [Critério $\mathrm{H}]$.

A partir de introduzidos os elementos de cálculo para análise dos impactos nos grupos de contas do balanço em cada uma das [alternativas], calcula-se os novos índices financeiros. Os resultados destes impactos no balanço e, consequentemente, nos índices financeiros da empresa, estão demonstrados na Tabela 39, que apresenta em destaque os índices

151 O detalhamento dos balanços, incluindo todas as premissas adotadas para introduzir estes elementos de cálculo nos grupos de contas do ativo, passivo e patrimônio líquido para cada [alternativa] está no Apêndice B deste texto. 
paramétricos estipulados pelo decisor. Pela tabela é possível observar que a [alternativa] - SP comprometeria o CGL acima do parâmetro desejado pelo decisor. As [alternativas] de não imobilização são as que menos impactam nos índices financeiros da empresa, mantendo-os acima dos parâmetros de referência.

\begin{tabular}{|c|c|c|c|c|c|c|}
\hline \multicolumn{7}{|c|}{$\begin{array}{c}\text { Indicadores - Critério H (Desoneração do Balanço) } \\
\text { EMPRESA DO CASO - IMÓVEL } 1 \text { (SEDE ADMINISTRATIVA) } \\
\text { (Valores em R\$ mil) }\end{array}$} \\
\hline Índices & \multicolumn{2}{|c|}{$\begin{array}{l}\text { Impactos } \\
\text { [alternativas]: } \\
\text { BTS, LLP, LCP }\end{array}$} & \multicolumn{2}{|c|}{$\begin{array}{c}\text { Impactos } \\
\text { [alternativa]: SP }\end{array}$} & \multicolumn{2}{|c|}{$\begin{array}{l}\text { Impactos } \\
\text { [alternativa]: } \\
\text { SP a prazo }\end{array}$} \\
\hline ILC & 1,07 & $-2,27 \%$ & 1,02 & $-7,23 \%$ & 1,04 & $-5,22 \%$ \\
\hline ILI & 0,15 & $-2,27 \%$ & 0,08 & $-50,26 \%$ & 0,12 & $-26,38 \%$ \\
\hline PTRT & 0,52 & $1,29 \%$ & 0,51 & $0,13 \%$ & 0,52 & $2,54 \%$ \\
\hline PTPL & 1,07 & $2,66 \%$ & 1,04 & $0,26 \%$ & 1,09 & $5,32 \%$ \\
\hline PECP & 0,56 & $1,02 \%$ & 0,55 & $0,00 \%$ & 0,54 & $-2,88 \%$ \\
\hline GIPL & 1,35 & $1,36 \%$ & 1,43 & $6,92 \%$ & 1,43 & $7,26 \%$ \\
\hline CGL & 19.153 & $-24,10 \%$ & 4.485 & $-82,23 \%$ & 10.427 & $-58,68 \%$ \\
\hline
\end{tabular}

Tabela 39 - Impactos nos índices financeiros do balanço para cada [alternativa] - Imóvel 1

Com base na Tabela 39 e nos parâmetros de referência estipulados pelo decisor em relação ao [Critério H], são feitas as ponderações das notas de atendimento das [alternativas] de modo comparativo entre elas, conforme apresentado no Quadro 17.

\section{Desoneração do Balanço [H]}

\begin{tabular}{c|c|c|c|c|c|c|c|c|c|c|c|c|c|c|c|c|c|c}
\hline [ALTERNATIVAS] & 9 & 8 & 7 & 6 & 5 & 4 & 3 & 2 & 1 & 2 & 3 & 4 & 5 & 6 & 7 & 8 & 9 & [ALTERNATIVAS] \\
\hline SP a Prazo & & & & & & & & & & & & & & & & & & BTS \\
\hline SP a Prazo & & & & & & & & & & & & & & & & & & LCP \\
\hline SP a Prazo & & & & & & & & & & & & & & & & & & LLP \\
\hline BTS & & & & & & & & & & & & & & & & & & LCP \\
\hline BTS & & & & & & & & & & & & & & & & & & LLP \\
\hline LCP & & & & & & & & & & & & & & & \\
\hline \\
Razão de Consistência da Avaliação
\end{tabular}

Quadro 17 - Ponderação de notas de atendimento para o [Critério H] - Imóvel 1

Com esta ponderação de notas os pesos relativos das [alternativas] para o [Critério H] são os encontrados no Gráfico 17. 
Perspectiva: Planejador (IMÓVEL 1) - CRITÉRIOH

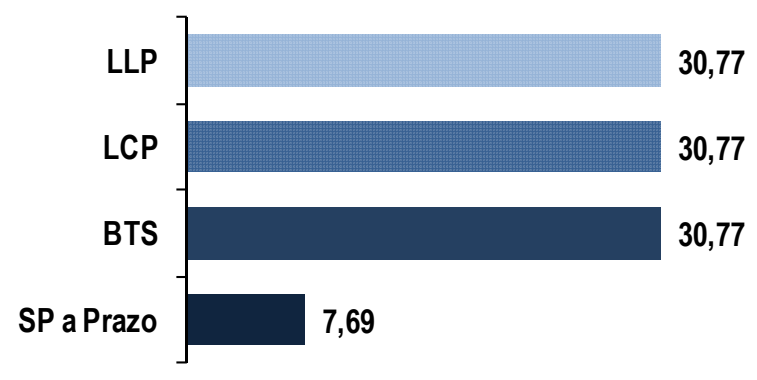

Gráfico 17 - Pesos relativos das [alternativas] para o critério - desoneração do balanço [Critério H]: Imóvel 1

\subsubsection{Redução dos Impactos Tributários - [Critério I]}

Para analisar a economia tributária em cada uma das [alternativas] calcula-se os fatores redutores do lucro tributável, que para o imóvel 1 são:

[i] Depreciação de 4\% ao ano sobre o valor da parcela depreciável do imóvel 1 (29.276 R\$ mil da base), calculada pelo valor de transação (41.500 R \$ mil da base) subtraído do valor do terreno (12.224 R \$ mil da base). Esta depreciação no valor de $1.171 \mathrm{R} \$$ mil por ano gera a ETD de cada exercício no valor de 398 R\$ mil (Depreciação x Alíquota de IR, CS). A ETD de cada exercício é considerada durante todo o horizonte de análise, que neste caso é de 25 anos (maior valor entre horizonte de uso e vida útil do ativo).

[ii] Despesas financeiras durante o prazo de amortização do financiamento (7 anos), para a opção pela imobilização a prazo. O fluxo das despesas financeiras é decrescente, ou seja, os juros reduzem à medida que as parcelas do financiamento são pagas.

[iii] Despesa operacional com a locação no intervalo [5.815 - 6.349] $\mathrm{R} \$$ mil por ano, que gera a ETDO em cada exercício no intervalo [1.977 - 2.159] R \$ mil por ano. A ETDO de cada exercício, calculada em intervalo, assim como o CCGA, é aplicada de forma randômica durante todo o horizonte de análise (25 anos).

As economias tributárias dos itens [i], [ii] e [iii] formam os fluxos para cada [alternativa] conforme apresentado na Tabela 20 do item 6.4, que descontados ao wacc da empresa, calculado no intervalo $[11,80 \%-23,22 \%]$ ao ano, resultam na economia tributária para cada uma das [alternativas], conforme apresentado na Tabela 40. Para cálculo destes indicadores em valores da base, como os demais indicadores do [MAOI], desconta-se dos fluxos de ETD e ETDDF em cada exercício a inflação acumulada, encontrada de forma randômica no 
intervalo $[3,5 \%-5,0 \%]$ ao ano. Para ETDO em cada exercício também se desconta a inflação acumulada no fluxo, no entanto, considera-se o reajuste dos preços de locação a cada 12 meses.

\begin{tabular}{|c|c|c|c|c|}
\hline \multicolumn{5}{|c|}{ CRITÉRIO I - IMÓVEL 1 (SEDE ADMINISTRATIVA) } \\
\hline \multicolumn{5}{|c|}{ Intervalos de Valor dos Indicadores relacionados à Economia Tributária } \\
\hline \multicolumn{5}{|c|}{ (Cenário Referencial) } \\
\hline \multirow{2}{*}{ Indicadores (em R\$ mil da base) } & \multirow{2}{*}{ Média } & \multirow{2}{*}{ Desvio } & \multicolumn{2}{|c|}{ Fronteiras da Amostra* } \\
\hline & & & Inferior & Superior \\
\hline ETDO para: LLP, BTS e LCP & 12.603 & 122 & 12.403 & 12.803 \\
\hline ETD:SP & 1.980 & 17 & 1.953 & 2.008 \\
\hline ETDDF: SP a Prazo & 4.194 & 31 & 4.144 & 4.244 \\
\hline
\end{tabular}

${ }^{*} 90 \%$ de confiabilidade do indicador se situar entre estas fronteiras

NOTA: estes indicadores são medidos em amostras de laboratório diferentes.

Nesse sentido, as fronteiras dos intervalos não representam pares de valores.

Tabela 40 - Intervalos de Valor dos Indicadores ETDO, ETD e ETDF - Imóvel 1

A economia tributária gerada pelas [alternativas] de não imobilização (ETDO) é muito superior à economia tributária gerada pelas opções de imobilização (ETD e ETDDF). A diferença entre ETDO e ETD é de $10.622 \mathrm{R} \$$ mil da base e entre ETDO e ETDDF é de 8.409 R \$ mil da base, a partir dos valores médios da amostra de laboratório. As [alternativas] de não imobilização geram uma vantagem tributária em relação à imobilização superior ao parâmetro desejado pelo decisor.

A partir dos indicadores ETDO, ETD, ETDDF e parâmetro de referência do decisor para o [Critério I], ponderam-se as notas de atendimento das [alternativas] conforme Quadro 18, resultando nos pesos relativos das [alternativas] para este critério apresentados no Gráfico 18.

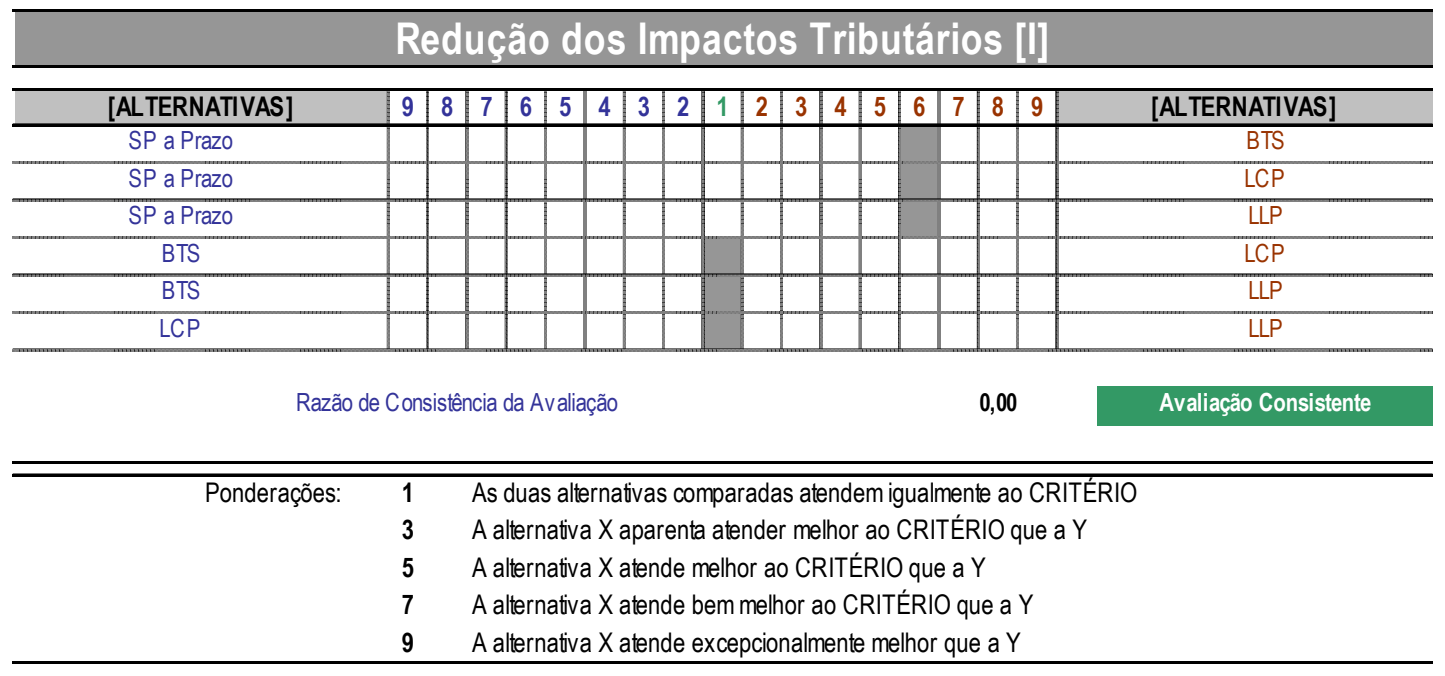

Quadro 18 - Ponderação de notas de atendimento para o [Critério I] - Imóvel 1 
Perspectiva: Planejador (IMÓVEL 1) - CRITÉRIO I

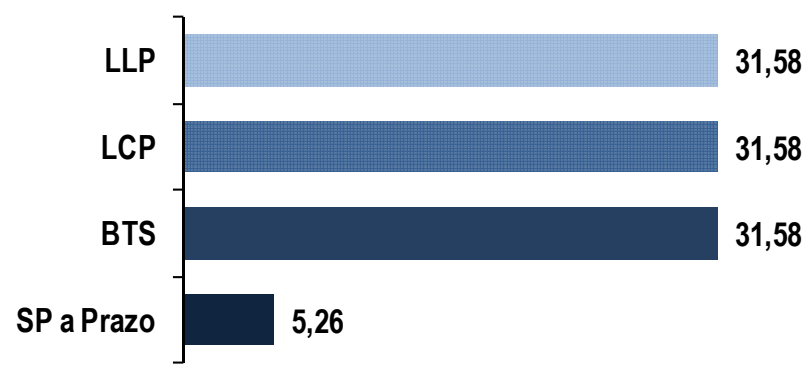

Gráfico 18 - Pesos relativos das [alternativas] para o critério - redução dos impactos tributários [Critério I]: Imóvel 1

\subsubsection{Referências Qualitativas do [MAOI] para o Imóvel 1}

As referências qualitativas do [MAOI] são aquelas relacionadas ao uso do espaço corporativo durante o ciclo operacional, as quais são: flexibilidade de mudança [Critério A]; rapidez na mobilização da atividade ao espaço [Critério B]; controle no uso do espaço [Critério C]; vínculo da operação com o imóvel [Critério D]; especificidade do imóvel [Critério E]; e oportunidade de tradução da imagem corporativa [Critério F]. Estes critérios qualitativos também são ponderados pelo planejador em relação à escala de atendimento das [alternativas], e priorizados pelos decisores a partir da atribuição de notas de importância relativa em conjunto aos critérios quantitativos.

A ponderação das notas de atendimento das [alternativas] para as referências qualitativas apresentadas a seguir baseia-se no conteúdo abordado no Capítulo 5, compilado na Tabela 7. Diferentemente das referências quantitativas, para as referências qualitativas as [alternativas] de não imobilização recebem pontuações distintas com base na sustentação legal e práticas de mercado, que se diferem entre as opções de locação (LLP, LCP e BTS).

A flexibilidade de mudança [Critério A] é comprometida na [alternativa] - BTS visto as multas em caráter indenizatório praticadas nos contratos desta natureza. A [alternativa] - LCP é a que melhor atende ao atributo, uma vez que a empresa tem maior liberdade de sair do imóvel quando desejado. Como se trata de um imóvel de padronização comum, com maior liquidez no mercado em relação aos demais imóveis da empresa, a opção pela imobilização traz aparentemente maior flexibilidade de mudança [Critério A] em comparação ao BTS. Sendo assim, as ponderações das [alternativas] para este critério são as apresentadas no Quadro 19. 
Flexibilidade de Mudança [A]

\begin{tabular}{|c|c|c|c|c|c|c|c|c|c|c|c|c|c|c|c|c|c|}
\hline [ALTERNATIVAS] & 9 & 8 & 7 & 6 & 5 & 4 & 3 & 2 & 1 & 2 & 3 & 4 & 5 & 6 & \begin{tabular}{|l|l|}
7 & 8 \\
\end{tabular} & 9 & [ALTERNATIVAS] \\
\hline SP a Prazo & & & & & & & & & & & & & & & & & BTS \\
\hline SP a Prazo & & & & & & & & & & & & & & & & & LCP \\
\hline SP a Prazo & & & & & & & & & & & & & & & & & LLP \\
\hline BTS & & & & & & & & & & & & & & & & & LCP \\
\hline BTS & & & & & & & & & & & & & & & & & LLP \\
\hline LCP & & & & & & & & & & & & & & & & & LLP \\
\hline \multicolumn{14}{|c|}{ Razão de Consistência da Avaliação } & \multicolumn{3}{|c|}{0,05} & Avaliação Consistente \\
\hline \multirow[t]{5}{*}{ Ponderações: } & 1 & & \multicolumn{15}{|c|}{ As duas alternativas comparadas atendem igualmente ao CRITÉRIO } \\
\hline & 3 & & \multicolumn{15}{|c|}{ A alternativa $X$ aparenta atender melhor ao CRITÉRIO que a Y } \\
\hline & 5 & & \multicolumn{15}{|c|}{ A alternativa $X$ atende melhor ao CRITÉRIO que a Y } \\
\hline & 7 & & \multicolumn{15}{|c|}{ A alternativa $X$ atende bem melhor ao CRITÉRIO que a $Y$} \\
\hline & 9 & & \multicolumn{15}{|c|}{ A alternativa $X$ atende excepcionalmente melhor que a $Y$} \\
\hline
\end{tabular}

Quadro 19 - Ponderação de notas de atendimento para o [Critério A] - Imóvel 1

O Gráfico 19 apresenta os pesos relativos das [alternativas] para o [Critério A] conforme ponderação de notas do Quadro 19.

Perspectiva: Planejador (IMÓVEL 1) - CRITÉRIO A

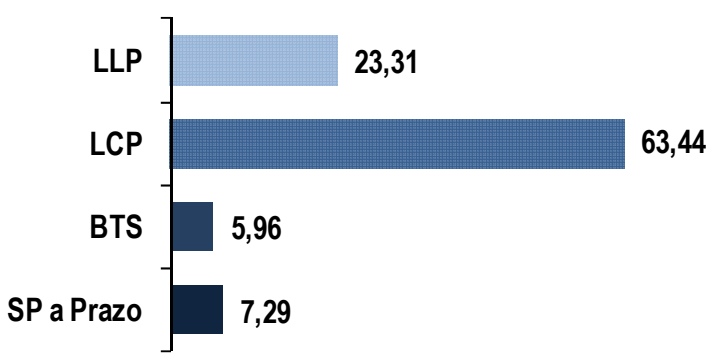

Gráfico 19 - Pesos relativos das [alternativas] para o critério - flexibilidade de mudança [Critério A]: Imóvel 1

Em relação à rapidez na mobilização da atividade ao espaço [Critério B] a [alternativa] - BTS é a que mais compromete o critério, já que depende da velocidade de negociações com investidores desta modalidade e o imóvel deve ainda ser concebido com todas as especificidades demandadas no espaço. Como este espaço tem padronização comum, a opção pela imobilização, para efeito de análise, refere-se a um imóvel pronto disponível no mercado para a venda. Por isso, neste caso, a opção pela imobilização compromete menos o critério e quase se iguala a opção de locação simples (LLP) para ponderação das notas de atendimento, conforme demonstrado no Quadro 20, as quais resultam nos pesos relativos das [alternativas] apresentados no Gráfico 20. 


\begin{tabular}{|c|c|c|c|c|c|c|c|c|c|c|c|c|c|c|c|c|}
\hline \multicolumn{17}{|c|}{ Rapidez na Mobilização da Atividade ao Espaço [B] } \\
\hline [ALTERNATIVAS] & 9 & 8 & 7 & 6 & 5 & 4 & 3 & 2 & 1 & \begin{tabular}{l|l}
2 & 3 \\
\end{tabular} & \begin{tabular}{|l|}
3 \\
\end{tabular} & 5 & 6 & \begin{tabular}{l|l|}
7 & 8 \\
\end{tabular} & 9 & [ALTERNATIVAS] \\
\hline SP a Prazo & & & & & & & & & & & & & & & & BTS \\
\hline SP a Prazo & & & & & & & & & & & & & & & & LCP \\
\hline SP a Prazo & & & & & & & & & & & & & & & & LLP \\
\hline BTS & & & & & & & & & & & & & & & & LCP \\
\hline BTS & & & & & & & & & & & & & & & & LLP \\
\hline LCP & & & & & & & & & & & & & & & & LLP \\
\hline \multicolumn{14}{|c|}{ Razão de Consistência da Avaliação } & 0,04 & & Avaliação Consistente \\
\hline \multirow[t]{5}{*}{ Ponderações: } & \multicolumn{16}{|c|}{ As duas alternativas comparadas atendem igualmente ao CRITÉRIO } \\
\hline & 3 & & \multicolumn{14}{|c|}{ A alternativa $X$ aparenta atender melhor ao CRITÉRIO que a Y } \\
\hline & 5 & \multicolumn{15}{|c|}{ A alternativa $X$ atende melhor ao CRITÉRIO que a $Y$} \\
\hline & 7 & \multicolumn{15}{|c|}{ A alternativa $X$ atende bem melhor ao CRITÉRIO que a $Y$} \\
\hline & 9 & & \multicolumn{14}{|c|}{ A alternativa $X$ atende excepcionalmente melhor que a $Y$} \\
\hline
\end{tabular}

Quadro 20 - Ponderação de notas de atendimento para o [Critério B] - Imóvel 1

Perspectiva: Planejador (IMÓVEL 1) - CRITÉRIO B

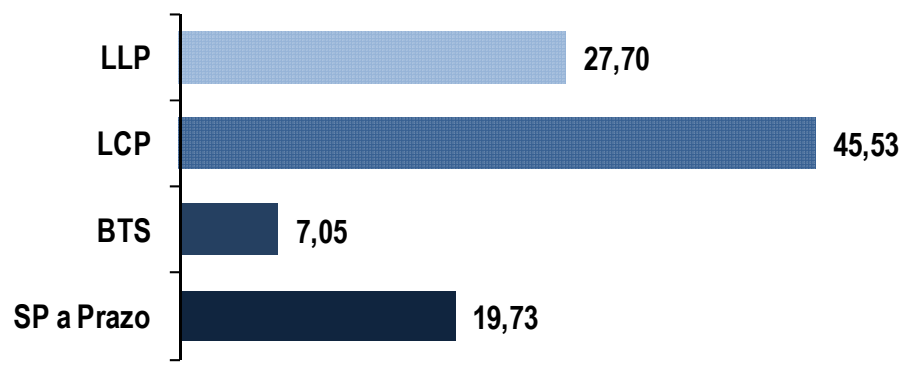

Gráfico 20 - Pesos relativos das [alternativas] para o critério - rapidez na mobilização da atividade para o espaço [Critério B]: Imóvel 1

Em relação ao controle no uso do espaço [Critério C] a [alternativa] - SP a Prazo é a que melhor atende ao critério, visto que a empresa sendo proprietária pode promover todas as intervenções no espaço para atender suas demandas durante a operação. Neste caso as intervenções durante o uso são classificadas como 'baixas intervenções', e referem-se essencialmente às mudanças de layout. No entanto, como o imóvel é de padronização comum e se enquadra ao uso de outros locatários, as intervenções pelos locadores são mais controladas e, portanto, as opções de locação (LLP e LCP) comprometem este critério, principalmente para contratos de curto prazo. No BTS como o imóvel é concebido para atender às demandas da empresa, em geral esta [alternativa] atende melhor ao atributo em relação às locações simples. Dessa forma, as ponderações das notas de atendimento das [alternativas] para o [Critério C] estão apresentadas no Quadro 21, que resultam nos pesos relativos do Gráfico 21. 
Controle no Uso do Espaço [C]

\begin{tabular}{c|c|c|c|c|c|c|c|c|c|c|c|c|c|c|c|c|c|c}
\hline [ALTERNATIVAS] & 9 & 8 & 7 & 6 & 5 & 4 & 3 & 2 & 1 & 2 & 3 & 4 & 5 & 6 & 7 & 8 & 9 & [ALTERNATIVAS] \\
\hline SP a Prazo & & & & & & & & & & & & & & & & & & BTS \\
\hline SP a Prazo & & & & & & & & & & & & & & & & & & LCP \\
\hline SP a Prazo & & & & & & & & & & & & & & & & & & LLP \\
\hline BTS & & & & & & & & & & & & & & & & & & LCP \\
\hline BTS & & & & & & & & & & & & & & & & & & LLP \\
\hline LCP & & & & & & & & & & & & \\
\hline
\end{tabular}

Quadro 21 - Ponderação de notas de atendimento para o [Critério C] - Imóvel 1

Perspectiva: Planejador (IMÓVEL 1) - CRITÉRIO C

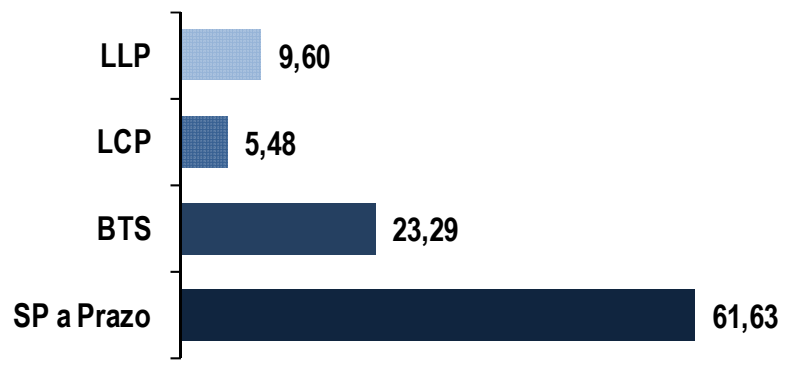

Gráfico 21 - Pesos relativos das [alternativas] para o critério - controle operacional no uso do espaço [Critério C]: Imóvel 1

O vínculo da operação com o imóvel [Critério D] é importante quando há dependência direta da atividade com o espaço, ou a localização é importante para a atividade, ou ainda o investimento imobilizado no imóvel com instalações e equipamentos é alto. O atendimento a este critério está relacionado com a garantia de permanência da empresa no imóvel durante horizonte de uso do espaço. Por isso, a [alternativa] - LCP compromete o critério, uma vez que não há direito de renovatória compulsória. A opção pela imobilização é a que melhor atende a este critério, seguida dos contratos BTS, conforme demonstrado no Quadro 22, resultando nos pesos relativos das [alternativas] apresentados no Gráfico 22. 


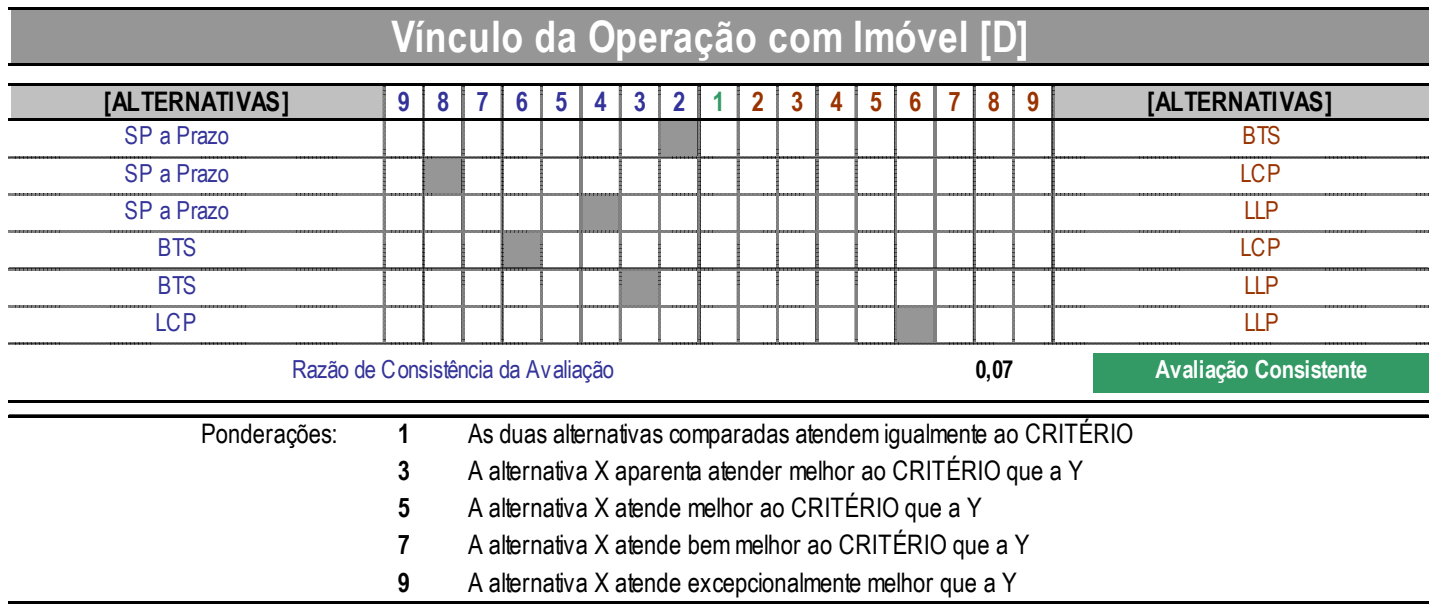

Quadro 22 - Ponderação de notas de atendimento para o [Critério D] - Imóvel 1

Perspectiva: Planejador (IMÓVEL 1) - CRITÉRIO D

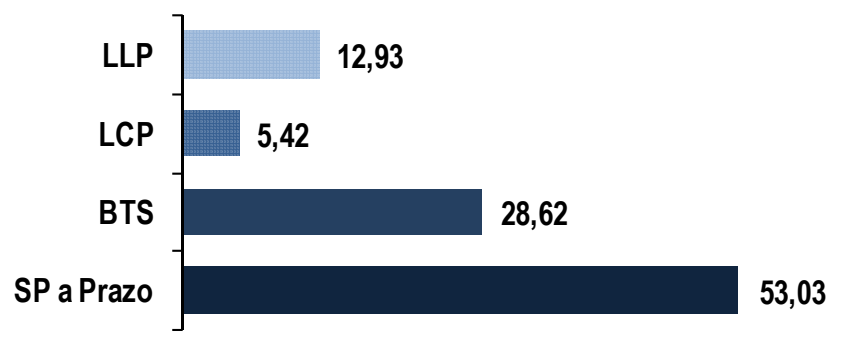

Gráfico 22 - Pesos relativos das [alternativas] para o critério - vínculo da operação com o imóvel [Critério D]: Imóvel 1

Quanto à especificidade do imóvel [Critério E], a [alternativa] - BTS é a melhor opção, uma vez que o imóvel é concebido para atender todas as especificações técnicas, de localização e arquitetura requeridas pela empresa. $\mathrm{Na}$ opção pela imobilização o imóvel, mesmo quando pronto disponível para a venda, pode ser adaptado para atender as demandas da empresa. As opções que mais comprometem o [Critério E] são as locações simples, principalmente para os contratos de curto prazo (LCP), já que a empresa deve se adequar a um imóvel disponível pronto para locação. Sendo assim, encontram-se no Quadro 23 as ponderações das notas para as [alternativas], as quais resultam nos pesos relativos do Gráfico 23. 


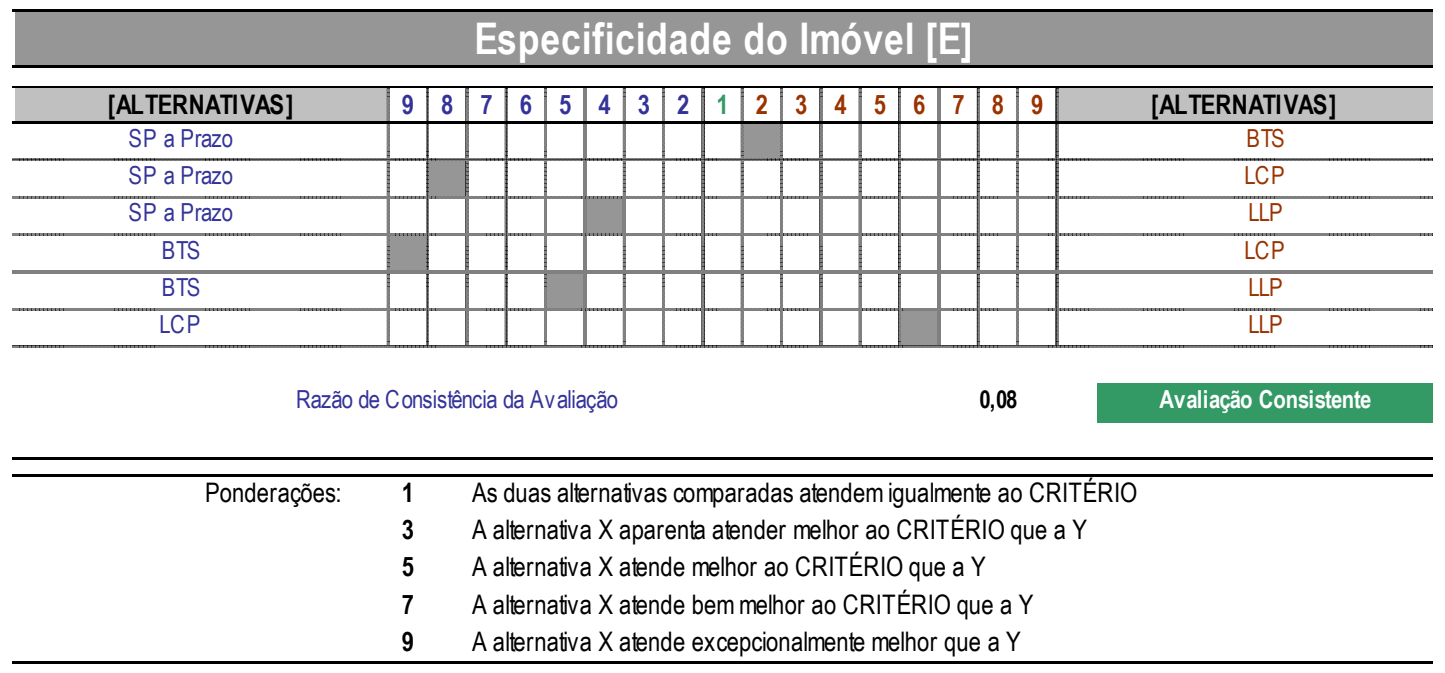

Quadro 23 - Ponderação de notas de atendimento para o [Critério E] - Imóvel 1

Perspectiva: Planejador (IMÓVEL 1) - CRITÉRIOE

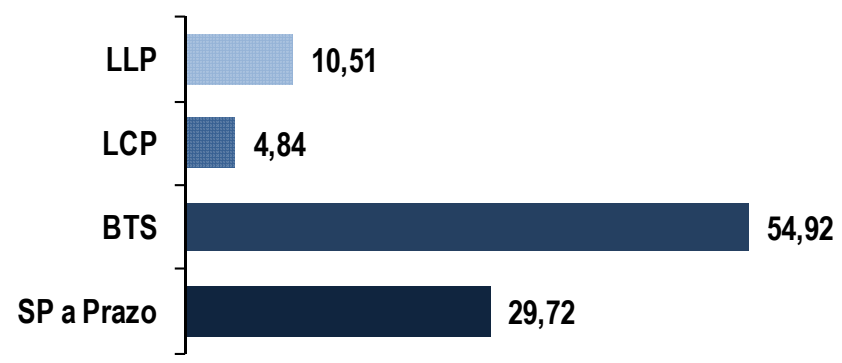

Gráfico 23 - Pesos relativos das [alternativas] para o critério - especificidade do imóvel [Critério E]: Imóvel 1

A depender do tipo de tradução da imagem corporativa desejada, as [alternativas] são pontuadas de modo distinto. Neste caso, como se trata da sede da empresa a tradução da imagem desejada pelo decisor além da localização é também na fachada do edifício, com elementos particulares que vinculem o edifício à marca da companhia. Sendo assim, as [alternativas] de locação simples comprometem mais o atributo, mas podem atender ao quesito localização e notoriedade na escolha de um edifício de alto padrão disponível para locação. Por este motivo, a ponderação das notas da [alternativa]-LLP não foi significativamente penalizada em relação às opções de imobilização e BTS que melhor atendem a este critério, conforme demonstrado no Quadro 24. Os pesos relativos das [alternativas] para o [Critério F] são os apresentados no Gráfico 24. 


\section{Oportunidade de Tradução da Imagem Corporativa [F]}

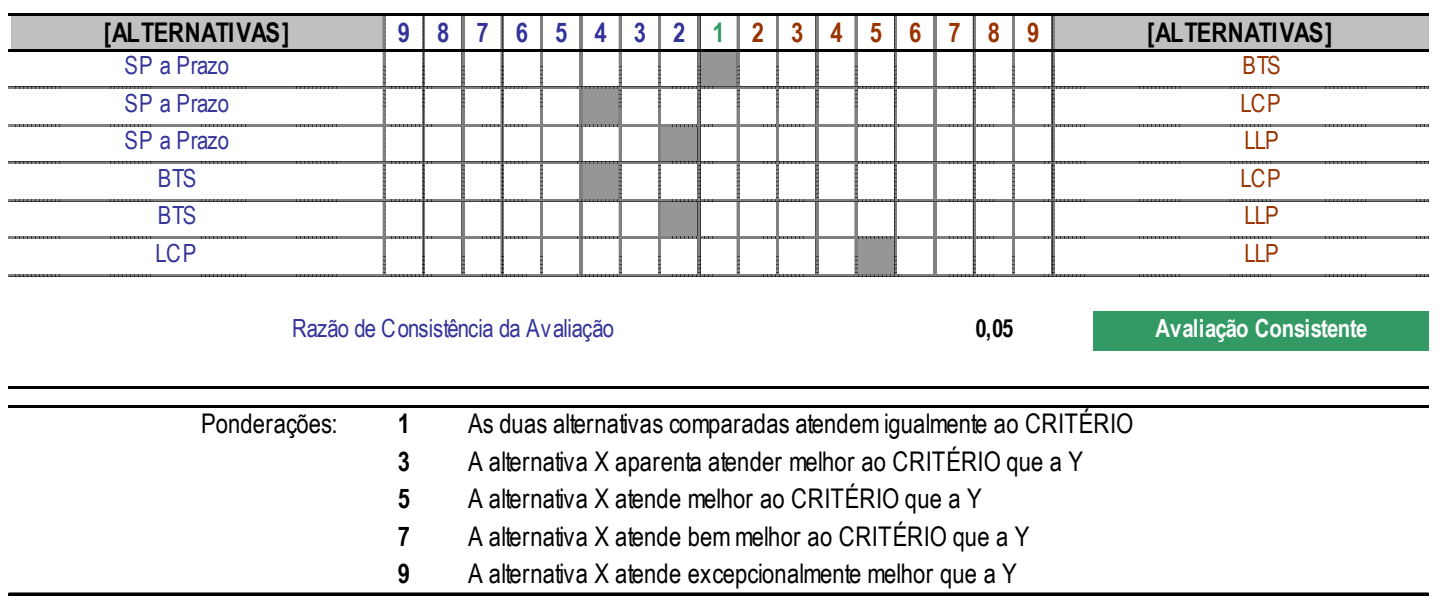

Quadro 24 - Ponderação de notas de atendimento para o [Critério F] - Imóvel 1

Perspectiva: Planejador (IMÓVEL 1) - CRITÉRIO F

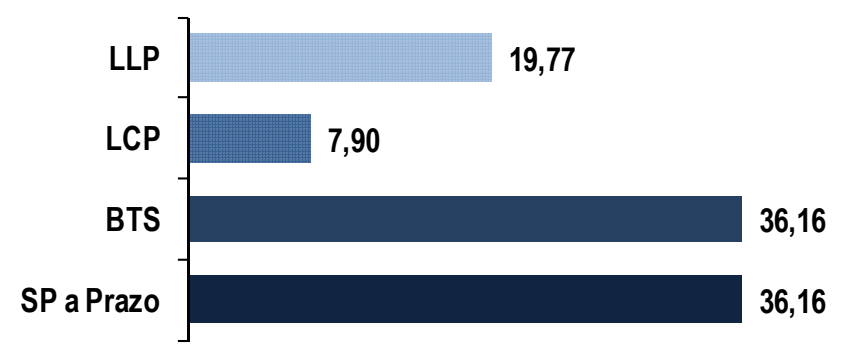

Gráfico 24 - Pesos relativos das [alternativas] para o critério - oportunidade de tradução da imagem corporativa [Critério F]: Imóvel 1

\subsubsection{Pesos relativos das [alternativas] para cada critério - Matrizes Nível 3 do AHP para o Imóvel 1}

Os pesos relativos apresentados no decorrer dos itens 8.4.1 e 8.4.2 para as referências quantitativas e qualitativas, respectivamente, estão compilados na Tabela 41, que apresenta as [alternativas] que mais comprometem e as que melhor atendem cada um dos critérios de decisão do [MAOI] para o imóvel 1. 


\begin{tabular}{|c|c|c|c|c|c|c|c|c|c|}
\hline \multicolumn{10}{|c|}{ PESOS RELATIVOS DAS [ALTERNATIVAS] X CRITÉRIOS - IMÓVEL 1 (SEDE ADMINISTRATIVA) } \\
\hline \multirow[t]{2}{*}{$\begin{array}{l}\text { [ALTERNA- } \\
\text { TIVAS] }\end{array}$} & $\begin{array}{l}\text { Flexibili- } \\
\text { dade de } \\
\text { Mudança }\end{array}$ & $\begin{array}{c}\text { Rapidezna } \\
\text { Mobilização } \\
\text { da Atividade } \\
\text { para o } \\
\text { Espaço }\end{array}$ & $\begin{array}{c}\text { Controle } \\
\text { Operacional } \\
\text { no Uso do } \\
\text { Espaço }\end{array}$ & $\begin{array}{l}\text { Vínculo da } \\
\text { Operação } \\
\text { com Imóvel }\end{array}$ & $\begin{array}{l}\text { Especifi- } \\
\text { dade do } \\
\text { Imóvel }\end{array}$ & $\begin{array}{l}\text { Oportunidade } \\
\text { de Tradução } \\
\text { da Imagem } \\
\text { Corporativa }\end{array}$ & $\begin{array}{c}\text { Canalizar } \\
\text { recursos em } \\
\text { oportunidades } \\
\text { do Negócio } \\
\text { Principal }\end{array}$ & $\begin{array}{c}\text { Desone- } \\
\text { ração } \\
\text { do Balanço }\end{array}$ & $\begin{array}{c}\text { Redução dos } \\
\text { Impactos } \\
\text { Tributários }\end{array}$ \\
\hline & {$[\mathrm{A}]$} & {$[\mathrm{B}]$} & [C] & [D] & {$[E]$} & {$[\mathrm{F}]$} & [G] & {$[\mathrm{H}]$} & [l] \\
\hline SP a Prazo & 7,29 & 19,73 & 61,63 & 53,03 & 29,72 & 36,16 & 6,72 & 7,69 & 5,26 \\
\hline BTS & 5,96 & 7,05 & 23,29 & 28,62 & 54,92 & 36,16 & 31,24 & 30,77 & 31,58 \\
\hline LCP & 63,44 & 45,53 & 5,48 & 5,42 & 4,84 & 7,90 & 30,79 & 30,77 & 31,58 \\
\hline LLP & 23,31 & 27,70 & 9,60 & 12,93 & 10,51 & 19,77 & 31,24 & 30,77 & 31,58 \\
\hline Soma & 100,00 & 100,00 & 100,00 & 100,00 & 100,00 & 100,00 & 100,00 & 100,00 & 100,00 \\
\hline \multicolumn{10}{|c|}{ Pesos Relativos das Matrizes X - Nível 3 do AHP (Ponderação feita pelo Planejador) } \\
\hline $\begin{array}{c}\text { CRITÉRIOS } x \\
\text { [ALTERNATIVAS] }\end{array}$ & {$[\mathrm{A}]$} & [B] & {$[\mathrm{C}]$} & [D] & [E] & [F] & [G] & {$[\mathrm{H}]$} & [l] \\
\hline melhor atende & LCP & LCP & SP a Prazo & SP a Prazo & BTS & SP a Prazo;BTS & BTS;LLP & BTS;LLP;LCP & BTS;LLP;LCP \\
\hline mais compromete & BTS & BTS & LCP & LCP & LCP & LCP & SP a Prazo & SP a Prazo & SP a Prazo \\
\hline
\end{tabular}

Tabela 41 - Pesos Relativos das [alternativas] para todos os critérios de decisão do [MAOI] - Imóvel 1

Concluídas as matrizes das [alternativas] para cada critério (Nível 3 do AHP) resta agora encontrar os pesos relativos dos critérios (Nível 2 do AHP), a partir das priorizações dadas pelo decisor, em função das referências qualitativas, quantitativas, necessidades operacionais em relação ao espaço e as estratégias corporativas.

\subsubsection{Priorização dos critérios - Matriz Nível 2 do AHP para o Imóvel 1}

Para o imóvel 1 o decisor da empresa do caso priorizou os critérios conforme Quadro 25, que apresenta as notas de importância atribuídas de forma comparativa par a par entre os critérios de decisão do [MAOI]. A matriz de comparação dos critérios (Nível 2 do AHP) gerada a partir das notas de importância atribuídas no Quadro 25 está ilustrada na Tabela 42. 


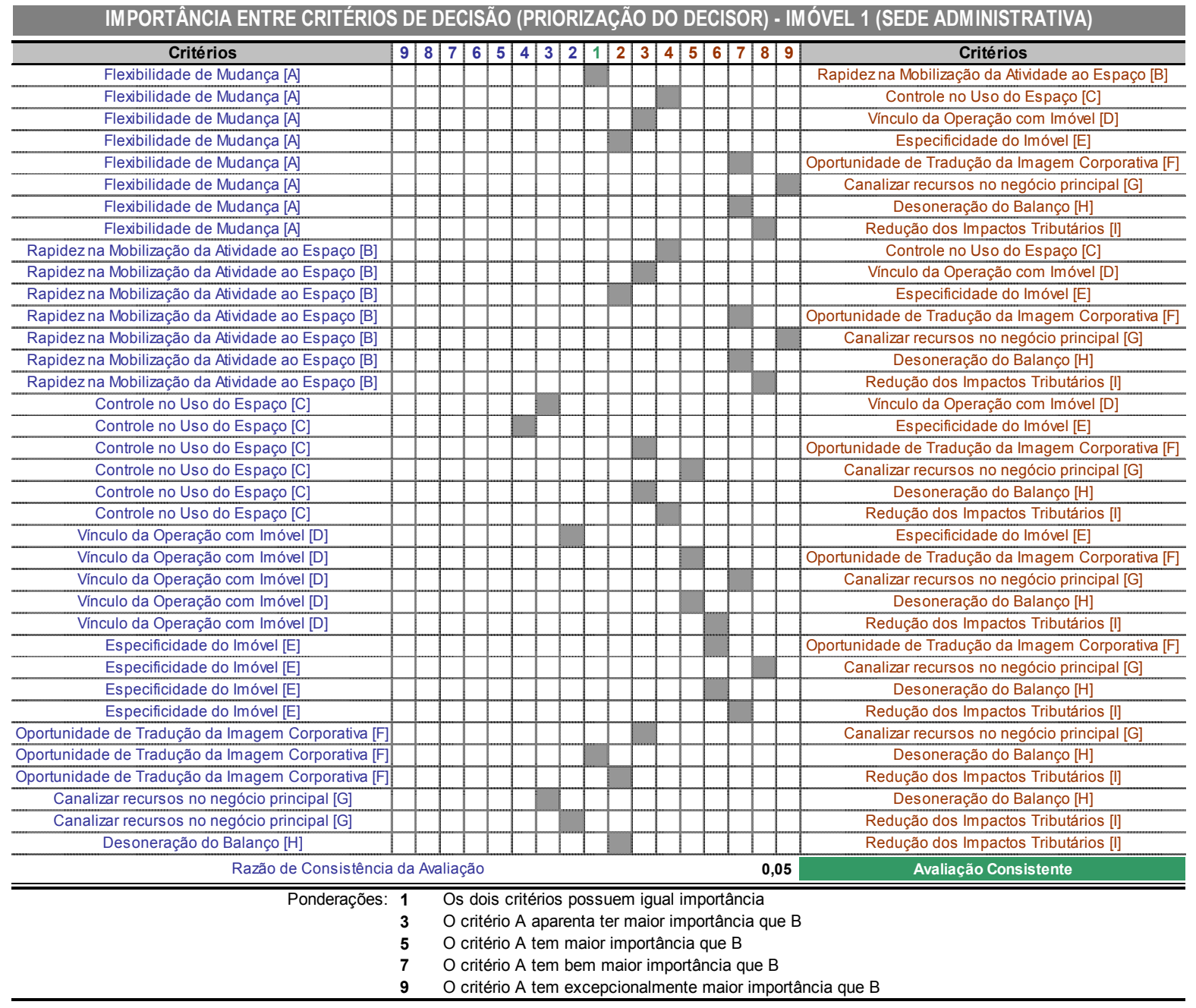

Quadro 25 - Ponderação de notas de importância entre os critérios de decisão do [MAOI] atribuídas pelo decisor da empresa do caso para o Imóvel1

MATRIZ DE COMPARAÇÃO ENTRE CRITÉRIOS - IMÓVEL 1

\begin{tabular}{ccccc|c|c|c|c|c|c}
\hline ITEM & {$[\mathrm{A}]$} & {$[\mathrm{B}]$} & {$[\mathrm{C}]$} & {$[\mathrm{D}]$} & {$[\mathrm{E}]$} & {$[\mathrm{F}]$} & {$[\mathrm{G}]$} & {$[\mathrm{H}]$} & {$[\mathrm{I}]$} \\
\hline$[\mathrm{A}]$ & 1 & 1,00 & 0,25 & 0,33 & 0,50 & 0,14 & 0,11 & 0,14 & 0,13 \\
\hline$[\mathrm{B}]$ & 1,00 & 1 & 0,25 & 0,33 & 0,50 & 0,14 & 0,11 & 0,14 & 0,13 \\
\hline$[\mathrm{C}]$ & 4,00 & 4,00 & 1 & 3,00 & 4,00 & 0,33 & 0,20 & 0,33 & 0,25 \\
\hline$[\mathrm{D}]$ & 3,00 & 3,00 & 0,33 & 1 & 2,00 & 0,20 & 0,14 & 0,20 & 0,17 \\
\hline$[\mathrm{E}]$ & 2,00 & 2,00 & 0,25 & 0,50 & 1 & 0,17 & 0,13 & 0,17 & 0,14 \\
\hline$[\mathrm{F}]$ & 7,00 & 7,00 & 3,00 & 5,00 & 6,00 & 1 & 0,33 & 1,00 & 0,50 \\
\hline$[\mathrm{G}]$ & 9,00 & 9,00 & 5,00 & 7,00 & 8,00 & 3,00 & 1 & 3,00 & 2,00 \\
\hline$[\mathrm{H}]$ & 7,00 & 7,00 & 3,00 & 5,00 & 6,00 & 1,00 & 0,33 & 1 & 0,50 \\
\hline$[\mathrm{I}]$ & 8,00 & 8,00 & 4,00 & 6,00 & 7,00 & 2,00 & 0,50 & 2,00 & 1 \\
\hline $\boldsymbol{\Sigma}$ & 42,00 & 42,00 & 17,08 & 28,17 & 35,00 & 7,99 & 2,86 & 7,99 & 4,81 \\
\hline
\end{tabular}

Tabela 42 - Matriz de comparação entre os critérios para o Imóvel 1

Os pesos relativos dos critérios apresentados no Gráfico 25 indicam a priorização do decisor dada aos critérios relacionados às estratégias de investimento e políticas corporativas. Como se trata da sede administrativa da empresa que tem menor dependência das atividades 
realizadas com o espaço, o decisor priorizou as oportunidades de ganho investindo o valor de transação do imóvel no negócio principal [Critério G], seguido da redução dos impactos tributários [Critério I] e da desoneração do balanço [Critério H]. A sede da empresa tem importante papel na tradução da imagem corporativa, por isso o critério priorizado em relação ao uso do espaço foi a oportunidade de tradução da imagem corporativa [Critério F]. Os demais critérios relacionados ao uso apresentam pouca importância para o decisor no caso do imóvel 1.

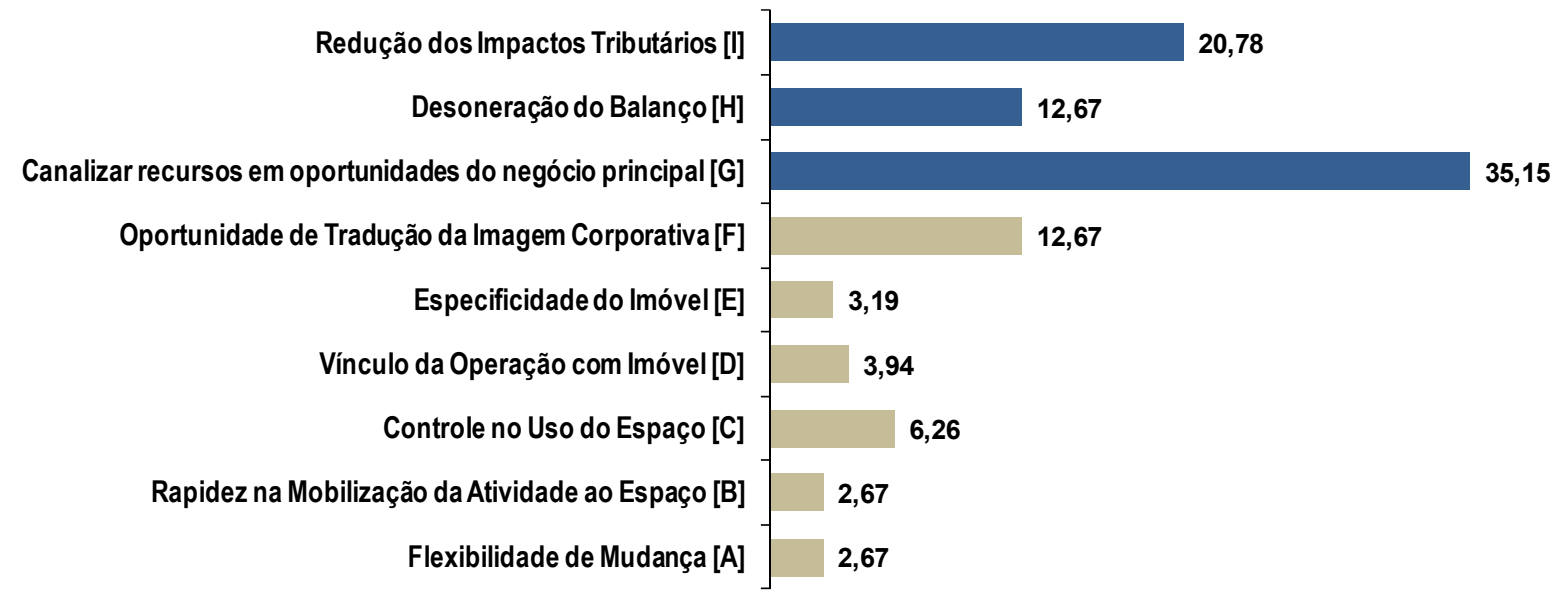

Gráfico 25 - Pesos relativos dos critérios para o Imóvel 1 conforme priorização do decisor

\subsubsection{Resultado AHP - [alternativa] Indicada pelo [MAOI] para o Imóvel 1}

Com os pesos relativos das [alternativas] para cada critério, apresentados na Tabela 41, e os pesos relativos dos critérios de decisão, apresentados no Gráfico 25, calcula-se a multiplicação das matrizes das [alternativas] (Nível 3 do AHP) com a matriz dos critérios (Nível 2 do AHP), resultando na hierarquização das [alternativas] para o imóvel 1, conforme Tabela 43 e Gráfico 26.

QUADRO RESULTADO IMÓVEL 1 (SEDE ADMINISTRATIVA): [Alternativas] x Critérios

\begin{tabular}{|c|c|c|c|c|c|c|c|c|c|c|c|c|}
\hline $\begin{array}{l}\text { [ALTERNA- } \\
\text { TIVAS] }\end{array}$ & $\begin{array}{l}\text { Flexibili- } \\
\text { dade de } \\
\text { Mudança }\end{array}$ & $\begin{array}{c}\text { Rapidezna } \\
\text { Mobilização } \\
\text { da Atividade } \\
\text { para o } \\
\text { Espaço }\end{array}$ & $\begin{array}{c}\text { Controle } \\
\text { Operacional } \\
\text { no Uso do } \\
\text { Espaço }\end{array}$ & $\begin{array}{l}\text { Vínculo da } \\
\text { Operação } \\
\text { com Imóvel }\end{array}$ & $\begin{array}{l}\text { Especifi- } \\
\text { dade do } \\
\text { Imóvel }\end{array}$ & $\begin{array}{c}\text { Oportunidade } \\
\text { de Tradução } \\
\text { da Imagem } \\
\text { Corporativa }\end{array}$ & $\begin{array}{c}\text { Canalizar } \\
\text { recursos em } \\
\text { oportunidades } \\
\text { do Negócio } \\
\text { Principal }\end{array}$ & $\begin{array}{c}\text { Desone- } \\
\text { ração } \\
\text { do Balanço }\end{array}$ & $\begin{array}{c}\text { Redução dos } \\
\text { Impactos } \\
\text { Tributários }\end{array}$ & & $\begin{array}{l}\text { Prioridade } \\
\text { Relativa }\end{array}$ & $\begin{array}{l}\text { Hierarquia } \\
\text { Composta }\end{array}$ \\
\hline & {$[\mathrm{A}]$} & [B] & [C] & [D] & {$[E]$} & [F] & [G] & {$[\mathrm{H}]$} & [l] & & & \\
\hline SP a Prazo & 7,29 & 19,73 & 61,63 & 53,03 & 29,72 & 36,16 & 6,72 & 7,69 & 5,26 & {$[\mathrm{~A}]$} & 2,67 & 16,63 \\
\hline BTS & 5,96 & 7,05 & 23,29 & 28,62 & 54,92 & 36,16 & 31,24 & 30,77 & 31,58 & [B] & 2,67 & 30,71 \\
\hline LCP & 63,44 & 45,53 & 5,48 & 5,42 & 4,84 & 7,90 & 30,79 & 30,77 & 31,58 & [C] & 6,26 & 25,91 \\
\hline LLP & 23,31 & 27,70 & 9,60 & 12,93 & 10,51 & 19,77 & 31,24 & 30,77 & 31,58 & [D] & 3,94 & 26,76 \\
\hline Soma & 100,00 & 100,00 & 100,00 & 100,00 & 100,00 & 100,00 & 100,00 & 100,00 & 100,00 & {$[\mathrm{E}]$} & 3,19 & \\
\hline & & \multicolumn{2}{|c|}{ Matrizes X (Planejador) } & \multicolumn{3}{|c|}{ Matriz Y (Decisor) } & \multicolumn{3}{|c|}{ Resultado AHP } & $\begin{array}{c}{[\mathrm{F}]} \\
{[\mathrm{G}]} \\
{[\mathrm{H}]} \\
{[\mathrm{l}]} \\
5\end{array}$ & \begin{tabular}{c|}
12,67 \\
35,15 \\
12,67 \\
20,78 \\
100,00
\end{tabular} & \\
\hline
\end{tabular}

Tabela 43 - Quadro com resultado do AHP para o Imóvel 1 


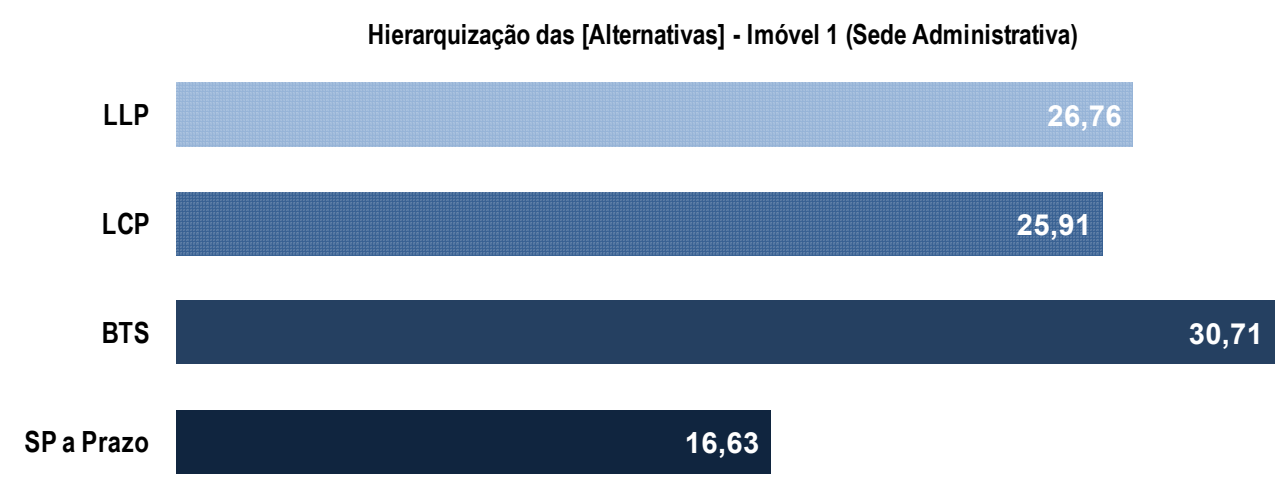

Gráfico 26 - Hierarquia das [alternativas] para o Imóvel 1

A [alternativa] que melhor atende em conjunto aos critérios priorizados pelo decisor é o BTS. Além de atender aos critérios quantitativos, o BTS melhor atende ao critério relacionado ao uso priorizado pelo decisor (tradução da imagem corporativa [Critério F]).

A [alternativa] com pontuação mais próxima é a LLP, visto que atende igualmente aos critérios quantitativos, no entanto, os critérios relacionados ao uso melhor atendidos por esta [alternativa] quando comparados ao BTS, como flexibilidade de mudança [Critério A] e rapidez na mobilização da atividade ao espaço [Critério B], não foram priorizados pelo decisor (ambos estão na última posição entre os critérios).

Como não foi priorizado o vínculo da operação com imóvel [Critério D] e o controle operacional durante o uso [Critério C], a opção pela imobilização é a última na hierarquia das [alternativas].

\subsubsection{Análise Comparativa da Situação Atual 'vs' [alternativa] Indicada pelo [MAOI]: Imóvel 1}

A [alternativa] - BTS indicada pelo [MAOI] é então comparada à situação atual do imóvell. Como mencionado, a empresa do caso é proprietária do imóvel, sendo esta [alternativa] a última indicada pelo [MAOI].

Nesse sentido, como o decisor acredita que o imóvel 1 será usado por mais 20 anos sem comprometer as atividades realizadas no espaço, analisa-se a opção da empresa desmobilizar o ativo, ou seja, promover o SLB, visto que a [alternativa] indicada pelo [MAOI] foi a não imobilização no imóvel conforme priorização feita pelo próprio decisor.

O imóvel 1 apresenta valor contábil baixo (247 R\$ mil da base), portanto, o lucro na venda seria de $41.253 \mathrm{R} \$$ mil da base, para uma venda do imóvel no valor de $41.500 \mathrm{R} \$$ mil da base. 
Esse lucro gera um total de impostos no valor de 14.026 R \$ mil da base (produto entre o lucro contabilizado na venda e a alíquota de IR e CS da empresa). Sendo assim, o CGA na opção pelo SLB seria de 27.474 R \$ mil da base (valor de venda subtraído dos impostos devidos). No entanto, como os preços de locação (CCGA) não mudam, uma vez que esta variável é função do valor de transação e da taxa de atratividade esperada pelo investidor, considera-se para um menor CGA o mesmo intervalo para o CCGA ([485 - 529] R\$ mil por mês).

Dessa forma, a RRCGA se situa no intervalo [3,52\% - 4,30\%] ao ano efetiva acima do IGP conforme indica a Tabela 44 para o cenário referencial. O saldo anual $(\mathrm{p})$ gerado entre RCGA e CCGA é de apenas $1.054 \mathrm{R} \$$ mil da base na média da amostra de laboratório. Para os cenários estressados, com perturbação sem compensação no ROE da empresa na mesma faixa (até - 20\% de desempenho), a RRCGA encontrada é muito baixa, conforme apresentado na Tabela 45.

CRITÉRIO J - IMÓVEL 1 (SEDE ADMINISTRATIVA) - SLB
\begin{tabular}{c|r|r|r|r}
\hline Intervalos de Valor dos Indicadores: RRCGA e ARC \\
(Cenário Referencial) \\
\hline Indicadores & \multicolumn{1}{|c|}{ Média } & \multicolumn{1}{c}{ Desvio } & \multicolumn{1}{c}{ Fronteiras da Amostra* } \\
\cline { 4 - 6 } & & & Inferior & \multicolumn{1}{c}{ Superior } \\
\hline RRCGA(\% ao ano efetiva acima do IGP) & $3,91 \%$ & $0,24 \%$ & $3,52 \%$ & $4,30 \%$ \\
\hline RCGA(R\$ mil da base/ano) & 7.002 & 44 & 6.930 & 7.074 \\
\hline Saldo(p): RCGA- CCGA (em R\$ mil da base/ano) & 1.054 & 63 & 951 & 1.158 \\
\hline ARC (\% ao ano) & $0,96 \%$ & $0,06 \%$ & $0,86 \%$ & $1,05 \%$ \\
\hline
\end{tabular}

${ }^{*} 90 \%$ de confiabilidade do indicador se situar entre estas fronteiras

NOTA: estes indicadores são medidos em amostras de laboratório diferentes.

Nesse sentido, as fronteiras dos intervalos não representam pares de valores.

Tabela 44 - Intervalos de Valor dos Indicadores RRCGA e ARC para a [alternativa] - SLB do Imóvel 1

\begin{tabular}{|c|c|c|c|c|}
\hline \multicolumn{5}{|c|}{ CRITÉRIO J - IMÓVEL 1 (SEDE ADMINISTRATIVA) - SLB } \\
\hline \multicolumn{5}{|c|}{ Intervalos de Valor dos Indicadores: RRCGA e ARC } \\
\hline \multicolumn{5}{|c|}{ (Desvio de ROE - faixa: + 0\% a -20\%) } \\
\hline \multirow{2}{*}{ Indicadores } & \multirow{2}{*}{ Média } & \multirow{2}{*}{ Desvio } & \multicolumn{2}{|c|}{ Fronteiras da Amostra* $^{*}$} \\
\hline & & & Inferior & Superior \\
\hline RRCGA (\% ao ano efetiva acima do IGP) & $1,24 \%$ & $0,51 \%$ & $0,41 \%$ & $2,08 \%$ \\
\hline RCGA(R\$ mil da base/ano) & 6.288 & 127 & 6.079 & 6.496 \\
\hline Saldo(p): RCGA - CCGA (em R\$ mil da base/ano) & 340 & 137 & 114 & 566 \\
\hline ARC (\% ao ano) & $0,31 \%$ & $0,12 \%$ & $0,10 \%$ & $0,51 \%$ \\
\hline
\end{tabular}

${ }^{*} 90 \%$ de confiabilidade do indicador se situar entre estas fronteiras

NOTA: estes indicadores são medidos em amostras de laboratório diferentes.

Nesse sentido, as fronteiras dos intervalos não representam pares de valores.

Tabela 45 - Intervalos de Valor dos Indicadores RRCGA e ARC para a [alternativa] - SLB do Imóvel 1 conforme Cenários Estressados 
Em relação à redução dos impactos tributários [Critério I], como existe o lucro na venda, a empresa pagará um total de impostos no valor de $14.026 \mathrm{R} \$$ mil da base, no início do horizonte de análise. O fluxo gerado pela economia tributária de cada exercício no intervalo [1.977 - 2.159] R\$ mil por ano em função da despesa operacional com a locação, descontado ao wacc da empresa, não é suficiente para cobrir o valor dos impostos devidos no início do fluxo, resultando em uma ETEDO negativa de (1.761) R $\$$ mil da base na média da amostra.

Na opção em continuar proprietária a ETD é nula, uma vez que o imóvel 1 está totalmente depreciado.

\begin{tabular}{|c|c|c|c|c|}
\hline \multicolumn{5}{|c|}{ CRITÉRIO I - IMÓVEL 1 (SEDE ADMINISTRATIVA) - SLB } \\
\hline \multicolumn{5}{|c|}{ Intervalos de Valor dos Indicadores relacionados à Economia Tributária } \\
\hline \multicolumn{5}{|c|}{ (Cenário Referencial) } \\
\hline \multirow{2}{*}{ Indicadores (em R\$ mil da base) } & \multirow{2}{*}{ Média } & \multirow{2}{*}{ Desvio } & \multicolumn{2}{|c|}{ Fronteiras da Amostra* } \\
\hline & & & Inferior & Superior \\
\hline ETEDO: SLB & $(1.761)$ & 131 & $(1.976)$ & $(1.545)$ \\
\hline ETD: Continuar SP & - & - & - & - \\
\hline
\end{tabular}

Tabela 46 - Intervalos de Valor do Indicador Economia Tributária Efetiva da Despesa Operacional dedutível (ETEDO) para a [alternativa] - SLB do Imóvel 1

No que tange ao balanço, que conforme situação atual (dezembro de 2009) apresenta os índices financeiros da Tabela 47, promover o SLB melhoria significativamente seus índices financeiros conforme demonstrado na Tabela 48, uma vez que o valor de venda é ativado ficando disponível para investimentos no negócio principal ou pagamento de dívidas de curto prazo $^{152}$. Ao continuar proprietária do imóvel 1 o balanço não se altera, mantendo os mesmos índices financeiros apresentados na Tabela 47.

152 O detalhamento do impacto da [alternativa] - SLB no balanço da empresa do caso também está no Apêndice B deste texto. 


\begin{tabular}{|c|c|c|c|}
\hline \multicolumn{4}{|c|}{$\begin{array}{l}\text { Balanço - EMPRESA DO CASO - IMÓVEL } 1 \text { (SEDE ADMINISTRATIVA) - SLB } \\
\text { Análise da Desmobilização a partir das características do imóvel e situação atual } \\
\text { (com base no Balanço de Dezembro/2009 - Valores em R\$ mil) }\end{array}$} \\
\hline Ativo Total & 926.789 & \multirow{3}{*}{\multicolumn{2}{|c|}{$\begin{array}{l}\text { Índices de Liquidez, } \\
\text { Endividamento e Grau } \\
\text { de Imobilização }\end{array}$}} \\
\hline Ativo Circulante & 286.853 & & \\
\hline Disponibilidades & 41.285 & & \\
\hline Ativo não Circulante & 639.936 & ILC & 1,10 \\
\hline Ativo Realizável a Longo Prazo & 32.414 & ILI & 0,16 \\
\hline Ativo Imobilizado+Investimentos+Intangível & 607.522 & PTRT & 0,51 \\
\hline Passivo Total & 926.789 & PTPL & 1,04 \\
\hline Passivo Circulante & 261.618 & PECP & 0,55 \\
\hline Passivo Não Circulante (exigível a longo prazo) & 210.466 & GIPL & 1,34 \\
\hline Patrimônio Líquido & 454.705 & CGL & 25.235 \\
\hline
\end{tabular}

Tabela 47 - Balanço e índices financeiros da empresa do caso, conforme situação atual (com base no balanço de dezembro de 2009)

\begin{tabular}{|c|c|c|c|c|}
\hline \multicolumn{5}{|c|}{$\begin{array}{c}\text { Indicadores - Critério H (Desoneração do Balanço) - SLB } \\
\text { EMPRESA DO CASO - IMÓVEL } 1 \text { (SEDE ADMINISTRATIVA) } \\
\text { (Valores em R\$ mil) }\end{array}$} \\
\hline Índices & Impactos [alt & a]: SLB & $\begin{array}{r}\operatorname{Imp} \\
\text { [alternativa]: }\end{array}$ & uar SP \\
\hline ILC & 1,17 & $6,30 \%$ & 1,10 & $0,00 \%$ \\
\hline ILI & 0,29 & $86,21 \%$ & 0,16 & $0,00 \%$ \\
\hline PTRT & 0,51 & $-0,18 \%$ & 0,51 & $0,00 \%$ \\
\hline PTPL & 1,03 & $-0,37 \%$ & 1,04 & $0,00 \%$ \\
\hline PECP & 0,57 & $3,29 \%$ & 0,55 & $0,00 \%$ \\
\hline GIPL & 1,28 & $-4,48 \%$ & 1,34 & $0,00 \%$ \\
\hline CGL & 46.627 & $84,77 \%$ & 25.235 & $0,00 \%$ \\
\hline
\end{tabular}

Tabela 48 - Índices financeiros para a [alternativa] - SLB do Imóvel 1

A análise da desmobilização patrimonial do imóvel 1 indica pouca vantagem em promover o SLB, já que considerando a situação atual do ativo no balanço da empresa tem-se o lucro na venda, o qual prejudica bastante os ganhos que a opção pela não imobilização traz (medidos pelos indicadores: RRCGA, ARC e ETEDO). Nesse sentido, embora o [MAOI] tenha indicado a não imobilização no imóvel 1, os resultados da análise da desmobilização patrimonial sustentam a decisão da empresa, que é manter o imóvel como propriedade do grupo, e adequá-lo para atender as demandas futuras nos próximos 20 anos.

A mesma rotina apresentada detalhadamente para a sede administrativa da empresa do caso é aplicada para os demais imóveis $(2,3,4,5$ e 6$)$. No entanto, será apresentada de forma concisa no decorrer deste capítulo a rotina de aplicação do [MAOI] também para os imóveis 3 (Laboratório e Armazenagem) e 4 (Complexo Industrial), e ao final do capítulo apresentados os resultados para todos os imóveis do portfolio da empresa. 


\subsection{Aplicação do [MAOI] para o Imóvel 3 (LABORATÓRIO E ARMAZENAGEM)}

O imóvel 3 é o laboratório de biotecnologia, onde também são produzidas as ampolas e frascos de vidros, e onde se concentram as operações de armazenagem da empresa. Este imóvel apresenta $12.954 \mathrm{~m}^{2}$ de área construída, com 20 anos de horizonte de uso. Segundo laudo de avaliação, o imóvel 3 tem valor de mercado de 51.000 R \$ mil da base. Considera-se este valor como o CGA deste imóvel.

A partir do valor de transação considerado (51.000 R \$ mil da base) e das mesmas variáveis para cálculo de VOI já apresentadas para a sede administrativa da empresa (imóvel 1), encontra-se o intervalo dos preços de locação do imóvel 3 de modo a resultar em um intervalo de VOI que contemple o valor de transação.

Para este imóvel o preço de locação no intervalo [531 - 596] R \$ mil por mês resulta no intervalo para VOI [50.680 - 51.733] R\$ mil da base, conforme apresentado no Gráfico 27 e na Tabela 49. O valor de transação fica bem próximo da média da amostra. Dessa forma, considera-se o intervalo [531 - 596] R\$ mil por mês como o CCGA para o imóvel 3.

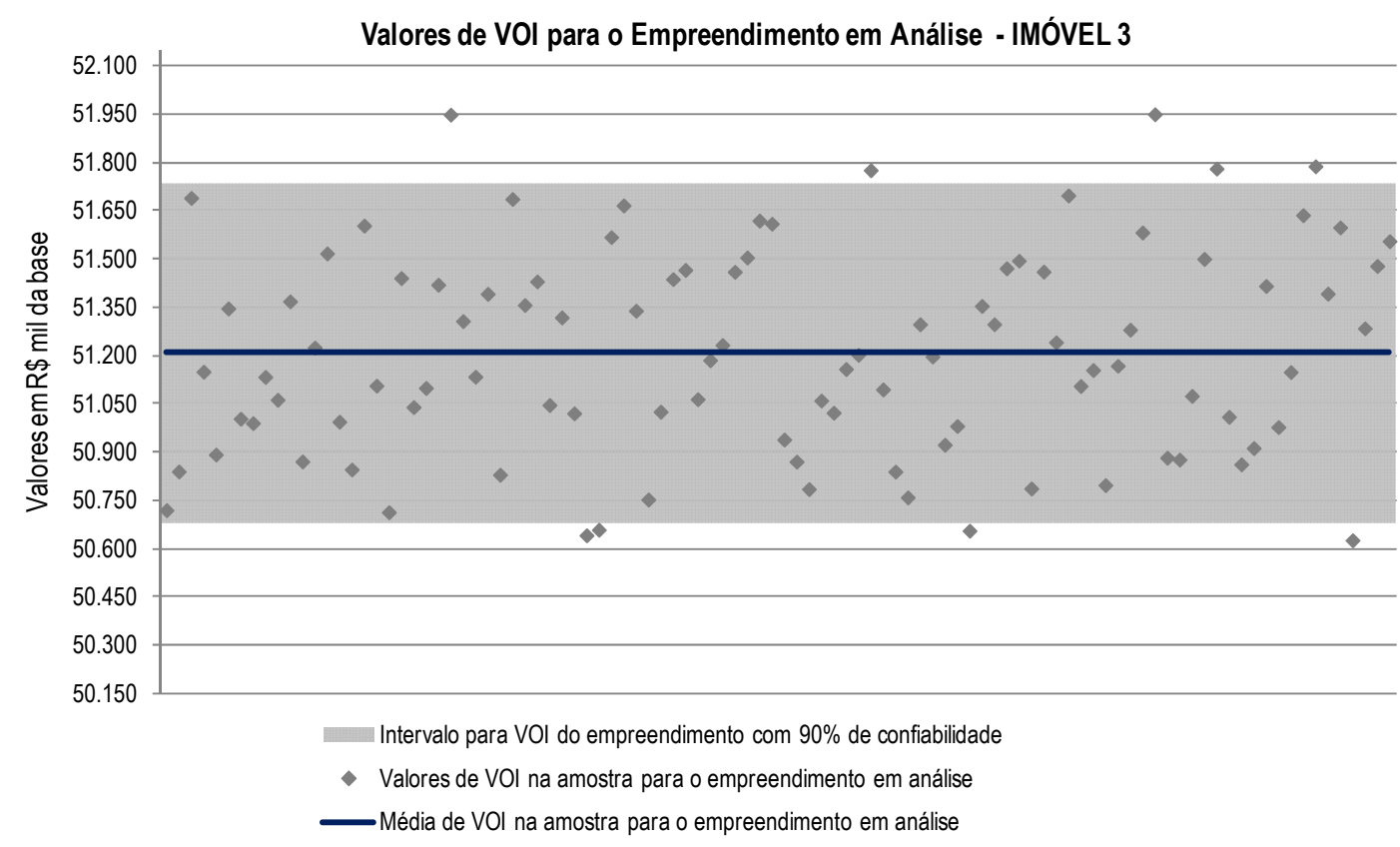

Gráfico 27 - Intervalo de VOI para o Imóvel 3 da empresa do caso 
Intervalos de Valor para: VOI, Participação de VOIn e TIR (investidor) - IMÓVEL 3

\begin{tabular}{c|c|c|c|c}
\multicolumn{3}{c}{ (Cenário Referencial) } \\
\hline \multirow{2}{*}{ Indicadores } & \multirow{2}{*}{ Média } & \multirow{2}{*}{ Desvio } & \multicolumn{2}{|c}{ Fronteiras da Amostra* } \\
\cline { 4 - 5 } & & & Inferior & Superior \\
\hline VOI (em R\$ mil da base) & 51.207 & 320 & 50.680 & 51.733 \\
\hline Participação de VOIn & $10,9 \%$ & $0,1 \%$ & $10,7 \%$ & $11,0 \%$ \\
\hline TIR (\% ao ano efetiva acima do IGP) & $10,5 \%$ & $0,1 \%$ & $10,4 \%$ & $10,6 \%$ \\
\hline
\end{tabular}

${ }^{*} 90 \%$ de confiabilidade do indicador se situar entre estas fronteiras

NOTA: estes indicadores são medidos em amostras de laboratório diferentes.

Nesse sentido, as fronteiras dos intervalos não representam pares de valores.

Tabela 49 - Intervalos de valor para: VOI, Participação de VOI $n$ e TIR - Imóvel 3

A Tabela 50 apresenta os dados e demandas do imóvel 3 para cálculo das referências quantitativas do [MAOI], bem como os parâmetros de decisão estipulados pelo decisor. Como o valor de transação é equivalente ao da sede administrativa, e este imóvel também é considerado de padronização comum em relação aos demais imóveis da empresa, o decisor estipula os mesmos parâmetros de referência definidos para a sede.

\begin{tabular}{|c|c|c|c|}
\hline \multicolumn{4}{|c|}{ DADOS DO IMÓVEL 3 (LABORATÓRIO EARMAZENAGEM) - ESTUDO DO CASO } \\
\hline \multicolumn{4}{|c|}{ Valores em R\$ mil da base } \\
\hline Tipologia e Atividades: & \multicolumn{3}{|c|}{$\begin{array}{l}\text { Laboratório de biotecnologia, produção de ampolas e frascos de vidros, com operações de } \\
\text { armazenagem e expedição de amostras grátis e materiais promocionais }\end{array}$} \\
\hline Área Construída & 12.954 & $\mathrm{~m}^{2}$ & \\
\hline Horizonte de uso (n) & 20 & anos & \\
\hline $\begin{array}{l}\text { Valor de Transação } \\
\text { Valor do Terreno }\end{array}$ & $\begin{array}{l}51.000 \\
14.021\end{array}$ & Valores inf & Iados pela empresa a partir de laudo de avaliação \\
\hline \multirow{2}{*}{ Preço de Locação } & Superior & Inferior & (faixas encontradas pela rotina de cálculo do VOI) \\
\hline & 531 & 596 & $\mathrm{R} \$$ mil por mês sem ajuste no ciclo de 1 ano \\
\hline Instrumento Jurídico Preferido & Contrato de Lo & cação & \\
\hline \multicolumn{4}{|c|}{ PARÂMETROS DE DECISÃO DETERMINADOS PELA EMPRESA DO CASO PARA O IMÓVEL 3} \\
\hline $\begin{array}{l}\text { Renda Relativa do Capital de } \\
\text { Giro Ativado }\end{array}$ & \multicolumn{3}{|c|}{$\begin{array}{l}\text { Mínimo de parâmetro de referência para a renda relativa gerada pelas [alternativas] de } \\
8 \% \text { ao ano não imobilização ou imobilzação a prazo }\end{array}$} \\
\hline $\begin{array}{l}\text { Acréscimo no resultado } \\
\text { corporativo }\end{array}$ & \multicolumn{3}{|c|}{$\begin{array}{l}\text { Mínimo de parâmetro de referência para o acréscimo do resultado corporativo gerado } \\
4 \% \text { ao ano pelas [alternativas] de não imobilização ou imobilzação a prazo }\end{array}$} \\
\hline Impacto no Balanço & $\begin{array}{c}\text { Até } 80 \% \\
>1,0 \\
>10.000 \mathrm{R} \$ \mathrm{mil}\end{array}$ & $\begin{array}{l}\text { PTRT } \\
\text { ILG } \\
\text { CGL }\end{array}$ & $\begin{array}{l}\text { manter o PTRT inferior a } 80 \% \\
\text { manter o ILC superior a } 1,0 \\
\text { manter o CGL superior a } 10.000 \mathrm{R} \$ \text { mil }\end{array}$ \\
\hline Economia Tributária & \multicolumn{3}{|c|}{$\begin{array}{c}7.000 \text { parâmetro de referência para a diferença entre a economia tributária das } \\
\mathrm{R} \$ \text { mil da base [alternativas] de não imobilização e a economia tributária da imobilização }\end{array}$} \\
\hline \multicolumn{4}{|c|}{ SITUAÇÃO ATUAL DO IMÓVEL 3 (LABORATÓRIO E ARMAZENAGEM) } \\
\hline Vida Útil Remanescente & 7 & anos & \\
\hline Valor de Registro & 2.566 & & \\
\hline
\end{tabular}

Tabela 50 - Dados do imóvel 3 para cálculo dos referências quantitativas do [MAOI] 


\subsubsection{Referências Quantitativas do [MAOI] para o Imóvel 3}

Com base nos dados e demandas do imóvel 3, identifica-se os indicadores do [MAOI] para cada uma das [alternativas].

\subsubsection{Canalização de recursos em oportunidades do negócio principal - [Critério G]}

A renda gerada a partir do investimento do CGA de $51.000 \mathrm{R} \$$ mil da base no negócio principal da empresa está no intervalo [1.064 - 1.150] R\$ mil por mês. Para cálculo do intervalo da renda utiliza-se o ROE da empresa no intervalo [2,09\% - 2,26\%] equivalente ao mês. Esta renda é gerada ocorrendo concomitantemente o CCGA referente ao pagamento dos aluguéis, calculado no intervalo [531 - 596] R \$ mil por mês para o imóvel 3 a partir da rotina de cálculo do VOI.

As variáveis RCGA e CCGA, encontradas de forma randômica no modelo, geram o saldo (p), que divido pelo CGA, resulta na RRCGA para as [alternativas] de não imobilização no intervalo [12,87\% - 13,70\%] ao ano efetiva acima do IGP, conforme Gráfico 28 e Tabela 51. No mesmo gráfico é possível verificar os valores da RRCGA na amostra de laboratório para os cenários estressados (com perturbação sem compensação no ROE da empresa na faixa [0\% a $-20 \%$ ] de desempenho).

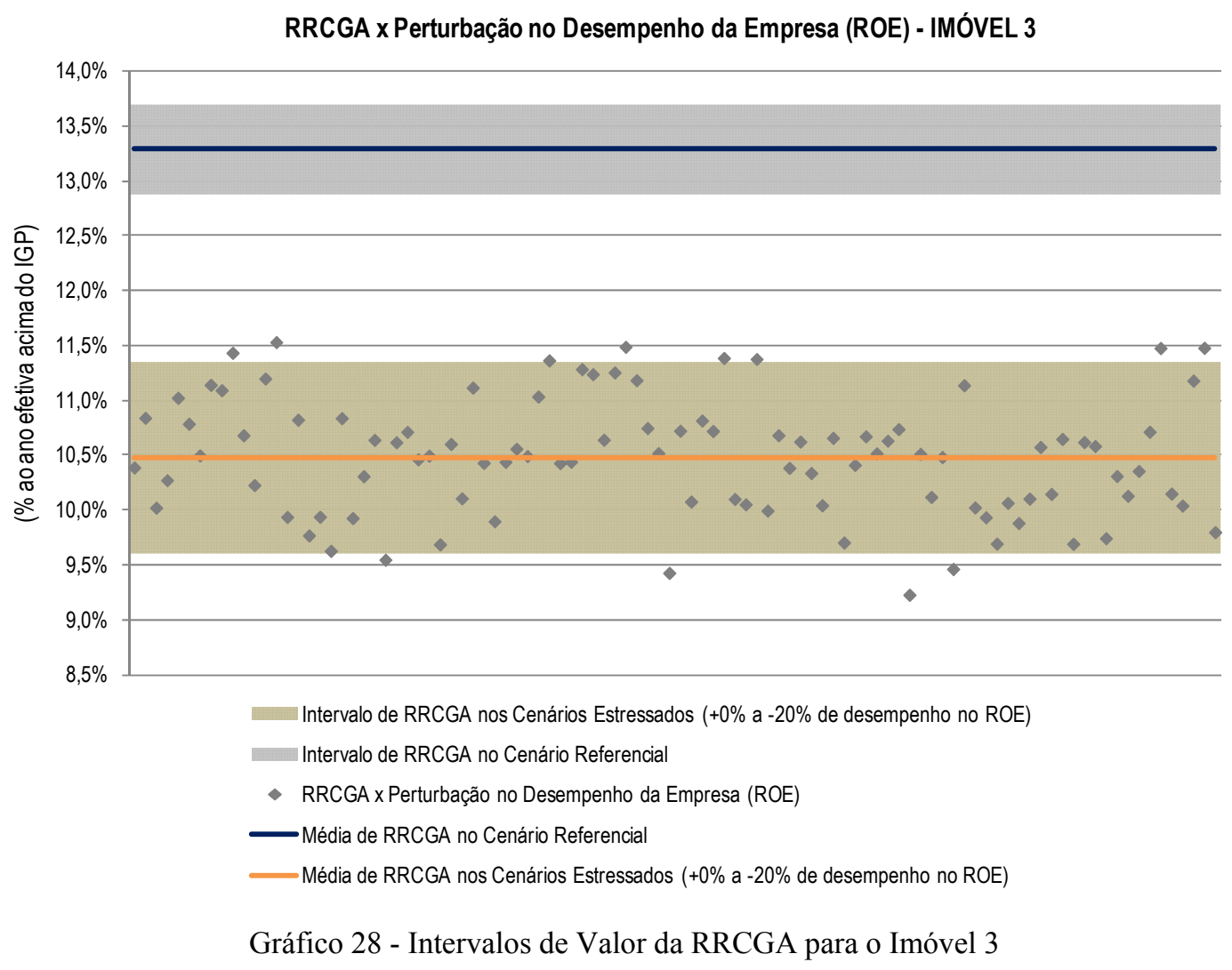


Mesmo para os cenários estressados a RRCGA se situa no intervalo [9,60\% - 11,35\%] ao ano efetiva acima do IGP, ainda acima do parâmetro de referência estipulado pelo decisor.

O saldo (p) gerado pela RCGA subtraído do CCGA está no intervalo [6.207 - 6.583] R\$ mil da base. Ou seja, apenas não imobilizando no ativo com estas características e demandas, a empresa geraria o saldo de $6.395 \mathrm{R} \$$ mil da base por ano na média da amostra, que representa um aumento no resultado corporativo da empresa de 5,80\% ao ano na média da amostra, também superior ao parâmetro desejado pelo decisor.

\begin{tabular}{|c|c|c|c|c|}
\hline \multicolumn{5}{|c|}{ CRITÉRIO G - IMÓVEL 3 (LABORATÓRIO EARMAZENAGEM) } \\
\hline \multicolumn{5}{|c|}{ Intervalos de Valor dos Indicadores: RRCGA e ARC } \\
\hline \multicolumn{5}{|c|}{ (Cenário Referencial) } \\
\hline \multirow{2}{*}{$\begin{array}{c}\text { Indicadores } \\
\text { [Alternativas]: BTS, LLP e LCP }\end{array}$} & \multirow{2}{*}{ Média } & \multirow{2}{*}{ Desvio } & \multicolumn{2}{|c|}{ Fronteiras da Amostra* } \\
\hline & & & Inferior & Superior \\
\hline RRCGA (\% ao ano efetiva acima do IGP) & $13,29 \%$ & $0,25 \%$ & $12,87 \%$ & $13,70 \%$ \\
\hline RCGA (R $\$$ mil da base/ano) & 13.005 & 93 & 12.853 & 13.157 \\
\hline Saldo(p): RCGA - CCGA (em R \$ mil da base/ano) & 6.395 & 114 & 6.207 & 6.583 \\
\hline ARC (\% ao ano) & $5,80 \%$ & $0,10 \%$ & $5,63 \%$ & $5,97 \%$ \\
\hline
\end{tabular}

${ }^{*} 90 \%$ de confiabilidade do indicador se situar entre estas fronteiras

NOTA: estes indicadores são medidos em amostras de laboratório diferentes.

Nesse sentido, as fronteiras dos intervalos não representam pares de valores.

Tabela 51 - Intervalos de Valor dos Indicadores RRCGA e ARC no Cenário Referencial - Imóvel 3

\begin{tabular}{|c|c|c|c|c|}
\hline \multicolumn{5}{|c|}{ CRITÉRIO G - IMÓVEL 3 (LABORATÓRIO E ARMAZENAGEM) } \\
\hline \multicolumn{5}{|c|}{ Intervalos de Valor dos Indicadores: RRCGA e ARC } \\
\hline \multicolumn{5}{|c|}{ (Desvio de ROE - faixa: + 0\% a -20\%) } \\
\hline \multirow{2}{*}{$\begin{array}{c}\text { Indicadores } \\
\text { [Alternativas]: BTS, LLP e LCP }\end{array}$} & \multirow{2}{*}{ Média } & \multirow{2}{*}{ Desvio } & \multicolumn{2}{|c|}{ Fronteiras da Amostra* } \\
\hline & & & Inferior & Superior \\
\hline RRCGA (\% ao ano efetiva acima do IGP) & $10,48 \%$ & $0,53 \%$ & $9,60 \%$ & $11,35 \%$ \\
\hline RCGA(R\$ mil da base/ano) & 11.713 & 236 & 11.324 & 12.102 \\
\hline Saldo(p): RCGA- CCGA (em R \$ mil da base/ano) & 5.103 & 247 & 4.696 & 5.510 \\
\hline ARC (\% ao ano) & $4,63 \%$ & $0,22 \%$ & $4,26 \%$ & $5,00 \%$ \\
\hline
\end{tabular}

Tabela 52 - Intervalos de Valor dos Indicadores RRCGA e ARC nos Cenários Estressados - Imóvel 3

Para cálculo dos indicadores relacionados ao [Critério G] na imobilização a prazo, considerase as mesmas condições de financiamento apresentadas para o imóvel 1, as quais são: [i] parcela financiada equivalente a $50 \%$ do valor de transação, [ii] juros de $13 \%$ ao ano, [iii] prazo de amortização de 7 anos e [iv] sistema Price de amortização.

A partir destas condições, o CGA da [alternativa] - SP a Prazo de 25.500 R \$ mil da base 
aplicado no negócio principal da empresa, com ROE no intervalo [2,09\% - 2,26\%] equivalente ao mês, gera um renda mensal no intervalo [532- 575] R \$ mil. Além desta renda, a empresa deixa de pagar os aluguéis no intervalo [531 - 596] R \$ mil por mês. No final do horizonte de análise o $\mathrm{VOI}_{\mathrm{n}}$, calculado em $41.178 \mathrm{R} \$$ mil da base, também é positivo ao fluxo de caixa desta [alternativa].

Os elementos de saída no fluxo de caixa para estas condições de financiamento são as parcelas para pagamento do principal e juros (454 R \$ mil por mês, durante 7 anos), e a perda de oportunidade de gerar renda no intervalo [532 - 575] R \$ mil por mês, referente ao montante equivalente à parcela não financiada do imóvel que deixa de gerar ROE.

A partir do fluxo de caixa gerado pelos valores apresentados calcula-se a RRIP para o imóvel 3, que conforme o Gráfico 29 e a Tabela 53 está no intervalo [2,27\% - 2,85\%] ao ano efetiva acima do IGP, inferior ao parâmetro de referência do decisor, mesmo para o cenário referencial.

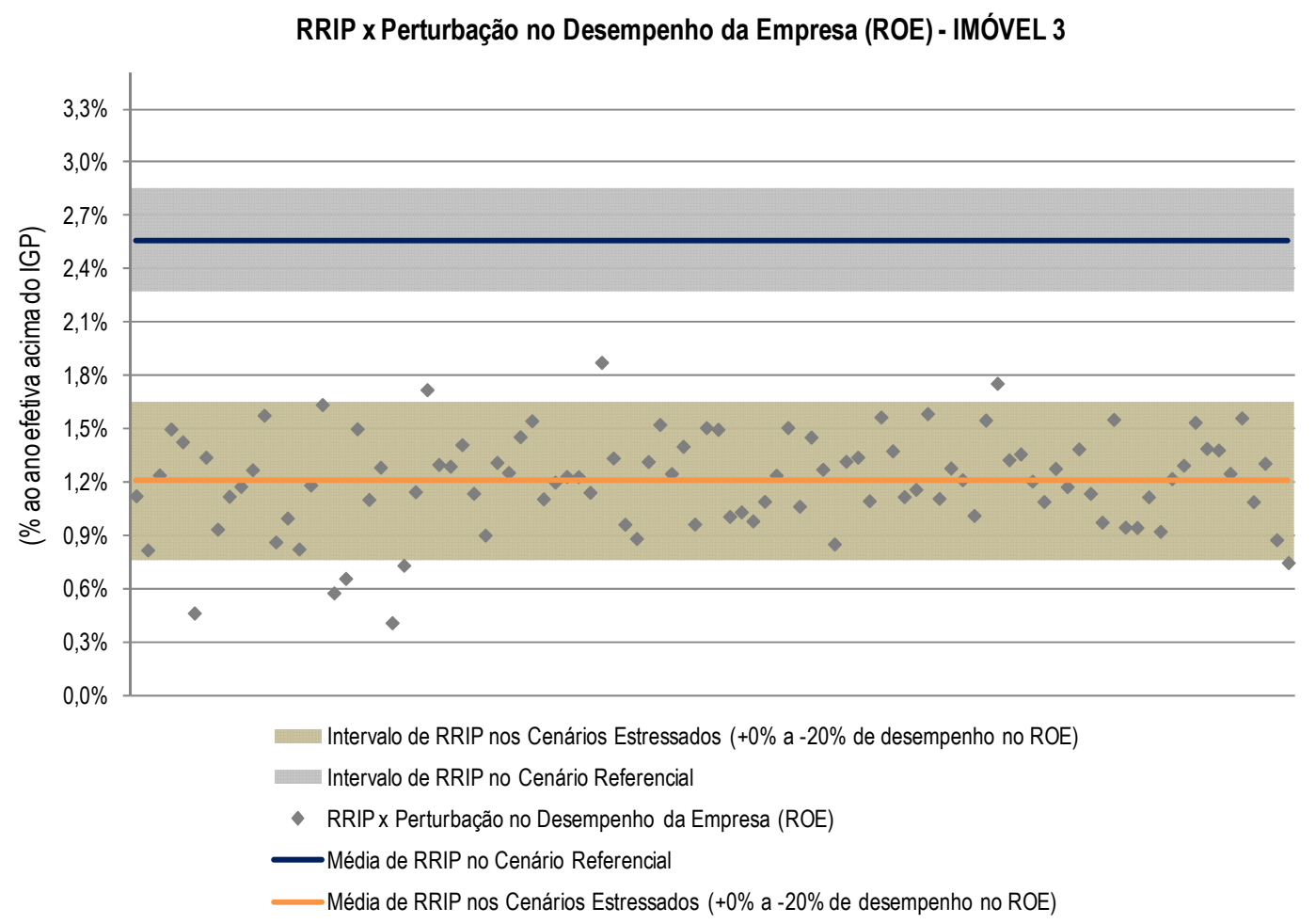

Gráfico 29 - Intervalos de Valor da RRIP para o Imóvel 3 


\begin{tabular}{|c|c|c|c|c|}
\hline \multicolumn{5}{|c|}{ CRITÉRIO G - IMÓVEL 3 (LABORATÓRIO E ARMAZENAGEM) } \\
\hline \multicolumn{5}{|c|}{ Intervalos de Valor dos Indicadores: RRIP, TRIP e ARC } \\
\hline \multicolumn{5}{|c|}{ (Cenário Referencial) } \\
\hline Indicadores & \multirow{2}{*}{ Média } & \multirow{2}{*}{ Desvio } & \multicolumn{2}{|c|}{ Fronteiras da Amostra* } \\
\hline [Alternativa]: SP a prazo & & & Inferior & Superior \\
\hline RRIP (\% ao ano efetiva acima do IGP) & $2,56 \%$ & $0,18 \%$ & $2,27 \%$ & $2,85 \%$ \\
\hline RCGA(R\$ mil da base/ano) & 6.495 & 45 & 6.421 & 6.569 \\
\hline Saldo $\mathrm{P}^{\prime}(\mathrm{R} \$$ mil da base/ano) & 1.291 & 88 & 1.146 & 1.436 \\
\hline ARC (\% ao ano) & $1,17 \%$ & $0,08 \%$ & $1,04 \%$ & $1,30 \%$ \\
\hline TRIP (\% ao ano efetiva acima do IGP) & $7,88 \%$ & $0,04 \%$ & $7,82 \%$ & $7,94 \%$ \\
\hline Participação VOIn & $17,68 \%$ & $0,12 \%$ & $17,48 \%$ & $17,89 \%$ \\
\hline
\end{tabular}

${ }^{*} 90 \%$ de confiabilidade do indicador se situar entre estas fronteiras

NOTA: estes indicadores são medidos em amostras de laboratório diferentes.

Nesse sentido, as fronteiras dos intervalos não representam pares de valores.

Tabela 53 - Intervalos de Valor dos Indicadores RRIP, TRIP e ARC no Cenário Referencial - Imóvel 3

Conforme se verifica na Tabela 53, até mesmo a TRIP se situa abaixo de $8 \%$ ao ano efetiva acima do IGP. A TRIP calculada no intervalo $[7,82 \%$ - 7,94\%] equivalente ano efetiva acima do IGP considera o valor de venda do ativo $\left(\mathrm{VOI}_{\mathrm{n}}\right)$ no final do horizonte de análise, que neste caso é responsável por produzir TRIP sobre 17,68\% do investimento (valor de transação). O intervalo encontrado para ARC $[1,04 \%$ - 1,30\%] ao ano também está bem abaixo do parâmetro estipulado pelo decisor (4\% ao ano).

Para os cenários estressados, os indicadores sofrem forte queda, conforme apresentado na Tabela 54, que indica uma redução na RRIP em aproximadamente 53\% na média da amostra para uma perturbação sem compensação no ROE da empresa de até $20 \%$ de desempenho.

\begin{tabular}{|c|c|c|c|c|}
\hline \multicolumn{5}{|c|}{ CRITÉRIO G - IMÓVEL 3 (LABORATÓRIO E ARMAZENAGEM) } \\
\hline \multicolumn{5}{|c|}{ Intervalos de Valor dos Indicadores: RRIP, TRIP e ARC } \\
\hline \multicolumn{5}{|c|}{ (Desvio de ROE - faixa: + 0\% a -20\%) } \\
\hline \multirow{2}{*}{$\begin{array}{c}\text { Indicadores } \\
\text { [Alternativa]: SP a prazo }\end{array}$} & \multirow{2}{*}{ Média } & \multirow{2}{*}{ Desvio } & \multicolumn{2}{|c|}{ Fronteiras da Amostra* } \\
\hline & & & Inferior & Superior \\
\hline RRIP (\% ao ano efetiva acima do IGP) & $1,21 \%$ & $0,27 \%$ & $0,76 \%$ & $1,65 \%$ \\
\hline RCGA(R\$ mil da base/ano) & 5.829 & 124 & 5.625 & 6.033 \\
\hline Saldo P' (R\$ mil da base/ano) & 612 & 137 & 387 & 838 \\
\hline ARC (\% ao ano) & $0,56 \%$ & $0,12 \%$ & $0,35 \%$ & $0,76 \%$ \\
\hline TRIP (\% ao ano efetiva acima do IGP) & $6,71 \%$ & $0,05 \%$ & $6,62 \%$ & $6,80 \%$ \\
\hline Participação VOIn & $21,99 \%$ & $0,23 \%$ & $21,61 \%$ & $22,36 \%$ \\
\hline
\end{tabular}

${ }^{*} 90 \%$ de confiabilidade do indicador se situar entre estas fronteiras

NOTA: estes indicadores são medidos em amostras de laboratório diferentes.

Nesse sentido, as fronteiras dos intervalos não representam pares de valores.

Tabela 54 - Intervalos de Valor dos Indicadores RRIP, TRIP e ARC nos Cenários Estressados - Imóvel 3

A Tabela 55 apresenta os testes de sensibilidade para a RRIP considerando diferentes 
condições para o financiamento do imóvel 3. Pelos testes de sensibilidade é possível verificar que a RRIP só estaria acima do parêmetro de referência do decisor para parcelas financiadas do imóvel acima de $70 \%$ com juros de até $14 \%$ ao ano. Para prazos de amortização superiores a 10 anos com parcela financiada do imóvel acima de 60\%, a RRIP já se encontra acima de $8 \%$ ao ano efetiva acima do IGP. Porém, considerando a parcela financiada conforme cenário referencial (50\%) e prazo de 5 anos para amortização do financiamento a RRIP seria negativa (perda de oportunidade de ganho).

\begin{tabular}{|c|c|c|c|c|c|c|c|}
\hline & & \multicolumn{6}{|c|}{ Variação da Taxa de Juros (\% ao ano nominal) } \\
\hline & & $11 \%$ & $12 \%$ & $13 \%$ & $14 \%$ & $15 \%$ & $16 \%$ \\
\hline \multirow{11}{*}{ 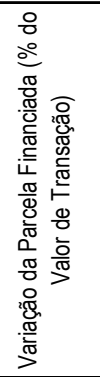 } & $100 \%$ & $20,55 \%$ & $19,55 \%$ & $18,78 \%$ & $18,40 \%$ & $17,47 \%$ & $16,89 \%$ \\
\hline & $95 \%$ & $18,22 \%$ & $17,72 \%$ & $17,37 \%$ & $16,71 \%$ & $16,39 \%$ & $15,31 \%$ \\
\hline & $90 \%$ & $16,97 \%$ & $16,32 \%$ & $15,27 \%$ & $14,92 \%$ & $14,54 \%$ & $13,71 \%$ \\
\hline & $85 \%$ & $14,52 \%$ & $14,18 \%$ & $13,88 \%$ & $13,36 \%$ & $12,48 \%$ & $12,57 \%$ \\
\hline & $80 \%$ & $13,41 \%$ & $13,09 \%$ & $12,38 \%$ & $11,72 \%$ & $11,05 \%$ & $10,52 \%$ \\
\hline & $75 \%$ & $11,29 \%$ & $10,90 \%$ & $10,54 \%$ & $10,19 \%$ & $9,95 \%$ & $9,05 \%$ \\
\hline & $70 \%$ & $9,64 \%$ & $8,97 \%$ & $8,57 \%$ & $8,51 \%$ & $7,79 \%$ & $7,57 \%$ \\
\hline & $65 \%$ & $7,99 \%$ & $7,64 \%$ & $7,35 \%$ & $6,90 \%$ & $6,43 \%$ & $6,65 \%$ \\
\hline & $60 \%$ & $6,25 \%$ & $6,22 \%$ & $5,49 \%$ & $5,49 \%$ & $4,98 \%$ & $4,85 \%$ \\
\hline & $55 \%$ & $5,05 \%$ & $4,15 \%$ & $3,96 \%$ & $3,72 \%$ & $3,41 \%$ & $2,91 \%$ \\
\hline & $50 \%$ & $3,22 \%$ & $2,69 \%$ & $2,38 \%$ & $2,38 \%$ & $1,77 \%$ & $1,76 \%$ \\
\hline \multicolumn{8}{|c|}{\begin{tabular}{|l|}
\multicolumn{2}{|l|}{ Testes de Sensibilid } \\
\end{tabular}} \\
\hline & & 15 & 12 & 10 & 8 & 7 & 5 \\
\hline \multirow{7}{*}{ 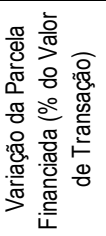 } & $100 \%$ & $27,06 \%$ & $25,56 \%$ & $23,61 \%$ & $20,93 \%$ & $19,04 \%$ & $13,11 \%$ \\
\hline & $90 \%$ & $21,97 \%$ & $21,52 \%$ & $19,28 \%$ & $17,63 \%$ & $15,50 \%$ & $10,42 \%$ \\
\hline & $80 \%$ & $18,25 \%$ & $17,00 \%$ & $15,86 \%$ & $13,53 \%$ & $12,12 \%$ & $7,87 \%$ \\
\hline & $70 \%$ & $13,83 \%$ & $12,71 \%$ & $11,79 \%$ & $10,10 \%$ & $8,87 \%$ & $4,77 \%$ \\
\hline & $60 \%$ & $10,01 \%$ & $9,20 \%$ & $8,06 \%$ & $6,40 \%$ & $5,32 \%$ & $2,49 \%$ \\
\hline & $55 \%$ & $7,81 \%$ & $7,24 \%$ & $6,45 \%$ & $5,21 \%$ & $4,08 \%$ & $1,01 \%$ \\
\hline & $50 \%$ & $6,19 \%$ & $5,27 \%$ & $4,81 \%$ & $3,24 \%$ & $2,49 \%$ & $-0,33 \%$ \\
\hline
\end{tabular}

Tabela 55 - Testes de sensibilidade para a RRIP em função de variações nas condições do financiamento para aquisição do Imóvel 3

A partir dos indicadores apresentados para o [Critério G] para cada uma das [alternativas], que inclui também as análises de risco, pontua-se as notas das [alternativas] no Nível 3 do AHP. O Gráfico 30 apresenta os pesos relativos das [alternativas] para o [Critério G] referentes ao imóvel 3. Verifica-se que os pesos relativos das [alternativas] para o [Critério G] são similares aos pesos relativos resultantes para o imóvel 1, visto que os indicadores do imóvel 3 relacionados a este critério estão muito próximos aos indicadores encontrados para a sede administrativa (imóvel 1). 
Perspectiva Planejador (Imóvel 3) - CRITÉRIO G

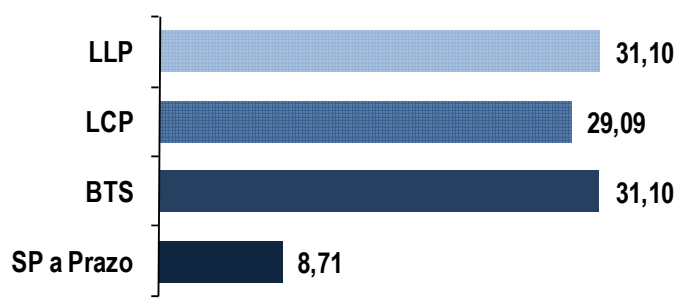

Gráfico 30 - Pesos relativos das [alternativas] para o [Critério G] - Imóvel 3

\subsubsection{Desoneração do Balanço - [Critério H]}

A Tabela 56 apresenta a situação do balanço da empresa quando é dada a baixa do imóvel 3 (na conta do imobilizado e patrimônio líquido). Assim como no caso da sede (imóvel 1), a baixa deste imóvel no balanço não provoca alterações significativas nos seus índices financeiros em relação à situação atual, visto o baixo valor contábil do imóvel 3 (2.566 R\$ mil da base).

\begin{tabular}{|c|c|c|c|}
\hline Ativo Total & 924.223 & \multirow{3}{*}{\multicolumn{2}{|c|}{$\begin{array}{c}\text { Índices de Liquidez, } \\
\text { Endividamento e Grau } \\
\text { de Imobilização }\end{array}$}} \\
\hline Ativo Circulante & 286.853 & & \\
\hline Disponibilidades & 41.285 & & \\
\hline Ativo não Circulante & 637.370 & ILC & 1,10 \\
\hline Ativo Realizável a Longo Prazo & 32.414 & ILI & 0,16 \\
\hline Ativo Imobilizado+Investimentos+Intangível & 604.956 & PTRT & 0,51 \\
\hline Passivo Total & 924.223 & PTPL & 1,04 \\
\hline Passivo Circulante & 261.618 & PECP & 0,55 \\
\hline Passivo Não Circulante (exigível a longo prazo) & 210.466 & GIPL & 1,34 \\
\hline Patrimônio Líquido & 452.139 & CGL & 25.235 \\
\hline
\end{tabular}

Tabela 56 - Índices financeiros da empresa para análise do impacto das [alternativas] em relação ao Imóvel 3 (Análise a partir das demandas e características do imóvel)

A Tabela 57 apresenta o impacto dos índices financeiros da empresa para cada uma das [alternativas]. Como o valor de transação é maior que o imóvel 1 as [alternativas] de imobilização (SP e SP a Prazo) impactam ainda mais nos índices financeiros do balanço. Neste caso, mesmo para a imobilização a prazo, o CGL calculado em $7.037 \mathrm{R} \$$ mil fica abaixo do parâmetro de referência estipulado pelo decisor (CGL de no mínimo 10.000 R\$ mil). O impacto da [alternativa] - SP no ILC está no limite do aceitável para o decisor (ILC 
sempre superior a 1,0). Quanto à participação dos recursos de terceiros em relação aos recursos totais (PTRT), é possível observar que os impactos causados por todas as [alternativas] comprometem o índice, porém nenhuma compromete acima do parâmetro de referência do decisor (PTRT sempre inferior a 0,8 ).

\begin{tabular}{|c|c|c|c|c|c|c|}
\hline \multicolumn{7}{|c|}{$\begin{array}{l}\text { Indicadores - Critério H (Desoneração do Balanço) } \\
\text { EMPRESA DO CASO - IMÓVEL } 3 \text { (LABORATÓRIO E ARMAZENAGEM) } \\
\text { (Valores em R\$ mil) }\end{array}$} \\
\hline Índices & $\begin{array}{l}\operatorname{Imp} \\
\text { [altern } \\
\text { BTS, L }\end{array}$ & $\begin{array}{l}\text { as]: } \\
\text { LCP }\end{array}$ & $\begin{array}{l}\text { Impa } \\
\text { [alternat }\end{array}$ & $\begin{array}{l}\text { tos } \\
\text { a]: SP }\end{array}$ & $\begin{array}{r}\operatorname{Imp} \\
\text { [alterr } \\
\mathrm{SP} \text { a }\end{array}$ & \\
\hline ILC & 1,07 & $-2,5 \%$ & 1,00 & $-8,9 \%$ & 1,03 & $-6,4 \%$ \\
\hline ILI & 0,15 & $-2,5 \%$ & 0,06 & $-61,8 \%$ & 0,11 & $-32,3 \%$ \\
\hline PTRT & 0,52 & $1,4 \%$ & 0,51 & $0,2 \%$ & 0,53 & $3,1 \%$ \\
\hline PTPL & 1,08 & $3,0 \%$ & 1,05 & $0,3 \%$ & 1,11 & $6,6 \%$ \\
\hline PECP & 0,56 & $1,1 \%$ & 0,55 & $0,0 \%$ & 0,53 & $-3,5 \%$ \\
\hline GIPL & 1,36 & $1,5 \%$ & 1,45 & $8,5 \%$ & 1,46 & $9,0 \%$ \\
\hline CGL & 18.473 & $-26,8 \%$ & (265) & $-101,1 \%$ & 7.037 & $-72,1 \%$ \\
\hline
\end{tabular}

Tabela 57 - Impacto nos índices financeiros do balanço para cada [alternativa] - Imóvel 3

Com base nos índices financeiros apresentados e nos parâmetros de referência do decisor para este critério, pontua-se as [alternativas] no Nível 3 do AHP. O Gráfico 31 apresenta os pesos relativos resultantes para o [Critério $\mathrm{H}$ ] a partir da ponderação de notas de atendimento atribuídas comparativamente entre as [alternativas].

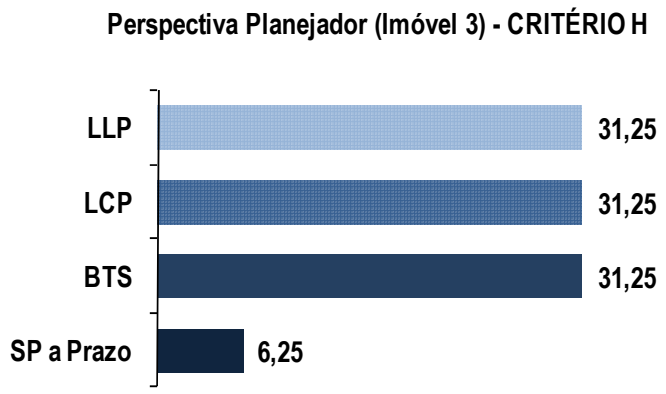

Gráfico 31 - Pesos relativos das [alternativas] para o [Critério H] - Imóvel 3

\subsubsection{Redução dos Impactos Tributários - [Critério I]}

No caso do imóvel 3 os fatores redutores do lucro tributável para gerar as economias tributárias em cada uma das [alternativas] são: 
[i] Depreciação de 4\% ao ano equivalente a 1.479 R \$ mil. Esta depreciação gera o fluxo de ETD em cada exercício no valor de $503 \mathrm{R} \$$ mil por ano, aplicada durante todo o horizonte de análise (25 anos).

[ii] Despesa financeira para a opção pela imobilização a prazo durante o prazo de amortização do financiamento ( 7 anos) do imóvel 3, que resulta no fluxo decrescente da economia tributária dos juros em cada exercício até final do prazo de amortização.

[iii] Despesa operacional com a locação no intervalo [6.373 - 7.151] R $\$$ mil por ano, que gera a ETDO em cada exercício no intervalo [2.167 - 2.431] R\$ mil, aplicada de forma randômica durante o horizonte de análise (25 anos).

As economias tributárias dos itens [i], [ii] e [iii] formam os fluxos para cada [alternativa], os quais descontados ao wacc da empresa, encontrado de forma randômica no modelo para o intervalo $[11,80 \%-23,22 \%]$ ao ano, resultam na economia tributária para cada uma das [alternativas] conforme apresentado na Tabela 58.

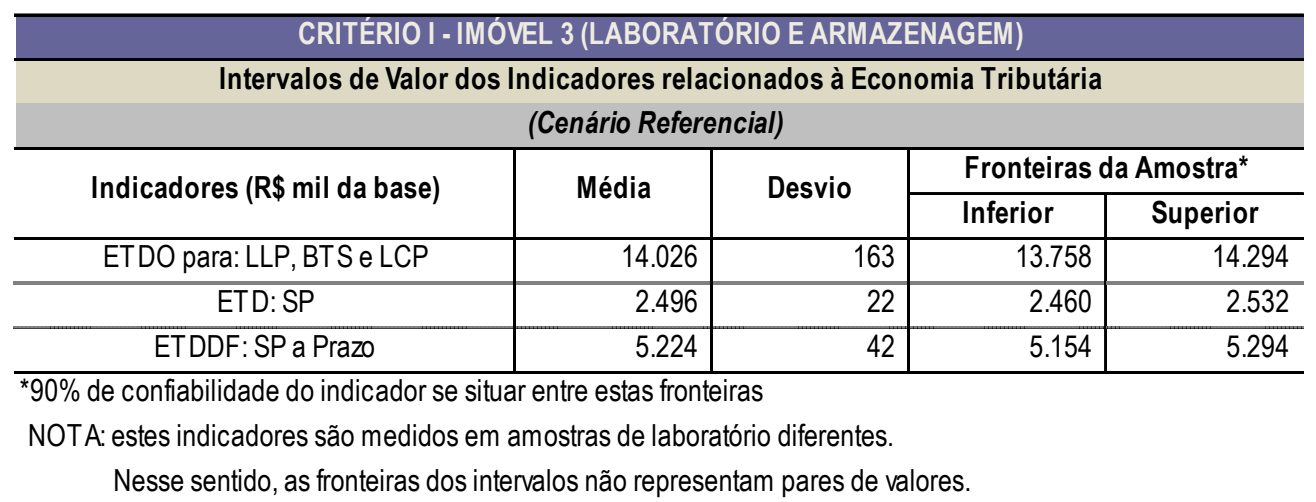

Tabela 58 - Intervalos de Valor dos Indicadores ETDO, ETD e ETDF - Imóvel 3

As diferenças entre a ETDO das [alternativas] de não imobilização em relação às [alternativas] SP e SP a Prazo são de 11.529 R\$ mil da base e 8.802 R\$ mil da base, respectivamente, ambas acima do parâmetro de referência entendido como atrativo para o decisor. Com base nestes indicadores, pontua-se as notas de atendimento das [alternativas] para o [Critério I]. Os pesos relativos das [alternativas] para o imóvel 3 em relação ao [Critério I] estão apresentados no Gráfico 32. 


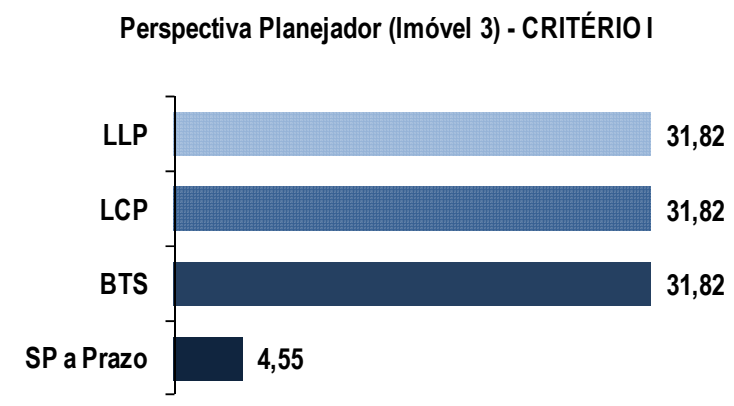

Gráfico 32 - Pesos relativos das [alternativas] para o [Critério I] - Imóvel 3

\subsubsection{Referências Qualitativas do [MAOI] para o Imóvel 3}

Neste item apresenta-se os pesos relativos resultantes das [alternativas] para os critérios de decisão relacionados ao uso do espaço corporativo, considerando as demandas e características do imóvel 3 para configurar o contexto da situação em análise.

O Gráfico 33 apresenta os pesos relativos das [alternativas] para o [Critério A] (flexibilidade de mudança) referentes ao imóvel 3. Como este imóvel pode apresentar padronização comum para atender às atividades desenvolvidas nele, que são principalmente pesquisas e operações de armazenagem, e o horizonte de uso do imóvel é no longo prazo, atribui-se as mesmas notas adotadas para o imóvel 1, resultando nos mesmos pesos relativos das [alternativas] para este critério. Assim como a sede, entende-se que o imóvel 3 pode se adequar ao uso de outros ocupantes e, portanto, a [alternativa] - SP a Prazo melhor atende ao [Critério A] em relação ao BTS, uma vez que a multa em caráter indenizatório praticada nestes contratos pode prejudicar a saída da empresa antes do horizonte de uso planejado, se desejado.

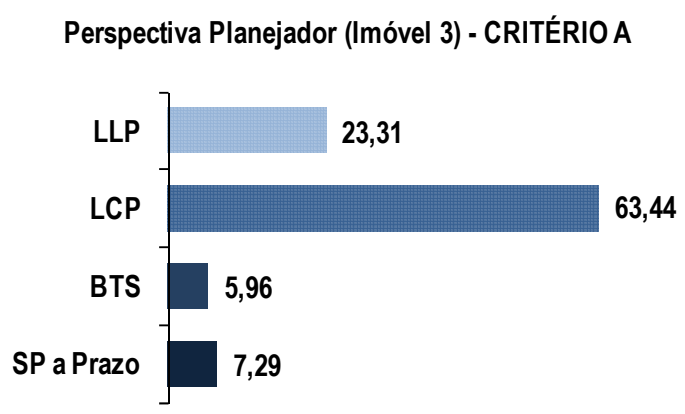

Gráfico 33 - Pesos relativos das [alternativas] para o [Critério A] - Imóvel 3

Em relação à rapidez na mobilização da atividade ao espaço [Critério B], conforme demonstrado no Gráfico 34, as [alternativas] de locação simples são as que melhor atendem a este critério. Para este imóvel a [alternativa] - SP a Prazo foi menos penalizada, em relação ao 
imóvel 1, resultado em pesos relativos um pouco distintos, já que o imóvel 3 é mais facilmente adaptado para atender as demandas operacionais, visto que estas demandas dependem muito mais dos equipamentos, instalações e máquinas, do que da escolha de um imóvel em boa localização e com necessidade de customizações.

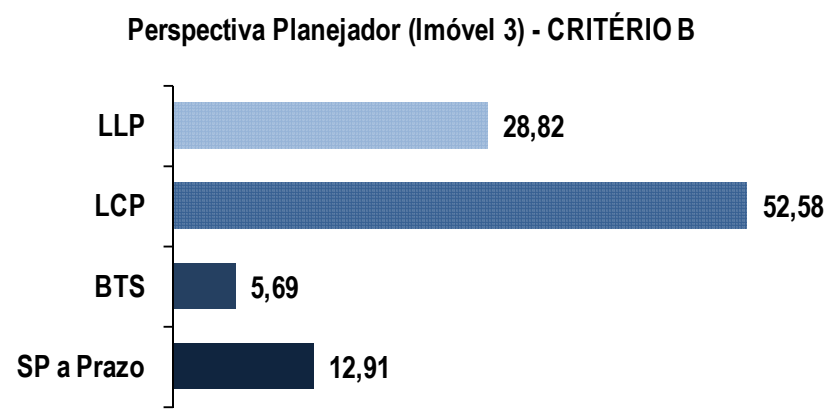

Gráfico 34 - Pesos relativos das [alternativas] para o [Critério B] - Imóvel 3

Como se verifica no Gráfico 35, para o controle operacional no uso do espaço [Critério C], ainda que a opção pela imobilização continue sendo a [alternativa] que melhor atende a este critério, as opções de locação simples (LLP e LCP) foram menos penalizadas em relação às demais [alternativas], principalmente para a LLP, visto que neste caso as intervenções no espaço são ainda menos frequentes, e em geral são feitas intervenções mais nos equipamentos instalados do que no próprio imóvel.

Perspectiva Planejador (Imóvel 3) - CRITÉRIO C

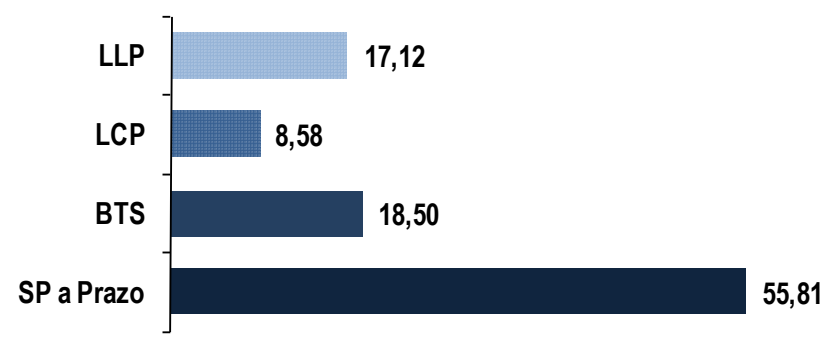

Gráfico 35 - Pesos relativos das [alternativas] para o [Critério C] - Imóvel 3

Em relação ao vínculo da operação com o imóvel [Critério D], para o imóvel 3 considera-se que a LLP atende igualmente à [alternativa] - BTS, já que o imóvel não é estratégico à atividade realizada no espaço, nem mesmo pela importância da localização. Com esta ponderação a opção pela imobilização também apresenta redução no seu peso relativo em relação ao peso resultante deste critério para o imóvel 1. 


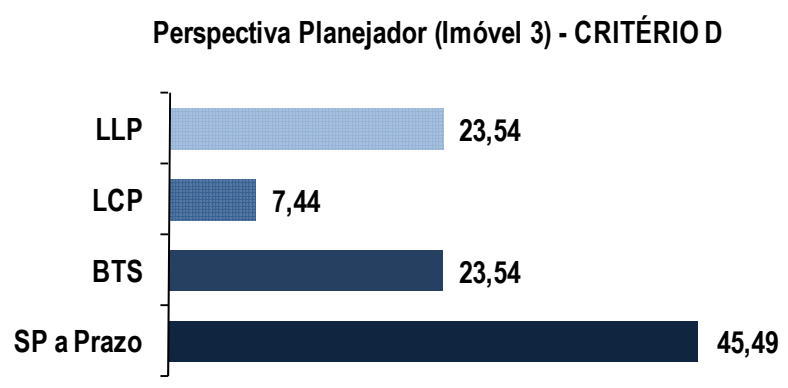

Gráfico 36 - Pesos relativos das [alternativas] para o [Critério D] - Imóvel 3

Como existe a facilidade de encontrar no mercado um imóvel tanto disponível para a venda como para a locação, que atenda as demandas operacionais da empresa, a [alternativa] - BTS não se difere da SP a Prazo em relação à especificidade do espaço [Critério E], já que mesmo para um imóvel BTS não seria necessário considerar significativas customizações no espaço para atender às demandas da empresa relativamente a outros imóveis já prontos para operação. Dessa forma, a atribuição das notas das [alternativas] de locação simples, em especial a LLP, estão com melhores pontuações para este critério em relação ao imóvel 1, resultando nos pesos relativos apresentados no Gráfico 37.

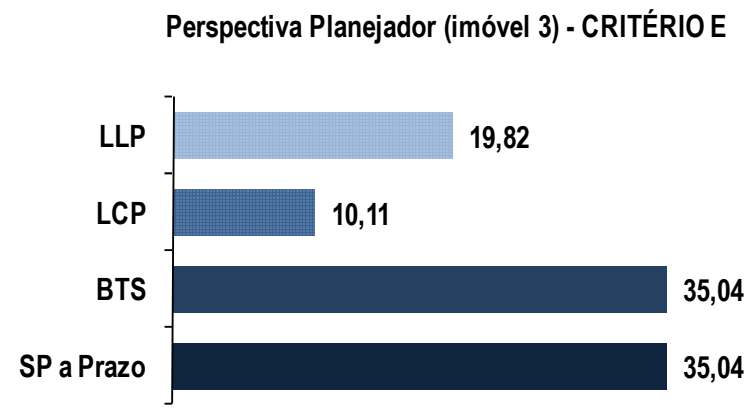

Gráfico 37 - Pesos relativos das [alternativas] para o [Critério E] - Imóvel 3

Em relação à oportunidade de traduzir a imagem corporativa [Critério F], verifica-se no Gráfico 38 que para o imóvel 3 a opção pela LLP atende igualmente a este critério em relação à [alternativa] - BTS. Isto porque mesmo imóveis disponíveis no mercado prontos para operação atenderiam ao [Critério F], pois não há necessidade de tradução da imagem, tanto externa como internamente ao espaço. Ainda assim, para contratos de longo prazo (LLP e BTS) existe maior liberdade de intervenções durante o uso, caso seja desejado promover adequações para vincular o edifício à marca da empresa. 


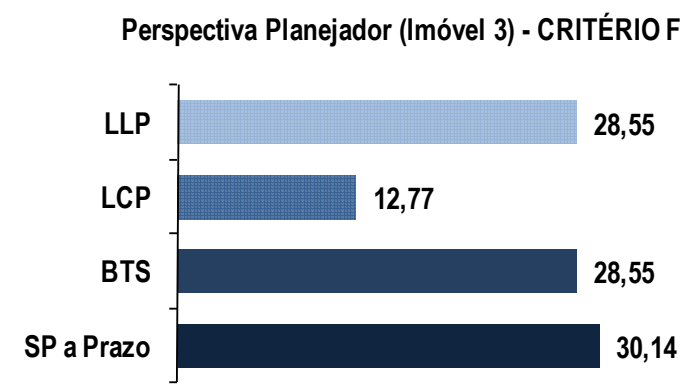

Gráfico 38 - Pesos relativos das [alternativas] para o [Critério F] - Imóvel 3

\subsubsection{Pesos relativos das [alternativas] para cada critério - Matrizes Nível 3 do AHP para o Imóvel 3}

Os pesos relativos das [alternativas] para os critérios quantitativos e qualitativos compilados na Tabela 59, indicam as [alternativas] que melhor atendem e mais comprometem cada um dos critérios de decisão do [MAOI] de acordo com o contexto do imóvel 3.

\begin{tabular}{|c|c|c|c|c|c|c|c|c|c|}
\hline & \multicolumn{9}{|c|}{ PESO RELATIVO DAS [ALTERNATIVAS] X CRITÉRIOS - IMÓVEL 3 (LABORATÓRIO E ARMAZENAGEM) } \\
\hline \multirow[t]{2}{*}{$\begin{array}{l}\text { [ALTERNA- } \\
\text { TIVAS] }\end{array}$} & $\begin{array}{l}\text { Flexibili- } \\
\text { dade de } \\
\text { Mudança }\end{array}$ & $\begin{array}{c}\text { Rapidezna } \\
\text { Mobilização } \\
\text { da Atividade } \\
\text { para o } \\
\text { Espaço }\end{array}$ & $\begin{array}{c}\text { Controle } \\
\text { Operacional } \\
\text { no Uso do } \\
\text { Espaço }\end{array}$ & $\begin{array}{l}\text { Vínculo da } \\
\text { Operação } \\
\text { com Imóvel }\end{array}$ & $\begin{array}{l}\text { Especifi- } \\
\text { dade do } \\
\text { Imóvel }\end{array}$ & $\begin{array}{c}\text { Oportunidade } \\
\text { de Tradução } \\
\text { da Imagem } \\
\text { Corporativa }\end{array}$ & $\begin{array}{c}\text { Canalizar } \\
\text { recursos em } \\
\text { oportunidades } \\
\text { do Negócio } \\
\text { Principal }\end{array}$ & $\begin{array}{c}\text { Desone- } \\
\text { ração } \\
\text { do Balanço }\end{array}$ & $\begin{array}{c}\text { Redução dos } \\
\text { Impactos } \\
\text { Tributários }\end{array}$ \\
\hline & {$[\mathrm{A}]$} & [B] & {$[\mathrm{C}]$} & [D] & [E] & {$[\mathrm{F}]$} & [G] & {$[\mathrm{H}]$} & [I] \\
\hline SP a Prazo & 7,29 & 12,91 & 55,81 & 45,49 & 35,04 & 30,14 & 8,71 & 6,25 & 4,55 \\
\hline BTS & 5,96 & 5,69 & 18,50 & 23,54 & 35,04 & 28,55 & 31,10 & 31,25 & 31,82 \\
\hline LCP & 63,44 & 52,58 & 8,58 & 7,44 & 10,11 & 12,77 & 29,09 & 31,25 & 31,82 \\
\hline LLP & 23,31 & 28,82 & 17,12 & 23,54 & 19,82 & 28,55 & 31,10 & 31,25 & 31,82 \\
\hline Soma & 100,00 & 100,00 & 100,00 & 100,00 & 100,00 & 100,00 & 100,00 & 100,00 & 100,00 \\
\hline \multicolumn{10}{|c|}{ Pesos Relativos das Matrizes X - Nivel 3 do AHP (Ponderação feita pelo Planejador) } \\
\hline $\begin{array}{c}\text { CRITÉRIOS } x \\
\text { [ALTERNATIVAS] }\end{array}$ & [A] & [B] & [C] & [D] & [E] & [F] & [G] & {$[\mathrm{H}]$} & [l] \\
\hline melhor atende & LCP & LCP & SP a Prazo & SP a Prazo & SP a Prazo;BTS & SP a Prazo & BTS;LLP & BTS;LLP;LCP & BTS;LLP;LCP \\
\hline mais compromete & BTS & BTS & LCP & LCP & LCP & LCP & SP a Prazo & SP a Prazo & SP a Prazo \\
\hline
\end{tabular}

Tabela 59 - Pesos Relativos das [alternativas] para todos os critérios de decisão do [MAOI] - Imóvel 3

\subsubsection{Priorização dos critérios - Matriz Nível 2 do AHP para o Imóvel 3}

As notas de importância atribuídas para os critérios de decisão do [MAOI], conforme priorização feita pelo decisor para o imóvel 3, resultam nos pesos relativos do critérios (Matriz dos critérios - Nível 2 do AHP) conforme Gráfico 39. 


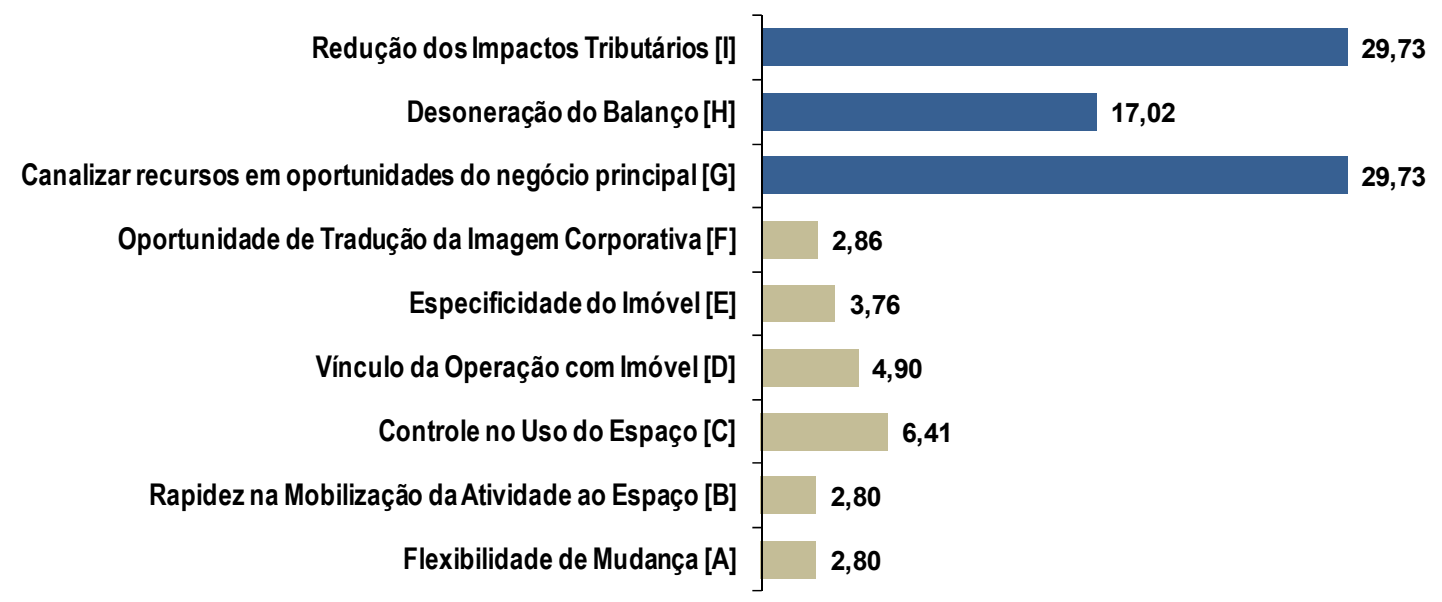

Gráfico 39 - Pesos relativos dos critérios para o Imóvel 3 conforme priorização do decisor

Para este imóvel a pontuação das notas de importância dos critérios relacionados ao uso foram ainda menores relativamente aos critérios relacionados às estratégias de investimento e políticas corporativas. A soma dos pesos relativos de todos os critérios relacionados ao uso é de apenas 23,52 do peso total (100) referente à soma dos pesos relativos de todos os critérios. Os dois critérios priorizados foram o [Critério G] - canalizar recursos no negócio principal e o [Critério I] - redução dos impactos tributários.

\subsubsection{Resultado AHP - [alternativa] Indicada pelo [MAOI] para Imóvel 3}

Com os pesos relativos das [alternativas] e os pesos relativos dos critérios para o imóvel 3 encontra-se a hierarquia das [alternativas] a partir da multiplicação das matrizes do Nível 2 pela matriz do Nível 3, conforme demonstrado na Tabela 60.

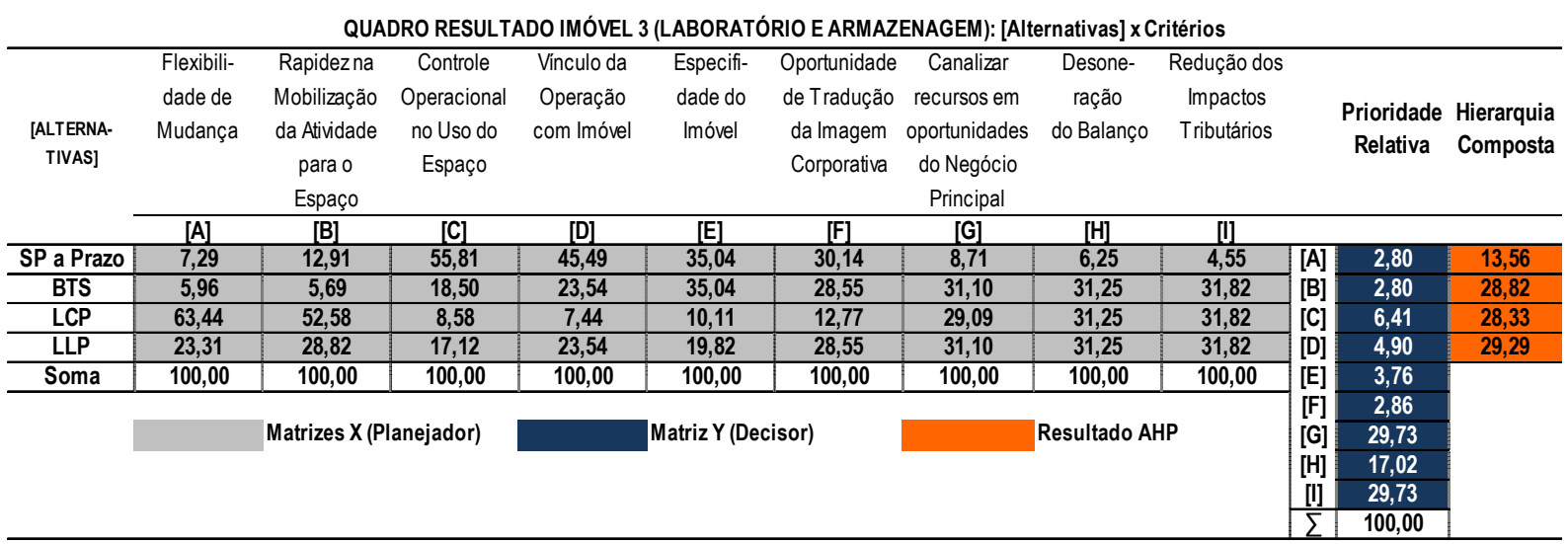


Para este imóvel a [alternativa] que melhor atende em conjunto aos critérios priorizados pelo decisor é a LLP, conforme indica o Gráfico 40. Pelo mesmo gráfico é possível verificar que as [alternativas] de não imobilização estão com pontuações próximas na hierarquização resultante e bem acima da opção pela imobilização.

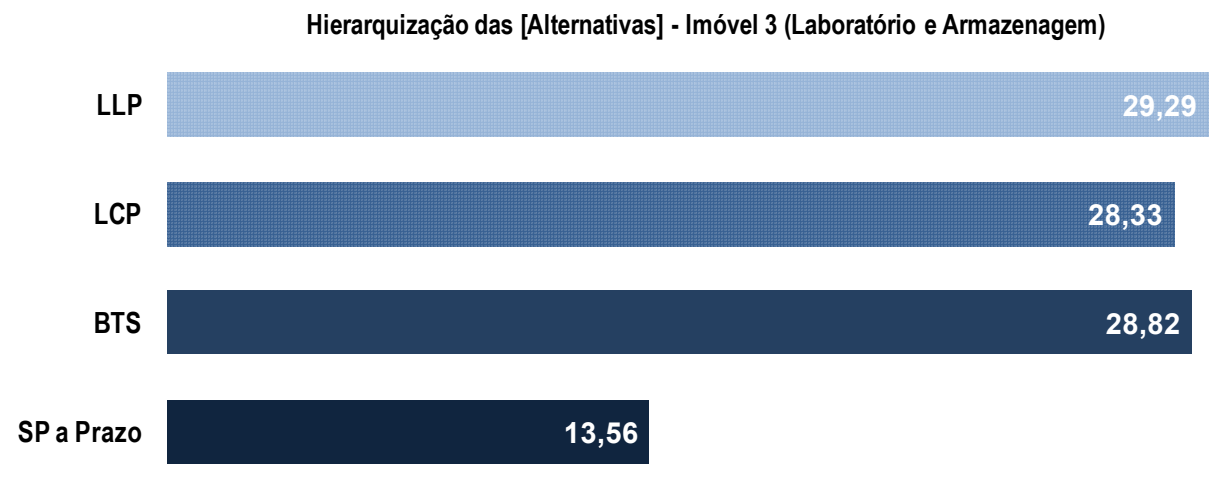

Gráfico 40 - Hierarquia das [alternativas] para o Imóvel 3

\subsubsection{Análise Comparativa da Situação Atual 'vs' [alternativa] Indicada pelo [MAOI]: Imóvel 3}

A empresa do caso é proprietária do imóvel 3, que é a última [alternativa] na hierarquização indicada pelo [MAOI]. Sendo assim, torna-se necessário avaliar os indicadores para a desmobilização patrimonial (SLB) também para o imóvel 3.

O valor contábil deste ativo é $2.566 \mathrm{R} \$$ mil da base. Para o valor de transação de $51.000 \mathrm{R} \$$ mil da base, o lucro na venda é de $48.434 \mathrm{R} \$$ mil da base, que resulta em um total de impostos devidos de $16.468 \mathrm{R} \$$ mil da base no início do horizonte de análise. Dessa forma, o CGA para análise dos indicadores na opção pelo SLB deste imóvel equivale a $34.532 \mathrm{R}$ \$ mil da base.

O CGA aplicado no negócio principal da empresa gera uma renda anual (RCGA) no intervalo [8.693 - 8.904] R \$ mil por ano. No entanto, a empresa passa a pagar os aluguéis no intervalo [6.373 - 7.151] R\$ mil por ano, que se refere ao CCGA para o imóvel 3. Estas variáveis de cálculo, encontradas de forma randômica no modelo, resultam na RRCGA para a [alternativa] - SLB, que conforme indicado na Tabela 61 está no intervalo [6,04\% - 6,99\%] ao ano efetiva acima do IGP. O saldo (p) composto pela RCGA subtraída do CCGA, calculado no intervalo [2.029 -2.340] R $\$$ mil da base, gera um acréscimo no resultado corporativo de 1,98\% ao ano na média da amostra. 


\begin{tabular}{|c|c|c|c|c|}
\hline \multirow{2}{*}{\multicolumn{5}{|c|}{$\begin{array}{c}\text { CRITÉRIO J - IMÓVEL } 3 \text { (LABORATÓRIO E ARMAZENAGEM } \\
\text { Intervalos de Valor dos Indicadores: RRCGA e ARC }\end{array}$}} \\
\hline & & & & \\
\hline \multicolumn{5}{|c|}{ (Cenário Referencial) } \\
\hline \multirow{2}{*}{ Indicadores } & \multirow{2}{*}{ Média } & \multirow{2}{*}{ Desvio } & \multicolumn{2}{|c|}{ Fronteiras da Amostra* } \\
\hline & & & Inferior & Superior \\
\hline RRCGA (\% ao ano efetiva acima do IGP) & $6,51 \%$ & $0,29 \%$ & $6,04 \%$ & $6,99 \%$ \\
\hline RCGA (R $\$$ mil da base/ano) & 8.799 & 64 & 8.693 & 8.904 \\
\hline Saldo(p): RCGA- CCGA (em R\$ mil da base/ano) & 2.185 & 95 & 2.029 & 2.340 \\
\hline ARC (\% ao ano) & $1,98 \%$ & $0,09 \%$ & $1,84 \%$ & $2,12 \%$ \\
\hline
\end{tabular}

${ }^{*} 90 \%$ de confiabilidade do indicador se situar entre estas fronteiras

NOTA: estes indicadores são medidos em amostras de laboratório diferentes.

Nesse sentido, as fronteiras dos intervalos não representam pares de valores.

Tabela 61 - Intervalos de Valor dos Indicadores RRCGA e ARC para a [alternativa] - SLB do Imóvel 3

Os valores encontrados para os indicadores RRCGA e ARC na [alternativa] - SLB do imóvel 3 são mais atrativos que os indicadores encontrados para a desmobilização patrimonial do imóvel 1, no entanto, ainda estão abaixo do parâmetro entendido como satisfatório para o decisor ( $8 \%$ ao ano efetiva acima do IGP para a RRCGA e 4\% ao ano para ARC). Esta análise já permite concluir o impacto que a situação atual do ativo no balanço causa aos indicadores e, por consequência, na escolha de quais ativos são mais adequados desmobilizar.

A Tabela 62 apresenta os indicadores RRCGA e ARC conforme cenários estressados. Com perturbação sem compensação no ROE da empresa a RRCGA ainda se situa no intervalo [2,87\% - 4,74\%] ao ano efetiva acima do IGP, que é próxima a RRCGA para a [alternativa] SLB do imóvel 1 para o cenário referencial (sem perturbação no ROE).

\begin{tabular}{|c|c|c|c|c|}
\hline \multicolumn{5}{|c|}{ CRITÉRIO J - IMÓVEL 3 (LABORATÓRIO E ARMAZENAGEM } \\
\hline \multicolumn{5}{|c|}{ (Desvio de ROE - faixa: + 0\% a -20\%) } \\
\hline \multirow{2}{*}{ Indicadores } & \multirow{2}{*}{ Média } & \multirow{2}{*}{ Desvio } & \multicolumn{2}{|c|}{ Fronteiras da Amostra* } \\
\hline & & & Inferior & Superior \\
\hline RRCGA (\% ao ano efetiva acima do IGP) & $3,81 \%$ & $0,57 \%$ & $2,87 \%$ & $4,74 \%$ \\
\hline RCGA (R $\$$ mil da base/ano) & 7.917 & 177 & 7.625 & 8.208 \\
\hline Saldo(p): RCGA- CCGA (em R\$ mil da base/ano) & 1.293 & 190 & 981 & 1.605 \\
\hline ARC (\% ao ano) & $1,17 \%$ & $0,17 \%$ & $0,89 \%$ & $1,46 \%$ \\
\hline
\end{tabular}

${ }^{*} 90 \%$ de confiabilidade do indicador se situar entre estas fronteiras

NOTA: estes indicadores são medidos em amostras de laboratório diferentes.

Nesse sentido, as fronteiras dos intervalos não representam pares de valores.

Tabela 62 - Intervalos de Valor dos Indicadores RRCGA e ARC para a [alternativa] - SLB do Imóvel 3 conforme Cenário Estressado 
A [alternativa] - SLB para o imóvel 3 resulta nos índices apresentados na Tabela 63, calculados a partir do impacto desta [alternativa] nos grupos de contas do balanço. Também para o [Critério H] (desoneração do balanço) a desmobilização do imóvel 3 gera melhores resultados para os índices financeiros relativamente à desmobilização do imóvel 1. O CGL aumenta em $110,05 \%$, o ILC vai de 1,10 para 1,19 , representando um aumento de $8,17 \%$. Quanto à participação de capital de terceiros sobre os recursos totais (PTRT), não há grande impacto com base nesta primeira leitura. Porém, caso a empresa utilize parte do capital ativado com a venda do imóvel para liquidação de dívidas de curto prazo este índice pode apresentar redução.

Como o imóvel 3 possui 7 anos de vida útil remanescente a opção em continuar proprietária ainda gera depreciação. Por isso, os impactos nos índices financeiros apresentados na Tabela 63 para a opção em continuar proprietária do imóvel ainda que irrelevantes, não são nulos, como verificado na desmobilização do imóvel 1, que já está totalmente depreciado.

\begin{tabular}{|c|c|c|c|c|}
\hline \multicolumn{5}{|c|}{$\begin{array}{c}\text { Indicadores - Critério H (Desoneração do Balanço) - SLB } \\
\text { EMPRESA DO CASO - IMÓVEL } 3 \text { (LABORATÓRIO E ARMAZENAGEM) } \\
\text { (Valores em R\$ mil) }\end{array}$} \\
\hline Índices & \multicolumn{2}{|c|}{ Impactos [alternativa]: SLB } & \multicolumn{2}{|c|}{$\begin{array}{c}\text { Impactos } \\
\text { [alternativa]: Continuar SP }\end{array}$} \\
\hline ILC & 1,19 & $8,17 \%$ & 1,10 & $0,00 \%$ \\
\hline ILI & 0,32 & $105,30 \%$ & 0,16 & $0,00 \%$ \\
\hline PTRT & 0,51 & $-0,29 \%$ & 0,51 & $0,16 \%$ \\
\hline PTPL & 1,03 & $-0,59 \%$ & 1,04 & $0,33 \%$ \\
\hline PECP & 0,58 & $3,77 \%$ & 0,55 & $0,00 \%$ \\
\hline GIPL & 1,26 & $-5,65 \%$ & 1,34 & $0,08 \%$ \\
\hline CGL & 53.005 & $110,05 \%$ & 25.235 & $0,00 \%$ \\
\hline
\end{tabular}

Tabela 63 - Índices financeiros para a [alternativa] - SLB do Imóvel 3

Em relação à redução dos impactos tributários [Critério I], é possível verificar pela Tabela 64 que o fluxo gerado pela economia tributária da despesa operacional com a locação durante todo o horizonte de análise (20 anos), descontado ao wacc da empresa, não é suficiente para cobrir os impostos devidos com o lucro da venda do imóvel 3, resultando em uma ETEDO negativa no valor de (2.815) R \$ mil da base na média da amostra. Porém, a ETEDO negativa não é representativa, pois está muito próxima ao saldo (p) de apenas um exercício (que é de $2.185 \mathrm{R} \$$ mil da base por ano na média da amostra), conforme Tabela 61. 


\begin{tabular}{|c|c|c|c|c|}
\hline \multicolumn{5}{|c|}{ CRITÉRIO I - IMÓVEL 3 (LABORATÓRIO E ARMAZENAGEM) - SLB } \\
\hline \multicolumn{5}{|c|}{ Intervalos de Valor dos Indicadores relacionados à Economia Tributária } \\
\hline \multicolumn{5}{|c|}{ (Cenário Referencial) } \\
\hline \multirow{2}{*}{ Indicadores (R\$ mil da base) } & \multirow{2}{*}{ Média } & \multirow{2}{*}{ Desvio } & \multicolumn{2}{|c|}{ Fronteiras da Amostra* } \\
\hline & & & Inferior & Superior \\
\hline ETEDO: SLB & $(2.815)$ & 193 & $(3.132)$ & $(2.498)$ \\
\hline ETD: Continuar SP & 1.880 & 18 & 1.850 & 1.909 \\
\hline
\end{tabular}

Tabela 64 - Intervalos de Valor do Indicador ETEDO para a [alternativa] - SLB do Imóvel 3

A partir dos indicadores comprova-se que a desmobilização do imóvel 3 é mais vantajosa em relação ao imóvel 1. Isto sustenta a idéia da empresa, que assinalou o interesse em desmobilizar o imóvel 3 durante a entrevista para priorização dos critérios de decisão.

\subsection{Aplicação do [MAOI] para o Imóvel 4 (COMPLEXO INDUSTRIAL)}

O imóvel 4 é o complexo industrial da empresa do caso, formado por quatro unidades fabris, cada uma focada na produção de um tipo de produto. Neste complexo se concentra $70 \%$ de toda a produção da empresa. É o maior imóvel do portfolio, tanto em área construída como em valor de mercado. O valor de mercado do imóvel 4 fornecido no laudo de avaliação é de 280.000 R\$ mil da base, que será o CGA deste imóvel para análise dos indicadores.

A mesma rotina de VOI é aplicada para identificar o intervalo dos preços de locação deste imóvel, considerando o valor de transação de 280.000 R \$ mil da base como um valor justo, ou seja, que deve estar contido no intervalo do VOI para este empreendimento.

A partir das variáveis de cálculo do VOI já apresentadas para o imóvel 1 e 3, ajusta-se o intervalo de aluguel mensal até o valor de transação estar contido no intervalo calculado para o VOI do imóvel 4. O intervalo de aluguel mensal [2.960 - 3.200] R\$ mil, resulta no intervalo [276.976 - 282.883] R\$ mil da base para o VOI do empreendimento. Verifica-se pelo Gráfico 41 e Tabela 65 que o valor de transação considerado para este imóvel (CGA) está próximo do valor médio da amostra de laboratório. Portanto, considera-se o intervalo [2.960 - 3.200] R\$ mil por mês como o CCGA para o imóvel 4. 


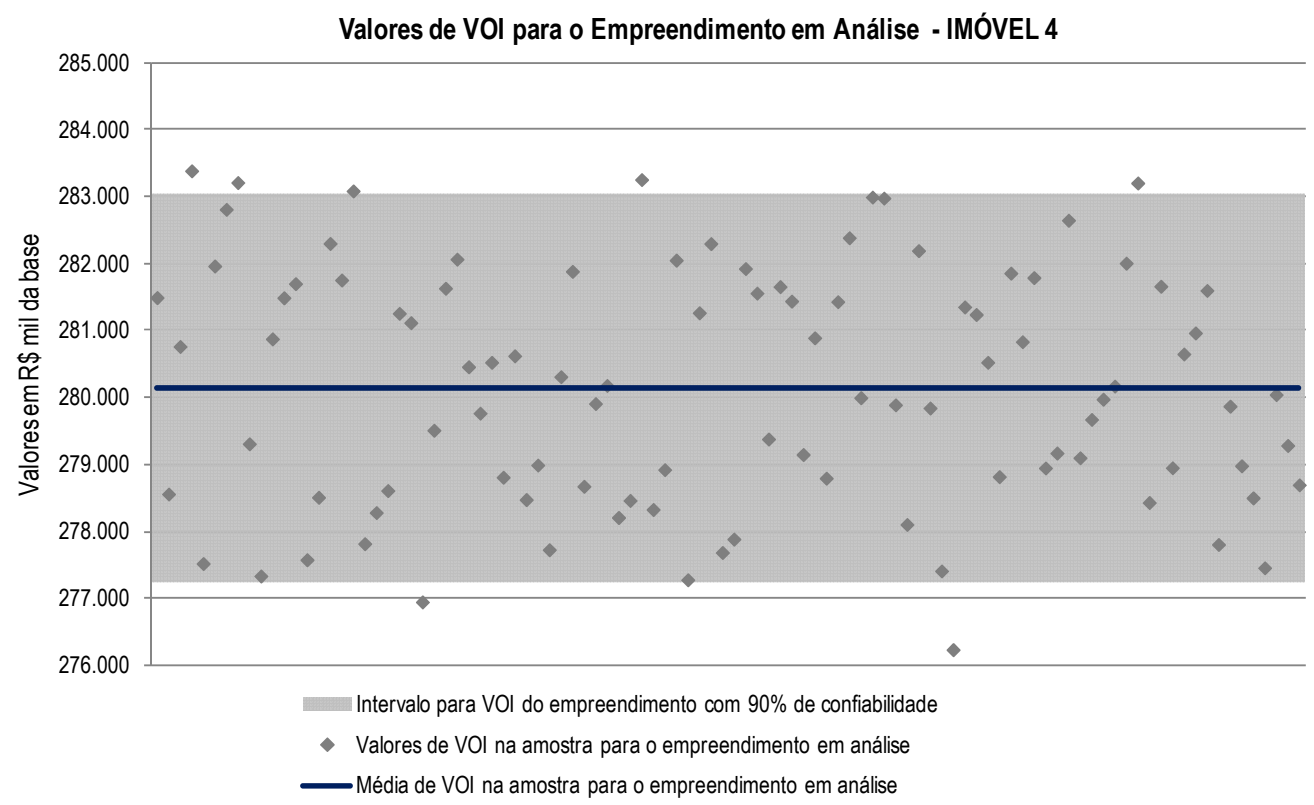

Gráfico 41 - Intervalo de VOI para o Imóvel 4 da empresa do caso

\section{Intervalos de Valor para: VOI, Participação de VOIn e TIR (investidor) - IMÓVEL 4}

\begin{tabular}{c|c|c|c|c}
\multicolumn{2}{c|}{ (Cenário Referencial) } \\
\hline Indicadores & \multirow{2}{*}{ Média } & \multirow{2}{*}{ Desvio } & \multicolumn{2}{c}{ Fronteiras da Amostra* } \\
\cline { 4 - 5 } & & & Inferior & Superior \\
\hline VOI (em R\$ mil da base) & 279.929 & 1.796 & 276.976 & 282.883 \\
\hline Participação de VOIn & $10,9 \%$ & $0,1 \%$ & $10,7 \%$ & $11,1 \%$ \\
\hline TIR (\% ao ano efetiva acima do IGP) & $10,5 \%$ & $0,1 \%$ & $10,4 \%$ & $10,6 \%$ \\
\hline
\end{tabular}

* $90 \%$ de confiabilidade do indicador se situar entre estas fronteiras

NOTA: estes indicadores são medidos em amostras de laboratório diferentes.

Nesse sentido, as fronteiras dos intervalos não representam pares de valores.

Tabela 65 - Intervalos de valor para: VOI, Participação de VOI $_{n}$ e TIR - Imóvel 4

A Tabela 66 apresenta os dados e demandas do imóvel 4, assim como os parâmetros de referência estipulados pelo decisor para este imóvel, entendidos como satisfatórios para avaliar a qualidade dos indicadores encontrados. 


\begin{tabular}{|c|c|c|c|}
\hline \multicolumn{4}{|c|}{$\begin{array}{c}\text { DADOS DO IMÓVEL } 4 \text { (COMPLEXO INDUSTRIAL) - ESTUDO DO CASO } \\
\text { Valores em R\$ mil da base }\end{array}$} \\
\hline Tipologia e Atividades: & \multicolumn{3}{|c|}{ Unidade fabril que concentra $70 \%$ de toda a produção da empresa } \\
\hline Área Construída & \multicolumn{3}{|c|}{$80.000 \quad \mathrm{~m}^{2}$} \\
\hline Horizonte de uso (n) & \multicolumn{3}{|c|}{$25 \quad$ anos } \\
\hline $\begin{array}{l}\text { Valor de Transação } \\
\text { Valor do Terreno }\end{array}$ & \multicolumn{3}{|c|}{$\begin{array}{c}280.000 \text { Valores informados pela empresa a partir de laudo de avaliação } \\
12.500\end{array}$} \\
\hline Preço de Locação & $\begin{array}{l}\text { Superior } \\
2.960\end{array}$ & $\begin{array}{l}\text { Inferior } \\
3.200\end{array}$ & $\begin{array}{l}\text { (faixas encontradas pela rotina de cálculo do VOI) } \\
\mathrm{R} \$ \text { mil por mês sem ajuste no ciclo de } 1 \text { ano }\end{array}$ \\
\hline Instrumento Jurídico Preferido & \multicolumn{3}{|c|}{ Contrato de Locação } \\
\hline \multicolumn{4}{|c|}{ PARAMMETROS DE DECISÃO DETERMINADOS PELA EMPRESA DO CASO PARA O IMÓVEL 4} \\
\hline $\begin{array}{l}\text { Renda Relativa do Capital de } \\
\text { Giro Ativado }\end{array}$ & \multicolumn{3}{|c|}{$\begin{array}{l}\text { Mínimo de parâmetro de referência para a renda relativa gerada pelas [alternativas] de } \\
12 \% \text { ao ano não imobilização ou imobilzação a prazo }\end{array}$} \\
\hline $\begin{array}{l}\text { Acréscimo no resultado } \\
\text { corporativo }\end{array}$ & \multicolumn{3}{|c|}{$\begin{array}{l}\text { Mínimo de parâmetro de referência para o acréscimo do resultado corporativo gerado } \\
8 \% \text { ao ano pelas [alternativas] de não imobilização }\end{array}$} \\
\hline Impacto no Balanço & $\begin{array}{c}\text { Até } 80 \% \\
>1,0 \\
>10.000 \mathrm{R} \$ \text { mil }\end{array}$ & $\begin{array}{l}\text { PTRT } \\
\text { ILG } \\
\text { CGL }\end{array}$ & $\begin{array}{l}\text { manter o PTRT inferior a } 80 \% \\
\text { manter o ILC superior a } 1,0 \\
\text { manter o CGL superior a } 10.000 \mathrm{R} \$ \text { mil }\end{array}$ \\
\hline Economia Tributária & \multicolumn{3}{|c|}{$\begin{array}{c}40.000 \text { parâmetro de referência para a diferença entre a economia tributária das } \\
\mathrm{R} \$ \text { mil da base [alternativas] de não imobilização e a economia tributária da imobilização }\end{array}$} \\
\hline \multicolumn{4}{|c|}{ SITUAÇÃO ATUAL DO IMÓVEL 4 (COMPLEXO INDUSTRIAL) } \\
\hline Vida Útil Remanescente & 25 & anos & \\
\hline Valor de Registro & 280.000 & & \\
\hline
\end{tabular}

Tabela 66 - Dados do imóvel 4 para cálculo dos referências quantitativas do [MAOI]

Como este imóvel é estratégico para a empresa, tanto para atender suas demandas atuais como para fazer frente ao projeto de internacionalização, os parâmetros de referência do decisor para compensar a escolha das [alternativas] de não imobilização são maiores em relação aos demais imóveis. Ou seja, a empresa estabelece um prêmio maior pelo risco de não ser proprietária deste ativo, que é estratégico para a operação atual e futura (RRCGA de no mínimo $12 \%$ ao ano efetiva acima do IGP e ARC de no mínimo 8\% ao ano).

Os impactos no balanço permanecem os mesmos, já que é uma política da empresa manter estes valores mínimos para os índices mais relevantes (ILC, PTRT e CGL).

A economia tributária para este imóvel entendida como atrativa para o decisor deve indicar uma diferença de pelo menos $40.000 \mathrm{R} \$$ mil da base entre a economia tributária das [alternativas] de não imobilização e a opção pela imobilização ${ }^{153}$.

153 Neste caso, em razão do alto volume de investimento envolvido para implantação deste imóvel a empresa é proprietária somente por meio de financiamento (SP a Prazo). 


\subsubsection{Referências Quantitativas do [MAOI] para o Imóvel 4}

Com base nos dados, demandas e parâmetros de referência do decisor apresentados na Tabela 66, calcula-se os indicadores do [MAOI] para o imóvel 4 em cada uma das [alternativas].

\subsubsection{Canalização de recursos em oportunidades do negócio principal - [Critério G]}

A partir do investimento no montante equivalente ao CGA (280.000 R $\$$ mil da base) no negócio principal da empresa, com ROE no intervalo [2,09\% - 2,26\%] equivalente mês, encontra-se a renda mensal de [5.844 - 6.316] R $\$$ mil para as [alternativas] de não imobilização.

O saldo (p) no intervalo [34.423 - 36.127] $\mathrm{R} \$$ mil da base por ano é gerado pela diferença entre esta renda (RCGA) e o custo dos aluguéis no intervalo [2.960 - 3.200] R\$ mil (CCGA). Este saldo dividido pelo CGA do imóvel 4 gera a RRCGA no intervalo [13,01\% - 13,69\%] ao ano efetiva acima do IGP. O saldo (p) resulta em um acréscimo do resultado (ARC) no intervalo [31,21\% - 32,76\%] ao ano. Ambos os indicadores, RRCGA e ARC, estão acima dos parâmetros de referência do decisor, em especial o ARC, que é quatro vezes superior.

O Gráfico 42 apresenta o intervalo de valor para a RRCGA conforme cenário referencial, assim como os valores da RRCGA na amostra de laboratório para os cenários estressados com perturbação sem compensação no ROE da empresa (com queda de até 20\%). Para os cenários estressados está RRCGA já se situa abaixo do parâmetro desejado, porém ainda é de 10,56\% ao ano efetiva acima do IGP na média da amostra.

\begin{tabular}{|c|c|c|c|c|}
\hline \multicolumn{5}{|c|}{ CRITÉRIO G -IMÓVEL 4 (COMPLEXO INDUSTRIAL) } \\
\hline \multicolumn{5}{|c|}{ Intervalos de Valor dos Indicadores: RRCGA e ARC } \\
\hline \multicolumn{5}{|c|}{ (Cenário Referencial) } \\
\hline Indicadores & \multirow{2}{*}{ Média } & \multirow{2}{*}{ Desvio } & \multicolumn{2}{|c|}{ Fronteiras da Amostra* } \\
\hline [Alternativas]: BTS, LLP e LCP & & & Inferior & Superior \\
\hline RRCGA(\% ao ano efetiva acima do IGP) & $13,35 \%$ & $0,21 \%$ & $13,01 \%$ & $13,69 \%$ \\
\hline RCGA(R\$ mil da base/ano) & 71.433 & 501 & 70.608 & 72.257 \\
\hline Saldo(p): RCGA- CCGA (em R\$ mil da base/ano) & 35.275 & 518 & 34.423 & 36.127 \\
\hline ARC (\% ao ano) & $31,99 \%$ & $0,47 \%$ & $31,21 \%$ & $32,76 \%$ \\
\hline
\end{tabular}

${ }^{*} 90 \%$ de confiabilidade do indicador se situar entre estas fronteiras

NOTA: estes indicadores são medidos em amostras de laboratório diferentes.

Nesse sentido, as fronteiras dos intervalos não representam pares de valores.

Tabela 67 - Intervalos de Valor dos Indicadores RRCGA e ARC no Cenário Referencial - Imóvel 4 


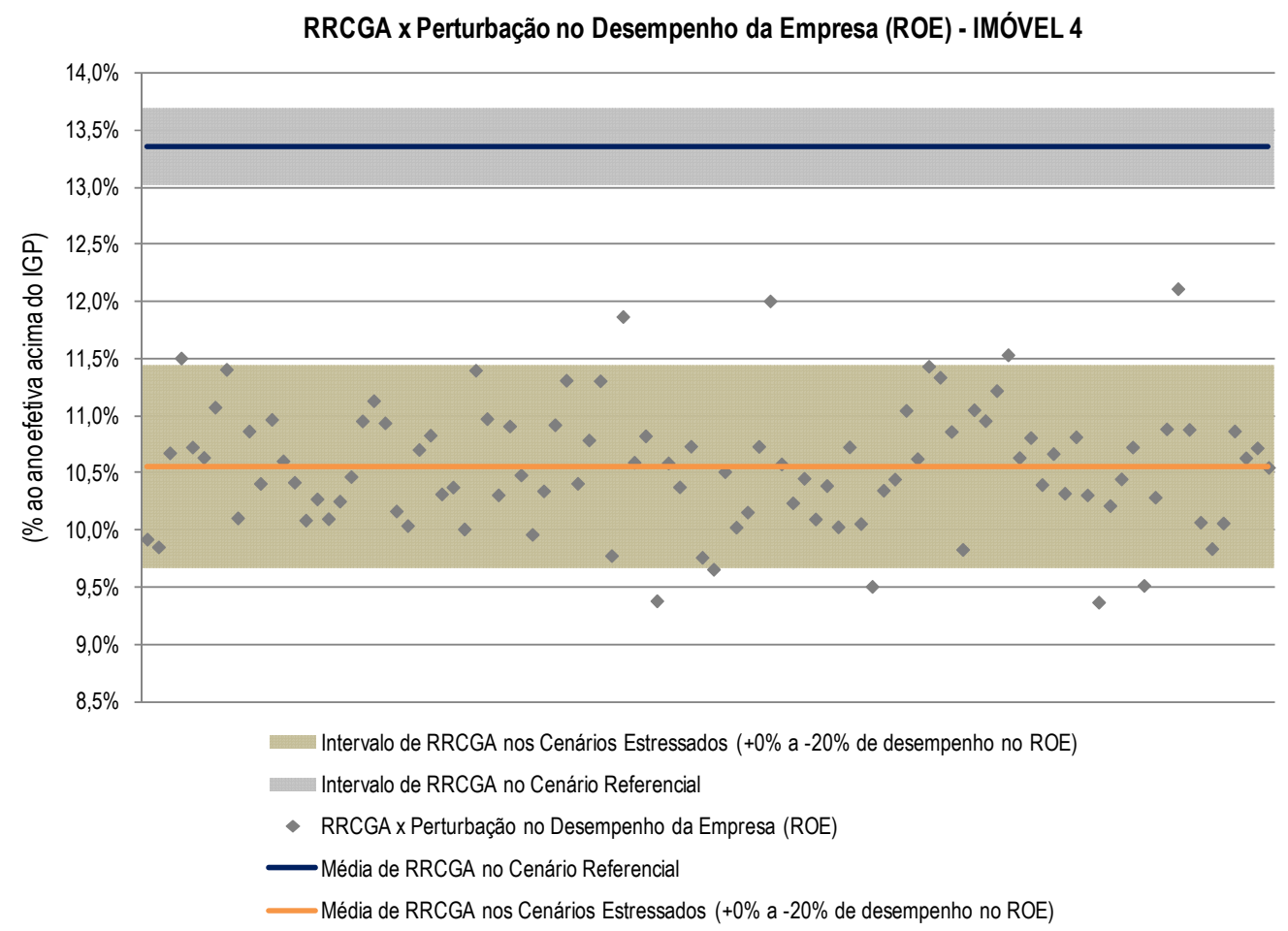

Gráfico 42 - Intervalos de Valor da RRCGA para o Imóvel 4

Conforme demonstrado na Tabela 68, o ARC mesmo para os cenários estressados está no intervalo $[23,53 \%-27,66 \%]$ ao ano, ainda significativamente acima do parâmetro mínimo estipulado pelo decisor.

\begin{tabular}{|c|c|c|c|c|}
\hline \multicolumn{5}{|c|}{ CRITÉRIO G - IMÓVEL 4 (COMPLEXO INDUSTRIAL) } \\
\hline \multicolumn{5}{|c|}{ Intervalos de Valor dos Indicadores: RRCGA e ARC } \\
\hline \multicolumn{5}{|c|}{ (Desvio de ROE - faixa: + 0\% a -20\%) } \\
\hline \multirow{2}{*}{$\begin{array}{c}\text { Indicadores } \\
\text { [Alternativas]: BTS, LLP e LCP }\end{array}$} & \multirow{2}{*}{ Média } & \multirow{2}{*}{ Desvio } & \multicolumn{2}{|c|}{ Fronteiras da Amostra* } \\
\hline & & & Inferior & Superior \\
\hline RRCGA(\% ao ano efetiva acima do IGP) & $10,56 \%$ & $0,54 \%$ & $9,67 \%$ & $11,45 \%$ \\
\hline RCGA(R\$ mil da base/ano) & 64.324 & 1.344 & 62.113 & 66.535 \\
\hline Saldo(p): RCGA- CCGA (em R\$ mil da base/ano) & 28.222 & 1.384 & 25.946 & 30.498 \\
\hline ARC (\% ao ano) & $25,59 \%$ & $1,25 \%$ & $23,53 \%$ & $27,66 \%$ \\
\hline
\end{tabular}

${ }^{*} 90 \%$ de confiabilidade do indicador se situar entre estas fronteiras

NOTA: estes indicadores são medidos em amostras de laboratório diferentes.

Nesse sentido, as fronteiras dos intervalos não representam pares de valores.

Tabela 68 - Intervalos de Valor dos Indicadores RRCGA e ARC nos Cenários Estressados - Imóvel 4

Para cálculo dos indicadores relacionados ao [Critério G] na [alternativa] - SP a Prazo considera-se as condições de financiamento do imóvel 4, que se difere dos demais imóveis, visto que neste caso trata-se de um financiamento junto ao BNDES com condições 
diferenciadas de crédito. Para este imóvel as seguintes condições de financiamento são consideradas nos cálculos dos indicadores RRIP, TRIP e ARC:

[i] parcela financiada equivalente a $40 \%$ do valor de transação;

[ii] taxa de juros equivalente a TJLP ( $6 \%$ ao ano) mais $3 \%$ ao ano, ou seja, de $9 \%$ ao ano;

[iii] prazo de amortização de 8 anos, e

[iv] sistema Price de amortização. O BNDES utiliza o sistema de amortização constante (SAC), entretanto, para efeito de análise, considera-se o mesmo sistema de amortização dos demais imóveis.

Neste caso o CGA da [alternativa] - SP a Prazo é de 112.000 R \$ mil da base que corresponde a $40 \%$ do valor de transação. A renda gerada a partir do investimento deste valor (CGA) no negócio principal da empresa está no intervalo [2.337 - 2.526] R\$ mil por mês. Além desta renda, a empresa tem o benefício do 'não custo' referente ao pagamento dos aluguéis no intervalo [2.960 - 3.200] R $\$$ mil por mês (CCGA) e o $\mathrm{VOI}_{\mathrm{n}}$ no final do horizonte de análise calculado em 209.090 R\$ mil da base.

As variáveis de saída do fluxo formado por esta [alternativa] - SP a Prazo são as parcelas do financiamento no valor de $1.620 \mathrm{R} \$$ mil por mês até o final do prazo de amortização e a perda de oportunidade de gerar renda durante todo o horizonte de análise (25 anos) no intervalo [3.506 - 3.790] R \$ mil por mês, referente à parcela não financiada do imóvel (168.000 R \$ mil da base) que deixa de gerar ROE.

Estas variáveis compõem o fluxo para cálculo dos indicadores RRIP, TRIP e ARC, os quais indicam a oportunidade de ganho, bem como a qualidade deste ganho na [alternativa] - SP a Prazo para o imóvel 4. Pelo Gráfico 43 é possível verificar os intervalos da RRIP tanto para o cenário referencial como para os cenários estressados (com perturbação sem compensação no ROE da empresa). Mesmo para o cenário referencial o intervalo da RRIP [0,84\% - 1,25\%] ao ano efetiva acima do IGP já indica o baixo potencial de ganho desta [alternativa]. Nos cenários estressados esta RRIP poderia ser negativa, ou seja, já registraria perda de oportunidade de ganho, conforme se verifica na fronteira inferior do intervalo da amostra de laboratório para $90 \%$ de confiabilidade. 


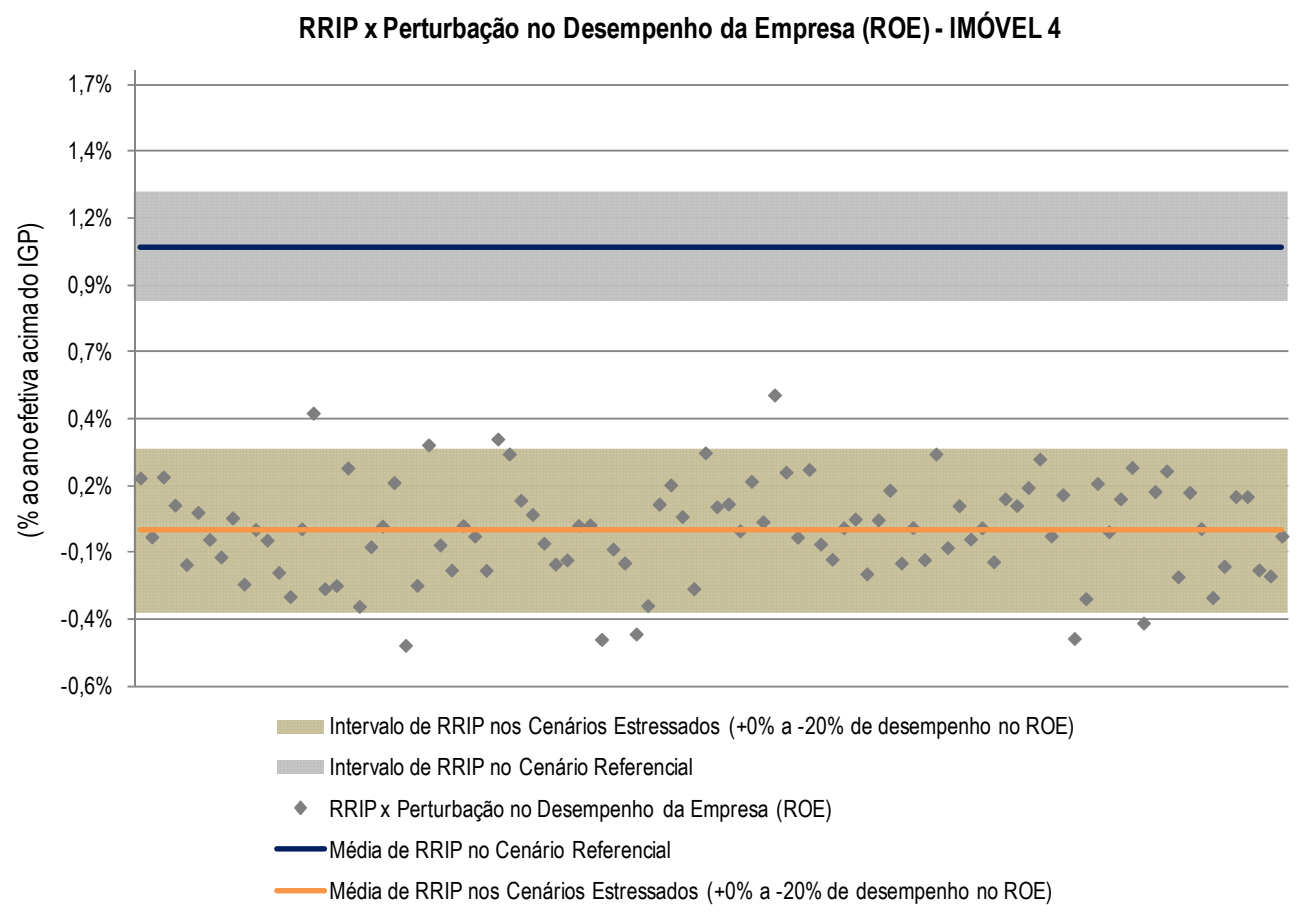

Gráfico 43 - Intervalos de Valor da RRIP para o Imóvel 4

Pela Tabela 69 é possível observar que nesse caso o VOI $_{n}$ é responsável por produzir a TRIP sobre $23,78 \%$ do investimento (valor de transação) conforme média da amostra de laboratório. Ou seja, embora a TRIP calculada no intervalo $[4,65 \%-4,73 \%]$ ao ano efetiva acima do IGP, represente um ganho superior a RRIP, a medida da qualidade deste ganho, calculada pela participação de VOIn para produzir TRIP, indica maior dependência do valor de saída ao final do ciclo de análise em relação aos demais imóveis com horizonte de uso semelhante.

\begin{tabular}{|c|c|c|c|c|}
\hline \multicolumn{5}{|c|}{ CRITÉRIO G -IMÓVEL 4 (COMPLEXO INDUSTRIAL) } \\
\hline \multicolumn{5}{|c|}{ Intervalos de Valor dos Indicadores: RRIP, TRIP e ARC } \\
\hline \multicolumn{5}{|c|}{ (Cenário Referencial) } \\
\hline Indicadores & \multirow{2}{*}{ Média } & \multirow{2}{*}{ Desvio } & \multicolumn{2}{|c|}{ Fronteiras da Amostra* } \\
\hline [Alternativa]: SP a prazo & & & Inferior & Superior \\
\hline RRIP (\% ao ano efetiva acima do IGP) & $1,04 \%$ & $0,12 \%$ & $0,84 \%$ & $1,25 \%$ \\
\hline RCGA (R $\$$ mil da base/ano) & 28.556 & 165 & 28.284 & 28.829 \\
\hline Saldo $\mathrm{P}^{\prime}(\mathrm{R} \$$ mil da base/ano) & 2.901 & 345 & 2.334 & 3.468 \\
\hline ARC (\% ao ano) & $2,63 \%$ & $0,31 \%$ & $2,12 \%$ & $3,14 \%$ \\
\hline TRIP (\% ao ano efetiva acima do IGP) & $4,69 \%$ & $0,02 \%$ & $4,65 \%$ & $4,73 \%$ \\
\hline Participação VOIn & $23,78 \%$ & $0,14 \%$ & $23,55 \%$ & $24,01 \%$ \\
\hline
\end{tabular}

${ }^{*} 90 \%$ de confiabilidade do indicador se situar entre estas fronteiras

NOTA: estes indicadores são medidos em amostras de laboratório diferentes.

Nesse sentido, as fronteiras dos intervalos não representam pares de valores.

Tabela 69 - Intervalos de Valor dos Indicadores RRIP, TRIP e ARC no Cenário Referencial - Imóvel 4 
O ARC gerado pelo saldo (p') da [alternativa] - SP a Prazo para o imóvel 4 é de 2,63\% ao ano na média da amostra, conforme cenário referencial. Em cenários estressados o indicador ARC seria quase nulo, ou até negativo, como se observa na Tabela 70.

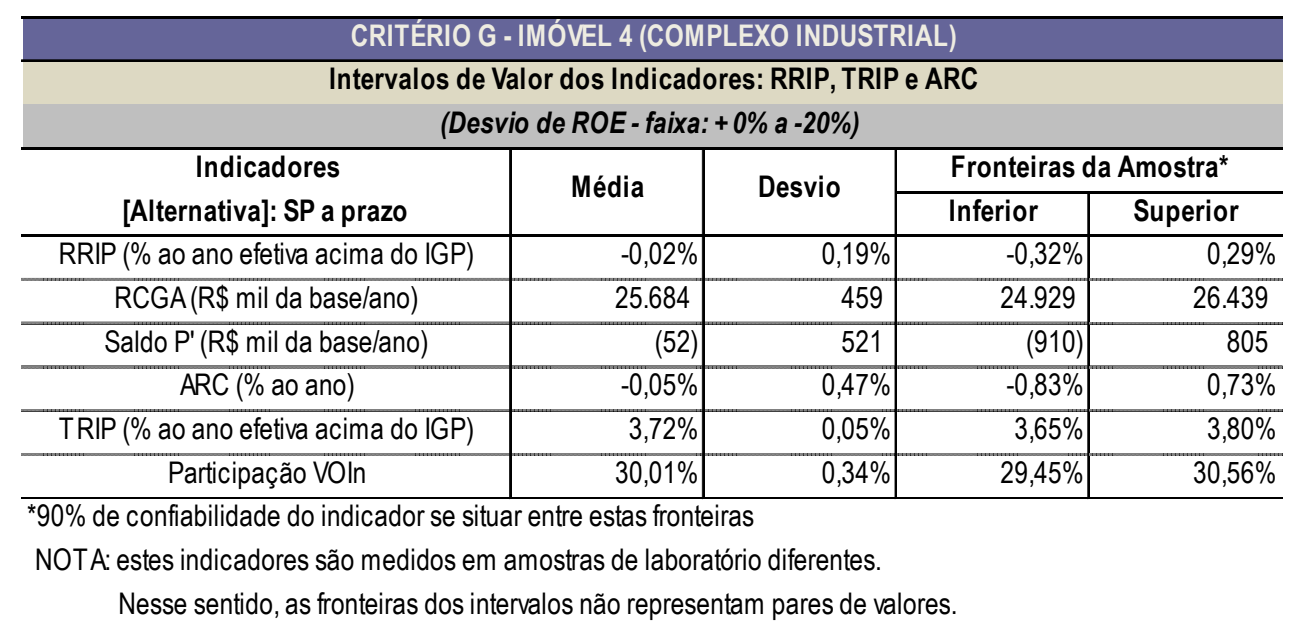

Tabela 70 - Intervalos de Valor dos Indicadores RRIP, TRIP e ARC nos Cenários Estressados - Imóvel 4

No intuito de avaliar as condições de financiamento que levariam a uma RRIP próxima ao parâmetro mínimo de ganho estipulado pelo decisor são feitos os testes de sensibilidade. Para uma parcela financiada superior a 75\% do valor de transação do imóvel 4 e taxa de juros de até $12 \%$ ao ano, a RRIP já se situaria acima de $12 \%$ ao ano efetiva acima do IGP, conforme indica a Tabela 71. Na hipótese da empresa do caso conseguir um financiamento de $90 \%$ do valor de transação com a mesma taxa de juros usada no cenário referencial ( $9 \%$ ao ano), a RRIP seria próxima de $20 \%$ ao ano efetiva acima do IGP, ou seja, bem superior a RRCGA encontrada para as [alternativas] de não imobilização. Na mesma tabela é possível verificar a variação da RRIP de acordo com os prazos de amortização. Para prazos de amortização igual ou superiores a 10 anos e parcela financiada de pelo menos $70 \%$ do valor de transação, a RRIP já seria superior a $12 \%$ ao ano efetiva acima do IGP. 
Testes de Sensibilidade para RRIP em função de variações na parcela financiada e taxa de juros do financiamento

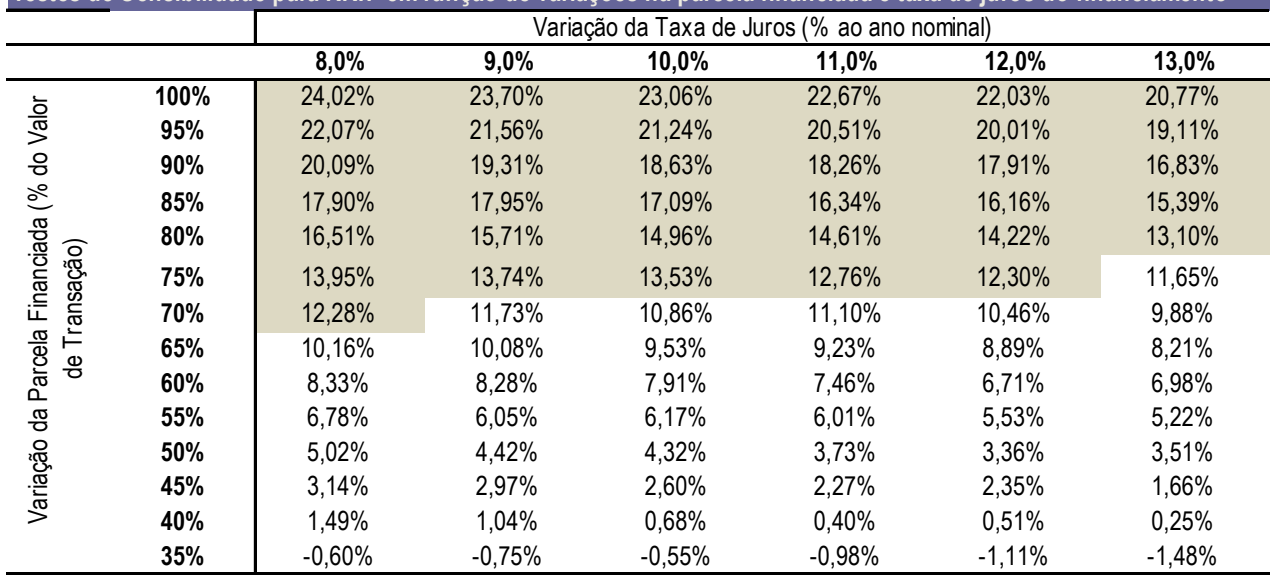

Testes de Sensibilidade para RRIP em função de variações na parcela financiada e no prazo do financiamento

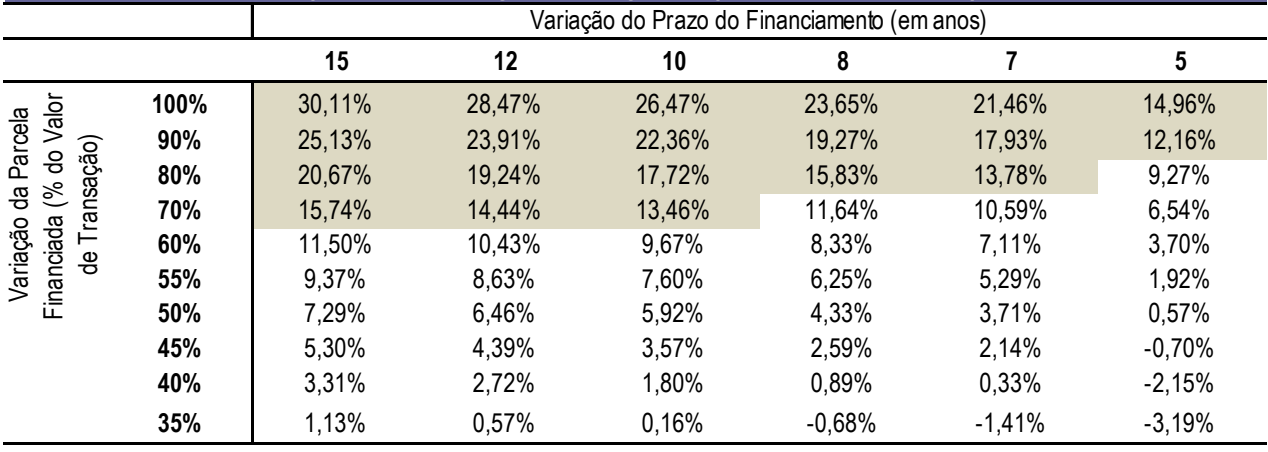

Tabela 71 - Testes de sensibilidade para a RRIP em função de variações nas condições do financiamento para aquisição do Imóvel 4

De acordo com os indicadores apresentados para o [Critério G] em cada uma das [alternativas] atribuí-se as notas de atendimento para este critério. O Gráfico 44 apresenta os pesos relativos das [alternativas] para o [Critério G] que corresponde ao peso de uma das matrizes no Nível 3 do AHP. Como para este imóvel a [alternativa] - SP a Prazo comprometeu mais este critério em relação aos demais imóveis, as notas de atendimento atribuídas a esta [alternativa] nas comparações par a par com as outras, foram ainda piores na escala de atendimento de 1 a 9 (conforme ponderação demonstrada detalhadamente para o imóvel 1 no Quadro 16).

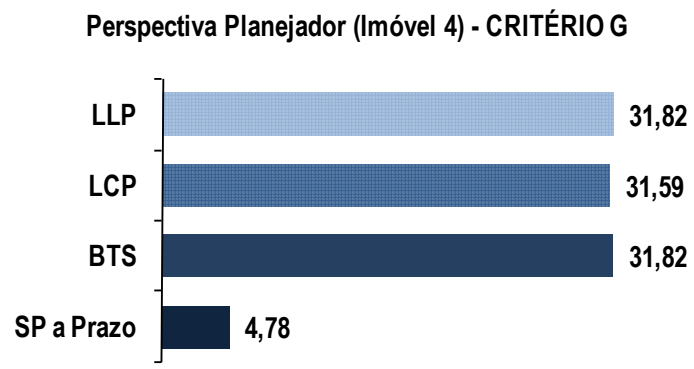

Gráfico 44 - Pesos relativos das [alternativas] para o [Critério G] - Imóvel 4 


\subsubsection{Desoneração do Balanço - [Critério H]}

Para a análise do impacto no balanço da empresa do caso a partir de uma situação nova baseada nas demandas e características do imóvel 4, é preciso levantar algumas informações que não foram necessárias para os demais imóveis da empresa, os quais estão em fase de operação e foram adquiridos há muito tempo.

Como o imóvel 4 envolve alto volume de investimento e ainda está em fase final de implantação é preciso também identificar como este imóvel está sendo contabilizado no balanço, para que a baixa do ativo seja feita corretamente. Dessa forma é preciso conhecer: [i] os desembolsos totais realizados recentemente para aquisição do imóvel, [ii] como foram pagos estes desembolsos (prazos e quais contas foram impactadas no balanço), [iii] como o endividamento com o financiamento deste imóvel está contabilizado no passivo circulante e não circulante, [iv] os pagamentos já realizados do principal e juros referentes ao financiamento do imóvel, e [v] o valor de registro deste imóvel na conta do imobilizado. $\mathrm{O}$ levantamento destes dados tem como propósito encontrar a situação do balanço mais próxima possível em relação àquela encontrada antes da entrada deste ativo ${ }^{154}$. A partir da coleta destes dados e do auxílio do gerente de contabilidade da empresa do caso, conclui-se que o balanço antes do início da fase de implantação deste imóvel é próximo ao apresentado na Tabela 72.

\begin{tabular}{|c|c|c|c|}
\hline \multicolumn{4}{|c|}{$\begin{array}{l}\text { Balanço - EMPRESA DO CASO - IMÓVEL } 4 \text { (COMPLEXO INDUSTRIAL) } \\
\text { Análise das [Alternativas] a partir das demandas e características do imóvel } \\
\text { (com base no Balanço de Dezembro/2009 - Valores em R\$ mil) }\end{array}$} \\
\hline Ativo Total & 691.789 & \multirow{3}{*}{\multicolumn{2}{|c|}{$\begin{array}{l}\text { Índices de Liquidez, } \\
\text { Endividamento e Grau } \\
\text { de Imobilização }\end{array}$}} \\
\hline Ativo Circulante & 331.853 & & \\
\hline Disponibilidades & 86.285 & & \\
\hline Ativo não Circulante & 359.936 & ILC & 1,40 \\
\hline Ativo Realizável a Longo Prazo & 32.414 & $\mathrm{ILI}$ & 0,36 \\
\hline Ativo Imobilizado+Investimentos+Intangível & 327.522 & PTRT & 0,56 \\
\hline Passivo Total & 691.789 & PTPL & 1,26 \\
\hline Passivo Circulante & 236.618 & PECP & 0,61 \\
\hline Passivo Não Circulante (exigível a longo prazo) & 148.466 & GIPL & 1,07 \\
\hline Patrimônio Líquido & 306.705 & CGL & 95.235 \\
\hline
\end{tabular}

Tabela 72 - Índices financeiros da empresa para análise do impacto das [alternativas] em relação ao Imóvel 4 (Análise a partir das demandas e características do imóvel)

Essa aproximação do balanço, para identificar a situação dos grupos de contas e dos índices

${ }^{154}$ Neste caso, como o imóvel 4 está em fase final de implantação o valor de registro é equivalente ao seu valor de mercado. 
financeiros da empresa antes do efeito provocado pela contabilização do imóvel em análise, é particular de cada caso, visto que depende de quando e como este imóvel foi adquirido. $\mathrm{O}$ planejador usuário do [MAOI] em cada situação tem que identificar junto à empresa como o ativo imobiliário está sendo contabilizado no balanço, conforme demonstrado para as diferentes situações dos imóveis da empresa do caso. Esta premissa de análise, embora dependa de uma aproximação que foge da realidade atual da empresa, permite uma leitura primária do impacto de cada imóvel no balanço, e ainda acaba levando para uma análise com viés mais conservador sobre o impacto das [alternativas] no balanço ${ }^{155}$.

É possível verificar o impacto que este ativo causa no balanço da empresa a partir dos novos índices financeiros encontrados para a situação antes da fase de implantação do imóvel 4 . O ILC encontrado é de 1,40, ou seja, o ativo circulante é maior que o passivo circulante em $40 \%$. O CGL indica uma folga financeira de 95.235 R \$ mil, visto a redução do passivo circulante (quando se exclui a dívida das parcelas do financiamento de cada exercício), bem como pelo acréscimo do ativo circulante (acrescido das disponibilidades já comprometidas com a implantação do imóvel).

A partir dos grupos de contas do balanço e dos índices financeiros estimados para a situação antes do efeito provocado pela contabilização do imóvel 4, conforme apresentado na Tabela 72, analisa-se o impacto de cada [alternativa] nos grupos de contas, e assim nos índices financeiros. A Tabela 73 resume os índices financeiros encontrados após a contabilização dos elementos de cálculo referentes ao imóvel 4 nos grupos do ativo, passivo e patrimônio líquido para cada uma das [alternativas], conforme rotina detalhada apresentada no item 6.3.3.5 para a situação modelo.

155 Esta premissa pode ser considerada como conservadora, uma vez que se a empresa não imobilizasse no imóvel os resultados dos exercícios anteriores tenderiam a se apresentar ainda melhores, visto às maiores oportunidades de ganho proporcionadas pelas [alternativas] de não imobilização. Com isto, os grupos de contas do balanço da empresa também tenderiam a ser mais favoráveis e, por consequência, os índices financeiros seriam menos sensíveis aos impactos causados pelas [alternativas] de imobilização do imóvel em análise. 


\begin{tabular}{|c|c|c|c|c|c|c|}
\hline \multicolumn{7}{|c|}{$\begin{array}{l}\text { Indicadores - Critério H (Desoneração do Balanço) } \\
\text { EMPRESA DO CASO - IMÓVEL } 4 \text { (COMPLEXO INDUSTRIAL) } \\
\text { (Valores em R\$ mil) }\end{array}$} \\
\hline Índices & \multicolumn{2}{|c|}{$\begin{array}{l}\text { Impactos } \\
\text { [alternativas]: } \\
\text { BTS, LLP, LCP }\end{array}$} & \multicolumn{2}{|c|}{$\begin{array}{l}\text { Impactos } \\
\text { [alternativa]: SP }\end{array}$} & \multicolumn{2}{|c|}{$\begin{array}{l}\text { Impactos } \\
\text { [alternativa]: } \\
\text { SP a prazo }\end{array}$} \\
\hline ILC & 1,21 & \begin{tabular}{|c|}
$-13,5 \%$ \\
\end{tabular} & 1,01 & $-28,1 \%$ & 1,08 & $-23,2 \%$ \\
\hline ILI & 0,32 & $-13,5 \%$ & $-0,03$ & $-108,2 \%$ & 0,12 & $-67,6 \%$ \\
\hline PTRT & 0,61 & $9,6 \%$ & 0,57 & $1,6 \%$ & 0,63 & $13,8 \%$ \\
\hline PTPL & 1,56 & $24,6 \%$ & 1,30 & $3,6 \%$ & 1,73 & $37,8 \%$ \\
\hline PECP & 0,65 & $5,5 \%$ & 0,61 & $0,0 \%$ & 0,51 & $-17,1 \%$ \\
\hline GIPL & 1,21 & $13,7 \%$ & 2,02 & $88,8 \%$ & 2,05 & $92,3 \%$ \\
\hline CGL & 58.275 & $-38,8 \%$ & 1.902 & $-98,0 \%$ & 19.789 & $-79,2 \%$ \\
\hline
\end{tabular}

Tabela 73 - Impacto nos índices financeiros do balanço para cada [alternativa] - Imóvel 4

A [alternativa] - SP compromete sensivelmente os índices financeiros. O CGL é impactado em 98\% em relação ao índice apresentado na Tabela 72, resultando em uma folga financeira de apenas $1.902 \mathrm{R} \$$ mil, que é inferior ao parâmetro mínimo determinado na política de planejamento financeiro da empresa (10.000 R\$ mil). O ILI seria negativo, ou seja, a empresa não teria disponibilidades em caixa para pagar as parcelas do imóvel que competem ao exercício, devendo, portanto, ser levantado capital de giro para cumprir com esta obrigação. Conforme informado pela empresa do caso, a imobilização para este imóvel somente é possível por meio de financiamento, como comprovado pela análise dos índices financeiros para a [alternativa] - SP.

As [alternativas] de não imobilização são as que menos impactam nos grupos de contas do balanço, e assim nos índices financeiros, mantendo-os acima dos parâmetros de referência para os ILC, PTRT e CGL.

A [alternativa] - SP a Prazo gera um aumento no índice de endividamento (PTRT), visto a contabilização da dívida do financiamento do imóvel no passivo. Porém, todos os índices atendem aos parâmetros de referência do decisor, com a ressalva para o PECP (participação do exigível a curto prazo), que apresenta redução, uma vez que a relação da dívida de curto prazo passa a ser menor em função do acréscimo do passivo exigível a longo prazo.

A partir da análise destes indicadores, em conjunto com os parâmetros de referência do decisor, atribuí-se as notas de atendimento das [alternativas] na matriz de comparação para o [Critério H] no Nível 3 do AHP, as quais resultam nos pesos relativos apresentados no Gráfico 45. 


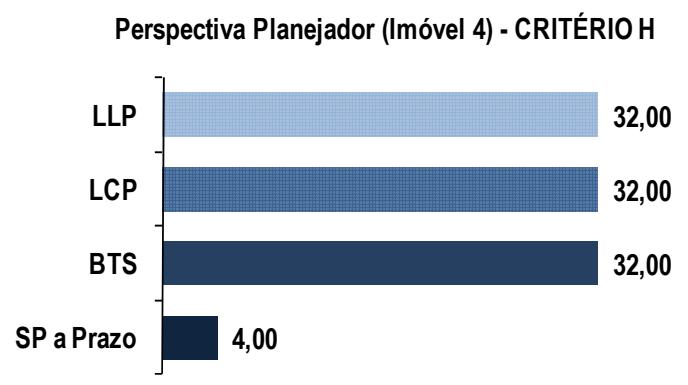

Gráfico 45 - Pesos relativos das [alternativas] para o [Critério H] - Imóvel 4

\subsubsection{Redução dos Impactos Tributários - [Critério I]}

Para cálculo da economia tributária proporcionada em cada [alternativa] identifica-se as economias tributárias geradas pelos fatores redutores do lucro, como a depreciação, despesa operacional e despesa financeira, que multiplicadas à alíquota de impostos da empresa resultam nas economias tributárias de cada exercício. As economias tributárias de cada exercício introduzidas nos períodos do horizonte de análise formam o fluxo de cada [alternativa], que descontados ao wacc indicam a economia tributária resultante para cada uma.

Neste caso são identificadas as seguintes economias tributárias para cada [alternativa]:

[i] Depreciação de 10.700 R \$ mil por ano, que resulta na ETD de $3.638 \mathrm{R} \$$ mil em cada exercício, durante todo o horizonte de análise ( 25 anos). Para cálculo dos indicadores em valores da base desconta-se a inflação acumulada em cada período;

[ii] Despesa financeira até final do prazo de amortização (8 anos) para a opção pela imobilização a prazo, que é variável no fluxo (decrescente). Assim como a depreciação, as despesas financeiras estão em reais nominais e para cálculo dos indicadores em valores da base desconta-se a inflação acumulada em cada período;

[iii] Despesa operacional com o pagamento dos aluguéis no intervalo [35.520 - 38.400] R\$ mil por ano, que resulta no intervalo de ETDO [12.077 - 13.056] R\$ mil em cada exercício, durante todo o horizonte de análise (25 anos). Para cálculo do indicador ETDO em valores da base, desconta-se a inflação acumulada em cada período, no entanto, para esta despesa considera-se o reajuste anual dos preços ao IGP-M.

Os fluxos formados pelas economias tributárias proporcionadas por cada uma das [alternativas], conforme expressões apresentadas no item 6.4 (Tabela 20), descontados ao wacc da empresa, considerado no intervalo $[11,80 \%-23,22 \%]$ ao ano, resultam nas 
economias tributárias da Tabela 74.

\begin{tabular}{|c|c|c|c|c|}
\hline \multicolumn{5}{|c|}{ CRITÉRIO I - IMÓVEL 4 (COMPLEXO INDUSTRIAL) } \\
\hline \multicolumn{5}{|c|}{ Intervalos de Valor dos Indicadores relacionados à Economia Tributária } \\
\hline \multicolumn{5}{|c|}{ (Cenário Referencial) } \\
\hline \multirow{2}{*}{ Indicadores (R\$ mil da base) } & \multirow{2}{*}{ Média } & \multirow{2}{*}{ Desvio } & \multicolumn{2}{|c|}{ Fronteiras da Amostra* } \\
\hline & & & Inferior & Superior \\
\hline ETDO para: LLP, BTS e LCP & 76.701 & 808 & 75.372 & 78.031 \\
\hline ETD: SP & 18.070 & 178 & 17.777 & 18.363 \\
\hline ETDDF: SP a Prazo & 26.982 & 224 & 26.613 & 27.351 \\
\hline \multicolumn{5}{|c|}{${ }^{*} 90 \%$ de confiabilidade do indicador se situar entre estas fronteiras } \\
\hline \multicolumn{5}{|c|}{ NOTA: estes indicadores são medidos em amostras de laboratório diferentes. } \\
\hline \multicolumn{5}{|c|}{ Nesse sentido, as fronteiras dos intervalos não representam pares de valores. } \\
\hline
\end{tabular}

Verifica-se que a ETDO para as [alternativas] de não imobilização geram uma economia tributária bem superior às economias geradas pelas [alternativas] de imobilização. A diferença entre ETDO e ETD é de 58.631 R\$ mil da base e entre ETDDF é de 49.719 R\$ mil da base, ou seja, ambas estão acima do parâmetro de referência definido pelo decisor (diferença de no mínimo 40.000 R \$ mil da base entre ETDO e as economias tributárias das [alternativas] de imobilização).

A partir destes indicadores são pontuadas as notas de atendimentos das [alternativas] para o [Critério I], as quais geram os pesos relativos apresentados no Gráfico 46.

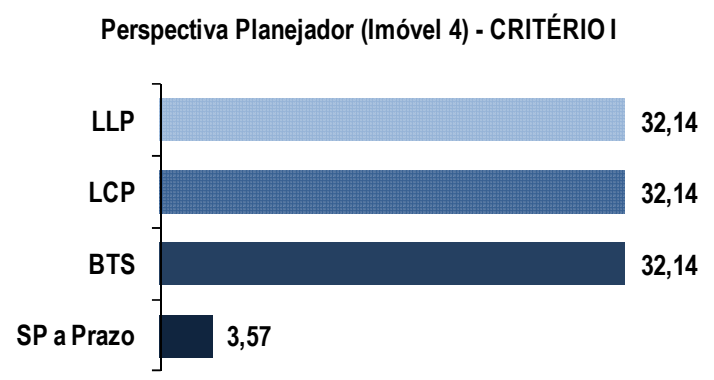

Gráfico 46 - Pesos relativos das [alternativas] para o [Critério I] - Imóvel 4

\subsubsection{Referências Qualitativas do [MAOI] para o Imóvel 4}

As referências qualitativas relacionadas às unidades produtivas da empresa são pontuadas de modo distinto aos outros dois imóveis apresentados, por serem imóveis estratégicos à operação e ao negócio da empresa, específicos, e ainda neste caso são também 
constantemente modificados, já que os órgãos reguladores do segmento da indústria farmacêutica (como a Agência Nacional de Vigilância Sanitária - ANVISA) requerem contínuas alterações para adequar os espaços e instalações aos padrões exigidos de segurança à saúde.

Em relação ao primeiro critério relacionado ao uso, que é o [Critério A] - flexibilidade de mudança, a opção pela imobilização é ainda mais penalizada em relação aos demais imóveis, visto a baixa liquidez do ativo em função da sua alta especificidade. No longo prazo a opção pelo BTS permite a empresa decidir pela continuidade ou não da operação no imóvel, e por isso recebe uma pontuação melhor em relação à imobilização. As locações simples melhor atendem a este critério, no entanto, comprometem significativamente os atributos relacionados à especificidade do imóvel, controle operacional no uso e tradução da imagem corporativa.

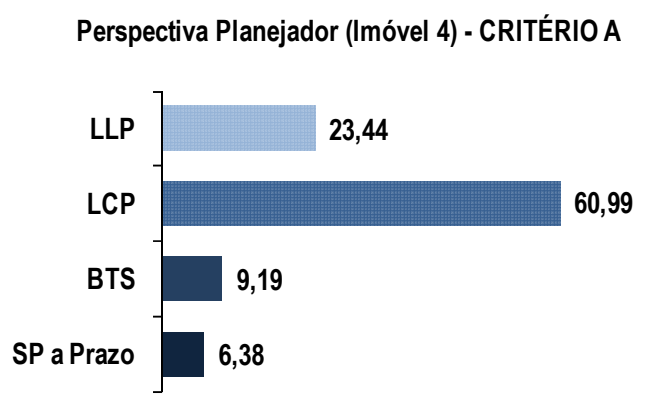

Gráfico 47 - Pesos relativos das [alternativas] para o [Critério A] - Imóvel 4

Quanto ao [Critério B] - rapidez na mobilização da atividade ao espaço, para imóveis desta natureza o critério é ainda mais comprometido para as [alternativas] - BTS e SP a Prazo, uma vez que o imóvel leva meses para ser concebido. No entanto, na priorização do decisor este critério esta sempre em última posição para as unidades produtivas.

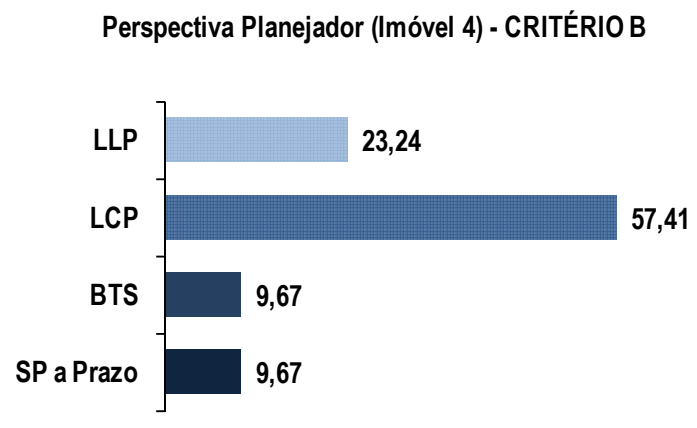

Gráfico 48 - Pesos relativos das [alternativas] para o [Critério B] - Imóvel 4 
Durante a operação a empresa promove contínuas intervenções para adequar o imóvel aos novos produtos e às exigências dos órgãos reguladores. Em geral as modificações são classificadas como - altas intervenções -, pois se referem às alterações nas estruturas e sistemas prediais (tais como: instalação de paredes duplas, construção de novos dutos para escoamento de líquidos específicos, entre outras). Por isso, a opção pela imobilização recebe melhor pontuação na atribuição das notas de atendimento, seguida da [alternativa] - BTS, pois o imóvel já é customizado para atender ao uso da empresa. Os pesos relativos resultantes das [alternativas] para o [Critério C] estão apresentados no Gráfico 49.

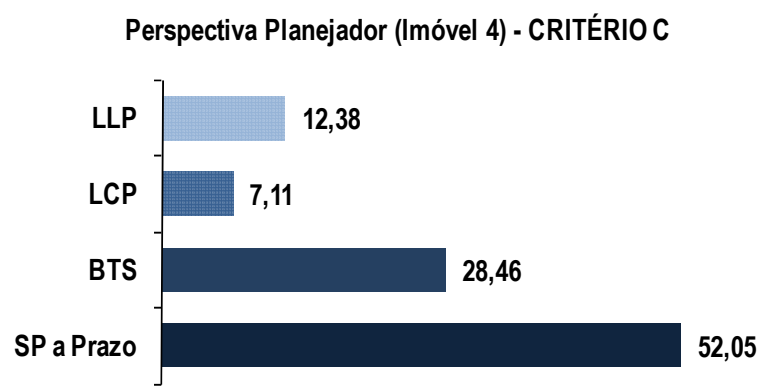

Gráfico 49 - Pesos relativos das [alternativas] para o [Critério C] - Imóvel 4

Como se trata de um imóvel estratégico e infungível à operação pelo investimento imobilizado com equipamentos pesados e instalações, e pela dependência direta da atividade com o espaço, o vínculo da operação com o imóvel [Critério D] é ainda mais importante para a empresa no caso do imóvel 4 e demais unidades fabris. Neste caso, as [alternativas] de locação simples (LCP e LLP) são ainda mais penalizadas na pontuação das notas de atendimento, resultando nos pesos relativos apresentados no Gráfico 50.

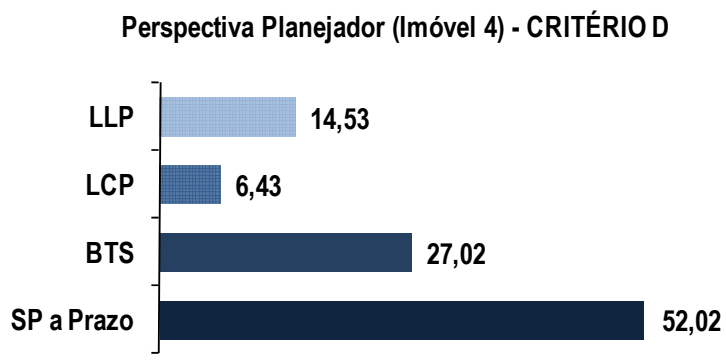

Gráfico 50 - Pesos relativos das [alternativas] para o [Critério D] - Imóvel 4

A alta especificidade do espaço somente é atendida pelas [alternativas] - BTS e SP a Prazo, conforme indica os pesos relativos do Gráfico 51 para o [Critério E] (especificidade do 
imóvel).

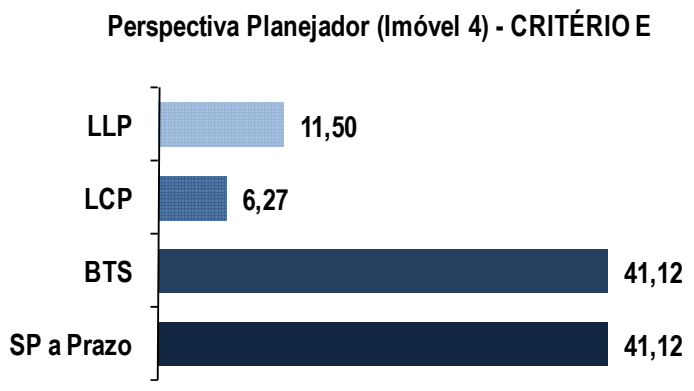

Gráfico 51 - Pesos relativos das [alternativas] para o [Critério E] - Imóvel 4

No caso do imóvel 4, assim como do imóvel 2 (unidade de produção dos antibióticos), a oportunidade de tradução da imagem corporativa [Critério F] é pontuada distintamente às demais unidades fabris. Verifica-se pelo Gráfico 52 que, nesse caso, a opção pela imobilização recebeu uma pontuação bem superior em relação às outras [alternativas]. Isto ocorre pelo fato do decisor enfatizar que é estratégico ser proprietário do imóvel tanto para o projeto de internacionalização, como para absorver a fabricação de produtos de outras marcas na sua capacidade instalada (terceirização).

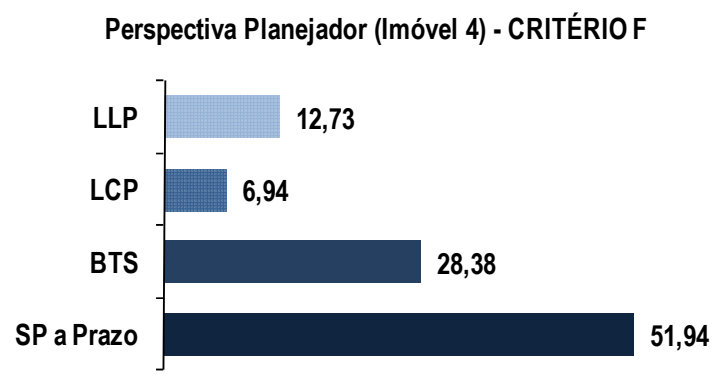

Gráfico 52 - Pesos relativos das [alternativas] para o [Critério F] - Imóvel 4

\subsubsection{Pesos relativos das [alternativas] para cada critério - Matrizes Nível 3 do AHP para o Imóvel 4}

Os pesos relativos das [alternativas] para os critérios qualitativos e quantitativos estão compilados na Tabela 75, e indicam as [alternativas] que melhor atendem e mais comprometem cada um dos critérios de decisão do [MAOI] para o imóvel 4. 


\begin{tabular}{|c|c|c|c|c|c|c|c|c|c|}
\hline \multicolumn{10}{|c|}{ PESO RELATIVO DAS [ALTERNATIVAS] X CRITÉRIOS - IMÓVEL 4 (COMPLEXO INDUSTRIAL) } \\
\hline \multirow[t]{2}{*}{$\begin{array}{l}\text { [ALTERNA- } \\
\text { TIVAS] }\end{array}$} & $\begin{array}{l}\text { Flexibili- } \\
\text { dade de } \\
\text { Mudança }\end{array}$ & $\begin{array}{c}\text { Rapidezna } \\
\text { Mobilização } \\
\text { da Atividade } \\
\text { para o } \\
\text { Espaço }\end{array}$ & $\begin{array}{c}\text { Controle } \\
\text { Operacional } \\
\text { no Uso do } \\
\text { Espaço }\end{array}$ & $\begin{array}{l}\text { Vínculo da } \\
\text { Operação } \\
\text { com Imóvel }\end{array}$ & $\begin{array}{l}\text { Especifi- } \\
\text { dade do } \\
\text { Imóvel }\end{array}$ & $\begin{array}{c}\text { Oportunidade } \\
\text { de Tradução } \\
\text { da Imagem } \\
\text { Corporativa }\end{array}$ & $\begin{array}{c}\text { Canalizar } \\
\text { recursos em } \\
\text { oportunidades } \\
\text { do Negócio } \\
\text { Principal }\end{array}$ & $\begin{array}{l}\text { Desone- } \\
\text { ração } \\
\text { do Balanço }\end{array}$ & $\begin{array}{c}\text { Redução dos } \\
\text { Impactos } \\
\text { Tributários }\end{array}$ \\
\hline & {$[\mathrm{A}]$} & [B] & [C] & [D] & {$[\mathrm{E}]$} & {$[\mathrm{F}]$} & [G] & {$[\mathrm{H}]$} & [l] \\
\hline SP a Prazo & 6,38 & 9,67 & 52,05 & 52,02 & 41,12 & 51,94 & 4,78 & 4,00 & 3,57 \\
\hline BTS & 9,19 & 9,67 & 28,46 & 27,02 & 41,12 & 28,38 & 31,82 & 32,00 & 32,14 \\
\hline LCP & 60,99 & 57,41 & 7,11 & 6,43 & 6,27 & 6,94 & 31,59 & 32,00 & 32,14 \\
\hline LLP & 23,44 & 23,24 & 12,38 & 14,53 & 11,50 & 12,73 & 31,82 & 32,00 & 32,14 \\
\hline Soma & 100,00 & 100,00 & 100,00 & 100,00 & 100,00 & 100,00 & 100,00 & 100,00 & 100,00 \\
\hline \multicolumn{10}{|c|}{ Pesos Relativos das Matrizes X - Nível 3 do AHP (Ponderação feita pelo Planejador) } \\
\hline $\begin{array}{c}\text { CRITÉRIOS } x \\
\text { [ALTERNATIVAS] }\end{array}$ & {$[\mathrm{A}]$} & [B] & [C] & [D] & [E] & [F] & [G] & {$[\mathrm{H}]$} & [l] \\
\hline melhor atende & LCP & LCP & SP a Prazo & SP a Prazo & SP a Prazo;BTS & SP a Prazo & BTS;LLP & BTS;LLP;LCP & BTS;LLP;LCP \\
\hline mais compromete & SP a Prazo & SP a Prazo;BTS & LCP & LCP & LCP & LCP & SP a Prazo & SP a Prazo & SP a Prazo \\
\hline
\end{tabular}

Tabela 75 - Pesos Relativos das [alternativas] para todos os critérios de decisão do [MAOI] - Imóvel 4

\subsubsection{Priorização dos critérios - Matriz Nível 2 do AHP para o Imóvel 4}

A priorização dos critérios dada pelo decisor para o imóvel 4, feita a partir da atribuição de notas de importância comparativa entre os critérios, resultam nos pesos relativos apresentados no Gráfico 53.

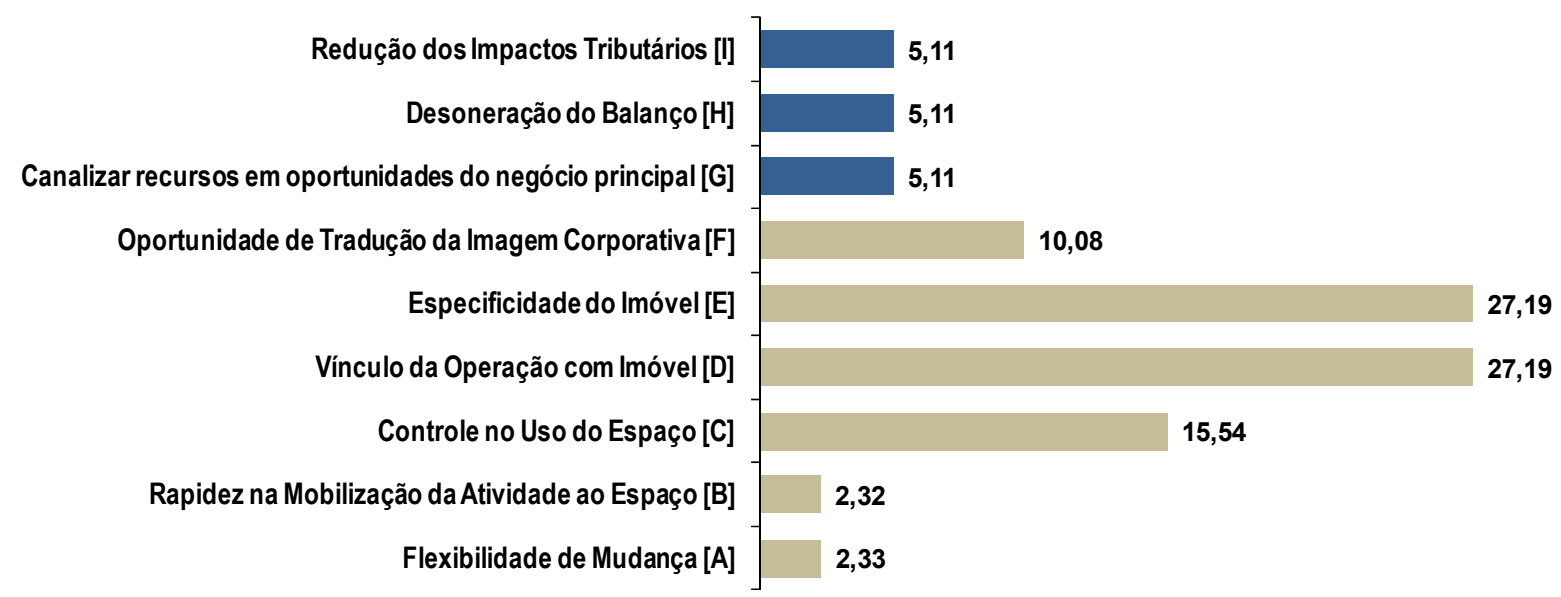

Gráfico 53 - Pesos relativos dos critérios para o Imóvel 4 conforme priorização do decisor

É possível notar que nesse caso os critérios relacionados ao uso do espaço corporativo são mais importantes do que os critérios relacionados às estratégias de investimento e políticas corporativas. Os pesos dos critérios relacionados ao uso do espaço somam 84,65 do total (100), com priorização destacada para o [Critério D] (vínculo da operação com o imóvel) e para o [Critério E] (especificidade do imóvel). 


\subsubsection{Resultado AHP - [alternativa] Indicada pelo [MAOI] para Imóvel 4}

Os pesos relativos das [alternativas] (Matrizes do Nível 3 do AHP) multiplicados pelos pesos relativos dos critérios (Matriz do Nível 2 do AHP) resultam na hierarquização entre as [alternativas] para o imóvel 4, apresentada na Tabela 76 e no Gráfico 54.

A [alternativa] que melhor atende em conjunto aos critérios priorizados pelo decisor para este imóvel é a SP a Prazo, seguida da [alternativa] - BTS. Como se observa no Gráfico 54 as [alternativas] de locação simples (LLP e LCP) estão com pesos bem distantes em relação às duas primeiras (SP a Prazo e BTS), visto que neste caso comprometem significativamente os critérios relacionados ao uso priorizados pelo decisor.

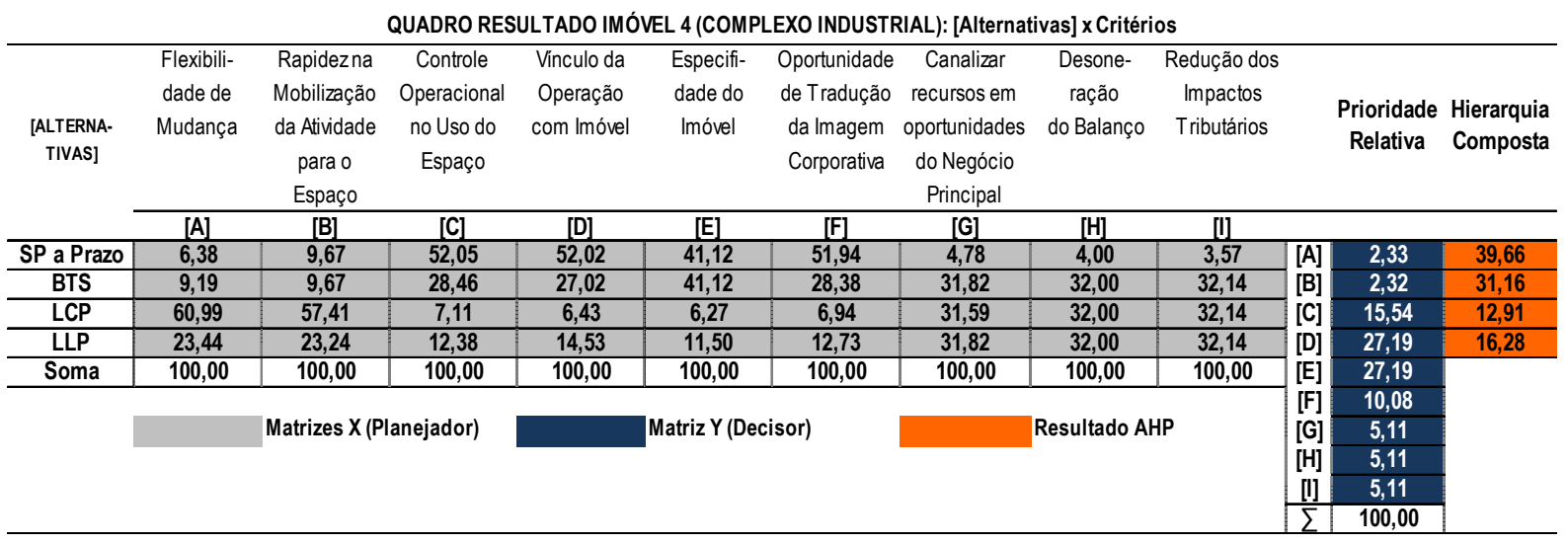

Tabela 76 - Quadro com resultado do AHP para o Imóvel 4

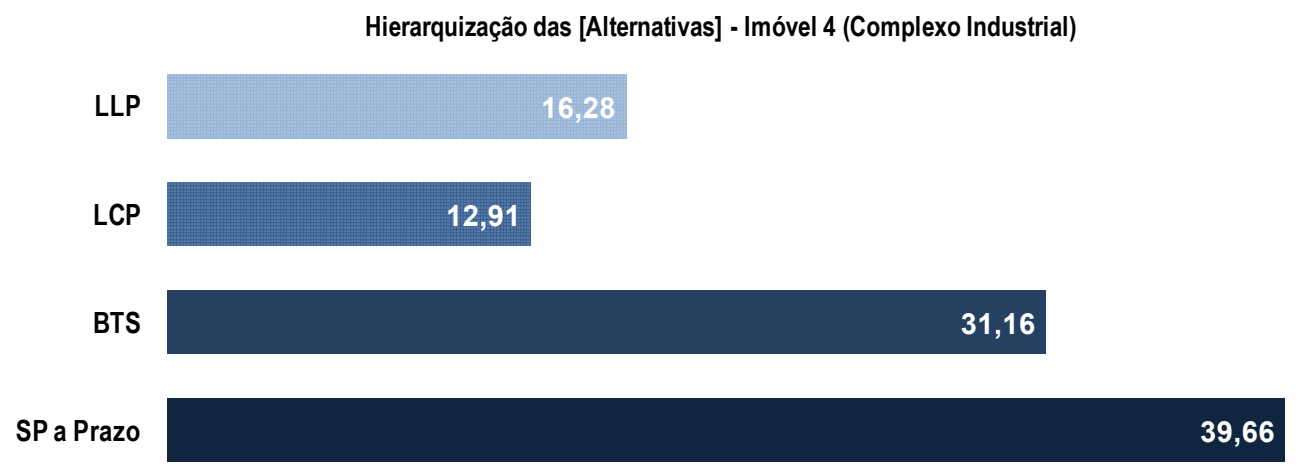

Gráfico 54 - Hierarquia das [alternativas] para o Imóvel 4

A aplicação do [MAOI] para o imóvel 4 indicou a opção pela imobilização a prazo (SP a Prazo) como a [alternativa] mais adequada para este imóvel, sustentando assim à decisão tomada pela empresa, que está alinhada à [alternativa] indicada pelo [MAOI]. 
Para os demais imóveis da empresa aplica-se a mesma rotina. No item que segue estão apresentados os resultados da aplicação do [MAOI] para todo o portfolio de real estate da empresa do caso.

\subsection{Resultados parciais e finais da aplicação do [MAOI] para o Portfolio de Real Estate da Empresa do Caso}

Os resultados parciais e finais da aplicação do [MAOI] sustentam as decisões tomadas pela empresa do caso para alguns imóveis do seu portfolio (2, 4, 5 e 6), mesmo que estas decisões tenham sido baseadas em parâmetros e variáveis diferentes aos analisados no [MAOI]. Para os outros imóveis (1 e 3), as [alternativas] indicadas pelo [MAOI] não estão alinhadas às decisões feitas pela companhia. Entretanto, a partir dos resultados parciais e finais da aplicação do [MAOI] é possível sugerir intervenções no portfolio, com intuito de gerar melhores resultados para a empresa, considerando a situação atual do portfolio no balanço, o contexto macroeconômico, os mercados de real estate, as práticas de mercado, a sustentação legal, contábil e tributária no Brasil, e os demais fatores que são contemplados na rotina de aplicação do [MAOI].

Essas intervenções sugeridas no portfolio, feitas a partir dos resultados parciais e finais, garantem melhores oportunidades de ganho, redução de impactos tributários, desoneração do balanço, entretanto, com alinhamento das estratégias do real estate com as necessidades operacionais e estratégias da corporação adiante.

Considera-se como resultados parciais do [MAOI]:

[i] os indicadores relacionados ao [Critério G] - canalizar recursos em oportunidades do negócio principal (RRCGA, ARC, RRIP e TRIP);

[ii] os indicadores relacionados ao [Critério J] - levantar capital de giro com a desmobilização para investir em oportunidades do negócio principal (mesmos indicadores do [Critério G], considerando a situação atual dos ativos no balanço da empresa);

[iii] as análises de risco para avaliar os impactos nos indicadores relacionados ao [Critério G] e ao [Critério J] a partir de perturbações no intervalo do ROE da empresa;

[iv] os indicadores relacionados ao [Critério H] - desoneração do balanço (que medem os impactos nos índices de liquidez, endividamento e grau de imobilização da empresa para cada [alternativa]); 
[v] os indicadores relacionados ao [Critério I] - redução dos impactos tributários (que medem as economias tributárias para cada [alternativa]: ETDO, ETD, ETDDF e ETEDO); e

[vi] as diretrizes conforme contexto de cada situação para pontuação das notas das [alternativas] nos critérios qualitativos relacionados ao uso do espaço corporativo, com base na sustentação legal e práticas prevalentes de mercado (conforme conteúdo detalhado no Capítulo 5, compilado na Tabela 7).

Considera-se como resultados finais do [MAOI]:

[i] os pesos relativos dos critérios de decisão do [MAOI] a partir da priorização feita pelo decisor para cada imóvel do portfolio da empresa do caso (Matriz do Nível 2 do AHP). Esta priorização encontrada a partir da atribuição de notas de importância relativa entre os critérios é dada com base nos resultados parciais (referências qualitativas e quantitativas do [MAOI]), e nas necessidades operacionais e estratégias da empresa adiante;

[ii] os pesos relativos das [alternativas] para cada critério de decisão do [MAOI] em cada imóvel do portfolio da empresa do caso (Matrizes do Nível 3 do AHP). Estes pesos relativos retratam as [alternativas] que melhor atendem e as que mais comprometem os critérios de decisão do [MAOI] de acordo com as referências qualitativas, quantitativas e a contextualização de cada situação em análise, que se difere por imóvel, conforme rotina detalhada apresentada para os imóveis 1, 3 e 4 da empresa do caso, e

[iii] a hierarquização das [alternativas] para cada imóvel (Resultado do AHP a partir da multiplicação das Matrizes do Nível 3 pela Matriz do Nível 2). Esta hierarquização entre as [alternativas] indica aquela que melhor atende em conjunto aos critérios priorizados pelo decisor para cada imóvel.

Primeiro serão apresentados para todos os imóveis da empresa do caso os resultados parciais da aplicação do [MAOI], e depois os resultados finais, conforme classificação acima descrita.

A Tabela 77 apresenta os indicadores relacionados ao [Critério G] para todos os imóveis do portfolio da empresa do caso em cada uma das [alternativas]. Os indicadores apresentados na Tabela 77 não consideram a situação atual do ativo na empresa, conforme rotina de aplicação do [MAOI] proposta para empresas já instaladas. Ou seja, a análise é feita, em um primeiro momento, a partir das características e demandas dos imóveis necessários à operação, para depois fazer a análise complementar com a situação atual dos ativos no balanço da empresa do caso. 
O saldo (p) gerado pela diferença entre RCGA e CCGA para o conjunto dos imóveis da empresa está no intervalo [52.806 - 55.581 ] R \$ mil da base por ano. Este saldo anual resulta em um acréscimo no resultado corporativo da empresa no intervalo [47,88\% - 50,40\%] ao ano. A maior contribuição para este saldo e este acréscimo do resultado é proporcionada pelo imóvel 4 (complexo industrial). O saldo (p) do conjunto, sem considerar o imóvel 4, está no intervalo [18.383 - 19.454 ] R $\$$ mil da base por ano, que resulta no intervalo [16,67\% 17,64\%] ao ano para ARC, resultados ainda bastante representativos para as [alternativas] de não imobilização.

\begin{tabular}{|c|c|c|c|c|c|c|c|c|c|c|c|c|c|c|c|c|c|}
\hline \multicolumn{18}{|c|}{ Análise das [Alternativas] a partir das demandas e características dos imóveis } \\
\hline \multirow{2}{*}{\multicolumn{2}{|c|}{ Indicadores }} & \multicolumn{6}{|c|}{ LLP, LCP e BTS } & \multicolumn{10}{|c|}{$\overline{\text { SP a PRAZO }}$} \\
\hline & & $\begin{array}{r}\text { Sald } \\
R \$ \text { mil d }\end{array}$ & $\begin{array}{l}\text { lo }(p) \\
\text { da base }\end{array}$ & $\begin{array}{r}\text { RRC } \\
\text { (\% ao } \\
\text { efetiva } \\
\text { do I }\end{array}$ & $\begin{array}{l}\text { CGA } \\
\text { o ano } \\
\text { acima } \\
\text { IGP) }\end{array}$ & $\begin{array}{r}\mathrm{AF} \\
\text { (\% ao }\end{array}$ & $\begin{array}{l}\text { RC } \\
\text { o ano) }\end{array}$ & $\begin{array}{r}\text { Sald } \\
\mathrm{R} \$ \mathrm{mil} \mathrm{c}\end{array}$ & $\begin{array}{l}\left.\text { do ( } p^{\prime}\right) \\
\text { da base }\end{array}$ & \multicolumn{2}{|c|}{$\begin{array}{c}\text { RRIP } \\
\text { ( } \% \text { ao ano } \\
\text { efetiva acima } \\
\text { do IGP) }\end{array}$} & \multicolumn{2}{|c|}{$\begin{array}{c}\text { TRIP } \\
\text { (\% equivalente } \\
\text { ano efetiva } \\
\text { acima do IGP) }\end{array}$} & \multicolumn{2}{|c|}{$\begin{array}{c}\text { Participação de } \\
\text { VOIn (para } \\
\text { produzir TRIP) }\end{array}$} & \multicolumn{2}{|c|}{$\begin{array}{c}\text { ARC } \\
\text { (\% ao ano) }\end{array}$} \\
\hline \multirow{3}{*}{ 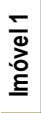 } & Parâmetros ${ }^{1}$ & \multicolumn{2}{|c|}{ (indicador auxiliar) } & \multicolumn{2}{|c|}{$>8 \%$ ao ano } & \multicolumn{2}{|c|}{$>4 \%$ ao ano } & \multicolumn{2}{|c|}{ (indicador auxiliar) } & \multicolumn{2}{|c|}{$>8 \%$ ao ano } & \multicolumn{2}{|c|}{ (indicador auxiliar) } & \multicolumn{2}{|c|}{ (indicador auxiliar) } & \multicolumn{2}{|c|}{$>4 \%$ ao ano } \\
\hline & Fron & Inferior & Superior & Inferior & Superior & Inferior & Superior & Inferior & Superior & Inferior & Superior & Inferior & Superior & Inferior & Superior & Inferior & Superior \\
\hline & rIOI & 4.505 & 4.765 & $11,4 \%$ & $12,1 \%$ & $4,1 \%$ & $4,3 \%$ & 1.509 & 1.738 & $3,7 \%$ & $4,3 \%$ & $9,2 \%$ & $9,3 \%$ & $14,9 \%$ & $15,3 \%$ & $1,4 \%$ & $1,6 \%$ \\
\hline \multirow{3}{*}{ 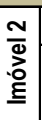 } & Parâmetros ${ }^{1}$ & \multicolumn{2}{|c|}{ (indicador auxiliar) } & \multicolumn{2}{|c|}{$>8 \%$ ao ano } & \multicolumn{2}{|c|}{$>4 \%$ ao ano } & \multicolumn{2}{|c|}{ (indicador auxiliar) } & \multicolumn{2}{|c|}{$>8 \%$ ao ano } & \multicolumn{2}{|c|}{ (indicador auxiliar) } & \multicolumn{2}{|c|}{ (indicador auxiliar) } & \multicolumn{2}{|c|}{$>4 \%$ ao ano } \\
\hline & Frontairac ${ }^{2}$ & Inferior & Superior & Inferior & Superior & Inferior & Superior & Inferior & Superior & \begin{tabular}{|l|} 
Inferior \\
\end{tabular} & Superior & Inferior & Superior & Inferior & Superior & \begin{tabular}{|l|} 
Inferior \\
\end{tabular} & Superior \\
\hline & riontends & 5.371 & 5.666 & $12,9 \%$ & $13,7 \%$ & $4,9 \%$ & $5,1 \%$ & 997 & 1.198 & $2,3 \%$ & $2,8 \%$ & $7,8 \%$ & $7,9 \%$ & $17,6 \%$ & $17,9 \%$ & $0,9 \%$ & $1,1 \%$ \\
\hline \multirow{3}{*}{ 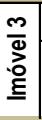 } & Parâmetros ${ }^{1}$ & \multicolumn{2}{|c|}{ (indicador auxiliar) } & $>8 \% \mathrm{a}$ & ao ano & $>4 \% a$ & ao ano & (indicado & or auxiliar) & $>8 \% \mathrm{a}$ & ao ano & (indicador & r auxiliar) & (indicado & or auxiliar) & $>4 \% a$ & ao ano \\
\hline & Fronteiras ${ }^{2}$ & \begin{tabular}{|l|} 
Inferior \\
\end{tabular} & Superior & Inferior & Superior & Inferior & Superior & Inferior & Superior & \begin{tabular}{|l|} 
Inferior \\
\end{tabular} & Superior & Inferior & Superior & Inferior & Superior & \begin{tabular}{|l|} 
Inferior \\
\end{tabular} & Superior \\
\hline & & 6.207 & 6.583 & $12,9 \%$ & $13,7 \%$ & $5,6 \%$ & $6,0 \%$ & 1.146 & 1.436 & $2,3 \%$ & $2,9 \%$ & $7,8 \%$ & $7,9 \%$ & $17,5 \%$ & $17,9 \%$ & $1,0 \%$ & $1,3 \%$ \\
\hline+ & Parâmetros $^{1}$ & (indicador & r auxiliar) & $>12 \%$ & ao ano & $>8 \% a$ & ao ano & (indicado & r auxiliar) & 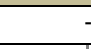 & - & (indicador & r auxiliar) & (indicado & r auxiliar) & & - \\
\hline .̊. & $a^{2}$ & Inferior & Superior & Inferior & Superior & Inferior & Superior & Inferior & Superior & Inferior & Superior & Inferior & Superior & Inferior & Superior & \begin{tabular}{|l|} 
Inferior \\
\end{tabular} & Superior \\
\hline$\underline{\underline{E}}$ & rivintellas & \begin{tabular}{|l|}
34.423 \\
\end{tabular} & 36.127 & $13,0 \%$ & $13,7 \%$ & $31,2 \%$ & $32,8 \%$ & 2.334 & 3.468 & $0,8 \%$ & $1,2 \%$ & $4,7 \%$ & $4,7 \%$ & $23,5 \%$ & $24,0 \%$ & $2,1 \%$ & $3,1 \%$ \\
\hline 10 & Parâmetros ${ }^{1}$ & (indicador & r auxiliar) & $>8 \% a$ & ao ano & $>4 \% a$ & ao ano & (indicado & or auxiliar) & $>8 \% a$ & ao ano & (indicador & r auxiliar) & (indicado & or auxiliar) & $>4 \% a$ & ao ano \\
\hline :ơ & Fronteiras 2 & Inferior & Superior & Inferior & Superior & Inferior & Superior & \begin{tabular}{|l|} 
Inferior \\
\end{tabular} & Superior & \begin{tabular}{|l|} 
Inferior \\
\end{tabular} & Superior & Inferior & Superior & Inferior & Superior & \begin{tabular}{|l|} 
Inferior \\
\end{tabular} & Superior \\
\hline$\underline{\underline{E}}$ & riominas & 1.466 & 1.536 & $12,9 \%$ & $13,6 \%$ & $1,3 \%$ & $1,4 \%$ & 281 & 332 & $2,4 \%$ & $2,8 \%$ & $5,4 \%$ & $5,6 \%$ & $53,8 \%$ & $54,6 \%$ & $0,3 \%$ & $0,3 \%$ \\
\hline$\bullet$ & Parâmetros $^{1}$ & (indicador & o auxiliar) & $>8 \% a$ & ao ano & $>4 \% a$ & ao ano & (indicador & or auxiliar) & $>8 \% a$ & ao ano & (indicador & r auxiliar) & (indicado & or auxiliar) & $>4 \% \mathrm{a}$ & ao ano \\
\hline. & Fronteiras ${ }^{2}$ & Inferior & Superior & Inferior & Superior & Inferior & Superior & Inferior & Superior & Inferior & Superior & Inferior & Superior & Inferior & Superior & Inferior & Superior \\
\hline$\underline{\underline{E}}$ & & 834 & 904 & $12,6 \%$ & $13,7 \%$ & $0,8 \%$ & $0,8 \%$ & 160 & 209 & $2,3 \%$ & $3,0 \%$ & $7,9 \%$ & $8,1 \%$ & $17,2 \%$ & $17,8 \%$ & $0,1 \%$ & $0,2 \%$ \\
\hline & -5.010 & & & & & & & & & & & & & & & & \\
\hline & & & & & & & & & & & & & & & & & \\
\hline
\end{tabular}

Tabela 77 - Indicadores relacionados ao [Critério G] (canalizar recursos em oportunidades do negócio principal) para cada imóvel da Empresa do Caso conforme Cenário Referencial

O intervalo da RRCGA encontrado para o conjunto é [12,13\% - 12,76\%] ao ano efetiva acima do IGP, que é similar a RRCGA encontrada para cada imóvel, conforme se observa na Tabela 77. Isto pelo fato do intervalo do ROE da empresa, bem como do intervalo das taxas de atratividade arbitradas para cálculo dos intervalos do CCGA a partir da rotina de cálculo do VOI, serem iguais para todos os imóveis do portfolio. 
Para todas as unidades fabris da empresa (imóveis 2, 4 e 6), bem como para o imóvel 5 (Centro de Pesquisas Clínicas) a [alternativa] indicada pelo [MAOI] é a imobilização (SP a Prazo), como detalhado no final deste capítulo. Para estes imóveis a [alternativa] indicada está alinhada à decisão escolhida pela empresa, conforme priorização dos critérios do [MAOI] feita pelo decisor. O conjunto das unidades fabris gera um saldo (p) no intervalo [42.094 44.233 ] R $\$$ mil da base por ano, que resulta em um ARC no intervalo [38,17\% - 40,11\%] ao ano. Os imóveis 5 e 6 pouco contribuem para gerar estes resultados.

Para os imóveis 1 e 3 as opções BTS e LLP são as [alternativas] indicadas pelo [MAOI], respectivamente. Estes dois imóveis juntos geram um saldo (p) no intervalo [10.711 11.348] R\$ mil da base por ano, resultando em um ARC no intervalo [9,71\% - 10,29\%] ao ano.

A [alternativa] - SP a Prazo gera resultados bem inferiores às [alternativas] de não imobilização. Como se verifica na Tabela 77, o saldo (p') calculado no intervalo [ 6.426 - 8.381 ] R \$ mil da base por ano, para o conjunto dos imóveis da empresa, resulta em uma RRIP no intervalo [1,48\% - 1,92\%] ao ano efetiva acima do IGP, com ARC no intervalo [5,83\% - 7,60\%] ao ano. Até mesmo a TRIP, que considera todo o horizonte de uso do imóvel e o $\mathrm{VOI}_{\mathrm{n}}$ ao final do ciclo operacional, está abaixo do parâmetro de referência estipulado pelo decisor para todos os imóveis do portfolio, exceto para o imóvel 1, com TRIP próxima de $8 \%$ equivalente ano efetiva acima do IGP.

A opção pela imobilização a prazo pode ser mais vantajosa em relação às [alternativas] de não imobilização a depender das condições de financiamento obtidas pela empresa, como comprovado pelos testes de sensibilidade apresentados para os imóveis 1, 3 e 4. Porém, nas condições de crédito obtidas pela empresa, a opção pela imobilização gera indicadores pouco atrativos.

A Tabela 78 apresenta os mesmos indicadores para os cenários estressados com perturbação sem compensação no ROE da empresa até uma queda de $20 \%$ de desempenho. Com estes cenários, a RRCGA para o conjunto dos imóveis se situa no intervalo [9,12\% - 10,71\%] ao ano efetiva acima do IGP, para um saldo (p) no intervalo [39.710 - 46.635 ] R\$ mil da base por ano, que resulta no intervalo $[36,01 \%-42,29 \%]$ ao ano para o ARC.

Como é possível observar na Tabela 78, em cenários estressados a alternativa - SP a Prazo indica forte queda dos indicadores, principalmente para o imóvel 4. 


\begin{tabular}{|c|c|c|c|c|c|c|c|c|c|c|c|c|c|c|c|c|c|}
\hline \multicolumn{18}{|c|}{ Análise das [Alternativas] a partir das demandas e características dos imóveis } \\
\hline \multirow{2}{*}{\multicolumn{2}{|c|}{ Indicadores }} & \multicolumn{6}{|c|}{ LLP, LCP e BTS } & \multicolumn{10}{|c|}{ SP a PRAZO } \\
\hline & & \multicolumn{2}{|l|}{$\mathrm{Sa}$} & \multicolumn{2}{|c|}{$\begin{array}{c}\text { RRCGA } \\
\text { ( } \% \text { ao ano } \\
\text { efetiva acima } \\
\text { do IGP) }\end{array}$} & \multicolumn{2}{|c|}{$\begin{array}{c}\text { ARC } \\
\text { (\% ao ano) }\end{array}$} & \multicolumn{4}{|c|}{$\begin{array}{c}\text { RRIP } \\
\text { ( } \% \text { ao ano } \\
\text { efetiva acima } \\
\text { do IGP) }\end{array}$} & \multicolumn{2}{|c|}{$\begin{array}{c}\text { TRIP } \\
\text { ( } \% \text { equivalente } \\
\text { ano efetiva } \\
\text { acima do IGP) }\end{array}$} & \multicolumn{2}{|c|}{$\begin{array}{c}\text { Participação de } \\
\text { VOIn (para } \\
\text { produzir TRIP) }\end{array}$} & \multicolumn{2}{|c|}{$\begin{array}{c}\text { ARC } \\
(\% \text { ao ano) }\end{array}$} \\
\hline \multirow{3}{*}{ 돟 } & Parâmetros $^{2}$ & \multicolumn{2}{|c|}{ (indicador auxiliar) } & \multicolumn{2}{|c|}{$>8 \%$ ao ano } & \multicolumn{2}{|c|}{$>4 \%$ ao ano } & \multicolumn{2}{|c|}{ (indicador auxiliar) } & \multicolumn{2}{|c|}{$>8 \%$ ao ano } & \multicolumn{2}{|c|}{ (indicador auxiliar) } & \multicolumn{2}{|c|}{ (indicador auxiliar) } & \multicolumn{2}{|c|}{$>4 \%$ ao ano } \\
\hline & Frontairac 3 & Inferior & Superior & Inferior & Superior & Inferior & Superior & Inferior & Superior & Inferior & Superior & Inferior & Superior & Inferior & Superior & Inferior & Superior \\
\hline & rronterras & 3.267 & 3.895 & $8,2 \%$ & $9,8 \%$ & $3,0 \%$ & $3,5 \%$ & 901 & 1.257 & $2,2 \%$ & $3,1 \%$ & $8,0 \%$ & $8,2 \%$ & $18,3 \%$ & $19,0 \%$ & $0,8 \%$ & $1,1 \%$ \\
\hline \multirow{3}{*}{ 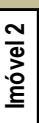 } & Parâmetros ${ }^{2}$ & \multicolumn{2}{|c|}{ (indicador auxiliar) } & \multicolumn{2}{|c|}{$>8 \%$ ao ano } & \multicolumn{2}{|c|}{$>4 \%$ ao ano } & \multicolumn{2}{|c|}{ (indicador auxiliar) } & \multicolumn{2}{|c|}{$>8 \%$ ao ano } & \multicolumn{2}{|c|}{ (indicador auxiliar) } & \multicolumn{2}{|c|}{ (indicador auxiliar) } & $>4 \% a$ & ao ano \\
\hline & Fronteiras 3 & Inferior & Superior & Inferior & Superior & Inferior & Superior & Inferior & Superior & Inferior & Superior & Inferior & Superior & Inferior & Superior & Inferior & Superior \\
\hline & Frontelras & 4.043 & 4.711 & $9,6 \%$ & $11,2 \%$ & $3,7 \%$ & $4,3 \%$ & 343 & 707 & $0,8 \%$ & $1,6 \%$ & $6,6 \%$ & $6,8 \%$ & $21,7 \%$ & $22,4 \%$ & $0,3 \%$ & $0,6 \%$ \\
\hline$m$ & Parâmetros $^{2}$ & (indicado & or auxiliar) & $>8 \% \sigma$ & ao ano & $>4 \% a$ & ao ano & (indicado & or auxiliar) & $>8 \% a$ & ao ano & (indicador & r auxiliar) & (indicado & or auxiliar) & $>4 \% a$ & ao ano \\
\hline ঐे & Fronteiras ${ }^{3}$ & Inferior & Superior & Inferior & Superior & Inferior & Superior & Inferior & Superior & \begin{tabular}{|l|} 
Inferior \\
\end{tabular} & Superior & Inferior & Superior & Inferior & Superior & Inferior & Superior \\
\hline$\underline{\underline{E}}$ & Frontelras & 4.696 & 5.510 & $9,6 \%$ & $11,4 \%$ & $4,3 \%$ & $5,0 \%$ & 387 & 838 & $0,8 \%$ & $1,7 \%$ & $6,6 \%$ & $6,8 \%$ & $21,6 \%$ & $22,4 \%$ & $0,4 \%$ & $0,8 \%$ \\
\hline$\Delta$ & Parâmetros $^{2}$ & (indicado & r auxiliar) & $>12 \%$ & ao ano & $>8 \% a$ & ao ano & (indicado & or auxiliar) & & - & (indicador & r auxiliar) & (indicado & or auxiliar) & & - \\
\hline.$\overline{0}$ & Fronte & Inferior & Superior & Inferior & Superior & Inferior & Superior & Inferior & Superior & Inferior & Superior & Inferior & Superior & Inferior & Superior & Inferior & Superior \\
\hline$\underline{\underline{E}}$ & Frontelras & 25.946 & 30.498 & $9,7 \%$ & $11,5 \%$ & $23,5 \%$ & $27,7 \%$ & (910) & 805 & $-0,3 \%$ & $0,3 \%$ & $3,6 \%$ & $3,8 \%$ & $29,4 \%$ & $30,6 \%$ & $-0,8 \%$ & $0,7 \%$ \\
\hline$\underline{\underline{n}}$ & Parâmetros $^{2}$ & (indicado & or auxiliar) & $>8 \% a$ & ao ano & $>4 \% a$ & ao ano & (indicado & or auxiliar) & $>8 \% a$ & ao ano & (indicador & r auxiliar) & (indicado & or auxiliar) & $>4 \% a$ & ao ano \\
\hline . & & Inferior & Superior & Inferior & Superior & Inferior & Superior & Inferior & Superior & \begin{tabular}{|l|} 
Inferior \\
\end{tabular} & Superior & Inferior & Superior & Inferior & Superior & Inferior & Superior \\
\hline$\underline{\underline{E}}$ & Frontelras ${ }^{\circ}$ & 1.118 & 1.285 & $9,7 \%$ & $11,2 \%$ & $1,0 \%$ & $1,2 \%$ & 105 & 192 & $0,9 \%$ & $1,6 \%$ & $4,1 \%$ & $4,4 \%$ & $60,3 \%$ & $61,8 \%$ & $0,1 \%$ & $0,2 \%$ \\
\hline$\underline{\underline{c}}$ & Parâmetros ${ }^{2}$ & (indicado & or auxiliar) & $>8 \% \mathrm{a}$ & ao ano & $>4 \% a$ & ao ano & (indicado & r auxiliar) & $>8 \% a$ & ao ano & (indicador & r auxiliar) & (indicado & or auxiliar) & $>4 \% a$ & ao ano \\
\hline .0 & Fronteiras 3 & Inferior & Superior & Inferior & Superior & Inferior & Superior & Inferior & Superior & \begin{tabular}{|l|} 
Inferior \\
\end{tabular} & Superior & Inferior & Superior & \begin{tabular}{|l|} 
Inferior \\
\end{tabular} & Superior & Inferior & Superior \\
\hline$\underline{\underline{E}}$ & Fronterras & 639 & 737 & $9,5 \%$ & $11,0 \%$ & $0,6 \%$ & $0,7 \%$ & 63 & 127 & $0,9 \%$ & $1,8 \%$ & $6,7 \%$ & $6,9 \%$ & $21,2 \%$ & $22,1 \%$ & $0,1 \%$ & $0,1 \%$ \\
\hline & $1-$ compe & & & & no $R$ & & & & & o] ue & & & & & & & \\
\hline & 2 - Parâmetr & os de re & ferência & estipul & dos pel & decisor & & & & & & & & & & & \\
\hline & 3-Fronteira & s da am & ostra co & n $90 \% d$ & onfial & 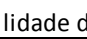 & do indi & rse & or & es & $e_{0}$ & & & & & & \\
\hline
\end{tabular}

para cada imóvel da Empresa do Caso conforme Cenários Estressados

A Tabela 79 apresenta os indicadores relacionados ao [Critério J] na análise da desmobilização patrimonial para os imóveis da empresa. Pela tabela é possível identificar os imóveis em que o SLB é mais atrativo no que tange aos indicadores relacionados às oportunidades de ganho.

Para os imóveis 1 e 3, nos quais o [MAOI] indica as [alternativas] de não imobilização, BTS e LLP, respectivamente, conforme priorização feita pelo decisor, avalia-se os indicadores novamente, considerando a situação atual de ambos os ativos no balanço da empresa (dados de registro, vida útil remanescente, lucro contabilizado com a venda e impostos devidos pelo lucro da venda). A desmobilização dos dois imóveis juntos gera um saldo (p) no intervalo [2.980 - 3.498 ] R \$ mil da base por ano, que resulta no intervalo [3,2\% - 3,8\%] ao ano efetiva acima do IGP para a RRCGA. Este saldo (p) gera um acréscimo no resultado corporativo no intervalo $[2,7 \%-3,2 \%]$ ao ano. Ambos indicadores, RRCGA e ARC, estão abaixo dos parâmetros de referência entendidos como satisfatórios para o decisor, entretanto, a desmobilização do imóvel 3 traz resultados mais próximos a estes parâmetros. 
Para as unidades fabris da empresa e o centro de pesquisa clínicas (imóveis 2, 5 e 6), o saldo (p) gerado pela desmobilização em conjunto destes imóveis estaria no intervalo [ 2.294 - 2.609] R $\$$ mil da base por ano. Este saldo resulta na RRCGA no intervalo $[3,6 \%-4,1 \%]$ ao ano efetiva acima do IGP.

É possível notar que as oportunidades de ganho são muito similares na desmobilização em conjunto dos imóveis 1 e 3, em relação à desmobilização em conjunto dos imóveis 2,5 e 6 . Isto demonstra para a empresa que a desmobilização dos imóveis 1 e 3 é mais adequada, considerando os indicadores encontrados e as [alternativa] indicadas pelo [MAOI], que para ambos (1 e 3) foi as [alternativas] de não imobilização (BTS e LLP). Dessa forma, gera-se uma melhora nos resultados corporativos, e garante-se o alinhamento do portfolio de real estate com as necessidades operacionais e estratégias da empresa, as quais estão refletidas na priorização dos critérios feita pelo decisor.

Na mesma Tabela 79 é possível verificar as oportunidades de ganho e acréscimo do resultado corporativo da empresa para os cenários estressados, com perturbação sem compensação no ROE da empresa. É possível observar, pela análise de risco na desmobilização dos ativos, que os indicadores são significativamente sensíveis, para a mesma queda de desempenho da empresa em gerar ROE (queda de até 20\%). Isto ocorre pelo fato do CCGA em cada imóvel ser o mesmo, no entanto, para um CGA menor a ser investido no negócio principal da empresa, em função dos descontos dos impostos devidos com os lucros contabilizados nas vendas dos ativos.

As oportunidades de ganho com a desmobilização dos ativos da empresa do caso são pouco atrativas, com base nos parâmetros de referência estipulados pelo decisor. Cada caso em particular e para cada empresa esta análise conferirá resultados distintos. Neste caso, promover o SLB para os imóveis da empresa é pouco vantajoso visto o baixo valor de registro dos imóveis em relação aos seus valores de mercado.

Cabe ressaltar que não é foco desta tese propor mecanismos para minimizar os impostos devidos com a venda dos ativos, mas sim identificar a partir das práticas prevalentes e legislações vigentes quais são os resultados dos indicadores com a contabilização dos impostos. Nada impede do planejador usuário do [MAOI] valer-se de mecanismos lícitos e inovadores para cálculo dos indicadores do [MAOI], de modo a contabilizar estes impostos de uma maneira menos impactante aos fluxos dos indicadores do [MAOI]. 


\begin{tabular}{|c|c|c|c|c|c|c|c|c|c|c|c|c|c|}
\hline \multicolumn{14}{|c|}{ Análise da Desmobilização (SLB) a partir das características do imóvel e situação atual } \\
\hline \multirow{2}{*}{\multicolumn{2}{|c|}{ Indicadores }} & \multicolumn{6}{|c|}{ SLB (Cenário Referencial) } & \multicolumn{6}{|c|}{ SLB (Cenários Estressados'1) } \\
\hline & & \multicolumn{2}{|c|}{$\begin{array}{c}\text { Saldo }(p) \\
R \$ \text { mil da base }\end{array}$} & \multicolumn{2}{|c|}{$\begin{array}{c}\text { RRCGA } \\
\text { ( } \% \text { ao ano } \\
\text { efetiva acima } \\
\text { do IGP) }\end{array}$} & \multicolumn{2}{|c|}{$\begin{array}{c}\text { ARC } \\
(\% \text { ao ano })\end{array}$} & \multicolumn{2}{|c|}{$\begin{array}{c}\text { Saldo }(p) \\
\text { R\$ mil da base }\end{array}$} & \multicolumn{2}{|c|}{$\begin{array}{c}\text { RRCGA } \\
\text { ( } \% \text { ao ano } \\
\text { efetiva acima } \\
\text { do IGP) }\end{array}$} & \multicolumn{2}{|c|}{$\begin{array}{c}\text { ARC } \\
\text { (\% ao ano) }\end{array}$} \\
\hline \multirow{3}{*}{ 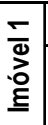 } & Parâmetros ${ }^{2}$ & \multicolumn{2}{|c|}{ (indicador auxiliar) } & \multicolumn{2}{|c|}{$>8 \%$ ao ano } & \multicolumn{2}{|c|}{$>4 \%$ ao ano } & \multicolumn{2}{|c|}{ (indicador auxiliar) } & \multicolumn{2}{|c|}{$>8 \%$ ao ano } & \multicolumn{2}{|c|}{$>4 \%$ ao ano } \\
\hline & \multirow{2}{*}{ Fronteiras $^{3}$} & Inferior & Superior & Inferior & Superior & Inferior & Superior & Inferior & Superior & Inferior & Superior & Inferior & Superior \\
\hline & & 951 & 1.158 & $3,5 \%$ & $4,3 \%$ & $0,9 \%$ & $1,0 \%$ & 114 & 566 & $0,4 \%$ & $2,1 \%$ & $0,1 \%$ & $0,5 \%$ \\
\hline \multirow{3}{*}{ 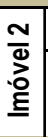 } & Parâmetros ${ }^{2}$ & \multicolumn{2}{|c|}{ (indicador auxiliar) } & \multicolumn{2}{|c|}{$>8 \%$ ao ano } & \multicolumn{2}{|c|}{$>4 \%$ ao ano } & \multicolumn{2}{|c|}{ (indicador auxiliar) } & \multicolumn{2}{|c|}{$>8 \%$ ao ano } & \multicolumn{2}{|c|}{$>4 \%$ ao ano } \\
\hline & \multirow{2}{*}{ Fronteiras $^{3}$} & Inferior & Superior & Inferior & Superior & Inferior & Superior & Inferior & Superior & Inferior & Superior & Inferior & Superior \\
\hline & & 1.603 & 1.826 & $5,7 \%$ & $6,5 \%$ & $1,5 \%$ & $1,7 \%$ & 742 & 1.198 & $2,6 \%$ & $4,2 \%$ & $0,7 \%$ & $1,1 \%$ \\
\hline \multirow{3}{*}{ 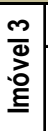 } & Parâmetros ${ }^{2}$ & \multicolumn{2}{|c|}{ (indicador auxiliar) } & \multicolumn{2}{|c|}{$>8 \%$ ao ano } & \multicolumn{2}{|c|}{$>4 \%$ ao ano } & (indicado & or auxiliar) & $>8 \% a$ & 10 & $>4 \% a$ & 0 \\
\hline & Fronteiras ${ }^{3}$ & Inferior & Superior & Inferior & Superior & Inferior & Superior & Inferior & Superior & \begin{tabular}{|l|} 
Inferior \\
\end{tabular} & Superior & \begin{tabular}{|l|} 
Inferior \\
\end{tabular} & Superior \\
\hline & & 2.029 & 2.340 & $6,0 \%$ & $7,0 \%$ & $1,8 \%$ & $2,1 \%$ & 981 & 1.605 & $2,9 \%$ & $4,7 \%$ & $0,9 \%$ & $1,5 \%$ \\
\hline \pm & Parâmetros ${ }^{2}$ & (indicado & Ir auxiliar) & $>12 \%$ & ao ano & $>8 \%$ & ao ano & (indicado & or auxiliar) & $>12 \%$ & ao ano & $>8 \% a$ & ao ano \\
\hline .0 & Fronteiras ${ }^{3}$ & Inferior & Superior & Inferior & Superior & Inferior & Superior & Inferior & Superior & Inferior & Superior & Inferior & Superior \\
\hline & & 34.341 & 35.920 & $13,0 \%$ & $13,6 \%$ & $31,1 \%$ & $32,6 \%$ & 25.794 & 30.163 & $9,6 \%$ & $11,3 \%$ & $23,4 \%$ & $27,4 \%$ \\
\hline$\underline{\pi}$ & Parâmetros ${ }^{2}$ & (indicado & ir auxiliar) & $>8 \%$ & ao ano & $>4 \%$ & ao ano & (indicado & or auxiliar) & $>8 \% a$ & ao ano & $>4 \% a$ & do ano \\
\hline . & Fronteiras ${ }^{3}$ & Inferior & Superior & Inferior & Superior & Inferior & Superior & Inferior & Superior & \begin{tabular}{|l|} 
Inferior \\
\end{tabular} & Superior & \begin{tabular}{|l|} 
Inferior \\
\end{tabular} & Superior \\
\hline & & 454 & 495 & $5,8 \%$ & $6,4 \%$ & $0,4 \%$ & $0,4 \%$ & 215 & 330 & $2,7 \%$ & $4,2 \%$ & $0,2 \%$ & $0,3 \%$ \\
\hline 0 & Parâmetros ${ }^{2}$ & (indicado & \begin{tabular}{l|l}
$r$ auxiliar) \\
\end{tabular} & $>8 \%$ & ao ano & $>4 \%$ & ao ano & (indicado & or auxiliar) & $>8 \% a$ & ao ano & $>4 \% \mathrm{a}$ & ao ano \\
\hline 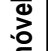 & Fronteiras $^{3}$ & Inferior & Superior & \begin{tabular}{|l|} 
Inferior \\
\end{tabular} & Superior & Inferior & Superior & \begin{tabular}{|l|} 
Inferior \\
\end{tabular} & Superior & Inferior & Superior & Inferior & Superior \\
\hline & & 237 & 287 & $5,2 \%$ & $6,4 \%$ & $0,2 \%$ & $0,3 \%$ & 104 & 182 & $2,3 \%$ & $4,0 \%$ & $0,1 \%$ & $0,2 \%$ \\
\hline & & & & & & & & & & & & & \\
\hline & 2 - Parâme & & & 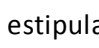 & & Ingin & & & & & & & \\
\hline & & & & & & & & & & & & & \\
\hline
\end{tabular}

Tabela 79 - Indicadores relacionados ao [Critério J] (levantar capital de giro para investir em oportunidades do negócio principal) para cada imóvel da Empresa do Caso - Análise da Desmobilização (SLB)

A Tabela 80 apresenta os indicadores relacionados ao [Critério H] para cada imóvel em cada uma das [alternativas]. Pela tabela é possível verificar que a [alternativa] - SP causa maior impacto no índice de liquidez (ILC), uma vez que as disponibilidades são comprometidas com as parcelas para aquisição dos imóveis. A média do impacto neste índice está registrada em [-7,93\%] em relação ao ILC antes da contabilização dos ativos, para o conjunto dos imóveis 1, 2 e 3 que apresentam valores próximos de transação. Ainda assim, em todos os imóveis a imobilização não comprometeria o ILC acima do parâmetro de referência estipulado pelo decisor (mínimo de 1,0).

O imóvel 4 é o que causa maior impacto para o ILC, mesmo com base em um melhor índice de liquidez antes da contabilização do ativo. O impacto do imóvel 4 na [alternativa] - SP já é 
de [-28,12\%] em relação ao ILC antes da contabilização deste ativo, que resulta no ILC igual a 1,01, ou seja, muito próximo do parâmetro mínimo de referência do decisor ${ }^{156}$.

Os imóveis 5 e 6 causam pouco impacto para o ILC, mesma para a [alternativa] - SP, visto o baixo valor de transação dos imóveis em relação ao ativo circulante da empresa.

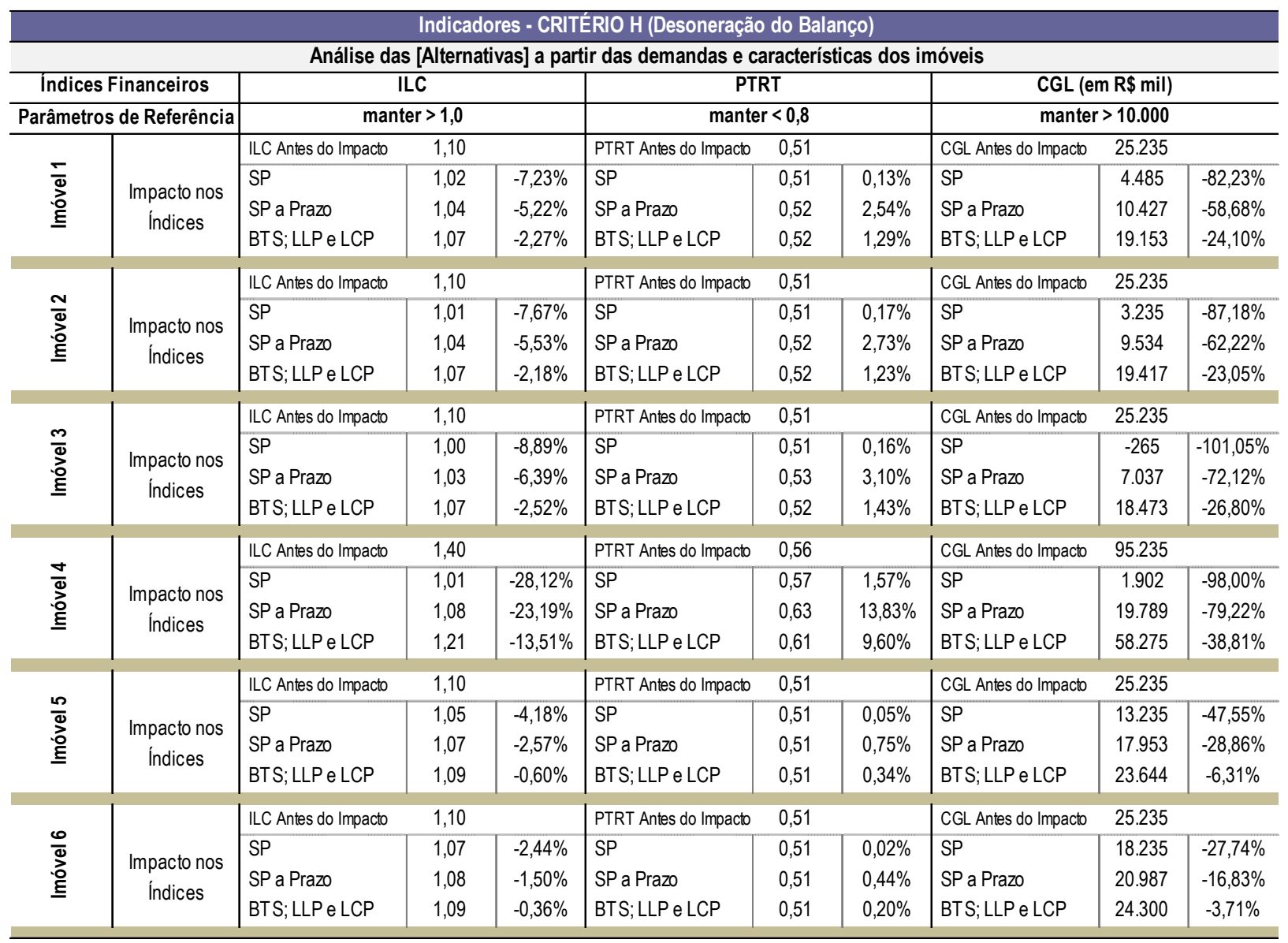

Tabela 80 - Indicadores relacionados ao [Critério H] (desoneração do balanço) para cada imóvel da Empresa do Caso

A imobilização por meio de financiamento (SP a Prazo) causa menor impacto em relação à [alternativa] - SP, porém ainda bem acima do impacto causado pelas [alternativas] de não imobilização, as quais registram uma média do impacto em ILC para o conjunto dos imóveis

${ }^{156} \mathrm{O}$ impacto do imóvel 4 nas [alternativas] de imobilização seria ainda maior se não fosse considerado o pagamento do imóvel em 36 parcelas. Sendo assim, a empresa utiliza o circulante de três exercícios para pagamento do ativo no valor de transação equivalente a $280.000 \mathrm{R} \$$ mil da base. Na [alternativa] - SP a Prazo as parcelas pagas durante 36 meses somam $168.000 \mathrm{R} \$$ mil da base (parcela não financiada pelo BNDES). Estas premissas podem ser encontradas nos balanços de cada imóvel para cada [alternativa] no Apêndice B deste texto. 
1, 2 e 3 de apenas [-2,32\%] em relação ao ILC antes da contabilização desses imóveis.

No que tange ao índice de endividamento PTRT, para nenhum dos imóveis em nenhuma das [alternativas] o comprometimento do índice está acima do parâmetro de referência do decisor (máximo de 0,8). O imóvel 4 na [alternativa] - SP a Prazo causa o maior impacto neste índice, uma vez que o valor da dívida do financiamento do imóvel (112.000 R\$ mil da base), é contabilizado no passivo, o que resulta em um PTRT de 0,63. A [alternativa] - SP é a que causa menor impacto, visto que não se gera passivo, somente se reduz do patrimônio líquido a depreciação periódica em cada exercício.

Nas [alternativas] de não imobilização a média do impacto para o conjunto dos imóveis 1,2 e 3 no PTRT é de apenas [1,32\%] de acréscimo em relação ao PTRT encontrado antes da contabilização dos ativos no balanço da empresa. Isto pelo fato de serem contabilizados apenas os aluguéis de cada exercício no passivo circulante.

Em relação ao CGL, que indica a folga financeira da empresa, para os imóveis 1, 2, 3 e 4 a [alternativa] - SP compromete o índice acima do parâmetro de referência estipulado pelo decisor (mínimo de $10.000 \mathrm{R}$ \$ mil). No entanto, na opção pela imobilização a prazo (SP a Prazo) o comprometimento do CGL está acima do desejado apenas para os imóveis 2 e 3 . As [alternativas] de não imobilização são as que causam menor impacto, já que o ativo circulante é mantido e o passivo circulante é acrescido apenas do valor de locação pago em cada exercício.

Na Tabela 81 verifica-se o impacto dos índices: ILC, CGL, e PTRT com a desmobilização dos ativos. O melhor ativo para desmobilizar, também sob a ótica do [Critério H], é o imóvel 3, pois resulta no melhor acréscimo para ILC e CGL. O PTRT é pouco impactado, visto a contabilização apenas dos aluguéis no passivo circulante, que passa a ocorrer com a desmobilização (SLB) do imóvel.

O imóvel 4 proporciona ainda melhores resultados, porém a desmobilização deste ativo só é possível a partir de 2012, quando a empresa concluir a amortização do financiamento do imóvel junto ao BNDES. 


\begin{tabular}{|c|c|c|c|c|c|c|c|c|c|c|}
\hline \multicolumn{11}{|c|}{ Indicadores - CRITÉRIO H (Desoneração do Balanço) - SLB } \\
\hline \multicolumn{11}{|c|}{ Análise da Desmobilização (SLB) a partir das características do imóvel e situação atual } \\
\hline \multicolumn{2}{|c|}{ Índices Financeiros } & \multicolumn{3}{|c|}{$\mathrm{ILC}=1,10$} & \multicolumn{3}{|c|}{ PTRT $=0,51$} & \multicolumn{3}{|c|}{ CGL $(\mathrm{em} \mathrm{R} \$ \mathrm{mil})=25.235$} \\
\hline \multirow{2}{*}{ Imóvel 1} & Impacto nos & SP (continuar) & 1,10 & $0,00 \%$ & SP (continuar) & 0,51 & $0,00 \%$ & SP (continuar) & 25.235 & $0,00 \%$ \\
\hline & Índices & SLB & 1,17 & $6,30 \%$ & SLB & 0,51 & $-0,18 \%$ & SLB & 46.627 & $84,77 \%$ \\
\hline \multirow{2}{*}{ Imóvel 2} & Impacto nos & SP (continuar) & 1,10 & $0,00 \%$ & SP (continuar) & 0,51 & $0,00 \%$ & SP (continuar) & 25.235 & $0,00 \%$ \\
\hline & Índices & SLB & 1,17 & $6,86 \%$ & SLB & 0,51 & $-0,33 \%$ & SLB & 48.478 & $92,11 \%$ \\
\hline \multirow{2}{*}{ Imóvel 3} & Impacto nos & SP (continuar) & 1,10 & $0,00 \%$ & SP (continuar) & 0,51 & $0,16 \%$ & SP (continuar) & 25.235 & $0,00 \%$ \\
\hline & Índices & SLB & 1,19 & $8,17 \%$ & SLB & 0,51 & $-0,29 \%$ & SLB & 53.005 & $110,05 \%$ \\
\hline \multirow{2}{*}{ Imóvel 4} & Impacto nos & SP (continuar) & 1,10 & $0,00 \%$ & SP (continuar) & 0,52 & $1,17 \%$ & SP (continuar) & 25.235 & $0,00 \%$ \\
\hline & Índices & SLB & 1,90 & $73,15 \%$ & SLB & 0,55 & $7,83 \%$ & SLB & 268.275 & $963,11 \%$ \\
\hline \multirow{2}{*}{ Imóvel 5} & Impacto nos & SP (continuar) & 1,10 & $0,00 \%$ & SP (continuar) & 0,51 & $0,00 \%$ & SP (continuar) & 25.235 & $0,00 \%$ \\
\hline & Índices & SLB & 1,12 & $1,99 \%$ & SLB & 0,51 & $-0,09 \%$ & SLB & 31.615 & $25,28 \%$ \\
\hline \multirow{2}{*}{ Imóvel 6} & Impacto nos & SP (continuar) & 1,10 & $0,00 \%$ & SP (continuar) & 0,51 & $0,00 \%$ & SP (continuar) & 25.235 & $0,00 \%$ \\
\hline & Índices & SLB & 1,11 & $1,16 \%$ & SLB & 0,51 & $-0,05 \%$ & SLB & 28.920 & $14,60 \%$ \\
\hline
\end{tabular}

Tabela 81 - Indicadores relacionados ao [Critério H] (desoneração do balanço) para cada imóvel da Empresa do Caso - Análise da Desmobilização (SLB)

A Tabela 82 apresenta os indicadores relacionados ao [Critério I] para cada imóvel da empresa em cada uma das [alternativas]. Na mesma tabela é possível observar a diferença entre as economias tributárias das [alternativas] de não imobilização em relação às economias tributárias das opções de imobilização (SP e SP a Prazo).

Exceto para os imóveis 5 e 6, as [alternativas] de não imobilização geram economias tributárias superiores aos parâmetros mínimos de referência estipulados pelo decisor. A soma das economias tributárias para o conjunto dos imóveis nas [alternativas] de não imobilização é de 120.622 R\$ mil da base, conforme as médias das amostras. Deste total a participação do imóvel 4 é de $63,6 \%$.

Para os imóveis 1 e 3, os quais as [alternativas] de não imobilização (BTS e LLP) são as indicadas pelo [MAOI], a economia tributária do conjunto (imóveis 1 e 3) é de 26.629 R\$ mil da base de acordo com as médias das amostras. Para o conjunto dos demais imóveis (2, 5 e 6 , exceto o imóvel 4), a economia tributária do conjunto é de apenas 17.293 R \$ mil da base para as [alternativas] de não imobilização. Isto confirma, também com base nos indicadores deste critério, a maior vantagem em não imobilizar nos imóveis 1 e 3, em relação ao conjunto dos imóveis 2, 5 e 6, que conforme aplicação do [MAOI], indica a [alternativa] - SP a Prazo como a melhor opção para atender aos critérios priorizados pelo decisor. 


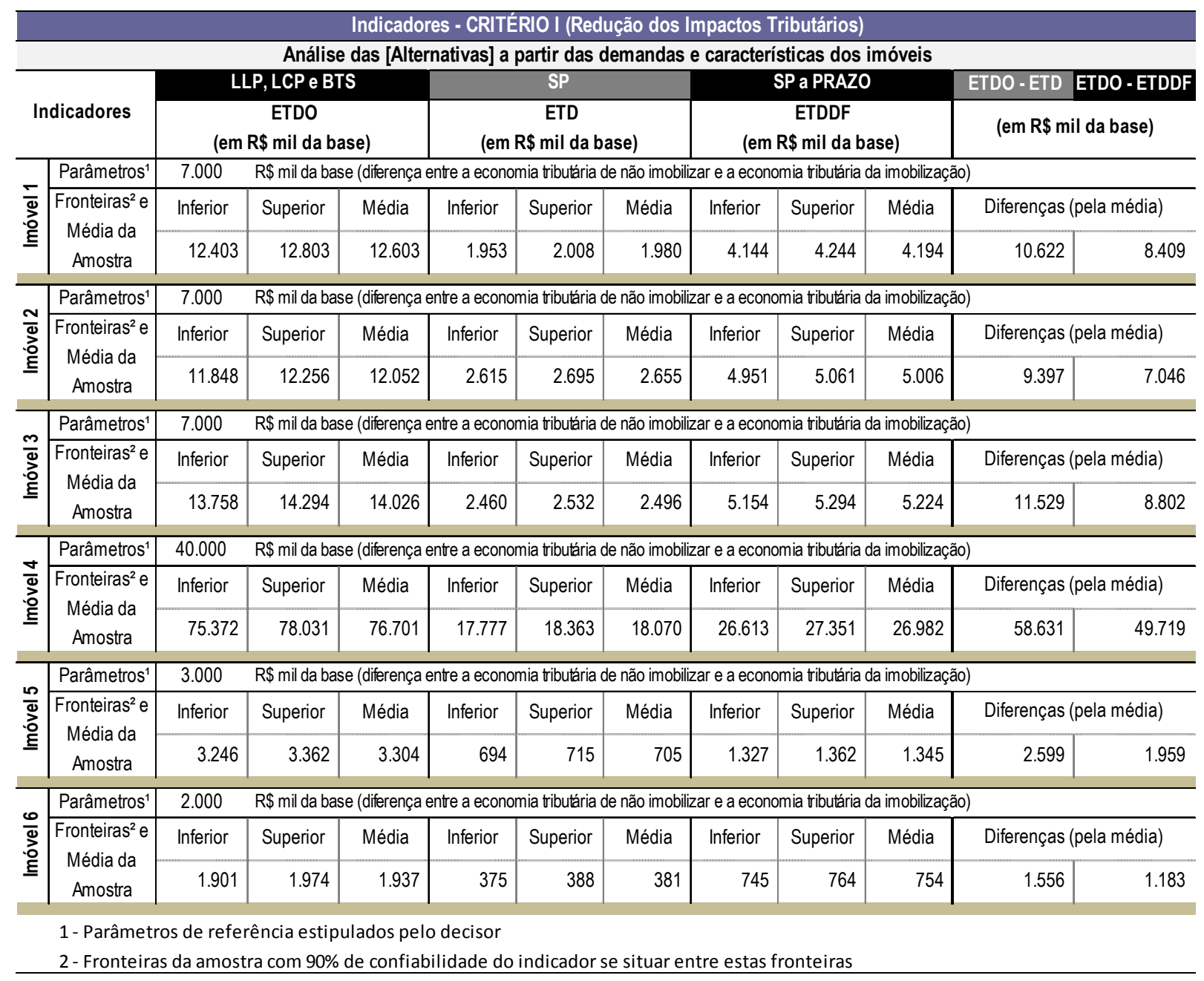

Tabela 82 - Indicadores relacionados ao [Critério I] (redução dos impactos tributários) para cada imóvel da Empresa do Caso

Na Tabela 83 verifica-se os indicadores relacionados ao [Critério I] para a desmobilização dos ativos ([alternativa] - SLB). Para todos os imóveis da empresa do caso, exceto para o imóvel 4, que esta em fase final de implantação, os indicadores ETEDO da [alternativa] - SLB são negativos, visto que os impostos devidos no início do horizonte de análise, advindo do lucro contabilizado na venda dos ativos, é maior que o valor do fluxo descontado ao wacc gerado pela economias tributárias da despesa operacional com a locação durante todo o horizonte de análise.

No entanto, estes valores negativos para as economias tributárias não são expressivos, uma vez que a soma destes valores é de (9.655) R $\$$ mil da base, que corresponde ao resultado líquido da empresa de apenas um mês. Também é possível gerar o saldo anual (p) com a desmobilização do conjunto dos ativos da empresa (exceto o imóvel 4), no intervalo [5.273 - 6.107 ] R \$ mil da base por ano, sendo necessário, portanto, apenas um ano e meio do saldo (p) para cobrir este valor negativo. 
Indicadores - CRITÉRIO I (Redução dos Impactos Tributários) - SLB

\begin{tabular}{|c|c|c|c|c|c|c|c|c|}
\hline \multicolumn{9}{|c|}{ Análise da Desmobilização (SLB) a partir das características do imóvel e situação atual } \\
\hline & & \multicolumn{3}{|c|}{ SLB } & \multicolumn{3}{|c|}{ SP (Continuar) } & ETEDO - ETD \\
\hline \multicolumn{2}{|c|}{ Indicadores } & \multicolumn{3}{|c|}{$\begin{array}{c}\text { ETEDO } \\
\text { R \$ mil da base) }\end{array}$} & \multicolumn{3}{|c|}{$\begin{array}{c}\text { ETD } \\
\text { (em R\$ mil da base) }\end{array}$} & (em $R \$$ mil da base) \\
\hline \multirow{3}{*}{ 㝘 } & \multirow{3}{*}{\begin{tabular}{|c} 
Parâmetros $^{1}$ \\
Fronteiras $^{2} \mathrm{e}$ \\
Média da \\
Amostra
\end{tabular}} & 7.000 R\$ mil da base (diferença entre a economia tributária de não imobilizar e a economia da imobilização) & \multicolumn{6}{|c|}{$\mathrm{R} \$$ mil da base (diferença entre a economia tributária de não imobilizar e a economia da imobilização) } \\
\hline & & Inferior & Superior & Média & Inferior & Superior & Média & Diferença (pela média) \\
\hline & & (1.976) & $(1.545)$ & $(1.761)$ & - & - & - & $(1.761)$ \\
\hline \multirow{3}{*}{ 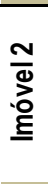 } & Parâmetros ${ }^{1}$ & 7.000 & \multicolumn{6}{|c|}{$\mathrm{R} \$$ mil da base (diferença entre a economia tributária de não imobilizar e a economia da imobilização) } \\
\hline & \multirow{2}{*}{\begin{tabular}{|c|} 
Fronteiras $^{2} \mathrm{e}$ \\
Média da \\
Amostra
\end{tabular}} & Inferior & Superior & Média & Inferior & Superior & Média & Diferença (pela média) \\
\hline & & (3.402) & $(3.007)$ & $(3.204)$ & - & - & - & (3.204) \\
\hline \multirow{3}{*}{ 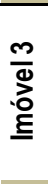 } & Parâmetros ${ }^{1}$ & 7.000 & \multicolumn{6}{|c|}{$\mathrm{R} \$$ mil da base (diferença entre a economia tributária de não imobilizar e a economia da imobilização) } \\
\hline & \multirow{2}{*}{$\begin{array}{c}\text { Fronteiras }{ }^{2} \mathrm{e} \\
\text { Média da } \\
\text { Amostra }\end{array}$} & Inferior & Superior & Média & Inferior & Superior & Média & Diferença (pela média) \\
\hline & & (3.132) & (2.498) & $(2.815)$ & 1.850 & 1.909 & 1.880 & (4.695) \\
\hline \multirow{3}{*}{ 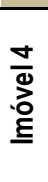 } & Parâmetros $^{1}$ & 40.000 & \multicolumn{6}{|c|}{$\mathrm{R} \$$ mil da base (diferença entre a economia tributária de não imobilizar e a economia da imobilização) } \\
\hline & \multirow{2}{*}{$\begin{array}{c}\text { Fronteiras }{ }^{2} \mathrm{e} \\
\text { Média da } \\
\text { Amostra }\end{array}$} & Inferior & Superior & Média & Inferior & Superior & Média & Diferença (pela média) \\
\hline & & 75.228 & 77.954 & 76.591 & 17.794 & 18.378 & 18.086 & 58.505 \\
\hline \multirow{3}{*}{ مू } & Parâmetros ${ }^{1}$ & 3.000 & \multicolumn{6}{|c|}{$\mathrm{R} \$$ mil da base (diferença entre a economia tributária de não imobilizar e a economia da imobilização) } \\
\hline & \multirow{2}{*}{$\begin{array}{c}\text { Fronteiras }^{2} \mathrm{e} \\
\text { Média da } \\
\text { Amostra }\end{array}$} & Inferior & Superior & Média & Inferior & Superior & Média & Diferença (pela média) \\
\hline & & (1.428) & $(1.340)$ & $(1.384)$ & - & - & - & (1.384) \\
\hline \multirow{3}{*}{ 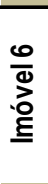 } & Parâmetros ${ }^{1}$ & 2.000 & \multicolumn{6}{|c|}{$\mathrm{R} \$$ mil da base (diferença entre a economia tributária de não imobilizar e a economia da imobilização) } \\
\hline & \multirow{2}{*}{$\begin{array}{c}\text { Fronteiras }^{2} \mathrm{e} \\
\text { Média da } \\
\text { Amostra }\end{array}$} & Inferior & Superior & Média & Inferior & Superior & Média & Diferença (pela média) \\
\hline & & (524) & $(457)$ & (490) & - & - & - & (490) \\
\hline & & & & & & & & \\
\hline & & & & & & & & \\
\hline
\end{tabular}

Tabela 83 - Indicadores relacionados ao [Critério I] (redução dos impactos tributários) para cada imóvel da Empresa do Caso - Análise da Desmobilização (SLB)

Até agora foram apresentados os resultados parciais da aplicação do [MAOI] no portfolio da empresa do caso. Os quadros que seguem apresentam os resultados finais, com os pesos relativos das [alternativas] em cada critério, os pesos relativos dos critérios a partir da priorização feita pelo decisor, e por fim o resultado do AHP com a hierarquização das [alternativas] para cada imóvel do portfolio.

O Quadro 26 apresenta os pesos relativos das [alternativas], que configuram as matrizes do Nível 3 do AHP. No mesmo quadro verifica-se ao final dos pesos de cada critério, para cada imóvel, as [alternativas] que mais comprometem e as que melhor atendem aos critérios de decisão do [MAOI]. 


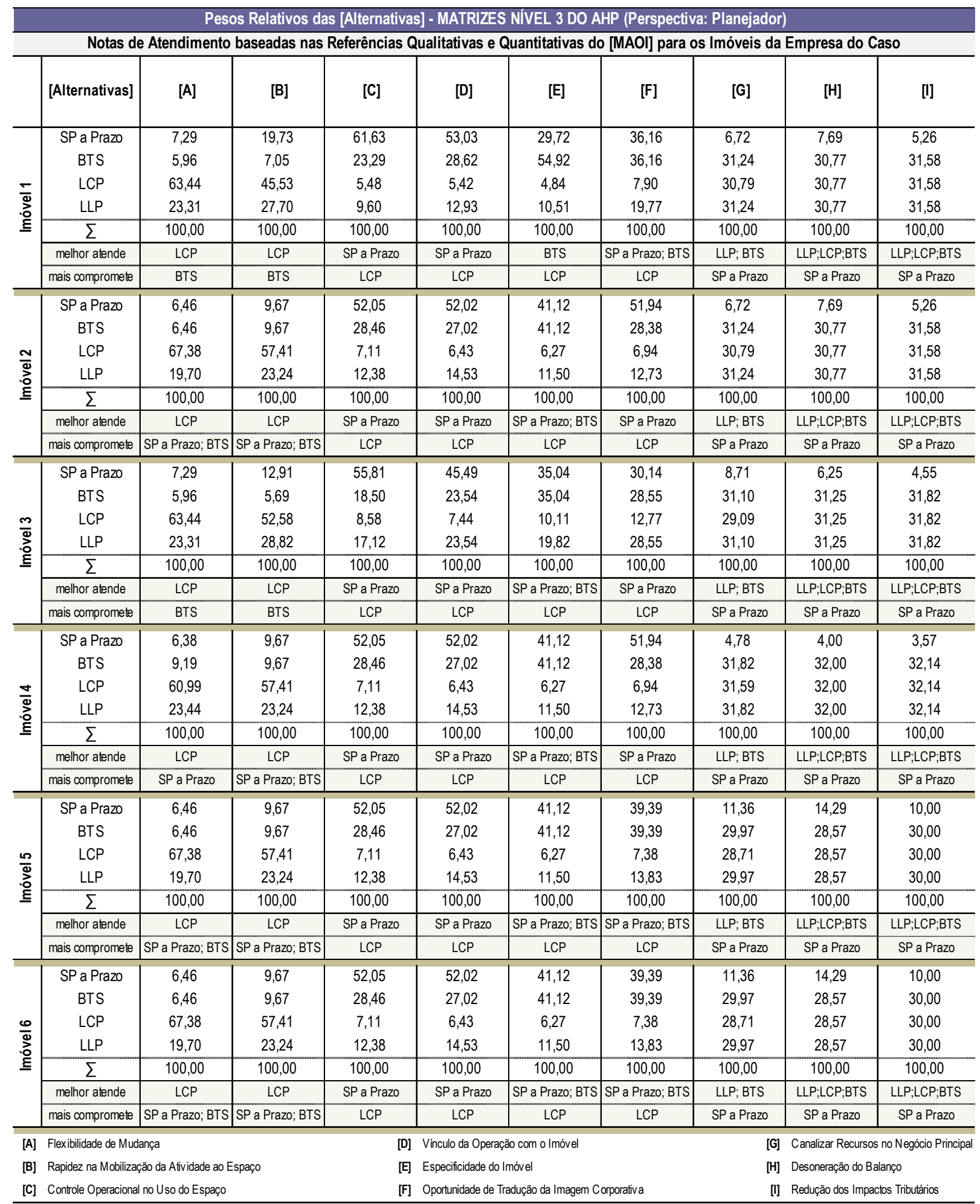

Quadro 26 - Pesos relativos das [alternativas] por critério de decisão do [MAOI] em cada imóvel da Empresa do Caso (Matrizes do Nível 3 do AHP)

Conforme se observa no Quadro 26, as [alternativas] apresentam pesos relativos em cada critério mais próximos para imóveis de mesma tipologia.

Para as unidades fabris os pesos relativos das [alternativas] são similares, exceto para o 
imóvel 2 e 4 no [Critério F], os quais apresentam maior peso relativo da [alternativa] de imobilização em relação às [alternativas] de não imobilização. Segundo contextualização da situação, identificada junto ao decisor, é importante para a tradução da imagem corporativa da empresa ser proprietária destas unidades para fazer frente ao projeto de internacionalização e para fabricação de produtos de outras marcas.

Isto comprova a possibilidade de aplicar o [MAOI] por tipo de espaço corporativo e não por imóvel como apresentado para o caso em análise. Para empresas com maior portfolio de real estate em relação ao portfolio da empresa do caso, a aplicação do [MAOI] por tipo de espaço corporativo é adequada, mesmo que as referências quantitativas devam ser calculadas isoladamente, uma vez que dependem das características e demandas de cada imóvel.

Para atribuição das notas de atendimento das [alternativas] nas referências qualitativas, o entendimento do contexto de cada situação faz parte da análise, conforme rotina detalhada apresentada para os imóveis 1, 3 e 4. As diretrizes para entendimento do contexto e atribuição das notas das [alternativas] para os critérios qualitativos, são baseadas no conteúdo do Capítulo 5, compilado na Tabela 7.

O Quadro 27 apresenta os pesos relativos dos critérios, que configuram a matriz do Nível 2 do AHP para cada imóvel. Estes pesos indicam a priorização dos critérios feita pelo decisor, para cada imóvel, de acordo com as referências quantitativas e qualitativas do [MAOI], as necessidades operacionais, estratégias de investimento e políticas da empresa.

Pelo Quadro 27 é possível observar que a priorização dos critérios do [MAOI] também é similar por tipo de espaço corporativo. Os imóveis considerados como mais estratégicos apresentam maior peso relativo dado aos critérios relacionados ao uso dos espaços corporativos, como se observa para as unidades fabris da empresa. Enquanto que para o imóvel 1 (sede administrativa) e o imóvel 3 (laboratório e armazenagem), que são menos estratégicos à operação realizada neles, os critérios relacionados às oportunidades de ganho, redução de impactos tributários e desoneração do balanço, recebem melhores pontuações nas atribuições de notas de importância relativa entre os critérios. 


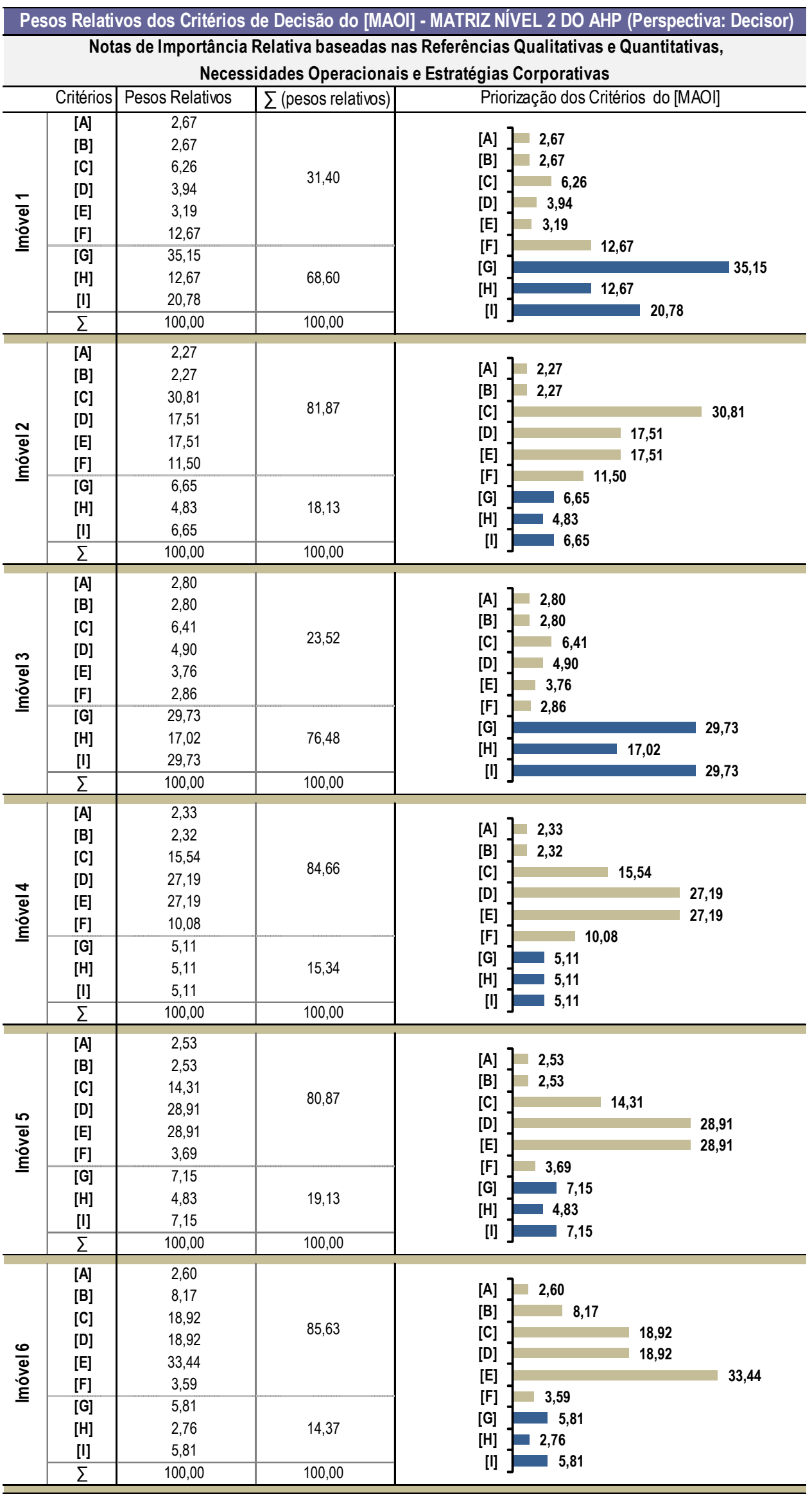

Quadro 27 - Pesos relativos dos critérios de decisão para cada imóvel da Empresa do Caso (Matriz do Nível 2 do AHP) 
Para cada imóvel é feita a multiplicação entre as matrizes dos pesos relativos das [alternativas] com a matriz dos pesos relativos dos critérios. Esta multiplicação entre as matrizes gera o resultado do AHP para cada imóvel da empresa do caso, conforme demonstrado no Quadro 28.

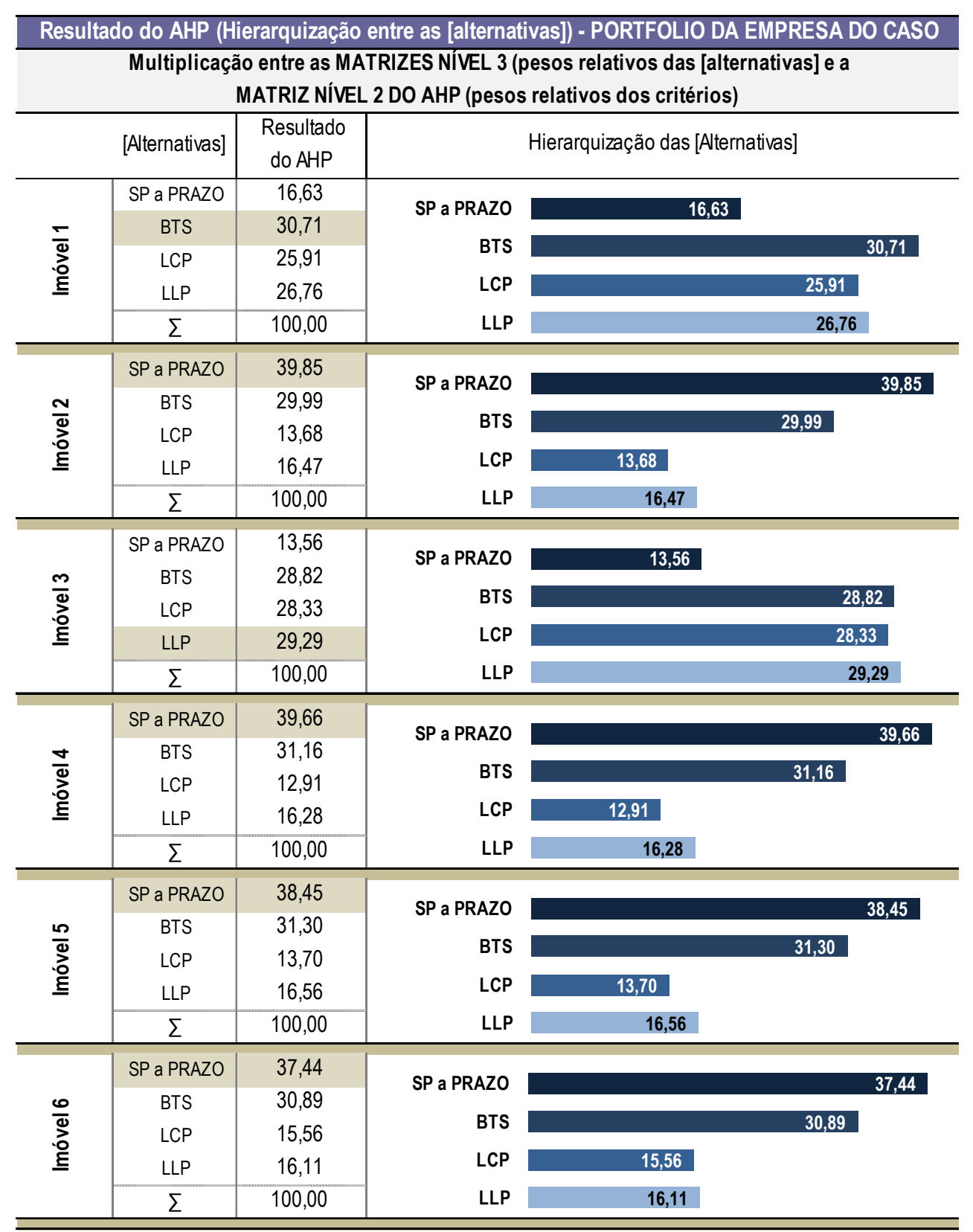

Quadro 28 - Hierarquização das [alternativas] para cada imóvel da Empresa do Caso (Resultado do AHP)

A [alternativa] de imobilização é a indicada pelo [MAOI] para todas as unidades fabris da empresa do caso, o que confirma o alinhamento entre a decisão informada pela aplicação do [MAOI] e a [alternativa] escolhida pela empresa.

Quanto ao imóvel 1 (sede administrativa), a [alternativa] - BTS é a indicada pelo [MAOI], 
conforme priorização dos critérios estipulada pelo decisor, se a decisão fosse feita hoje pela empresa para um espaço corporativo com as mesmas características e demandas. Ou seja, a opção indicada é não imobilizar diferentemente da opção escolhida pela empresa, que é proprietária do ativo. Sabe-se que esta decisão depende do contexto de cada situação, e no momento da decisão as referências qualitativas e quantitativas poderiam ser bem diferentes às apresentadas para o contexto atual. No entanto, a análise da desmobilização (SLB) do imóvel 1, que considera a situação atual do ativo no balanço, proporciona poucas vantagens para a empresa, conforme resultados apresentados para os indicadores. Isto sustenta a decisão da empresa, que é manter o imóvel no portfolio do grupo, adequando-o para atender as demandas futuras da companhia.

Em relação ao imóvel 3, a [alternativa] indicada pelo [MAOI] é a LLP também contrária à [alternativa] escolhida pela empresa. Contudo, a análise da desmobilização (SLB) deste ativo é mais vantajosa em relação ao imóvel 1, com indicadores mais próximos aos parâmetros de referência estipulados pelo decisor, principalmente para a RRCGA.

Outra recomendação quanto à intervenção no portfolio de real estate da empresa, seria a desmobilização do imóvel 4, visto as oportunidade de ganho, redução dos impactos tributários e melhora dos índices financeiros da empresa com a desmobilização deste ativo. Pelos indicadores do [MAOI] calculados para a [alternativa] - SLB do portfolio da empresa é possível verificar que quanto mais tempo se passa entre a contabilização do ativo no balanço e a sua venda, piores são os indicadores gerados pela desmobilização. Por isso, a intervenção recomendada é desmobilizar o imóvel 4, assim que o financiamento no BNDES for amortizado (em 2012) e a empresa estabilizar a ocupação da sua capacidade instalada, seja pela expansão do seu portfolio de produtos, como pela fabricação de produtos de outras marcas.

Como visto pelo Quadro 28 esta decisão deveria ser realinhada na empresa, a partir de nova aplicação do [MAOI] para o imóvel 4 na ocasião do interesse em avaliar a desmobilização, visto que a [alternativa] indicada pelo [MAOI] é a opção pela imobilização, que está em conformidade com a [alternativa] escolhida pela empresa. Cabe a cada decisor priorizar os critérios novamente, considerando a importância de se manter proprietária para o processo de internacionalização e fabricação de produtos de outras marcas, após estabilização do empreendimento, em comparação às oportunidades de ganho e demais vantagens proporcionadas pela não imobilização deste ativo no portfolio da empresa, conforme resultados apresentados. 


\section{CONSIDERAÇÕES FINAIS}

A crescente competição nos diferentes mercados, e por consequência, a necessidade de sustentar o crescimento por meio de constantes investimentos nas atividades fins, aumentam a demanda por recursos financeiros nas corporações. Além disso, para manter crescentes padrões de competitividade deve-se reavaliar a estrutura de capital internada nas suas bases instaladas, que em geral inclui, com significativa participação, o recurso real estate. Uma empresa pode apresentar diferente grau de rentabilidade e risco em relação a outra empresa de mesmo segmento de atuação, em função da sua composição de funding para a base instalada.

Ainda incipiente no caso brasileiro, apesar dos avanços nos últimos anos, o mercado de capitais cria oportunidades para as corporações investirem com maior produtividade. Isto porque, via mercado de capitais, é possível derivar recursos de poupança aplicados direta ou indiretamente (fundos) para a estruturação do funding das empresas, principalmente para os recursos com longo prazo de maturação, como o caso do real estate.

Por meio do levantamento de campo foi possível observar que muitas empresas estão com recursos imobilizados em real estate, como herança dos períodos das altas inflacionárias, instabilidade econômica, ausência de linhas de crédito e de outros instrumentos de captação de recursos para financiamentos de longo prazo.

Esses fatores configuram um cenário promissor para originar os negócios para os ambientes que segregam ativos desta natureza, como as empresas proprietárias de real estate e os fundos de investimento. Esses ambientes geram os instrumentos para derivar recursos de investidores poupadores na composição do funding das corporações brasileiras, como ocorre nas economias mais evoluídas. Por outro lado, para as corporações criam-se oportunidades de captação de recursos em condições mais compatíveis em relação aos custos financeiros e prazos de amortização para compor as equações de funding para suas bases instaladas, que acabam por refletir em melhores margens e preços mais competitivos.

No Brasil, esta percepção por parte das corporações ainda é embrionária. Não é comum observar nas corporações brasileiras a importância dada aos recursos financeiros que foram, e ainda são, internados em ativos imobilizados, como o real estate usado nas operações. Nesse sentido, o [MAOI] desenvolvido na tese pode ser uma importante ferramenta de apoio às diretrizes de governança corporativa para decisões em relação ao portfolio de real estate das 
corporações. Conforme o IBGC (Instituto Brasileiro de Governança Corporativa) ${ }^{157}$ : “ $a$ boa governança assegura aos sócios equidade, transparência, responsabilidade pelos resultados e obediência às leis do país". Sendo assim, a governança corporativa procura definir diretrizes e princípios que compreendem os diversos interesses dos agentes envolvidos com a corporação, de modo a respeitar as leis, regras corporativas, regulamentos internos, procedimentos gerenciais, que orientam o governo da companhia para promover a sua valorização pelo mercado e criar valor aos acionistas.

O [MAOI] desenvolvido na tese com base na sustentação legal, práticas contábeis, tributárias, conceitos de valuation e práticas prevalentes de mercado, é uma forma de orientar as decisões em relação ao portfolio de real estate de forma alinhada às regras, legislações e práticas brasileiras, e concomitantemente permitir o alinhamento do recurso real estate com as necessidades operacionais e estratégias da corporação a diante, sem deixar de considerar as oportunidades de ganho, redução dos impactos tributários e desoneração do balanço nas decisões. Esse alinhamento pode ser possível a partir da aplicação do [MAOI], uma vez que os critérios de decisão, os quais resultam nas referências qualitativas e quantitativas do [MAOI], são concebidos sob a ótica das corporações usuárias, que têm o real estate como recurso operacional e não como um ativo de investimento.

A partir das aplicações do [MAOI] para os diferentes imóveis apresentados no decorrer da tese é possível verificar que se pode concluir por diferentes estratégias do portfolio de real estate a depender de como o decisor prioriza os critérios qualitativos e quantitativos.

O [MAOI] também pode ser aplicado sob priorização dos critérios formulados por decisores de diferentes áreas da corporação, com intuito de garantir o alinhamento da decisão com os objetivos estratégicos. No estudo do caso, a priorização foi oferecida apenas por um dos decisores da companhia para efeito de explanação da aplicação do [MAOI]. No entanto, como diretriz da sua aplicação nas companhias é possível definir que a priorização dos critérios do [MAOI] necessita ser feita por decisores de diferentes áreas. Dessa forma, durante a aplicação do AHP para priorização dos critérios de decisão é possível buscar este alinhamento entre os principais decisores da companhia com base nas demandas e estratégias de médio e longo prazo.

$\mathrm{O}$ [MAOI] pode ser aplicado em empresas de diferentes segmentos de atuação, inclusive no

157 Disponível em www.ibgc.org.br. Acesso em julho de 2010. 
setor público. Cada situação é analisada isoladamente em função da sua contextualização e priorização dos critérios de decisão, assim, para um mesmo tipo de espaço corporativo é possível encontrar diferentes matrizes para as [alternativas] e para os critérios, e por consequência, diferentes resultados.

Durante o desenvolvimento da tese algumas legislações sofreram alterações, como a Lei do Inquilinato em 2009 (Lei 12.112/09) e as normas de contabilidade em 2007 e 2009 (Leis 11.638/07 e 11.941/09). Futuras alterações de normas e legislações podem alterar os cálculos de alguns indicadores do [MAOI] e a maneira de pontuar as notas de atendimento das [alternativas] no AHP, já que a atribuição de notas e cálculo dos indicadores dependem de aspectos legais e das práticas contábeis e tributárias. Isto não invalida o [MAOI], somente fazse necessário considerar nos cálculos e atribuição de notas do AHP as normas e leis vigentes, que impactam também nas relações comerciais entre corporações usuárias e investidores (práticas de mercado).

As alterações no contexto da realidade brasileira e nas práticas de mercado podem indicar a necessidade de submeter os critérios de decisão do [MAOI] à crítica, por meio de novo levantamento de campo, bem como incluir ou excluir [alternativas] em relação às decisões do portfolio de real estate das corporações de acordo com novos mecanismos que venham a surgir.

Para muitas empresas brasileiras a aplicação do [MAOI] pode facilitar o processo decisório, já que o método estrutura a decisão em relação ao recurso real estate sob a ótica das corporações usuárias, sendo este um dos principais veios da sua originalidade. Espera-se que a facilidade em decidir por meio da aplicação do [MAOI] e da qualidade da informação gerada, desperte o interesse por parte das corporações em reavaliar seus portfolios de real estate, como forma de gerar melhores resultados, ganhar vantagem competitiva, reduzir grau de riscos e ao mesmo tempo atender às demandas operacionais.

Por outro lado, com um maior número de corporações informadas sobre as melhores estratégias para os imóveis utilizados nas suas operações, mais negócios podem ser originados para investidores interessados em real estate corporativo, o que pode refletir no amadurecimento dos mercados de fundos de investimentos e outros mercados voltados a derivar recursos de investidores conservadores.

$\mathrm{O}$ [MAOI] desenvolvido nesta tese auxilia as decisões em relação ao real estate corporativo na esfera do gerenciamento de ativos (estratégias do portfolio). Sendo assim, um tema 
complementar à tese como sugestão para pesquisa futura seria o desenvolvimento de um método capaz de analisar o portfolio de real estate de maneira verticalizada nas corporações, ou seja, com base no gerenciamento de facilidades, passando pelo gerenciamento de propriedades, avaliar quais espaços poderiam ser otimizados, quais poderiam ser alienados, bem como quais unidades poderiam ser terceirizadas. Dessa forma, a aplicação do [MAOI] desenvolvido nesta tese seria feita para os espaços corporativos realmente necessários às operações das corporações, após a análise da otimização do portfolio de real estate.

Outro possível tema para pesquisa futura seria analisar a proposta de mecanismos mitigadores de riscos nas relações comerciais entre investidores e corporações usuárias, de maneira a aumentar a gama de empresas capazes de desmobilizar seus ativos ou recorrer a operações de BTS. As operações estruturadas, como as que utilizam da securitização dos recebíveis de contratos de SLB ou BTS para captação de recursos no mercado de capitais, requerem elevada classificação do rating da operação para que tenham acesso, no mercado de capitais, aos recursos de investidores conservadores, aos quais, em geral, se destinam os títulos. Sendo assim, a proposta de mecanismos mitigadores de riscos nestas transações poderia facilitar o enquadramento de muitas operações às exigências desses investidores. 


\section{REFERÊNCIAS}

AKIYAMA, Y. e MONETTI, E. Contrato de concessão do direito real de superfície e análise do seu valor. In: CONGRESSO BRASILEIRO DE CADASTRO TÉCNICO MULTIFINALITÁRIO. Anais. Florianópolis, 2006. p.1-9.

Aluguel Garantido por um lance. Jornal Valor Econômico. 10 set. 2002.

AMATO, Fernando B. Arbitragem de valor: uma rotina de análise para empreendimentos de base imobiliária. 2001. 134p. Dissertação (Mestrado) - Escola Politécnica da Universidade de São Paulo. São Paulo, 2001.

AVIS, M., GIBSON, V. e WATTS, J. Managing operational assets. Graduates to Industry, London, 1989.

BACEN - BANCO CENTRAL DO BRASIL. Apresenta dados sobre a evolução do crédito no Brasil. Disponível em: <http://www.bacen.gov.br/>. Acesso em: 18 nov. 2006.

BARROS, A. B. T. Perspectivas e limitações de uma transação de sale leaseback imobiliário e proposta de método de precificação. 2002. 140 p. Trabalho de Formatura do Curso de Graduação - Escola Politécnica da Universidade de São Paulo. São Paulo, 2006.

BLATT, A. Dicas para conceder crédito com menos risco. São Paulo: Casa da Qualidade, 1998. 104p.

Bolsa de Valores Mobiliários - BOVESPA. Apresenta informações financeiras padronizadas sobre empresas abertas, prospectos, publicações sobre o tema, negociações no mercado de capitais. Disponível em: < www.bovespa.com.br $>$ Acesso em: 10 jul. 2006.

BRAZ, S. A evolução do crédito no período 2000 - 2004. Análise Conjuntural, v. 27, n. 7-8, p. 13-14, jul./ago. 2005. Disponível em: $<$ http://www.ipardes.gov.br/pdf/bol ana_conjuntural/bol_27_4f.pdf $>$. Acesso em: 18 nov. 2006.

BROUNEN, D. e EICHHOLTZ, P. M. A. Corporate real estate ownership implications: international performance evidence. The Journal of Real Estate Finance and Economics, 2005. p. 429-445.

BRYAN, A. B. The state of sale-leaseback: What corporations should expect today. Journal of Corporate Real Estate, v. 6, n. 1, Sep., 2003. p. 15-23.

CAMINHA, Uinie. Securitização. São Paulo: Saraiva, 2005. 203p.

CAMINHA, Uinie. Securitização. 2. ed. São Paulo: Saraiva, 2007. 205p.

CARVALHO, L. N.; LEMES, S.; COSTA, F.M. Contabilidade Internacional: aplicação IFRS 2005. 1. ed. São Paulo: Atlas, 2006. 274p. 
CATELLI, A.; PARISI, C. e SANTOS, E. S. Gestão Econômica de Investimentos em Ativos Fixos. Revista Contabilidade e Finanças - USP. São Paulo, n. 31, p. 26-44. jan./abr. 2003.

CERQUEIRA, L. F. Dinâmica da Inflação no Brasil, 1960 - 2005. Faculdade de Economia, Universidade Federal Fluminense. Texto para discussão n. 200, 45p., set. 2006.Disponível em: $<$ http://www.uff.br/econ/download/tds/UFF_TD200.pdf $>$. Acesso em: 25 nov. 2006.

CONSELHO REGIONAL DE ECONOMIA DO DISTRITO FEDERAL. A crise econômica internacional e os impactos no brasil. Revista de Conjuntura, n. 36, ano VIII, out./dez., 2008. Disponível em: < www.corecondf.org.br/discovirtual/revdownload/corecon_ed36.pdf >. Acesso em: 17 jan. 2010.

CURRIE, D. e SCOTT, A. The place of commercial property in the UK economy. Centre for Economic Forecasting, London Business School, 1991.

CVM - COMISSÃO DE VALORES MOBILIÁRIOS. Apresenta dados sobre a evolução dos fundos de investimento imobiliário e quotas de recebíveis imobiliários, assim como os prospectos de distribuição pública desses instrumentos. Disponível em:

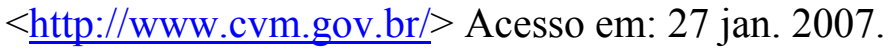

DAMODARAN, A. Avaliação de investimentos: ferramentas e técnicas para a determinação do valor de qualquer ativo. Rio de Janeiro: Qualitymark Editora, 1997. 630p.

Investment valuation: tools and techniques for determining the value of any asset. 2. ed. New York: John Wiley \& Sons, Inc., 2002. 992p.

Avaliação de empresas. 2. ed. São Paulo: Pearson Prentice Hall, 2007. 464p.

DE MAGALHÃES, C. S. Social agents, the provision of buildings and property booms: the case of São Paulo. International Journal of Urban and Regional Research, v. 23, n. 3. Joint Editors and Blackwell Publishers Ltd. 1999. p. 445-463.

DEPED - DEPARTAMENTO DE ESTUDOS E PESQUISAS. Juros e spread bancário no Brasil. Banco Central do Brasil. out. 1999. Disponível em: $<$ http://www.bcb.gov.br/ftp/jurosspread1.pdf>. Acesso em: 18 nov. 2006.

DEVANEY, S. e LIZIERI, C. Sale and Leaseback, asset outsourcing and capital market impacts. Journal of Corporate Real Estate, v. 6, n. 2, p 118-132, Jan., 2004.

DRS - Direito Real de Superfície. Estabelece normas de ordem pública e interesse social que regulam o uso da propriedade urbana. Disponível em $<\underline{\text { www.planalto.gov.br }}>$ Acesso em 12 dez. 2006.

EHRLICH, P. J. Modelos quantitativos de apoio às decisões. RAE - Revista de Administração de Empresas. São Paulo, v. 36, n. 2, abr./mai./jun. 1996. p. 44-52.

Estratégia: Mãos a obra - Incorporadoras e construtoras investem em transparência para acessar o mercado de capitais via CRI, FIDC, FII e ações. Revista Capital Aberto. 19. ed. mar. 2005. p. 22-25. 
FAGUNDES, C. Importância do sale-leaseback no Brasil. Periódico Balanço Financeiro. São Paulo: FEBRABAN, 30 jun. 1982, p. 3-4.

GAIARSA, C. M. Financiamento do infraestrutura urbana com base na valorização imobiliária: um estudo comparado de mecanismos de quatro países. Dissertação (Mestrado). Escola Politécnica, Universidade de São Paulo, São Paulo, 2010. 141p.

GALESNE, A.; FENSTERSEIFER, J. E. e LAMB, R. Decisões de investimento da empresa. São Paulo: Editora Atlas, 1999. 295p.

GIBSON, V. e LOUARGAND, M., 2002. Risk management and the corporate real estate portfolio. In.: AMERICAN REAL ESTATE SOCIETY - ARES. Annual Metting de 2002.

IBGC - INSTITUTO BRASILEIRO DE GOVERNANÇA CORPORATIVA. Disponível em $<$ http://www.ibgc.org.br>. Acesso em: 18 Jul. 2008

INTERNATIONAL VALUATION STANDARDS COMMITTEE (IVSC). International Valuation Standards. 8. ed. Chicago: Appraisal Institute, 2007. 462 p.

IPEA - Instituto de Pesquisa Econômica Aplicada. Dados sobre a evolução da inflação e

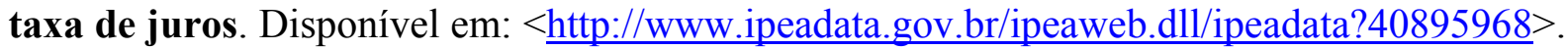
Acesso em: 18 nov. 2006.

IPEA - INSTITUTO DE PESQUISA ECONÔMICA APLICADA. A crise econômica global e seus reflexos sobre a economia brasileira. Carta de Conjuntura. Dez. 2008. Disponível em: < www.ipea.gov.br/sites/000/2/publicacoes/cartaconjuntura/carta05/1_Crise.pdf $>$. Acesso em: 15 jan. 2010.

IUDÍCIBUS, S. e MARION, J. C. Curso de contabilidade para não contadores: para as áreas de administração, economia, direito e engenharia. 3. ed. São Paulo: Editora Atlas, 2000. 282p.

IUDÍCIBUS, S. et al. Contabilidade introdutória. 9. ed. São Paulo: Editora Atlas, 1998. $293 p$.

IUDÍCIBUS, S.; MARTINS, E. e GELBCKE, E. R. Manual de contabilidade das sociedades por ações - aplicável às demais sociedades. 7. ed. São Paulo: Editora Atlas, 2007. 646p.

JONES LANG LA SALLE - LaSalle investment management. Property futures: organizing corporate real estate for growth. v. 1, 2002.

JONES LANG LA SALLE HOTELS. Hotel Sale-Leaseback Transactions. Issue 11, June, 2002. Disponível em < www.joneslanglasallehotels.com $>$ Acesso em: 15 out. 2006.

JONES LANG LA SALLE. Corporate Real Estate Impact Survey: Faster, Better and Cheaper. December, 2003.

August, 2004.

Corporate Real Estate Impact Survey: Turning the Corner. Third Edition, 
$\overline{\text { September, } 2005 .}$

KRUMM, P. "History of real estate management from a corporate perspective". Facilities. v. 19. n. 7/8, 2001.

"Value creation through the management of corporate real estate". Journal of

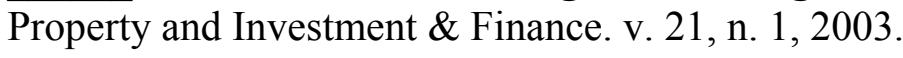

KULICHOVÁ, M. 2003. Managing Corporate Real Estate and Strategic Planning: Cases studies on Swedish production companies, Master Thesis, KUNGL TEKNISKA HOGSKOLAN, Stockholm, 2003.

LASFER, M. Driving Shareholder Value - Corporate Real Estate Freehold ' $v$ s' Leasehold. Patrocinado por Donaldsons Research, London, 2003.

LEI DO INQUILINATO. Apresenta as regras para locação urbana no Brasil. Disponível em: $<$ https://www.planalto.gov.br/>. Acesso em 20 nov. 2006.

LONGO, C. A. Execução satisfatória. Boletim de Informações da FIPE, São Paulo, ago 1989. Artigo. p. 9-17.

MANNING, C e ROULAC, S. Structuring the corporate real property function for grater bottom line impact. Journal of Real Estate Research. v. 12, n. 3, 1996.

MANNING, C, RODRIGUES, M e ROULAC, S. Which corporate real estate management function should be outsourced? Journal of Real Estate Research. v. 14, n. 3, 1997.

MANNING, C. A. "Leasing versus purchase of corporate real property: leases with residual equity interests". The Journal of Real Estate Research. v. 6, n. 1, 1991.

MARTINS, C. L. L.; AGUIAR, L.; MARQUES, S. R. Plano Real: Panorama dos 10 anos de sua criação. Revista Acadêmica Alpha, Goiânia, v. 1, n. 1, Maio-Outubro de 2004. Disponível em: $<$ http://www.alfa.br/revista/pdf/9eco.pdf $>$. Acesso em 25 nov. 2006.

MOREIRA, A. C. A. Contratos Built-to-Suit. Publicação de Alborgheti Moreira Advocacia em Novembro de 2005. Disponível em $<$ www.alborghetimoreira.com.br/bts.pdf $>$ Acesso em 10 out. 2006.

NELSON, T.R., POTTER, T. e WILDE, H. Real Estate assets on corporate balance sheets. Journal of Corporate Real Estate. v. 2, n. 1, 1999.

NOBRE, E. A. C. Reestruturação Econômica e Território: Expansão recente do terciário na marginal do Rio Pinheiros. 2000. 253p. Tese (Doutorado) - Faculdade de Arquitetura e Urbanismo da Universidade de São Paulo. São Paulo, 2000.

O’MARA, M. A. Strategy and place. New York: Free Press, 1999. 349p.

Strategies for demand forecasting in corporate real estate portfolio management. Journal of Corporate Real Estate, v. 2, n. 2, 2000. 
OLIVEIRA, M. L. A locação Built-to-suit e sua aplicação no direito brasileiro. 2002. 46p. Monografia. UniFMU. São Paulo, 2002

PEDERSON, R. e WOOTTEN, T. Regular feature - market focus. Journal of Corporate Real Estate, v. 5, n. 4, 2003.

PHILLIPS, S. The place of securitization in the financial system: implications for banking and monetary policy. In: KENDALL, Leon T.; FISHMAN, Michael J. A primer of securitization. Cambridge: MIT Press, 1996.

PINHEIRO, A. C.; GIAMBIAGI, F.; MOREIRA, M. M. O Brasil na década de 90: Uma transição bem-sucedida? BNDES. Textos para discussão n. 91. Rio de Janeiro, nov. 2001. Disponível em: <http://www.bndespar.com.br/conhecimento/td/td-91.pdf $>$. Acesso em 25 nov. 2006.

PORTER, M. E. Competitive strategy. The Free Press, New York, 1998. 397p.

POTTINGER, G; DIXON, T e MARSTON, A. Occupational futures? Divesting real estate and corporate pfi. Property management, v. 20, n. 1, p. 31-48, 2002.

Prospecto de Distribuição Pública de Quotas do FUNDO DE INVESTIMENTO IMOBILIÁRIO EDIFÍCIO ALMIRANTE BARROSO (Sede administrativa da Caixa Econômica Federal). nov. 2002. Disponível em: < http://downloads.caixa.gov.br/voce/_arquivos/prospecto_FII.pdf $>$ Acesso em: 20 jul. 2006;

RIR - Regulamento do Imposto de Renda. Dispõe sobre as regras fiscais para efeito de tributação. Disponível em < www.receita.fazenda.gov.br > Acesso em: 18 dez. 2006.

ROCHA LIMA Jr, J. Arbitragem de valor de portfolios de base imobiliária. São Paulo: EPUSP, 1994. (Boletim Técnico da Escola Politécnica da USP, Departamento de Engenharia de Construção Civil, BT/PCC/132).

Fundo de investimento imobiliário, com portfolio de base imobiliária: notas sobre a depreciação do ativo. São Paulo: EPUSP, 1997. (Boletim Técnico da Escola Politécnica da USP, Departamento de Engenharia de Construção Civil, BT/PCC/187).

Decidir sobre investimentos no setor da Construção Civil. São Paulo: EPUSP, 1998a. (Boletim Técnico da Escola Politécnica da USP, Departamento de Engenharia de Construção Civil, BT/PCC/200).

Formação da Taxa de Retorno em Empreendimentos de Base Imobiliária. São Paulo: EPUSP, 1998b. (Boletim Técnico da Escola Politécnica da USP, Departamento de Engenharia de Construção Civil, BT/PCC/218).

Novos produtos financeiros e o mercado imobiliário: investimentos via títulos de securitização. In: I SEMINÁRIO DA LATIN AMERICA REAL ESTATE SOCIETY. São Paulo, set. 1999. Anais. 24p. 
. Arbitragem de valor de hotéis. São Paulo: EPUSP, 2000. (Boletim Técnico da Escola Politécnica da USP, Departamento de Engenharia de Construção Civil, BT/PCC/267).

Fundos de investimento imobiliário e real estate investment trusts. In: CONGRESSO URBAN LAND INSTITUTE - REAL ESTATE NA AMÉRICA LATINA. São Paulo, ago. 2001. Anais. 7p.

. CARTA DO NRE-POLI: Notas sobre valuation de empresas e empreendimentos: the dark side of valuation. São Paulo: EPUSP, 2006.

ROCHA LIMA Jr, J.; GREGÓRIO, C. A. G. A capacidade de recuperação dos preços das ações das empresas de real estate cotadas na Bovespa. In: IX CONFERÊNCIA INTERNACIONAL DA LARES - LATIN AMERICAN REAL ESTATE SOCIETY. São Paulo, 2009. Anais. p. 1-16. Disponível em: < http://www.realestate.br/images/File/arquivosPDF/Joao_Carolina.pdf >. Acesso em: 25 jan. 2010 .

ROMERO, Bianca de Cássia. Análise da localização de plataformas logísticas: aplicação ao caso do ETSP - Entreposto Terminal São Paulo - da CEAGESP. 2006. 144p. Dissertação (Mestrado) - Escola Politécnica da Universidade de São Paulo. São Paulo, 2006.

ROSSI JR, J.L.; FERREIRA, P. C. Evolução da produtividade industrial brasileira e abertura comercial. IPEA. Texto para discussão n. 651. Rio de Janeiro, jun. 1999. 36p. Disponível em: <http://www.ipea.gov.br/pub/td/td0651.pdf>. Acesso em: 18 nov. 2006.

SAATY, T. L. The analytic hierarchy process. New York: Mc Graw-Hill, 1980. 269 p.

Método de análise hierárquica. São Paulo: Editora Makron, 1991.

SCARMAN, I. e KOOYMANS, R. Australian Federal Government property sales 19962001. In: TWELFTH ANNUAL PACIFIC-RIM REAL ESTATE SOCIETY CONFERENCE. Auckland, New Zealand, 22-25 January, 2006. 12p.

SCHMIDT, P.; SANTOS, J. L. e KLOECKNER, G. Avaliação de empresas: foco na gestão de valor da empresa - teoria e prática. São Paulo: Editora Atlas, 2006. 235p.

SECURATO, J.R. Decisões financeiras em condições de risco. 2. ed. São Paulo: Saint Paul Editora, 2007. 264p.

Securitização e mercado imobiliário: direito de superfície versus locação. Revista Capital Aberto. 33. ed. mai. 2006. p. 49.

SIROTA, D. Essentials of real estate investment. 7. ed. Chicago: Dearborn, , 2001. 259p.

SOARES, Marcelo G. Classificação de operadores terceirizados, visando o estabelecimento de parcerias de negócio no contexto logístico empresarial. 2002. Dissertação (Mestrado) - Escola Politécnica da Universidade de São Paulo. São Paulo, 2002. 
SOARES, R. P. Evolução do crédito de 1994 a 1999: uma Explicação. IPEA. Texto para discussão n. 808. Brasília, jul. 2001. 45p. Disponível em: $<$ http://www.ipea.gov.br/pub/ppp/ppp25/parte2.pdf>. Acesso em: 18 nov. 2006.

VALENÇA, M. J. L. Built to suit - operação de crédito imobiliário estruturada. Revista Direito Bancário. São Paulo: FEBRABAN, jan./mar., 2005, p. 328-343. 


\section{APÊNDICE A - LEVANTAMENTO DE CAMPO: QUESTIONÁRIOS DAS ENTREVISTAS}

\section{IDENTIFICAÇÃO DOS CRITÉRIOS DE DECISÃO - CORPORAÇÕES [CR]}

\section{DADOS DA ENTREVISTA}

1.1. Empresa:

1.2. Data:

1.3. Contato:

1.4. Função / Cargo:

2. DECISÃO EM RELAÇÃO AO REAL ESTATE CORPORATIVO - [alternativas] - Contextualização da Pesquisa

2.1. Necessidade:

Mais Espaço:

Ser Proprietário [SP]:

Build-to-Suit [BTS]:

Capital de Giro:

Locação Longo Prazo [LLP]

Locação Curto Prazo [LCP]

3. DADOS DA CORPORAÇÃO

\subsection{Setor de Atuação:}

Manufatura $\square$

Varejo $\square$

Continuar Proprietário [SP]

Sale-Leaseback [SLB]:

3.2. Tipos de Espaços Corporativos:

$\square$ Escritórios (ex.: sedes administrativas, regionais, etc.)

$\square$ Unidades de produção / operação (ex.: fábricas, laboratórios, centros de desenvolvimento, etc.)

$\square$ Armazéns (ex.: centros de distribuição, operações logísticas, etc.)

$\square$ Pontos de venda ou prestação de serviços (ex.: lojas, concessionárias, agências, etc.)

$\square$ Outros (especifique):

\section{ALTERNATIVAS E RECONHECIMENTO DOS MOTIVOS DA ESCOLHA}

4.1. Quais [alternativas] em relação ao Real Estate, das mencionadas acima, a empresa tem adotado, adotou ou pretende adotar para cada tipo de espaço corporativo demandado na operação?

\begin{tabular}{|c|c|c|c|c|c|c|}
\hline \multirow{2}{*}{$\begin{array}{l}\square \text { Ser Proprietário [SP] } \\
\text { Tipo }\end{array}$} & $\square$ Build-to-Suit [BTS] & \multicolumn{2}{|c|}{$\square$ Loc. Longo Prazo [LP] } & \multicolumn{2}{|c|}{$\square$ Loc. Curto Prazo [CP] } & \multirow{2}{*}{$\begin{array}{l}\square \text { Sale-Leaseback [SLB] } \\
\text { to de renovatória }\end{array}$} \\
\hline & \multicolumn{2}{|c|}{ Prazo de locação } & \multicolumn{2}{|c|}{ Multa rescisória } & Direito de renovatória & \\
\hline & \multicolumn{2}{|c|}{$\begin{array}{l}\text { Garantia de permanência } \\
\text { mínima }\end{array}$} & \multicolumn{2}{|c|}{ Permissão de sublocação } & \multicolumn{2}{|c|}{$\begin{array}{l}\text { Condições prazo/preço } \\
\text { Renovatória }\end{array}$} \\
\hline
\end{tabular}




\begin{tabular}{|c|c|c|c|}
\hline \multicolumn{4}{|c|}{ Motivos (estratégicos, operacionais, financeiros, riscos, necessidade de capital de giro, etc.) } \\
\hline \multirow[t]{3}{*}{ Flexibilidade de Mudança } & Muito importante na decisão & \multirow[t]{3}{*}{ Controle no uso do espaço } & Muito importante na decisão \\
\hline & Fez parte da decisão & & Fez parte da decisão \\
\hline & Não fez parte da decisão & & Não fez parte da decisão \\
\hline \multirow{3}{*}{$\begin{array}{l}\text { Vínculo da operação com o } \\
\text { imóvel }\end{array}$} & Muito importante na decisão & \multirow{3}{*}{$\begin{array}{l}\text { Especificidade do espaço } \\
\text { (dificuldade em encontrar no } \\
\text { mercado imóveis nas } \\
\text { demandas requeridas) }\end{array}$} & Muito importante na decisão \\
\hline & Fez parte da decisão & & Fez parte da decisão \\
\hline & Não fez parte da decisão & & Não fez parte da decisão \\
\hline \multirow{3}{*}{$\begin{array}{l}\text { Tradução da Imagem } \\
\text { Corporativa } \\
\text { (ambiente interno e externo) }\end{array}$} & Muito importante na decisão & \multirow{3}{*}{$\begin{array}{l}\text { Desoneração do Balanço } \\
\text { (ou não oneração do balanço) }\end{array}$} & Muito importante na decisão \\
\hline & Fez parte da decisão & & Fez parte da decisão \\
\hline & Não fez parte da decisão & & Não fez parte da decisão \\
\hline \multirow{3}{*}{$\begin{array}{l}\text { Canalizar recursos em } \\
\text { oportunidades do Negócio } \\
\text { Principal }\end{array}$} & Muito importante na decisão & \multirow{3}{*}{$\begin{array}{l}\text { Necessidade de Capital de Giro } \\
\text { (caso da desmobilização - SLB) }\end{array}$} & Muito importante na decisão \\
\hline & Fez parte da decisão & & Fez parte da decisão \\
\hline & Não fez parte da decisão & & Não fez parte da decisão \\
\hline \multirow[t]{3}{*}{ Outros: } & Muito importante na decisão & \multirow[t]{3}{*}{ Outros: } & Muito importante na decisão \\
\hline & Fez parte da decisão & & Fez parte da decisão \\
\hline & Não fez parte da decisão & & Não fez parte da decisão \\
\hline
\end{tabular}

4.2. Por que a empresa mantém imobilizados recursos em ativos imobiliários? Quais são os riscos operacionais e financeiros quando proprietária?

\subsection{Sendo locatária, quais são os riscos operacionais e financeiros envolvidos?}

Build-to-Suit [BTS]:

Locação Longo Prazo [LP]:

Locação Curto Prazo [CP]:

Sale-Leaseback [SLB]: 
4.4. Quais são as intervenções no espaço, nas [alternativas] de locação abaixo, que a corporação pode realizar durante 0 uso (ex.: layout, infraestrutura, sistemas de abastecimento, fachadas, etc.)? É necessário aceite prévio do proprietário em quais tipos de intervenções? Quais intervenções são indenizáveis?

Build-to-Suit [BTS]:

Locação Longo Prazo [LP]:

Locação Curto Prazo [CP]:

Sale-Leaseback [SLB]

4.5. Nas decisões em relação ao Real Estate, quais são os métodos usados para avaliar a escolha entre as [alternativas]?

4.6. A empresa já adotou algum BTS ou SLB com contratos de Cessão de Direito Real de Superfície como instrumento jurídico para vincular legalmente a empresa com o proprietário do imóvel?

4.7. Se sim, quais foram as principais particularidades dos contratos em relação a:

\begin{tabular}{l|l}
\hline Flexibilidade de Mudança & $\begin{array}{l}\text { Prazo Mínimo de Permanência } \\
\text { Multa no caso de rescisão do } \\
\text { contrato de cessão }\end{array}$ \\
\hline Controle no uso do espaço & $\left.\begin{array}{l}\text { Liberdade de Intervenção para } \\
\text { adequações (ex.: Layout, } \\
\text { infraestrutura, sistemas de } \\
\text { abastecimento, fachadas, etc). } \\
\text { Intervenções são indenizáveis? }\end{array}\right]$ \\
\hline Vínculo com o imóvel & $\begin{array}{l}\text { Direito Preferencial de } \\
\text { Renovação (condiçóes e prazos } \\
\text { pré-definidos) e Direito } \\
\text { Preferencial de Compra }\end{array}$ \\
\hline
\end{tabular}

4.8. Os impactos fiscais (tributação), contábeis e financeiros (balanço patrimonial - medidas financeiras: ROA, ROE, índice de liquidez, etc.) foram / são levados em consideração na decisão? Se sim, por quê?

\section{PERCEPÇÃO EM RELAÇÃO AO RECURSO REAL ESTATE}

5.1. Que configuração ideal entre as [alternativas] a corporação adotaria atualmente caso fossem reestruturados todos os seus ativos imobiliários

\begin{tabular}{|c|c|c|}
\hline Tipo: & [alternativa]/particularidades & Motivos \\
\hline Tipo: & [alternativa]/particularidades & Motivos \\
\hline Tipo: & [alternativa]/particularidades & Motivos \\
\hline
\end{tabular}


ANÁLISE DA PERTINÊNCIA DAS [ALTERNATIVAS] - EMPRESAS DE REAL ESTATE [ERE]

\section{DADOS DA ENTREVISTA}

1.1. Empresa:

1.2. Data:

1.3. Contato:

1.4. Função / Cargo:

2. DECISÃO EM RELAÇÃO AO REAL ESTATE CORPORATIVO - [alternativas] - Contextualização da Pesquisa

\subsection{Necessidade:}

Mais Espaço:
Ser Proprietário [SP]:
Build-to-Suit [BTS]:
Locação Longo Prazo [LLP]
Locação Curto Prazo [LCP]

\subsection{Tipos de Espaços Corporativos:}

Escritórios (ex.: sedes administrativas, regionais, etc.)

Unidades de produção / operação (ex.: fábricas, laboratórios, centros de desenvolvimento, etc.)

Armazéns (ex.: centros de distribuição, operações logísticas, etc.)

Pontos de venda ou prestação de serviços (ex.: lojas, concessionárias, agências, etc.)

\subsection{Atributos Qualitativos para Decisão}

\begin{tabular}{l|l}
\hline & Atributos a serem considerados durante o uso \\
Flexibilidade de Mudança (relacionada com o horizonte de & \\
uso do espaço) & \\
Controle no Uso do Espaço Corporativo (liberdade de \\
intervenções)
\end{tabular}




\section{ALTERNATIVAS E RECONHECIMENTO DOS MOTIVOS DA ESCOLHA}

3.1. Que tipo de espaços corporativos são comumente locados por curto prazo ou prazo indeterminado?

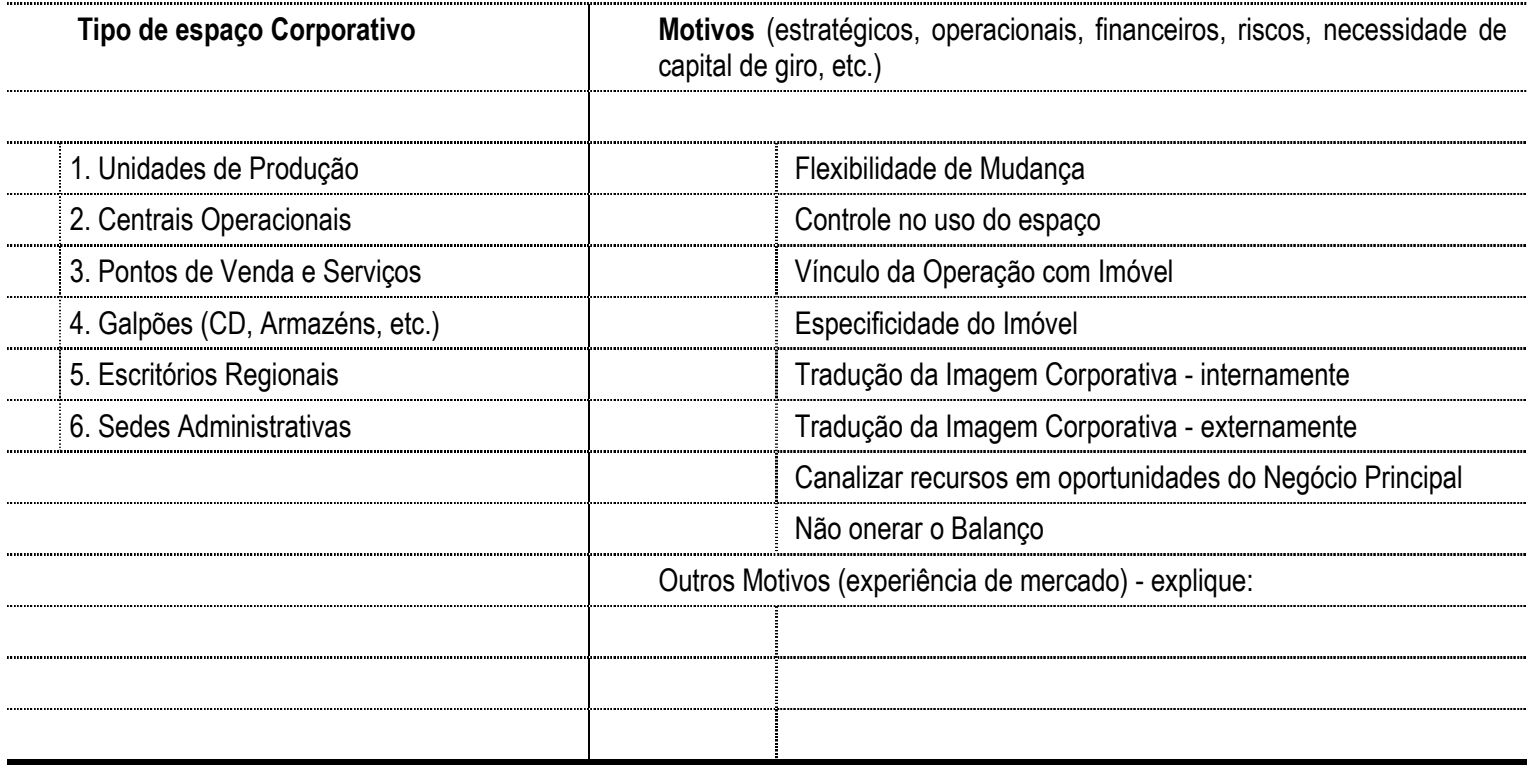

3.2. Que tipo de espaços corporativos são comumente locados por longo prazo ( $>=5$ anos)?

Tipo de espaço Corporativo

Motivos (estratégicos, operacionais, financeiros, riscos, necessidade de capital de giro, etc.)

\begin{tabular}{l|l|l|}
\hline 1. Unidades de Produção & \multicolumn{1}{|l|}{ Flexibilidade de Mudança } \\
\hline 2. Centrais Operacionais & Controle no uso do espaço \\
\hline 3. Pontos de Venda e Serviços & Vínculo da Operação com Imóvel \\
\hline 4. Galpões (CD, Armazéns, etc.) & Especificidade do Imóvel \\
\hline 5. Escritórios Regionais & Tradução da Imagem Corporativa - internamente \\
\hline 6. Sedes Administrativas & Tradução da Imagem Corporativa - externamente \\
\hline & & Canalizar recursos em oportunidades do Negócio Principal \\
\hline & & Não onerar o Balanço \\
\hline
\end{tabular}




\begin{tabular}{|c|c|}
\hline \multicolumn{2}{|c|}{ 3.3 Para que tipo de espaços corporativos a modalidade BTS é mais comumente observada? } \\
\hline Tipo de espaço Corporativo & $\begin{array}{l}\text { Motivos (estratégicos, operacionais, financeiros, riscos, necessidade de } \\
\text { capital de giro, etc.) }\end{array}$ \\
\hline 1. Unidades de Produção & Flexibilidade de Mudança \\
\hline 2. Centrais Operacionais & Controle no uso do espaço \\
\hline 3. Pontos de Venda e Serviços & Vínculo da Operação com Imóvel \\
\hline 4. Galpões (CD, Armazéns, etc.) & Especificidade do Imóvel \\
\hline 5. Escritórios Regionais & Tradução da Imagem Corporativa - internamente \\
\hline \multirow[t]{5}{*}{ 6. Sedes Administrativas } & Tradução da Imagem Corporativa - externamente \\
\hline & Impacto da Desocupação do Imóvel para a Operação \\
\hline & Canalizar recursos em oportunidades do Negócio Principal \\
\hline & Não onerar o Balanço \\
\hline & Outros Motivos (experiência de mercado) - explique: \\
\hline & \\
\hline & \\
\hline \multicolumn{2}{|c|}{ 3.4. Para que tipo de espaços corporativos a modalidade SLB é mais comumente observada? } \\
\hline Tipo de espaço Corporativo & $\begin{array}{l}\text { Motivos (estratégicos, operacionais, financeiros, riscos, necessidade de } \\
\text { capital de giro, etc.) }\end{array}$ \\
\hline 1. Unidades de Produção & Flexibilidade de Mudança \\
\hline 2. Centrais Operacionais & Controle no uso do espaço \\
\hline 3. Pontos de Venda e Serviços & Vínculo da Operação com Imóvel \\
\hline 4. Galpões (CD, Armazéns, etc.) & Especificidade do Imóvel \\
\hline 5. Escritórios Regionais & Tradução da Imagem Corporativa - internamente \\
\hline \multirow[t]{4}{*}{ 6. Sedes Administrativas } & Tradução da Imagem Corporativa - externamente \\
\hline & Levantar Capital de Giro \\
\hline & Desonerar o Balanço \\
\hline & Outros Motivos (experiência de mercado) - explique: \\
\hline & \\
\hline & \\
\hline & \\
\hline
\end{tabular}




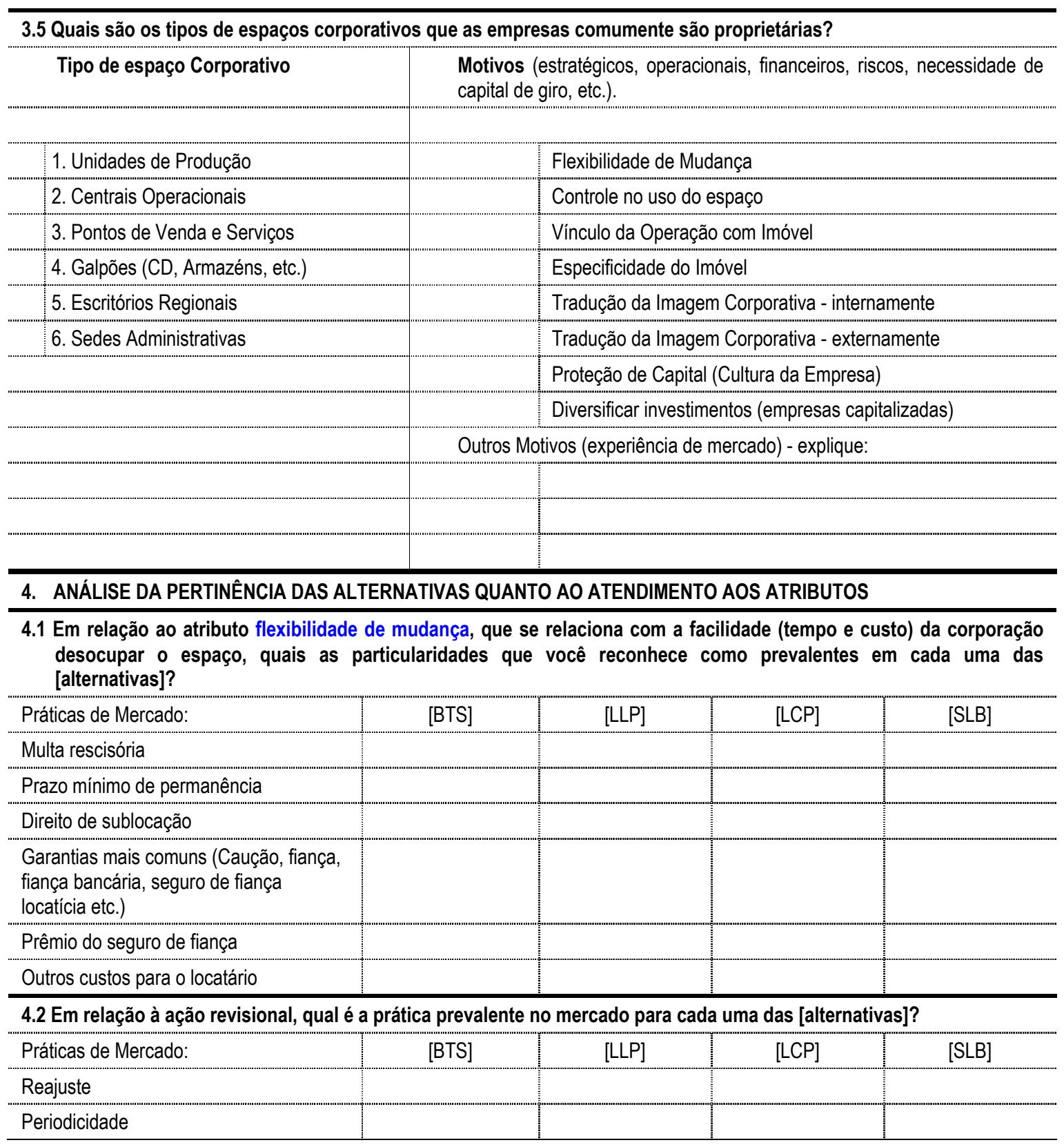


4.3 Em relação ao controle no uso do espaço, como cada uma das [alternativas] atende este atributo conforme práticas prevalentes do mercado, ou seja, qual o grau de liberdade de intervenção no espaço durante o prazo contratual?

\begin{tabular}{|c|c|c|c|c|}
\hline Práticas de Mercado: & [BTS] & [LLP] & {$[\mathrm{LCP}]$} & [SLB] \\
\hline \multicolumn{5}{|c|}{$\begin{array}{l}\text { Grau de liberdade comparativo }(1 \text { a } 4) \\
1=\text { maior liberdade } / 4 \text { = menor liberdade }\end{array}$} \\
\hline \multicolumn{5}{|l|}{ Periodicidade } \\
\hline \multicolumn{5}{|l|}{$\begin{array}{l}\text { Intervenções permitidas (layout, } \\
\text { infraestrutura, sistemas de } \\
\text { abastecimento, fachadas, etc.) }\end{array}$} \\
\hline \multicolumn{5}{|l|}{$\begin{array}{l}\text { Restrições (aceite do proprietário, } \\
\text { contratuais, etc.) }\end{array}$} \\
\hline $\begin{array}{l}\text { Benfeitorias indenizáveis (úteis, } \\
\text { necessárias, voluptuárias) }\end{array}$ & & & & \\
\hline
\end{tabular}

4.4 Em quais situações o locatário tem que desocupar o imóvel (mesmo tendo, por lei, direito de renovatória e direito preferencial de compra)? Existe algum mecanismo praticado no mercado para proteção do locatário em permanecer no imóvel nas situações citadas?

4.5 Em relação à tradução da imagem corporativa, interna e externamente, como cada uma das [alternativas] atende este atributo?

\begin{tabular}{l} 
Práticas de Mercado: \\
\hline Oportunidade de tradução interna \\
\hline Oportunidade de tradução externa \\
\hline 5. ANÁLISE DA PERTINÊNCIA DAS ALTERNATIVAS QUANTO AO ATENDIMENTO AOS ATRIBUTOS \\
\hline $\begin{array}{l}\text { 5.1 Sabe-se da indisponibilidade no mercado para locação de imóveis específicos e customizados. Para uma corporação } \\
\text { adotar a modalidade BTS (ou SLB), seu rating de crédito é parte da escolha de investidores / empreendedores dessa } \\
\text { modalidade? }\end{array}$
\end{tabular}

5.2 Você acredita que existam evidências para fazer a modalidade (BTS) mais difundida no Brasil, ainda que em certas situações exista a referência sobre insegurança jurídica? Por quê?

5.3 Por que nas transações de BTS e SLB tem sido usado outro instrumento jurídico: Cessão de Direito Real de Superfície? Quais as vantagens e desvantagens para o locador e locatário usando este instrumento? (Lembrando dos atributos qualitativos da decisão)

5.3.1- Flexibilidade - multa rescisória e tempo de garantia de permanência no imóvel:

\begin{tabular}{|c|c|c|}
\hline \multirow{4}{*}{$\begin{array}{l}\text { 5.3.2- Controle no uso do espaço - Liberdade de intervenções } \\
\text { no espaço durante o uso quando se utiliza esse instrumento } \\
\text { jurídico (comparar com item 4.3): }\end{array}$} & $\begin{array}{l}\text { Liberdade de } \\
\text { Intervenções: }\end{array}$ & Menor \\
\hline & $\begin{array}{l}\text { Intervenções } \\
\text { Permitidas: }\end{array}$ & $\begin{array}{l}\text { Layout, Infraestrutura, Sistema de } \\
\text { Abastecimento, Fachadas, outros: }\end{array}$ \\
\hline & Restrições: & Aceite do Proprietário, Contratuais: \\
\hline & $\begin{array}{l}\text { Benfeitorias } \\
\text { Indenizáveis: }\end{array}$ & \\
\hline
\end{tabular}


5.3.3. Vínculo da operação com o imóvel:

Direito de

Renovação:

Direito

Preferencial de

Compra:

Possibilidades de

Desocupação do

Imóvel:

\section{ASPECTOS QUANTITATIVOS}

6.1 Existe variação no valor de locação em função do prazo contratual? Qual é, em geral, essa variação (comparando para um mesmo imóvel um contrato de curto e outro de longo prazo)? As carências são diferentes em função do prazo contratual?

6.2 Os imóveis de contratos BTS e SLB, em geral, possuem valor de mercado menor ao final dos contratos (em razão da sua especificidade funcional), porém, há uma melhor qualidade da renda (fluxo homogêneo e credibilidade da corporação). Como são considerados esses aspectos na definição dos preços de locação? São menores ou maiores que contratos simples de locação de longo prazo?

6.3 Os custos operacionais, para o locatário, se diferem entre as [alternativas] de locação (BTS, SLB, LLP, LCP)? Quais são as diferenças (ex. garantias, seguros, manutenção ordinária, etc)? 0 que, em geral, se divide em manutenção ordinária e reposição de ativos? (divisão pela lei de locação urbana: despesas ordinárias (locatário) e despesas extraordinárias (locador)) 


\section{APÊNDICE B - IMPACTO NOS GRUPOS DE CONTAS DO BALANÇO DA EMPRESA DO CASO 'VS' [ALTERNATIVAS] PARA CADA IMÓVEL DO PORTFOLIO}

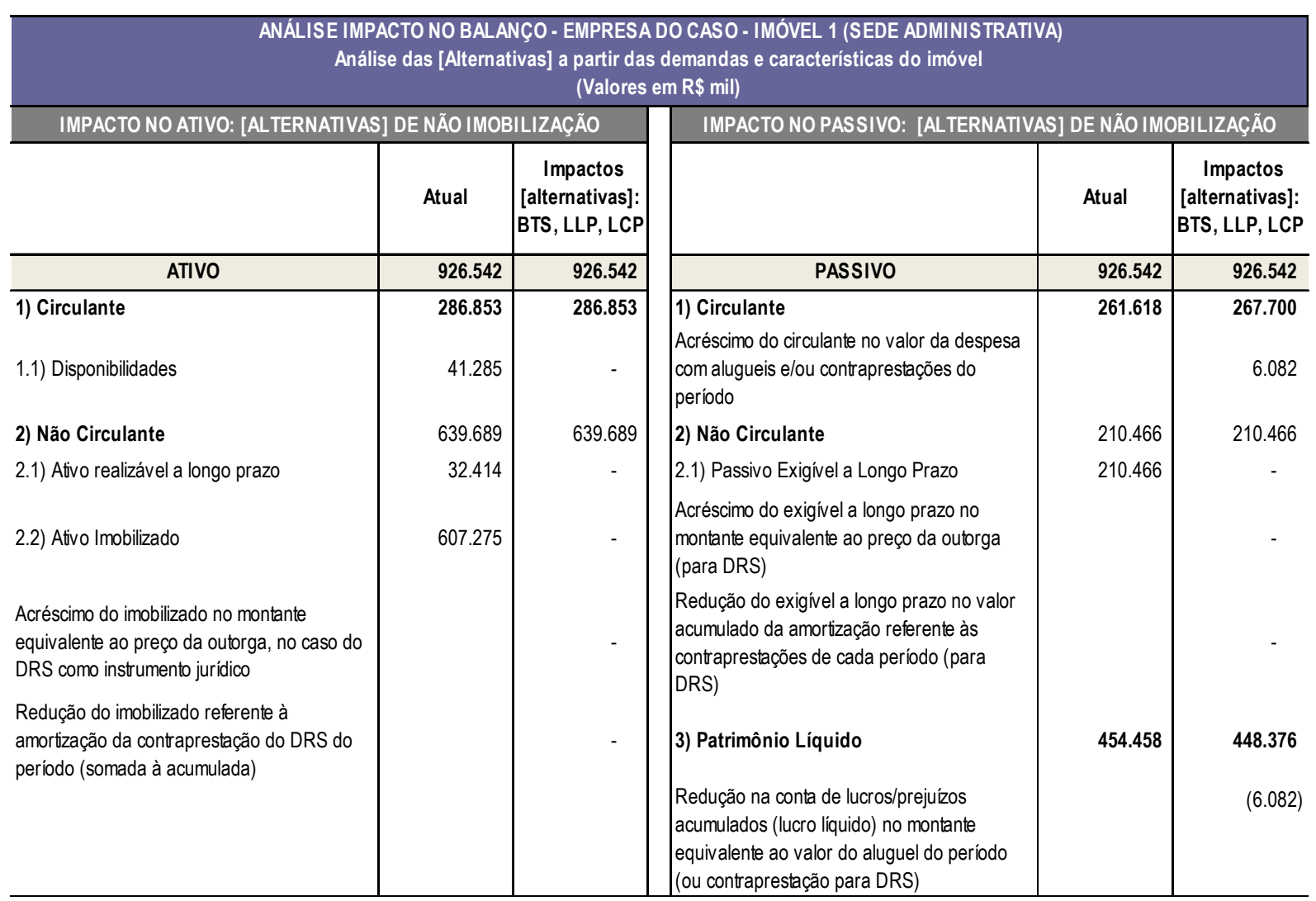

Quadro 29 - [alternativas] - BTS, LLP, LCP e impactos nos grupos de contas do balanço da empresa do caso Imóvel 1 


\begin{tabular}{|c|c|c|c|c|c|}
\hline \multicolumn{6}{|c|}{$\begin{array}{c}\text { ANÁLISE IMPACTO NO BALANÇO - EMPRESA DO CASO - IMÓVEL } 1 \text { (SEDE ADMINISTRATIVA) } \\
\text { Análise das [Alternativas] a partir das demandas e características do imóvel } \\
\text { (Valores em R\$ mil) }\end{array}$} \\
\hline \multicolumn{3}{|c|}{ IMPACTO NO ATIVO: [SP] } & \multicolumn{3}{|c|}{ IMPACTO NO PASSIVO: [SP] } \\
\hline & Atual & $\begin{array}{c}\text { Impactos } \\
\text { [alternativa]: } \\
{[\mathrm{SP}]}\end{array}$ & & Atual & $\begin{array}{c}\text { Impactos } \\
\text { [alternativa]: } \\
\text { [SP] }\end{array}$ \\
\hline ATIVO & 926.542 & 925.371 & PASSIVO & 926.542 & 925.371 \\
\hline 1) Circulante & 286.853 & 266.103 & 1) Circulante & 261.618 & 261.618 \\
\hline 1.1) Disponibilidades & 41.285 & $(20.750)$ & & & \\
\hline $\begin{array}{l}\text { Redução do circulante no montante equivalente } \\
\text { à parcela do valor de transação do imóvel com } \\
\text { desembolsos considerados no exercíico, ou } \\
\text { seja, em até } 12 \text { meses }\end{array}$ & & $(20.750)$ & & & \\
\hline 2) Não Circulante & 639.689 & 659.268 & 2) Não Circulante & 210.466 & 210.466 \\
\hline 2.1) Ativo realizável a longo prazo & 32.414 & $(20.750)$ & 2.1) Passivo Exigivel a Longo Prazo & 210.466 & - \\
\hline $\begin{array}{l}\text { Redução do circulante futuro no montante } \\
\text { equivalente à parcela de transação do imóvel } \\
\text { com desembolsos nos próximos exercícios, ou } \\
\text { seja, com pagamentos ocorrendo após } 12 \\
\text { meses }\end{array}$ & & $(20.750)$ & & & \\
\hline $\begin{array}{l}\text { 2.2) Ativo Imobilizado } \\
\text { Acréscimo do imobilizado no montante } \\
\text { equivalente ao valor de transação do imóvel }\end{array}$ & 607.275 & 41.500 & $\begin{array}{l}\text { 3) Patrimônio Líquido } \\
\text { Redução na conta de lucros/prejuízos } \\
\text { acumulados (lucro líquido) no montante } \\
\text { equivalente à depreciação do ativo no periodo }\end{array}$ & 454.458 & $\begin{array}{r}453.287 \\
(1.171)\end{array}$ \\
\hline $\begin{array}{l}\text { Redução do imobilizado referente à } \\
\text { depreciação do ativo no período (somada à } \\
\text { acumulada) }\end{array}$ & & $(1.171)$ & & & \\
\hline
\end{tabular}

\section{Observações:}

1 - Em função do tamanho do imóvel e do volume de investimento envolvido, para efeito de análise do impacto no ativo circulante para as [alternativas] de imobilização (SP e SP a prazo) considera-se o pagamento do valor de transação do imóvel em 24 meses. Ou seja, parte do valor é pago com as disponibilidades do exercício e o restante a partir de 12 meses. Por isso, parte do pagamento é deduzida somente no ativo circulante do próximo exercício.

2 - Considera-se para análise do impacto das [alternativas] de imobilização a situação do ativo em regime operacional (ou seja, quando em uso), mesmo que existam parcelas do imóvel a serem pagas nos próximos exercícios. Portanto, a depreciação já começa a ser contabilizada como conta redutora do ativo imobilizado. Esta premissa é coerente com o valor do ativo que está sendo considerado para análise dos impactos da imobilização no balanço. Ou seja, como o valor do imóvel considerado no balanço é o seu valor de mercado (fornecido no laudo de avaliação), considera-se que este seja o valor do imóvel quanto colocado pronto para uso, que contempla, portanto, as remunerações/encargos dos investidores/financiadores para conceber 0 ativo.

3 - Estas premissas adotadas para efeito de cálculo dos indicadores do Critério H (Desoneração do Balanço) do [MAOI] não alteram significativamente a análise, já que os impactos mais representativos são contabilizados sempre da mesma forma: [i] no ativo circulante (redução do caixa para pagamento do valor de transação do imóvel) e [ii] no ativo imobilizado (valor de transação)

Quadro 30 - [alternativa] - SP e impactos nos grupos de contas do balanço da empresa do caso - Imóvel 1 


\begin{tabular}{|c|c|c|c|c|c|}
\hline \multicolumn{6}{|c|}{$\begin{array}{l}\text { ANÁLISE IMPACTO NO BALANÇO - EMPRESA DO CASO - IMÓVEL } 1 \text { (SEDE ADMINISTRATIVA) } \\
\text { Análise das [Alternativas] a partir das demandas e caracteristicas do imóvel } \\
\text { (Valores em R\$ mil) }\end{array}$} \\
\hline \multicolumn{3}{|c|}{ IMPACTO NO ATIVO: [SP] a prazo (por meio de financiamento) } & \multicolumn{3}{|c|}{ IMPACTO NO PASSIVO: [SP] a prazo (por meio de financiamento) } \\
\hline & Atual & $\begin{array}{c}\text { Impactos } \\
\text { [alternativa]: } \\
\text { [SP] a prazo }\end{array}$ & & Atual & $\begin{array}{l}\text { Impactos } \\
\text { [alternativa]: } \\
\text { [SP] a prazo }\end{array}$ \\
\hline ATIVO & 926.542 & 946.121 & PASSIVO & 926.542 & 946.121 \\
\hline $\begin{array}{l}\text { 1) Circulante } \\
\text { 1.1) Disponibilidades } \\
\text { Redução do circulante referente à parcela não } \\
\text { financiada do valor do imóvel com } \\
\text { desembolsos considerados no exercício, ou } \\
\text { seja, em até } 12 \text { meses }\end{array}$ & $\begin{array}{r}286.853 \\
41.285\end{array}$ & $\begin{array}{l}276.478 \\
(10.375)\end{array}$ & \begin{tabular}{|l|} 
1) Circulante \\
Acréscimo do circulante referente à parcela do \\
financiamento do imóvel (principal e juros) em \\
cada exercício
\end{tabular} & 261.618 & $\begin{array}{r}266.051 \\
4.433\end{array}$ \\
\hline 2) Não Circulante & 639.689 & 669.643 & 2) Não Circulante & 210.466 & 228.252 \\
\hline 2.1) Ativo realizável a longo prazo & 32.414 & (10.375) & 2.1) Passivo Exigível a Longo Prazo & 210.466 & 17.786 \\
\hline $\begin{array}{l}\text { Redução do circulante futuro referente à } \\
\text { parcela não financiada do valor do imóvel com } \\
\text { desembolsos nos próximos exercícios, ou } \\
\text { seja, com pagamentos ocorrendo após } 12 \\
\text { meses }\end{array}$ & & (10.375) & Saldo da Dívida & & 26.601 \\
\hline 2.2) Ativo Imobilizado & 607.275 & 40.329 & $\begin{array}{l}\text { Acréscimo do exigível a longo prazo no } \\
\text { montante equivalente ao valor financiado } \\
\text { do imóvel acrescido dos encargos }\end{array}$ & & 31.034 \\
\hline $\begin{array}{l}\text { Acréscimo do imobilizado no montante } \\
\text { equivalente ao valor de transação do imóvel }\end{array}$ & & 41.500 & $\begin{array}{l}\text { Redução do exigivel a longo prazo no } \\
\text { valor acumulado das parcelas já } \\
\text { amortzadas do financiamento }\end{array}$ & & $(4.433)$ \\
\hline $\begin{array}{l}\text { Redução do imobilizado referente à } \\
\text { depreciação do ativo no período (somada à } \\
\text { acumulada) }\end{array}$ & & $(1.171)$ & Encargos dos exercíicios futuros & & $(8.815)$ \\
\hline & & & Encargos financeiros a apropriar & & $(10.284)$ \\
\hline & & & $\begin{array}{l}\text { Encargos do ano transferidos } \\
\text { para resultado }\end{array}$ & & 1.469 \\
\hline & & & 3) Patrimônio Líquido & 454.458 & 451.818 \\
\hline & & & $\begin{array}{l}\text { Redução na conta de lucros/prejuízos } \\
\text { acumulados (lucro liquido) no montante } \\
\text { equivalente à depreciação do ativo no periodo }\end{array}$ & & (1.171) \\
\hline & & & $\begin{array}{l}\text { Redução na conta de lucros/prejuizos } \\
\text { acumulados (lucro liquido) no montante } \\
\text { equivalente aos encargos financeiros do } \\
\text { período }\end{array}$ & & (1.469) \\
\hline
\end{tabular}

\footnotetext{
Observações:

1 - Em função do tamanho do imóvel e do volume de investimento envolvido, para efeito de análise do impacto no ativo circulante para as [alternativas] de imobilização (SP e SP a prazo) considera-se o pagamento do valor de transação do imóvel em 24 meses. Ou seja, parte do valor é pago com as disponibilidades do exercício e o restante a partir de 12 meses. Por isso, parte do pagamento é deduzida no ativo circulante do próximo exercício.
}

2 - Considera-se para análise do impacto das [alternativas] de imobilização a situação do ativo em regime operacional (ou seja, quando em uso), mesmo que existam parcelas do imóvel a serem pagas nos próximos exercícios. Portanto, os encargos financeiros do financiamento do imóvel estão contabilizados como despesa operacional, e a depreciação já começa a ser contabilizada como conta redutora do ativo imobilizado. Esta premissa é coerente com o valor do ativo que está sendo considerado para análise dos impactos da imobilização no balanço. Ou seja, como o valor do imóvel considerado no balanço é o seu valor de mercado (fornecido no laudo de avaliação), considera-se que este seja o valor do imóvel quanto colocado pronto para uso, que contempla, portanto, as remunerações/encargos dos investidores/financiadores para conceber 0 ativo.

3 - Estas premissas adotadas para efeito de cálculo dos indicadores do Critério $\mathrm{H}$ (Desoneração do Balanço) do [MAOI] não alteram significativamente a análise, já que os impactos mais representativos são contabilizados sempre da mesma forma: [i] no ativo circulante (redução do caixa com as parcelas não financiadas do imóvel), [ii] no ativo imobilizado (valor de transação) e, [iii] no passivo exigível a longo prazo (valor do financiamento do imóvel, incluindo os encargos financeiros). Para efeito de contabilização dos juros no balanço considera-se o valor médio dos juros das parcelas Price (que são decrescentes à medida que as parcelas são pagas).

Quadro 31 - [alternativa] -SP a Prazo e impactos nos grupos de contas do balanço da empresa do caso - Imóvel 1 
ANÁLISE IMPACTO NO BALANÇO - EMPRESA DO CASO - IMÓVEL 1 (SEDE ADMINISTRATIVA) - SLB

IMPACTO NO ATIVO: DESMOBILIZAÇÃO (SLB)

\begin{tabular}{l}
\hline \multicolumn{1}{c}{ ATIVO } \\
\hline 1) Circulante \\
1.1) Disponibilidades \\
Acréscimo do circulante no valor de \\
transação do imóvel
\end{tabular}

2) Não Circulante

2.1) Ativo realizável a longo prazo

2.2) Ativo Imobilizado

Acréscimo do imobilizado, no montante equivalente ao preço da outorga, no caso do DRS como instrumento jurídico

Redução do imobilizado, referente à amortização da contraprestação (DRS) do período (somada à acumulada)

Redução do imobilizado, no montante equivalente ao valor contábil do imóvel

607.522
IMPACTO NO PASSIVO: DESMOBILIZAÇÃO (SLB)

\begin{tabular}{|l|r|r|}
\hline & Atual & $\begin{array}{c}\text { Impactos } \\
\text { [alternativa]: } \\
\text { SLB }\end{array}$ \\
\hline \multicolumn{1}{|c|}{ PASSIVO } & $\mathbf{9 2 6 . 7 8 9}$ & $\mathbf{9 6 8 . 0 4 2}$ \\
\hline $\begin{array}{l}\text { 1) Circulante } \\
\text { Acréscimo do circulante no valor da } \\
\text { despesa com alugueis e/ou } \\
\text { contraprestações do período } \\
\text { Acréscimo do circulante referente à } \\
\text { provisão dos impostos no caso da }\end{array}$ & $\mathbf{2 6 1 . 6 1 8}$ & $\mathbf{2 8 1 . 7 2 6}$ \\
\hline existo de luco na venda do atvo & & 6.082 \\
\hline
\end{tabular}

existência de lucro na venda do ativo

2) Não Circulante

2.1) Passivo Exigivel a Longo Prazo

Acréscimo do exigível a longo prazo,

montante equivalente ao preço da outorga (para DRS)

Redução do exigível a longo prazo, no valor acumulado da amortização referente às contraprestações de cada período (para DRS)

3) Patrimônio Líquido

210.466

210.466

$-$

$-$

454.705

475.850

Acréscimo na conta de lucros/prejuízos acumulados no montante equivalente à diferença entre o valor de venda e 0 valor contábil do ativo (já deduzido os impostos com a venda)

Redução na conta de lucros/prejuizos acumulados, no montante equivalente ao valor do aluguel do período (ou contraprestações para o DRS)

Quadro 32 - [alternativa] - SLB e impactos nos grupos de contas do balanço da empresa do caso - Imóvel 1 


\begin{tabular}{|c|c|c|c|c|c|}
\hline \multicolumn{6}{|c|}{$\begin{array}{l}\text { ANÁLISE IMPACTO NO BALANÇO - EMPRESA DO CASO - IMÓVEL } 2 \text { (UNIDADE FABRIL - ANTIBIÓTICOS) } \\
\text { Análise das [Alternativas] a partir das demandas e caracteristicas do imóvel } \\
\text { (Valores em R\$ mil) }\end{array}$} \\
\hline \multicolumn{3}{|c|}{ IMPACTO NO ATIVO: [ALTERNATIVAS] DE NÃO IMOBILIZAÇÃO } & \multicolumn{3}{|c|}{ IMPACTO NO PASSIVO: [ALTERNATIVAS] DE NÃO IMOBILIZAÇÃO } \\
\hline & Atual & $\begin{array}{l}\text { Impactos } \\
\text { [alternativas]: } \\
\text { BTS, LLP, LCP }\end{array}$ & & Atual & $\begin{array}{l}\text { Impactos } \\
\text { [alternativas]: } \\
\text { BTS, LLP, LCP }\end{array}$ \\
\hline ATIVO & 926.727 & 926.727 & PASSIVO & 926.727 & 926.727 \\
\hline $\begin{array}{l}\text { 1) Circulante } \\
\text { 1.1) Disponibilidades }\end{array}$ & $\begin{array}{r}286.853 \\
41.285\end{array}$ & 286.853 & $\begin{array}{l}\text { 1) Circulante } \\
\text { Acréscimo do circulante no valor da despesa } \\
\text { com alugueis e/ou contraprestações do } \\
\text { período }\end{array}$ & 261.618 & $\begin{array}{r}267.436 \\
5.818\end{array}$ \\
\hline 2) Não Circulante & 639.874 & 639.874 & 2) Não Circulante & 210.466 & 210.466 \\
\hline 2.1) Ativo realizável a longo prazo & 32.414 & - & $\begin{array}{l}\text { 2.1) Passivo Exigivel a Longo Prazo } \\
\text { Acréscimo do exigível a longo prazo no }\end{array}$ & 210.466 & - \\
\hline $\begin{array}{l}\text { 2.2) Ativo Imobilizado } \\
\text { Acréscimo do imobilizado no montante } \\
\text { equivalente ao preço da outorga, no caso do } \\
\text { DRS como instrumento jurídico }\end{array}$ & 607.460 & - & $\begin{array}{l}\text { montante equivalente ao preço da outorga } \\
\text { (para DRS) } \\
\text { Redução do exigível a longo prazo no valor } \\
\text { acumulado da amortização referente às } \\
\text { contraprestações de cada período (para } \\
\text { DRS) }\end{array}$ & & - \\
\hline $\begin{array}{l}\text { Redução do imobilizado referente à } \\
\text { amortização da contraprestação do DRS do } \\
\text { período (somada à acumulada) }\end{array}$ & & - & $\begin{array}{l}\text { 3) Patrimônio Líquido } \\
\text { Redução na conta de lucros/prejuízos } \\
\text { acumulados (lucro líquido) no montante } \\
\text { equivalente ao valor do aluguel do período } \\
\text { (ou contraprestação para DRS) }\end{array}$ & 454.643 & $\begin{array}{r}448.826 \\
(5.818)\end{array}$ \\
\hline
\end{tabular}

Quadro 33 - [alternativas] - BTS, LLP, LCP e impactos nos grupos de contas do balanço da empresa do caso Imóvel 2 


\begin{tabular}{|c|c|c|c|c|c|}
\hline \multicolumn{6}{|c|}{$\begin{array}{l}\text { ANÁLISE IMPACTO NO BALANÇO - EMPRESA DO CASO - IMÓVEL } 2 \text { (UNIDADE FABRIL - ANTIBIÓTICOS) } \\
\text { Análise das [Alternativas] a partir das demandas e características do imóvel } \\
\text { (Valores em R\$ mil) }\end{array}$} \\
\hline \multicolumn{3}{|c|}{ IMPACTO NO ATIVO: [SP] } & \multicolumn{3}{|c|}{ IMPACTO NO PASSIVO: [SP] } \\
\hline & Atual & $\begin{array}{c}\text { Impactos } \\
\text { [alternativa]: } \\
\text { [SP] }\end{array}$ & & Atual & $\begin{array}{c}\text { Impactos } \\
\text { [alternativa]: } \\
{[\mathrm{SP}]}\end{array}$ \\
\hline ATIVO & 926.727 & 925.156 & PASSIVO & 926.727 & 925.156 \\
\hline $\begin{array}{l}\text { 1) Circulante } \\
\text { 1.1) Disponibilidades } \\
\text { Redução do circulante no montante } \\
\text { equivalente à parcela do valor de transação } \\
\text { do imóvel com desembolsos considerados no } \\
\text { exercício, ou seja, em até } 12 \text { meses }\end{array}$ & $\begin{array}{r}286.853 \\
41.285\end{array}$ & $\begin{array}{l}264.853 \\
(22.000) \\
(22.000)\end{array}$ & 1) Circulante & 261.618 & 261.618 \\
\hline 2) Não Circulante & 639.874 & 660.303 & 2) Não Circulante & 210.466 & 210.466 \\
\hline $\begin{array}{l}\text { 2.1) Ativo realizável a longo prazo } \\
\text { Redução do circulante futuro no montante } \\
\text { equivalente à parcela de transação do imóvel } \\
\text { com desembolsos nos próximos exercícios, ou } \\
\text { seja, com pagamentos ocorrendo após } 12\end{array}$ & 32.414 & $(22.000)$ & 2.1) Passivo Exigível a Longo Prazo & 210.466 & - \\
\hline $\begin{array}{l}\text { 2.2) Ativo Imobilizado } \\
\text { Acréscimo do imobilizado no montante } \\
\text { equivalente ao valor de transação do imóvel }\end{array}$ & 607.460 & $\begin{array}{l}42.429 \\
44.000\end{array}$ & $\begin{array}{l}\text { 3) Patrimônio Líquido } \\
\text { Redução na conta de lucros/prejuizos } \\
\text { acumulados (lucro líquido) no montante } \\
\text { equivalente à depreciação do ativo no período }\end{array}$ & 454.643 & $\begin{array}{r}453.072 \\
(1.571)\end{array}$ \\
\hline $\begin{array}{l}\text { Redução do imobilizado referente à } \\
\text { depreciação do ativo no período (somada à } \\
\text { acumulada) }\end{array}$ & & (1.571) & & & \\
\hline
\end{tabular}

\section{Observações:}

1 - Em função do tamanho do imóvel e do volume de investimento envolvido, para efeito de análise do impacto no ativo circulante para as [alternativas] de imobilização (SP e SP a prazo) considera-se o pagamento do valor de transação do imóvel em 24 meses. Ou seja, parte do valor é pago com as disponibilidades do exercício e o restante a partir de 12 meses. Por isso, parte do pagamento é deduzida somente no ativo circulante do próximo exercício.

2 - Considera-se para análise do impacto das [alternativas] de imobilização a situação do ativo em regime operacional (ou seja, quando em uso), mesmo que existam parcelas do imóvel a serem pagas nos próximos exercícios. Portanto, a depreciação já começa a ser contabilizada como conta redutora do ativo imobilizado. Esta premissa é coerente como valor do ativo que está sendo considerado para análise dos impactos da imobilização no balanço. Ou seja, como o valor do imóvel considerado no balanço é o seu valor de mercado (fornecido no laudo de avaliação), considera-se que este seja o valor do imóvel quanto colocado pronto para uso, que contempla, portanto, as remunerações/encargos dos investidores/inanciadores para conceber 0 ativo.

3 - Estas premissas adotadas para efeito de cálculo dos indicadores do Critério $\mathrm{H}$ (Desoneração do Balanço) do [MAOI] não alteram significativamente a análise, já que os impactos mais representativos são contabilizados sempre da mesma forma: [i] no ativo circulante (redução do caixa para pagamento do valor de transação do imóvel) e [ii] no ativo imobilizado (valor de transação).

Quadro 34 - [alternativa] - SP e impactos nos grupos de contas do balanço da empresa do caso - Imóvel 2 


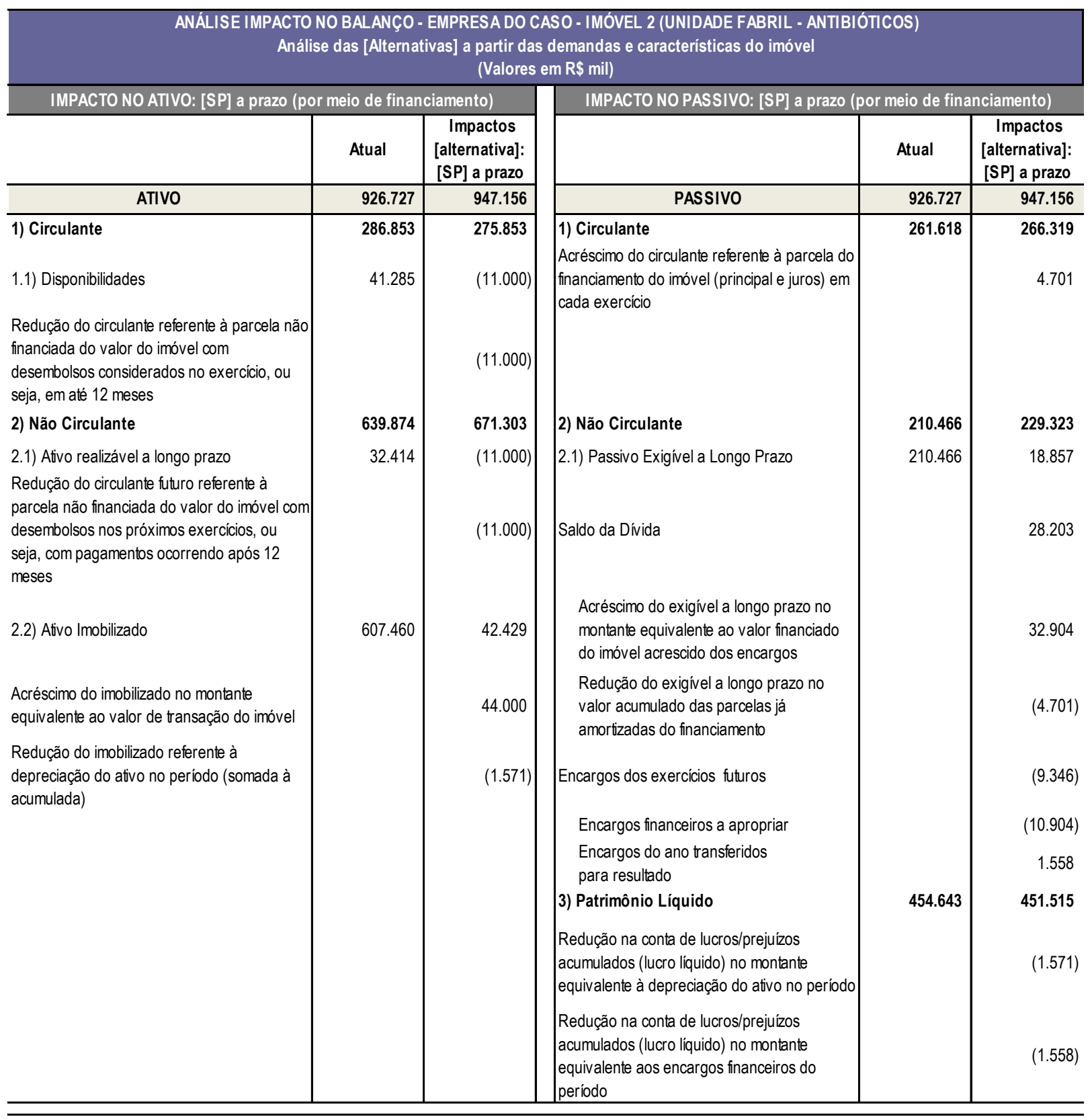

\section{Observações:}

1 - Em função do tamanho do imóvel e do volume de investimento envolvido, para efeito de análise do impacto no ativo circulante para as [alternativas] de imobilização (SP e SP a prazo) considera-se o pagamento do valor de transação do imóvel em 24 meses. Ou seja, parte do valor é pago com as disponibilidades do exercício e o restante a partir de 12 meses. Por isso, parte do pagamento é deduzida no ativo circulante do próximo exercício.

2 - Considera-se para análise do impacto das [alternativas] de imobilização a situação do ativo em regime operacional (ou seja, quando em uso), mesmo que existam parcelas do imóvel a serem pagas nos próximos exercícios. Portanto, os encargos financeiros do financiamento do imóvel estão contabilizados como despesa operacional, e a depreciação já começa a ser contabilizada como conta redutora do ativo imobilizado. Esta premissa é coerente com o valor do ativo que está sendo considerado para análise dos impactos da imobilização no balanço. Ou seja, como o valor do imóvel considerado no balanço é o seu valor de mercado (fornecido no laudo de avaliação), considera-se que este seja o valor do imóvel quanto colocado pronto para uso, que contempla, portanto, as remunerações/encargos dos investidores/financiadores para conceber 0 ativo.

3 - Estas premissas adotadas para efeito de cálculo dos indicadores do Critério H (Desoneração do Balanço) do [MAOI] não alteram significativamente a análise, já que os impactos mais representativos são contabilizados sempre da mesma forma: [i] no ativo circulante (redução do caixa com as parcelas não financiadas do imóvel), [ii] no ativo imobilizado (valor de transação) e, [iii] no passivo exigível a longo prazo (valor do financiamento do imóvel, incluindo os encargos financeiros). Para efeito de contabilização dos juros no balanço considera-se o valor médio dos juros das parcelas Price (que são decrescentes à medida que as parcelas são pagas).

Quadro 35 - [alternativa] -SP a Prazo e impactos nos grupos de contas do balanço da empresa do caso - Imóvel 2 
ANÁLISE IMPACTO NO BALANÇO - EMPRESA DO CASO - IMÓVEL 2 (UNIDADE FABRIL - ANTIBIÓTICOS) - SLB IMPACTO NO ATIVO: DESMOBILIZAÇÃO (SLB)

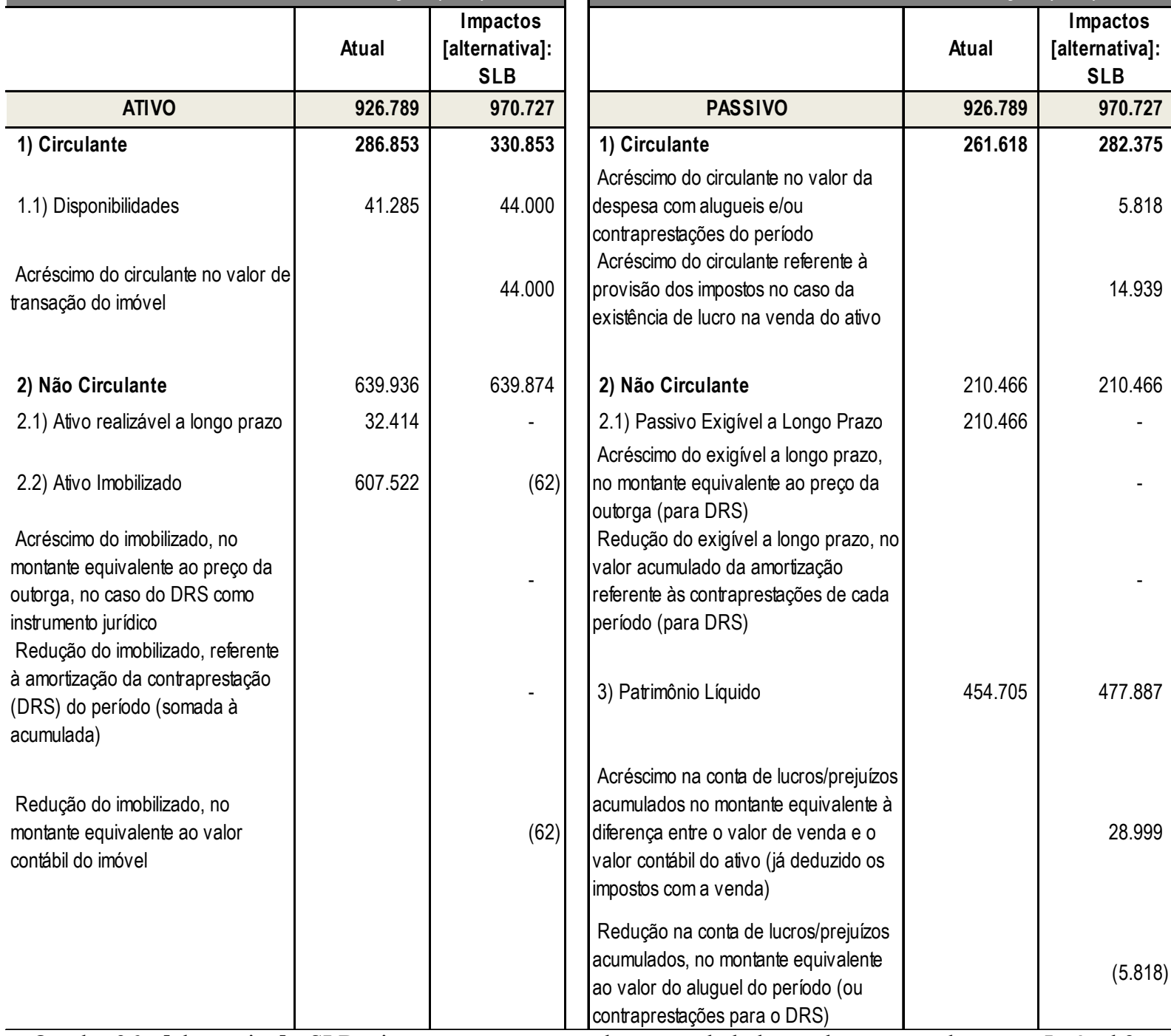

Quadro 36 - [alternativa] - SLB e impactos nos grupos de contas do balanço da empresa do caso - Imóvel 2 


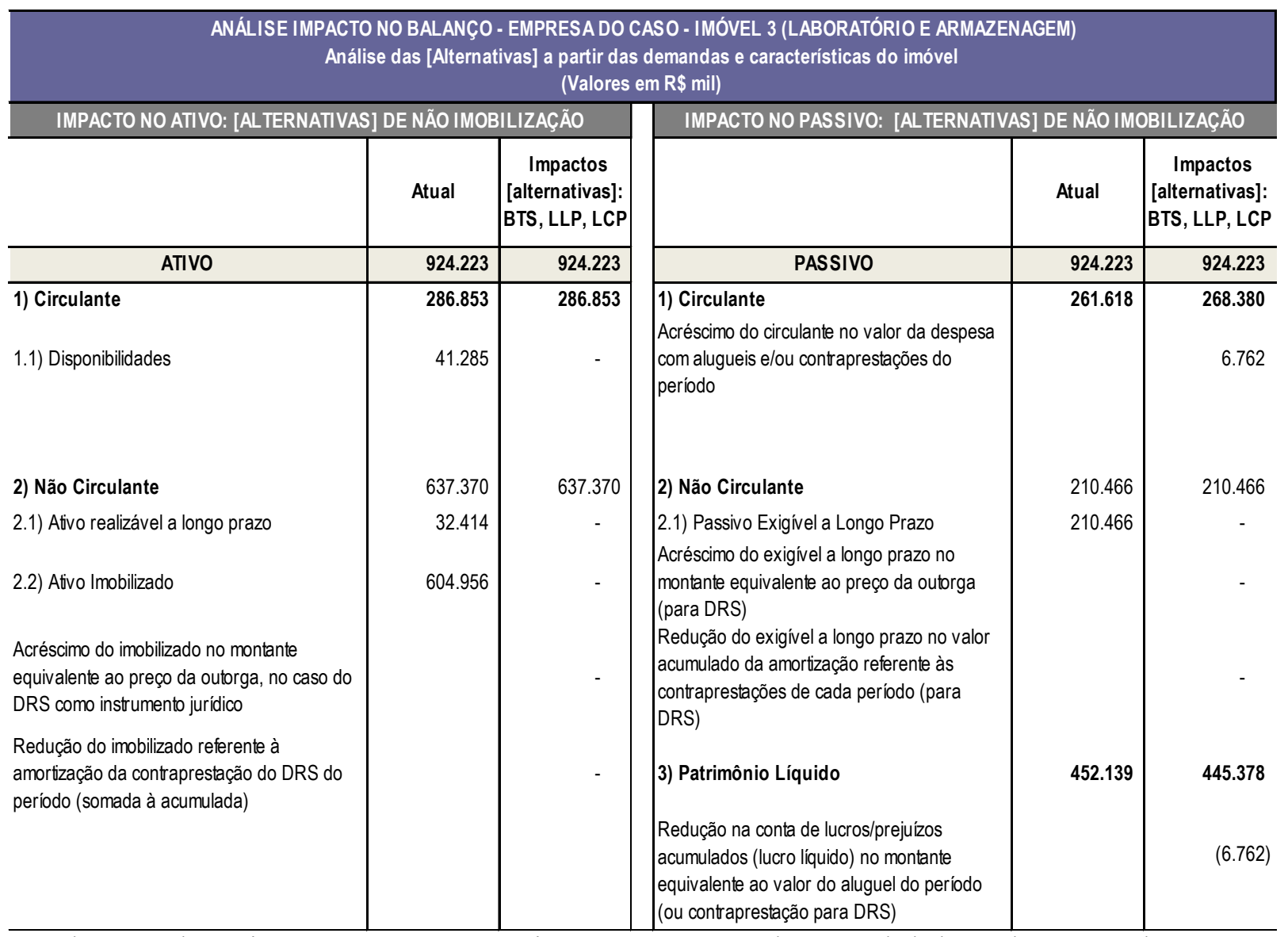

Quadro 37 - [alternativas] - BTS, LLP, LCP e impactos nos grupos de contas do balanço da empresa do caso Imóvel 3 


\begin{tabular}{|c|c|c|c|c|c|}
\hline \multicolumn{6}{|c|}{$\begin{array}{l}\text { ANÁLISE IMPACTO NO BALANÇO - EMPRESA DO CASO - IMÓVEL } 3 \text { (LABORATÓRIO E ARMAZENAGEM) } \\
\text { Análise das [Alternativas] a partir das demandas e características do imóvel } \\
\text { (Valores em R\$ mil) }\end{array}$} \\
\hline \multicolumn{3}{|c|}{ IMPACTO NO ATIVO: [SP] } & \multicolumn{3}{|c|}{ IMPACTO NO PASSIVO: [SP] } \\
\hline & Atual & $\begin{array}{c}\text { Impactos } \\
\text { [alternativa]: } \\
{[\mathrm{SP}]}\end{array}$ & & Atual & $\begin{array}{l}\text { Impactos } \\
\text { [alternativa]: } \\
{[\text { SP] }}\end{array}$ \\
\hline ATIVO & 924.223 & 922.744 & PASSIVO & 924.223 & 922.744 \\
\hline 1) Circulante & 286.853 & 261.353 & 1) Circulante & 261.618 & 261.618 \\
\hline 1.1) Disponibilidades & 41.285 & $(25.500)$ & & & \\
\hline $\begin{array}{l}\text { Redução do circulante no montante } \\
\text { equivalente à parcela do valor de transação } \\
\text { do imóvel com desembolsos considerados no } \\
\text { exercício, ou seja, em até } 12 \text { meses }\end{array}$ & & $(25.500)$ & & & \\
\hline 2) Não Circulante & 637.370 & 661.391 & 2) Não Circulante & 210.466 & 210.466 \\
\hline 2.1) Ativo realizável a longo prazo & 32.414 & $(25.500)$ & 2.1) Passivo Exigível a Longo Prazo & 210.466 & - \\
\hline $\begin{array}{l}\text { Redução do circulante futuro no montante } \\
\text { equivalente à parcela de transação do imóvel } \\
\text { com desembolsos nos próximos exercícios, ou } \\
\text { seja, com pagamentos ocorrendo após } 12 \\
\text { meses }\end{array}$ & & $(25.500)$ & & & \\
\hline 2.2) Ativo Imobilizado & 604.956 & 49.521 & & 452.139 & 450.660 \\
\hline $\begin{array}{l}\text { Acréscimo do imobilizado no montante } \\
\text { equivalente ao valor de transação do imóvel }\end{array}$ & & 51.000 & $\begin{array}{l}\text { Redução na conta de lucros/prejuízos } \\
\text { acumulados (lucro liquido) no montante } \\
\text { equivalente à depreciação do ativo no periodo }\end{array}$ & & $(1.479)$ \\
\hline $\begin{array}{l}\text { Redução do imobilizado referente à } \\
\text { depreciação do ativo no período (somada à } \\
\text { acumulada) }\end{array}$ & & $(1.479)$ & & & \\
\hline
\end{tabular}
acumulada)

\section{Observações:}

1 - Em função do tamanho do imóvel e do volume de investimento envolvido, para efeito de análise do impacto no ativo circulante para as [alternativas] de imobilização (SP e SP a prazo) considera-se o pagamento do valor de transação do imóvel em 24 meses. Ou seja, parte do valor é pago com as disponibilidades do exercício e o restante a partir de 12 meses. Por isso, parte do pagamento é deduzida somente no ativo circulante do próximo exercício.

2 - Considera-se para análise do impacto das [alternativas] de imobilização a situação do ativo em regime operacional (ou seja, quando em uso), mesmo que existam parcelas do imóvel a serem pagas nos próximos exercícios. Portanto, a depreciação já começa a ser contabilizada como conta redutora do ativo imobilizado. Esta premissa é coerente com o valor do ativo que está sendo considerado para análise dos impactos da imobilização no balanço. Ou seja, como o valor do imóvel considerado no balanço é o seu valor de mercado (fornecido no laudo de avaliação), considera-se que este seja o valor do imóvel quanto colocado pronto para uso, que contempla, portanto, as remunerações/encargos dos investidores/financiadores para conceber 0 ativo.

3 - Estas premissas adotadas para efeito de cálculo dos indicadores do Critério H (Desoneração do Balanço) do [MAOI] não alteram significativamente a análise, já que os impactos mais representativos são contabilizados sempre da mesma forma: [i] no ativo circulante (redução do caixa para pagamento do valor de transação do imóvel) e [ii] no ativo imobilizado (valor de transação).

Quadro 38 - [alternativa] - SP e impactos nos grupos de contas do balanço da empresa do caso - Imóvel 3 


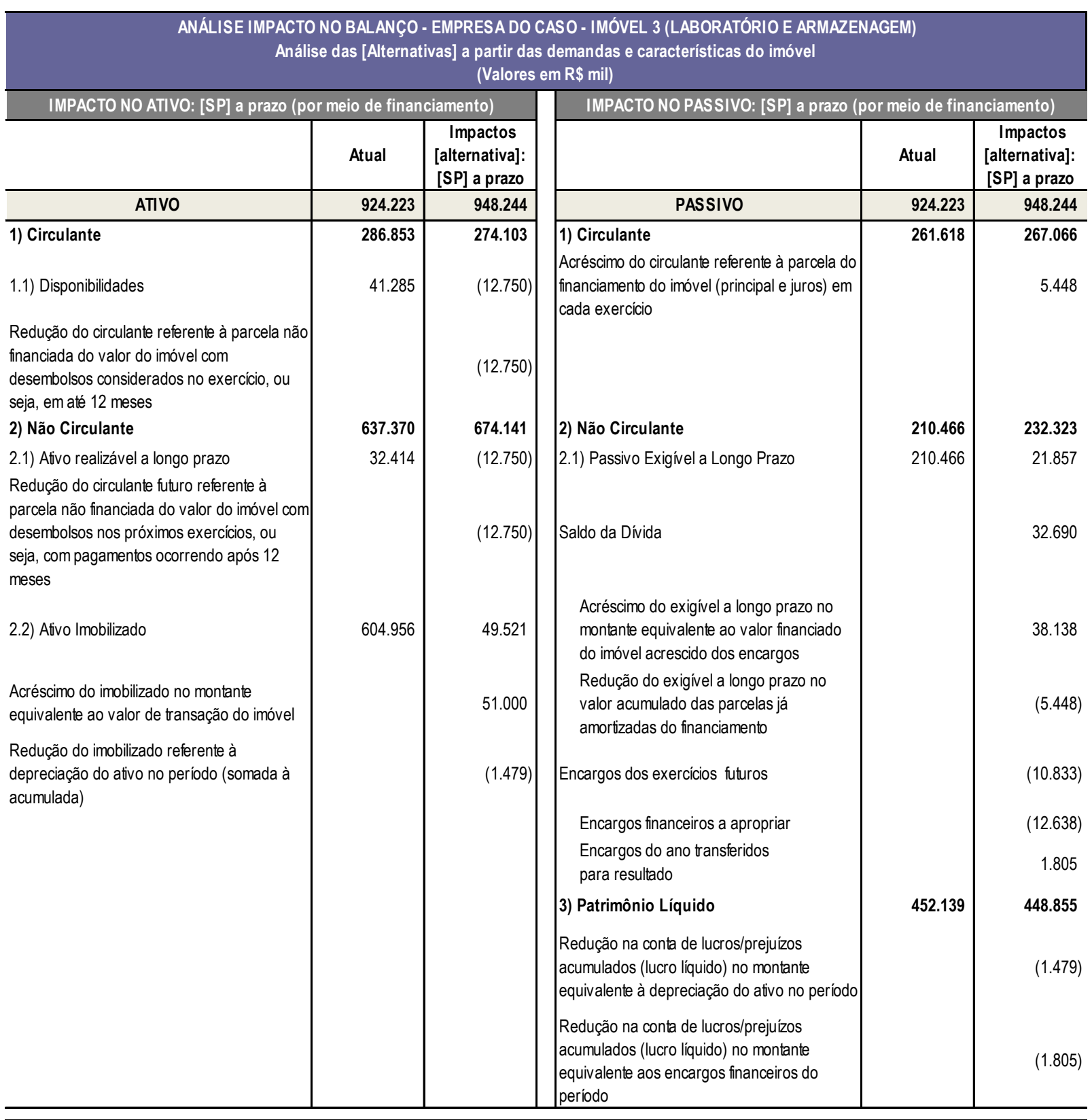

\section{Observações:}

1 - Em função do tamanho do imóvel e do volume de investimento envolvido, para efeito de análise do impacto no ativo circulante para as [alternativas] de imobilização (SP e SP a prazo) considera-se o pagamento do valor de transação do imóvel em 24 meses. Ou seja, parte do valor é pago com as disponibilidades do exercício e o restante a partir de 12 meses. Por isso, parte do pagamento é deduzida no ativo circulante do próximo exercício.

2 - Considera-se para análise do impacto das [alternativas] de imobilização a situação do ativo em regime operacional (ou seja, quando em uso), mesmo que existam parcelas do imóvel a serem pagas nos próximos exercícios. Portanto, os encargos financeiros do financiamento do imóvel estão contabilizados como despesa operacional, e a depreciação já começa a ser contabilizada como conta redutora do ativo imobilizado. Esta premissa é coerente com o valor do ativo que está sendo considerado para análise dos impactos da imobilização no balanço. Ou seja, como o valor do imóvel considerado no balanço é o seu valor de mercado (fornecido no laudo de avaliação), considera-se que este seja o valor do imóvel quanto colocado pronto para uso, que contempla, portanto, as remunerações/encargos dos investidores/financiadores para conceber 0 ativo.

3 - Estas premissas adotadas para efeito de cálculo dos indicadores do Critério $\mathrm{H}$ (Desoneração do Balanço) do [MAOI] não alteram significativamente a análise, já que os impactos mais representativos são contabilizados sempre da mesma forma: [i] no ativo circulante (redução do caixa com as parcelas não financiadas do imóvel), [ii] no ativo imobilizado (valor de transação) e, [iii] no passivo exigível a longo prazo (valor do financiamento do imóvel, incluindo os encargos financeiros). Para efeito de contabilização dos juros no balanço considera-se o valor médio dos juros das parcelas Price (que são decrescentes à medida que as parcelas são pagas).

Quadro 39 - [alternativa] -SP a Prazo e impactos nos grupos de contas do balanço da empresa do caso - Imóvel 3 
ANÁLISE IMPACTO NO BALANÇO - EMPRESA DO CASO - IMÓVEL 3 (LABORATÓRIO E ARMAZENAGEM) - SLB

IMPACTO NO ATIVO: DESMOBILIZAÇÃO (SLB)

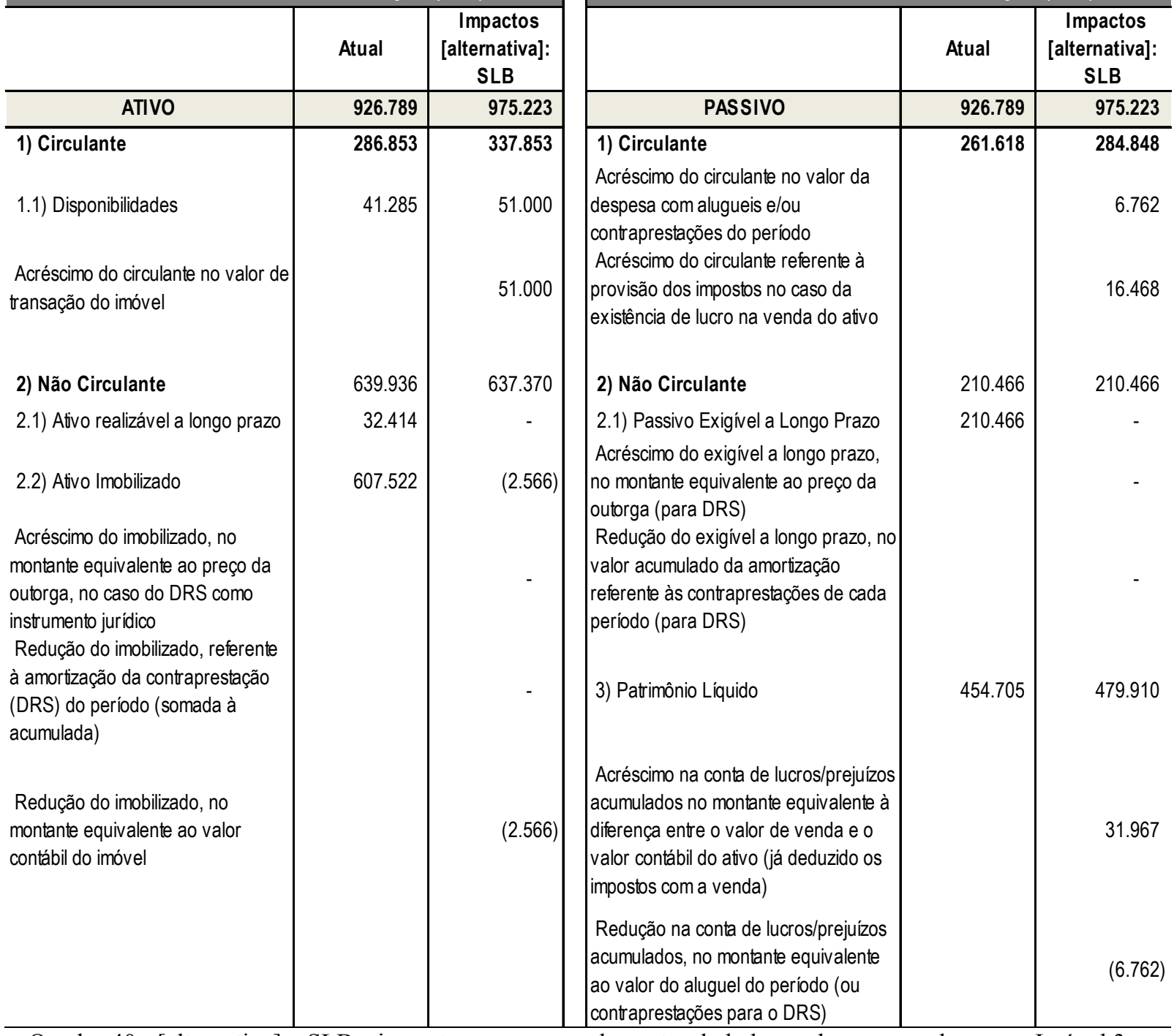

Quadro 40 - [alternativa] - SLB e impactos nos grupos de contas do balanço da empresa do caso - Imóvel 3 


\begin{tabular}{|c|c|c|c|c|c|}
\hline \multicolumn{6}{|c|}{$\begin{array}{c}\text { ANÁLISE IMPACTO NO BALANÇO - EMPRESA DO CASO - IMÓVEL } 4 \text { (COMPLEXO INDUSTRIAL) } \\
\text { Análise das [Alternativas] a partir das demandas e características do imóvel } \\
\text { (Valores em R\$ mil) }\end{array}$} \\
\hline \multicolumn{3}{|c|}{ IMPACTO NO ATIVO: [ALTERNATIVAS] DE NÃO IMOBILIZAÇÃO } & \multicolumn{3}{|c|}{ IMPACTO NO PASSIVO: [ALTERNATIVAS] DE NÃO IMOBILIZAÇÃO } \\
\hline & Atual & $\begin{array}{c}\text { Impactos } \\
\text { [alternativas]: } \\
\text { BTS, LLP, LCP }\end{array}$ & & Atual & $\begin{array}{l}\text { Impactos } \\
\text { [alternativas]: } \\
\text { BTS, LLP, LCP }\end{array}$ \\
\hline ATIVO & 691.789 & 691.789 & PASSIVO & 691.789 & 691.789 \\
\hline 1) Circulante & 331.853 & 331.853 & 1) Circulante & 236.618 & 273.578 \\
\hline 1.1) Disponibilidades & 86.285 & - & $\begin{array}{l}\text { Acréscimo do circulante no valor da despesa } \\
\text { com alugueis e/ou contraprestações do } \\
\text { período }\end{array}$ & & 36.960 \\
\hline 2) Não Circulante & 359.936 & 359.936 & 2) Não Circulante & 148.466 & 148.466 \\
\hline 2.1) Ativo realizável a longo prazo & 32.414 & - & $\begin{array}{l}\text { 2.1) Passivo Exigível a Longo Prazo } \\
\text { Acréscimo do exigivel a longo prazo no }\end{array}$ & 148.466 & \\
\hline $\begin{array}{l}\text { 2.2) Ativo Imobilizado } \\
\text { Acréscimo do imobilizado no montante } \\
\text { equivalente ao preço da outorga, no caso do } \\
\text { DRS como instrumento juríico }\end{array}$ & 327.522 & - & $\begin{array}{l}\text { montante equivalente ao preço da outorga } \\
\text { (para DRS) } \\
\text { Redução do exigivel a longo prazo no valor } \\
\text { acumulado da amorizzação referente às } \\
\text { contraprestações de cada período (para } \\
\text { DRS) }\end{array}$ & & - \\
\hline $\begin{array}{l}\text { Redução do imobilizado referente à } \\
\text { amortzação da contraprestação do DRS do } \\
\text { período (somada à acumulada) }\end{array}$ & & - & $\begin{array}{l}\text { 3) Patrimônio Líquido } \\
\text { Redução na conta de lucros/prejuizos } \\
\text { acumulados (lucro líquido) no montante } \\
\text { equivalente ao valor do aluguel do periodo } \\
\text { (ou contraprestação para DRS) }\end{array}$ & 306.705 & $\begin{array}{r}269.745 \\
(36.960)\end{array}$ \\
\hline
\end{tabular}

Quadro 41 - [alternativas] - BTS, LLP, LCP e impactos nos grupos de contas do balanço da empresa do caso Imóvel 4 


\begin{tabular}{|c|c|c|c|c|c|}
\hline \multicolumn{6}{|c|}{$\begin{array}{c}\text { ANÁLISE IMPACTO NO BALANÇO - EMPRESA DO CASO - IMÓVEL } 4 \text { (COMPLEXO INDUS TRIAL) } \\
\text { Análise das [Alternativas] a partir das demandas e características do imóvel } \\
\text { (Valores em } R \$ \text { mil) }\end{array}$} \\
\hline \multicolumn{3}{|c|}{ IMPACTO NO ATIVO: [SP] } & \multicolumn{3}{|c|}{ IMPACTO NO PASSIVO: [SP] } \\
\hline & Atual & $\begin{array}{c}\text { Impactos } \\
\text { [alternativa]: } \\
{[\mathrm{SP}]}\end{array}$ & & Atual & $\begin{array}{c}\text { Impactos } \\
\text { [alternativa]: } \\
{[\mathrm{SP}]}\end{array}$ \\
\hline ATIVO & 691.789 & 681.089 & PASSIVO & 691.789 & 681.089 \\
\hline 1) Circulante & 331.853 & 238.520 & 1) Circulante & 236.618 & 236.618 \\
\hline 1.1) Disponibilidades & 86.285 & (93.333) & & & \\
\hline $\begin{array}{l}\text { Redução do circulante no montante } \\
\text { equivalente à parcela do valor de transação } \\
\text { do imóvel com desembolsos considerados no } \\
\text { exercício, ou seja, em até } 12 \text { meses }\end{array}$ & & (93.333) & & & \\
\hline 2) Não Circulante & 359.936 & 442.569 & 2) Não Circulante & 148.466 & 148.466 \\
\hline 2.1) Ativo realizável a longo prazo & 32.414 & $(186.667)$ & 2.1) Passivo Exigível a Longo Prazo & 148.466 & - \\
\hline $\begin{array}{l}\text { Redução do circulante futuro no montante } \\
\text { equivalente à parcela de transação do imóvel } \\
\text { com desembolsos nos próximos exercícios, ou } \\
\text { seja, com pagamentos ocorrendo após } 12\end{array}$ & & $(186.667)$ & & & \\
\hline 2.2) Ativo Imobilizado & 327.522 & 269.300 & 3) Patrimônio Líquido & 306.705 & 296.005 \\
\hline $\begin{array}{l}\text { Acréscimo do imobilizado no montante } \\
\text { equivalente ao valor de transação do imóvel }\end{array}$ & & 280.000 & $\begin{array}{l}\text { Redução na conta de lucros/prejúzos } \\
\text { acumulados (lucro líquido) no montante } \\
\text { equivalente à depreciação do ativo no período }\end{array}$ & & $(10.700)$ \\
\hline $\begin{array}{l}\text { Redução do imobilizado referente à } \\
\text { depreciação do ativo no período (somada à } \\
\text { acumulada) }\end{array}$ & & $(10.700)$ & & & \\
\hline
\end{tabular}

\section{Observações:}

1 - Em função do tamanho do imóvel e do volume de investimento envolvido, para efeito de análise do impacto no ativo circulante para as [alternativas] de imobilização (SP e SP a prazo) considera-se o pagamento do valor de transação do imóvel em 36 meses. Ou seja, parte do valor é pago com as disponibilidades do exercício e 0 restante a partir de 12 meses. Por isso, parte do pagamento é deduzida no ativo circulante do próximo exercício.

2 - Considera-se para análise do impacto das [alternativas] de imobilização a situação do ativo em regime operacional (ou seja, quando em uso), mesmo que existam parcelas do imóvel a serem pagas nos próximos exercícios. Portanto, a depreciação já começa a ser contabilizada como conta redutora do ativo imobilizado. Esta premissa é coerente com o valor do ativo que está sendo considerado para análise dos impactos da imobilização no balanço. Ou seja, como o valor do imóvel considerado no balanço é o seu valor de mercado (fornecido no laudo de avaliação), considera-se que este seja o valor do imóvel quanto colocado pronto para uso, que contempla, portanto, as remunerações/encargos dos investidores/financiadores para conceber 0 ativo.

3 - Estas premissas adotadas para efeito de cálculo dos indicadores do Critério $\mathrm{H}$ (Desoneração do Balanço) do [MAOl] não alteram significativamente a análise, já que os impactos mais representativos são contabilizados sempre da mesma forma: [i] no ativo circulante (redução do caixa para pagamento do valor de transação do imóvel) e [ii] no ativo imobilizado (valor de transação).

Quadro 42 - [alternativa] - SP e impactos nos grupos de contas do balanço da empresa do caso - Imóvel 4 


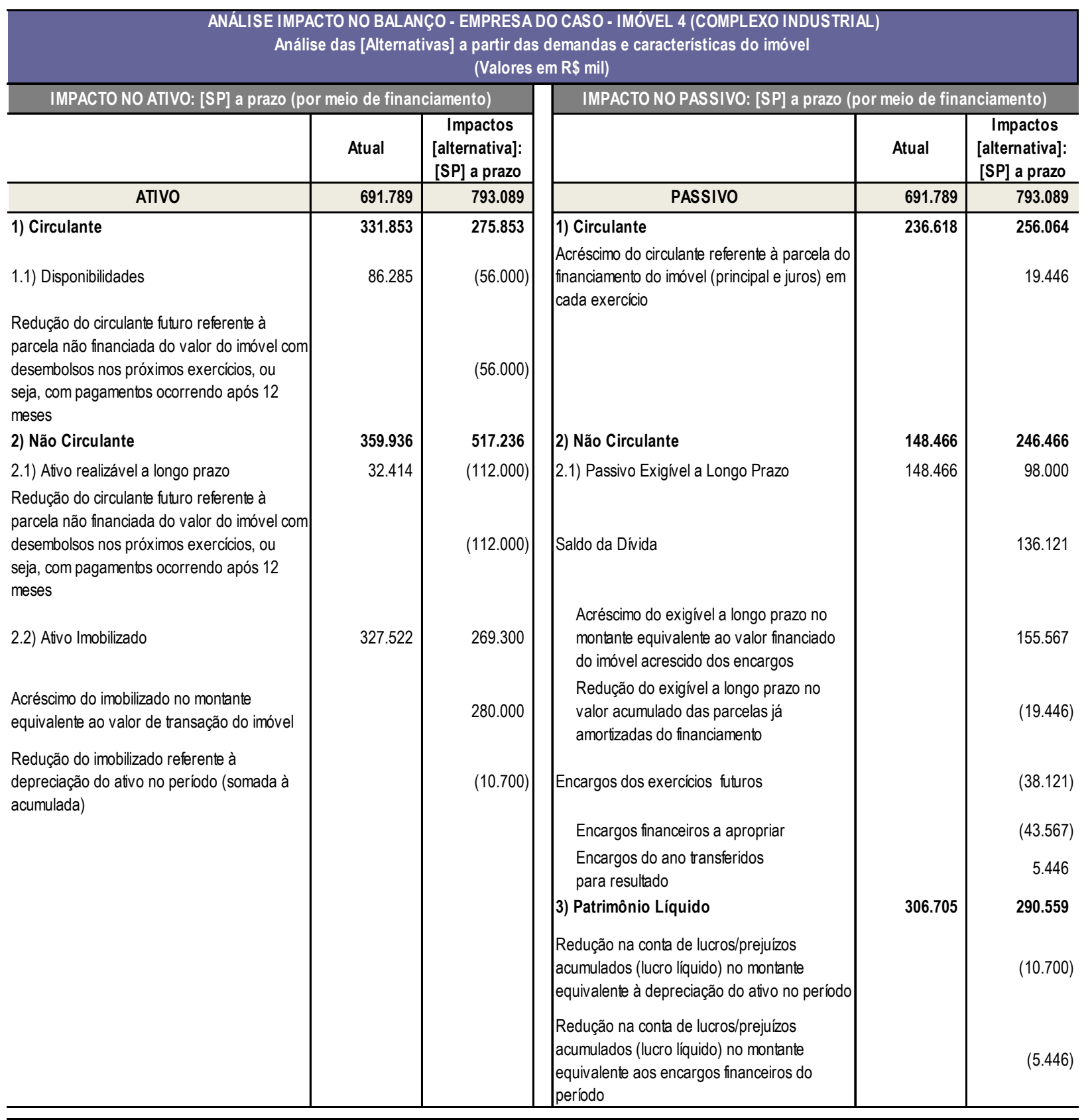

\section{Observações:}

1 - Em função do tamanho do imóvel e do volume de investimento envolvido, para efeito de análise do impacto no ativo circulante para as [alternativas] de imobilização (SP e SP a prazo) considera-se o pagamento do valor de transação do imóvel em 36 meses. Ou seja, parte do valor é pago com as disponibilidades do exercício e o restante a partir de 12 meses. Por isso, parte do pagamento é deduzida no ativo circulante do próximo exercício.

2 - Considera-se para análise do impacto das [alternativas] de imobilização a situação do ativo em regime operacional (ou seja, quando em uso), mesmo que existam parcelas do imóvel a serem pagas nos próximos exercícios. Portanto, os encargos financeiros do financiamento do imóvel estão contabilizados como despesa operacional, e a depreciação já começa a ser contabilizada como conta redutora do ativo imobilizado. Esta premissa é coerente com o valor do ativo que está sendo considerado para análise dos impactos da imobilização no balanço. Ou seja, como o valor do imóvel considerado no balanço é o seu valor de mercado (fornecido no laudo de avaliação), considera-se que este seja o valor do imóvel quanto colocado pronto para uso, que contempla, portanto, as remunerações/encargos dos investidores/financiadores para conceber o ativo.

3 - Estas premissas adotadas para efeito de cálculo dos indicadores do Critério H (Desoneração do Balanço) do [MAOI] não alteram significativamente a análise, já que os impactos mais representativos são contabilizados sempre da mesma forma: [i] no ativo circulante (redução do caixa com as parcelas não financiadas do imóvel), [ii] no ativo imobilizado (valor de transação) e, [iii] no passivo exigível a longo prazo (valor do financiamento do imóvel, incluindo os encargos financeiros). Para efeito de contabilização dos juros no balanço considera-se o valor médio dos juros das parcelas Price (que são decrescentes à medida que as parcelas são pagas).

Quadro 43 - [alternativa] -SP a Prazo e impactos nos grupos de contas do balanço da empresa do caso - Imóvel 4 
ANÁLISE IMPACTO NO BALANÇO - EMPRESA DO CASO - IMÓVEL 4 (COMPLEXO INDUSTRIAL) - SLB

IMPACTO NO ATIVO: DESMOBILIZAÇÃO (SLB)

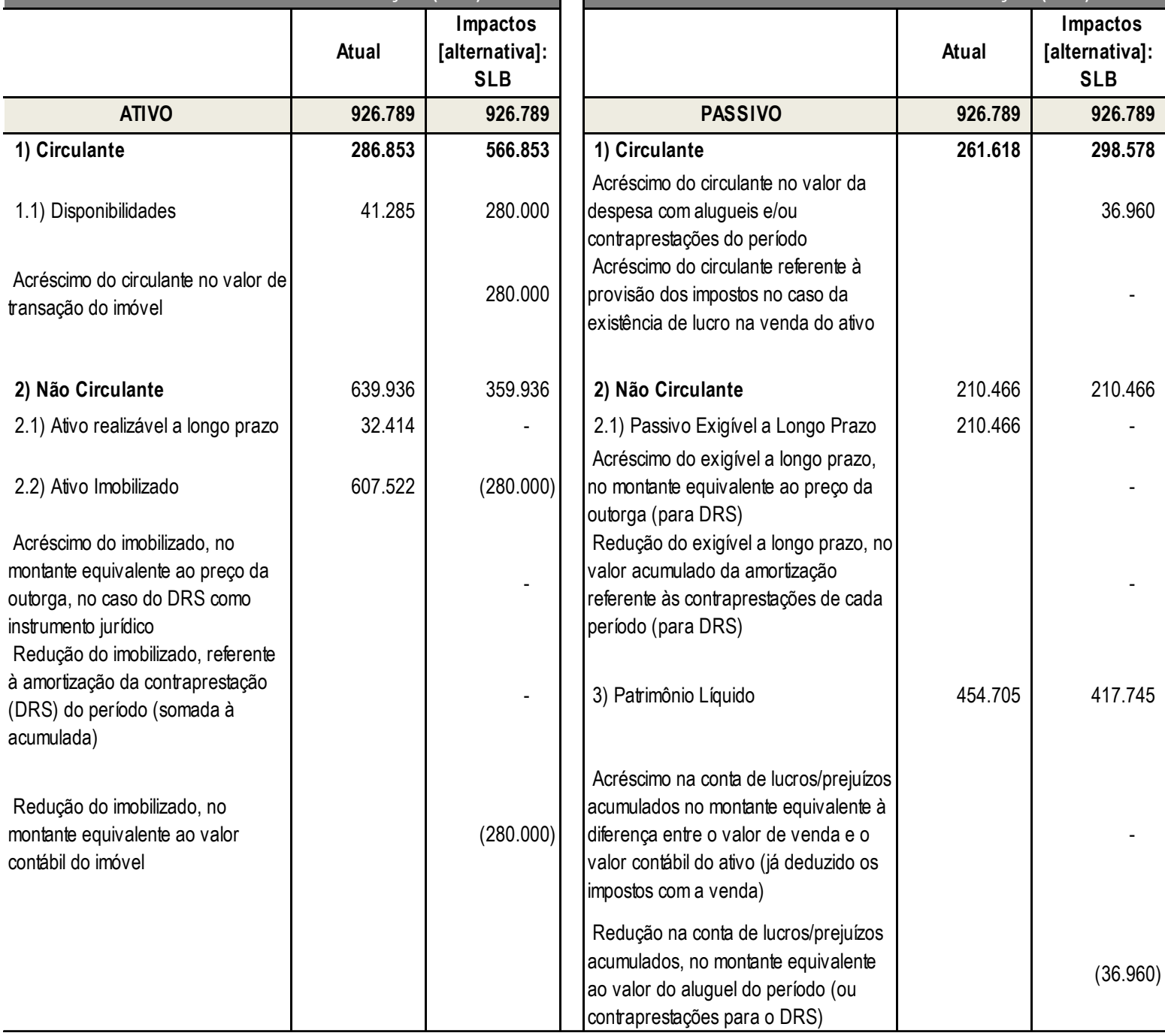

Quadro 44 - [alternativa] - SLB e impactos nos grupos de contas do balanço da empresa do caso - Imóvel 4 
ANÁLISE IMPACTO NO BALANÇO - EMPRESA DO CASO - IMÓVEL 5 (CENTRO DE PESQUISAS CLÍNICAS) Análise das [Alternativas] a partir das demandas e caracteristicas do imóvel

\section{(Valores em R\$ mil)}

IMPACTO NO ATIVO: [ALTERNATIVAS] DE NÃO IMOBILIZAÇÃO

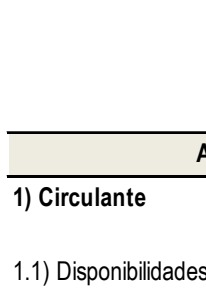

2) Não Circulante

2.1) Ativo realizável a longo prazo

2.2) Ativo Imobilizado

Acréscimo do imobilizado no montante equivalente ao preço da outorga, no caso do DRS como instrumento jurídico

Redução do imobilizado referente à amortização da contraprestação do DRS do período (somada à acumulada)
IMPACTO NO PASSIVO: [ALTERNATIVAS] DE NÃO IMOBILIZAÇÃO

\begin{tabular}{|c|c|c|}
\hline & Atual & $\begin{array}{c}\text { Impactos } \\
\text { [alternativas]: } \\
\text { BTS, LLP, LCP }\end{array}$ \\
\hline PASSIVO & 926.637 & 926.637 \\
\hline $\begin{array}{l}\text { 1) Circulante } \\
\text { Acréscimo do circulante no valor da despesa } \\
\text { com alugueis e/ou contraprestações do } \\
\text { período }\end{array}$ & 261.618 & $\begin{array}{r}263.209 \\
1.591\end{array}$ \\
\hline $\begin{array}{l}\text { 2) Não Circulante } \\
\text { 2.1) Passivo Exigível a Longo Prazo } \\
\text { Acréscimo do exigível a longo prazo no } \\
\text { montante equivalente ao preço da outorga } \\
\text { (para DRS) } \\
\text { Redução do exigivel a longo prazo no valor } \\
\text { acumulado da amortização referente às } \\
\text { contraprestações de cada período (para } \\
\text { DRS) }\end{array}$ & $\begin{array}{l}210.466 \\
210.466\end{array}$ & $\begin{array}{c}210.466 \\
- \\
-\end{array}$ \\
\hline $\begin{array}{l}\text { 3) Patrimônio Líquido } \\
\text { Redução na conta de lucros/prejuízos } \\
\text { acumulados (lucro líquido) no montante } \\
\text { equivalente ao valor do aluguel do periodo } \\
\text { (ou contraprestação para DRS) }\end{array}$ & 454.553 & $\begin{array}{r}452.962 \\
(1.591)\end{array}$ \\
\hline
\end{tabular}

Quadro 45 - [alternativas] - BTS, LLP, LCP e impactos nos grupos de contas do balanço da empresa do caso Imóvel 5 


\begin{tabular}{|c|c|c|c|c|c|}
\hline \multicolumn{6}{|c|}{$\begin{array}{l}\text { ANÁLISE IMPACTO NO BALANÇO - EMPRESA DO CASO - IMÓVEL } 5 \text { (CENTRO DE PESQUISAS CLÍNICAS) } \\
\text { Análise das [Alternativas] a partir das demandas e caracteristicas do imóvel } \\
\text { (Valores em R\$ mil) }\end{array}$} \\
\hline \multicolumn{3}{|c|}{ IMPACTO NO ATIVO: [SP] } & \multicolumn{3}{|c|}{ IMPACTO NO PASSIVO: [SP] } \\
\hline & Atual & $\begin{array}{l}\text { Impactos } \\
\text { [alternativa]: } \\
{[\mathrm{SP}]}\end{array}$ & & Atual & $\begin{array}{l}\text { Impactos } \\
\text { [alternativa]: } \\
{[\mathrm{SP}]}\end{array}$ \\
\hline ATIVO & 926.637 & 926.220 & PASSIVO & 926.637 & 926.220 \\
\hline 1) Circulante & 286.853 & 274.853 & 1) Circulante & 261.618 & 261.618 \\
\hline 1.1) Disponibilidades & 41.285 & (12.000) & & & \\
\hline $\begin{array}{l}\text { Redução do circulante no valor de transação } \\
\text { do imóvel }\end{array}$ & & (12.000) & & & \\
\hline 2) Não Circulante & 639.784 & 651.367 & 2) Não Circulante & 210.466 & 210.466 \\
\hline 2.1) Ativo realizável a longo prazo & 32.414 & - & 2.1) Passivo Exigível a Longo Prazo & 210.466 & - \\
\hline 2.2) Ativo Imobilizado & 607.370 & 11.583 & 3) Patrimônio Líquido & 454.553 & 454.136 \\
\hline $\begin{array}{l}\text { Acréscimo do imobilizado no montante } \\
\text { equivalente ao valor de transação do imóvel }\end{array}$ & & 12.000 & $\begin{array}{l}\text { Redução na conta de lucros/prejúzzos } \\
\text { acumulados (lucro liquido) no montante } \\
\text { equivalente à depreciação do ativo no período }\end{array}$ & & $(417)$ \\
\hline $\begin{array}{l}\text { Redução do imobilizado referente à } \\
\text { depreciação do ativo no período (somada à } \\
\text { acumulada) }\end{array}$ & & (417) & & & \\
\hline
\end{tabular}

\section{Observações:}

1 - Considera-se para análise do impacto das [alternativas] de imobilização a situação do ativo em regime operacional (ou seja, quando em uso). Portanto, a depreciação já começa a ser contabilizada como conta redutora do ativo imobilizado. Esta premissa é coerente com o valor do ativo que está sendo considerado para análise dos impactos da imobilização no balanço. Ou seja, como o valor do imóvel considerado no balanço é o seu valor de mercado (fornecido no laudo de avaliação), considera-se que este seja o valor do imóvel quanto colocado pronto para uso, que contempla, portanto, as remunerações/encargos dos investidores/financiadores para conceber 0 ativo.

2 - Estas premissas adotadas para efeito de cálculo dos indicadores do Critério H (Desoneração do Balanço) do [MAOI] não alteram significativamente a análise, já que os impactos mais representativos são contabilizados sempre da mesma forma: [i] no ativo circulante (redução do caixa para pagamento do valor de transação do imóvel) e [ii] no ativo imobilizado (valor de transação).

Quadro 46 - [alternativa] - SP e impactos nos grupos de contas do balanço da empresa do caso - Imóvel 5 


\begin{tabular}{|c|c|c|c|c|c|}
\hline \multicolumn{6}{|c|}{$\begin{array}{l}\text { ANÁLISE IMPACTO NO BALANÇO - EMPRESA DO CASO - IMÓVEL } 5 \text { (CENTRO DE PESQUISAS CLÍNICAS) } \\
\text { Análise das [Alternativas] a partir das demandas e características do imóvel } \\
\text { (Valores em R\$ mil) }\end{array}$} \\
\hline \multicolumn{3}{|c|}{ IMPACTO NO ATIVO: [SP] a prazo (por meio de financiamento) } & \multicolumn{3}{|c|}{ IMPACTO NO PASSIVO: [SP] a prazo (por meio de financiamento) } \\
\hline & Atual & $\begin{array}{c}\text { Impactos } \\
\text { [alternativa]: } \\
\text { [SP] a prazo }\end{array}$ & & Atual & $\begin{array}{l}\text { Impactos } \\
\text { [alternativa]: } \\
\text { [SP] a prazo }\end{array}$ \\
\hline ATIVO & 926.637 & 932.220 & PASSIVO & 926.637 & 932.220 \\
\hline $\begin{array}{l}\text { 1) Circulante } \\
\text { 1.1) Disponibilidades } \\
\text { Redução do circulante referente à parcela não } \\
\text { financiada do valor do imóvel }\end{array}$ & $\begin{array}{r}286.853 \\
41.285\end{array}$ & $\begin{array}{r}280.853 \\
(6.000) \\
(6.000)\end{array}$ & $\begin{array}{l}\text { 1) Circulante } \\
\text { Acréscimo do circulante referente à parcela do } \\
\text { financiamento do imóvel (principal e juros) em } \\
\text { cada exercício }\end{array}$ & 261.618 & 262.900 \\
\hline 2) Não Circulante & 639.784 & 651.367 & 2) Não Circulante & 210.466 & 215.609 \\
\hline 2.1) Ativo realizável a longo prazo & 32.414 & - & 2.1) Passivo Exigível a Longo Prazo & 210.466 & 5.143 \\
\hline 2.2) Ativo Imobilizado & 607.370 & 11.583 & Saldo da Dívida & & 7.692 \\
\hline $\begin{array}{l}\text { Acréscimo do imobilizado no montante } \\
\text { equivalente ao valor de transação do imóvel }\end{array}$ & & 12.000 & $\begin{array}{l}\text { Acréscimo do exigivel a longo prazo no } \\
\text { montante equivalente ao valor financiado } \\
\text { do imóvel acrescido dos encargos }\end{array}$ & & 8.974 \\
\hline $\begin{array}{l}\text { Redução do imobilizado referente à } \\
\text { depreciação do ativo no período (somada à } \\
\text { acumulada) }\end{array}$ & & (417) & $\begin{array}{l}\text { Redução do exigível a longo prazo no } \\
\text { valor acumulado das parcelas já } \\
\text { amortizadas do financiamento }\end{array}$ & & $(1.282)$ \\
\hline & & & Encargos dos exercíios futuros & & (2.549) \\
\hline & & & Encargos financeiros a apropriar & & (2.974) \\
\hline & & & $\begin{array}{l}\text { Encargos do ano transferidos } \\
\text { para resultado }\end{array}$ & & 425 \\
\hline & & & 3) Patrimônio Líquido & 454.553 & 453.711 \\
\hline & & & $\begin{array}{l}\text { Redução na conta de lucros/prejúzos } \\
\text { acumulados (lucro líquido) no montante } \\
\text { equivalente à depreciação do ativo no período }\end{array}$ & & (417) \\
\hline & & & $\begin{array}{l}\text { Redução na conta de lucros/prejuízos } \\
\text { acumulados (lucro líquido) no montante } \\
\text { equivalente aos encargos financeiros do } \\
\text { período }\end{array}$ & & $(425)$ \\
\hline
\end{tabular}

\section{Observações:}

1 - Considera-se para análise do impacto das [alternativas] de imobilização a situação do ativo em regime operacional (ou seja, quando em uso), mesmo que existam parcelas do imóvel a serem pagas nos próximos exercícios. Portanto, os encargos financeiros do financiamento do imóvel estão contabilizados como despesa operacional, e a depreciação já começa a ser contabilizada como conta redutora do ativo imobilizado. Esta premissa é coerente com o valor do ativo que está sendo considerado para análise dos impactos da imobilização no balanço. Ou seja, como o valor do imóvel considerado no balanço é o seu valor de mercado (fornecido no laudo de avaliação), considera-se que este seja o valor do imóvel quanto colocado pronto para uso, que contempla, portanto, as remunerações/encargos dos investidores/financiadores para conceber 0 ativo.

2 - Estas premissas adotadas para efeito de cálculo dos indicadores do Critério $\mathrm{H}$ (Desoneração do Balanço) do [MAOI] não alteram significativamente a análise, já que os impactos mais representativos são contabilizados sempre da mesma forma: [i] no ativo circulante (redução do caixa com as parcelas não financiadas do imóvel), [ii] no ativo imobilizado (valor de transação) e, [iii] no passivo exigível a longo prazo (valor do financiamento do imóvel, incluindo os encargos financeiros). Para efeito de contabilização dos juros no balanço considera-se o valor médio dos juros das parcelas Price (que são decrescentes à medida que as parcelas são pagas).

Quadro 47 - [alternativa] -SP a Prazo e impactos nos grupos de contas do balanço da empresa do caso - Imóvel 5 
ANÁLISE IMPACTO NO BALANÇO - EMPRESA DO CASO - IMÓVEL 5 (CENTRO DE PESQUISAS CLÍNICAS) - SLB IMPACTO NO ATIVO: DESMOBILIZAÇÃO (SLB) IMPACTO NO PASSIVO: DESMOBILIZAÇÃO (SLB)

\begin{tabular}{|c|c|c|c|c|c|}
\hline & Atual & $\begin{array}{c}\text { Impactos } \\
\text { [alternativa]: } \\
\text { SLB }\end{array}$ & & Atual & $\begin{array}{c}\text { Impactos } \\
\text { [alternativa]: } \\
\text { SLB } \\
\end{array}$ \\
\hline ATIVO & 926.789 & 938.637 & PASSIVO & 926.789 & 938.637 \\
\hline $\begin{array}{l}\text { 1) Circulante } \\
\text { 1.1) Disponibilidades } \\
\text { Acréscimo do circulante no valor de } \\
\text { transação do imóvel }\end{array}$ & $\begin{array}{r}286.853 \\
41.285\end{array}$ & \begin{tabular}{r|}
298.853 \\
12.000 \\
12.000
\end{tabular} & $\begin{array}{l}\text { 1) Circulante } \\
\text { Acréscimo do circulante no valor da } \\
\text { despesa com alugueis e/ou } \\
\text { contraprestações do periodo } \\
\text { Acréscimo do circulante referente à } \\
\text { provisão dos impostos no caso da } \\
\text { existência de lucro na venda do ativo }\end{array}$ & 261.618 & $\begin{array}{l}1.591 \\
4.028\end{array}$ \\
\hline 2) Não Circulante & 639.936 & 639.784 & 2) Não Circulante & 210.466 & 210.466 \\
\hline $\begin{array}{l}\text { 2.1) Ativo realizável a longo prazo } \\
\text { 2.2) Ativo Imobilizado } \\
\text { Acréscimo do imobilizado, no } \\
\text { montante equivalente ao preço da } \\
\text { outorga, no caso do DRS como } \\
\text { instrumento jurídico } \\
\text { Redução do imobilizado, referente } \\
\text { à amortização da contraprestação } \\
\text { (DRS) do periodo (somada à } \\
\text { acumulada) } \\
\text { Redução do imobilizado, no } \\
\text { montante equivalente ao valor } \\
\text { contábil do imóvel }\end{array}$ & $\begin{array}{r}32.414 \\
607.522\end{array}$ & $\begin{array}{c}- \\
(152)\end{array}$ & $\begin{array}{l}\text { 2.1) Passivo Exigível a Longo Prazo } \\
\text { Acréscimo do exigível a longo prazo, } \\
\text { no montante equivalente ao preço da } \\
\text { outorga (para DRS) } \\
\text { Redução do exigível a longo prazo, no } \\
\text { valor acumulado da amortização } \\
\text { referente às contraprestações de cada } \\
\text { período (para DRS) } \\
\text { 3) Patrimônio Líquido } \\
\text { Acréscimo na conta de lucros/prejuizos } \\
\text { acumulados no montante equivalente à } \\
\text { diferença entre o valor de venda e o } \\
\text { valor contábil do ativo (já deduzido os } \\
\text { impostos com a venda) } \\
\text { Redução na conta de lucros/prejuizos } \\
\text { acumulados, no montante equivalente } \\
\text { ao valor do aluguel do período (ou } \\
\text { contraprestações para o DRS) }\end{array}$ & 210.466 & $\begin{array}{r}7.820 \\
(1.591)\end{array}$ \\
\hline
\end{tabular}

Quadro 48 - [alternativa] - SLB e impactos nos grupos de contas do balanço da empresa do caso - Imóvel 5 


\begin{tabular}{|c|c|c|c|c|c|}
\hline \multicolumn{6}{|c|}{$\begin{array}{l}\text { ANÁLISE IMPACTO NO BALANÇO - EMPRESA DO CASO - IMÓVEL } 6 \text { (UNIDADE FABRIL - VETERINÁRIOS) } \\
\text { Análise das [Alternativas] a partir das demandas e caracteristicas do imóvel } \\
\text { (Valores em R\$ mil) }\end{array}$} \\
\hline \multicolumn{3}{|c|}{ IMPACTO NO ATIVO: [ALTERNATIVAS] DE NÃO IMOBILIZAÇÃO } & \multicolumn{3}{|c|}{ IMPACTO NO PASSIVO: [ALTERNATIVAS] DE NÃO IMOBILIZAÇÃO } \\
\hline & Atual & $\begin{array}{l}\text { Impactos } \\
\text { [alternativas]: } \\
\text { BTS, LLP, LCP }\end{array}$ & & Atual & $\begin{array}{l}\quad \text { Impactos } \\
\text { [alternativas]: } \\
\text { BTS, LLP, LCP }\end{array}$ \\
\hline ATIVO & 926.789 & 926.789 & PASSIVO & 926.789 & 926.789 \\
\hline $\begin{array}{l}\text { 1) Circulante } \\
\text { 1.1) Disponibilidades }\end{array}$ & $\begin{array}{r}286.853 \\
41.285\end{array}$ & 286.853 & $\begin{array}{l}\text { 1) Circulante } \\
\text { Acréscimo do circulante no valor da despesa } \\
\text { com alugueis e/ou contraprestações do } \\
\text { período }\end{array}$ & 261.618 & $\begin{array}{r}262.553 \\
935\end{array}$ \\
\hline 2) Não Circulante & 639.936 & 639.936 & 2) Não Circulante & 210.466 & 210.466 \\
\hline 2.1) Ativo realizável a longo prazo & 32.414 & - & $\begin{array}{l}\text { 2.1) Passivo Exigivel a Longo Prazo } \\
\text { Acréscimo do exigivel a longo prazo no }\end{array}$ & 210.466 & - \\
\hline $\begin{array}{l}\text { 2.2) Ativo Imobilizado } \\
\text { Acréscimo do imobilizado no montante } \\
\text { equivalente ao preço da outorga, no caso do } \\
\text { DRS como instrumento juríico }\end{array}$ & 607.522 & - & $\begin{array}{l}\text { montante equivalente ao preço da outorga } \\
\text { (para DRS) } \\
\text { Redução do exigivel a longo prazo no valor } \\
\text { acumulado da amortização referente às } \\
\text { contraprestações de cada período (para } \\
\text { DRS) }\end{array}$ & & - \\
\hline $\begin{array}{l}\text { Redução do imobilizado referente à } \\
\text { amortização da contraprestação do DRS do } \\
\text { período (somada à acumulada) }\end{array}$ & & & $\begin{array}{l}\text { 3) Patrimônio Líquido } \\
\text { Redução na conta de lucros/prejúzos } \\
\text { acumulados (lucro líquido) no montante } \\
\text { equivalente ao valor do aluguel do período } \\
\text { (ou contraprestação para DRS) }\end{array}$ & 454.705 & $\begin{array}{r}453.770 \\
(935)\end{array}$ \\
\hline
\end{tabular}

Quadro 49 - [alternativas] - BTS, LLP, LCP e impactos nos grupos de contas do balanço da empresa do caso Imóvel 6 


\begin{tabular}{|c|c|c|c|c|c|}
\hline \multicolumn{6}{|c|}{$\begin{array}{l}\text { ANÁLISE IMPACTO NO BALANÇO - EMPRESA DO CASO - IMÓVEL } 6 \text { (UNIDADE FABRIL - VETERINÁRIOS) } \\
\text { Análise das [Alternativas] a partir das demandas e características do imóvel } \\
\text { (Valores em R\$ mil) }\end{array}$} \\
\hline \multicolumn{3}{|c|}{ IMPACTO NO ATIVO: [SP] } & \multicolumn{3}{|c|}{ IMPACTO NO PASSIVO: [SP] } \\
\hline & Atual & $\begin{array}{c}\text { Impactos } \\
\text { [alternativa]: } \\
{[\mathrm{SP}]}\end{array}$ & & Atual & $\begin{array}{l}\text { Impactos } \\
\text { [alternativa]: } \\
{[\mathrm{SP}]}\end{array}$ \\
\hline ATIVO & 926.789 & 926.563 & PASSIVO & 926.789 & 926.563 \\
\hline $\begin{array}{l}\text { 1) Circulante } \\
\text { 1.1) Disponibilidades } \\
\text { Redução do circulante no valor de transação } \\
\text { do imóvel }\end{array}$ & $\begin{array}{r}286.853 \\
41.285\end{array}$ & $\begin{array}{r}279.853 \\
(7.000) \\
(7.000)\end{array}$ & 1) Circulante & 261.618 & 261.618 \\
\hline 2) Não Circulante & 639.936 & 646.710 & 2) Não Circulante & 210.466 & 210.466 \\
\hline 2.1) Ativo realizável a longo prazo & 32.414 & - & 2.1) Passivo Exigível a Longo Prazo & 210.466 & - \\
\hline $\begin{array}{l}\text { 2.2) Ativo Imobilizado } \\
\text { Acréscimo do imobilizado no montante } \\
\text { equivalente ao valor de transação do imóvel }\end{array}$ & 607.522 & $\begin{array}{l}6.774 \\
7.000\end{array}$ & $\begin{array}{l}\text { 3) Patrimônio Líquido } \\
\text { Redução na conta de lucros/prejuizos } \\
\text { acumulados (lucro líquido) no montante } \\
\text { equivalente à depreciação do ativo no período }\end{array}$ & 454.705 & $\begin{array}{r}454.479 \\
(226)\end{array}$ \\
\hline $\begin{array}{l}\text { Redução do imobilizado referente à } \\
\text { depreciação do ativo no período (somada à } \\
\text { acumulada) }\end{array}$ & & (226) & & & \\
\hline
\end{tabular}

\section{Observações:}

1 - Considera-se para análise do impacto das [alternativas] de imobilização a situação do ativo em regime operacional (ou seja, quando em uso). Portanto, a depreciação já começa a ser contabilizada como conta redutora do ativo imobilizado. Esta premissa é coerente como valor do ativo que está sendo considerado para análise dos impactos da imobilização no balanço. Ou seja, como o valor do imóvel considerado no balanço é o seu valor de mercado (fornecido no laudo de avaliação), considera-se que este seja o valor do imóvel quanto colocado pronto para uso, que contempla, portanto, as remunerações/encargos dos investidores/financiadores para conceber 0 ativo.

2 - Estas premissas adotadas para efeito de cálculo dos indicadores do Critério $\mathrm{H}$ (Desoneração do Balanço) do [MAOI] não alteram significativamente a análise, já que os impactos mais representativos são contabilizados sempre da mesma forma: [i] no ativo circulante (redução do caixa para pagamento do valor de transação do imóvel) e [ii] no ativo imobilizado (valor de transação).

Quadro 50 - [alternativa] - SP e impactos nos grupos de contas do balanço da empresa do caso - Imóvel 6 


\begin{tabular}{|c|c|c|c|c|c|}
\hline \multicolumn{6}{|c|}{$\begin{array}{l}\text { ANÁLISE IMPACTO NO BALANÇO - EMPRESA DO CASO - IMÓVEL } 6 \text { (UNIDADE FABRIL - VETERINÁRIOS) } \\
\text { Análise das [Alternativas] a partir das demandas e características do imóvel } \\
\text { (Valores em R\$ mil) }\end{array}$} \\
\hline \multicolumn{3}{|c|}{ IMPACTO NO ATIVO: [SP] a prazo (por meio de financiamento) } & \multicolumn{3}{|c|}{ IMPACTO NO PASSIVO: [SP] a prazo (por meio de financiamento) } \\
\hline & Atual & $\begin{array}{c}\text { Impactos } \\
\text { [alternativa]: } \\
\text { [SP] a prazo }\end{array}$ & & Atual & $\begin{array}{l}\text { Impactos } \\
\text { [alternativa]: } \\
\text { [SP] a prazo }\end{array}$ \\
\hline ATIVO & 926.789 & 930.063 & PASSIVO & 926.789 & 930.063 \\
\hline $\begin{array}{l}\text { 1) Circulante } \\
\text { 1.1) Disponibilidades } \\
\text { Redução do circulante referente à parcela não } \\
\text { financiada do valor do imóvel }\end{array}$ & $\begin{array}{r}286.853 \\
41.285\end{array}$ & $\begin{array}{r}283.353 \\
(3.500) \\
(3.500)\end{array}$ & $\begin{array}{l}\text { 1) Circulante } \\
\text { Acréscimo do circulante referente à parcela do } \\
\text { financiamento do imóvel (principal e juros) em } \\
\text { cada exercício }\end{array}$ & 261.618 & 262.366 \\
\hline 2) Não Circulante & 639.936 & 646.710 & 2) Não Circulante & 210.466 & 213.466 \\
\hline 2.1) Ativo realizável a longo prazo & 32.414 & - & 2.1) Passivo Exigivel a Longo Prazo & 210.466 & 3.000 \\
\hline 2.2) Ativo Imobilizado & 607.522 & 6.774 & Saldo da Dívida & & 4.487 \\
\hline $\begin{array}{l}\text { Acréscimo do imobilizado no montante } \\
\text { equivalente ao valor de transação do imóvel }\end{array}$ & & 7.000 & $\begin{array}{l}\text { Acréscimo do exigível a longo prazo no } \\
\text { montante equivalente ao valor financiado } \\
\text { do imóvel acrescido dos encargos }\end{array}$ & & 5.235 \\
\hline $\begin{array}{l}\text { Redução do imobilizado referente à } \\
\text { depreciação do ativo no período (somada à } \\
\text { acumulada) }\end{array}$ & & (226) & $\begin{array}{l}\text { Redução do exigível a longo prazo no } \\
\text { valor acumulado das parcelas já } \\
\text { amortizadas do financiamento }\end{array}$ & & $(748)$ \\
\hline & & & Encargos dos exercícios futuros & & $(1.487)$ \\
\hline & & & Encargos financeiros a apropriar & & $(1.735)$ \\
\hline & & & $\begin{array}{l}\text { Encargos do ano transferidos } \\
\text { para resultado }\end{array}$ & & 248 \\
\hline & & & 3) Patrimônio Líquido & 454.705 & 454.231 \\
\hline & & & $\begin{array}{l}\text { Redução na conta de lucros/prejuízos } \\
\text { acumulados (lucro líquido) no montante } \\
\text { equivalente à depreciação do ativo no período }\end{array}$ & & (226) \\
\hline & & & \begin{tabular}{|l|} 
Redução na conta de lucros/prejuízos \\
acumulados (lucro liquido) no montante \\
equivalente aos encargos financeiros do \\
período
\end{tabular} & & (248) \\
\hline
\end{tabular}

\section{Observações:}

1 - Considera-se para análise do impacto das [alternativas] de imobilização a situação do ativo em regime operacional (ou seja, quando em uso), mesmo que existam parcelas do imóvel a serem pagas nos próximos exercícios. Portanto, os encargos financeiros do financiamento do imóvel estão contabilizados como despesa operacional, e a depreciação já começa a ser contabilizada como conta redutora do ativo imobilizado. Esta premissa é coerente com o valor do ativo que está sendo considerado para análise dos impactos da imobilização no balanço. Ou seja, como o valor do imóvel considerado no balanço é o seu valor de mercado (fornecido no laudo de avaliação), considera-se que este seja o valor do imóvel quanto colocado pronto para uso, que contempla, portanto, as remunerações/encargos dos investidores/financiadores para conceber 0 ativo.

2 - Estas premissas adotadas para efeito de cálculo dos indicadores do Critério H (Desoneração do Balanço) do [MAOI] não alteram significativamente a análise, já que os impactos mais representativos são contabilizados sempre da mesma forma: [i] no ativo circulante (redução do caixa com as parcelas não financiadas do imóvel), [ii] no ativo imobilizado (valor de transação) e, [iii] no passivo exigível a longo prazo (valor do financiamento do imóvel, incluindo os encargos financeiros). Para efeito de contabilização dos juros no balanço considera-se o valor médio dos juros das parcelas Price (que são decrescentes à medida que as parcelas são pagas).

Quadro 51 - [alternativa] -SP a Prazo e impactos nos grupos de contas do balanço da empresa do caso - Imóvel 6 
ANÁLISE IMPACTO NO BALANÇO - EMPRESA DO CASO - IMÓVEL 6 (UNIDADE FABRIL - VETERINÁRIOS) - SLB IMPACTO NO ATIVO: DESMOBILIZAÇÃO (SLB)

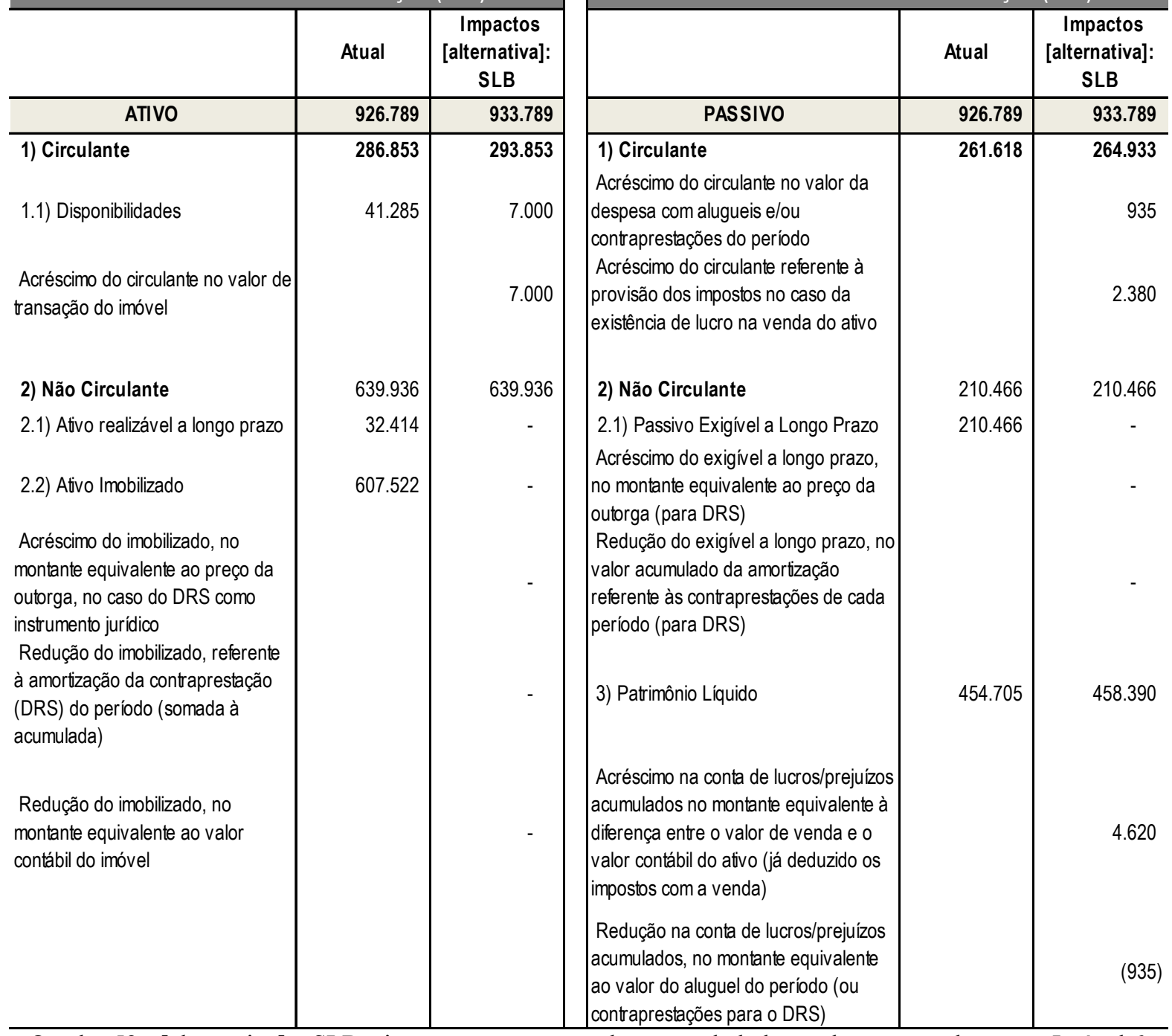

Quadro 52 - [alternativa] - SLB e impactos nos grupos de contas do balanço da empresa do caso - Imóvel 6 